\title{
Catalog of Hawaiian Earthquakes, 1823-1959
}

U.S. Geological Survey Professional Paper 1623

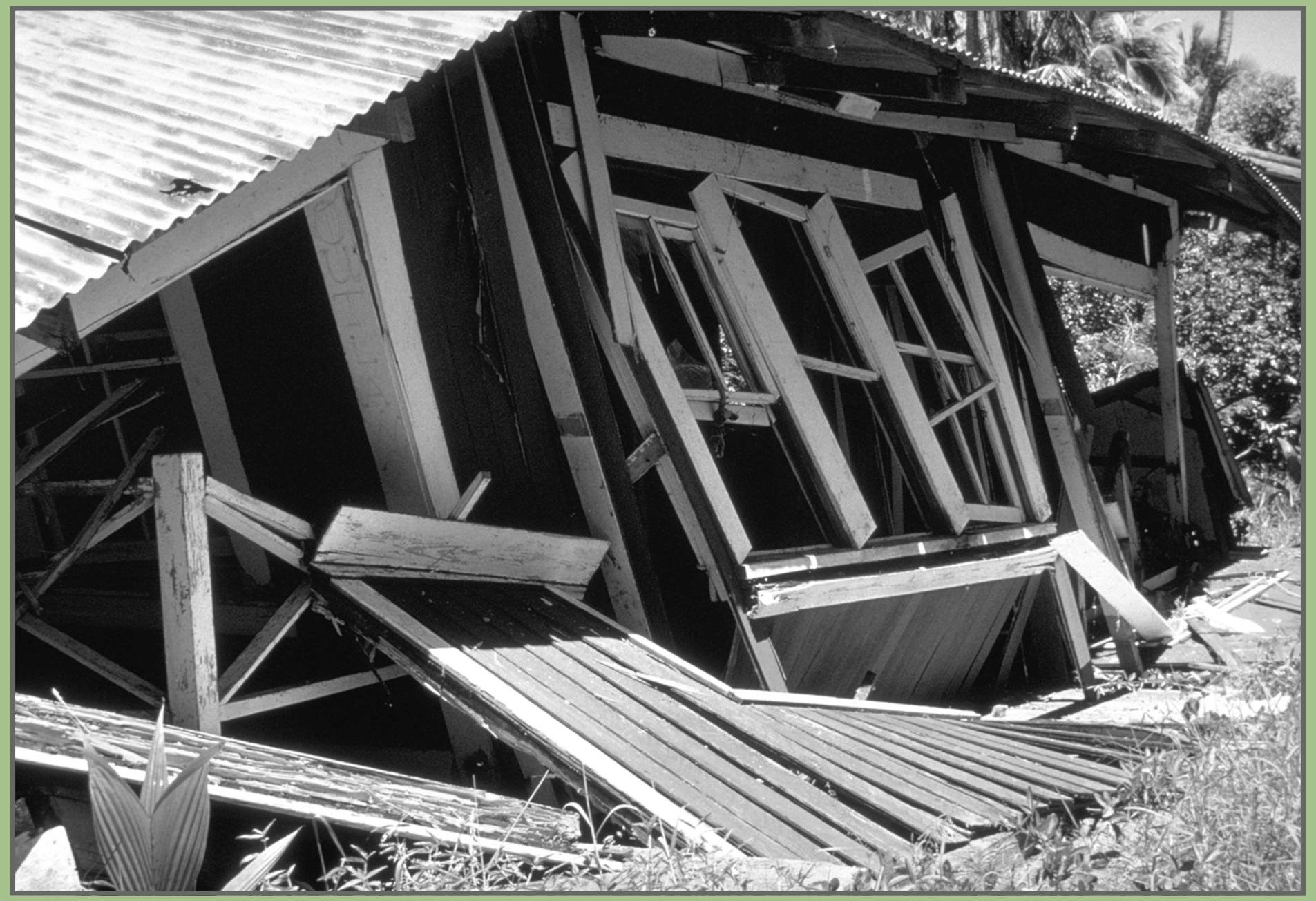




\section{Availability of Publications of the U.S. Geological Survey}

Order U.S. Geological Survey (USGS) publications from the offices listed below. Detailed ordering instructions, along with prices of the last offerings, are given in the current-year issues of the catalog "New Publications of the U.S. Geological

Survey."

\section{Books, Maps, and Other Publications}

\section{By Mail}

Books, maps, and other publications are available by mail from-

USGS Information Services

Box 25286, Federal Center

Denver, CO 80225

Publications include Professional Papers, Bulletins, WaterSupply Papers, Techniques of Water-Resources Investigations, Circulars, Fact Sheets, publications of general interest, single copies of permanent USGS catalogs, and topographic and thematic maps.

\section{Over the Counter}

Books, maps, and other publications of the U.S. Geological Survey are available over the counter at the following USGS Earth Science Information Centers (ESIC's), all of which are authorized agents of the Superintendent of Documents:

- Anchorage, Alaska-Rm. 101, 4230 University Dr.

- Denver, Colorado-Bldg. 810, Federal Center

- Menlo Park, California-Rm. 3128, Bldg. 3, 345 Middlefield Rd.

- Reston, Virginia-Rm. 1C402, USGS National Center, 12201 Sunrise Valley Dr.

- Salt Lake City, Utah-2222 West, 2300 South (books and maps available for inspection only)

- Spokane, Washington-Rm. 135, U.S. Post Office Building, 904 West Riverside Ave.

- Washington, D.C.-Rm. 2650, Main Interior Bldg., 18th and C Sts., NW.

Maps only may be purchased over the counter at the following USGS office:

- Rolla, Missouri-1400 Independence Rd.

\section{Electronically}

Some USGS publications, including the catalog "New Publications of the U.S. Geological Survey" are also available electronically on the USGS's World Wide Web home page at http://www.usgs.gov

\section{Preliminary Determination of Epicenters}

Subscriptions to the periodical "Preliminary Determination of Epicenters" can be obtained only from the Superintendent of
Documents. Check or money order must be payable to the Superintendent of Documents. Order by mail from-

Superintendent of Documents

Government Printing Office

Washington, DC 20402

\section{Information Periodicals}

Many Information Periodicals products are available through the systems or formats listed below:

\section{Printed Products}

Printed copies of the Minerals Yearbook and the Mineral Commodity Summaries can be ordered from the Superintendent of Documents, Government Printing Office (address above). Printed copies of Metal Industry Indicators and Mineral Industry Surveys can be ordered from the Center for Disease Control and Prevention, National Institute for Occupational Safety and Health, Pittsburgh Research Center, P.O. Box 18070, Pittsburgh, PA 15236-0070.

\section{Mines FaxBack: Return fax service}

1. Use the touch-tone handset attached to your fax machine's telephone jack. (ISDN [digital] telephones cannot be used with fax machines.)

2. Dial (703) 648-4999.

3. Listen to the menu options and punch in the number of your selection, using the touch-tone telephone.

4. After completing your selection, press the start button on your fax machine.

\section{CD-ROM}

A disc containing chapters of the Minerals Yearbook (199395), the Mineral Commodity Summaries (1995-97), a statistical compendium (1970-90), and other publications is updated three times a year and sold by the Superintendent of Documents, Government Printing Office (address above).

\section{World Wide Web}

Minerals information is available electronically at http://minerals.er.usgs.gov/minerals/

\section{Subscription to the catalog "New Publications of the U.S. Geological Survey"}

Those wishing to be placed on a free subscription list for the catalog "New Publications of the U.S. Geological Survey" should write to-

U.S. Geological Survey

903 National Center

Reston, VA 20192 


\section{Catalog of Haw aiian Earthquakes, 1823- 1959}

By Fred W. Klein and Thomas L. Wright

U.S. Geological Survey Professional Paper 1623 


\section{U.S. Department of the Interior Bruce Babbitt, Secretary}

\section{U.S. Geological Survey}

Charles G. Groat, Director

Any use of trade, product, or firm names in this publication is for descriptive purposes only and does not imply endorsement by the U.S. Government.

United States Government Printing Office: 2000

For additional copies please contact:

USGS Information Services

B ox 25286

Denver, CO 80225

For more information about the USGS and its products:

Telephone: 1-888- ASK- USGS

World Wide Web: http://w w w.usgs.gov/

Text edited by George A. Havach

Layout and design by Sara Boore

M anuscript approved for publication, A pril 26, 2000

Library of Congress Cataloging-in-Publication Data

Klein, Fred W.

Catalog of Hawaiian earthquakes, 1823-1959 / by Fred W. Klein and Thomas L. Wright. p. cm. - (U.S. Geological Survey professional paper ; 1623)

Includes bibliographical references.

ISBN 0-607-94328-9 (alk. paper)

1. Earthquakes-Hawaii-History-19th century. 2. Earthquakes-Hawaii-20th century

I. Wright, Thomas L. (Thomas Llewellyn), 1935- II. Title. III. Series. 


\section{Contents}

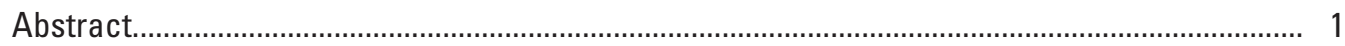

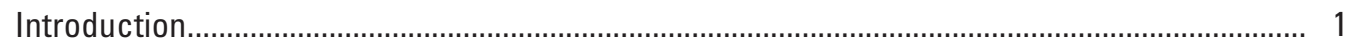

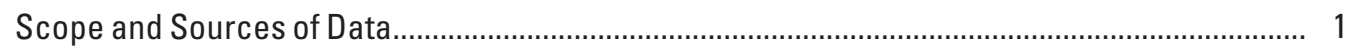

Records of the Honolulu Magnetic Observatory..................................................................... 2

Seismogram Microfilm Records.................................................................................... 3

History of Seismology at the Hawaiian Volcano Observatory................................................ 4

Records of the Hawaiian Volcano Observatory................................................................... 4

The Lyman Diary, 1833-1917........................................................................................ 10

Newspaper Reports, 1856-1959................................................................................. 10

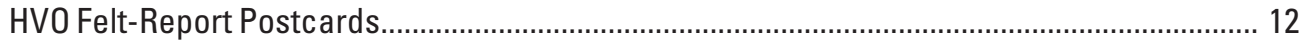

Other Earthquake Reports.............................................................................................. 12

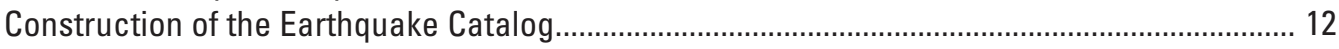

Definition of Geographic Regions and the Assignment of Earthquakes to Them................... 14

Calculation of Earthquake Magnitude..................................................................................... 18

Derivation of the Magnitude Scale for HMO Seismograms.............................................. 18

Magnitudes from the Milne Seismometer, 1903-21_...................................................... 18

Milne-Shaw Intermediate Period, 1921-59................................................................... 19

Horizontal and Vertical Short Period......................................................................... 20

Magnitude Determination for Earthquakes Not Recorded in Honolulu.................................. 20

HVO Magnitude Data, 1928-57 .................................................................................... 20

HVO Magnitude Data, 1912-17........................................................................................ 23

HVO Magnitude Data, 1917-27................................................................................... 24

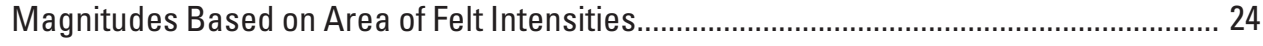

Magnitudes Based on Maximum Intensity.................................................................... 24

Adoption of a "Preferred" Magnitude................................................................................. 25

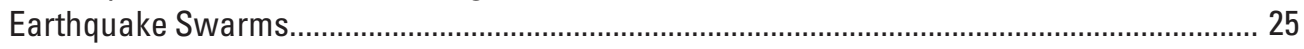

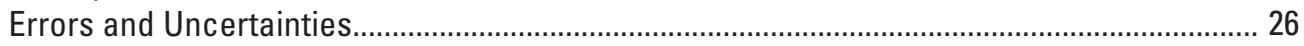

Location and Magnitude Profile of the 1933-59 Catalog............................................................ 26

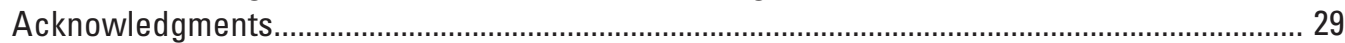

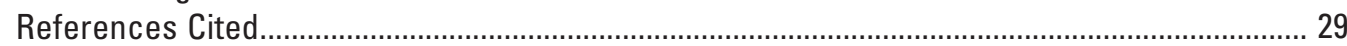

Appendixes:

Appendix 1. Files Available on the Accompanying CD-ROM..................................................... 33

Appendix 2. Calculation of a "Characteristic" Amplitude for HVO Earthquake Classes.............. 34

Appendix 3. Errors and Uncertainties.................................................................................... 34

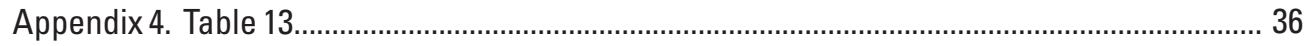

\section{Figures}

1. Chart Showing History of Instrumentation and Reporting of Earthquakes at the Honolulu Magnetic Observatory and the Hawaiian Volcano Observatory...

2. Chart Comparing Intensity and Amplitude Scales Used by the Hawaiian Volcano Observatory...

3. Chart Showing Publication History of Hawaiian Newspapers and Other Sources of Information for Felt Earthquakes on Hawaii..................................................................... 11

4. Maps Showing Geographic Regions Defined for Earthquakes in Hawaii............................... 15

5. Plot Used for Empirical Calibration of Milne Seismometer................................................... 19

6. Nomogram for Determining Magnitude of Earthquakes Recorded at the Hawaiian Volcano Observatory During the Period 1928-57............................................................. 21

7. Plots Comparing Magnitudes for Earthquakes During the Period 1933-59............................... 22

8. Plot of Maximum Intensity Versus Magnitude for Hawaiian Earthquakes............................. 25

9. Map of the Island of Hawaii, Showing Locations of All Earthquakes of $M \geq 3$ During Two 27-Year Periods Beneath the Island and Adjacent Ocean.................................................... 27

10. Plots Showing Magnitude Distribution of Hawaiian Earthquakes.......................................... 28 


\section{Tables}

1. History of Instrumentation and Reporting of Earthquakes at the Honolulu Magnetic Observatory.

2. History of Instrumentation and Reporting of Earthquakes at the Hawaiian Volcano Observatory.

3. Cancani Scale of Seismic Intensity.

4. Early (1932-57) Classification of Earthquake Magnitudes at the Hawaiian Volcano Observatory.

5. Beginning and Ending Dates of Publication of Hawaiian Newspapers................................. 11

6. Hawaiian Volcano Observatory Intensity Scale Used on Postcards After 1933....................... 13

7. Explanation of Column Headings Used in Our Catalog.......................................................... 13

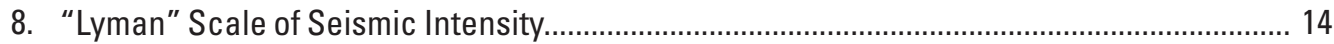

9. Synonymy Relating the Geographic Regions Defined in Figure 4 to the Abbreviations in Our Catalog... 16

10. Station Constants from the January 1957 Film Record.......................................................... 18

11. Magnitude Types and Codes Used to Identify Them, with Associated Uncertainties............. 23

12. Numbers of Cataloged Earthquakes, by Magnitude......................................................... 28

13. All Earthquakes of $M \geq 4.0$ During the Period 1903-59........................................................ 36

14. Column Headings and Formatting for ASCII Catalog Data.................................................... 33 


\title{
Catalog of Hawaiian Earthquakes, 1823-1959
}

\author{
By Fred W. Klein and Thomas L. Wright
}

\begin{abstract}
We have prepared a catalog of more than 17,000 earthquakes located in the Hawaiian Islands, principally on the Island of Hawaii, from 1823 through the third quarter of 1959, ending at the beginning date for the modern computer-based earthquake catalog. We have estimated the magnitude of all earthquakes for which seismograms or published amplitudes exist, which is more than 80 percent of the earthquakes we cataloged. We have compiled instrumental amplitudes from the Honolulu Magnetic Observatory (1903-59) and the Hawaiian Volcano Observatory (HVO) (1912-59) and combined these data with published felt reports for the entire time period, including newspaper accounts from 1856 to 1959 and unpublished felt reports sent to HVO from 1932 to 1941 and 1951 to 1958. We have devised means to assign location and magnitude for all events with at least a published distance from HVO, or those events that were widely felt. Locations for most of the small, and many large, earthquakes before 1950 are crude estimates because only one or a few stations with poor timing were used. We have expanded the determination of magnitude and intensity to levels lower than previously reported for this period in Hawaii-magnitudes about 5, intensities of greater than or equal to $\mathrm{V}$. This catalog is designed to expand our ability to evaluate seismic hazard in Hawaii and also to greatly expand our knowledge of Hawaiian seismic rhythms as they relate to eruption cycles at Kilauea and Mauna Loa and to subcrustal earthquake patterns related to the tectonic evolution of the Hawaiian chain. This report attempts no interpretation but does provide a catalog of earthquake data heretofore unavailable in other than narrative accounts. We also evaluate the data sources and errors associated with them as a constraint on interpretations made from our catalog's listing of locations and magnitudes.
\end{abstract}

\section{Introduction}

A catalog of earthquakes registered by the seismic network maintained by the U.S. Geological Survey's Hawaiian Volcano Observatory (HVO) is currently available in computer form, dating from the fourth quarter of 1959 (Hawaiian Volcano Observatory, unpub. data, 1998). The beginning date of October 1, 1959 , for the modern catalog is somewhat arbitrary, representing a time after which the local network was sufficient to give an accurate representation of hypocenter and magnitude using a computer-based earthquake-location program. Our catalog extends the documentation of Hawaiian earthquakes backward from October 1, 1959, to an early written earthquake account, of an event in 1823 that occurred just before the first visit of missionaries to the Island of Hawaii.
Knowledge of the seismicity of the Hawaiian Islands over the longest possible timespan supports the following goals: (1) evaluation of the seismic hazard for different parts of the Hawaiian Islands and (2) an improved understanding of how Hawaii's active volcanoes work. The relation of seismic release to eruptions, the interaction of one volcano with another, and the tectonics of a volcanic chain formed over a hotspot depend on knowledge of the long-term patterns of seismic release expressed by earthquake magnitudes, depth, and epicentral locations.

Our catalog builds on an earlier catalog and comprehensive analysis by Wyss and Koyanagi (1992), who listed events from 1833 to 1939 with a maximum intensity of $\mathrm{V}$ or more (generally in Hilo) and thus deal mostly with magnitudes of $5^{1 / 2}$ or larger. They determined approximate magnitudes and locations from isoseismal maps for 20 of the larger earthquakes from 1868 to 1950 . Their sources were primarily felt reports. We relied heavily on their catalog and methods, but we greatly expanded our catalog to cover all reported events, primarily those instrumentally recorded.

Going backward in time, the uncertainties in interpreting the critical earthquake parameters increase; to interpret older earthquake data, there is an essential contribution from (1) modern earthquake patterns established using an adequate seismic network and their relation to volcanic activity, and (2) inferences made as to the behavior of fault zones and deeper seismicity not directly tied to volcanic activity. Interpretation is required both because the observations from seismometers and people are sparse and because many of the original data are lost. Our purposes in this report are to outline the methodology that we used to extend our catalog backward in time and to make this earthquake data available for use by interested persons. Interpretations based on our catalog that address the two fundamental goals listed above are beyond the scope of the present report but will be the subject of future reports that make use of this catalog.

The text of this report emphasizes the sources of earthquake data and the methods we have employed to create this catalog. A companion CD-ROM contains all of the files formatted for use on VAX or UNIX workstations or desktop (PC or Macintosh) computers. A list of files on the CD-ROM is included in appendix 1 . We anticipate that additional and revised files will become available in the future and will be added to those on the CD-ROM.

\section{Scope and Sources of Data}

We have consulted all of the reports of Hawaiian earthquakes that we could find, including published and unpublished data generated by HVO, published data from the seismometer(s) housed at the U.S. Coast and Geodetic Survey's 
Honolulu Magnetic Observatory (HMO), a diary of earthquakes felt in Hilo, Hawaii, by the Lyman family, and earthquakes reported as felt in Hawaiian newspapers. Finally, we have incorporated (and, in some cases, refined) magnitude and intensity determinations for the larger earthquakes published in the compilations of Furumoto and others (1972), Cox (1986), and Wyss and Koyanagi (1992). The scope and limitations of each source of earthquake data are discussed in the following paragraphs.

\section{Records of the Honolulu Magnetic Observatory}

The first seismograph in Hawaii was installed on the grounds of Oahu College (now Punahou School) in 1899 by the surveyor W.D. Alexander (1899), and some of the earthquake records were subsequently published (Reid, 1905, 1906). Once established, the magnetic observatory was run by the U.S. Coast and Geodetic Survey as part of a network of magnetic observatories in the United States and Canada. The history of seismic instrumentation at the Honolulu station, taken from the January-June 1935 microfilm record of Honolulu seismograms (see next subsection), is summarized in figure 1 and table 1 .

The records of earthquakes recorded at HMO from April 1903 through December 1927 are published in two series. The first series, entitled "Results of Observations Made at the Coast and Geodetic Survey Magnetic Observatory near Honolulu, Hawaii," were issued biannually, beginning in 1905-6 (Hazard, 1910, 1911, 1912, 1913, 1916, 1918, 1920, 1922, 1924;

McFarland, 1929). A short section in each report entitled "Earthquakes" gives data from the single-component Milne seismometer and, after 1921, from the two-component MilneShaw seismometer housed at the observatory. The report for 1905-6 includes Milne data back to its time of installation in April 1903. Data given for each earthquake are beginning and ending times, times of long-wave motion and time of maximum amplitude along with the maximum amplitude registered, and remarks on the possible source and character of the seismogram. In reports from 1919 and later, $P$ - and $S$-wave arrivals are specified.

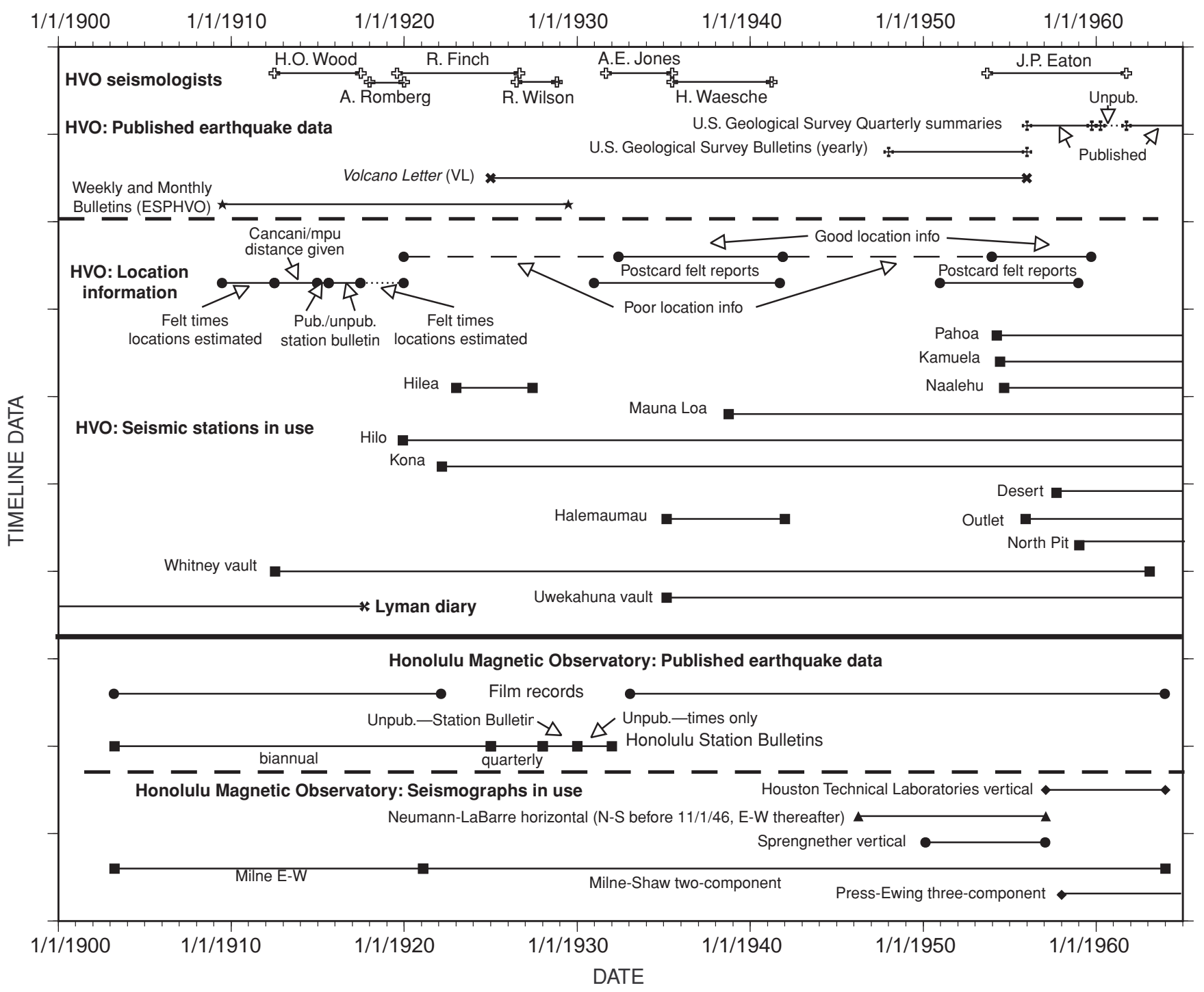

Figure 1. History of instrumentation and reporting of earthquakes at the Honolulu Magnetic Observatory and the Hawaiian Volcano Observatory (HVO). 
Table 1. History of instrumentation and reporting of earthquakes at the Honolulu Magnetic Observatory

\begin{tabular}{|c|c|}
\hline Period & Description \\
\hline April 1903 & $\begin{array}{l}\text { Milne seismometer belonging to the Seismological Committee of the British Association was } \\
\text { transferred from Oahu College to the C\&GS Magnetic Observatory, located } 3 \mathrm{~km} \text { SW. of } \\
\text { Ewa Beach. Note: Graph paper microfilmed showing that scaling is the same horizontally } \\
\text { and vertically. }\end{array}$ \\
\hline February 1921 & $\begin{array}{l}\text { Milne-Shaw horizontal seimometers replaced older instrument, referred to in our catalog as } \\
\text { "M-S (N-S)" and "M-S (E-W)." Note: Before February 1921, the boom of the Milne } \\
\text { seismometer was displaced daily, producing a signal with about a 12-s period, decaying } \\
\text { over time. }\end{array}$ \\
\hline 1926 & Cooperative project begun with the University of Hawaii. \\
\hline April 1946 & $\begin{array}{l}\text { Neumann-LaBarre N-S seismometer installed, referred to in our catalog as "hor N-L." Note: } \\
\text { Microfilm records are labeled "N-S short-period" through November 1, 1946, and "E-W } \\
\text { short-period" thereafter. Evidently, the seismometer was rotated } 90^{\circ} \text { at that time. }\end{array}$ \\
\hline October 1946 & $\begin{array}{l}\text { Instruments relocated to a new C\&GS Magnetic and Seismological Observatory at Barbers } \\
\text { Point. }\end{array}$ \\
\hline September 1948 & $\begin{array}{l}\text { Visual recording seismograph installed as part of tsunami-warning system. Station became } \\
\text { central headquarters of the warning program. }\end{array}$ \\
\hline $\begin{array}{l}\text { October 1949- } \\
\text { February } 1950\end{array}$ & $\begin{array}{l}\text { Experimental N-S short-period and long-period seismometers } \\
\text { temporarily in stalled; discontinued when Sprengnether vertical } \\
\text { seismometer was installed. }\end{array}$ \\
\hline March 1950 & Sprengnether vertical seismometer installed, referred to in our catalog as "vert." \\
\hline $\begin{array}{l}\text { November- } \\
\text { December } 1954\end{array}$ & $\begin{array}{l}\text { Two short-period vertical seismometers installed: Wilson-Lamison } \\
\text { (more sensitive) and Sprengnether (less sensitive). }\end{array}$ \\
\hline October 1956 & $\begin{array}{l}\text { Houston Technical Laboratories vertical seismometer installed, referred to in our catalog as } \\
\text { "vert." }\end{array}$ \\
\hline January 1957 & $\begin{array}{l}\text { Neumann-LaBarre and Sprengnether seismometers discontinued. Note: Records for vertical } \\
\text { (Sprengnether) seismometer extend through January 1957, and records for vertical } \\
\text { (Houston Technical Laboratories) seismometer begin in February } 1957 \text {. }\end{array}$ \\
\hline $\begin{array}{l}\text { January } 1958 \\
\text { June } 1960\end{array}$ & $\begin{array}{l}\text { Three-component Press-Ewing seismometer operated for Lamont Geological Observatory. } \\
\text { New observatory site occupied at Ewa Beach. }\end{array}$ \\
\hline
\end{tabular}

The Milne seismometer recorded at a low gain of about 6 to 15 (Abe, 1988) on a paper strip at a rate of about $6 \mathrm{~cm} / \mathrm{h}$. Sensitivity and time resolution were thus very low. The seismometer was also underdamped and rings for many minutes with its own decay rate. These factors make the recognition of phases difficult and amplitude scaling imprecise. Small events appear as a thickening of the line or a small blip, and it is often impossible to distinguish local from distant events. Some fine detail is also lost in the microfilm process. We used the Milne records to estimate the magnitudes of events that were strongly felt. We could not identify new earthquakes that were not reported elsewhere.

Beginning at the end of 1914 (Humphreys, 1914) and extending through the end of 1924 (Humphreys, 1924), information from the biannual reports was reprinted each month in the Monthly Weather Review as part of "Section V. Seismology." So far as we can determine, these reports only duplicate information available from HMO.

From 1925 through 1927, the seismic data were published separately in a series of quarterly reports of the U.S. Coast and Geodetic Survey entitled "Seismological Report" (Neumann, 1926a, b, 1927, 1928a-c, 1929, 1930a, b, 1931; Neumann and Service, 1926, 1927) These reports contain data from the entire network of magnetic observatories, including the station at Honolulu. These reports are more detailed than the earlier series, containing, in addition to the instrumental record, a section covering noninstrumental, felt reports from places all over the world. There are many entries for earthquakes felt in Hawaii, often from several different places in the Hawaiian Islands.

In 1928 the "Seismological Report" series was discontinued in favor of a publication series entitled "United States Earthquakes" (Heck and Bodle, 1930, 1931; Neumann, 1932, 1934, 1935, 1936, 1937, 1938, 1940, 1941, 1942, 1943;
Neumann and Bodle, 1932; Bodle, 1944, 1945, 1946; Bodle and Murphy, 1947, 1948; Murphy, 1950; Murphy and Ulrich, 1951, 1952; Murphy and Cloud, 1953, 1954, 1955, 1956, 1957; Brazee and Cloud, 1958, 1960; Eppley and Cloud, 1961). Unfortunately for our catalog, this publication series treated only the larger earthquakes, estimating location, magnitude, and intensities but omitting the station data and felt reports used to make these estimates that were found in earlier publications. In perusing "United States Earthquakes," we noted many incomplete and possibly erroneous records. The national scope may not have allowed time to research or confirm each felt report.

The U.S. Coast and Geodetic Survey, however, continued to make available by private subscription mimeographed reports of Honolulu-station data. For 1928 and 1929, the data follows the format of the "Seismological Report" but without the noninstrumental data. In 1930, the mimeographed reports revert to the format of "United States Earthquakes," and all detail is lost.

\section{Seismogram Microfilm Records}

Microfilm records of seismograms from the network of geomagnetic observatories, including the Honolulu station HON, were made in the early 1980's under the auspices of the "Historical Seismogram Filming Project," headed by Willie Lee of the U.S. Geological Survey (Glover and others, 1985; Lee and others, 1988). The Honolulu film records cover all or parts of the years 1903-22, and 1933-63. The film records from 1933 onward are critical to our data base because no issues of the Honolulu Station Bulletin were published for this period of time. 
The Milne-Shaw seismograms provide better information than the published bulletins. Depending on the size of the event, we can estimate distance, measure amplitude and period of the maximums of the seismogram (essential for determining magnitude), and note the dominant frequency of the initial arrival as a clue to the earthquake's depth. The film records for both the Milne and Milne-Shaw seismograms are also important because they show that some earthquakes on the Island of Hawaii are present on the station $\mathrm{HON}$ film record at the appropriate time but were not clear enough to warrant inclusion in the published Honolulu Station Bulletin. This allows us to assign a Honolulu magnitude near the threshold magnitude of the respective instruments. For many events, we read the noise at periods of 1 to $3 \mathrm{~s}$ to establish a maximum magnitude. Timeline data outlining the reporting history are summarized in figure 1.

The "Historical Seismogram Filming Project" demonstrates the great importance of preserving seismic records for future generations. As long as we know the characteristics of the seismometer recording the earthquake traces, we can apply modern knowledge to old records. As the time of this writing, the records generated on smoked paper at HVO are deteriorating, even in humidity-controlled storage, such that they are very difficult to separate from each other. Our catalog would be considerably improved had we been able to look at original traces or recover original measurements.

\section{History of Seismology at the Hawaiian Volcano Observatory}

Thomas Jaggar, at the time of the founding of HVO in 1912, was able to establish a seismic program that in many ways was ahead of its time. Seismology in 1912 was only in the formative stages in the United States; installation of the first seismographs in the Western Hemisphere at Berkeley and Mount Hamilton, Calif., had taken place only 15 years earlier (J.P. Eaton, written commun., 1986), and the classic work of Beno Gutenberg and Charles Richter (1945) was more than two decades in the future. Jaggar was able to acquire a BoschOmori seismometer, the most advanced of its time, which he installed in the basement of the new observatory. He called this room the "Whitney Laboratory of Seismology." Significant improvements in the seismic network occurred in 1913-22, 1927$28,1938,1948,1950-54$, and $1957-58$, as summarized in figure 1 and table 2 .

Seismology at HVO depended critically on having a professionally trained seismologist on the staff (see staff profiles in Takahashi and Wright, 1987). This was the case for only two periods before the U.S. Geological Survey assumed control of HVO in 1948. H.O. Wood came with Jaggar in 1912 and left in 1917. Wood trained as a seismologist at Harvard. Wood's Station Bulletin (see below) is one of the most thorough earthquake records for the time. Had it been continued, the HVO record would rank among the best seismic catalogs produced in the first half of the 20th century.

Ruy Finch served well as a seismologist from 1919 to 1926. R.M. Wilson admirably filled the role of seismologist from 1926 to 1928 , although we remember him primarily as a topographic engineer. From his many short articles in the $\mathrm{Vol}$ cano Letter, he appears to be a prime mover in the installation and calibration of the "Hawaiian type" mechanical seismograph. Austin Jones was the second staff scientist with formal training as a seismologist. Jones arrived in 1931 and left in 1935; he wrote many interpretative articles and improved seismic reporting. Hugh Waesche succeeded Jones, reporting seismic data from 1935 to 1941. Ruy Finch returned to the staff in 1940 and remained there until 1951.

The quality of HVO instrumentation progressed over the years, largely owing to the ability to build and modify instruments provided by a trained machinist on staff. However, the reporting of seismic data was erratic at times when HVO was without a trained seismologist, particularly during the period between Wood's departure and Jones' arrival, and during the period after Waesche's departure. By 1948, HVO was far behind the standards of the seismological profession.

The revitalization of seismology at HVO began in 1953, with the arrival of Jerry Eaton, a young seismologist trained at Berkeley. He was able to take advantage of new technologies available to seismology to greatly expand the number of stations in HVO's network. By the end of his 10-year tenure, a true seismic network was in place. Beginning in 1957, HVO was assigning magnitudes based on recordings of the classic Wood-Anderson seismometer. By 1958, HVO no longer reported the qualitative earthquake size classes begun in the Volcano Letter in 1932. The size class was greatly inferior to magnitude because it only measured the amplitude on a lowgain mechanical seismometer and, unlike magnitude, was not a property of the earthquake size alone. Further information on the development of the seismic network at HVO was summarized by Klein and Koyanagi (1980).

\section{Records of the Hawaiian Volcano Observatory}

Our primary catalog of data from 1912 through 1959 comes from determinations made by HVO. Earthquakes were first recorded in the weekly and monthly bulletins and special reports published by HVO, now reprinted and bound in three volumes (Bevens and others, 1988), supplemented by material published for the seismic buildup to the Mauna Loa eruption of 1914 (Wood, 1915a), and much later for (1) the period 191213 (Jaggar, 1947, p. 5-88) and (2) May 1924, encompassing detailed observations from the explosive eruption of Halemaumau (Jaggar, 1947, p. 214-259). Systematic reporting in the bulletin series begins with the week ending April 11, 1912 (Jaggar, 1947, p. 9), and ends with the month of July 1929 (Bevens and others, 1988, v. 3, p. 1217). Information on earthquakes felt at Kilauea's summit before the founding of HVO was summarized by Jaggar (Bevens and others, 1988, v. 1, p. 17-49, 1912) and Wood (Bevens and others, 1988, v. 1, p. 117-118; 1917b, charts 1, 2).

Instrumental estimates of earthquake locations were made after the arrival of the Bosch-Omori seismometer in July 1912 (Jaggar, 1947, p. 22-23). By October, some earthquakes were assigned distances, presumably based on a reading of s-p time, 
Table 2. History of instrumentation and reporting of earthquakes at the Hawaiian Volcano Observatory

A. Network history

\begin{tabular}{|c|c|c|c|}
\hline Site & Date & Instrumentation & References \\
\hline & $1 / 12$ & Founding of HVO. & \\
\hline \multirow[t]{4}{*}{$\begin{array}{l}\text { Whitney vault } \\
19^{\circ} 25^{\prime} 53^{\prime \prime} \mathrm{N} . \text {., } \\
155^{\circ} 15^{\prime} 40^{\prime \prime} \mathrm{W} .\end{array}$} & $\begin{array}{l}7 / 1 / 12 \\
1913\end{array}$ & $\begin{array}{l}\text { Station established. } \\
\text { Omori: } 100-\mathrm{kg} \text { long-period; mechanical }\end{array}$ & Jaggar (1947, p. 22-23). \\
\hline & 1913 & $\begin{array}{l}\text { Bosch-Omori: two-component having } \\
\text { pendulum with mechanical recording; } \\
T_{0}=15 \mathrm{~s}, V=115 ; \text { damping ratios, } 7.8 / 1 \mathrm{~N}-\mathrm{S} \\
\text { and } 4.9 / 1 \mathrm{E}-\mathrm{W} ; \varepsilon=0.5 \text { critical; recording } \\
\text { speed, ?; in use } 1913-61 ; \text { by } 1950 \text {, period } \\
\text { changed to } 7.7 \mathrm{~s} \text {. }\end{array}$ & Wood (1915b). \\
\hline & $10 / 28$ & $\begin{array}{l}\text { Jaggar vertical: short-period, } T_{0}=0.4 \mathrm{~s}, V=250 \text {, } \\
\text { vertical with mechanical recording; in use } \\
1929-41 \text {. } \\
\text { Station discontinued. }\end{array}$ & $\begin{array}{l}\text { Finch and Macdonald (1953). } \\
\text { Fiske and others (1987); Volcano } \\
\text { Letter, no. 464, p. 1-4. }\end{array}$ \\
\hline & 1961 & & \\
\hline \multirow[t]{6}{*}{$\begin{array}{l}\text { Hilo } \\
19^{\circ} 43^{\prime} 11^{\prime \prime} \mathrm{N} . \\
155^{\circ} 05^{\prime} 20^{\prime \prime} \mathrm{W}\end{array}$} & 1919 & $\begin{array}{l}\text { Station established. } \\
\text { Romberg: one-component short-period } \\
\text { vertical; } V=25 \text {; operated at St. Mary's } \\
\text { school; in use } 1919-21 \text {. }\end{array}$ & $\begin{array}{l}\text { Bevens and others (1988, v. } 2 \text {, p. } 1065 \text {, } \\
\text { v. } 3 \text {, p. 1033). }\end{array}$ \\
\hline & $9 / 21$ & $\begin{array}{l}\text { Romberg: one-component small-mass long- } \\
\text { period; } M=30 \mathrm{~kg}, T_{0}=7.0 \mathrm{~s}, V=70, \varepsilon=2.6 / 1 ; \\
\text { paper speed, } 23.5 \mathrm{~mm} / \mathrm{min} ; \text { operated at } \\
\text { Brothers' school. }\end{array}$ & \\
\hline & $9 / 27$ & $\begin{array}{l}\text { Hawaiian type: two-component long-period; } \\
M=70 \mathrm{~kg}, T_{0}=6 \mathrm{~s}, V=120, \varepsilon \sim 2.6 / 1 ; \text { paper } \\
\text { speed, } 30 \mathrm{~mm} / \mathrm{min}\end{array}$ & \\
\hline & $10 / 50$ & $\begin{array}{l}\text { Loucks-Omori: two-component long-period; } \\
M=100 \mathrm{~kg}, T_{0}=3 \mathrm{~s}, V=175 \text { (Hilo only; all } \\
\text { others had } V=200 \text { ), } \varepsilon=\text { critical; paper speed, } \\
30 \mathrm{~mm} / \mathrm{min} ; \text { operated at St. Joseph's school; } \\
\text { removed, } 10 / 58 \text {. }\end{array}$ & \\
\hline & $7 / 58$ & $\begin{array}{l}\text { Wood-Anderson: two-component; } V=2,080 \\
T_{0}=0.8 \mathrm{~s}, \varepsilon=0.7 \text { critical; removed, } 10 / 92 . \\
\text { HVO- } 1 \text { : vertical, electromagnetic; } T_{0}=0.5 \mathrm{~s} ;\end{array}$ & Klein and Koyanagi (1980). \\
\hline & $10 / 58$ & $\begin{array}{l}\text { galvanometer period, } 0.5 \mathrm{~s} \text {, overdamped; } \\
V=20,000 \text { at period of } 0.25 \mathrm{~s}\end{array}$ & Klein and Koyanagi (1980). \\
\hline \multirow[t]{2}{*}{$\begin{array}{l}\text { Kona } \\
19^{\circ} 30^{\prime} 47^{\prime \prime} \mathrm{N} . \text {., } \\
155^{\circ} 55^{\prime} 07^{\prime \prime} \mathrm{W}\end{array}$} & $3 / 4 / 22$ & $\begin{array}{l}\text { Station established. } \\
\text { Romberg: one-component long-period; see } \\
\text { Hilo; replaced } 6 / 28 \text {. }\end{array}$ & $\begin{array}{l}\text { Fiske and others (1987); Volcano } \\
\text { Letter, no. } 183 .\end{array}$ \\
\hline & $6 / 28$ & $\begin{array}{l}\text { Hawaiian type: long-period; } T_{0}=7.3 \mathrm{~s}, V=115 \\
\text { operated intermittently until } 12 / 60 \text {. }\end{array}$ & Finch and Macdonald (1953). \\
\hline \multirow{2}{*}{$\begin{array}{l}\text { Hilea } \\
19^{\circ} 08^{\prime} 19^{\prime \prime} \mathrm{N} . \\
155^{\circ} 32^{\prime} 12^{\prime \prime} \mathrm{W}\end{array}$} & & $\begin{array}{l}\text { Station established. } \\
\text { Romberg: one-component; see Hilo. }\end{array}$ & \multirow{2}{*}{$\begin{array}{l}\text { Bevens and others (1988, v. } 3 \text {, p. } 588) \text {. } \\
\text { Bevens and others (1988, v. 3, p. } 970 \text {, } \\
\text { 989). }\end{array}$} \\
\hline & $5 / 27$ & Station discontinued. & \\
\hline $\begin{array}{l}\text { Uwekahuna Museum } \\
19^{\circ} 25^{\prime} 26^{\prime \prime} \mathrm{N} ., \\
155^{\circ} 17^{\prime} 36^{\prime \prime} \mathrm{W} .\end{array}$ & $12 / 27$ & $\underset{V=15}{\text { Imamura }}$ strong-motion seismometer; $T_{0}=3.0 \mathrm{~s}$ & $\begin{array}{l}\text { Fiske and others (1987); Volcano } \\
\text { Letter, no. 197; Volcano Letter, no. } \\
\text { 268, photograph. }\end{array}$ \\
\hline $\begin{array}{l}\text { Halemaumau } \\
19^{\circ} 24^{\prime} 26^{\prime \prime} \mathrm{N} . \\
155^{\circ} 16^{\prime} 59^{\prime \prime} \mathrm{W} .\end{array}$ & $9 / 28$ & Romberg: one-component; see Hilo, 9/21. & $\begin{array}{l}\text { Fiske and others (1987); Volcano } \\
\text { Letter, no. } 197\end{array}$ \\
\hline $\begin{array}{l}\text { Waikii } \\
19^{\circ} 51^{\prime} 35^{\prime \prime} \mathrm{N} . \\
155^{\circ} 39^{\prime} 36^{\prime \prime} \mathrm{W}\end{array}$ & $1 / 32 ?$ & Station established; in use until $9 / 34(?)$ & $\begin{array}{l}\text { Macdonald and Eaton (1957, table 1, } \\
\text { p. 22). }\end{array}$ \\
\hline \multirow{4}{*}{$\begin{array}{l}\text { Mauna Loa truck trail } \\
19^{\circ} 29^{\prime} 32^{\prime \prime} \mathrm{N} ., \\
155^{\circ} 23^{\prime} 29^{\prime \prime} \mathrm{W}\end{array}$} & $10 / 38$ & \multirow{4}{*}{$\begin{array}{l}\text { Seismic station established. } \\
\text { Hawaiian-type: see Hilo, } 9 / 27 \text {; phantom } \\
\text { telephone circuit tested to tie time to } \\
\text { Whitney vault. } \\
\text { Loucks-Omori: see Hilo, } 10 / 50 ; \text { replaced, } 4 / 57 \text {. } \\
\text { HVO-2: ; vertical; electromagnetic; } T_{0}=0.8 \mathrm{~s} \text {, } \\
\text { response similar to HVO-1; hardwired for } \\
\text { recording at HVO. }\end{array}$} & \multirow{3}{*}{$\begin{array}{l}\text { Fiske and others (1987); Volcano } \\
\text { Letter, no. } 464, \text { p. } 1 .\end{array}$} \\
\hline & 1938-39 & & \\
\hline & $6 / 53$ & & \\
\hline & $4 / 57$ & & Eaton and Krivoy (1963a). \\
\hline \multirow{4}{*}{$\begin{array}{l}\text { Haleakala } \\
20^{\circ} 46^{\prime} 00^{\prime \prime} \mathrm{N} . \\
156^{\circ} 15^{\prime} 00^{\prime \prime} \mathrm{W}\end{array}$} & 1940 & \multirow{4}{*}{$\begin{array}{l}\text { Station established. } \\
\text { Hawaiian-type: see Hilo, } 1927 \text {. } \\
\text { Loucks-Omori: see Hilo, 10/50; replaced, 5/57. } \\
\text { HVO-1: see Hilo, } 10 / 58 \text {. } \\
\text { Wood-Anderson: see Hilo, 10/58. }\end{array}$} & \multirow{4}{*}{$\begin{array}{l}\text { Eaton and Krivoy (1963a); Finch and } \\
\text { Macdonald (1953). }\end{array}$} \\
\hline & $8 / 53$ & & \\
\hline & $5 / 57$ & & \\
\hline & $5 / 57$ & & \\
\hline
\end{tabular}


Table 2. History of instrumentation and reporting of earthquakes at the Hawaiian Volcano Observatory-Continued

\begin{tabular}{|c|c|c|c|}
\hline Site & Date & Instrumentation & References \\
\hline $\begin{array}{l}\text { HNP hq basement } \\
\text { (see Whitney) }\end{array}$ & 1941 & $\begin{array}{l}\text { Station established. } \\
\text { Jaggar: vertical: see Whitney, } 10 / 28 \text {; in use } \\
\text { until } 1948 \text {. }\end{array}$ & \\
\hline \multirow[t]{4}{*}{$\begin{array}{l}\text { Uwekahuna vault } \\
19^{\circ} 25^{\prime} 26^{\prime \prime} \mathrm{N} . \\
155^{\circ} 17^{\prime} 36^{\prime \prime} \mathrm{W} .\end{array}$} & $1 / 48$ & \multirow{4}{*}{$\begin{array}{l}\text { Station established. } \\
\text { Jaggar: vertical; see Whitney, } 10 / 28 \text {; in use, } \\
\text { 1948-57 } \\
\text { Sprengnether: vertical and E-W; galva- } \\
\text { nometer, } 1.5 \mathrm{~s} ; T_{0}=0.5 \mathrm{~s}, V=1,500 \text { at } 0.5 \mathrm{~s} \text {, } \\
\varepsilon=2 \text { times critical; discontinued, } 10 / 92 . \\
\text { Press-Ewing: three-component electro- } \\
\text { magnetic; } T_{0}=15 \mathrm{~s} \text {; galvanometer, } 90 \mathrm{~s} \text {. } \\
\text { HVO-1: see Hilo, } 10 / 58\end{array}$} & Finch and Macdonald (1951, p. 106). \\
\hline & $11 / 53$ & & \multirow{3}{*}{ Eaton and Krivoy (1963a). } \\
\hline & $4 / 57$ & & \\
\hline & $4 / 57$ & & \\
\hline $\begin{array}{l}\text { Pahoa } \\
19^{\circ} 29^{\prime} 39^{\prime \prime} \text { N., }\end{array}$ & $4 / 1 / 54$ & & $\begin{array}{l}\text { Fiske and others }(1987) ; \text { Volcano } \\
\text { Letter, no. } 524, \text { p. } 9 .\end{array}$ \\
\hline $154^{\circ} 56^{\prime} 47^{\prime \prime} \mathrm{W}$ & $1 / 58$ & $\begin{array}{l}\text { Loucks-Omori: see Hilo, } 10 / 50 \text {. } \\
\text { HVO-1: see Hilo, 10/58; discontinued, } 7 / 61 \text {. }\end{array}$ & Eaton and Krivoy (1963a). \\
\hline \multirow{2}{*}{$\begin{array}{l}\text { Kamuela (Waimea) } \\
20^{\circ} 01^{\prime} 20^{\prime \prime} \mathrm{N} ., \\
155^{\circ} 40^{\prime} 18^{\prime \prime} \mathrm{W} .\end{array}$} & $6 / 9 / 54$ & & \multirow{2}{*}{$\begin{array}{l}\text { Fiske and others (1987); Volcano } \\
\text { Letter, no. 524, p. } 10 . \\
\text { Eaton and Krivoy (1963a). }\end{array}$} \\
\hline & $1959(?)$ & $\begin{array}{l}\text { Loucks-Omori: see Hilo, 10/50; locally } \\
\text { recorded; discontinued, } 1 / 62 \text {. }\end{array}$ & \\
\hline $\begin{array}{c}\text { Naalehu } \\
19^{\circ} 03^{\prime} 48^{\prime \prime} \mathrm{N}\end{array}$ & $9 / 1 / 54$ & $\begin{array}{l}\text { Station established. } \\
\quad \text { Loucks-Omori: see Hilo, } 10 / 50\end{array}$ & \multirow[t]{2}{*}{ Eaton and Krivoy (1963a). } \\
\hline $155^{\circ} 35^{\prime} 10^{\prime \prime} \mathrm{W}$ & $1959(?)$ & $\begin{array}{l}\text { HVO-2: see Mauna Loa, 4/57; locally } \\
\text { recorded; discontinued, } 12 / 60 \text {. }\end{array}$ & \\
\hline \multirow{3}{*}{$\begin{array}{c}\text { Outlet } \\
19^{\circ} 23^{\prime} 24^{\prime \prime} \mathrm{N} . \\
155^{\circ} 16^{\prime} 56^{\prime \prime} \mathrm{W}\end{array}$} & 1954 & \multirow{3}{*}{$\begin{array}{l}\text { Vault built. } \\
\text { HVO-2 (developmental): } T_{0}=1.0 \mathrm{~s}, V=10,000 \text {. } \\
\text { HVO-2: see Mauna Loa, } 4 / 57 .\end{array}$} & \\
\hline & $12 / 55$ & & Finch and Macdonald (1953). \\
\hline & $6 / 57$ & & Eaton and Krivoy (1963a). \\
\hline Barbers Point, Oahu & $6 / 57$ & $\begin{array}{l}\text { HVO-1: see Hilo, 10/50; paper records sent } \\
\text { back to HVO. }\end{array}$ & \\
\hline $\begin{array}{l}\text { Desert } \\
19^{\circ} 20^{\prime} 12^{\prime \prime} \mathrm{N} . \\
155^{\circ} 23^{\prime} 20^{\prime \prime} \mathrm{W}\end{array}$ & $9 / 57$ & $\begin{array}{l}\text { Station established. } \\
\text { HVO-2: see Mauna Loa, 4/57. }\end{array}$ & Eaton and Krivoy (1963a). \\
\hline $\begin{array}{c}\text { North Pit Halemaumau } \\
19^{\circ} 24^{\prime} 54^{\prime \prime} \mathrm{N} ., \\
155^{\circ} 17^{\prime} 00^{\prime \prime} \mathrm{W} .\end{array}$ & $7 / 58$ & $\begin{array}{l}\text { Station established. } \\
\text { HVO-2: see Mauna Loa, 4/57. }\end{array}$ & Eaton and Krivoy (1963a). \\
\hline
\end{tabular}

B. Staffing and changes in procedure

\begin{tabular}{|c|c|c|}
\hline Date & Seismologist/procedure & References \\
\hline $1 / 12$ & Founding of $\mathrm{HVO}$ & $\begin{array}{l}\text { Jaggar (1947, p. 5-88, 205-259); Bevens and others } \\
\text { (1988). }\end{array}$ \\
\hline $7 / 12-6 / 17$ & Harry Wood- & Takahashi and Wright (1987). \\
\hline $6 / 18-9 / 19$ & Arnold Romberg - & Bevens and others (1988, v. 2 , p. 787$)$. \\
\hline $1919-26$ & Ruy Finch & Takahashi and Wright (1987). \\
\hline $7 / 26-10 / 28$ & Ronald M. Wilson & Fiske and others (1987); Volcano Letter, no. 235. \\
\hline $11 / 26$ & Radio time corrections applied to Kona station- & Fiske and others (1987); Volcano Letter, no. 98. \\
\hline $9 / 31-6 / 35$ & Austin Jones & $\begin{array}{l}\text { Fiske and others (1987); Volcano Letter, no. 351, p. } \\
\text { 2; Volcano Letter, no. } 371 .\end{array}$ \\
\hline $2 / 32$ & Jones formalizes earthquake-size classification & $\begin{array}{l}\text { Fiske and others (1987); Volcano Letter, no. 371, p. } \\
\quad 2 .\end{array}$ \\
\hline $3 / 35-12 / 41$ & $\begin{array}{l}\text { Seismographs at Uwekahuna and Halemaumau used to } \\
\text { refine locations local to Kilauea. }\end{array}$ & Fiske and others (1987); Volcano Letter, no. 421. \\
\hline $7 / 35-3 / 41$ & Hugh Waesche & $\begin{array}{l}\text { Fiske and others (1987); Volcano Letter, no. 435, p. } \\
2 .\end{array}$ \\
\hline $12 / 36-12 / 38$ & $\begin{array}{l}\text { Recording speed and summit network timing im-proved at } \\
\text { Whitney vault. }\end{array}$ & $\begin{array}{l}\text { Fiske and others (1987); Volcano Letter, no. 464, p. } \\
\text { 1-4. }\end{array}$ \\
\hline 1952 & $\begin{array}{l}\text { Synchronized time signal at Whitney, Uwekahuna, and } \\
\text { Halemaumau stations. }\end{array}$ & Klein and Koyanagi (1980, p. 4). \\
\hline $9 / 53-12 / 62$ & Jerry Eaton & Takahashi and Wright (1987). \\
\hline 1957 & First routine computation of local earthquake mag-nitude. & Eaton and Fraser (1957a). \\
\hline 1958 & $\begin{array}{l}\text { Common recording of four high-gain summit-area stations } \\
\text { at HVO July; Jones magnitude classifi-cation } \\
\text { abandoned. }\end{array}$ & Eaton and Krivoy (1958a). \\
\hline $10 / 1 / 59$ & $\begin{array}{l}\text { Systematic notebooks of accurate } P \text { and } S \text { times form the } \\
\text { basis for the existing computer catalog. }\end{array}$ & --- \\
\hline
\end{tabular}


Table 2. History of instrumentation and reporting of earthquakes at the Hawaiian Volcano Observatory-Continued

C. Publication history

\begin{tabular}{|c|c|c|}
\hline Date & Publication series & References \\
\hline $1 / 12$ & $\begin{array}{l}\text { Founding of HVO; publication of weekly and monthly } \\
\text { summaries. }\end{array}$ & $\begin{array}{l}\text { Jaggar (1947, p. 5-88, 205-259); Bevens and others } \\
(1988, \text { v. 1). }\end{array}$ \\
\hline $1 / 1 / 25$ & The Volcano Letter begins publication- & Fiske and others (1987). \\
\hline $7 / 29$ & Weekly and monthly summaries discontinued- & Bevens and others $(1988$, v. 3$)$ \\
\hline $1948-55$ & $\begin{array}{l}\text { U.S. Geological Survey Bulletins covering volcanic and } \\
\text { seismic activity for the year. }\end{array}$ & $\begin{array}{l}\text { Finch and Macdonald (1951); Macdonald and } \\
\text { Wentworth (1954); Macdonald (1955); Macdonald } \\
\text { and Eaton }(1955,1957,1964) .\end{array}$ \\
\hline $12 / 31 / 55$ & The Volcano Letter ceases publication- & Fiske and others (1987); Volcano Letter, no. \\
\hline $1 / 1 / 56$ & HVO quarterly summaries begin & Macdonald and Eaton, 1956 \\
\hline
\end{tabular}

applied to traveltime tables developed in Germany (Jaggar, 1947, p. 45). The direction of motion on the two components sometimes permitted guesses about the earthquake location deduced from one station and felt reports.

Intensities based on amplitudes were expressed as a fraction of the amplitude at which an earthquake would become perceptible to the senses (minimum perceptible unit or "mpu"). In December 1912, Wood began reporting intensities in terms of the Cancani scale (Jaggar, 1947, p. 59), a logarithmic scale with 12 levels based on the acceleration of earthquake motion as viewed on the seismic record (table 3). Level IV, with accelerations of 10 to $25 \mathrm{~mm} / \mathrm{s} / \mathrm{s}$, corresponds to 1.0 to $2.5 \mathrm{mpu}$. Cancani ratings of $\mathrm{V}$ and above were thus likely to be felt. Wood continued reporting mpu and Cancani readings through the end of 1914. These intensities reflect the strength of ground shaking at the recording site and must be combined with distance to infer a magnitude.

Figure 2, which summarizes our understanding of the various "intensity" scales used at HVO, is a logarithmic diagram of both ground motion amplitude and acceleration combined. The various scales will be discussed where appropriate in the text. The first scales used were based on amplitude of the BoschOmori seismometer. The anchor of the early scales is the felt threshold, defined as $1.0 \mathrm{mpu}$ and the intensity III-IV Cancani boundary. This corresponds to $12.5 \mathrm{~mm}$ peak to peak of amplitude on the Bosch-Omori seismogram at a period of $0.5 \mathrm{~s}$. The period of oscillation does not enter directly into this diagram, and the diagram is a mixture of acceleration and displacement measures. Correspondence of the different scales is thus approximate.

Beginning in 1915, Wood established a bimonthly publication devoted exclusively to earthquake data (Wood, 1915b). He called it the Systematic Report of the Whitney Laboratory of Seismology, and it was patterned after the earthquake bulletins of other seismological laboratories. Only four bimonthly issues were published, even though Wood stayed on the HVO staff through the summer of 1917. During this time earthquake reporting in HVO's weekly bulletins (Bevens and others, 1988) was greatly curtailed. Curious as to why the earthquake reporting had died off, we sought to discover whether Wood had left any unpublished records. Remarkably, we found the missing data from September 1915 through June 1917 in the H.O. Wood archives at the California Institute of Technology (Wood, 1917a), thereby almost doubling the time during which his quantitative reporting of $\mathrm{HVO}$ earthquake data was available.
Wood left HVO in July 1917. With his departure, reporting of earthquake data was much less satisfactory. Most events have a time, no distance, and a terminology to describe earthquake size (for example, small, feeble, slight) that is not entirely consistent with similar terminology formalized in the 1930's (see below). Earthquakes listed from the second half of 1917 through the end of 1919 generally have no distance estimated. Thus, we had to guess their locations from associated volcanic activity (for example, Mauna Loa eruption, draining of Halemaumau lava lake) or from felt reports. Beginning in 1920, distances are given for some events, presumably as a result of the installation of an additional station at Hilo in 1919. Sporadic reporting of distance and location remains the case after two more stations were installed, Kona in March 1922 and Hilea (Kau) sometime before July 1924. Distances were estimated from uncertain s-p intervals, and locations relied only on approximate station distances because of the absence of accurate relative timing. The weekly and monthly bulletins describe volcanic activity in great detail, particularly the activity of Halemaumau lava lake up to its demise in 1924, and the different Kilauea and Mauna Loa eruptions that occurred during its time of publication. The volcanic detail is an invaluable aid to locating earthquakes that are temporally associated with volcanic activity.

A second HVO publication began in 1925, the Volcano Letter, also published at weekly, monthly, or quarterly intervals, and has been reprinted in a single volume (Fiske and others, 1987). The two publications overlapped through the last Monthly Bulletin (Bevens and others, 1988) published for July 1929. The Volcano Letter had a different emphasis, geared more to broad volcanologic topics than to detailed monitoring data. During the period of overlap, the Volcano Letter sometimes gave additional felt information for earthquakes tabulated in the weekly and monthly bulletins, but otherwise it did not add to the monitoring data. After July 1929, the Volcano Letter did not immediately pick up the monitoring focus of the earlier publication. This difference showed up immediately for the big earthquake swarm at Hualalai in September and October 1929, where the summary of what actually occurred seismically has to be pieced together from many different tabulations. Over the next few years, earthquake data were embedded in the narrative associated with a subsection of each Volcano Letter, beginning with "Kilauea Report No. 677" covering the first week of 1925. These reports were short and commonly listed only the number 


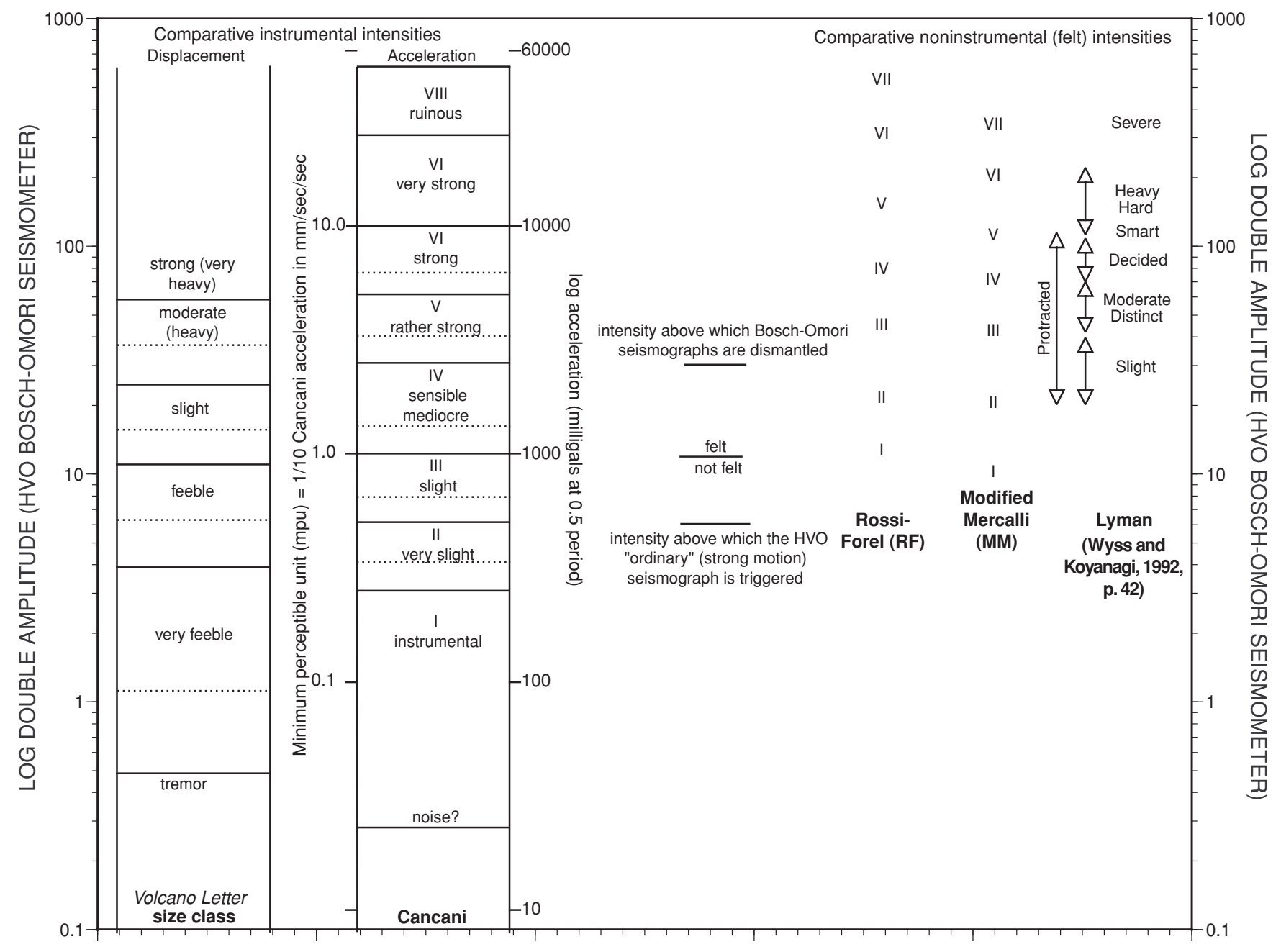

Figure 2. Comparison of intensity and amplitude scales used by the Hawaiian Volcano Observatory (HVO).

of events during the week, with times and distances given for a very small number of the total events.

In June 1932, the reporting of earthquakes became more systematic, with a separate section devoted to them and with more information on actual location (narrative description; rarely latitude and longitude), and greater consistency in the reporting of the size of events. The impetus to improved reporting was the arrival on the HVO staff of another trained seismologist, the first since Wood left in 1917. Ironically, this improvement in reporting coincided with drastic funding cuts that forced the Volcano Letter to change from a weekly to a monthly publication (Fiske and others, 1987; Volcano Letter, no. 385).

Austin E. Jones arrived in September 1931 (Fiske and others, 1987; Volcano Letter, no. 351, p. 2) and immediately busied himself with summarizing the seismicity for the year (Fiske and others, 1987; Volcano Letter, no. 371). He also formalized the reporting of earthquake classes, related directly to amplitude ranges of signals on the Bosch-Omori seismometer, as listed in table 4. He used the weighted numbers of earthquakes in each class to calculate weekly indices of seismicity. After July 1932, there is increased reporting of location in terms of latitude and longitude; beginning in 1934, latitude and longitude are routinely estimated. Jones' last report was in
June 1935 (Fiske and others, 1987; Volcano Letter, no. 424), but the earthquake reporting continued in much the same manner (fig. 1).

Jones was the first of HVO's seismologists to attempt to quantify the interpretation of seismic data. In addition to formalizing the reporting of seismicity, he attempted to track seismicity associated with eruptions of Kilauea and Mauna Loa (Jones, 1934, 1935a, 1935c) and was the first person to derive traveltime curves applicable to the Island of Hawaii (Jones, 1935b). Finally, Jones was the first to identify different types of earthquakes and tremor (Jones, 1938). Unfortunately, Jones' best efforts were severely compromised by the absence of an adequate local network and the lack of common timing for the seismometers at different locations. Short-lived efforts to tie several stations together by means of telephone lines were attempted in 1931 by Jones and in 1938 by Waesche, but neither effort was sustained for long.

Earthquake reporting in the Volcano Letter changes toward the end of 1941 for unspecified reasons. The reporting of latitude and longitude is discontinued beginning in the third quarter of 1941 (Fiske and others, 1987; Volcano Letter, no. 473) although narrative descriptions of location continued. At the end of the fourth quarter of 1941 (Fiske and others, 1987; Volcano Letter, no. 474), reporting of earthquake data dropped off 
Table 3. Cancani scale of seismic intensity

[Maximum and minimum accelerations in millimeters per second squared. Minimum perceptible unit (mpu) is directly related to Cancani scale, with $1.0 \mathrm{mpu}$, occurring at the Cancani intensity III-IV boundary, defined as the intensity above which an earthquake is perceptible (felt)]

\begin{tabular}{|c|c|c|c|c|}
\hline II & Very slight & 2.5 & 5.0 & $.25-0.5$ \\
\hline III & Slight & 5.0 & 10.0 & $.5-1.0$ \\
\hline IV & Sensible, mediocre & 10.0 & 25.0 & $1.0-2.5$ \\
\hline VII & Very strong & 100.0 & 250.0 & $10.0-25.0$ \\
\hline VIII & Ruinous & 250.0 & 500.0 & $25.0-50.0$ \\
\hline IX & Disastrous & 500.0 & 1000.0 & $50.0-100.0$ \\
\hline $\mathrm{X}$ & Very disastrous & $1,000.0$ & $2,500.0$ & $100.0-250.0$ \\
\hline $\mathrm{XI}$ & Catastrophic & $2,500.0$ & $5,000.0$ & $250.0-500.0$ \\
\hline XII & Great catastrophe & $5,000.0$ & $10,000.0$ & $500.0-1,000.0$ \\
\hline
\end{tabular}

Table 4. Early (1932-57) classification of earthquake magnitudes at the Hawaiian Volcano Observatory

[Weight was used to calculate a seismicity index for the week. From Volcano Letter, no. 371]

\begin{tabular}{|c|c|c|c|}
\hline $\begin{array}{l}\text { Amplitude } \\
\text { class }\end{array}$ & Weight & $\begin{array}{l}\text { Bosch-Omori } \\
\text { amplitude (mm) }\end{array}$ & Qualitative description \\
\hline Tremor $(\mathrm{t})$ & $1 / 4$ & $<0.5$ & $\begin{array}{l}\text { Can barely be seen on the seismograph records; when continuous, the } \\
\text { unit is the minute of duration. }\end{array}$ \\
\hline Very feeble (vf) & $1 / 2$ & $.5-4$ & $\begin{array}{l}\text { Not felt or only very rarely felt by very few persons in especially favorable } \\
\text { positions, generally lying down. }\end{array}$ \\
\hline Feeble (f) & 1 & $4-11$ & $\begin{array}{l}\text { Not felt or felt by few persons in favorable positions. Upper range of feeble } \\
\text { is intensity I on the Rossi-Forel and modified Mercalli scales. }\end{array}$ \\
\hline Slight (s) & 2 & $11-25$ & $\begin{array}{l}\text { Felt by many persons at rest. Hanging objects may swing. Inten-sity II on } \\
\text { the Rossi-Forel and modified Mercalli scales. }\end{array}$ \\
\hline Moderate (m) & 3 & $25-60$ & $\begin{array}{l}\text { Felt generally, by persons in or out of doors. Hanging objects swing. } \\
\text { Intensity III on the Rossi-Forel and modified Mercalli scales. }\end{array}$ \\
\hline Strong (st) & 4 & $>60$ & $\begin{array}{l}\text { Felt by everyone or nearly everyone. Objects swing. Dishes, doors, and } \\
\text { windows rattle. Minor damage may result. Intensity IV or larger on the } \\
\text { Rossi-Forel and modified Mercalli scales. }\end{array}$ \\
\hline
\end{tabular}

further. Although the number of earthquakes reported seems comparable to earlier periods, many events have only the time given with no indication of location whatsoever. This situation continued through 1953.

Following the arrival of Jerry Eaton, HVO's third trained seismologist, on September 15, 1953, earthquake reporting again became more quantitative. The Volcano Letter ceased publication at the end of 1955, its last issue covering the second half of the year (Fiske and others, 1987; Volcano Letter, nos. 529-530). Meanwhile, a new series had begun, entitled "Hawaii Volcanoes During [Year]," beginning with 1948-49, also ending in 1955 (Finch and Macdonald, 1951; Finch and Macdonald, 1953; Macdonald and Wentworth, 1954; Macdonald, 1955; Macdonald and Eaton, 1955, 1957, 1964); these issues were published as U.S. Geological Survey Bulletins. They largely duplicate information published in the Volcano Letter, though with some differences noted below in the subsection entitled "Errors and Uncertainties."

Eaton greatly advanced the conduct of seismology at HVO, including (1) more sophisticated discrimination of earthquake "families" based on their seismic signatures and (2) derivation of greatly improved traveltime curves related to a more realistic velocity structure for the Island of Hawaii. These topics are discussed and illustrated in Eaton's report on the 1955 eruption of Kilauea (Macdonald and Eaton, 1964, p. 113-140 and associated figures).

Beginning in 1956, HVO began publishing quarterly reports, retaining the qualitative classification of earthquake size initiated by Austin Jones. The first "local" magnitudes were assigned, beginning in $1957^{1}$; and by 1958 , magnitudes were assigned to all events, and the terms used by Jones to classify earthquake size were no longer reported. Reporting of local magnitudes $\left(M_{L}\right)$ was based on the installation of Wood-Anderson torsion seismometers in Hilo. The instrumentation and magnitude calculation emulated that begun by Richter at the California Institute of Technology in the 1930's (see Richter, 1958). These quarterly "summaries" have a higher size threshold (M 2.5) and report fewer events than previously.

Quarterly reports were continuous through the third quarter of 1959 (Eaton and Fraser, 1956a, b, 1957a-d, 1958a, b; Macdonald and Eaton, 1956a, b; Eaton and Krivoy, 1958a, b, $1963 \mathrm{a}-\mathrm{c})$ and from the fourth quarter of 1961 to the present.

${ }^{1} \mathrm{HVO}$ is listed as a source of magnitude estimates for six large events in 1954-56, reported in the revised history of seismicity in the United States (Stover and Coffmann, 1993). It is unclear how these estimates were obtained and reported because they do not appear in any HVO publication series covering this period. 
The paired Kilauea eruptions of 1959 and 1960 produced such a backlog of seismic records that formal publication did not take place for 2 years. Seismograms from the last three quarters of 1960 and the first three quarters of 1961 were subsequently read, and earthquake locations were directly entered into a computer data base along with the data from unpublished compilations for the fourth quarter of 1959 and the first quarter of 1960. Our catalog thus fills in the data from before the beginning of the present computer catalog in October 1959.

\section{The Lyman Diary, 1833-1917}

Sarah Lyman and her daughter Isabella Lyman, members of a large early missionary family living on the Island of Hawaii, kept a diary of earthquakes felt at their homes in Hilo, covering the period 1833-1917. The diary has recently been reprinted with a commentary (Wyss and others, 1992). This is an invaluable reference for the early seismic history, particularly in the days before any instrumentation was available to record earthquakes. Comparison with contemporary newspaper reports (see below) and instrumental data shows that the Lyman diary is not a complete record of events felt in Hilo. The most likely explanation for events reported as being felt in Hilo but missing from the Lyman compilation is that Sarah or Isabella Lyman were not at home. Unfortunately, their travels are not documented in the diary. There are some events recorded in the diary for which there is no corroborative newspaper or other documentation. We assume that these events were either local to Hilo (which is shown by modern records to have a low but persistent record of seismic activity) or were near the threshold magnitude of events that would be widely felt and therefore newsworthy.

\section{Newspaper Reports, 1856-1959}

Newspaper mention of earthquakes is critical to our data base for several reasons. Before instrumental records were available, the newspapers are the sole source of information, with the exception of the Lyman diary (see above), for any but the very largest earthquakes. Even after the installation of seismometers in 1903 and 1912, newspaper reports expand the information on where, and with what effect, earthquakes were felt. Felt information is essential for recreating intensity maps for the larger events (for example, Wyss and Koyanagi, 1992) and refining locations for events less widely felt. Figure 3 and table 5 list the newspapers we have consulted, since continuous reporting began in 1856 . Of those listed, we have not yet been able to access the Kona Echo, published in Japanese over much of its history and in English for a limited number of years.

Newspaper information is abstracted in the "Location/felt" column of our catalog. Newspaper accounts are distinguished from other felt reports by preceding the information with "Warshauer notes:" (see section below entitled "Acknowledgments"). Fuller description of events, including detailed damage reports, are included in the abstract field of the bibliographic file and in quotations in Wyss and Koyanagi (1992).
The newspapers continue to be of use after HVO began systematic recording and publication of information on earthquakes. We have found instances where newspapers reported earthquakes as felt that were not reported by HVO. In a few instances, newspaper dates or times differ markedly from those reported by $\mathrm{HVO}$ or $\mathrm{HMO}$, a result of recording errors that can be corrected from the newspaper accounts. We make judgments to choose as correct the information that is most corroborated.

One of the most complete and interesting newspaper sources was the Pacific Commercial Advertiser's monthly meteorologic reports (1900-4), succeeded in 1905 by weekly reports published under various titles. Correspondents were employed at several places on the more populous Hawaiian Islands to report rainfall and temperature data, as well as making note of unusual weather conditions such as storms that did significant damage. Folded into these accounts were reports of felt earthquakes. Some of these reports match events reported in the Lyman diary or at HMO; for others, the meteorologic reports are the only record. These reports end in 1911, very close to the founding of HVO.

Newspaper accounts, like the HVO reporting, tend to be uneven, especially for events not felt over an entire island or over more than one island. The founding of HVO led newspapers in both Hilo and Honolulu to accept, over certain periods of time, reports directly from HVO, probably reducing their tendency to gather and publish felt reports independently of what was being recorded by HVO. However, in one peculiar circumstance, a newspaper actually gives more information than was published by HVO. In 1941, the Hilo Tribune-Herald published a weekly column entitled "Volcano Report." These columns, obtained directly from HVO, contain distances and felt information not reported in the Volcano Letter for these dates.

Times of earthquakes as reported in newspaper accounts are quite variable relative to the precise times reported by HVO and HMO, for two principal reasons. The first reason is that the newspapers are not charged with recording exact times, relying on their own experience or that of their correspondents. Often the accounts say an earthquake occurred "about" a certain time. The second reason is the use of "plantation time."2 According to this practice, peculiar to Hawaii, each plantation or ranch had the option of keeping its own time, separate and independent from adjacent plantations. Each of these times could differ, in turn, from the time recorded in the larger cities. Thus, it is hard to know what time is being used when someone calls a newspaper to report an earthquake. We have assumed that widely reported events with felt times that differ by as much as half an hour are most likely the same event. If an instrumental record is available we use that time; otherwise an arbitrary time within the range reported is used. After the attack on Pearl Harbor in December 1941, Hawaii went briefly on "war time," equivalent to our current daylight-saving time, exactly 1 hour later than Hawaii standard time (H.s.t.). Both HVO and HMO continued to report earthquakes in Hawaii standard time, explaining why some newspaper times during this period differ by one hour from the observatory times.

\footnotetext{
${ }^{2}$ The description of plantation time was provided by Doak Cox.
} 
Table 5. Beginning and ending dates of publication of Hawaiian newspapers

[Do., ditto]

\begin{tabular}{|c|c|c|c|}
\hline Place of publication & Dates of publication & Full name & $\begin{array}{l}\text { Abbreviation in } \\
\text { catalog }\end{array}$ \\
\hline Honolulu & $7 / 2 / 1856-3 / 30 / 1921$ & Pacific Commercial Advertiser & PCA \\
\hline Do. & $1 / 1 / 1865-11 / 29 / 1918$ & Hawaiian Gazette & $\mathrm{HG}$ \\
\hline Do. & $3 / 28 / 1893-6 / 29 / 1912$ & Hawaiian Star- & HS \\
\hline Do. & $5 / 16 / 1895-6 / 29 / 1912$ & Evening Bulletin & HEB \\
\hline Hilo & $11 / 23 / 1895-6 / 27 / 1917$ & Hilo Tribune - & HT \\
\hline Do. & $8 / 13 / 1896-2 / 22 / 1923$ & Hawaii Herald & $\mathrm{HH}$ \\
\hline Do. & $11 / 1 / 1916-9 / 25 / 1917$ & Hawaii Post- & HP \\
\hline Holualoa & $2 / 3 / 1897-1951$ & Kona Echo & KE \\
\hline Wailuku, Maui & $2 / 17 / 1900$-present & Maui News ______________ & $\mathrm{MN}$ \\
\hline Hilo & $7 / 1 / 1917-2 / 18 / 1923$ & Hilo Daily Tribune-_- & HDT \\
\hline Do. & $9 / 26 / 1917-12 / 1 / 1917$ & Hawaii Daily Post-_- & HDP \\
\hline Do. & $12 / 3 / 1917-2 / 17 / 1923$ & Daily Post Herald & DPH \\
\hline Do. & $2 / 19 / 1923-3 / 1 / 1964$ & Hilo Tribune-Herald & HTH \\
\hline Honolulu & $7 / 1 / 1912$-present & Honolulu Star-Bulletin- & HSB \\
\hline Do. & 3/31/1921-present & Honolulu Advertiser & HA \\
\hline
\end{tabular}

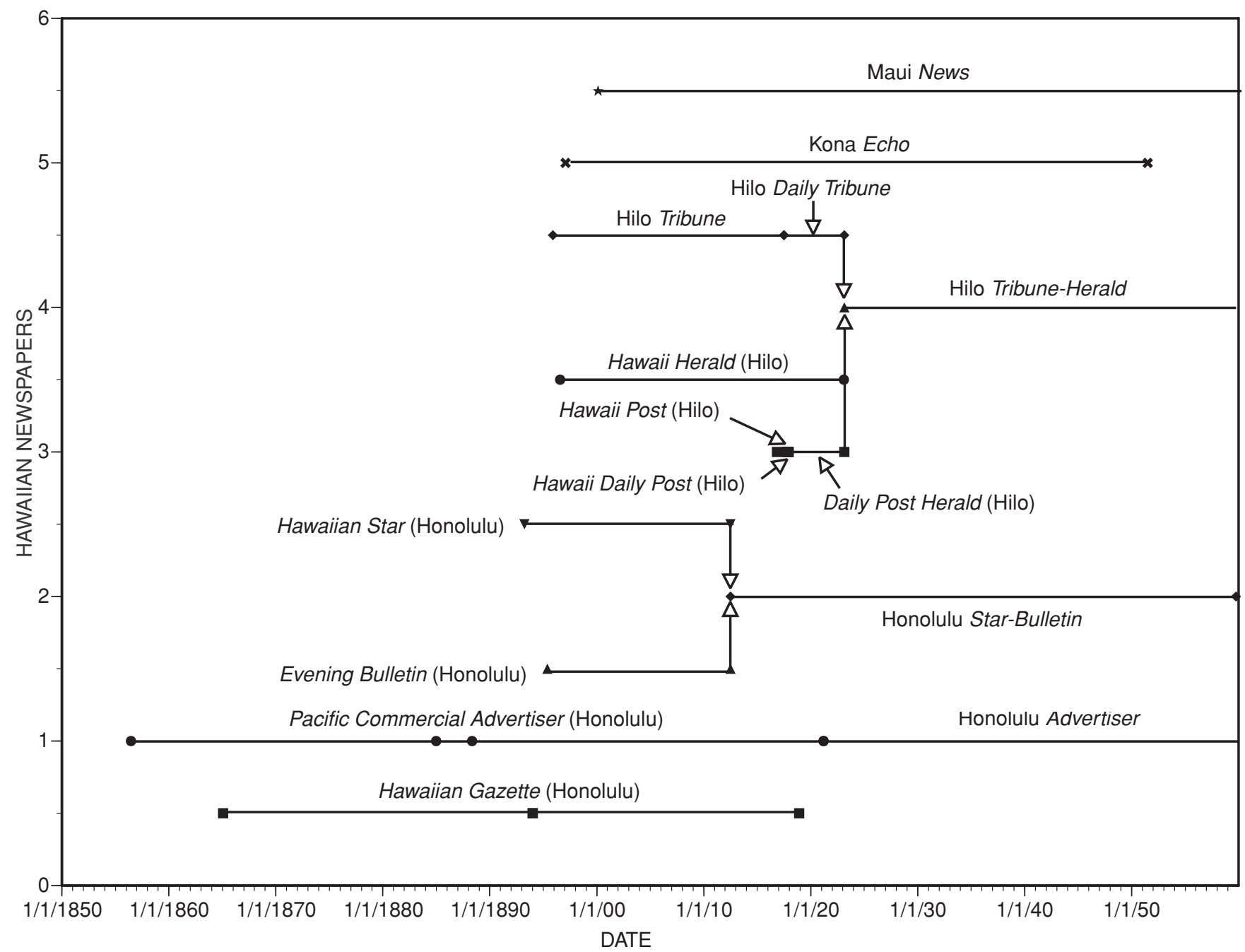

Figure 3. Publication history of Hawaiian newspapers and other sources of information for felt earthquakes in Hawaii. 


\section{HVO Felt-Report Postcards}

HVO used various means to try to increase its receipt of felt information. In 1913, after a large earthquake felt throughout the island chain, Thomas Jaggar issued a newspaper plea for the public to send HVO detailed information on how the earthquake of October 25, 1913, had been experienced (Pacific Commercial Advertiser, 1913; reprinted in Bevens and others, 1988 , v. 2, p. 64). The form provided had a list of questions that could apply to any earthquake which was felt. There is no published evidence that this plea was heeded.

Beginning in 1932, HVO distributed postcards to persons situated at various locations on the Island of Hawaii, with an abbreviated version of Jaggar's questionnaire including, in different versions, an intensity scale (table 6 ) and (or) a checklist of factors used to estimate intensity. Postcards filled in with information on felt earthquakes have been saved at HVO and were consulted by us. Whereas the Volcano Letter reports where an earthquake was felt, the postcards provide relative intensities for those locations. ${ }^{3}$ They provide a check on the HVO location and provide data with which isoseismal maps may be prepared for widely felt events. Our use of postcard information is cited in the "Comment" column of our catalog with the designation "HVO, unpub."

We mapped the HVO postcard intensities into modified Mercalli intensities for comparison with other intensity sources (table 6). The lower postcard intensities are defined solely in terms of the number of persons feeling the event rather than the severity of the event used by other scales, making the postcard intensities useful but imprecise.

\section{Other Earthquake Reports}

The earliest accounts of earthquakes are contained in magazines or newspapers that were circulated within more specific groups. Some of these early papers include those published locally, such as The Friend, the Sandwich Islands Gazette, The Polynesian, and at least one, the Missionary Herald, published in London and Boston for the missionary community. Surprisingly and unpredictably, these journals contain important narrative information on certain events, particularly in association with trips made to the Island of Hawaii. Later newspapers, such as the Hilo Tribune-Herald or the Pacific Commercial Advertiser, were directed at the entire population. Other sources are early diaries, not as complete as the Lyman

\footnotetext{
${ }^{3}$ We acknowledge Amy Greenwell of Captain Cook, Kona, for her unusually complete and accurate information, which contributes directly to our evaluation of seismic intensity. She reported every earthquake felt in Kona from 1951 to the late 1950 's, relying not only on herself but also on her many acquaintances in the local community. She faithfully records where the earthquake was felt and by how many, what type of structure the person(s) feeling it was in, and whether persons were asleep or awake. She also describes the type of earthquake motion, discriminating rapid "jolts" from much longer and gentler motions, both occurring over a range of strengths. Finally, for the larger events, she gives the relative strength of an earthquake as perceived at various locations along the mid-Kona coast. If all correspondents had been as assiduous in their reporting, valid macroseismic (contoured intensity) maps could have been produced for all widely felt events.
}

diary but nonetheless a source of information for larger felt earthquakes. Entries from the diary of the Greenwell family, long-time residents of the Kona section of the Island of Hawaii, were provided to us by Jean Greenwell, a descendant who works closely with the Kona Historical Society.

The Volcano House, founded in 1865 as a hotel on the edge of Kilauea Caldera, kept a register in which travelers recorded their observations on volcanic activity. The register has been transcribed (Bevens and transcriber, 1988) and is available for viewing in Hawaii Volcanoes National Park. It contains some references to earthquakes, although these references are scattered throughout the volumes and record only those earthquakes felt in the immediate vicinity.

Some earthquake accounts are scattered through books and articles about the volcanic activity of Kilauea and Mauna Loa (for example, Dana, 1888; Hitchcock, 1909), as well as published reports of specific eruptions or earthquakes. The Bulletin of the Seismological Society of America, published as a monthly journal beginning in 1911, included a section entitled "Seismological Notes" as part of each issue. All information on Hawaiian events appears to be drawn from other sources and so does not add any information. Unfortunately, inaccuracies in locations and times of events seemed to have crept into these summaries. Therefore, it is best to use the original instrumental reports from $\mathrm{HMO}$ and $\mathrm{HVO}$ when they are available.

We include as a separate file on the CD-ROM a bibliography of all published reports of earthquakes and earthquake swarms, drawn from the Hawaii bibliographic data base, recently made available (Wright and Takahashi, 1998).

\section{Construction of the Earthquake Catalog}

Our master earthquake catalogs have as many as 26 columns, formatted so as to print legibly on 8.5- by 11-in. paper in landscape mode. We have divided them into four files: (1) preApril 1903, the date of installation of the first seismometer on Oahu; (2) April 1903 to February 1921, when the one-component Milne seismometer was replaced by the two-component Milne-Shaw seismometer; (3) February 1921 through 1932; and (4) 1933 to September 30, 1959, the time period for which we have continuous film records of seismograms generated on Oahu. The column headings used in files 1 through 4 are listed in table 7. Table 13 (see app. 1) is the 1903-59, $M \geq 4$ portion of the entire catalog.

Published data from HMO, and from Wood's published and unpublished HVO Station Bulletin, use Greenwich mean time (G.m.t.). Until June 8, 1947, Hawaii standard time was 10 $1 / 2$ hours earlier than Greenwich mean time; after that date, it became 10 hours earlier (Fiske and others, 1987; Volcano Letter, no. 496, p. 3). Hawaii standard time has been the time used by HVO for all other published geologic and seismologic reports. We have corrected all times to Hawaiian standard time in our catalog.

Latitude and longitude are given for some events reported in the Volcano Letter. For these events, no location information is given in the "Comment" column of our catalog. Where latitude and longitude are not published but a precise narrative de- 
Table 6. Hawaiian Volcano Observatory intensity scale used on postcards after 1933

\begin{tabular}{cll}
\hline HVO intensity & Modified Mercalli equivalent & Felt designation \\
\hline I & I & Not felt. \\
II & II & Felt by very few people. \\
III & III, IV & Felt by several people. \\
IV & III, IV & Felt by many people. \\
V & IV, V & Felt generally. \\
VI & V & Felt by nearly everyone. \\
VIII & VI, VII & Flight from houses; some damage. \\
IX & VIII, IX & Ruinous; great terror, some people wounded, much damage. \\
X & X, XI & Disastrous; a few lives lost, general ruin. \\
& XII & Very disastrous; great loss of life, utter ruin. \\
& & \\
& & Greenwell diary descriptions \\
\hline--- & II & Windows rattle; slight, gentle., \\
-- & III, IV & Dogs bark; “a pretty good one”; a jar (III). \\
\hline
\end{tabular}

Table 7. Explanation of column headings used in our catalog

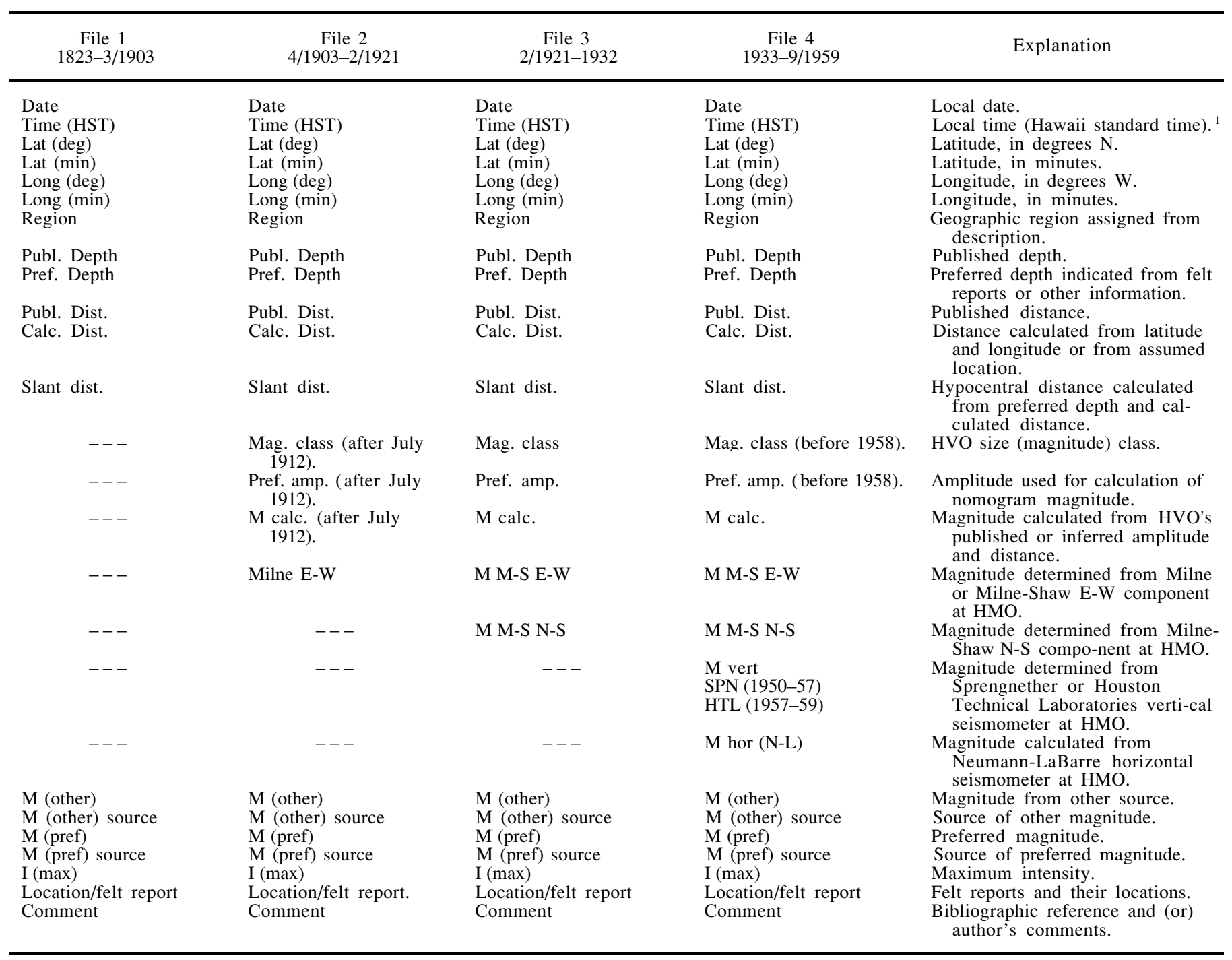

${ }^{1}$ After June 8, 1947, Hawaii standard time (H.s.t.) = Greenwich mean time (G.m.t.) minus 10 hours. Before that date, H.s.t. $=$ G.m.t. minus 10.5 hours $($ Fiske and others, 1987; Volcano Letter, no. 496, p. 3). 
scription of location is available, we have converted the description to latitude and longitude, using Hawaii base maps, and entered the coordinates. Thus, inclusion of narrative locations means that our derived coordinates were not explicitly given in the Volcano Letter. For each earthquake, we assign a geographic region based on latitude and longitude, or on the basis of distance from the Whitney seismometer, supplemented by felt reports. For events where only the general area of Hawaii rather than the specific region can be inferred, we use the broad regional names. Definition of earthquake regions is discussed below.

Depths and epicentral distances are included when published. We default to a preferred depth of $9 \mathrm{~km}$ where none is given. For some events, we assigned depth on the basis of felt reports. Where this depth differs from a published depth, we fill in both the "Preferred depth" and "Published depth" columns in our catalog. There is some ambiguity regarding distance in the earlier HVO reports. Where only distance and no real location is given, we assumed that these values were derived from s-p time and so are hypocentral (that is, slant) distances rather than epicentral distances, and we listed them as such. Distance is to the seismometer measuring the amplitude, generally the Whitney laboratory at HVO. If distance is to another station, this difference is noted in the "Comment" column of our catalog.

Magnitude class is that used in the published HVO reports and is irrelevant for the period before 1912 and after 1957. It appears that the classification using terms ranging from "tremor" to "strong," formalized as noted above in 1931, may apply back as far as 1928 . We use this classification to calculate magnitudes for the period $1928-57$ by the methods outlined below. For data utilizing the Cancani scale and the minimum perceptible unit (1912-17), we had to devise different methodologies to estimate magnitude, as outlined below. Between 1917 and 1928 and before 1903, we made approximate assignments of magnitude, calibrated to be consistent with felt information. In this period, the familiar terms-for example, "feeble"- do not appear to refer to the same amplitude range as later, and additional terms - for example, "small"are not used consistently enough to be able to define them in terms of specific amplitude ranges.

We calculated magnitudes from HMO or HVO data, using the methods outlined below. Agreement is generally better than the error estimates listed in table 11. Where discrepancies occur, we note these in the "Comment" column of our catalog. After 1930, earthquakes of $M>6$ commonly have an externally determined magnitude, for example, one determined at Berkeley or Pasadena. Wyss and Koyanagi (1992) calculated the magnitudes for many large events from their isoseismal maps; we put these values in the "Other magnitude" column of our catalog and cite their source. Preferred magnitudes represent our evaluation of the best source or averages derived from multiple sources, using the criteria outlined below.

We derived intensities from felt reports and (or) $\mathrm{HVO}$ or HMO information. Where a single intensity is given, it represents the maximum reported or observed. Most intensities are from HVO or Hilo, and the location and source are generally given. Magnitudes and intensities of the largest events $(M \geq 5.5$,
Table 8. “Lyman” scale of seismic intensity

[Approximate modified Mercalli intensity interpreted from Wyss and Koyanagi (1992 p. 42 , table 8)]

\begin{tabular}{lc}
\hline $\begin{array}{l}\text { Attribute used to } \\
\text { describe shaking }\end{array}$ & $\begin{array}{c}\text { Approximate modified } \\
\text { Mercalli intensity }\end{array}$ \\
\hline Severe & VII \\
Heavy & V-VI \\
Hard & V-VI \\
Smart & V, IV-V 1 \\
Decided- IV-V \\
Moderate- III-IV \\
Distinct- & III-IV \\
Slight- & II-III \\
Protracted ${ }^{2}$ & II-V \\
\hline
\end{tabular}

${ }^{1}$ Interpreted by us from newspaper reports of events recorded in the Lyman diary. ${ }^{2}$ Not used by us for intensity assignment because the range is too large.

$I \geq \mathrm{V}$ ) are cross-referenced to, and rarely modified from, Wyss and Koyanagi (1992).

All intensities ( $I$ values) are modified Mercalli (MM) unless otherwise noted. Early HVO accounts commonly used Rossi-Forel (RF), which is about the same as MM below an intensity of V. Some early intensities are derived from descriptive words used in the Lyman diary. We generally follow Wyss and Koyanagi (1992) in the use of the "Lyman" scale to convert their terms to intensities (table 8).

The "Comment" column of our catalog lists the primary references from which the earthquake information is derived; our comments are enclosed in brackets, including discrepancies in published magnitudes or intensities and their reconciliation. The "Location/felt report" column records duration and felt information gathered from the references cited. Both columns are used to give information regarding the beginning and end of eruptions, the relation of earthquake swarms to eruptions, important changes in the seismic network, and the like.

\section{Definition of Geographic Regions and the Assignment of Earthquakes to Them}

We have defined geographic regions for the Island of Hawaii within which earthquakes are clustered, as shown in figure 4. Mauna Loa and Kilauea, Hawaii's two recently active volcanoes, are subdivided into several regions, on the basis of concentrations of modern (post-1959) earthquakes associated with known fault zones or tectonically active areas. Older, less seismically active volcanoes are covered by a single region. We append the abbreviation "os" to indicate earthquakes whose epicenters lie in the offshore part of a region.

Over much of the time period covered, the assignment of an earthquake to a particular geographic region is based on recordings on a primitive network of one to three stations and so is subject to large error (see subsection below entitled "Errors and Uncertainties"). Our regional assignment is made directly from the latitude and longitude, or from felt reports where no other information is available. When only the distance from HVO was given, we generally assigned the event to the most active region at that distance. We preferentially chose regions 

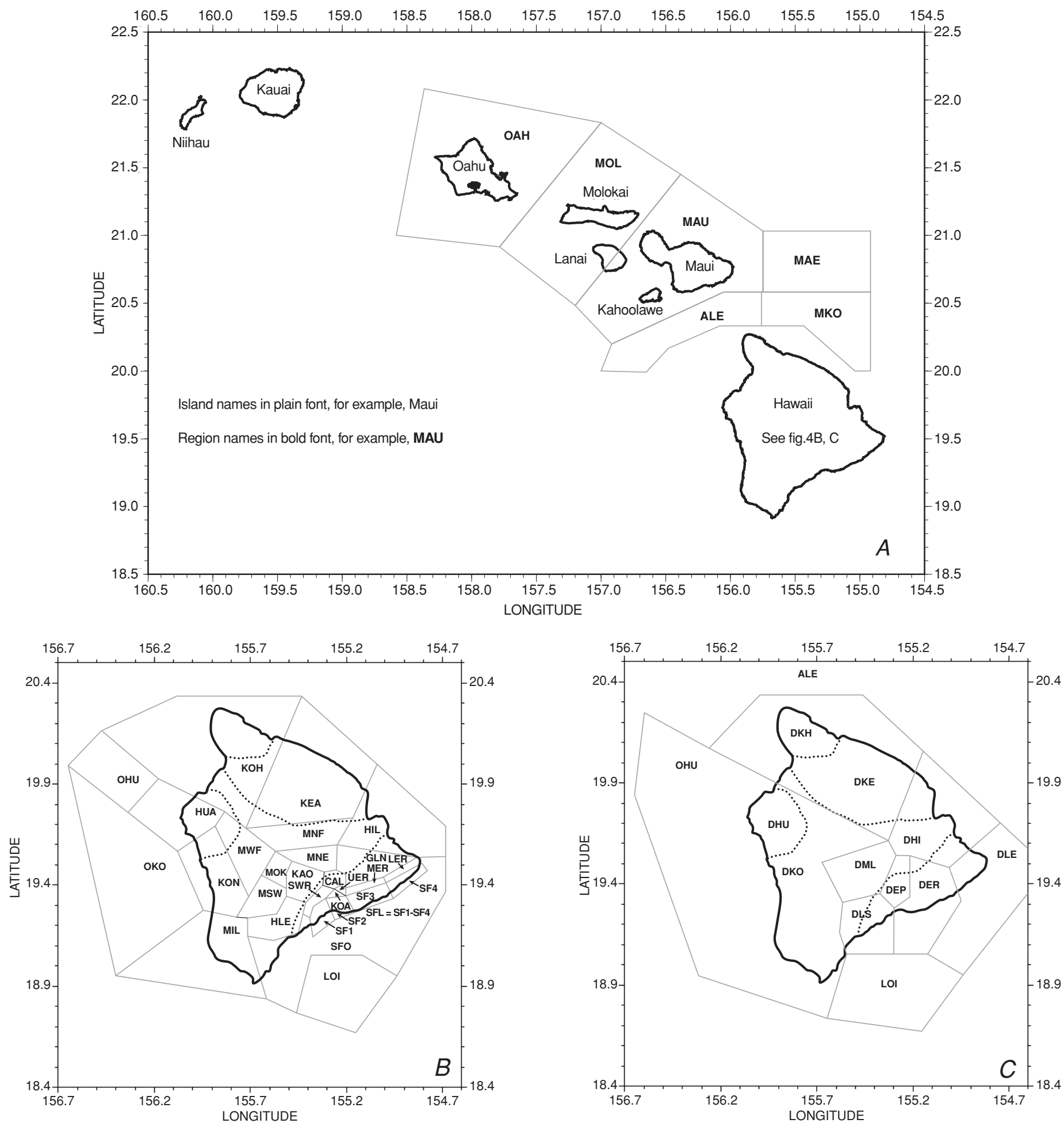

Figure 4. Geographic regions defined for earthquakes in Hawaii. $A$, State of Hawaii, showing regions other than Hawaii County. $B$, Hawaii County, showing shallow-earthquake $(<20-\mathrm{km}$ depth) regions broadly defined from density of earthquake occurrence. Dotted lines, boundaries of five volcanoes that make up island. $C$, Hawaii County, showing deep-earthquake (>20-km depth) regions broadly defined from density of earthquake occurrence. Dotted lines, boundaries of five volcanoes that make up island.

in or adjacent to areas of concurrent eruptions or main shocks. Rarely, we revised or reinterpreted the region to place the event in an active seismic area. We use general terms, such as "south Hawaii," when specific information is unavailable to choose a region. Even when latitude and longitude or detailed narrative descriptions were published, errors could still be several to a few tens of kilometers.

Commonly, the errors are such that many earthquakes could be in a region adjacent to the one that we assigned. Earthquakes large enough to be widely recorded and widely 
Table 9. Synonymy relating the geographic regions defined in figure 4 to the abbreviations in our catalog

A. Shallow-earthquake regions

\begin{tabular}{|c|c|c|c|c|c|}
\hline Name $^{1}$ & Region $^{2}$ & $\begin{array}{c}\text { D typ } \\
(\mathrm{km})\end{array}$ & $\begin{array}{c}\mathrm{D} \text { all } \\
(\mathrm{km})\end{array}$ & Abbreviation $^{5}$ & Map $^{6}$ \\
\hline Loihi-_ & Loihi undersea edifice- & All & All & loihi & LOI \\
\hline Kilauea & $\begin{array}{l}\text { Glenwood (north flank) } \\
\text { Summit caldera- } \\
\text { Summit caldera- } \\
\text { Summit caldera } \\
\text { Upper East Rift Zone- } \\
\text { Middle East Rift Zone } \\
\text { Lower East Rift Zone } \\
\text { Southwest Rift Zone } \\
\text { Koae Fault Zone- } \\
\text { South flank (unspecified) } \\
\text { Far-eastern south flank- } \\
\text { Eastern south flank } \\
\text { Central south flank- } \\
\text { Western south flank- } \\
\text { South flank offshore- }\end{array}$ & $\begin{array}{c}-- \\
1-3 \\
7-10 \\
10-13 \\
1-4 \\
1-4 \\
1-6 \\
1-4 \\
1-4 \\
5-10 \\
5-10 \\
5-10 \\
5-10 \\
5-10 \\
5-10\end{array}$ & $\begin{array}{c}0-20 \\
0-5 \\
5-10 \\
10-20 \\
0-20 \\
0-20 \\
0-20 \\
0-20 \\
0-20 \\
0-20 \\
0-20 \\
0-20 \\
0-20 \\
0-20 \\
0-20\end{array}$ & $\begin{array}{l}\text { kl gln } \\
\text { kl cal } 0-5 \\
\text { kl cal } 05-10 \\
\text { kl cal } 10-20 \\
\text { kl ue r } \\
\text { kl mer } \\
\text { kl ler } \\
\text { kl swr } \\
\text { kl koae } \\
\text { kl sf } \\
\text { kl ler sf } \\
\text { kl mer sf } \\
\text { kl kuer sf } \\
\text { kl swr sf } \\
\text { kl sf os }\end{array}$ & $\begin{array}{l}\text { GLN } \\
\text { CAL } \\
\text { INT } \\
\text { INT } \\
\text { UER } \\
\text { MER } \\
\text { LER } \\
\text { SWR } \\
\text { KOA } \\
\text { SFL } \\
\text { SF4 } \\
\text { SF3 } \\
\text { SF2 } \\
\text { SF1 } \\
\text { SFO }\end{array}$ \\
\hline Mauna Loa-_ & $\begin{array}{l}\text { Summit (Mokuaweoweo)- } \\
\text { Northeast Rift Zone } \\
\text { Southwest Rift Zone- } \\
\text { Kaoiki Fault Zone- } \\
\text { Hilea Fault Zone } \\
\text { Milolii (includes offshore) } \\
\text { Kona (including near offshore) } \\
\text { Kona offshore } \\
\text { North flank (including ml-mk saddle) } \\
\text { West flank (includes offshore) } \\
\text { Hilo area (inclu }\end{array}$ & $\begin{array}{l}0-5 \\
0-5 \\
0-5 \\
4-16 \\
4-16 \\
-- \\
-- \\
-- \\
-- \\
-- \\
--\end{array}$ & $\begin{array}{l}0-20 \\
0-20 \\
0-20 \\
0-20 \\
0-20 \\
0-20 \\
0-20 \\
0-20 \\
0-20 \\
0-20 \\
0-20\end{array}$ & $\begin{array}{l}\text { ml mok } \\
\text { ml ner } \\
\text { ml swr } \\
\text { kaoiki } \\
\text { hilea } \\
\text { milolii } \\
\text { kona } \\
\text { kona os } \\
\text { ml nf } \\
\text { ml wf } \\
\text { hilo }\end{array}$ & $\begin{array}{l}\text { MOK } \\
\text { MNE } \\
\text { MSW } \\
\text { KAO } \\
\text { HLE } \\
\text { MIL } \\
\text { KON } \\
\text { OKO } \\
\text { MNF } \\
\text { MWF } \\
\text { HIL }\end{array}$ \\
\hline Hualalai-_ & $\begin{array}{l}\text { Onshore } \\
\text { Offshore- }\end{array}$ & $\begin{array}{l}-- \\
--\end{array}$ & $\begin{array}{l}\text { All } \\
\text { All }\end{array}$ & $\begin{array}{l}\text { hualalai } \\
\text { hualalai os }\end{array}$ & $\begin{array}{l}\text { HUA } \\
\text { OHU }\end{array}$ \\
\hline Mauna Kea $\longrightarrow$ & $\begin{array}{l}\text { Onshore- } \\
\text { Offshore- }\end{array}$ & $\begin{array}{l}-- \\
--\end{array}$ & $\begin{array}{l}\text { All } \\
\text { All }\end{array}$ & $\begin{array}{l}\text { mauna kea } \\
\text { mauna kea os }\end{array}$ & $\begin{array}{l}\text { KEA } \\
\text { MKO }\end{array}$ \\
\hline Kohala & Kohala (includes near offshore) & -- & All & kohala & $\mathrm{KOH}$ \\
\hline Alenuihaha_- & Channel between Hawaii and Maui & -- & All & alenuihaha & ALE \\
\hline Maui- & $\begin{array}{l}\text { Maui (includes near offshore)- } \\
\text { Maui (far offshore east) }\end{array}$ & $\begin{array}{l}-- \\
--\end{array}$ & $\begin{array}{l}\text { All } \\
\text { All }\end{array}$ & $\begin{array}{l}\text { maui } \\
\text { maui east }\end{array}$ & $\begin{array}{l}\text { MAU } \\
\text { MAE }\end{array}$ \\
\hline Lanai-_ & $\begin{array}{l}\text { Lanai northwest } \\
\text { Lanai southeast- }\end{array}$ & $\begin{array}{l}-- \\
--\end{array}$ & $\begin{array}{l}\text { All } \\
\text { All }\end{array}$ & $\begin{array}{l}\text { lanai nw } \\
\text { lanai se }\end{array}$ & $\begin{array}{l}\text { MOL } \\
\text { MAU }\end{array}$ \\
\hline Molokai- & Molokai (includes offshore) & -- & All & molokai & MOL \\
\hline Oahu & Oahu & -- & All & oahu & $\mathrm{OAH}$ \\
\hline
\end{tabular}

${ }^{1}$ Volcano (on the Island of Hawaii) or island.

${ }^{2}$ Subdivision defined by concentrations of earthquake epicenters within volcanoes on the Island of Hawaii (see fig. $4 B$ ) or for the rest of the Hawaiian chain (see fig. $4 A$ ).

${ }^{3}$ Typical depth range of well-defined hypocenters in our catalog.

${ }_{5}^{4}$ Depth range assumed where accurate depth determinations are unavailable.

${ }^{5}$ Abbreviation used in the "Region" column of our catalog.

${ }^{6}$ Three-letter regional code (see fig. 4) conforming to regions identified in our catalog, also used as code in the fixed-column computer file.

felt, or which are aftershocks or associated with a volcanic swarm, are probably located in the region assigned. Smaller earthquakes not associated with a well-located event will have larger uncertainties. It is possible but rare that an earthquake is two regions away from the one assigned.

In our catalog, the notation "(?)" after the region indicates a moderate uncertainty, for example, where only distance and a rough direction from one station is known. The notation "(??)" indicates a region that is inferred without any specified location and for which the true location error cannot be determined. A location may be precisely specified by HVO without stating how many data were actually used. For example, many early descriptions placed earthquakes in the saddle area between Mauna Loa and Mauna Kea. This area currently is nearly aseismic, and so we suspect that the early locations are in error, rather than that a cessation of activity occurred in the saddle coinciding with the time when the network improved.

For some earthquakes, the geographic coordinates are outside the assigned region. We assigned a region by using all location information described by HVO plus a knowledge of where earthquake activity was most likely at the time. We thus tended to assign aftershocks to the same region as the main shock and earthquakes during an eruption to the rift or adjacent flank, even if the coordinates stated by HVO placed them elsewhere.

Catalog abbreviations for geographic regions in relation to the Hawaiian volcanoes and tectonic subregions are listed in table 9 . 
Table 9. Synonymy relating the geographic regions defined in figure 4 to the abbreviations in our catalog-Continued

B. Deep-earthquake regions

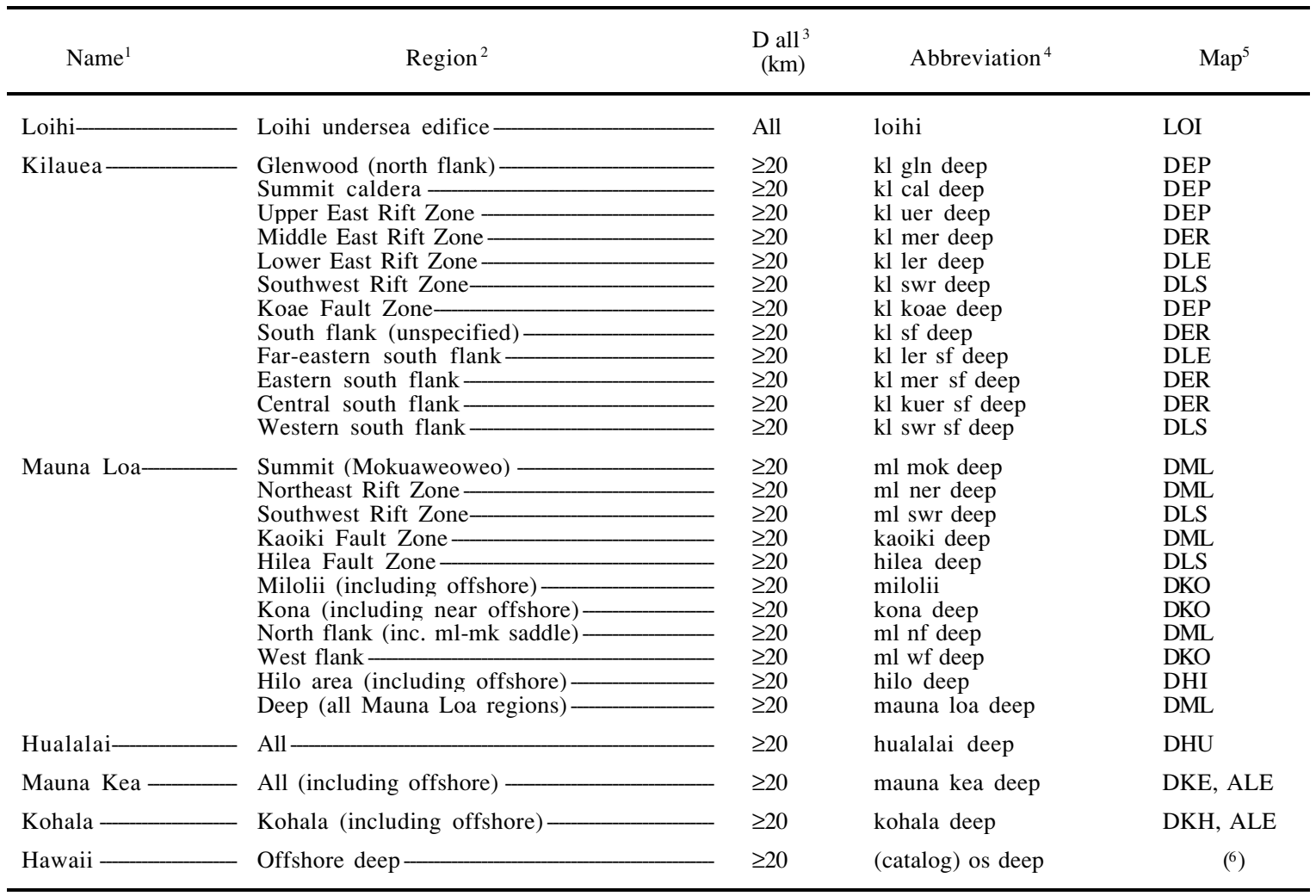

${ }^{1}$ Volcano (on the Island of Hawaii) or island.

${ }^{2}$ Subdivision defined by concentrations of earthquake epicenters within volcanoes on the Island of Hawaii (see fig. $4 C$ ).

${ }^{3}$ Depth range assumed where accurate depth determinations are unavailable.

${ }^{4}$ Abbreviation used in the "Region" column of our catalog.

${ }^{5}$ Three-letter regional code (see fig. 4) conforming to regions identified in our catalog, also used as code in the fixed-column computer file.

${ }^{6}$ See figure $4 C$.

C. Earthquake regions specified in the absence of definitive instrumental data or felt reports

\begin{tabular}{|c|c|c|c|}
\hline Name $^{1}$ & Region $^{2}$ & Catalog ${ }^{1}$ & Code \\
\hline Kilauea & $\begin{array}{l}\text { Unspecified; assume distance and depth for central part } \\
\text { of Kilauea Volcano. }\end{array}$ & \multirow{4}{*}{$\begin{array}{l}\text { kilauea } \\
\text { mauna loa } \\
\text { hawaii } \\
\text { south hawaii }\end{array}$} & KIL \\
\hline Mauna Loa & Unpecified; assume Kaoiki distance and depth- & & \multirow{3}{*}{$\begin{array}{l}\text { MLO } \\
\text { HAW } \\
\text { SHA }\end{array}$} \\
\hline Hawaii & Island of Hawaii & & \\
\hline South Hawaii & $\begin{array}{l}\text { Southern part of the Island of Hawaii (including south- } \\
\text { flank regions of Mauna Loa and Kilauea). }\end{array}$ & & \\
\hline East Hawaii & $\begin{array}{l}\text { Eastern part of the Island of Hawaii (including Hilo and } \\
\text { eastern part of Mauna Kea). }\end{array}$ & east hawaii & EHA \\
\hline North Hawaii & $\begin{array}{l}\text { Northern part of the Island of Hawaii (including Kohala } \\
\text { and parts of Mauna Kea). }\end{array}$ & north hawaii & NHA \\
\hline West Hawaii & $\begin{array}{l}\text { Western part of the Island of Hawaii; north and south } \\
\text { Kona (including Hualalai and Mauna Loa west flank). }\end{array}$ & west hawaii & WHA \\
\hline Offshore & Far offshore, outside of Hawaiian chain & off chain & DIS \\
\hline $\mathrm{a} 0513$ & Annulus of 5 to $13 \mathrm{~km}$ around the Whitney vault & a0513 & A05 \\
\hline a1320 & Annulus of 13 to $20 \mathrm{~km}$ around the Whitney vault & a1320 & A13 \\
\hline a2025 & Annulus of 20 to $25 \mathrm{~km}$ around the Whitney vault & a2025 & $\mathrm{A} 20$ \\
\hline a2530 & Annulus of 25 to $30 \mathrm{~km}$ around the Whitney vault & a2530 & $\mathrm{A} 25$ \\
\hline a3035 & Annulus of 30 to $35 \mathrm{~km}$ around the Whitney vault & a3035 & $\mathrm{A} 30$ \\
\hline a3540 & Annulus of 35 to $40 \mathrm{~km}$ around the Whitney vault & a3540 & $\mathrm{A} 35$ \\
\hline
\end{tabular}

${ }^{1}$ Used when only distance from the seismometer in Whitney vault is known.

${ }^{2}$ Distance range from Whitney vault (hypocentral); for example, "a3035" could refer to a shallow earthquake below Mokuaweoweo, or to an earthquake at $30-\mathrm{km}$ depth beneath Kilauea caldera.

${ }^{3}$ Used in the fixed-column computer file. 


\section{Calculation of Earthquake Magnitude}

The method of calculating earthquake magnitude differs for each of the seismometers used at HMO and HVO. Calculations are based on a relation for the seismometer recording the event, using the maximum peak-to-peak amplitude of the seismic trace and the hypocentral distance from the seismometer. If we know the response parameters, we convert the response to that of a Wood-Anderson seismometer and use the local magnitude calculated from the formulas of Richter (1958). If we cannot convert the response to that of a Wood-Anderson seismometer and we do not know the period of the maximum amplitude, we develop an empirical relation between earthquake magnitude and the logarithm of amplitude.

\section{Derivation of the Magnitude Scale for HMO Seismograms}

Station constants from the January 1957 film record are listed in table 10. We looked at the Honolulu records for all earthquakes reported by HVO as "moderate" or larger after converting the Hawaii standard time given in the Volcano Letter to Greenwich mean time. After deriving the nomogram for the HVO Bosch-Omori seismometer (see below), we looked for additional earthquakes reported as "slight" or "feeble," whose distance from the Whitney vault resulted in a calculation of $M>4.0$. For many undetected events we recorded the level of background noise as a threshold magnitude, designated "M<" in our catalog. A few earthquakes, by accident or design, were reread at different times, and agreement was excellent. This result gave us confidence that our readings were precise and consistent. Repeats are included in the CD-ROM files covering the Honolulu readings and noted in the corresponding catalog entry.

Records are available only from the Honolulu station; commonly, magnitudes can be averaged from different HON components, but not from a set of independent stations.

\section{Magnitudes from the Milne Seismometer, 1903-21}

Magnitudes determined from the Milne seismometer are empirical. We assume that magnitudes are of the form

$$
M=a+b\left[\log \left(\frac{A_{\mathrm{pp}}}{2}\right)-\log A_{0}\right]
$$

where $a$ and $b$ are constants to be determined, $A_{\mathrm{pp}}$ is the peakto-peak amplitude, and - $\log A_{0}$ is the distance term defined by Richter (1958). Ideally, we would want to know the period response of the Milne seismometer relative to the Wood-Anderson seismometer. This value would relate amplitudes measured on the Milne seismometer to the local magnitude scale defined for the Wood-Anderson seismometer. At least three factors, however, prevent us from knowing this value: (1) The period response of the Milne seismometer is underdamped and not well known; (2) the 1- to 3-s periods of local Hawaii earthquakes place them in the displacement response part of the Milne seismometer's spectrum (free period, $12 \mathrm{~s}$ ), but the acceleration part of the Wood-Anderson seismometer's spectrum (free period, $0.8 \mathrm{~s}$ ) and, thus, the ratio of their gains is frequency dependent; and (3) periods are unmeasurable on the $6-\mathrm{cm} / \mathrm{h}$ Milne records. Therefore, we chose an empirical approach.

To calibrate the Milne magnitude scale, we could find only three Hawaiian earthquakes with previously determined magnitudes recorded on the Milne seismometer with measurable amplitudes (fig. 5). These earthquakes all have $M=6.1-6.8$. In addition, for several earthquakes recorded on the Milne seismometer, we can crudely estimate magnitude from the maximum felt intensity: two earthquakes of intensity VI $(M=5.9)$ and five earthquakes of intensity $\mathrm{V}(M=5.3)$ earthquakes. Also, four earthquakes were recorded on the Milne seismometer with magnitude estimates from the size class recorded on HVO's Bosch-Omori seismometer (discussed below). Derivation of the Milne magnitude relation from HVO magnitudes determined from the Bosch-Omori seismometer is difficult because the Bosch-Omori seismometer goes off scale and begins to dismantle at about the magnitude at which the Milne seismometer just begins to record. We gave low weights to these points with approximate size class and maximum intensity magnitudes in fitting the Milne magnitude relation because we did not want to calibrate one empirical scale from another. We graphically fitted the empirical line through the earthquakes plotted in figure 5 to derive the Milne magnitude relation

$$
M=3.16+0.625\left[\log \left(\frac{A_{\mathrm{pp}}}{2}\right)-\log A_{0}\right]
$$

Milne magnitudes are thus poorly calibrated but probably good in a relative sense. Our fit of the Milne magnitude relation means that various magnitudes should be self-consistent. Milne magnitudes probably have accuracies comparable to those esti-

Table 10. Station constants from the January 1957 film record

\begin{tabular}{|c|c|c|c|c|c|}
\hline Seismometer & Component & Free period (s) & Magnification & Damping & Up \\
\hline Neumann-LaBarre & \multirow{5}{*}{$\begin{array}{l}\text { East-west } \\
\text { North-south } \\
\text { East-west } \\
\text { Vertical } \\
\quad \text { do- }\end{array}$} & \multirow{5}{*}{$\begin{array}{l}0.85 \\
12 \\
12 \\
1.65 \\
--\end{array}$} & \multirow{5}{*}{$\begin{array}{c}-- \\
152 \\
159 \\
4,000(?) \\
--\end{array}$} & \multirow{5}{*}{$\begin{array}{c}-- \\
20: 1 \\
20: 1 \\
\text { Critical } \\
--\end{array}$} & \multirow{5}{*}{$\begin{array}{l}\text { E } \\
\text { S } \\
\text { E } \\
\text { Up } \\
--\end{array}$} \\
\hline Milne-Shaw & & & & & \\
\hline Do & & & & & \\
\hline Sprengnether & & & & & \\
\hline $\begin{array}{l}\text { Houston Technical } \\
\text { Laboratories. }\end{array}$ & & & & & \\
\hline
\end{tabular}

[Do., ditto] 


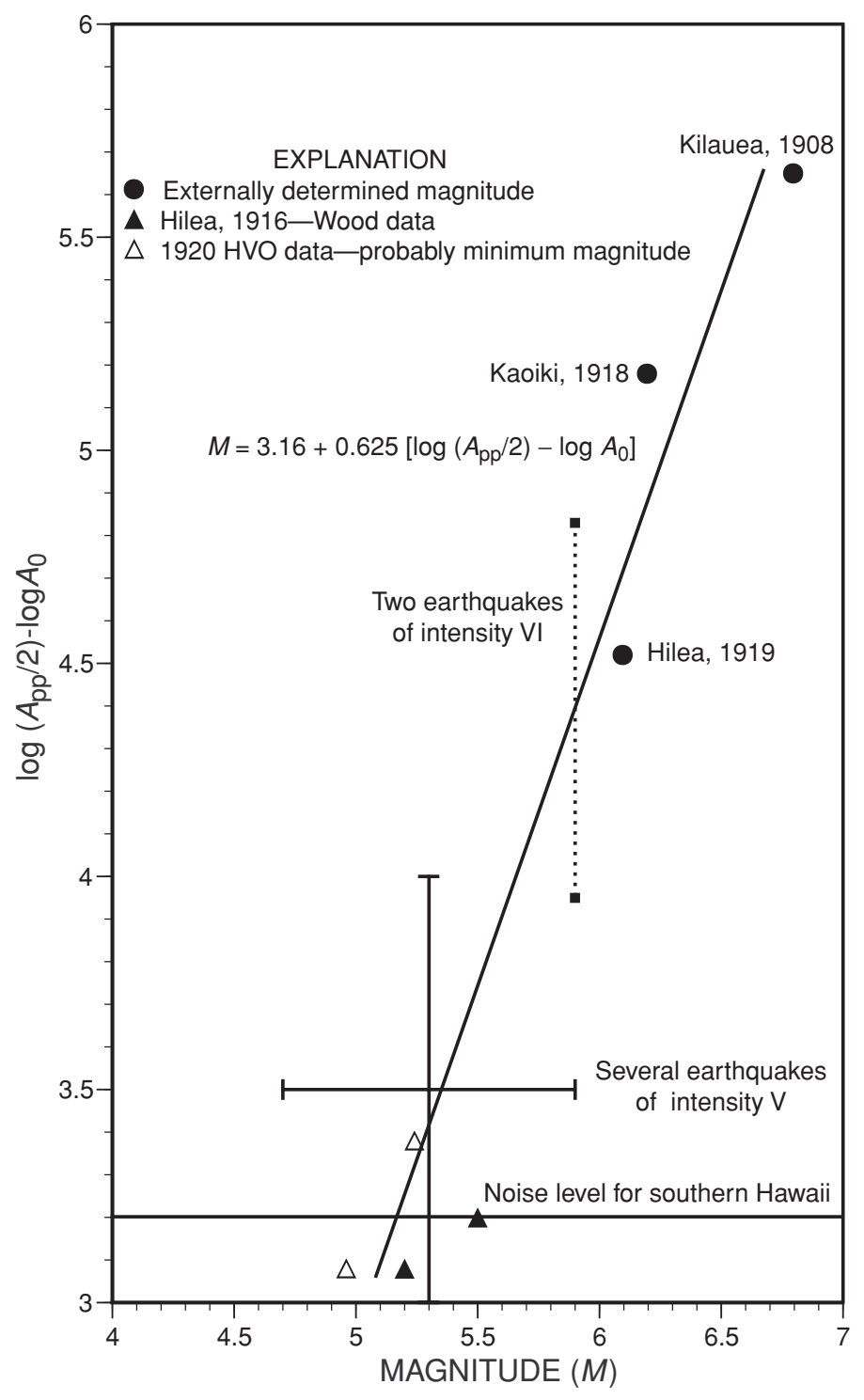

Figure 5. Empirical calibration of Milne seismometer. Small squares, two earthquakes of maximum intensity VI plotted at $M=5.9$; triangles, earthquake magnitudes determined by Hawaiian Volcano Observatory's Bosch-Omori seismometer. Error bars represent five earthquakes of intensity V: Vertical bar shows range of amplitudes, and horizontal bar shows probable error in magnitude defined by maximum intensity. Line is graphically fitted to magnitude-amplitude relation. Equation was used to calculate Milne magnitude $(M)$ from peak-to-peak amplitude $\left(A_{\mathrm{pp}}\right)$ and distance term $\left(-\log A_{0}\right)$.

mated by other methods used on early earthquakes, such as from areas of felt intensities or from maximum intensity.

\section{Milne-Shaw Intermediate Period, 1921-59}

The method to derive a magnitude relation for the MilneShaw horizontal seismometers uses an "absolute" formulation of the response of the seismometer and a conversion of amplitudes to what would have been seen on a Wood-Anderson seismometer. The theoretical response of the Milne-Shaw was ratioed to the theoretical response of the Wood-Anderson and the ratio was used to convert Milne-Shaw to Wood-Anderson amplitudes. The magnification is a function of these three parameters:

Static (very short period) magnification $(v)$

Seismometer period ( $\tau$, in seconds)

Damping factor $(h)$

$\begin{array}{lc}\text { Milne- } & \text { Wood- } \\ \text { Shaw } & \text { Anderson } \\ 155 & 2,080 \\ 12 & .8 \\ .69 & .7\end{array}$

The dynamic magnification of a seismometer is given by (Richter, 1958)

$$
H=\frac{v}{\sqrt{A^{2}+B^{2}}} \quad \mid A=1-\frac{T^{2}}{\tau^{2}}, B=\frac{2 h T}{\tau},
$$

where $T$ is the period of ground motion, $v$ is the static magnification, $\tau$ is the seismometer free period, and $h$ is the damping factor. The ratio of zero-to-peak Wood-Anderson amplitude $A_{\mathrm{wA}}$ to peak-to-peak Milne-Shaw amplitude $A_{\mathrm{MS}}$ is then

$$
\frac{A_{\mathrm{WA}}}{A_{\mathrm{MS}}}=0.5 \frac{H_{\mathrm{WA}}}{H_{\mathrm{MS}}} \text {. }
$$

We plotted this ratio and did a graphical fit in the period range $1-3 \mathrm{~s}$ to obtain the approximation

$$
A_{\mathrm{WA}}=0.5 \cdot 7.18\left(\frac{1}{T^{1.9}}\right) A_{\mathrm{MS}} .
$$

In the period range of interest (1-3 s), the Milne-Shaw displacement response is nearly flat, and the Wood-Anderson response falls off as $1 / T^{1.9}$ with period $T$.

Richter's original magnitude formula is $M_{\mathrm{wA}_{\mathrm{A}}}=\log A_{\mathrm{WA}}-\log$ $A_{0}$, where $A_{\mathrm{wA}}$ is the maximum half-amplitude on a WoodAnderson seismometer and $-\log A_{0}$ is a tabulated term that depends on distance and regional attenuation. The Milne-Shaw version of this formula is

$$
M_{\mathrm{MS}}=\log \left[0.5 \cdot 7.18\left(\frac{1}{T^{1.9}}\right) A_{\mathrm{MS}}\right]-\log A_{0},
$$

where $T$ is the period (limited to $1-3 \mathrm{~s}$ if outside that range; that is, periods of $1-3 \mathrm{~s}$ are taken as given, periods less than $1 \mathrm{~s}$ are assigned $1 \mathrm{~s}$, and periods greater than $3 \mathrm{~s}$ are assigned $3 \mathrm{~s}$ ), $A_{\mathrm{MS}}$ is the maximum peak-to-peak amplitude (in millimeters), and $-\log A_{0}$ is the distance term, either obtained from a table in Richter (1958) or approximated by Eaton's (1975) relation

$$
\begin{array}{ll}
-\log A_{0}=-0.15+1.6 \log \mathrm{SD} & \text { for } \mathrm{SD}<200 \mathrm{~km} \\
-\log A_{0}=-3.38+3.0 \log \mathrm{SD} & \text { for } \mathrm{SD}>200 \mathrm{~km},
\end{array}
$$

where SD is the slant distance (in kilometers). We considered but did not find it necessary to use geographic correction terms for $M_{\mathrm{MS}}$.

The distance term $-\log A_{0}$ depends on the typical attenuation factor $Q$ for the region. We use the $-\log A_{0}$ relation that Richter developed for southern California. We realize that the attenuation along the volcanic path from Hawaii to Honolulu is probably larger, but comparisons of Honolulu magnitudes with local Wood-Anderson magnitudes from Hilo during a limited time period suggest that an adjustment is unnecessary. Data for earthquakes that have both an external magnitude estimate and a Milne-Shaw magnitude show good agreement (figs. 7A, 7C). 


\section{Horizontal and Vertical Short Period}

The approach used for the verticals does not attempt an absolute formula for instruments whose response is not well known, but simply regresses the logarithm of amplitude against the Milne-Shaw magnitude for events observed on both instruments. The form of the relation is

$$
M_{\mathrm{v}}=\log A_{\mathrm{v}}-\log A_{0}-B-C,
$$

where $A_{\mathrm{v}}$ is the maximum peak-to-peak amplitude on the vertical seismometer, $-\log \mathrm{A}_{0}$ is the distance term described above, $B$ is a correction for the epicentral and depth region, and $C$ is a term determined for each of the three vertical instruments used in Honolulu.

The $B$ and $C$ values were determined iteratively by graphically fitting plots of $\log \mathrm{A}_{\mathrm{v}}-\log A_{0}$ versus $M_{\mathrm{MS}}$ with a line of slope 1.0. Plots of data for each instrument where the $C$ values were fitted alternated with plots of each region where the $B$ values were fitted. Deep ( $>20 \mathrm{~km}$ ) earthquakes were fitted differently from shallow (crustal) earthquakes for several regions. It took about three to four iterations until the $B$ and $C$ values were chosen and the data fit well. The tradeoff of the "floating constant" between the $B$ and $C$ values was fixed by letting the average of the regional $B$ values be about zero.

The $C$ values for each vertical seismometer are 0.52 for the Neumann-LaBarre, 0.17 for the Sprengnether, and 0.66 for the Houston Technical Laboratories.

The $B$ values for each region are as follows:

-0.17 for Kilauea south flank (SFL), Koae fault zone
(KOA), and Kilauea Caldera shallow (CAL)
0.22 for Kaoiki (KAO) and Hilea (HLE)
0.06 for Mauna Loa shallow (MOK, MNE, SAD, MSW)
and Hilo shallow (HIL), and Mauna Kea shallow
(KEA)
0.09 for Kona (KON), Mauna Loa west flank (MWF),
and Milolii (MIL)
-0.10 for Kohala and Hualalai (KOH, HUA)
-0.02 for Kilauea Caldera deep (DEP) and Kilauea rift
and south flank deep (DER)
0.65 for Hilo and Mauna Kea deep (DHI, DKE) and
Mauna Loa deep (DML)
0.51 for Maui (MAU, MAE)

The $-\log A_{0}$ values for each region (when distances cannot be calculated directly from epicenter coordinates) are as follows:

3.80 for Kohala offshore

3.85 for Kohala

3.95 for Hualalai

4.05 for Kona

4.10 for Mauna Kea, Mauna Loa north flank, and Mokuaweoweo

4.15 for Mauna Loa northeast rift and Mauna Loa southwest rift

4.20 for Kaoiki, Hilea, and Hilo

4.30 for all Kilauea (4.4 for south flank off shore)
The governing equations on the spreadsheet for calculating magnitudes are as follows:

for the Milne-Shaw seismometer:

$$
M=\log \left[0.5 \cdot 7.18\left(\frac{1}{T^{1.9}}\right) A_{\mathrm{pp}}\right]
$$

for the Neumann-LaBarre, Sprengnether, and Houston Technical Laboratories seismometers:

$$
M=\log A_{\mathrm{pp}}-\log A_{0}-B-C
$$

where $T$ is the period (in seconds) and $A_{\mathrm{pp}}$ is the peak-topeak amplitude (in millimeters).

The magnitude determined from the Neumann-LaBarre seismometer was not used from the time of its installation on May 1, 1946, until it was rotated, rebuilt, and reinstalled in the new vault on September 28, 1946. There were no calibration events during this early period, and Neumann-LaBarre magnitudes, assuming the latter calibration, are typically 0.5 to 0.8 units higher than the other components.

\section{Magnitude Determination for Earthquakes Not Recorded in Honolulu}

For HVO data before 1958, we had to develop methods for assigning magnitudes to earthquakes for which we had a location, or at least an epicentral distance, but lacked a directly determined amplitude. Earthquakes lacking both location and amplitude were assigned a provisional location and magnitude only if they were large enough to be felt. The following subsections describe how we assigned magnitudes to earthquakes recorded by HVO or noted in newspaper reports but not recorded on Oahu.

\section{HVO Magnitude Data, 1928-57}

A nomogram (fig. 6) was constructed relating magnitude, hypocentral distance from Kilauea's summit, and the size class on the Bosch-Omori seismometer. We used two sets of earthquake data to determine the magnitude contours. The first set of about 20 earthquakes is from the 1957 HVO "Summaries" (Eaton and Fraser, 1957a-d), for which both size classes and Wood-Anderson magnitudes are available. The second set of earthquakes, from 1951-56, have both Milne-Shaw magnitudes and a qualitative size class from the Volcano Letter. The bands in figure 6 correspond to the size classes defined as ranges of Bosch-Omori amplitudes (table 4).

The magnitude contours were drawn by hand through the data at equal intervals to give the best fit to all of the earthquake data used. For the Bosch-Omori seismometer in the Whitney vault, we empirically found that peak amplitude decays approximately as distance to the -1.24 power, though this relation is not well constrained. Richter's near-source decay for the Wood-Anderson local magnitudes in southern California 


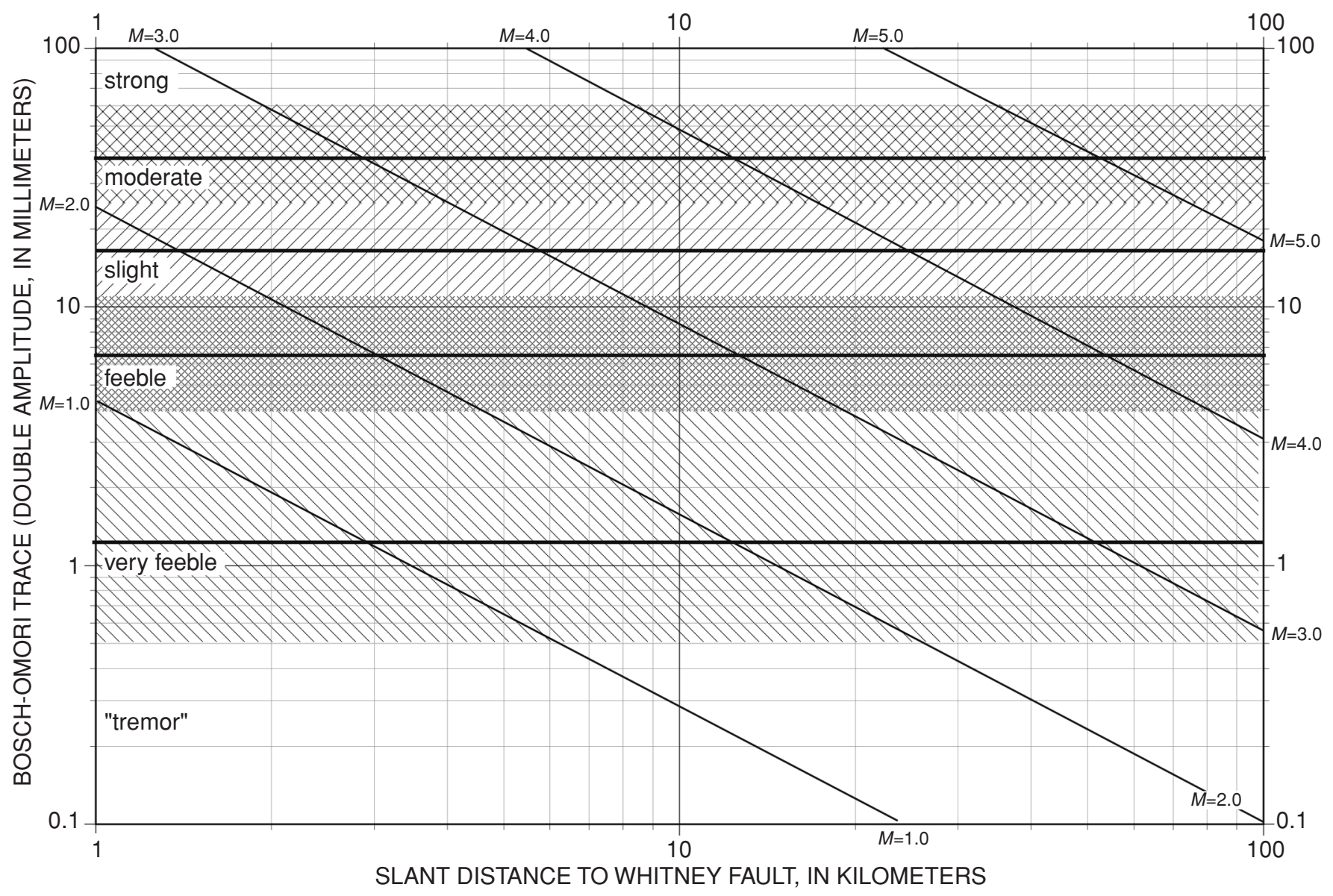

Figure 6. Nomogram for determining magnitude of earthquakes recorded at the Hawaiian Volcano Observatory during period 1928-57, using distance and size class given in the Volcano Letter. Governing equation: magnitude $(M)=1.35 \log$ (amplitude, in millimeters)+1.6log (distance, in kilometers) +0.15 .

(also used in Hawaii) is distance to the -1.6 power. Our graphical fit finds $M$ proportional to $1.35 \log A$, in comparison with $\mathrm{M} \sim 1.0 \log A$ assumed for the Wood-Anderson seismometer. The success of our initial calibration is shown in figures $7 B$ and $7 D$, where the magnitudes derived from our nomogram are plotted against the corresponding magnitudes determined on the Milne-Shaw seismometer for a much larger set of events. Agreement for most events lies within 0.5 magnitude unit, well within the expected error (see table 11).

The nomogram relates Bosch-Omori amplitude (ordinate) to slant distance from the Whitney vault (abscissa) and is contoured for magnitude. This relation allows us to compute magnitude given the numerical amplitude, but how do we assume an amplitude representative for a class when only the class is known? We assumed a linear F-M (logarithm of frequency versus magnitude) Gutenburg-Richter distribution of earthquake magnitudes within each size group (for example, "feeble"), and a characteristic amplitude for each group is plotted as a heavy horizontal line in the nomogram. The characteristic amplitude is such that 100 "characteristic"-size earthquakes in the class have the same total moment as 100 earthquakes that follow a linear F-M distribution throughout the magnitude class, with slope $b=1.0$. The characteristic amplitude for each size class are: very feeble, $1.12 \mathrm{~mm}$; feeble, 6.3 $\mathrm{mm}$; slight, $16 \mathrm{~mm}$; and moderate, $37 \mathrm{~mm}$. (See app. 2 for derivation of these amplitudes.)
Earthquakes are assigned a magnitude based on where the slant distance intersects the characteristic amplitude for its class. Our catalog magnitudes might thus show some steps or irregularities, but the magnitudes should conserve seismic moment when taken all together. In our catalog, magnitudes are calculated by using the analytical expression

$M=1.35 \log$ (preferred amplitude) +0.15

$$
+1.6 \log (\text { slant distance) }
$$

and are tabulated in the "M calc." column of our catalog.

Beginning in 1951 (and, rarely, earlier) the size classification of earthquakes was reported from more than one station (for example, very feeble at Whitney, feeble at Mauna Loa). For these events, we adjusted the Whitney amplitude within the constraints of its class to fit, if possible, a magnitude range calculated for the other station. The amplitudes are adjusted according to the magnification of the different seismometers, as listed in table 2. For example, the range $11-25 \mathrm{~mm}$ for a feeble classification at Whitney is reduced by 115/200 for a feeble classification at Pahoa before calculating a range of magnitudes for the Pahoa station. Horizontal distances are either the calculated station distance or are derived from the written description of earthquake location in the Volcano Letter. Slant distances are then calculated by using the depth either given or 

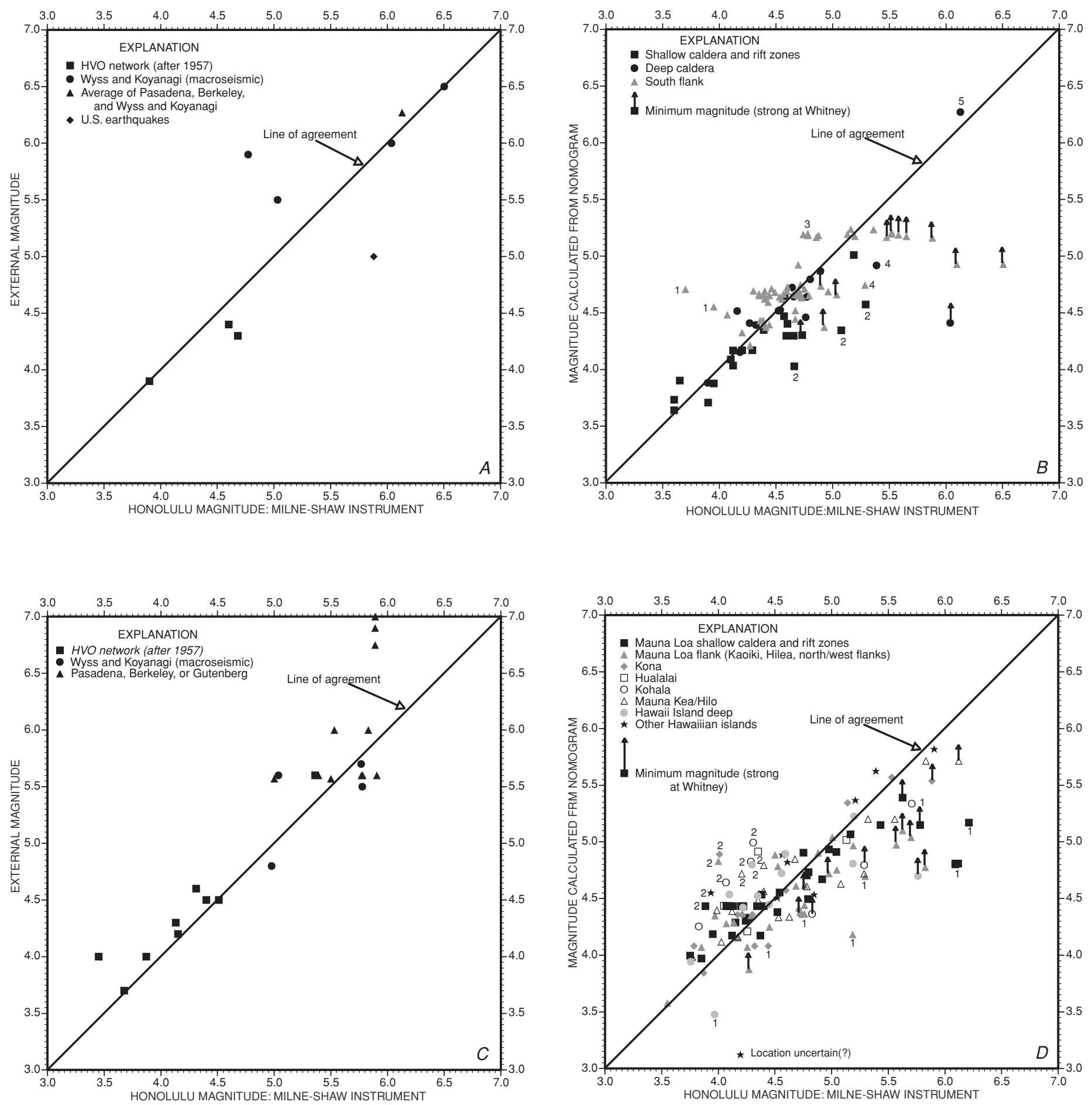

Figure 7. Magnitude comparisons for earthquakes during period 1933-59. A, Kilauea earthquakes, comparing Milne-Shaw (Honolulu) magnitudes with those determined from external data sources. $B$, Kilauea earthquakes, comparing Milne-Shaw (Honolulu) magnitudes with Hawaiian Volcano Observatory (HVO) magnitudes calculated from nomogram (fig. 6). Numbered data points denote earthquakes that fall outside normal range, for the following reasons: (1) Milne-Shaw magnitude low, Sprengnether and (or) Neumann-LaBarre magnitude agrees with nomogram magnitude; (2) nomogram magnitude, calculated at 7-km depth, would fit if $30 \mathrm{~km}$ deep or if strong at Whitney; (3) magnitude fits if Volcano Letter class were one unit higher (for example, slight $\rightarrow$ moderate); (4) magnitude fits if Volcano Letter class were one unit lower (for example, strong $\rightarrow$ moderate); (5) magnitude "very strong" at Whitney, amplitude assumed. $C$, Non-Kilauea earthquakes, comparing Milne-Shaw (Honolulu) magnitudes with those determined from external data sources. $D$, Non-Kilauea earthquakes, comparing Milne-Shaw (Honolulu) magnitudes with HVO magnitudes calculated from nomogram (fig. 6). Numbers denote earthquakes that fall outside normal range, reasons for which are as follows: (1) Magnitude fits if Volcano Letter class were one unit higher (for example, slight $\rightarrow$ moderate); (2) magnitude fits if Volcano Letter class were one unit lower (for example, strong $\rightarrow$ moderate). 
Table 11. Magnitude types and codes used to identify them, with associated uncertainties

[Listed in approximate order of decreasing reliability. Uncertainty is estimated absolute error in magnitude $(M)$, based on our experience and self-agreement of values]

\begin{tabular}{|c|c|c|c|}
\hline Code & Name & Description & Uncertainty \\
\hline $\mathrm{L}$ & hvo & Local magnitude from Wood-Anderson or Sprengnether seismograph- & $\pm 0.3(1957-92)$ \\
\hline $\mathrm{S}$ & gute & Surface-wave magnitude as from Gutenberg and Richter (1945)-- & $\begin{array}{l} \pm 0.3, \pm 0.6 \\
(1903-21)\end{array}$ \\
\hline $\mathrm{H}$ & hono & Amplitude on one of the Honolulu seismographs & $\pm 0.4(1921-59)$ \\
\hline A & aver & Average of two magnitudes & \pm 0.4 \\
\hline $\mathrm{I}$ & $\mathrm{w} \& \mathrm{k}$ & Determined by Wyss and Koyanagi (1992) from isoseismal map & \pm 0.4 \\
\hline $\mathrm{N}$ & nomo & $\begin{array}{l}\text { Nomogram, using "average" amplitude for size class on HVO's Bosch-Omori } \\
\text { seismometer. }\end{array}$ & \pm 0.6 \\
\hline M & int & Maximum intensity observed - & \pm 0.6 \\
\hline $\mathrm{P}$ & poor & Poor; location known only generally, for example, Kilauea- & \pm 0.7 \\
\hline $\mathrm{F}$ & felt & Reliable felt report; intensity and location uncertain- & \pm 0.8 \\
\hline $\mathrm{D}$ & desp & $\begin{array}{l}\text { Desperate; guessed from an undefined term, used only when nothing else is } \\
\text { available. }\end{array}$ & \pm 1.0 \\
\hline $\mathrm{E}$ & ind & Indeterminate & -- \\
\hline $\mathrm{C}$ & calc & $\begin{array}{l}\text { Equivalent magnitude calculated from the moment sum of an earthquake } \\
\text { swarm where times for individual events are unspecified. }\end{array}$ & -- \\
\hline
\end{tabular}

assumed. The nomogram magnitude is given for the Whitney station or for the station nearest to the epicenter. Magnitude ranges for additional stations are summarized in the "Comment" column of our catalog. For most events, agreement is satisfactory for different stations. Where it is not, this discrepancy is also noted in the "Comment" column.

\section{HVO Magnitude Data, 1912-17}

During his time at HVO (1912-17), Wood tried to directly relate the seismograms recorded at Whitney to quantified intensity scales as felt by people. However, these two measures do not record the same motion. At the periods of local south Hawaii earthquakes $(0.2-1 \mathrm{~s})$, the Bosch-Omori seismometer (period, $8 \mathrm{~s}$ ) records ground displacement, but the human body feels acceleration. Also, the sensitivity of the seismometer and human sensibility generally did not overlap: earthquakes too small to feel were easy to record and measure, but most earthquakes large enough to be widely felt dismantled the mechanical seismographs.

HVO and Wood generally preferred stating recorded earthquake size in units of acceleration or scales related to acceleration. Wood related seismography and "felt intensity" by converting seismogram displacement measurements to acceleration in milligals. HVO also adopted the Cancani intensity scale, which is tied to units of acceleration (fig. 2; table 3); the Cancani scale was listed in most of the early weekly reports. HVO derived Cancani intensities primarily from seismometric measurements (Jaggar, 1947, p. 59). Some accelerations (Cancani intensities) were apparently inferred from such other low-gain instruments as the triggered "ordinary" seismograph because intensities are published for events that flung the pens off the Bosch-Omori seismometer. Unlike the Rossi-Forel and modified Mercalli intensity scales, the Cancani scale has several intensities below the felt threshold and so was theoretically suitable for both instrumental and human-perception use.

The anchor of the Cancani scale is the felt threshold set at the Cancani intensity III-IV boundary. The felt threshold was also anchored at 1,000 mGal. Because $g$, the force of gravity, is $980,000 \mathrm{mGal}$, the felt threshold is thus about $0.001 \mathrm{~g}$, which is generally true from experience. Units of the Cancani scale were defined by limits of acceleration in millimeters per second squared, where $1 \mathrm{~mm} / \mathrm{s}^{2}$ equals $100 \mathrm{mGal}$. The felt threshold is also 1.0 on the scale of minimum perceptible units. HVO thus had three equivalent acceleration scales spanning the whole range of possible sizes, which were used at different timesacceleration in milligals, Cancani intensity, and size in minimum perceptible units (fig. 2).

Wood converted measured seismogram amplitudes (displacements) to accelerations for many of the published reports of size, and we reversed his procedure to recover approximate amplitudes for the magnitude calculations. For harmonic motion $d=\sin \omega t$, where the frequency $\omega=2 \pi / T$, the physical relation between maximum ground displacement $d$ (zero-to-peak amplitude, in millimeters), the maximum acceleration $a$ (in millimeters per second squared), and the period $T$ (in seconds) is given by

$$
a=(2 \pi / T)^{2} d
$$

or

$$
d=0.025 T^{2} a \text {. }
$$

The version of this relation used by Wood (1915) is

$$
d^{\prime}=0.25 T^{2} a^{\prime}
$$

where $d^{\prime}$ is the ground amplitude (in micrometers) and $a^{\prime}$ is the acceleration (in milligals).

Our tables and magnitude scale use the double amplitude (peak to peak) measured on the Bosch-Omori seismometer running at a gain of 115 . When only the acceleration (expressed as Cancani intensity, minimum perceptible units, or acceleration in milligals) is available, we attempt to convert back to the seismogram peak-to-peak amplitude (in millimeters) that Wood originally measured but never published in that form. This conversion ties Wood's accelerations with the later size classes used by $\mathrm{HVO}$ measured from amplitudes on the Bosch-Omori 
seismograms. We assumed that the typical period is $0.5 \mathrm{~s}$, which was the most common period published by Wood (1915) for local earthquakes. The relation we use, as expressed in figure 2 , is

$$
D=0.012 a^{\prime},
$$

where $D$ is the peak-to-peak amplitude (in millimeters) on the seismogram and $a^{\prime}$ is the acceleration (in milligals).

It is legitimate to ask whether the amplitudes that we derived from the "acceleration" descriptions published by HVO for 1912-17 give magnitudes comparable to those from the amplitude classes used during 1928-57. HVO may have used (but did not publish) a shorter period to convert from measured amplitude to published acceleration. If the period assumed by HVO when going from $\mathrm{D}$ to $a^{\prime}$ was $0.2 \mathrm{~s}$ but the period used by us when converting back from $a^{\prime}$ to $D$ was $0.5 \mathrm{~s}$, our inferred amplitudes would be increased by the factor $(0.5 / 0.2)^{2}=6.2$, resulting in our overestimation of magnitude by 0.8 . We do not believe that we are making systematic errors this large, and the Milne calibration shown in figure 5 suggests that we are not. Individual earthquakes could, however, easily have a cumulative error from several uncertainties amounting to 0.5 to 1.0 magnitude unit in either direction.

However, there are very few ways to compare magnitudes from this early 1912-17 catalog. A small magnitude window exists near $M=5$ below which earthquakes are too small to record on the Milne seismometer in Honolulu and above which they clip or dismantle the Bosch-Omori seismometers at HVO. We could find only four earthquakes on scale on both instruments (fig. 5): two from 1916 and two from 1920. Several earthquakes in our catalog were recorded in Honolulu with intensities at HVO estimated by Jaggar (1947), Wyss and Koyanagi (1992), or us. When these intensities are converted to Bosch-Omori amplitudes, using figure 2 , the resulting magnitudes do not systematically deviate from the Honolulu magnitudes, but their scatter is about 0.5 to 1.0 magnitude unit. In addition, many earthquakes with calculated magnitudes exceeding 4 have no published felt reports, but we interpret this absence as an incompleteness in felt reporting rather than a systematic overestimation of the magnitude scale.

\section{HVO Magnitude Data, 1917-27}

We tried without much success to establish a magnitude scale responsive to the various terms used to describe earthquakes in the HVO publications. As noted above, some terms are identical to those used later-for example, "feeble"-yet do not yield magnitudes consistent with each other or with felt reports when the post-1928 nomogram formulation is applied. Other terms (such as "small") are peculiar to this time period. This problem is made essentially intractable by the fact that the terms are used inconsistently. For this period, we have been rather arbitrary in assigning magnitudes within the constraints of felt reports and descriptions of relative strength (for example, "This earthquake was the largest of this series.").

The best test of magnitudes derived from HVO's magnitude classes during the period 1921-27 is comparison with the
Milne-Shaw magnitudes from Honolulu. The close agreement of station HON and HVO magnitudes after 1932 (figs. 7B, 7D) gives us confidence in the station $\mathrm{HON}$ and $\mathrm{HVO}$ magnitude scales when the size classes are defined and adhered to. ${ }^{4}$

If the only description of the event is one of the undefined terms "light," "medium," or "heavy" and no intensity or felt information is recorded, we interpret these terms to correspond to "very feeble," "feeble," and "slight." If this nomogram magnitude is the only one available, we note the preferred magnitude as "desperate."

\section{Magnitudes Based on Area of Felt Intensities}

Wyss and Koyanagi (1992) based most of their new magnitude determinations on the areas of intensity V or VI from their isoseismal maps. For some earthquakes before 1920, not enough intensities were available for them to draw an isoseismal map, and no seismogram amplitudes are recorded. When enough intensities are available to estimate the approximate location, we use their magnitude-versus-intensity area relation to approximate the earthquake magnitude. If $A(\mathrm{VI})$ is the area (in square kilometers) of modified Mercalli intensity VI and $A(\mathrm{~V})$ is the area of modified Mercalli intensity $\mathrm{V}$, then

and

$$
M=1.0 \log A(\mathrm{VI})+2.9
$$

$$
M=1.1 \log A(\mathrm{~V})+1.6 .
$$

\section{Magnitudes Based on Maximum Intensity}

Many older earthquakes have only one or two felt reports from which an intensity can be inferred or guessed. Magnitudes inferred from maximum intensity are subject to error but are better than nothing. Maximum intensities for events with a

\footnotetext{
${ }^{4}$ There are eight events with both HON and HVO magnitudes during 192127 . We proceed by assuming that the size-class names were used loosely before 1933, and with definite numerical limits designed to approximate their former usage after the arrival of Austin Jones. The classes "very feeble," "feeble," and "slight" all refer to a range of sizes, because each has a class above it. There is one earthquake in the slight class $(3 / 20 / 26)$ whose HVO magnitude is 1.0 unit larger than the station HON magnitude, and one feeble earthquake (7/31/27) whose HVO magnitude is 1.1 unit smaller than the station HON magnitude. We believe that there is no justification for altering the HVO magnitudes from their post-1932 definition of these three class names because no large and systematic shift is apparent. Later analysis of the catalog, however, might reveal a better assumption.

The class name "moderate" as used during 1917-27, however, does not appear to be as consistently applied as it was after 1932. We suspect that this class includes both the "moderate" and "strong" classes as later defined, and thus the "moderate" class during circa 1917-27 has no maximum amplitude. If we use the post-1932 definition of moderate and use the "median" amplitude for that class, six earthquakes from 1922-27 have HVO magnitudes too small by an average of 0.78 unit in comparison with station HON magnitudes. We therefore quote only the minimum "moderate" magnitude using a peak-to-peak amplitude of $25 \mathrm{~mm}$, or $40 \mathrm{~mm}$ if the seismographs were dismantled by the earthquake. We note these magnitudes with "M>". In our catalog, we prefer magnitudes determined from station HON (if available) or derived from an intensity to the minimum magnitude derived from a "moderate" magnitude classification. During the period 1917-27, we quote the HVO nomogram magnitude as preferred only if no other magnitude is available.
} 


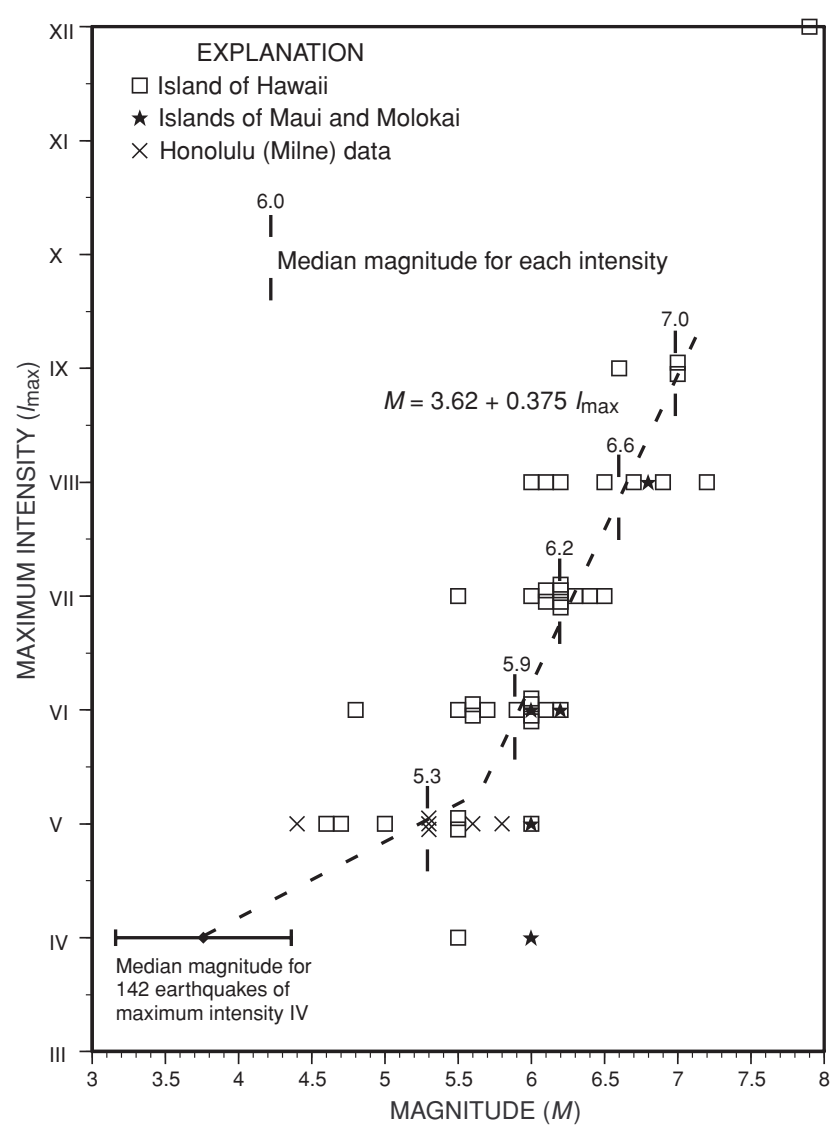

Figure 8. Maximum intensity $\left(I_{\max }\right)$ versus magnitude $(M)$ for Hawaiian earthquakes. For intensity IV, we use a median magnitude of 3.76 , based on 142 earthquakes during period 1933-59. Steeper dashed line is fit to data with equation shown; shallower dashed line connects median magnitudes for intensities IV and V.

well-determined instrumental or intensity-area magnitude are plotted in figure 8 . The median magnitude for each intensity range (marked by vertical bars) is surprisingly linear with magnitude in the range VI-IX but is less than the extrapolated value (5.3) for intensity V. The relation

$$
M=3.62+0.375 I_{\max }
$$

fits the data for $I_{\max } \geq \mathrm{IV}$ and is close to the relation $M=3.7$ $+0.4 I_{\max }$ found by Wyss and Koyanagi (1992), using fewer earthquakes.

\section{Adoption of a "Preferred" Magnitude}

We have tabulated magnitudes determined from the six principal sources listed in table 11 . The magnitudes are listed in their approximate order of reliability. The order is generally that used by us in selecting the preferred magnitude. Modern magnitudes have the luxury of different magnitude scales based on different phases with different periods, each consisting of averages from several stations. Our catalog seldom has redundancy of either different magnitude types or different stations. When it does, the redundancy is commonly the source for calibrating one magnitude scale against another. Our catalog preserves original magnitudes, and the use of averages or a different preference order is easy to accomplish. Where discrepancies among magnitudes obtained from different sources are evident, data may be averaged, indicated in the "Preferred magnitude source" column of our catalog; possible reasons for a discrepancy are noted in the "Comment" column. Where we have no way of calculating an earthquake magnitude, or just have terms like "light," "medium," or "heavy" (see above), our "best guesses" as to magnitude are entered directly into the "Preferred magnitude" column, and the source is noted as "desperate."

\section{Earthquake Swarms}

Earthquake swarms are commonly noted in the published HVO sources. We want to make use of all information for estimating total seismic-moment release during a time interval. For swarms, we list the number and size of events in the "Comment" column of our catalog when only the location and number of events are also listed. Only a small subset of individual swarm events are tabulated with a time and a magnitude classification. Commonly, events registering as "moderate" or "strong" are reported with individual times, and the number of "slight" and smaller events is listed for at least the early part of the sequence. For many of these events, we were able to read additional events on the Honolulu records, evidently obscured in the traces of the larger events on the Whitney records. These events are listed in our catalog with the time adjusted to Hawaii local time and "Not in VL" entered in the "Comment" column. We have handled the swarm earthquakes that are not individually tabulated in two different ways, both of which assume that all or parts of the swarm within a particular magnitude range fit a Richter magnitude distribution.

When swarm events are not individually listed in the Volcano Letter, we attempt to account for the total seismic moment released from whatever information is available. We generally list the daily number of earthquakes in each size class for the swarm. When these numbers are not published directly, we infer them from published weekly event counts by size class. When only the total number of events in a range of size classes is published, we distribute them in different size classes to approximate a Richter distribution. We then calculate the contribution for each size class by converting the representative nomogram magnitude for that class to a moment, multiplying by the number of events in the class and converting back to a magnitude.

During the years 1957-59, when local magnitudes are tabulated only for the largest events, we use a Richter distribution with a $b$ value of 1.5 to estimate the minimum magnitude and number of events in each magnitude interval: and

$$
\log (\text { total number of events reported })=1.5\left(M_{\max }-M_{\min }\right)
$$

$$
\log (\text { number of events larger than } M)=1.5\left(M_{\max }-M\right) \text {. }
$$

The moments are summed in increments of 0.1 magnitude unit for each interval between the minimum and maximum magnitude (up to the total number of events), then converted to a calculated magnitude for the group of events contributing to the swarm. The contribution of small events to the total moment is 
thus always an approximation but generally is small in comparison with that of the larger events.

For both classes of events, the calculated magnitude is listed in the "Preferred magnitude" column of our catalog, and "Calc." is entered as the preferred magnitude source. The preferred magnitude emphasizes the fact that during earthquake swarms, a significant amount of additional seismic moment is tied up in events that are not reported individually.

\section{Errors and Uncertainties}

For much of the period of our catalog, the primary seismic station used for locations was the Whitney vault at HVO. The independent stations at Kona and Hilo were sometimes, but not always, available. The absence of an accurate, common time base meant that the measurable quantities were s-p time (and thus a distance estimate), relative amplitudes, comparison with other seismograms from better located earthquakes, and the polarization to infer the approximate azimuth to the source of the seismic waves. A feel for the seismograms and the types of uncertainties involved can be gleaned from the early seismic reports (see Jones, 1938). In constructing a catalog from early seismic data, we were unable to recover original HVO seismograms or notebook entries. The original Whitney seismograms are nearly impossible to reread, and we have found no tabulations of actual amplitudes from which the qualitative assignment of earthquake size in the Volcano Letter was made. Locations are approximate because at most five seismometers (typically, 1-3) were operating on the Island of Hawaii before 1957, when expansion and modernization of the HVO net began (see above). Discrepancies that we found in the course of compiling our catalog are summarized in appendix 3 .

The reporting of earthquakes changed after the introduction of the U.S. Geological Survey Bulletin series, the first of which covered the years 1948-49 and did not report any seismic data. Bulletins covering the years 1950-55 repeated, with one exception noted in appendix 3, the Volcano Letter tabulations for the same years. Through the first quarter of 1954, both the Volcano Letter and the Bulletins tabulated earthquakes of class "very feeble" and stronger. Without any explanation, however, the last three quarters of 1954 reported only "feeble" and greater, and from 1955 through the end of 1957 cut back further to report only "slight" and greater. We use the more complete listing in the Volcano Letter for our catalog. Beginning in 1958, a lower threshold magnitude of 2.5 was adopted, with some exceptions for smaller events of special interest or those that were favorably located such that a smaller magnitude could be reasonably estimated. The same threshold was honored through 1963, the last year in which Honolulu records for the Milne-Shaw seismometer are available.

Viewed in hindsight, it is unfortunate that more attention was not given to the transition between the old ways of reporting and the assignment of increasingly precise magnitudes from the expanding HVO network. We recognize that the constraints of frequent new seismic events, in combination with no reasonable anticipation that someone would actually try to assign magnitudes to early earthquakes, probably explains the ab- sence of analysis of the overlap time between old and new instruments. The Bosch-Omori seismometer, which was in use as a tiltmeter through 1962, would have served to improve the calibration of the earlier records if Bosch-Omori amplitudes had continued to be tabulated up to the time the seismometer was retired. Likewise the continuation of the Jones classification scheme for several more years after 1957 would have made it easier to calibrate the older data by using the expanded HVO network.

The arbitrary changes in reporting threshold affect the completeness of our catalog, particularly for the years 195457. We cannot assure uniformity of the 1958-63 record with the pre-1954 catalog because different criteria were used for reporting. If our nomogram determinations are correct and reporting in the Volcano Letter is complete, reporting of earthquakes of $M \geq 3.0$ should be complete, at least in the 1950's. A future study will address the issue of our catalog's completeness.

\section{Location and Magnitude Profile of the 1933-59 Catalog}

A sample catalog output for Kilauea earthquakes of $M \geq 4.0$ is included in table 13 (see app. 1). A detailed analysis of our catalog will be the subject of future papers and is beyond the scope of this report, but a few comments are necessary. We have attempted to catalog the time, location, and magnitude of every Hawaiian earthquake documented during this period, using all available materials. The locations of most events, however, are those originally assigned by HVO. We could not relocate them because the original records are lost or unusable. We also could not estimate the errors in locations and the personal biases of the person assigning the location without the original data. An insight into errors and completeness can come from comparisons with the modern catalog.

A map of the 27-year 1933-59 catalog (fig. 9A) shows a generally similar pattern to the succeeding 27 years of computer-located earthquakes (fig. 9B). Kilauea, its rift zones, and the south flank are active during both periods. Many of the earthquakes assigned to Kilauea's East Rift Zone during 1933-59 may actually be south-flank events, but they were placed on the rift because that was believed to be the more active feature. Mauna Loa's summit and rifts were more seismically active during 1933-59 because seven eruptions occurred (including the large 1950 eruption), versus the two eruptions in the period 1960-86. Like Kilauea, some Mauna Loa flank events may have been placed on

Figure 9. Island of Hawaii, showing locations of all earthquakes of $M \geq 3$ during two 27-year periods beneath island and adjacent ocean. Squares, shallow (less than $20-\mathrm{km}$ depth) earthquakes mostly within volcanic edifice and crust; diamonds, upper-mantle earthquakes below $20-\mathrm{km}$ depth. $A, 1933-59$ earthquakes in our catalog. Most locations are those originally assigned by the Hawaiian Volcano Observatory and listed in the Volcano Letter, additional earthquakes without a specific location are plotted at center of likely geographic region as interpreted by us. Earthquakes assigned only to a general region (for example, Kilauea) are omitted. $B, 1960-86$ earthquakes, located from accurately timed phases of seismic network and computer calculations (omitted from our catalog). 

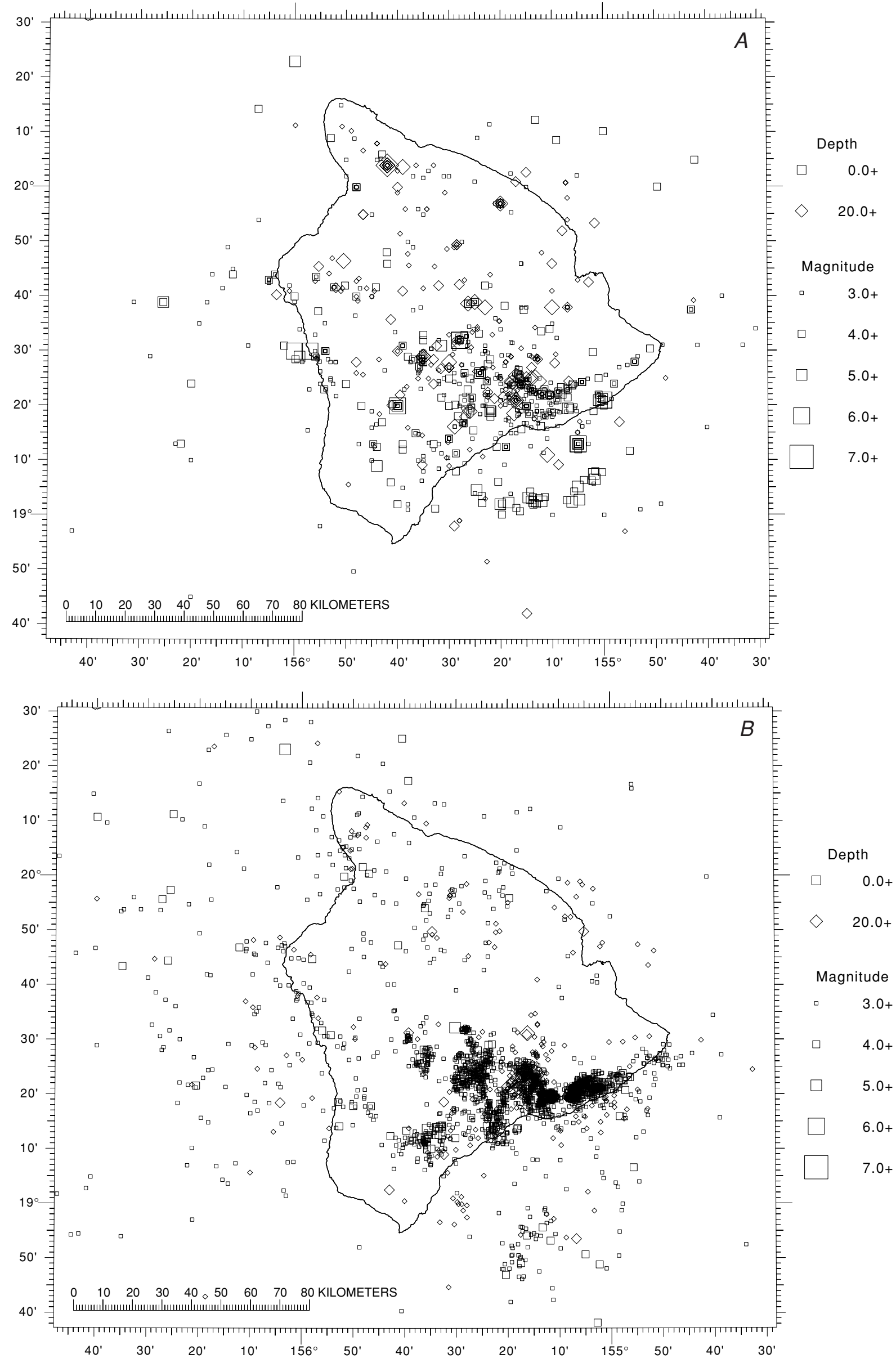
Table 12. Numbers of cataloged earthquakes, by magnitude

\begin{tabular}{|c|c|c|c|c|}
\hline $\begin{array}{l}\text { Magnitude } \\
\text { range }\end{array}$ & $1933-59$ & $1960-86$ & 1933-59 (cumulative) & $\begin{array}{c}1960-86 \\
\text { (cumulative) }\end{array}$ \\
\hline No magnitude & 895 & 10,947 & 5,244 & 75,848 \\
\hline $0.1-0.4$ & 5 & 303 & 4,349 & 64,901 \\
\hline $.5-0.9$ & 170 & 693 & 4,344 & 64,598 \\
\hline $1.0-1.4$ & 545 & 1,885 & 4,174 & 63,905 \\
\hline $1.5-1.9$ & 483 & 15,784 & 3,629 & 62,020 \\
\hline $2.0-2.4$ & 623 & 27,653 & 3,146 & 46,236 \\
\hline $2.5-2.9$ & 885 & 12,857 & 2,523 & 18,583 \\
\hline $3.0-3.4$ & 753 & 3,880 & 1,638 & 5,726 \\
\hline $3.5-3.9$ & 440 & 1,332 & 885 & 1,846 \\
\hline $4.0-4.4$ & 269 & 380 & 440 & 514 \\
\hline $4.5-4.9$ & 102 & 102 & 171 & 134 \\
\hline $5.0-5.4$ & 41 & 18 & 69 & 32 \\
\hline $5.5-5.9$ & 21 & 10 & 28 & 14 \\
\hline $6.0-6.4$ & 4 & 2 & 7 & 4 \\
\hline $6.5-6.9$ & 3 & 1 & 3 & 2 \\
\hline $7.0-7.4$ & 0 & 1 & 0 & 1 \\
\hline
\end{tabular}
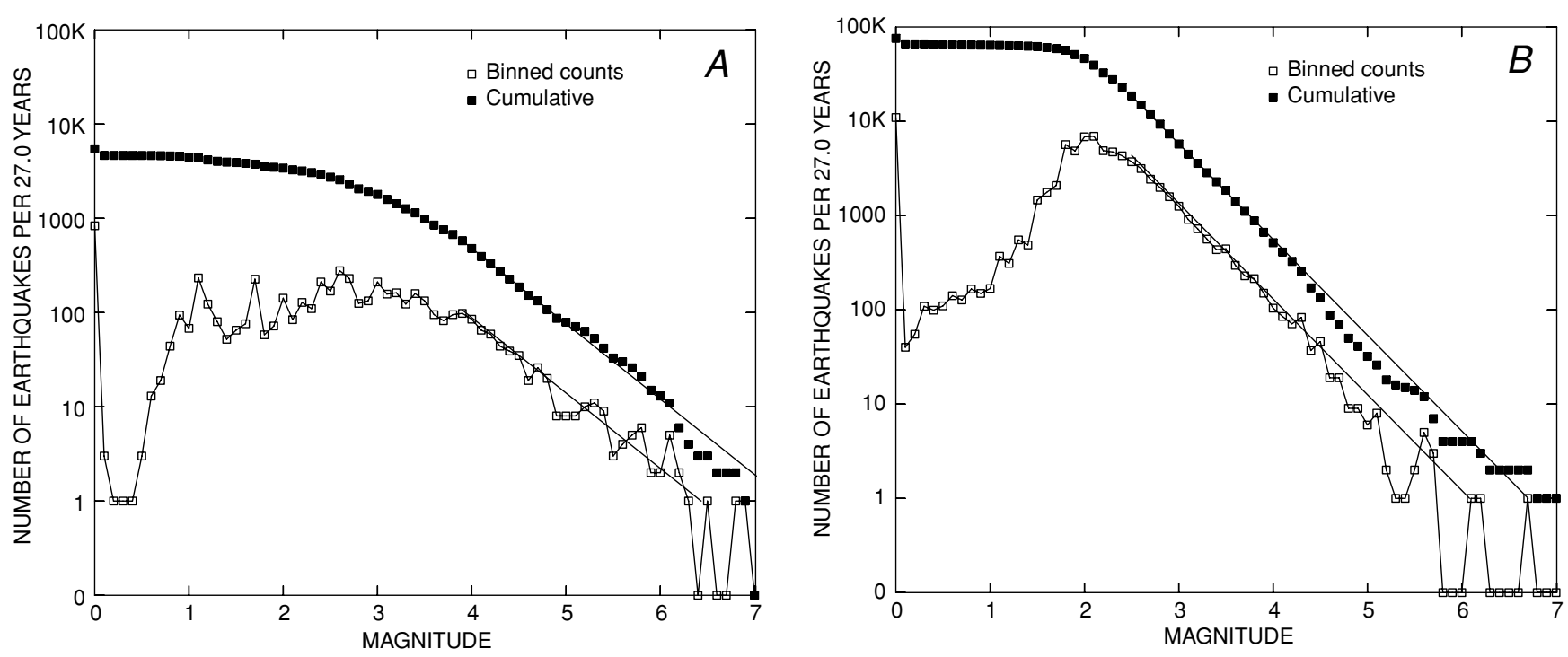

Figure 10. Magnitude distribution of Hawaiian earthquakes. Solid squares, cumulative numbers of earthquakes; open squares, number of earthquakes per 0.1 magnitude interval. Lines are of maximum-likelihood fit. $a$ and $b$ values were derived by using Richter's formula relating earthquake magnitude to number of events. $A, 1933-59$. $a=4.4223$ for $M \geq 3.9 ; b=0.793 \pm 0.03$, using 576 events over 27 years. $B, 1960-86$. $a=5.3760$ for $M \geq 2.5 ; b=1.015 \pm 0.01$, using 18,583 events over 27 years.

the summit caldera or rift zones because of poor station coverage in the earlier period. Mauna Loa's south flank (the Kaoiki and Hilea seismic zones) and west flank (Kona) were active in both periods. Mauna Loa's north flank (excluding deeper events) is essentially aseismic in the modern period. We do not know whether the earlier north-flank events are mislocations or are caused by the higher level of Mauna Loa volcanism. The modern network locates many more small offshore earthquakes than were detectable in the period 1933-59.

We believe that there are no major and systematic magnitude biases in our catalog, although this claim is difficult to check without independent magnitude determinations. A detailed analysis of magnitudes is beyond the scope of this report but will be the subject of future efforts. Figures $7 A$ and $7 C$ suggest that MilneShaw magnitudes generally agree with those derived external to our catalog over a wide magnitude range. This result gives us confidence that our assumption of an absolute magnitude scale based on station constants and correction to Wood-Anderson response is correct.

The nomogram magnitudes based on HVO's Bosch-Omori seismometer should show a larger scatter because they are based on "average" amplitudes for a size class rather than on a specific amplitude. The nomogram magnitude should be unbiased, at least in the range $M=3.5-5.0$ where it was empirically calibrated against local Wood-Anderson magnitudes. The Milne-Shaw is the only numerous and stable magnitude to serve as a comparison basis for the nomogram magnitude. Figure $7 B$ shows no systematic deviation of nomogram magnitude for Kilauea earthquakes. As expected, the minimum magnitudes of events assigned to the largest open-ended "strong" class (arrowed symbols, fig. 7B) fall below the equality line because of the minimum amplitude assumed. Many magnitudes of larger earthquakes recorded as "moderate" or "strong" on the Bosch-Omori seismometer may be underestimates because the smoked-paper recording of mechani- 
cal pens does not permit accurate tracking of amplitudes at the largest excursions. Nomogram magnitudes of non-Kilauea earthquakes generally exceed their Milne-Shaw magnitudes for $M<4.5$ (fig. 7D), a point that we are still investigating.

More than 5,000 earthquakes are listed in the 1933-59 cata$\log$. The number of earthquakes by magnitude for both of the 27year catalogs is listed in table 12, and the logarithm of the number of earthquakes versus magnitude for both catalogs is plotted in figure 10. Both figure 10 and table 12 include earthquakes from all regions, including those with unknown locations. For the Island of Hawaii, the magnitude distribution's deviation from the Gutenberg-Richter law indicates that the 1933-59 catalog is probably complete for $M \geq 3.9$, whereas the 1960-86 catalog is probably complete at $M=2.4$. The completeness magnitudes and $b$ slope vary regionally, and these plots are useful only in a gross sense of assessing our catalog.

It is unwise to draw conclusions about the comparative level of activity strictly from figure 10 and table 11 , which are like the shadow of an object that reveals a hint of shape but nothing about its structure. All regions are summed together, including off shore, and each region has its own time behavior and completeness level. The listing of earthquakes of $M \geq 4$ should be approximately complete for onshore Hawaii in both catalogs. The numbers of $M \geq 4$ events in the two catalogs are comparable (440 versus 514). Even with the errors and biases that we are still investigating, our catalog will be useful for the stated goals of earthquake-hazard assessment and understanding volcano behavior, using the pattern of seismic release.

\section{Acknowledgments}

Fred Klein read the Honolulu records, derived the equations used to calculate magnitude from seismogram amplitudes and from amplitude classes, and derived the constants and corrections in those equations, following the principles established by Richter (1958). He also developed the catalog format to match the computerized ASCII catalog of modern earthquakes and wrote a program to read comma-delimited output from spreadsheets maintained on a PC. Tom Wright measured the distances at azimuths reported in the Volcano Letter, assigned the Kilauea earthquakes to regions initially developed to study the moment history of Kilauea seismicity (Wright and Klein, 1995), and calculated latitude and longitude from azimuth and distance where not reported directly. He set up computer-based spreadsheets on which he entered all the information from the Honolulu records, HVO publications, and felt information from newspaper accounts, the Lyman diary, and postcards sent to HVO. The nomogram for calculating magnitudes from amplitude classes published in the Volcano Letter was jointly derived through several iterations of plotting. Both authors developed standards for choosing the best data to determine location and magnitude and laboriously applied them to the incomplete and sometimes-contradictory earthquake data.

We are indebted to Jerry Eaton for directing us to the Honolulu seismograms and for information about the early HVO network and the procedures used to determine magnitudes. He also summarized the early seismographic and station history that we incorporated into table 2. Jennifer Nakata, with the assistance of HVO volunteers, provided copies of the felt reports sent to HVO on postcards. Jerry Eaton and John Lahr reviewed the manuscript and made many suggestions for its improvement.

We are gratefully indebted to Doak C. Cox for making available unpublished intensities of earthquakes derived from the Lyman and other diaries. We thank Kent Warshauer, HVO volunteer, for allowing us to see and copy his file of newspaper references, many of which contained reports of earthquakes.

His files demonstrated the necessity of using newspaper data in our location estimates and magnitude assignments. We followed up on his work by spending many additional hours looking at newspapers on microfilm.

\section{References Cited}

Abe, K., 1988, Magnitudes and origin times from Milne seismograph data; earthquakes in China and California, 1898-1912, in Lee, W.H.K., Meyers, H., and Shimazaki, K., eds., Historical seismograms and earthquakes of the world: San Diego, Calif., Academic Press, p. 37-50.

Alexander, W.D., 1899, The seismograph: Pacific Commercial Advertiser, July 18, 1899, p. 1.

Bevens, D., and transcriber, 1988, Volcano House Register, 1865-1955: Hawaii Volcanoes National Park Library record, 10 v., with supp. of newspaper clippings [transcription funded by Hawaii Natural History Association; available for research use at the libraries of the Hawaiian Volcano Observatory and Hawaii Volcanoes National Park].

Bevens, D., Takahashi, T.J., and Wright, T.L., eds., 1988, The early serial publications of the Hawaiian Volcano Observatory: Hawaii National Park, Hawaii Natural History Association, $3 \mathrm{v}$.

Bodle, R.R., 1944, Hawaiian Islands, in United States earthquakes, 1942: U.S. Coast and Geodetic Survey report, serial no. 662, p. 16 [compiled as "United States Earthquakes, 1941-1945," and reissued by the National Earthquake Information Center].

1945, Hawaiian Islands, in United States earthquakes, 1943: U.S. Coast and Geodetic Survey report, serial no. 672, p. 20 [compiled as “United States Earthquakes, 1941-1945," and reissued by the National Earthquake Information Center].

1946, Hawaiian Islands, in United States earthquakes, 1944: U.S. Coast and Geodetic Survey report, serial no. 682, p. 24 [compiled as "United States Earthquakes, 1941-1945," and reissued by the National Earthquake Information Center].

Bodle, R.R., and Murphy, L.M., 1947, Hawaiian Islands, in United States earthquakes, 1945: U.S. Coast and Geodetic Survey report, serial no. 699, p. 18 [compiled as "United States Earthquakes, 1941-1945," and reissued by the National Earthquake Information Center].

_1948, Hawaiian Islands, in United States earthquakes, 1946: U.S. Coast and Geodetic Survey report, serial no. 714, p. 22.

Brazee, R.J., and Cloud, W.K., 1958, Hawaiian Islands, in United States earthquakes, 1956: U.S. Coast and Geodetic Survey report, p. 36-37.

-1959, Hawaiian Islands, in United States earthquakes, 1957: U.S. Coast and 
Geodetic Survey report, p. 42-43.

1960, Hawaiian Islands, in United States earthquakes, 1958: U.S. Coast and Geodetic Survey report, p. 34.

Cox, D.C., 1986, Earthquakes felt on Oahu, Hawaii and their intensities: Honolulu, University of Hawaii, Environmental Center, 120 p.

Dana, J.D., 1888, History of the changes in the Mt. Loa craters, on Hawaii: American Journal of Science, 3d ser., v. 35, p. 15-34, 213-228, 282-289 [includes maps]; v. 36, p. 14-32, 81-112, 167-175 [includes maps].

Eaton, J.P., 1975, Harmonic magnification of the complete telemetered seismic system, from seismometer to film viewer screen: U.S. Geological Survey Open-File Report 75-95, 46 p.

Eaton, J.P., and Fraser, G.D., 1956a, Hawaiian Volcano Observatory summary, 03July-September 1956: U.S. Geological Survey Administrative Report, 5 p.

1956b, Hawaiian Volcano Observatory summary, 04-October-December 1956: U.S. Geological Survey Administrative Report, 5 p.

1957a, Hawaiian Volcano Observatory summary, 05-January to March 1957: U.S. Geological Survey Administrative Report, 12 p.

1957b, Hawaiian Volcano Observatory summary, 06-April-June 1957: U.S. Geological Survey Administrative Report, 10 p.

_ 1957c, Hawaiian Volcano Observatory summary, 07-July-September 1957: U.S. Geological Survey Administrative Report, 8 p.

-1957d, Hawaiian Volcano Observatory summary, 08-October-December 1957: U.S. Geological Survey Administrative Report, 6 p.

1958a, Hawaiian Volcano Observatory summary, 09-January to March 1958: U.S. Geological Survey Administrative Report, 8 p.

-1958b, Hawaiian Volcano Observatory summary, 10-April-June 1958 : U.S. Geological Survey Administrative Report, 9 p.

Eaton, J.P., and Krivoy, H.L., 1958a, Hawaiian Volcano Observatory summary, 11-JulySeptember 1958: U.S. Geological Survey Administrative Report, 13 p.

1958b, Hawaiian Volcano Observatory summary, 12-October-December 1958: U.S. Geological Survey Administrative Report, 8 p.

1963a, Hawaiian Volcano Observatory summary, 13-January-March 1959: U.S. Geological Survey Administrative Report, 26 p.

-1963b, Hawaiian Volcano Observatory summary, 14-April-June 1959: U.S. Geological Survey Administrative Report, 25 p.

1963c, Hawaiian Volcano Observatory summary, 15-July-September 1959: U.S. Geological Survey Administrative Report, 32 p.

Eppley, R.A., and Cloud, W.K., 1961, Hawaiian Islands, in United States earthquakes, 1959: U.S. Coast and Geodetic Survey report, p. 60-61.

Finch, R.H., and Macdonald, G.A., 1951, Report of the Hawaiian Volcano Observatory for 1948 and 1949: U.S. Geological Survey Bulletin 974-D, p. 103133.

1953, Hawaiian volcanoes during 1950: U.S. Geological Survey Bulletin 996-B, p. 27-89.
Fiske, R.S., Simkin, T., and Nielsen, E.A., eds., 1987, The Volcano Letter: Washington, D.C., Smithsonian Institution Press, 539 p. [compiled and reprinted; originally published $1925-1955$ by the Hawaiian Volcano Observatory].

Furumoto, A.S., Nielsen, N.N., and Phillips, W.R., 1972, A study of past earthquakes, isoseismic zones of intensity, and recommended zones for structural design for Hawaii: Honolulu, University of Hawaii Engineering Bulletin, PACE 72033, 53 p. [Joint report with the Center for Engineering Research, with minor corrections (notably tables 1 and 2, and figures 3 and 6 ) and additions to the text (two appendixes); originally issued by the University of Hawaii, Center for Engineering Research, as Engineering Bulletin, PACE 72033, June 15, 1972, under the same authorship].

Glover, D.P., Meyers, H., Herrmann, R.B., and Whittington, M., 1985, Inventory of filmed historical seismograms and station bulletins at World Data Center A: Boulder, Colo., U.S. Department of Commerce, National Oceanic and Atmospheric Administration Report SE-37, $215 \mathrm{p}$.

Gutenberg, Beno, and Richter, C.F., 1945, Seismicity of the Earth: Geological Society of America Bulletin, v. 56 supp., p. 644-645.

Hazard, D.L., 1910, Earthquakes, in Results of observations made at the Coast and Geodetic Survey magnetic observatory near Honolulu, Hawaii, 1905 and 1906: U.S. Coast and Geodetic Survey, p. 90-95.

1911, Earthquakes, in Results of observations made at the Coast and Geodetic Survey magnetic observatory near Honolulu, Hawaii, 1907 and 1908: U.S. Coast and Geodetic Survey, p. 90-94 [see abstract for Hazard (1910)].

1912, Earthquakes, in Results of observations made at the Coast and Geodetic Survey magnetic observatory near Honolulu, Hawaii, 1909 and 1910: U.S. Coast and Geodetic Survey, p. 90-94 [see abstract for Hazard (1910)].

1913, Earthquakes, in Results of observations made at the Coast and Geodetic Survey magnetic observatory near Honolulu, Hawaii, 1911 and 1912: U.S. Coast and Geodetic Survey, p. 94-98 [see abstract for Hazard (1910)].

-1916, Earthquakes, in Results of observations made at the Coast and Geodetic Survey magnetic observatory near Honolulu, Hawaii, 1913 and 1914: U.S. Coast and Geodetic Survey, serial no. 21, p. 98-104 [see abstract for Hazard (1910)].

-1918, Earthquakes, in Results of observations made at the Coast and Geodetic Survey magnetic observatory near Honolulu, Hawaii, 1915 and 1916: U.S. Coast and Geodetic Survey, serial no. 86, p. 95-100 [see abstract for Hazard (1910)].

1920, Earthquakes, in Results of observations made at the Coast and Geodetic Survey magnetic observatory near Honolulu, Hawaii, 1917 and 1918: U.S. Coast and Geodetic Survey, serial no. 133, p. 97-103 [see abstract for Hazard (1910)].

-1922, Earthquakes, in Results of observations made at the Coast and Geodetic Survey magnetic observatory near Honolulu, Hawaii, 1919 and 1920: U.S. Coast and Geodetic Survey, serial no. 200, p. 91-96 [see abstract for Hazard (1910)].

1924, Earthquakes, in Results of observations made at the Coast and Geodetic Survey magnetic observatory near Honolulu, Hawaii, 1921 and 1922: U.S. Coast and Geodetic Survey, serial no. 276, p. 93-104. 
Heck, N.H., and Bodle, R.R., 1930, Hawaiian Islands, in United States earthquakes, 1928: U.S. Coast and Geodetic Survey report, serial no. 483, p. 3 [This series takes up where the quarterly seismological reports of the U.S. Coast and Geodetic Survey leave off. Station data are omitted from the "United States Earthquakes" series but were preserved as monthly mimeographed reports made available by subscription].

Heck, N.H., and Bodle, R.R., 1931, Hawaiian Islands, in United States earthquakes, 1929: U.S. Coast and Geodetic Survey report, serial no. 511, p. 16.

Hitchcock, C.H., 1909, Hawaii and its volcanoes: Honolulu, Hawaiian Gazette Co., 314 p. [2d ed., with supp., 1911, 314 p.].

Humphreys, W.J., 1914, Seismology, in Marvin, C.F., ed., Section V-Seismology: Monthly Weather Review, v. 42, no. 12, p. 687-689 [no data for Honolulu given in this issue].

1924, Seismology, in Marvin, C.F., ed., Section V-Seismology: Monthly Weather Review, v. 52, no. 7, p. 375 [The "Seismology" section was discontinued, coincident with the end of the biannual Coast and Geodetic Survey Reports (see Hazard, 1929)].

Jaggar, T.A., Jr., 1912, [Kilauea in 1909-1912], in [First Special] Report of the Hawaiian Volcano Observatory: Boston, Massachusetts Institute of Technology, Society of Arts, p. 1-74 [compiled and reprinted in Bevens, D., Takahashi, T.J., and Wright, T.L., 1988, The early serial publications of the Hawaiian Volcano Observatory: Hawaii National Park, Hawaii Natural History Association, v. 1, p. 1-80].

1947, Origin and development of craters: Geological Society of America Memoir 21, 508 p.

Jones, A.E., 1934, Earthquakes associated with the 1933 eruption of Mauna Loa, Hawaii: Washington Academy of Sciences Journal, v. 24, p. 413-418.

1935a, Earthquakes associated with the 1934 eruption of Kilauea, Hawaii: Washington Academy of Sciences Journal, v. 25, p. 429-435.

1935b, Hawaiian travel times: Seismological Society of America Bulletin, v. 25, p. 33-61.

-1935c, A seismologic study of the Kilauea eruption, 1931-1932: University of Hawaii Research Publication 9, 60 p.

1938, Empirical studies of some of the seismic phenomena of Hawaii: Seismological Society of America Bulletin, v. 28, p. 313-337.

Klein, F.W., and Koyanagi, R.Y., 1980, Hawaiian Volcano Observatory seismic network history 1950-1979: U.S. Geological Survey Open-File Report 80-302, $84 \mathrm{p}$.

Lee, W.H.K., Meyers, H., and Shimazaki, K., 1988, Historical seismograms and earthquakes of the world: San Diego, Calif., Academic Press, 513 p.

Macdonald, G.A., 1955, Hawaiian volcanoes during 1952: U.S. Geological Survey Bulletin 1021-B, p. 15-107.

Macdonald, G.A., and Eaton, J.P., 1955, Hawaiian volcanoes during 1953: U.S. Geological Survey Bulletin 1021-D, p. 127-166.

1956a, Hawaiian Volcano Observatory summary 01-January to March 1956: U.S. Geological Survey Administrative Report, 5 p. -1956b, Hawaiian Volcano Observatory summary 02-April-June 1956: U.S. Geological Survey Administrative Report, 5 p.

1957, Hawaiian volcanoes during 1954: U.S. Geological Survey Bulletin 1061-B, p. 17-72.

1964, Hawaiian volcanoes during 1955: U.S. Geological Survey Bulletin 1171, p. 1-170.

Macdonald, G.A., and Wentworth, C.K., 1954, Hawaiian volcanoes during 1951: U.S. Geological Survey Bulletin 996-D, p. 141-216.

McFarland, W.N., 1929, Earthquakes, in Results of observations made at the Coast and Geodetic Survey magnetic observatory near Honolulu, Hawaii, 1923 and 1924: Washington, DC, Department of Commerce and Labor, Coast and Geodetic Survey, serial no. 452, p. 99-104 [See abstract for Hazard, (1924). This series of reports ends with June 1924; subsequent data are in quarterly seismological reports (Neumann, 1926-31)].

Murphy, L.M., 1950, Hawaiian Islands, in United States earthquakes, 1947: U.S. Coast and Geodetic Survey report, serial no. 730, p. 29.

Murphy, L.M., and Cloud, W.K., 1953, Hawaiian Islands, in United States earthquakes, 1951: U.S. Coast and Geodetic Survey report, serial no. 762, p. 18-20.

1954, Hawaiian Islands, in United States earthquakes, 1952: U.S. Coast and Geodetic Survey report, serial no. 773, p. 48-49.

-1955, Hawaiian Islands, in United States earthquakes, 1953: U.S. Coast and Geodetic Survey report, serial no. 785, p. 27-29.

1956, Hawaiian Islands, in United States earthquakes, 1954: U.S. Coast and Geodetic Survey report, serial no. 793, p. 55-56.

1957, Hawaiian Islands, in United States earthquakes, 1955: U.S.

Coast and Geodetic Survey report, p. 36-38.

Murphy, L.M., and Ulrich, F.P., 1951, Hawaiian Islands, in United States earthquakes, 1948: U.S. Coast and Geodetic Survey report, serial no. 746, p. 27.

1952, Hawaiian Islands, in United States earthquakes, 1950: U.S. Coast and Geodetic Survey report, serial no. 755, p. 18.

Neumann, F., 1926a, Seismological report; January, February, March, 1925: U.S. Coast and Geodetic Survey, Serial no. 328, p. 20-24, 42-43 [This series of reports is the successor to the biannual seismology summaries published by the U.S. Coast and Geodetic survey (see Hazard, 1910-13, 1916, 1918, 1920, 1922, 1924; McFarland, 1929)].

1926b, Seismological report: July, August, September, 1925: U.S. Coast and Geodetic Survey, serial no. 328, p. 20-24, 42-43.

1927, Seismological report: October, November, December, 1925 and supplement for 1924: U.S. Coast and Geodetic Survey, serial no. 388 , p. 9, 33-38, 56-57, 97-103 [covers July 1-December 31, 1924 in addition to the fourth quarter of 1925].

1928a, Seismological report: April, May, June, 1926: U.S. Coast and Geodetic Survey, serial no. 406, p. 5-6, 9-11, 31-39, 53, 55-56.

1928b, Seismological report: July, August, September, 1926: U.S. Coast and Geodetic Survey, serial no. 424, p. 5, 7, 32-46, 67, 69. 
-1928c, Seismological report: October, November, December, 1926:

U.S. Coast and Geodetic Survey, serial no. 431, p. 18, 44-53.

1929, Seismological report: January, February, March, 1927: U.S. Coast and Geodetic Survey, serial no. 463, p. 8, 13, 34-37, 75.

1930a, Seismological report: April, May, June, 1927: U.S. Coast and Geodetic Survey, serial no. 468, p. 6, 26-29, 40, 42-43.

1930b, Seismological report: July, August, September, 1927: U.S. Coast and Geodetic Survey, serial no. 495, p. 5-7, 12, 31-38, 53-56.

1931, Seismological report: October, November, December, 1927: U.S. Coast and Geodetic Survey, serial no. 503, p. 24-25, 41-42 [This issue ends formal publication of the results of the magnetic observatories run by the U.S. Coast and Geodetic Survey. Subsequent material is abstracted for the "United States Earthquakes" series (see Heck and Bodle, 1930), published yearly without the detailed readings for each earthquake. These reports were mimeographed and made available to interested parties by subscription].

1932, Hawaiian Islands, in United States earthquakes, 1931: U.S. Coast and Geodetic Survey report, serial no. 553, p. 22.

1934, Hawaiian Islands, in United States earthquakes, 1932: U.S. Coast and Geodetic Survey report, serial no. 563, p. 18.

1935, Hawaiian Islands, in United States earthquakes, 1933: U.S. Coast and Geodetic Survey report, Serial no. 579, p. 22.

1936, Hawaiian Islands, in United States earthquakes, 1934: U.S. Coast and Geodetic Survey report, serial no. 593, p. 40.

1937, Hawaiian Islands, in United States earthquakes, 1935: U.S. Coast and Geodetic Survey report, serial no. 600, p. 39.

1938, Hawaiian Islands, in United States earthquakes, 1936: U.S. Coast and Geodetic Survey report, serial no. 610, p. 24 [compiled as "United States Earthquakes, 1936-1940," and reissued by the National Earthquake Information Center].

1940, Hawaiian Islands, in United States earthquakes, 1938: U.S. Coast and Geodetic Survey report, serial no. 629, p. 28-30 [compiled as "United States Earthquakes, 1936-1940," and reissued by the National Earthquake Information Center].

1941, Hawaiian Islands, in United States earthquakes, 1939: U.S. Coast and Geodetic Survey report, serial no. 637, p. 29 [compiled as "United States Earthquakes, 1936-1940," and reissued by the National Earthquake Information Center].

-1942, Hawaiian Islands, in United States earthquakes, 1940: U.S. Coast and Geodetic Survey report, serial no. 647, p. 32-33 [compiled as "United States Earthquakes, 1936-1940," and reissued by the National Earthquake Information Center].

1943, Hawaiian Islands, in United States earthquakes, 1941: U.S. Coast and Geodetic Survey report, serial no. 655, p. 21-22 [compiled as "United States Earthquakes, 1941-1945," and reissued by the National Earthquake Information Center].

Neumann, F., and Bodle, R.R., 1932, Hawaiian Islands, in United States earthquakes, 1930: U.S. Coast and Geodetic Survey report, serial no. 539, p. 15.
Neumann, F., and Service, J.H., 1926, Seismological report; April, May, June, 1925: U.S. Coast and Geodetic Survey, serial no. 337, p. 20-26.

1927, Seismological report; January, February, March, 1926: U.S. Coast and Geodetic Survey, serial no. 395, p. 5-8, 27-31, 45-47.

Pacific Commercial Advertiser, 1913, Instruments broken by quake; Professor Jaggar, from Kilauea, tells of Earth tremors that awakened Hilo-people of other islands asked to send in reports whether or not they felt the shocks: November 3, 1913, p. 9 [reprinted in Bevens and others, 1988, v. 2, p. 64].

Reid, H.F., 1905, Records of seismographs in North America and the Hawaiian Islands: Terrestrial Magnetism and Atmospheric Electricity, v. 10, no. 2 , p. 81-96; no. 4, p. 177-189.

1906, Records of seismographs in North America and the Hawaiian Islands: Terrestrial Magnetism and Atmospheric Electricity, v. 11, no. 4, p. 185-187 [The first two papers of this series appeared in this journal for June and December 1905 (v. 10, p. 81 and 177, respectively)].

Richter, C.F., 1958, Elementary seismology: San Francisco, W.H.Freeman, 768 p.

Stover, C.W., and Coffmann, J.L., 1993, Seismicity of the United States, 1568-1989 (revised): U.S. Geological Survey Professional Paper 1527, p. 201-213.

Takahashi, T.J., and Wright, T.L., 1987, Staff of the Hawaiian Volcano Observatory, 1912-present, chap. 62 of Decker, R.W., Wright, T.L., and Stauffer, P.H., eds., Volcanism in Hawaii: U.S. Geological Survey Professional Paper 1350, v. 2, p. 1645-1662.

Wood, H.O., 1915a, The seismic prelude to the 1914 eruption of Mauna Loa: Seismological Society of America Bulletin, v. 5, p. 39-51.

-1915b, Systematic report of the Whitney Laboratory of Seismology: Hawaiian Volcano Observatory Seismometric Bulletin, v. 1, no. 1-4.

1917a, [no title]: Pasadena, Calif., H.O. Wood archives, unpub. earthquake catalog [Hawaii], September 1915-June 1917, [unpag.] 228 p.

1917b, On cyclical variations in eruption at Kilauea, in Second Special Report of the Hawaiian Volcano Observatory: Cambridge, Massachusetts Institute of Technology, 59 p. [compiled and reprinted in Bevens, D., Takahashi, T.J., and Wright, T.L., 1988, The early serial publications of the Hawaiian Volcano Observatory: Hawaii National Park, Hawaii Natural History Association, v. 1, p. 81-143].

Wright, T.L., and Klein, F.W., 1995, Seismic moment history of Kilauea Volcano, Hawaii, 1933-1975 [abs.]: Eos (American Geophysical Union Transactions), supp., v. 76, no. 46, p. F681-682.

Wright, T.L., and Takahashi, T.J., 1998, Hawaii bibliographic database: Bulletin of Volcanology, v. 59, no. 4, p. 276-280.

Wyss, M., and Koyanagi, R.Y., 1992, Isoseismal maps, macroseismic epicenters, and estimated magnitudes of historical earthquakes in the $\mathrm{Ha}$ waiian Islands: U.S. Geological Survey Bulletin 2006, 93 p.

Wyss, M., Koyanagi, R.Y., and Cox, D.C., 1992, The Lyman Hawaiian earthquake diary, 1833-1917: U.S. Geological Survey Bulletin 2072, 34 p.

Zuniga, F.R., Wyss, M., and Scherbaum, F., 1988, A moment-magnitude relation for Hawaii: Seismological Society of America Bulletin, v. 78, no. 1, p. 370-373. 


\section{Appendix 1. Files Available on the Accompanying CD-ROM}

The accompanying CD-ROM is in ISO 9660 level 2 format (PC, Macintosh, Unix) and contains the following files and formats. The earthquake-catalog files are stored in native Excel format for use by persons with PC or Macintosh workstations, as comma-delimited text files and fixed-column ASCII files for other programs or computers, and in formatted tables in PDF and PostScript formats. A bibliographic file is available in ASCII EndNote format and as a text file. Information is complete for files covering the period 1903-59 for which instrumental records are available. We are working on a noninstrumental catalog covering the period 1823-1903, a preliminary version of which is on the CD-ROM. These files will be posted online. Catalog filenames consist of a base name indicating the time period, and a file extension indicating the platform and format. For example, "1903-1921cat.xls" is that part of the catalog in PC Excel format. More details including system requirements and software versions are given in the file 1_README.TXT on the CD-ROM.
Table 14. Column headings and formatting for ASCII catalog data [HST, Hawaii standard time. Do., ditto]

\begin{tabular}{|c|c|c|}
\hline Columns & Format & Data \\
\hline $1-8$ & $\mathrm{I} 4,2 \mathrm{I} 2,1 \mathrm{X}$ & Year, month, and day, HST. \\
\hline $10-13$ & $2 \mathrm{I} 2$ & Hour and minute, HST. \\
\hline $14-19$ & F6.2 & Origin time (seconds). \\
\hline $20-22$ & F3.0, $1 \mathrm{X}$ & Latitude (degrees). \\
\hline $24-28$ & F5.2 & Latitude (minutes). \\
\hline $29-32$ & $\mathrm{~F} 4.0,1 \mathrm{X}$ & Longitude (degrees). \\
\hline $34-38$ & F5.2 & Longitude (minutes). \\
\hline $39-45$ & F7.2 & Depth, in kilometers. \\
\hline 46 & $1 \mathrm{X}$ & --- \\
\hline 47 & A1 & Preferred magnitude-type code. \\
\hline $48-52$ & F5.2 & Preferred magnitude. \\
\hline $53-55$ & $\mathrm{I} 3$ & Unused. \\
\hline $56-58$ & $\mathrm{I} 4$ & Year, including century. \\
\hline $60-64$ & F5.1 & Unused. \\
\hline $65-69$ & F5.2 & Do. \\
\hline $70-74$ & F5.1 & Do. \\
\hline $75-79$ & F5.1 & Do. \\
\hline 80 & A1 & $\begin{array}{l}\text { Remark: “*” if lat/long assigned as } \\
\text { region center }\end{array}$ \\
\hline 81 & A1 & $\begin{array}{l}\text { Remark: "?" if region assignment is } \\
\text { questionable }\end{array}$ \\
\hline 82 & $\mathrm{~A} 1,13 \mathrm{X}$ & Remark: Unused. \\
\hline $84-86$ & A3 & Geographic-region code. \\
\hline
\end{tabular}

\title{
Earthquake-catalog filenames
}

Base filename
1823-1903cat
1903-1921cat
1921-1932cat
1933-1959cat
1959-1963cat
Appendix table1

1823-1903: all earthquakes- Description
1903-21: all earthquakes-
1921-32: all earthquakes-
1933-59: all earthquakes-
1959-63: earthquakes with new magnitude information-
1903-59: M $\geq 4.0$ earthquakes -

Status

In process. Complete. Complete. Complete. Complete. Complete.

\section{Filename extensions and platforms}

$\begin{array}{cl}\text { Filename extension } & \text { Directory } \\ \text { csv } & \text { csv } \\ \mathrm{H} 72 & \mathrm{H} 72 \\ \text { exl } & \text { mac } \\ \text { xls } & \text { pc } \\ \text { pdf } & \text { pdf } \\ \text { ps } & \text { postscript }\end{array}$

\author{
ASCII, comma-delimited fields. \\ Platform and format \\ ASCII, fixed columns, hypo71-2000 format (see table 14). \\ Microsoft Excel, Macintosh platform. \\ Microsoft Excel 2000, PC-windows platform. \\ Adobe Acrobat, multiplatform, formatted table. \\ PostScript printer file, UNIX or other workstation (Adobe illustrator compatible)
}

\section{Bibliographic files in the bib directory}

Filename

Eqbibi.txt

Eqbibf.txt

eqpcardi.txt

eqpcardf.txt
Description

Newspaper and other accounts of felt earthquakes do- felt reports sent to $\mathrm{HVO}$
Format ASCII, importable by EndNote software. ASCII text, bibliographic format. ASCII, importable by EndNote software. ASCII text, bibliographic format.

\section{Honolulu readings}

$\begin{gathered}\text { Base filename } \\ \text { Honmilne } \\ \text { Honm-s } \\ \text { Hon59-63 }\end{gathered}$

Base filename

Hon59-63
Status

Milne seismometer readings, 1903-21

Milne-Shaw seismometer readings, 1921-59 Complete. Complete. Complete. 
Table 13 shows a useful portion of our catalog, listing all 1903-1959 earthquakes of $M \geq 4.0$, representing our best-determined magnitude range.

Table 14 shows the formatting of the ASCII files for use on mainframe computers, designed for consistency with the post-1959 earthquake catalog. The latitude and longitude are normally from the Volcano Letter or the original source. If no coordinates were assigned but a region was inferred, the latitude and longitude are the center of the region, and a "*" remark is entered in column 78. The format specifications are for format statements in the FORTRAN language: $\mathrm{I}$ is a rightaligned integer, $\mathrm{A}$ is an alphanumeric, and Fm.n is a real number in $m$ columns with $n$ decimal places.

\section{Appendix 2. Calculation of a "Characteristic" Amplitude for HVO Earthquake Classes}

The "average" or "moment preserving" magnitude in a range of magnitudes for a given magnitude class is derived as follows. Moment $(\mathbf{M})$ is related to magnitude $(M)$ by a relation of the form

$$
\log \mathbf{M}=c+d M
$$

For Hawaii, we use the relation of Zuniga and others (1988):

$$
\log \mathbf{M}=16.59+1.1 M
$$

We also use the Gutenberg-Richter law:

$$
\log N=A-b M
$$

where $N$ is the number of earthquakes of magnitude $M$ or larger. Its differential form is

$$
\log n=a-b M,
$$

where $n$ is the number of events in a small interval $d M$. Then, $10^{A} \mathrm{~b}$ ln $10=10^{a}$. Let $\mathbf{M}_{\text {avg }}$ be the average moment of events between $\mathbf{M}_{1}$ and $\mathbf{M}_{2}$. Let $M_{\text {avg }}$ be the "average" magnitude of events between $M_{1}$ and $M_{2}$. Let $D M=M_{2}-M_{1} . \mathbf{M}_{\text {avg }}$ and $M_{\text {avg }}$ are related by the equation above. The total moment $\mathbf{M}_{\mathrm{t}}$ of events between $M_{1}$ and $M_{2}$ is given by

$$
\mathbf{M}_{\mathrm{t}}=\int_{M_{1}}^{M_{2}} \mathbf{M}(M) n(M) d M .
$$

The total number of events between $M_{1}$ and $M_{2}$ is given by

$$
N_{1}-N_{2}=10^{A}\left(10^{-b M_{1}}-10^{-b M_{2}}\right) .
$$

The average moment of an event in the magnitude range is the ratio of the two above equations:

$$
\mathbf{M}_{\mathrm{avg}}=\mathbf{M}_{1} \frac{-b}{d-b} \frac{10^{(d-b) D M}-1}{10^{-b D M}-1} .
$$

This average moment then yields the "average" magnitude and "average" amplitude for the size class.

\section{Appendix 3. Errors and Uncertainties}

The qualitative magnitude class of most, if not all, earthquakes originating beneath Hualalai Volcano was apparently referenced to distances from the much closer Kona seismometer, which had the same magnification as the Whitney seismometer. Magnitudes calculated from the nomogram using the Kona distance are consistent with magnitudes measured in Honolulu, whereas if the Whitney distance is assumed, nomogram magnitudes are consistently too high. Some smaller events have nomogram magnitudes of a size that should have been detected in Honolulu if the Whitney distance is assumed, but calculate to well below $M=4.0$ if the Kona distance is assumed. This discrepancy is particularly vexing because nowhere in the earthquake tabulations in the Volcano Letter is it stated that anything other than the Whitney seismometer was used, until 1951, when both Kona and Whitney qualitative classes were reported. Our preferred magnitudes are based either on the Honolulu determination or on an assumed distance from Kona, as noted in our catalog.

Epicentral locations and magnitude classes reported in the Volcano Letter agree surprisingly well with the magnitudes recorded in Honolulu and with modern understanding of the distribution of earthquakes at Kilauea. Note that the Honolulu and HVO nomogram magnitude scales were derived independently. We note two exceptions to this agreement. First, in May and August 1938, earthquake swarms were reported as occurring in the upper east rift and eastern Koae Fault Zone. In the modern era, earthquakes in these areas rarely exceed $M=3$. Empirically, we find that even strong earthquakes at shallow $(<5 \mathrm{~km})$ depths are not recorded on Oahu. However we find that many events at depths characteristic of Kilauea's south flank or Mauna Loa's Kaoiki Fault Zone (approx $10 \mathrm{~km}$ ) are recorded on Oahu. We recorded several events on Oahu during the period covered by the two 1938 swarms, some at times not given in the Volcano Letter. We conclude that these "extra" 1938 events were significantly deeper than earthquakes in well-located modern rift swarms. We consider two possibilities, which we will evaluate in subsequent papers: (1) a south flank response to rift intrusion, consistent with what we have seen at Kilauea in the modern era, or (2) deep (20-35 km) "magma supply" earthquakes, also well defined in the modern era as having followed certain eruption/intrusion sequences (Wright and Klein, 1995).

Second, on March 7, 1955, a series of strong earthquakes was reported in the Volcano Letter as being on Kilauea's East Rift Zone near Heiheiahulu. These earthquakes were relocated and reported by Macdonald and Eaton (1964) as being near Kalapana, on Kilauea's south flank. The appearance of earthquakes under both the East Rift Zone and the south flank on modern seismographs is generally similar, and it is easy to see how events recorded on older seismographs could be confused.

The apparent discrepancy between the earthquakes described by HVO before the modern network as being located under rift systems but larger relative to modern flank earth- 
quakes could result from early misconceptions. First, our prejudices of where the earthquake "should" be located can be made consistent with the poor ability of HVO to locate with one or two low-gain stations. Second, the concept of large earthquakes under the mobile volcano flanks is a modern one. Many early reports favored the rift systems as fault lines and a natural source of earthquakes, and so it is natural to suspect them as the origin of most earthquakes.

Depths are far more uncertain. In our magnitude calculations, we use a depth of $9 \mathrm{~km}$ where none is reported in the Volcano Letter, indicated by no entry in the "Depth given" column of our catalog. Except for the Kilauea Caldera area, we believe that the only depth discrimination resolvable with the pre-1959 seismic network was between crustal earthquakes (typically, 5-12-km depth) and upper-mantle earthquakes (typically, 30-40-km depth). We guess the typical depth error might be 20 to $25 \mathrm{~km}$, and so crust and mantle earthquakes are not always separable. Near Kilauea Caldera, greater depth resolution is generally possible because of the proximity of the epicenter to the recording station. For such events, the slant distance used in the magnitude calculation depends far more on depth than on horizontal distance from the Whitney vault. Some earthquakes reported as shallow were both widely felt and recorded on Oahu. This combination is not by itself sufficient to prove that an earthquake is deep. We also take into account the calculated magnitude in our evaluation of depth. For example, moderate earthquakes that are widely felt are more likely to be deep than large earthquakes that would be widely felt and recorded no matter what their depth. Earthquakes for which we believe that the reported depth is in error are recognized by differences in the "Depth given" and "Depth preferred" columns of our catalog, and also noted in the "Comment" column. Particularly for larger earthquakes beneath or close to Kilauea Caldera, depth can be estimated from matching a calculated nomogram magnitude with an independent determination of magnitude made in Honolulu. 


\begin{tabular}{|c|c|c|c|c|c|c|c|c|c|c|c|c|c|c|c|c|c|c|c|c|c|c|c|c|}
\hline Date & $\begin{array}{l}\text { Time } \\
\text { (HST) }\end{array}$ & $\begin{array}{c}\text { Lat } \\
(\mathrm{deg})\end{array}$ & $\begin{array}{c}\text { Lat } \\
(\mathrm{min})\end{array}$ & $\begin{array}{l}\text { Lon } \\
(\mathrm{deg})\end{array}$ & $\begin{array}{l}\text { Lon } \\
(\min )\end{array}$ & Region & $\begin{array}{l}\text { Publ. } \\
\text { Depth }\end{array}$ & $\begin{array}{l}\text { Pref. } \\
\text { Depth }\end{array}$ & $\begin{array}{l}\text { Publ. } \\
\text { Dist. }\end{array}$ & $\begin{array}{c}\text { Calc. } \\
\text { Dist }\end{array}$ & $\begin{array}{c}\text { Slant } \\
\text { dist }\end{array}$ & Mag class & $\begin{array}{c}\mathrm{M} \\
\text { nomo }\end{array}$ & $\begin{array}{c}\text { M M-S } \\
\text { E-W }\end{array}$ & $\underset{\mathrm{N}-\mathrm{S}}{\mathrm{M} \text { M-S }}$ & $M$ vert & $\begin{array}{c}\text { M hor } \\
\mathrm{N}-\mathrm{L}\end{array}$ & $\begin{array}{c}\mathrm{M} \\
\text { other }\end{array}$ & $\begin{array}{c}\mathrm{M} \\
\text { (other) } \\
\text { source }\end{array}$ & $\underset{\text { pref }}{\mathrm{M}}$ & $\begin{array}{c}\mathrm{M} \\
\text { (pref) } \\
\text { source }\end{array}$ & $I(\max )$ & Location/felt report & Comment \\
\hline 9/01/1903 & 19:16 & & & & & $\begin{array}{l}\text { east } \\
\text { hawaii }\end{array}$ & & & & & & & & 5.16 & & & & & & 5.16 & hono & felt & Warshauer notes: Felt at Hilo. & $\begin{array}{l}\text { Not listed in Honolulu Station Bulletin } \\
\text { (Hazard, 1910); found on station HON } \\
\text { film record; PCA, 10/14/1903; HG, } \\
\text { 10/16/1903; not found in HS, HEB, } \\
\text { HH, HT, or MN. }\end{array}$ \\
\hline $2 / 18 / 04$ & $10: 25$ & & & & & $\begin{array}{l}\text { east } \\
\text { hawaii }\end{array}$ & & & & & & & & 4.97 & & & & & & 4.97 & hono & IV? & $\begin{array}{l}\text { Warshauer notes: Vigorous earthquake felt in } \\
\text { Hilo between } 10 \text { and } 11 \text { o'clock. }\end{array}$ & $\begin{array}{l}\text { Not found in Honolulu Station Bulletin } \\
\text { (Hazard, 1910); found on station HON } \\
\text { film record; PCA, 2/22/1904; HS, } \\
\text { 2/20/1904; HT, 2/19/1904; not found in } \\
\text { HG, HEB, HH, or MN. }\end{array}$ \\
\hline 3/19/04 & 21:00 & & & & & $\begin{array}{l}\text { east } \\
\text { hawaii }\end{array}$ & & & & & & & & $<5.2$ & & & & & & 5.00 & int & $\mathrm{V}$ ? & Lyman notes: One smart shock from SW. & $\begin{array}{l}\text { Not found in Honolulu Station Bulletin } \\
\text { (Hazard, 1910); not found on station } \\
\text { HON film record; WKC, 1992, p. 28; } \\
\text { not found in HS, HEB, HG, MN, HT, } \\
\text { HH, or PCA. }\end{array}$ \\
\hline $3 / 29 / 04$ & $11: 45$ & & & & & kohala & & & & & & & & 5.38 & & & & & & 5.38 & hono & felt & $\begin{array}{l}\text { Warshauer notes: A severe earthquake was felt } \\
\text { in Kohala on the afternoon of the } 29 t h \text { inst. It } \\
\text { lasted ten minutes, moved NW from Kohala } \\
\text { toward Mahukona; felt in Kohala [11:45] and } \\
\text { Waimea [no time]. }\end{array}$ & $\begin{array}{l}\text { Found on station HON film record; } \\
\text { HG, } 4 / 5 / 1904 \text {; PCA, 4/13/1904; not } \\
\text { found in HS, HEB, MN, HH, or HT. }\end{array}$ \\
\hline $3 / 29 / 04$ & 11:48 & & & & & kohala(?) & & & & & & & & 5.32 & & & & & & 5.32 & hono & & & $\begin{array}{l}\text { Not recognized in newspaper reports; } \\
\text { Honolulu seismogram suggests } \\
\text { different location. }\end{array}$ \\
\hline 4/4/04 & 7:39 & & & & & molokai? & & & & & & & & & & & & & & 5.30 & int & $\mathrm{V}(\mathrm{S} \& \mathrm{C})$ & $\begin{array}{l}\text { Honolulu notes: Local earthquake about 18:05 } \\
\text { [G.m.t. April 4]; instrument not recording at } \\
\text { that time. Warshauer notes: Quite a severe } \\
\text { shock was felt here Monday morning at 7:30. } \\
\text { No damage done. }\end{array}$ & $\begin{array}{l}\text { Honolulu Station Bulletin (Hazard, } \\
\text { 1910); PCA, 4/11/1904; HH, 4/7/1904; } \\
\text { not found in MN. }\end{array}$ \\
\hline $4 / 29 / 04$ & $22: 30$ & & & & & kaoiki?? & & & & & & & & 5.79 & & & & & & 5.79 & hono & VI? & $\begin{array}{l}\text { Warshauer notes: On Friday, April 29, at } 10: 30 \\
\text { o'clock [p.m.] a most severe earthquake shock } \\
\text { was felt at Keauhou and Punalual The shock } \\
\text { lasted about eight seconds and was apparently } \\
\text { from north to south; heavy shock at Pepeekeo } \\
\text { [10:15] [same quake?]. }\end{array}$ & $\begin{array}{l}\text { Not listed in Honolulu Station Bulletin } \\
\text { (Hazard, 1910); found on station HON } \\
\text { film record; PCA, 5/7/1904; 5/16/1904; } \\
\text { not found in HH or HT. }\end{array}$ \\
\hline 6/4/04 & $12: 25$ & & & & & molokai? & & & & & & & & 5.63 & & & & & & 5.63 & hono & VI; V (S\&C) & $\begin{array}{l}\text { HON notes: Local; boom caught by spider web. } \\
\text { Lyman notes: A long gentle shake about } 12 \\
\text { noon [suggests farther from Hilo than Kilauea's } \\
\text { distance]. Warshauer notes: Felt sharply at } \\
\text { Wailuku and around the island of Maui; some } \\
\text { damage done outside of Wailuku. }\end{array}$ & $\begin{array}{l}\text { Honolulu Station Bulletin (Hazard, } \\
\text { 1910) [appearance of Honolulu } \\
\text { seismogram suggests distance of } \\
\text { Hawaii or closer]; WKC, 1992, p. 28; } \\
\text { MN, 6/11/1904. }\end{array}$ \\
\hline 7/17/04 & 14:00 & & & & & kaoiki?? & & & & & & & & 4.97 & & & & & & 4.97 & hono & $\begin{array}{l}\mathrm{V}-\mathrm{VI} \text { (hilo); } \leq \mathrm{V} \\
\text { (Kau) }\end{array}$ & $\begin{array}{l}\text { Lyman notes: A two-shock quake, the second } \\
\text { quite hard; In the afternoon [of July } 17 \text { there } \\
\text { was an earthquake accompanied by rumbling } \\
\text { sounds; ;slso felt and heard by the Lymans } \\
\text { while resting by the three craters. }\end{array}$ & $\begin{array}{l}\text { Not reported in Honolulu Station } \\
\text { Bulletin (Hazard, 1910); found on } \\
\text { station HON film record; WKC, 1992, } \\
\text { p. 28; VHR, v. 4, W.D. Westerveldt } \\
\text { entry dated 7/20/1904. }\end{array}$ \\
\hline $10 / 14 / 04$ & 3:40 & & & & & maui? & & & & & & & & 5.35 & & & & & & 5.35 & hono & $\mathrm{v}$ & $\begin{array}{l}\text { Lyman notes: A slight shock. Warshauer notes: } \\
\text { 3:40 a.m.; sistinct shock in Hilos sharp and } \\
\text { prolonged in Honolulu; heavy at Lahaina; } \\
\text { violent shaking in East Maui; felt reports from } \\
\text { Kohala, Puueo (Hilo), Waiawa and Aliamanu } \\
\text { (Oahu), and Kipahulu (Maui). }\end{array}$ & $\begin{array}{l}\text { Not reported in Honolulu Station } \\
\text { Bulletin (Hazard, 1910; seen on } \\
\text { station HON film record; WKC, 1992, } \\
\text { p. 28; HT, 10/18/1904; PCA, 10/15; 17, } \\
11 / 18 / 1900 ; \text { MN, 10/15/1904; not } \\
\text { found in HH. }\end{array}$ \\
\hline $5 / 3 / 05$ & 15:16 & & & & & kl sf? & & & & & & & & 5.33 & & & & & & 5.33 & hono & $\mathrm{v}$ & $\begin{array}{l}\text { Lyman notes: A long tremble, hard at the end, } \\
\text { throwing down some things, } 3: 30 \text { p.m. } \\
\text { Warshauer notes: First of } 3 \text { shocks, felt in Hilo } \\
\text { (heaviest in } 9 \text { yr) and volcano (distinct) and } \\
\text { Hamakua coast; dishes rattled and damage to } \\
\text { furniture and bric-a-brac (Hilo). }\end{array}$ & $\begin{array}{l}\text { WKC, 1992, p. 28; HH, 5/4/1905; HT, } \\
\text { 5/9/1905; PCA, 5/10; } 12 / 19005 \text { time } \\
\text { given as 3:18 p.m.; HS, 5/6; } 10,1905 \\
\text { [Lyman comment may be exchanged } \\
\text { with the following event; possible } \\
\text { foreshock to event at 16:07]. }\end{array}$ \\
\hline $5 / 3 / 05$ & 16:07 & & & & & kl sf? & & & & & & & & 6.18 & & & & & & 6.18 & hono & $\begin{array}{l}\mathrm{VI} ; \mathrm{V}(\mathrm{W} \& \mathrm{~K} ; \\
\mathrm{S} \& \mathrm{C})\end{array}$ & $\begin{array}{l}\text { Lyman notes: A long tremble and a twister. } \\
\text { W\&K notes: E or } S \text { Hawaii. Warshauer notes: } \\
\text { Another shock at } 4: 10 \text { p.m., stronger (Hilo) } \\
\text { than the first; ;ang church belll, damage to } \\
\text { furniture, bric-a-brau, and china; also felt- } \\
\text { volcano and Hamakua coast. }\end{array}$ & $\begin{array}{l}\text { Hon Station Bulletin (Hazard, 1910); } \\
\text { WKC, 1992, p. 22; WK, 1992, p. 32; } \\
\text { HH, 5/4/1905; HT, 5/9/1905; PCA, } \\
5 / 10,12 / 1905 ; \text { HS, } 5 / 6,10 / 1905 ; \text { not in } \\
\text { MN [Lyman comment exchanged with } \\
\text { previous event(?); seismogram shows } \\
\text { this as larger event, s-p about } 1 \text { min]. }\end{array}$ \\
\hline
\end{tabular}


Table 13. All earthquakes of $M \geq 4.0$ during the period 1903-59-Continued

\begin{tabular}{|c|c|c|c|c|c|c|c|c|c|c|c|c|c|c|c|c|c|c|c|c|c|c|c|c|}
\hline Date & $\begin{array}{c}\text { Time } \\
\text { (HST) }\end{array}$ & $\begin{array}{c}\text { Lat } \\
\text { (deg) }\end{array}$ & $\begin{array}{l}\text { Lat } \\
(\mathrm{min})\end{array}$ & $\begin{array}{l}\text { Lon } \\
(\operatorname{deg})\end{array}$ & $\begin{array}{l}\text { Lon } \\
(\min )\end{array}$ & Region & $\begin{array}{l}\text { Publ. } \\
\text { Depth }\end{array}$ & $\begin{array}{l}\text { Pref. } \\
\text { Depth }\end{array}$ & $\begin{array}{l}\text { Publ. } \\
\text { Dist. }\end{array}$ & $\begin{array}{l}\text { Calc. } \\
\text { Dist }\end{array}$ & $\begin{array}{l}\text { Slant } \\
\text { dist }\end{array}$ & Mag class & $\begin{array}{c}\mathrm{M} \\
\text { nomo }\end{array}$ & $\begin{array}{l}\text { M M-S } \\
\text { E-W }\end{array}$ & $\begin{array}{c}\text { M M-S } \\
\text { N-S }\end{array}$ & $M$ vert & $\begin{array}{c}\text { M hor } \\
N-L\end{array}$ & $\begin{array}{c}\mathrm{M} \\
\text { other }\end{array}$ & $\begin{array}{c}\mathrm{M} \\
\text { (other) } \\
\text { source }\end{array}$ & $\begin{array}{c}\mathrm{M} \\
\text { pref }\end{array}$ & $\begin{array}{c}\mathrm{M} \\
\text { (pref) } \\
\text { source }\end{array}$ & $I(\max )$ & Location/felt report & Comment \\
\hline $5 / 3 / 05$ & $18: 40$ & & & & & kl sf? & & & & & & & & $<5.22$ & & & & & & 5.00 & desp & felt & $\begin{array}{l}\text { Lyman notes: A long tremble slight, at } 6: 40 \\
\text { p.m. Warshauer notes: Probably felt on } \\
\text { Hamakua coast; 6:35 p.m., weakest of three } \\
\text { shocks felt in Hilo; shock at 6:34 p.m. }\end{array}$ & $\begin{array}{l}\text { Aftershock; not found on station HON } \\
\text { film record; WKC, 1992, p. } 28 ; \mathrm{HH}, \\
\text { 5/4/1905; HT, 5/9/1905; PCA, 5/10; } \\
\text { 12/1905; HS, 5/6; 10/1905. }\end{array}$ \\
\hline $5 / 7 / 05$ & 19:20 & & & & & kl sf? & & & & & & & & 5.03 & & & & & & 5.03 & hono & felt & $\begin{array}{l}\text { Warshauer notes: A shock at 7:20 p.m. felt in } \\
\text { Hilo. }\end{array}$ & $\begin{array}{l}\text { Aftershock(?); found on station HON } \\
\text { film record; PCA, } 5 / 12 / 1905 ; \mathrm{HT}, \\
\text { 5/9/1905; not found in HS. }\end{array}$ \\
\hline $5 / 28 / 05$ & 9:22 & & & & & $\begin{array}{l}\text { north } \\
\text { hawaii }\end{array}$ & & & & & & & & $<5.22$ & & & & & & 4.50 & desp & IV? & $\begin{array}{l}\text { Lyman notes: One smart shock and a tremble. } \\
\text { Warshauer notes: Felt at Honomu (10 a.m.; } \\
\text { sharp), Kohala Mission }(9: 27 \text { a.m.), Waimea } \\
\text { (10:25 a.m. [9:25?]; smart), and Kealakekua } \\
(9: 15 \text { a.m.). }\end{array}$ & $\begin{array}{l}\text { Not reported in Hon Station Bulletin } \\
\text { (Hazard, 1910); not found on station } \\
\text { HON film record; WKC, 1992, p. 28; } \\
\text { PCA, 6/6/1905; not found in MN, HH, } \\
\text { or HT. }\end{array}$ \\
\hline $4 / 25 / 06$ & 1:47 & & & & & $\begin{array}{l}\text { north } \\
\text { hawaii }\end{array}$ & & & & & & & & 6.01 & & & & & & 6.01 & hono & $\mathrm{v}$ & $\begin{array}{l}\text { HON notes: Seismogram impulsive, incorrect } \\
\text { amp in Honolulu Station Bulletin. Lyman } \\
\text { notes: A smart shake at } 2 \text { a.m. Warshauer } \\
\text { notess : Heavy in ( } 2 \text { a.m.), followed by two } \\
\text { slight at intervals of } 10 \text { min., Hakalau }(1.57 \\
\text { a.m.) and Kau (2 a.m.); direction, N to S. }\end{array}$ & $\begin{array}{l}\text { Honolulu Station Bulletin (Hazard, } \\
\text { 1910); WKC, 1992, p. 29; PCA, } \\
5 / 11 / 1906 ; \text {; ot found in MN; fred-check } \\
\text { berkeley. }\end{array}$ \\
\hline $9 / 4 / 06$ & 3:15 & & & & & $\begin{array}{l}\text { east } \\
\text { hawaii }\end{array}$ & & & & & & & & $<5.41$ & & & & & & 5.30 & int & $\mathrm{v}$ & $\begin{array}{l}\text { Lyman notes: [9/3-wrong?] a smart shake, } 2 \\
\text { shocks, SE \& NW. Warshauer notes: Severe [in } \\
\text { Hilo] at 3:15 a.m.; not perceived at the Volcano } \\
\text { House, felt lightly a Mountain View. A sharp } \\
\text { earthquake shock awakened most Hilonians at } \\
\text { 3:15 a.m., no damage. }\end{array}$ & $\begin{array}{l}\text { Not reported in Honolulu Station } \\
\text { Bulletin (Hazard, 1910); not found on } \\
\text { station HON film record-disturbed } \\
\text { record; WKC, W992, p. 29; PCA, } \\
\text { 9/5/1906; HH, 9/4/1906, quoted in } \\
\text { PCA, 9/10/1906. }\end{array}$ \\
\hline $1 / 8 / 07$ & 15:00 & & & & & ml swr? & & & & & & & & $<5.35$ & & & & & & 5.90 & int & VI? & $\begin{array}{l}\text { Warshauer notes: Slight shocks felt at several } \\
\text { stations [north Hawaii] from 8th to } 10 \text { th incl. } \\
\text { [no individual reports]; over 50 shocks at } \\
\text { Pahala, } 8 \text { 8th-9th, one quite heavy on p.m. of the } \\
\text { 8th with swaying bushes/trees [not mentioned } \\
\text { in Lyman diary]. }\end{array}$ & $\begin{array}{l}\text { Time assumed; not found on station } \\
\text { HON film recordi PCA, 1/111, 15; } \\
\text { 18/1907; HG, 1/11/1907; HS, } \\
\text { 1/11/1907; HEB, 1/11/1907; HT, } \\
\text { 1/15/1907; not in HH or MN } \\
\text { [precursory seismicity north of } \\
\text { Mokuaweoweo saddle(?); large event } \\
\text { might be Hilea]. }\end{array}$ \\
\hline $1 / 10 / 07$ & 13:31 & & & & & hilea? & & & & & & & & 5.82 & & & & & & 5.82 & hono & felt & $\begin{array}{l}\text { HON notes: Probably local; [Honolulu } \\
\text { seismogram is impulsive]. Lyman notes: A } \\
\text { slight long tremble at } 1.30 \text { p.m. Warshauer } \\
\text { notess Earthquake shocks were felt during the } \\
\text { week at a number of stations in the western and } \\
\text { southern parts of Hawaii. }\end{array}$ & $\begin{array}{l}\text { Honolulu Station Bulletin (Hazard, } \\
\text { 1911); WKC, 1992, p. 29; PCA, } \\
\text { 1/22/1907; HS, 1/22/1907; HT, } \\
\text { 1/15/1907: Warshauer note-con.: } \\
\text { Observer at Kau (Waiohinu) reports } \\
\text { many earthquake shocks felt on the } \\
\text { 10th and 11th, and a light one on the } \\
\text { 16th. }\end{array}$ \\
\hline $1 / 10 / 07$ & 13:31 & & & & & hilea? & & & & & & & & 5.82 & & & & & & 5.82 & hono & felt & $\begin{array}{l}\text { Warshauer notes: At Kapapala numerous } \\
\text { earthquakes yesterday, none very severe. One } \\
\text { shock at 1:30 o'clock...; quite a heavy shock } \\
\text { [at Pahala], plainly observing the trees and } \\
\text { bushes swaying back and forth; several thumps } \\
\text { felt, rotary motion. }\end{array}$ & $\begin{array}{l}\text { HEB, 1/12/1907; HG, 1/18/1907; HS, } \\
\text { 1/22/1907; HEB, 1/31/1907. }\end{array}$ \\
\hline $6 / 11 / 07$ & $3: 40$ & & & & & hilea? & & & & & & & & $<5.27$ & & & & & & 4.50 & int & IV-V? & $\begin{array}{l}\text { Lyman notes: A two-shock mild shake. } \\
\text { Warshauer notes: Heavy shocks of earthquakes } \\
\text { at } 3: 43 \text { on Hawaii, also felt at Paauilo, } \\
\text { Laupahoehoee, Naalehu-heavy, and Kealakekua; } \\
\text { Honuapo-most severe shake; duration, about } 40 \\
\text { s; also felt at Hilo, Kona, and Waiohinu. }\end{array}$ & $\begin{array}{l}\text { Not reported in Honolulu Station } \\
\text { Bulletin (Hazard, 1911); ;nt found on } \\
\text { sta. HON film record; no mention in } \\
\text { VHR entry on this date; WKC, 1992, p. } \\
\text { 29; PCA , 6/15, 18/1907; HS \& HEB, } \\
\text {; 6/14/1907; not in MN, HH, or HT; } \\
\text { poss. analog to 8/20/24 quake (WK, p. } \\
\text { 31). }\end{array}$ \\
\hline $7 / 5 / 07$ & 23:45 & & & & & molokai?? & & & & & & & & 4.60 & & & & & & 4.60 & hono & felt & $\begin{array}{l}\text { Lyman notes: A long continued shake near } 12 \\
\text { last night. Warshauer notess Slight shock felt } \\
\text { over Honolulu at 11:55 p.m.; duration, a few } \\
\text { seconds, quite distinct; slight at Makawao } \\
\text { [Maui\} a } 11 \text { 11:40 p.m; distinct on Maui and } \\
\text { throughout territory at 11:45. }\end{array}$ & $\begin{array}{l}\text { Not reported in Honolulu Station } \\
\text { Bulletin (Hazard, 1911); found on } \\
\text { station HON film record; WKC, 1992, } \\
\text { p. 29; PCA, 7/6; 16/1907; MN, } \\
\text { 7/113/1907; not found in HEB, HH, or } \\
\text { HT. }\end{array}$ \\
\hline
\end{tabular}


ש્ Table 13. All earthquakes of $M \geq 4.0$ during the period 1903-59-Continued

\begin{tabular}{|c|c|c|c|c|c|c|c|c|c|c|c|c|c|c|c|c|c|c|c|c|c|c|c|c|}
\hline Date & $\begin{array}{l}\text { Time } \\
\text { (HST) }\end{array}$ & $\begin{array}{c}\text { Lat } \\
(\mathrm{deg})(\end{array}$ & $\begin{array}{c}\text { Lat } \\
(\mathrm{min})\end{array}$ & $\begin{array}{l}\text { Lon } \\
\text { (deg) }\end{array}$ & $\begin{array}{l}\text { Lon } \\
(\min )\end{array}$ & Region & $\begin{array}{l}\text { Publ. } \\
\text { Depth }\end{array}$ & $\begin{array}{l}\text { Pref. } \\
\text { Depth }\end{array}$ & $\begin{array}{l}\text { Publ. } \\
\text { Dist. }\end{array}$ & $\begin{array}{l}\text { Calc. } \\
\text { Dist }\end{array}$ & $\begin{array}{l}\text { Slant } \\
\text { dist }\end{array}$ & Mag class & $\begin{array}{c}\mathrm{M} \\
\text { nomo }\end{array}$ & $\begin{array}{l}\text { M M-S } \\
\text { E-W }\end{array}$ & $\underset{\mathrm{N}-\mathrm{S}}{\mathrm{M} \text { M-S }}$ & $M$ vert & $\begin{array}{c}\text { M hor } \\
\mathrm{N}-\mathrm{L}\end{array}$ & $\begin{array}{c}\mathrm{M} \\
\text { other }\end{array}$ & $\begin{array}{l}\mathrm{M} \\
\text { (other) } \\
\text { source }\end{array}$ & $\underset{\mathrm{pref}}{\mathrm{M}}$ & $\begin{array}{c}\begin{array}{c}\mathrm{M} \\
\text { (pref) } \\
\text { source }\end{array} \\
\end{array}$ & $I(\max )$ & Location/felt report & Comment \\
\hline 9/5/07 & 18:52 & & & & & kl sf? & & & & & & & & 5.16 & & & & & & 5.16 & hono & $\mathrm{v}$ & $\begin{array}{l}\text { HON notes: Tremor. Lyman notes: A smart 2- } \\
\text { shock quake, dur several s. Warshauer notes: } \\
\text { Severe quake in Hilio, dur several min; ship in } \\
\text { dock shook stem to stern, wharf shaken; felt-all } \\
\text { Hawaii I., esp. Kohala, Kau, Papaikou; volcano } \\
\text { light, wire interrupted. }\end{array}$ & $\begin{array}{l}\text { Hazard, 1911; WKC, 1992, p. 29; } \\
\text { HEB, 9/6; 7/1907; PCA, 9/8/1907. }\end{array}$ \\
\hline $12 / 19 / 07$ & 20:55 & & & & & $\begin{array}{l}\text { alenuihah } \\
\text { a deep? }\end{array}$ & & & & & & & & 5.63 & & & & & $\begin{array}{c}\text { this } \\
\text { catalog- } \\
\text { area of } \\
\text { intensity } \\
\mathrm{V} \text { (W\&K, } \\
\text { p. 26) }\end{array}$ & 5.63 & hono & $\mathrm{v}$ & $\begin{array}{l}\text { HON notes: Local shock. Warshauer notes: An } \\
\text { earthquake felt all over Honolulu. Two shocks } \\
\text { followed within a few seconds, the entire } \\
\text { disturbance occupying about } 15 \mathrm{~s} \text {; also felt in } \\
\text { Nuuanu valley, Palolo, Waikiki, and Kalihi; } \\
\text { details in references. }\end{array}$ & $\begin{array}{l}\text { Hazard, 1911; PCA, 12/20; MN, } \\
\text { 12/21/1907 [not mentioned by Cox, } \\
\text { 1986, or WK, 1992]. }\end{array}$ \\
\hline $9 / 20 / 08$ & 20:15 & & & & & $\mathrm{kl} \mathrm{sf}$ & & & & & & & & 6.70 & & & & $\begin{array}{l}6.2 ; \\
6.8\end{array}$ & $\begin{array}{l}\text { USSR; } \\
\text { (S\&C) } \\
\text { [from } \\
\text { Abe, } \\
1981]\end{array}$ & 6.70 & hono & VII; VI (S\&C) & $\begin{array}{l}\text { HON notes: A sharp local shock, which } \\
\text { probably has its origin near Kilauea Volcano } \\
\text { on the Island of Hawaii. W\&K notes: int } 5-6 \\
\text { Hilo to Puna, probably Kilauea south flank. }\end{array}$ & $\begin{array}{l}\text { Hazard, } 1911 \text { [amp on Honolulu } \\
\text { seismogram much larger than } M=6.2 \\
11 / 2 / 18 \text {, traces large and obscure each } \\
\text { other, max amp extrapolated]; WK, } \\
\text { 1992, p. 32, } 62 \text {. }\end{array}$ \\
\hline $9 / 26 / 08$ & 20:05 & & & & & $\mathrm{kl} \mathrm{sf}$ & & & & & & & & $<5.2$ & & & & & & 4.00 & desp & IV? & $\begin{array}{l}\text { Lyman notes: Quite a smart shake. Warshauer } \\
\text { notes: Two quakes, this one at } 8: 04 \text { p.m., short } \\
\text { but particularly sharp [largest aftershock of } \\
9 / 20 / 08] \text {. }\end{array}$ & $\begin{array}{l}\text { Aftershock; not found on station HON } \\
\text { film record; WKC, 1992, p. 30; PCA, } \\
\text { 10/5/1908; HH, 10/11/1908. }\end{array}$ \\
\hline $10 / 24 / 08$ & $17: 45$ & & & & & hilea? & & & & & & & & 5.16 & & & & & & 5.16 & hono & felt & $\begin{array}{l}\text { Warshauer notes: The following earthquake } \\
\text { shocks were resorted felt-all from Hawaii: } \\
\text { 24th-Naalehu, light followed by heavier, } \\
\text { Kealakekua (Davis) 5:45 p.m., lasting } 2 \mathrm{~s} \text {. }\end{array}$ & $\begin{array}{l}\text { Found on station HON film record; } \\
\text { PCA, } 11 / 4 / 1908 ; \text { not found in HS, } \\
\text { HEB, HH, or HT. }\end{array}$ \\
\hline $3 / 13 / 09$ & $3: 30$ & & & & & $\begin{array}{l}\mathrm{kl} \mathrm{cal} \\
\text { deep?? }\end{array}$ & & & & & & & & 5.35 & & & & & & 5.35 & hono & $\mathrm{v}$ & $\begin{array}{l}\text { HON notes: Local shock, felt generally over } \\
\text { Island of Hawaii, recorded on magnetograph. } \\
\text { Lyman notes: Shook water out of vases, no } \\
\text { damage done. }\end{array}$ & $\begin{array}{l}\text { Hazard, } 1912 \text { [time of large waves and } \\
\text { ending time given]; no mention in } \\
\text { VHR entry on this date; WKC, 1992, p. } \\
\text { 30; PCA, 3/23/1909 [in USE, no int or } \\
\text { mag]. }\end{array}$ \\
\hline $4 / 19 / 10$ & $3: 45$ & & & & & kilauea? & & & & & & & & & & & & & & 5.30 & int & $\mathrm{v}$ & $\begin{array}{l}\text { Lyman notes: A smart two-shock shake, } N \& S \text {. } \\
\text { Warshauer notes: Very yharp shock Tuesday } \\
\text { [Apr. 19] at about } 3: 50 \text { a.m., awakened persons } \\
\text { in Hilo; short duration; little damage except to } \\
\text { crockery too close to shelf edges. Kilauea } \\
\text { flared up after quake. }\end{array}$ & $\begin{array}{l}\text { Not found on station HON film record; } \\
\text { ESPNVO, v. 1, p. } 28 \text { [repeats info]; } \\
\text { WKC, 1992, p. 3; HH, } 421 / 111910 \text {; not } \\
\text { found in PCA, HG, HS, HEB, or HT. }\end{array}$ \\
\hline $7 / 14 / 11$ & $11: 30$ & & & & & $\begin{array}{l}\text { maui } \\
\text { deep? }\end{array}$ & & & & & & & & 5.91 & & & & & & 5.91 & hono & $\mathrm{V}$ ? & $\begin{array}{l}\text { HON notes: Local shock. Lyman notes: Long } \\
\text { continued slight tremble. Warshauer notes: Felt- } \\
\text { all territory; Honolulu-duration } 20 \text { s, nowhere } \\
\text { severe; Mauiutwwo severe shocks at Wailuku, } \\
\text { buildings shook, people ran out; Hawaii-felt } \\
\text { generally, not at Halemaumau. }\end{array}$ & 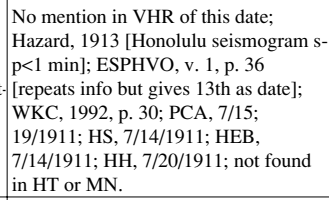 \\
\hline $8 / 25 / 11$ & $7: 15$ & & & & & kl mer? & & & & & & & & $<5.3$ & & & & & & 4.50 & int & IV-V & $\begin{array}{l}\text { A strong shock [felt at Halemaumaul causing a } \\
\text { heavy landslide from the north black ledge. }\end{array}$ & $\begin{array}{l}\text { Not found on station HON film record; } \\
\text { ESPHVO, v. 1, p. 44-45; do. }\end{array}$ \\
\hline $4 / 10 / 12$ & 10:00 & & & & & $\begin{array}{l}\text { south } \\
\text { hawaii }\end{array}$ & & & & & & & & & & & & & & 5.30 & int & V; IV (W\&K) & $\begin{array}{l}\text { Lyman notes: A slight shake, rattling things } \\
\text { some. Warshauer notes: Shock felt by hundreds } \\
\text { in Hilo, inside and out; motion, west to east; } \\
\text { duration, } 17 \text { s, 5-s pause, 20-- shake, 30-s } \\
\text { pause, three slight 10-s shocks, separated by 2- } \\
\text { to 3-s pauses. }\end{array}$ & $\begin{array}{l}\text { Not reported in Honolulu Station } \\
\text { Bulletin (Hazard, 1913); not on sta. } \\
\text { HON film record, not in ESPHVO } \\
\text { supp. (Jaggar, 1947); WKC, 1992, p. } \\
\text { 31; HH, 4/11/1912; HS, 4/13/1912; not } \\
\text { in PCA, HG, HEB, or HT [akaiki } \\
\text { guessed if s-p is } 5 \mathrm{~s} \text { and possible } \\
\text { aftershocks]. }\end{array}$ \\
\hline $5 / 5 / 12$ & 8:58 & & & & & hilea? & & & & & & & & 5.16 & & & & & & 5.16 & hono & $\mathrm{V}$ & $\begin{array}{l}\text { Warshauer notes: It appears that the shock } \\
\text { reported at Hilo on Sunday week [May 5] was } \\
\text { severely felt on the Kau coast as well. The } \\
\text { quake was distinctly felt aboard the steamer } \\
\text { Kilauea lying at Honuapo; landslide from } \\
\text { seacliffs observed. }\end{array}$ & $\begin{array}{l}\text { Honolulu Station Bulletin (Hazard, } \\
\text { 1913); not mentioned in ESPHVO } \\
\text { supp. (Jaggar, 1947); HS, 5/6/1912, } \\
\text { quoted in HH, 5/16/1912; not found in } \\
\text { HT, HEB, HG, or PCA. }\end{array}$ \\
\hline
\end{tabular}


Table 13. All earthquakes of $M \geq 4.0$ during the period 1903-59-Continued

\begin{tabular}{|c|c|c|c|c|c|c|c|c|c|c|c|c|c|c|c|c|c|c|c|c|c|c|c|c|}
\hline Date & $\begin{array}{l}\text { Time } \\
\text { (HST) }\end{array}$ & $\begin{array}{r}\text { Lat } \\
(\mathrm{deg})\end{array}$ & $\begin{array}{c}\text { Lat } \\
(\mathrm{min})\end{array}$ & $\begin{array}{l}\text { Lon } \\
(\operatorname{deg})\end{array}$ & $\begin{array}{l}\text { Lon } \\
(\mathrm{min})\end{array}$ & Region & $\begin{array}{l}\text { Publ. } \\
\text { Depth }\end{array}$ & $\begin{array}{l}\text { Pref. } \\
\text { Depth }\end{array}$ & $\begin{array}{l}\text { Publ. } \\
\text { Dist. }\end{array}$ & $\begin{array}{c}\text { Calc. } \\
\text { Dist }\end{array}$ & $\begin{array}{c}\text { Slant } \\
\text { dist }\end{array}$ & Mag class & $\begin{array}{c}\mathrm{M} \\
\text { nomo }\end{array}$ & $\begin{array}{l}\text { M M-S } \\
\text { E-W }\end{array}$ & $\begin{array}{c}\text { M M-S } \\
\text { N-S }\end{array}$ & $M$ vert & $\begin{array}{c}\text { M hor } \\
\text { N-L }\end{array}$ & $\begin{array}{c}\mathrm{M} \\
\text { other }\end{array}$ & $\begin{array}{c}\mathrm{M} \\
\text { (other) } \\
\text { source }\end{array}$ & $\begin{array}{c}\mathrm{M} \\
\text { pref }\end{array}$ & $\begin{array}{c}\mathrm{M} \\
\text { (pref) } \\
\text { source }\end{array}$ & $I(\max )$ & Location/felt report & Comment \\
\hline $5 / 14 / 12$ & $13: 43$ & & & & & $\begin{array}{l}\text { east } \\
\text { hawaii }\end{array}$ & & & & & & & & 5.52 & & & & & & 5.52 & 2 hono & & $\begin{array}{l}\text { Honolulu notes: Very slight; amplitude, } 0.3 \\
\mathrm{~mm} \text {; duration, } 1 \mathrm{~h} 16.3 \text { min [strange that this } \\
\text { doesn't correspond to the much heavier event } \\
\text { on the 22d!]. Lyman notes: May } 15 \text {, quite a } \\
\text { shake [no time given; event on the } 14 \text { th or the } \\
\text { 22d]. }\end{array}$ & $\begin{array}{l}\text { Honolulu Station Bulletin (Hazard, } \\
\text { 1913); not mentioned in ESPHVO } \\
\text { supp. (Jaggar, 1947); WKC, 1992, p. } \\
\text { 31; not found in HT, HG, HS, HEB, or } \\
\text { PCA. }\end{array}$ \\
\hline $5 / 22 / 12$ & 23:00 & & & & & $\mathrm{kl} \mathrm{sf?}$ & & & & & & & & $<5.33$ & & & & & & 5.90 & 0 int & VI-VII & $\begin{array}{l}\text { Quake felt [Volcano-no date] and elsewhere in } \\
\text { Hawaii. Warshauer notes: Heaviest shake in } \\
\text { years [Hilo, tidal waves in ponds, livestock } \\
\text { terrorized, little damage, brief but distinct in } \\
\text { Kau; west to east; duration, } 7 \mathrm{~s} \text {; many smaller } \\
\text { events earlier in week. }\end{array}$ & $\begin{array}{l}\text { Not reported in Honolulu Station } \\
\text { Bulletin (Hazard, 1913); not found on } \\
\text { station HON film record; ESPHVO } \\
\text { supp. (Jaggar, 1947, p. 15); PCA, 5/24; } \\
\text { 2711912; HT, 5/28/1912; HH, } \\
5 / 30 / 1912 ; \text { [int dist analog to k1 sf } \\
\text { events of } 3 / 54 \text { and 9/79(?)]. }\end{array}$ \\
\hline $10 / 13 / 12$ & $5: 45$ & & & & & $\begin{array}{l}\text { alenuihah } \\
\text { a deep? }\end{array}$ & & 40 & 130.0 & 130.0 & 136.0 & & & 5.02 & & & & & & 5.02 & 2 hono & $\mathrm{V} ; \mathrm{V}(\mathrm{W} \& \mathrm{~K})$ & $\begin{array}{l}\text { HON notes: Local shock, felt on all the islands; } \\
8 \text { maxima, wakened light sleepers at Volcano } \\
\text { House, felt distinctly at Hilo, lightly in } \\
\text { Honolulu; submarine shock, fairly deep, slight } \\
\text { energy. Lyman notes: About } 5: 30 \text { a.m., a long } \\
\text { continued shake, not hard. }\end{array}$ & $\begin{array}{l}\text { Hazard, } 1913 \text { [seismogram shape } \\
\text { indicates some distance and not Oahu]; } \\
\text { ESPHVO supp (Jaggar, 1947, p. 44) } \\
\text { [origin at a moderate rather than great } \\
\text { distancee; PCA, } 10 / 15521 / 1912 \\
\text { [repeats info in Jaggar, 1947]; WKC, } \\
\text { 1992, p. 31. }\end{array}$ \\
\hline $12 / 5 / 12$ & 2:14 & & & & & oahu & & & & & 448.0 & & & 5.25 & & & & & & 5.25 & 5 hono & & $\begin{array}{l}\text { Honolulu amp, } 1.1 \mathrm{~mm} \text {; moderate shock at its } \\
\text { origin } 280 \mathrm{mi} \text { from HVO; very small at HVO; } \\
\text { duration many minutes; second phase at } \\
2: 15: 06 \text { and third phase at } 2: 15: 53 \text {, both very } \\
\text { distinct. }\end{array}$ & $\begin{array}{l}\text { Hazard, } 1913 \text { [assume double amp of } 1 \\
\text { mm to get separate phases]; ESPHVO } \\
\text { supp. (Jaggar, 1947, p. p5); not } \\
\text { reported in PCA, HSB, HH, or MN. }\end{array}$ \\
\hline $12 / 17 / 12$ & $15: 21$ & & & & & kaoiki?? & & & & & 22.4 & $\begin{array}{l}\text { IV } \\
\text { (cancani) }\end{array}$ & 4.03 & & & & & & & 4.03 & 3 nomo & felt & $\begin{array}{l}\text { Duration, approx } 4 \mathrm{~min} \text {; distance } 13-15 \mathrm{mi} \text {; not } \\
\text { reported felt. }\end{array}$ & t ESPHVO supp. (Jaggar, 1947, p. 59). \\
\hline $3 / 25 / 13$ & $22: 57$ & & & & & $\mathrm{kl} \mathrm{sf?}$ & & & & & 32.0 & $\begin{array}{c}\text { IV-V } \\
\text { (Cancani) }\end{array}$ & 4.58 & $<5.1$ & & & & & & 4.58 & 8 nomo & & Duration, $3 \mathrm{~min} 13 \mathrm{~s}$. & $\begin{array}{l}\text { Not reported in Honolulu Station } \\
\text { Bulletin (Hazard, 1913); ESPHVO } \\
\text { supp. (Jaggar, 1947, p. 80); not } \\
\text { reported in HG, HSB, or HH. }\end{array}$ \\
\hline $5 / 15 / 13$ & $8: 30$ & & & & & kohala?? & & & & & 108.0 & $\begin{array}{l}\text { medium II } \\
\text { (Cancani) }\end{array}$ & 4.23 & & & & & & & 4.23 & 3 nomo & & $\begin{array}{l}\text { Moderate local shock; duration, } 4 \mathrm{~min} \text {; } \\
\text { distance, } 65-70 \mathrm{mi} \text {. }\end{array}$ & $\begin{array}{l}\text { ESPHVO supp. (Jaggar, 1947, p. 86); } \\
\text { PCA, 5/25/1913; repeats HVO info; not } \\
\text { reported in HH or HT. }\end{array}$ \\
\hline $5 / 18 / 13$ & 19:51 & & & & & kl sf? & & & & & 14.0 & $\begin{array}{l}\text { high VII } \\
\text { (Cancani); } \\
\text { off scale; } \\
\text { medium } \\
\text { VI } \\
\text { assumed } \\
\text { to agree } \\
\text { with Rossi- } \\
\text { Forel }\end{array}$ & $>4.6$ & 5.22 & & & & & & 5.22 & 2 hono & V; IV-V (R-F) & $\begin{array}{l}\text { Lyman notes: At 7:40 p.m., } 2 \text { slight tremors } \\
\text { followed by } 2 \text { short sharp shocks; a few } \\
\text { minutes before } 8 \text { p.m. a moderately strong } \\
\text { focal shock was felt at Volcano House and } \\
\text { generally felt in Hilo; pens offscale to E and S, } \\
\text { probably close to HVO, direction NW. }\end{array}$ & $\begin{array}{l}\text { Not listed in Honolulu Station Bulletin } \\
\text { (Hazard, 1916); seen on station HON } \\
\text { film record; WKC, 1992, p. 31; } \\
\text { ESPHVO supp (Jaggar, 1947, p. 86). }\end{array}$ \\
\hline $6 / 19 / 13$ & 3:38 & & & & & $\begin{array}{l}\mathrm{kl} \mathrm{cal} \\
\text { deep?? }\end{array}$ & & & & & 32.0 & $\begin{array}{l}\text { III-IV } \\
\text { (Cancani); } \\
1.0 \mathrm{mpu}\end{array}$ & 4.04 & & & & & & & 4.04 & 4 nomo & & Duration, $1 \mathrm{~min} 43 \mathrm{~s}$. & ESPHVO, v. 2, p. 2. \\
\hline $6 / 28 / 13$ & $17: 58$ & & & & & hilea?? & & & & & 48.0 & $\begin{array}{l}\text { III-IV } \\
\text { (Cancani); } \\
1.0 \mathrm{mpu}\end{array}$ & 4.32 & & & & & & & 4.32 & 2 nomo & & Duration, $3 \mathrm{~min} 33 \mathrm{~s}$. & $\begin{array}{l}\text { Not found in Honolulu Station Bulletin } \\
\text { (Hazard, 1916); looked for but not seen } \\
\text { on station HON film record; ESPHVO, } \\
\text { v. 2, p. 5; not found in HG, HSB, or } \\
\text { HH. }\end{array}$ \\
\hline $7 / 1 / 13$ & $9: 27$ & & & & & hilea?? & & & & & 48.0 & $\begin{array}{l}\underset{\text { medium }}{\text { III }} \\
\text { (Cancani); } \\
0.8 \mathrm{mpu}\end{array}$ & 4.19 & & & & & & & 4.19 & 9 nomo & & Duration, $2 \mathrm{~min} 54 \mathrm{~s}$. & $\begin{array}{l}\text { Not found in Honolulu Station Bulletin } \\
\text { (Hazard, 1916); looked for but not seen } \\
\text { on station HON film record; ESPHVO, } \\
\text { v. 2, p. } 5 \text {; not reported in HH. }\end{array}$ \\
\hline $7 / 4 / 13$ & $8: 22$ & & & & & $\mathrm{ml} \mathrm{mok??}$ & & & & & 33.6 & $\begin{array}{c}\text { III-IV } \\
\text { (Cancani); } \\
1.0 \mathrm{mpu}\end{array}$ & 4.07 & & & & & & & 4.07 & 7 nomo & & Duration, $52 \mathrm{~s}$. & $\begin{array}{l}\text { Not found in Honolulu Station Bulletin } \\
\text { (Hazard, 1916); looked for but not seen } \\
\text { on station HON film record; ESPHVO, } \\
\text { v. 2, p. 6; not reported in HH. }\end{array}$ \\
\hline $7 / 9 / 13$ & $2: 24$ & & & & & hilea?? & & & & & 41.6 & $\begin{array}{c}\text { medium } \\
\text { III } \\
\text { (Cancani); } \\
0.75 \mathrm{mpu} \\
\end{array}$ & 4.05 & & & & & & & & 5 nomo & & Duration, $1 \mathrm{~min} 3 \mathrm{~s}$. & $\begin{array}{l}\text { Not found in Honolulu Station Bulletin } \\
\text { (Hazard, 1916); looked for but not seen } \\
\text { on station HON film record; ESPHVO, } \\
\text { v. 2, p. } 7 \text {. }\end{array}$ \\
\hline
\end{tabular}




\begin{tabular}{|c|c|c|c|c|c|c|c|c|c|c|c|c|c|c|c|c|c|c|c|c|c|c|c|c|}
\hline Date & $\begin{array}{l}\text { Time } \\
\text { (HST) }\end{array}$ & $\begin{array}{r}\text { Lat } \\
(\mathrm{deg})\end{array}$ & $\begin{array}{l}\text { Lat } \\
\text { (min) }\end{array}$ & $\begin{array}{l}\text { Lon } \\
\text { (deg) }\end{array}$ & $\begin{array}{l}\text { Lon } \\
(\mathrm{min})\end{array}$ & Region & $\begin{array}{l}\text { Publ. } \\
\text { Depth } 1\end{array}$ & $\begin{array}{l}\text { Pref. } \\
\text { Depth }\end{array}$ & $\begin{array}{l}\text { Publ. } \\
\text { Dist. }\end{array}$ & $\begin{array}{l}\text { Calc. } \\
\text { Dist }\end{array}$ & $\begin{array}{l}\text { Slant } \\
\text { dist }\end{array}$ & Mag class & $\begin{array}{c}\mathrm{M} \\
\text { nomo }\end{array}$ & $\begin{array}{l}\text { M M-S } \\
\text { E-W }\end{array}$ & $\underset{\mathrm{N}-\mathrm{S}}{\mathrm{M} \text { M-S }}$ & $M$ vert & $\begin{array}{c}\text { M hor } \\
\text { N-L }\end{array}$ & $\begin{array}{c}\mathrm{M} \\
\text { other }\end{array}$ & $\begin{array}{c}\mathrm{M} \\
\text { (other) } \\
\text { source }\end{array}$ & $\underset{\text { pref }}{\mathrm{M}}$ & $\begin{array}{c}\mathrm{M} \\
\text { (pref) } \\
\text { source }\end{array}$ & $I(\max )$ & Location/felt report & Comment \\
\hline $7 / 12 / 13$ & 3:59 & & & & & hilea?? & & & & & 48.0 & $\begin{array}{c}\text { III-IV } \\
\text { (Cancani); } \\
1.0 \mathrm{mpu}\end{array}$ & 4.32 & & & & & & & 4.32 & nomo & felt & Felt, Kapapala. & $\begin{array}{l}\text { Not found in Honolulu Station Bulletin } \\
\text { (Hazard, 1916); looked for but not seen } \\
\text { on station HON film record; ESPHVO, } \\
\text { v. 2, p. 12; not reported in HH. }\end{array}$ \\
\hline $9 / 8 / 13$ & 11:37 & & & & & kaoiki?? & & & & & 22.4 & $\begin{array}{c}\mathrm{VI} \\
\text { (Cancani); } \\
\text { t off scale }\end{array}$ & 4.88 & $<5.22$ & & & & & & 4.88 & nomo & IV (R-F) & $\begin{array}{l}\text { Local shock felt at margin of Kilauea, sharply } \\
\text { in Hilo; all pens swept off. Lyman notes: A } \\
\text { long sharp tremble, then a short sharp shake. } \\
\text { Warshauer notes: A very yharp and short shock } \\
\text { was felt in Hilo Monday morning just before } \\
\text { noon; [mag too high?]. }\end{array}$ & $\begin{array}{l}\text { Not found in Honolulu Station Bulletin } \\
\text { (Hazard, 1916; looked for but not seen } \\
\text { on station HON film record; ESPHVO, } \\
\text { v. 2, p. 19; ESPHVO, v. 2, p. 38; } \\
\text { WKC, 1992, p. 31; PCA, 9/10/1913; } \\
\text { not found in HG, HSB, HT, or HH; no } \\
\text { additional felt reports in PCA. }\end{array}$ \\
\hline $10 / 2 / 13$ & $7: 29$ & & & & & hilea?? & & & & & 44.8 & $\begin{array}{c}\text { II-III } \\
\text { (Cancani); } \\
0.8 \mathrm{mpu}\end{array}$ & 4.14 & & & & & & & 4.14 & nomo & & Duration, $2 \min 0 \mathrm{~s}$. & $\begin{array}{l}\text { ESPHVO, v. 2, p. 55; not found in } \\
\text { Honolulu Station Bulletin (Hazard, } \\
\text { 1916); looked for but not seen on } \\
\text { station HON film record; not reported } \\
\text { in HH. }\end{array}$ \\
\hline $10 / 25 / 13$ & $0: 57$ & & & & & $\mathrm{kl} \mathrm{sf}$ & & & & & 15.0 & off scale & 5.27 & 5.81 & & & & & & 5.81 & hono & VII; VI (R-F) & $\begin{array}{l}\text { Honolulu notes: Felt strongly at Hilo; [at HVO] } \\
\text { shook buildings, objects fell, pictures swayed, } \\
\text { walls cracked, rockslides, seismometers } \\
\text { broken; felt most strongly between Hilo and } \\
\text { HVOO. Lyman notes: A long smart shaking } \\
\text { north and southeast. }\end{array}$ & $\begin{array}{l}\text { Hazard, 1916; ESPHVO, v. 2, p. } 62,64 \\
65 \text { [distance est. 10-20 km; distance } \\
\text { and felt reports implies Kilauea south } \\
\text { flank]; WKC, 1992, p. 31. }\end{array}$ \\
\hline $11 / 7 / 13$ & 10:07 & & & & & hualalai? & & & & & 76.8 & $\begin{array}{c}\text { low I } \\
\text { (Cancani); } \\
0.5[0.05 ?] \\
0 \\
\text { mpu }\end{array}$ & 4.24 & & & & & & & 4.24 & nomo & & Duration, $57 \mathrm{~s}$. & $\begin{array}{l}\text { Not found in Honolulu Station Bulletin } \\
\text { (Hazard, 1916); looked for but not seen } \\
\text { on station HON film record; ESPHVO, } \\
\text { v. } 2 \text {, p. } 69 \text {; not reported in HH. }\end{array}$ \\
\hline $11 / 10 / 13$ & 13:13 & & & & & hilea?? & & & & & 41.6 & $\begin{array}{c}\text { III } \\
\text { (Cancani); } \\
0.9 \text { mpu }\end{array}$ & 4.16 & & & & & & & 4.16 & nomo & & Duration, $25 \mathrm{~s}$. & $\begin{array}{l}\text { Not found in Honolulu Station Bulletin } \\
\text { (Hazard, 1916); looked for but not seen } \\
\text { on station HON film record; ESPHVO, } \\
\text { v. 2, p. 69; not reported in HH. }\end{array}$ \\
\hline $11 / 27 / 13$ & 13:27 & & & & & kona? & & & & & 73.6 & $\begin{array}{c}\text { III } \\
\text { (Cancani); } \\
0.8 \text { mpu }\end{array}$ & 4.49 & & & & & & & 4.49 & nomo & & Duration, $2 \mathrm{~min} 20 \mathrm{~s}$ [mag high?]. & $\begin{array}{l}\text { Not found in Honolulu Station Bulletin } \\
\text { (Hazard, 1916); looked for but not seen } \\
\text { on station HON film record; ESPHVO, } \\
\text { v. 2, p. } 78 \text {; not reported in HH. }\end{array}$ \\
\hline $12 / 14 / 13$ & $5: 33$ & & & & & $\begin{array}{l}\text { alenuihah } \\
\text { a?? }\end{array}$ & & & & & 108.8 & $\begin{array}{c}\text { III } \\
\text { (Cancani); } \\
0.6 \mathrm{mpu}\end{array}$ & 4.59 & & & & & & & 4.59 & nomo & & Duration, 3 min $1 \mathrm{~s}$ [mag high?]. & $\begin{array}{l}\text { Not found in Honolulu Station Bulletin } \\
\text { (Hazard, 1916); looked for but not seen } \\
\text { on station HON film record; ESPHVO, } \\
\text { v. } 2 \text {, p. } 79 \text {; not reported in HH. }\end{array}$ \\
\hline $2 / 14 / 14$ & 19:49 & & & & & $\mathrm{kl} \mathrm{sf??}$ & & & & & 17.9 & $\begin{array}{c}\text { III-IV? } \\
\text { (Cancani); } \\
2.5 \mathrm{mpu}\end{array}$ & 4.10 & & & & & & & 4.10 & nomo & & $d>2 \mathrm{mpu}$, rapid vibration; duration, $1 \mathrm{~min} 49 \mathrm{~s}$. & ESPHVO, v. 2, p. 116 \\
\hline $3 / 8 / 14$ & 2:07 & & & & & $\mathrm{kl} \mathrm{sf??}$ & & & & & 10.9 & $\begin{array}{c}\mathrm{VI} \\
\text { (Cancani); } \\
3 \mathrm{mpu}\end{array}$ & 4.47 & & & & & & & 4.47 & nomo & IV & $\begin{array}{l}\text { Wakened one sleeping person; several times } \\
\text { the mpu; duration, } 1 \mathrm{~min} 38 \mathrm{~s} \text {. }\end{array}$ & $\begin{array}{l}\text { Not found in Honolulu Station Bulletin } \\
\text { (Hazard, 1916); looked for but not seen } \\
\text { on station HON film record; ESPHVO, } \\
\text { v. 2, p. } 148 \text {. }\end{array}$ \\
\hline $3 / 25 / 14$ & $9: 38$ & & & & & hilea?? & & & & & 42.0 & $\begin{array}{c}\text { VII [IV?] } \\
\text { (Cancani); } \\
11 \mathrm{mpu}\end{array}$ & 4.28 & $<5.2$ & & & & & & 4.28 & nomo & IV & $\begin{array}{l}10-12 \mathrm{mpu} \text { [cannot be correct; } 1.0-1.2 \mathrm{mpu} \text { ?]; } \\
\text { rattled windows at HVO. }\end{array}$ & $\begin{array}{l}\text { Not found in Honolulu Station Bulletin } \\
\text { (Hazard, 1916); looked for but not seen } \\
\text { on station HON film record; ESPHVO, } \\
\text { v. 2, p. 136, 148; HT, 3/31/1914 } \\
\text { repeats ESPHVO info; not found in } \\
\text { HH. }\end{array}$ \\
\hline $3 / 25 / 14$ & 19:49 & & & & & hilea?? & & & & & 51.2 & $\begin{array}{c}\text { III } \\
\text { (Cancani); } \\
20.6 \mathrm{mpu}\end{array}$ & 4.07 & & & & & & & 4.07 & nomo & & Duration, $37 \mathrm{~s}$. & ESPHVO, v. 2, p. 148. \\
\hline $3 / 29 / 14$ & 20:04 & & & & & molokai? & & & & & 230.0 & $\begin{array}{c}\text { IV } \\
\text { (Cancani); } \\
1.5 \mathrm{mpu}\end{array}$ & 5.65 & 5.22 & & & & & & 5.22 & hono & felt & $\begin{array}{l}\text { Honolulu notes: Local. Felt at Honolulu but not } \\
\text { at HMO; felt on SE flank of Mauna Loa, more } \\
\text { strongly on Maui and Oahu. Warshauer notes: } \\
\text { Felt strongly in all parts of Honolulu; most } \\
\text { severe in Maui in many years; recorded in } \\
\text { Washington, D.C. }\end{array}$ & $\begin{array}{l}\text { [HVO mag high(?), station HON mag } \\
\text { low]; Honolulu Station Bulletin } \\
\text { (Hazard, 1916; ESPHVO, v. 2, p. 140, } \\
\text { 149; PCA, 3/30/1914, repeated in HG, } \\
\text { 3/31/1914; MN, 4/4/1914; not found in } \\
\text { HH. }\end{array}$ \\
\hline
\end{tabular}


Table 13. All earthquakes of $M \geq 4.0$ during the period 1903-59-Continued

\begin{tabular}{|c|c|c|c|c|c|c|c|c|c|c|c|c|c|c|c|c|c|c|c|c|c|c|c|c|}
\hline Date & $\begin{array}{c}\text { Time } \\
\text { (HST) }\end{array}$ & $\begin{array}{c}\text { Lat } \\
\text { (deg) }\end{array}$ & $\begin{array}{l}\text { Lat } \\
\text { (min) }\end{array}$ & $\begin{array}{c}\text { Lon } \\
(\operatorname{deg})\end{array}$ & $\begin{array}{l}\text { Lon } \\
(\min )\end{array}$ & Region & $\begin{array}{l}\text { Publ. } \\
\text { Depth }\end{array}$ & $\begin{array}{l}\text { Pref. } \\
\text { Depth }\end{array}$ & $\begin{array}{l}\text { Publ. } \\
\text { Dist. }\end{array}$ & $\begin{array}{l}\text { Calc. } \\
\text { Dist }\end{array}$ & $\begin{array}{c}\text { Slant } \\
\text { dist }\end{array}$ & Mag class & $\begin{array}{c}\mathrm{M} \\
\text { nomo }\end{array}$ & $\begin{array}{l}\text { M M-S } \\
\text { E-W }\end{array}$ & $\begin{array}{c}\text { M M-S } \\
\text { N-S }\end{array}$ & M vert & $\begin{array}{l}\text { M hor } \\
\mathrm{N}-\mathrm{L}\end{array}$ & $\begin{array}{c}\mathrm{M} \\
\text { other }\end{array}$ & $\begin{array}{c}\mathrm{M} \\
\text { (other) } \\
\text { source }\end{array}$ & $\begin{array}{c}\mathrm{M} \\
\text { pref }\end{array}$ & $\begin{array}{c}\mathrm{M} \\
\text { (pref) } \\
\text { source }\end{array}$ & $I(\max )$ & Location/felt report & Comment \\
\hline $4 / 13 / 14$ & 4:15 & & & & & hilea?? & & & & & 46.4 & $\begin{array}{l}\text { IV } \\
\text { (Cancani); } \\
1.1 \mathrm{mpu}\end{array}$ & 4.35 & & & & & & & 4.35 & nomo & & Duration, 1 min $31 \mathrm{~s}$. & $\begin{array}{l}\text { ESPHVO, v. 2, p. } 149 \text {; repeated in } \\
\text { Wood, } 1915 \text {, table 3, p. } 49 \text {. }\end{array}$ \\
\hline $4 / 13 / 14$ & $21: 28$ & & & & & hilea?? & & & & & 48.0 & $\begin{array}{c}\text { IV } \\
\text { (Cancani); } \\
1.1 \mathrm{mpu}\end{array}$ & 4.25 & & & & & & & 4.25 & nomo & felt & $\begin{array}{l}\text { Barely felt at HVO; duration, } 2 \text { min } 53 \mathrm{~s} \text { s?) } \\
\text { [start time in ESPHVO given as } 9: 58 \text { p.m., in } \\
\text { disagreement with end time]; a slight tremor } \\
\text { [see below] [mag too high?]. }\end{array}$ & $\begin{array}{l}\text { Not found in Honolulu Station Bulletin } \\
\text { (Hazard, 1916); ESPHVO, v. 2, p. 149; } \\
\text { repeated in Wood, 1915, table 3, p. 49; } \\
\text { WKC, 1992, p. 31 }\end{array}$ \\
\hline $4 / 29 / 14$ & $14: 50$ & & & & & $\mathrm{ml} \mathrm{mok??}$ & & & & & 32.0 & $\begin{array}{c}\text { VI-VII } \\
\text { (Cancani); } \\
6 \mathrm{mpu}\end{array}$ & 5.09 & $<5.22$ & & & & & & 5.09 & 9 nomo & II; II (R-F) & $\begin{array}{l}\text { Felt, feeble; duration, } 19 \text { min; } \min 6 \mathrm{mpu} . \\
\text { Lyman notes: A long shake E\&W then N\&S; } \\
\text { [Rossi-Forel and Cancani readings conflict]; } \\
\text { mild shock felt in Hilo by thoses seated or lying } \\
\text { down; long duration [mag high?]. }\end{array}$ & $\begin{array}{l}\text { Not found in Honolulu Station Bulletin } \\
\text { (Hazard, 1916); looked for but not seen } \\
\text { on station HON film record; ESPHVO, } \\
\text { v. 2, p. 193 [ESPHVO time given as } \\
\text { 14:50]; repeated in Wood, 1915, table } \\
\text { 3, p. 49; WKC, 1992, p. 31; HT, } \\
\text { 5/5/1914; not found in HH or PCA. }\end{array}$ \\
\hline $4 / 29 / 14$ & 14:59 & & & & & $\mathrm{ml} \mathrm{mok??}$ & & & & & 32.0 & $\begin{array}{c}\mathrm{V}-\mathrm{VI} \\
\text { (Cancani); } \\
4.0 \mathrm{mpu}\end{array}$ & 4.85 & & & & & & & 4.85 & 5 nomo & felt & $\begin{array}{l}\text { Felt(?); } 2 \mathrm{~d} \text { maximum in preceding shock; } \\
\text { distance approximate; duration, } 18 \mathrm{~s}[\mathrm{mag} \\
\text { high?]. }\end{array}$ & $\begin{array}{l}\text { ESPHVO, v. 2, p. 193; repeated in } \\
\text { Wood, 1915, table 3, p. } 49 \\
\text { [aftershock(?)]. }\end{array}$ \\
\hline $5 / 13 / 14$ & $15: 41$ & & & & & $\mathrm{kl} \mathrm{sf??}$ & & & & & 16.0 & $\begin{array}{l}\underset{\text { medium }}{\text { IV }} \\
\text { (Cancani); } \\
2.5 \mathrm{mpu}\end{array}$ & 4.09 & & & & & & & 4.09 & 9 nomo & & Duration, $37 \mathrm{~s}$. & $\begin{array}{l}\text { ESPHVO, v. 2, p. 194; repeated in } \\
\text { Wood, } 1915 \text {, table 3, p. } 49 \text {. }\end{array}$ \\
\hline $6 / 1 / 14$ & 6:29 & & & & & $\mathrm{kl} \mathrm{sf??}$ & & & & & 20.0 & offscale & 4.76 & 5.22 & & & & & & 5.22 & 2 hono & IV; III (R-F) & $\begin{array}{l}\text { HON notes: Apparently of a local character, } \\
\text { amp, } 0.1 \mathrm{~mm} \text {; nearby; felt locally, duration, } 6 \\
\text { min } 37 \text { s. Lyman notes: Quite a smart four- } \\
\text { shock earthquake [no day or time given]. } \\
\text { Warshauer notes: At } 6: 20, \text { two distinct shocks } \\
\text { in Hilo, first heavier, no damage. }\end{array}$ & $\begin{array}{l}\text { Hazard, 1916; ESPHVO, v. 2, p. 194; } \\
\text { repeated in Wood, 1915, table 3, p. } 49 \\
\text { [6 assumed as minimum mpu for } \\
\text { offscale]; WKC, 1992, p. 31; HH, } \\
\text { 6/5/1914; not found in PCA, HSB, HT } \\
\text { or MN [south flank(?)]. }\end{array}$ \\
\hline $6 / 19 / 14$ & $11: 20$ & & & & & $\mathrm{ml} \mathrm{mok??}$ & & & & & 31.0 & $\begin{array}{c}\text { III-IV } \\
\text { (Cancani); } \\
1.0 \mathrm{mpu}\end{array}$ & 4.02 & & & & & & & 4.02 & 2 nomo & & Duration, $1 \mathrm{~min} 9 \mathrm{~s}$. & $\begin{array}{l}\text { ESPHVO, v. 2, p. 194; repeated in } \\
\text { Wood, } 1915 \text {, table 3, p. } 49\end{array}$ \\
\hline $6 / 25 / 14$ & 9:29 & & & & & $\mathrm{ml} \mathrm{mok??}$ & & & & & 32.0 & $\begin{array}{l}\text { III-IV } \\
\text { (Cancani); } \\
1.2 \mathrm{mpu}\end{array}$ & 4.15 & & & & & & & 4.15 & 5 nomo & & $\begin{array}{l}\text { Duration, } 3 \text { min } 18 \mathrm{~s} \text {; started the ordinary } \\
\text { seismograph. }\end{array}$ & $\begin{array}{l}\text { ESPHVO, v. 2, p. } 195 \text {; repeated in } \\
\text { Wood, 1915, table 3, p. } 49 \text {. }\end{array}$ \\
\hline $7 / 5 / 14$ & $15: 16$ & & & & & kaoiki?? & & & & & 19.8 & $\begin{array}{c}\mathrm{V} \\
\text { (Cancani); } \\
3.3 \mathrm{mpu}\end{array}$ & 4.41 & & & & & & & 4.41 & 1 nomo & & $\begin{array}{l}\text { Not perceived, moderate-strong; duration, } 5 \\
\text { min } 35 \mathrm{~s} \text {. }\end{array}$ & $\begin{array}{l}\text { ESPHVO, v. 2, p. } 195 \text {; repeated in } \\
\text { Wood, } 1915 \text {, table 3, p. } 49 .\end{array}$ \\
\hline $7 / 5 / 14$ & 19:18 & & & & & kaoiki?? & & & & & 20.8 & $\begin{array}{c}\mathrm{VI} \\
\text { (Cancani); } \\
6.2 \mathrm{mpu}\end{array}$ & 4.81 & $<5.2$ & & & & & & 4.81 & 1 nomo & felt & Moderate-strong; distinctly felt in volcano. & $\begin{array}{l}\text { Not found in Honolulu Station Bulletin } \\
\text { (Hazard, 1916;); looked for but not seen } \\
\text { on station HON film record; ESPHVO, } \\
\text { v. 2, p. 195; repeated in Wood, 1915, } \\
\text { table 3, p. 49; HT, 7/14/1914; not } \\
\text { found in PCA or HH. }\end{array}$ \\
\hline $7 / 20 / 14$ & 4:03 & & & & & $\mathrm{ml} \mathrm{mok??}$ & & & & & 32.0 & $\begin{array}{c}\text { Intensity } \\
\text { IV-V } \\
\text { (Cancani); } \\
2.5 \mathrm{mpu}\end{array}$ & 4.58 & 5.03 & & & & & & 5.03 & 3 hono & V (hilo); II (R-F) & $\begin{array}{l}\text { Distinctly felt by two persons, one or two more } \\
\text { were awakened [Hawaii National Park?]; a felt } \\
\text { shock. . ymanan notes: A Asarp shock at } 4.15 \\
\text { a.m. Warshauer notes: Shock felt from Hilo to } \\
\text { volcano, sharp, } 3 \text { distinct parts; duration, } \\
\text { several seconds; no damage. }\end{array}$ & $\begin{array}{l}\text { Not found in Honolulu Station Bulletin } \\
\text { (Hazard, 1916); detected(?) on station } \\
\text { HON film record, ESPHVO v. } 2 \\
\text { p.193, 196; repeated in Wood, 1915, } \\
\text { table 3, p. 49; WKC, 1992, p. 31; HH, } \\
\text { 7/24/1914; not found in PCA. }\end{array}$ \\
\hline $9 / 27 / 14$ & 10:06 & & & & & hilea? & & & & & & $\begin{array}{c}\text { observed- } \\
\text { off scale }\end{array}$ & & 5.35 & & & & & & 5.35 & 5 hono & II-III & $\begin{array}{l}\text { No instrumental record; probably a succession } \\
\text { of shocks, or several maxima in one shock. } \\
\text { Lyman notes: At } 10: 15 \text { a.m., two slight shocks } \\
\text { \& long tremble at end. Warshauer notes: Rather } \\
\text { severe shock at } 10: 14 \text { a am., N to S; duration, } 15 \\
\mathrm{~s} \text {; also felt elsewhere. }\end{array}$ & $\begin{array}{l}\text { ESPHVO, v. 2, p. 227; repeated in } \\
\text { Wood, 1915, table 1, p. } 43 \text { [shocks of } \\
9 / 27-2 \text { considered precursory to ML } \\
\text { erpution } 2 \text { months later]; WKC, } 1992, \\
\text { p. 31: see below; second shock closer } \\
\text { r to time recorded in Honolulu } \\
\text { [foreshock?]; HH, 10/2/1914; not in } \\
\text { PCA. }\end{array}$ \\
\hline 9/27/14 & 13:11 & & & & & hilea? & & & & & 33.6 & $\begin{array}{c}\text { IV } \\
\text { (Cancani); } \\
1.5 \mathrm{mpu}\end{array}$ & 4.31 & & & & & & & 4.31 & 1 nomo & felt & $\begin{array}{l}\text { Duration, } 3 \min 2 \mathrm{~s} \text {; not felt at HVO. } \\
\text { Warshauer notes: Quake felt tHilol at 1:17 } \\
\text { p.r.m., not as pronounced as the one at 10:14 } \\
\text { a.m.; also felt elsewhere [unspecified]. }\end{array}$ & $\begin{array}{l}\text { ESPHVO, v. 2, p. 227; repeated in } \\
\text { Wood, 1915, table 1, p. 43; HT, } \\
\text { 10/2/1914; not found in PCA. }\end{array}$ \\
\hline $11 / 6 / 14$ & $19: 24$ & & & & & kaoiki?? & & & & & 18.9 & $\begin{array}{c}\text { IV } \\
\text { (Cancani); } \\
2.2 \mathrm{mpu}\end{array}$ & 4.13 & & & & & & & & 3 nomo & & $\begin{array}{l}1 \text { mpu in ESPHVO; duration, } 19 \mathrm{~s} ; \\
\text { exceptionally short period; not perceived at } \\
\text { HVO. }\end{array}$ & $\begin{array}{l}\text { ESPHVO, v. 2, p. } 249 \text {; repeated in } \\
\text { Wood, } 1915 \text {, table } 1 \text {, p. } 43\end{array}$ \\
\hline
\end{tabular}


N Table 13. All earthquakes of $M \geq 4.0$ during the period 1903-59-Continued

\begin{tabular}{|c|c|c|c|c|c|c|c|c|c|c|c|c|c|c|c|c|c|c|c|c|c|c|c|c|}
\hline Date & $\begin{array}{l}\text { Time } \\
\text { (HST) }\end{array}$ & $\begin{array}{c}\text { Lat } \\
\text { (deg) }\end{array}$ & $\begin{array}{c}\text { Lat } \\
(\mathrm{min})\end{array}$ & $\begin{array}{r}\text { Lon } \\
(\mathrm{deg})\end{array}$ & $\begin{array}{l}\text { Lon } \\
(\min )\end{array}$ & Region & $\begin{array}{l}\text { Publ. } \\
\text { Depth }\end{array}$ & $\begin{array}{l}\text { Pref. } \\
\text { Depth }\end{array}$ & $\begin{array}{l}\text { Publ. } \\
\text { Dist. }\end{array}$ & $\begin{array}{l}\text { Calc. } \\
\text { Dist }\end{array}$ & $\begin{array}{c}\text { Slant } \\
\text { dist }\end{array}$ & Mag class & $\begin{array}{c}\mathrm{M} \\
\text { nomo }\end{array}$ & $\begin{array}{l}\text { M M-S } \\
\text { E-W }\end{array}$ & $\begin{array}{c}\text { M M-S } \\
\text { N-S }\end{array}$ & M vert & $\begin{array}{c}\text { M hor } \\
\text { N-L }\end{array}$ & $\begin{array}{c}\text { M } \\
\text { other }\end{array}$ & $\begin{array}{c}\mathrm{M} \\
\text { (other) } \\
\text { source }\end{array}$ & $\begin{array}{c}\mathrm{M} \\
\text { pref }\end{array}$ & $\begin{array}{c}\mathrm{M} \\
\text { (pref) } \\
\text { source }\end{array}$ & $I(\max )$ & Location/felt report & Comment \\
\hline $11 / 13 / 14$ & 19:57 & & & & & kaoiki?? & & & & & 24.8 & $\begin{array}{l}\text { low IV } \\
\text { (Cancani); } \\
1.6 \mathrm{mpu}\end{array}$ & 4.14 & $<5.16$ & & & & & & 4.14 & nomo & $\mathrm{v}$ & $\begin{array}{l}\text { 1.2-1.6 mpu; duration, } 2 \text { min } 10 \mathrm{~s} ; \text { not felt at } \\
\text { HVO. Warshauer notes: [Nov. } 13] \text { at } 7: 50 \mathrm{p} . \mathrm{m} \text {. } \\
\text { a shake of duration } 15 \mathrm{~s} \text {; distinctly felt ta } \\
\text { Puueo, where pictures hanging from walls } \\
\text { swung to and fro; no damage. }\end{array}$ & $\begin{array}{l}\text { Not found in Honolulu Station Bulletin } \\
\text { (Hazard, 1916); looked for but not seen } \\
\text { on station HON film record; ESPHVO, } \\
\text { v. 2, p. 250; repeated in Wood, 1915, } \\
\text { table 1, p. } 44 \text {; HH, 11/20/1914; PCA, } \\
\text { 11/23/1914. }\end{array}$ \\
\hline $11 / 15 / 14$ & $12: 50$ & & & & & kaoiki?? & & & & & 18.7 & $\begin{array}{l}\text { low IV } \\
\text { (Cancani); } \\
2.2 \mathrm{mpu}\end{array}$ & 4.13 & $<5.16$ & & & & & & 4.13 & nomo & $\mathrm{v}$ & $\begin{array}{l}\text { Duration, } 2 \text { min } 48 \mathrm{~s} \text {; felt gently. Warshauer } \\
\text { notes: Before } 1: 00 \text { p.m. [Nov. } 15] \text { ] a more } \\
\text { severe shake [than on the } 13 \text { th]; direction, } \\
\text { south to north; duration, } 10 \mathrm{~s} \text {; rattled windows } \\
\text { and threw pictures out of plumb again. }\end{array}$ & $\begin{array}{l}\text { Not found in station HON film record; } \\
\text { ESPHVO, v. 2, p. } 250 \text {; repeated in } \\
\text { Wood, 1915, table 1, p. 44; HH, } \\
\text { 11/20/1914; not found in PCA. }\end{array}$ \\
\hline $11 / 25 / 14$ & $12: 23$ & & & & & $\mathrm{ml} \mathrm{mok}$ ? & & & & & 34.4 & $\begin{array}{c}>I V \\
\text { (Cancani); } \\
2.4 \mathrm{mpu}\end{array}$ & 4.63 & $<5.2$ & & & & & & 4.63 & nomo & & $\begin{array}{l}\text { ESPHVO, v. 2, p. 261; repeated in Wood, } \\
1915 \text {, table 1, p. } 44 \text {; not perceived at HVO. }\end{array}$ & $\begin{array}{l}\text { Not found in Honolulu Station Bulletin } \\
\text { (Hazard, 1916); looked for but not seen } \\
\text { on station HON film record; minimum } \\
\text { mpi; recording pen swept from } \\
\text { cylinder; distance, 21-22 mi. }\end{array}$ \\
\hline $11 / 25 / 14$ & $14: 13$ & & & & & $\mathrm{ml} \mathrm{mok}$ ? & & & & & & $\begin{array}{l}\text { IV } \\
\text { (Cancani); } \\
1.08 \text { mpu }\end{array}$ & 4.18 & & & & & & & 4.18 & nomo & & Duration, $4 \min 38 \mathrm{~s}$; not perceived at HVO. & $\begin{array}{l}\text { ESPHVO, v. 2, p. } 262 \text {; repeated in } \\
\text { Wood, 1915, table } 1 \text {, p. } 44\end{array}$ \\
\hline $12 / 13 / 14$ & 19:40 & & & & & $\mathrm{ml} \mathrm{mok??}$ & & & & & & $\begin{array}{l}\text { IV } \\
\text { (Cancani); } \\
1.0 \mathrm{mpu}\end{array}$ & 4.31 & & & & & & & 4.31 & nomo & & $\begin{array}{l}\text { Minimum mpu; duration, } 1 \text { min } 20 \mathrm{~s} \text {; not } \\
\text { perceived at HVO. }\end{array}$ & $\begin{array}{l}\text { ESPHVO, v. 2, p. 262; repeated in } \\
\text { Wood, 1915, table 2, p. } 46\end{array}$ \\
\hline $1 / 13 / 15$ & 19:38 & & & & & a3035 & & & & & 32.0 & & 4.25 & $<5.22$ & & & & & & 4.25 & nomo & II-III & $\begin{array}{l}\text { Felt in Hilo. Lyman notes: Slight shock, long } \\
\text { duration at } 7: 45 \text { p.m. }\end{array}$ & $\begin{array}{l}\text { Not found in Honolulu Station Bulletin } \\
\text { (Hazard, 1918); looked for but not seen } \\
\text { on station HON film record; ESPHVO, } \\
\text { v. 2, p. 267; SBHVO, v. 1, no. 1; } \\
\text { WKC, 1992, p. 31; not found in HH or } \\
\text { PCA. }\end{array}$ \\
\hline $1 / 25 / 15$ & $15: 35$ & & & & & ml swr? & & & & & 50.0 & & 4.16 & & & & & & & 4.16 & poor & & $\begin{array}{l}\text { Distance calculated from Wood's catalog, using } \\
\text { the time difference between the maximum } \\
\text { signal and the inferred } S \text { arrival. }\end{array}$ & SBHVO, v. 1, no. 1 \\
\hline $3 / 28 / 15$ & 8:26 & & & & & kaoiki?? & & & & & 21.0 & & $>5.07$ & 6.37 & & & & & & 6.37 & hono & $\mathrm{V} ; \mathrm{IV}-\mathrm{V}(\mathrm{R}-\mathrm{F})$ & $\begin{array}{l}\text { Shaking for 5-7 s, } 6 \text { maxima, third was } \\
\text { strongest, pens thrown off to } \mathrm{S} \text { and E; clock } \\
\text { stopped in Waiohinu, where shock strongest to } \\
\text { SW of HVO, neeedles thrown off to } \mathrm{N}(?) \text { and } \mathrm{E} \\
\text { [inferred direction NE (SE?) or SW]. }\end{array}$ & $\begin{array}{l}\text { Hazard, 1918; not mentioned in WK; } \\
\text { ESPHVO, v. 2, p. 285; SHHVO, v. } 1 \text {, } \\
\text { no. } 2 \text { [distance assumed from preceding } \\
\text { and succeeding quakes]. }\end{array}$ \\
\hline $3 / 28 / 15$ & 9:06 & & & & & kaoiki?? & & & & & 21.0 & & & 5.52 & & & & & & 5.52 & hono & & & $\begin{array}{l}\text { [Aftershock(?)]; recorded in Honolulu; } \\
\text { lost in main shock, so not noted in } \\
\text { SBHVO, v. 1, no. 2. }\end{array}$ \\
\hline $5 / 26 / 15$ & 7:26 & & & & & $\mathrm{kl} \mathrm{sf??}$ & & & & & 31.0 & & 5.24 & & & & & & & 5.24 & nomo & felt & $\begin{array}{l}\text { Felt by several at Volcano House as a slow } \\
\text { swing; origin, SE or NW; N-S amp 32, E-W } \\
\text { amp 101; unusually discrepant. Warshauer } \\
\text { notess: Another quiver felt in Hilo at about 7:30 } \\
\text { a.m. [mag high?]. }\end{array}$ & $\begin{array}{l}\text { Not found in Honolulu Station Bulletin } \\
\text { (Hazard, 1918); looked for but not seen } \\
\text { on station HON film record; ESPHVO, } \\
\text { v. 2, p. 314; SBHVO, v. 1, no. 3; HH, } \\
5 / 28 / 1914 \text {; HT, 6/11/1915; not found in } \\
\text { PCA or HSB. }\end{array}$ \\
\hline $8 / 15 / 15$ & 5:15 & & & & & a2025 & & & & & 22.0 & & 4.79 & $<5.2$ & & & & & & 4.79 & nomo & felt & $\begin{array}{l}\text { About 5:20; felt at the Volcano House and } \\
\text { generally in the vicinity of HVO. Warshauer } \\
\text { notes: Sharp shock felt in Hilo near 5:15 a.m. }\end{array}$ & $\begin{array}{l}\text { Not found in Honolulu Station Bulletin } \\
\text { (Hazard, 1918); looked for but not seen } \\
\text { on station HON film record; ESPHVO, } \\
\text { v. 2, p. 347; SBHVO, v. 1, no. 4; HH, } \\
\text { 8/20/1915. }\end{array}$ \\
\hline $8 / 16 / 15$ & 13:56 & & & & & a2025 & & & & & 21.0 & & 4.10 & & & & & & & 4.10 & nomo & & & SBHVO, v. 1 , no. 4 \\
\hline $8 / 31 / 15$ & 4:58 & & & & & a2025 & & & & & 21.0 & & 4.92 & $<5.2$ & & & & & & 4.92 & nomo & felt & $\begin{array}{l}\text { During week ending 9/1/15, } 6 \text { shocks, } 3 \text { in one } \\
\text { day, one felt locally, two felt in Hilo; felt } \\
\text { generally in the vicinity of HVO [and in Hilo, } \\
\text { from ESPHVO note]. }\end{array}$ & $\begin{array}{l}\text { Not found in Honolulu Station Bulletin } \\
\text { (Hazard, 1918); looked for but not seen } \\
\text { on station HON film record; ESPHVO, } \\
\text { v. 2, p. 354; SBHVO, v. 1, no. 4; not } \\
\text { found in HH }\end{array}$ \\
\hline $9 / 25 / 15$ & 13:24 & & & & & $\begin{array}{l}\text { mauna } \\
\text { kea? }\end{array}$ & & & & & 47.0 & & 4.20 & & & & & & & 4.20 & nomo & felt & $\begin{array}{l}\text { Warshauer notes: Several rather severe shocks } \\
\text { during the past week, and one on Sunday last } \\
\text { [Sept. 25] was rather strenuous. It was felt at } \\
\text { Honokaa and Kukuihaele more than near Hilo. } \\
\text { Other quakes have been felt along the coast and } \\
\text { all over the island. }\end{array}$ & $\begin{array}{l}\text { Not found in Honolulu Station Bulletin } \\
\text { (Hazard, 1918); looked for but not seen } \\
\text { lon station HON film recordd SBHVO } \\
\text { (Wood, unpub.); HH, 10/1/1915. }\end{array}$ \\
\hline $9 / 25 / 15$ & 13:52 & & & & & $\begin{array}{l}\text { mauna } \\
\text { kea? }\end{array}$ & & & & & 40.0 & & 4.09 & & & & & & & 4.09 & nomo & felt & Felt(?)—see above. & SBHVO (Wood, unpub.). \\
\hline
\end{tabular}


Table 13. All earthquakes of $M \geq 4.0$ during the period 1903-59-Continued

\begin{tabular}{|c|c|c|c|c|c|c|c|c|c|c|c|c|c|c|c|c|c|c|c|c|c|c|c|c|}
\hline Date & $\begin{array}{c}\text { Time } \\
\text { (HST) }\end{array}$ & $\begin{array}{c}\text { Lat } \\
\text { (deg) }\end{array}$ & $\begin{array}{l}\text { Lat } \\
(\mathrm{min})\end{array}$ & $\begin{array}{c}\text { Lon } \\
(\operatorname{deg})\end{array}$ & $\begin{array}{l}\text { Lon } \\
(\min )\end{array}$ & Region & $\begin{array}{l}\text { Publ. } \\
\text { Depth }\end{array}$ & $\begin{array}{l}\text { Pref. } \\
\text { Depth }\end{array}$ & $\begin{array}{l}\text { Publ. } \\
\text { Dist. }\end{array}$ & $\begin{array}{l}\text { Calc. } \\
\text { Dist }\end{array}$ & $\begin{array}{c}\text { Slant } \\
\text { dist }\end{array}$ & Mag class & $\begin{array}{c}\mathrm{M} \\
\text { nomo }\end{array}$ & $\begin{array}{c}\text { M M-S } \\
\text { E-W }\end{array}$ & $\begin{array}{c}\text { M M-S } \\
\text { N-S }\end{array}$ & M vert & $\begin{array}{l}\text { M hor } \\
\mathrm{N}-\mathrm{L}\end{array}$ & $\begin{array}{c}\mathrm{M} \\
\text { other }\end{array}$ & $\begin{array}{c}\mathrm{M} \\
\text { (other) } \\
\text { source }\end{array}$ & $\underset{\text { pref }}{\mathrm{M}}$ & $\begin{array}{c}\mathrm{M} \\
\text { (pref) } \\
\text { source }\end{array}$ & $I(\max )$ & Location/felt report & Comment \\
\hline $9 / 25 / 15$ & $16: 25$ & & & & & kl sf? & & & & & 21.0 & off scale & $>4.56$ & $<5.2$ & & & & & & 4.60 & 9 poor & felt & Felt-volcano; amplitude assumed. & $\begin{array}{l}\text { Not found in Honolulu Station Bulletin } \\
\text { (Hazard, 1918); looked for but not seen } \\
\text { on station HON film record; SBHVO } \\
\text { (Wood, unpub.); not found in HH. }\end{array}$ \\
\hline $10 / 21 / 15$ & $3: 58$ & & & & & a2025 & & & & & 21.0 & & 4.22 & & & & & & & 4.22 & 2 nomo & felt & Morning; probably felt locally. & $\begin{array}{l}\text { ESPHVO, v. 2, p. 369; SBHVO } \\
\text { (Wood, unpub.). }\end{array}$ \\
\hline $11 / 7 / 15$ & 15:01 & & & & & a3035 & & & & & 32.0 & & 4.02 & & & & & & & 4.02 & 2 nomo & & & SBHVO (Wood, unpub.). \\
\hline $11 / 20 / 15$ & 12:04 & & & & & kona? & & & & & 73.0 & & 4.07 & & & & & & & 4.07 & 7 nomo & & & Do. \\
\hline $12 / 5 / 15$ & $5: 25$ & & & & & a3035 & & & & & 32.0 & & 4.86 & & & & & & & 4.86 & 6 nomo & II? & Felt at volcano house—-see below. & Do. \\
\hline $12 / 8 / 15$ & 1:09 & & & & & a3035 & & & & & 32.0 & & 4.51 & & & & & & & 4.51 & 1 nomo & & & Do. \\
\hline $1 / 4 / 16$ & 23:15 & & & & & a2025 & & & & & 21.0 & & 4.06 & & & & & & & 4.06 & 6 nomo & & & Do. \\
\hline $1 / 10 / 16$ & $17: 24$ & & & & & a2025 & & & & & 21.0 & & 4.33 & & & & & & & 4.33 & 3 nomo & felt & Early evening, January 10; two felt in Hilo. & $\begin{array}{l}\text { ESPHVO, v. 2, p. } 385 ; \text { SBHVO } \\
\text { (Wood, unpub.). }\end{array}$ \\
\hline $1 / 10 / 16$ & $18: 46$ & & & & & a2025 & & & & & 21.0 & & 4.19 & & & & & & & 4.19 & 9 nomo & felt & $\begin{array}{l}\text { Early evening, January } 10 \text {; two felt in Hilo, not } \\
\text { locally. }\end{array}$ & SBHVO (Wood, unpub.). \\
\hline $4 / 9 / 16$ & 22:00 & & & & & $\mathrm{ml} \mathrm{mok}$ ? & & & & & 35.0 & & 4.91 & 5.16 & & & & & & 5.16 & 6 desp & III & $\begin{array}{l}\text { Warshauer notes: Earthquakes shook the } \\
\text { district severely last night and dismantled the } \\
\text { instruments in the Volcano Observatory [Tom- } \\
\text { get original newspaper]. }\end{array}$ & $\begin{array}{l}\text { Time assumed; not reported in SBHVO } \\
\text { (Wood, unpub.) or in Honolulu Station } \\
\text { Bulletin (Haard, 1918); ; vent on } \\
\text { station HON film record at } 14: 53,4 / 08 \\
\text { [differs from newspaper account]; HT, } \\
\text { 4/10/1916; not found in PCA, HG, } \\
\text { MN, or HH. }\end{array}$ \\
\hline $4 / 28 / 16$ & $7: 34$ & & & & & kaoiki? & & & & & 20.0 & & 4.14 & & & & & & & 4.14 & 4 nomo & felt & Felt in Hilo, not locally. & SBHVO (Wood, unpub.). \\
\hline $5 / 20 / 16$ & 8:39 & & & & & ml swr? & & & & & 47.0 & & 4.22 & & & & & & & 4.22 & 2 nomo & felt & $\begin{array}{l}\text { The first fairly strong shock of the spasm, } \\
\text { followed by a brief lull; felt-Hilea. }\end{array}$ & Do. \\
\hline $5 / 20 / 16$ & $16: 40$ & & & & & $\mathrm{ml} \mathrm{swr}$ ? & & & & & 40.0 & & 4.14 & & & & & & & 4.14 & 4 nomo & felt & Felt-Hilea. & Do. \\
\hline $5 / 20 / 16$ & 17:07 & & & & & hilea? & & & & & 47.0 & & 4.57 & & & & & & & 4.57 & 7 nomo & felt & Do. & Do. \\
\hline $5 / 21 / 16$ & 8:21 & & & & & hilea? & & & & & 45.0 & & 5.24 & $<5.2$ & & & & & & 5.24 & 4 nomo & felt & Felt; presumed felt $\mathrm{HVO}, \mathrm{S}$ Hawaii. & $\begin{array}{l}\text { Not found in Honolulu Station Bulletin } \\
\text { (Hazard, 1918); looked for but not seen } \\
\text { on station HON film record; SBHVO } \\
\text { (Wood, unpub.); ESPHVO, v. 2, p. } \\
453,456 \text {; not found in PCA, HSB, or } \\
\text { MN. }\end{array}$ \\
\hline $5 / 21 / 16$ & $8: 33$ & & & & & hilea? & & & & & 46.0 & & 4.70 & $<5.2$ & & & & & & 4.70 & 0 nomo & felt & Felt; presumed felt S Hawaii. & $\begin{array}{l}\text { Not found in Honolulu Station Bulletin } \\
\text { (Hazard, 1918); SBHVO (Wood, } \\
\text { unpub.); ESPVD, v. 2, p. 453, 456; } \\
\text { not found in PCA, HBB, or MN. }\end{array}$ \\
\hline $5 / 21 / 16$ & $17: 51$ & & & & & hilea? & & & & & 47.0 & & 4.37 & & & & & & & 4.37 & 7 nomo & felt & Felt. & SBHVO (Wood, unpub.). \\
\hline $5 / 22 / 16$ & 0:02 & & & & & $\mathrm{ml}$ wf?? & & & & & 58.0 & & $>5.06$ & $<5.2$ & & & & & & 5.10 & 0 nomo & felt & $\begin{array}{l}\text { Minimum amplitude; pens swept off cylinders; } \\
\text { presumed felt at HVO, S Hawaii. }\end{array}$ & $\begin{array}{l}\text { Not found in Honolulu Station Bulletin } \\
\text { (Hazard, 1918); looked for but not seen } \\
\text { on station HON film record; SBHVO } \\
\text { (Wood, unpub.); ESPHVO, v. 2, p. } \\
453 \text {. }\end{array}$ \\
\hline $5 / 22 / 16$ & 7:40 & & & & & hilea? & & & & & 55.0 & & 4.42 & & & & & & & 4.42 & 2 nomo & & & SBHVO (Wood, unpub.). \\
\hline $5 / 22 / 16$ & 7:42 & & & & & hilea? & & & & & 48.0 & & 5.07 & $<5.2$ & & & & & & 5.07 & 7 nomo & felt & Presumed felt HVO, $\mathrm{S}$ Hawaii. & $\begin{array}{l}\text { Not found in Honolulu Station Bulletin } \\
\text { (Hazard, 1918); SBHVO (Wood, } \\
\text { unpub.); record being changed; } \\
\text { ESPHVO, v. 2, p. } 453 \text {. }\end{array}$ \\
\hline $5 / 22 / 16$ & 8:14 & & & & & hilea? & & & & & 50.0 & & 5.16 & $<5.2$ & & & & & & 5.16 & 6 nomo & felt & $\begin{array}{l}\text { Minimum amplitude; pens swept off cylinders; } \\
\text { presumed felt HVO, S Hawaii. }\end{array}$ & $\begin{array}{l}\text { Not found in Honolulu Station Bulletin } \\
\text { (Hazard, 1918); looked for but not seen } \\
\text { on station HON film record; SBHVO } \\
\text { (Wood, unpub.); ESPHVO, v. 2, p. } \\
453 \text {. }\end{array}$ \\
\hline $5 / 22 / 16$ & 13:27 & & & & & hilea? & & & & & 48.0 & & 4.70 & $<5.2$ & & & & & & 4.70 & 0 nomo & felt & Presumed felt-S Hawaii. & $\begin{array}{l}\text { Not found in Honolulu Station Bulletin } \\
\text { (Hazard, 1918); looked for but not seen } \\
\text { on station HON film record; SBHVO } \\
\text { (Wood, unpub.); ESPHVO, v. 2, p. } \\
453 \text {. }\end{array}$ \\
\hline $5 / 22 / 16$ & $14: 26$ & & & & & hilea? & & & & & 50.0 & & 4.53 & & & & & & & 4.53 & 3 nomo & felt & Do. & $\begin{array}{l}\text { Not found in Honolulu Station Bulletin } \\
\text { (Hazard, 1918); SBHVO (Wood, } \\
\text { unpub.); ESPVO, v. 2, p. 453. }\end{array}$ \\
\hline
\end{tabular}


$\$ \quad$ Table 13. All earthquakes of $M \geq 4.0$ during the period 1903-59-Continued

\begin{tabular}{|c|c|c|c|c|c|c|c|c|c|c|c|c|c|c|c|c|c|c|c|c|c|c|c|c|}
\hline Date & $\begin{array}{c}\text { Time } \\
\text { (HST) }\end{array}$ & $\begin{array}{c}\text { Lat } \\
\text { (deg) }\end{array}$ & $\begin{array}{c}\text { Lat } \\
(\mathrm{min})\end{array}$ & $\begin{array}{c}\text { Lon } \\
\text { (deg) }\end{array}$ & $\begin{array}{c}\text { Lon } \\
(\min )\end{array}$ & Region & $\begin{array}{l}\text { Publ. } \\
\text { Depth } 1\end{array}$ & $\begin{array}{l}\text { Pref. } \\
\text { Depth }\end{array}$ & $\begin{array}{l}\text { Publ. } \\
\text { Dist. }\end{array}$ & $\begin{array}{l}\text { Calc. } \\
\text { Dist }\end{array}$ & $\begin{array}{l}\text { Slant } \\
\text { dist }\end{array}$ & Mag class & $\begin{array}{c}\mathrm{M} \\
\text { nomo }\end{array}$ & $\begin{array}{c}\text { M M-S } \\
\text { E-W }\end{array}$ & $\begin{array}{c}\text { M M-S } \\
\text { N-S }\end{array}$ & M vert & $\begin{array}{c}\text { M hor } \\
\mathrm{N}-\mathrm{L}\end{array}$ & $\begin{array}{c}\mathrm{M} \\
\text { other }\end{array}$ & $\begin{array}{l}\mathrm{M} \\
\text { (other) } \\
\text { source }\end{array}$ & $\underset{\text { pref }}{\mathrm{M}}$ & $\begin{array}{c}\mathrm{M} \\
\text { (pref) } \\
\text { source }\end{array}$ & $I(\max )$ & Location/felt report & Comment \\
\hline $5 / 22 / 16$ & 16:05 & & & & & hilea? & & & & & 52.0 & & 4.48 & & & & & & & 4.48 & nomo & & & $\begin{array}{l}\text { Not found in Honolulu Station Bulletin } \\
\text { (Hazard, 1918); SBHVO (Wood, } \\
\text { unpub.). }\end{array}$ \\
\hline $5 / 22 / 16$ & $16: 52$ & & & & & $\mathrm{ml}$ wf?? & & & & & 66.0 & & 5.44 & & & & & & & 5.44 & nomo & felt & $\begin{array}{l}\text { Pens swept off cylinders; presumed felt HVO, } \\
\text { S Hawaii. }\end{array}$ & $\begin{array}{l}\text { Not found in Honolulu Station Bulletin } \\
\text { (Hazard, 1918); looked for but not seen } \\
\text { on station HON film record; SBHVO } \\
\text { (Wood, unpub.); ESPHVO, v. 2, p. } \\
453 .\end{array}$ \\
\hline $5 / 22 / 16$ & $20: 21$ & & & & & ml wf?? & & & & & 55.0 & & 4.75 & $<5.2$ & & & & & & 4.75 & nomo & felt & Presumed felt-S Hawaii. & $\begin{array}{l}\text { Not found in Honolulu Station Bulletin } \\
\text { (Hazard, 1918); looked for but not seen } \\
\text { on station HON film record; SBHVO } \\
\text { (Wood, unpub.); ESPHVO, v. 2, p. } \\
\text { 453. }\end{array}$ \\
\hline $5 / 22 / 16$ & $21: 36$ & & & & & ml swr? & & & & & 46.0 & & 4.34 & & & & & & & 4.34 & nomo & & & SBHVO (Wood, unpub.). \\
\hline $5 / 22 / 16$ & $21: 44$ & & & & & ml swr? & & & & & 45.0 & & 4.42 & & & & & & & 4.42 & nomo & & & SBHVO (Wood, unpub.). \\
\hline $5 / 23 / 16$ & 4:59 & & & & & ml wf? & & & & & 65.0 & & 4.71 & $<5.2$ & & & & & & 4.71 & nomo & felt & Presumed felt-S Hawaii. & $\begin{array}{l}\text { Not found in Honolulu Station Bulletin } \\
\text { (Hazard, 1918); looked for but not seen } \\
\text { on station HON film record; SBHVO } \\
\text { (Wood, unpub.); ESPHVO, v. 2, p. } \\
\text { 453. }\end{array}$ \\
\hline $5 / 23 / 16$ & 5:37 & & & & & hilea? & & & & & 48.0 & & 4.76 & $<5.2$ & & & & & & 4.76 & nomo & felt & Presumed felt-S Hawaii. & $\begin{array}{l}\text { Not found in Honolulu Station Bulletin } \\
\text { (Hazard, 1918); looked for but not seen } \\
\text { on station HON film record, SBHVO } \\
\text { (Wood, unpub.); ESPHVO, v. 2, p. } \\
\text { 453. }\end{array}$ \\
\hline $5 / 23 / 16$ & 5:53 & & & & & ml wf? & & & & & 57.5 & & 5.50 & 5.16 & & & & & & 5.16 & aver & felt & $\begin{array}{l}\text { Preferred magnitude calculated as average of } \\
\text { nomogram and Honolulu; presumed felt-HVO, } \\
\text { S Hawaii. }\end{array}$ & $\begin{array}{l}\text { Not found in Honolulu Station Bulletin } \\
\text { (Hazard, 1918); event seen on station } \\
\text { HON film record at 05:50, amp 0.2 mm } \\
\text { [Wood time off?]; SBHVO (Wood, } \\
\text { unpub.); ESPHVO, v. 2, p. } 453 \text {. }\end{array}$ \\
\hline $5 / 23 / 16$ & 7:13 & & & & & ml swr? & & & & & 48.0 & & 4.09 & & & & & & & 4.09 & nomo & & & SBHVO (Wood, unpub.). \\
\hline $5 / 23 / 16$ & $7: 48$ & & & & & hilea? & & & & & 55.0 & & 4.37 & & & & & & & 4.37 & nomo & & & Do. \\
\hline $5 / 23 / 16$ & 9:07 & & & & & ml swr? & & & & & 55.0 & & 4.34 & & & & & & & 4.34 & nomo & & & Do. \\
\hline $5 / 23 / 16$ & $13: 48$ & & & & & ml wf? & & & & & 62.0 & & 4.02 & & & & & & & 4.02 & nomo & & & Do. \\
\hline 5/23/16 & 17:02 & & & & & ml swr? & & & & & 55.0 & & 4.12 & & & & & & & 4.12 & nomo & & & Do. \\
\hline $5 / 23 / 16$ & 23:37 & & & & & ml wf? & & & & & 65.0 & & 4.13 & & & & & & & 4.13 & nomo & & & Do. \\
\hline $5 / 24 / 16$ & 6:04 & & & & & ml wf? & & & & & 63.0 & & 5.50 & $<5.2$ & & & & & & 5.00 & aver & felt & $\begin{array}{l}\text { Preferred magnitude calculated as average of } \\
\text { nomogram and Honolulu; presumed felt-HVO, } \\
\text { S Hawaii. }\end{array}$ & $\begin{array}{l}\text { Not found in Honolulu Station Bulletin } \\
\text { (Hazard, 1918); looked for but not seen } \\
\text { on station HON film record, SBHVO } \\
\text { (Wood, unpub.); ESPHVO, v. 2, p. } \\
\text { 453. }\end{array}$ \\
\hline $5 / 24 / 16$ & 6:51 & & & & & hilea? & & & & & 50.0 & & & 5.71 & & & & & & 5.71 & hono & felt & $\begin{array}{l}\text { Pens swept off cylinder; the strongest shock of } \\
\text { the series, up to this time, accompanying the } \\
\text { eruption; presumed felt-HVO, S Hawaii. }\end{array}$ & $\begin{array}{l}\text { Not found in Honolulu Station Bulletin } \\
\text { (Hazard, 1918); seen on station HON } \\
\text { film record; SBHVO (Wood, unpub.); } \\
\text { ESPHVO, v. 2, p. } 453 \text {. }\end{array}$ \\
\hline $5 / 24 / 16$ & $12: 37$ & & & & & hilea? & & & & & 46.0 & & 4.51 & & & & & & & 4.51 & nomo & felt & Presumed felt-S Hawaii. & $\begin{array}{l}\text { SBHVO (Wood, unpub.); ESPHVO, v. } \\
\text { 2, p. } 453 \text {. }\end{array}$ \\
\hline $5 / 24 / 16$ & $13: 42$ & & & & & ml swr? & & & & & 48.0 & & 4.06 & & & & & & & 4.06 & nomo & & & SBHVO (Wood, unpub.). \\
\hline $5 / 24 / 16$ & 16:09 & & & & & ml swr? & & & & & 48.0 & & 4.09 & & & & & & & 4.09 & nomo & & & Do. \\
\hline $5 / 24 / 16$ & $19: 29$ & & & & & hilea? & & & & & 49.0 & & 5.32 & 5.08 & & & & & & 5.08 & aver & felt & $\begin{array}{l}\text { Preferred magnitude calculated as average of } \\
\text { nomogram and Honolulu; presumed felt-HVO, } \\
\text { S Hawaii. }\end{array}$ & $\begin{array}{l}\text { Not found in Honolulu Station Bulletin } \\
\text { (Hazard, 1918); seen on station HON } \\
\text { film record; SBHVO (Wood, unpub.); } \\
\text { ESPHVO, v. 2, p. } 453 \text {. }\end{array}$ \\
\hline $5 / 25 / 16$ & 13:41 & & & & & $\mathrm{ml}$ wf? & & & & & 58.0 & & 5.45 & $<5.2$ & & & & & & 5.00 & aver & felt & Presumed felt-HVO, $\mathrm{S}$ Hawaii. & $\begin{array}{l}\text { Not found in Honolulu Station Bulletin } \\
\text { (Hazard, 1918); looked for but not seen } \\
\text { on station HON film record; SBHVO } \\
\text { (Wood, unpub.); ESPHVO, v. 2, p. } 453\end{array}$ \\
\hline $5 / 25 / 16$ & $17: 36$ & & & & & hilea? & & & & & 50.0 & & 4.49 & & & & & & & 4.49 & nomo & & & SBHVO (Wood, unpub.). \\
\hline $5 / 25 / 16$ & $21: 50$ & & & & & kaoiki? & & & & & 26.0 & & 4.23 & & & & & & & 4.23 & nomo & & & Do. \\
\hline
\end{tabular}


Table 13. All earthquakes of $M \geq 4.0$ during the period 1903-59-Continued

\begin{tabular}{|c|c|c|c|c|c|c|c|c|c|c|c|c|c|c|c|c|c|c|c|c|c|c|c|}
\hline Date & $\begin{array}{l}\text { Time } \\
\text { (HST) }\end{array}$ & $\begin{array}{ll}\text { Lat } & \text { Lat } \\
\text { (deg) } & \text { (min) }\end{array}$ & $\begin{array}{l}\text { Lon } \\
(\operatorname{deg})\end{array}$ & $\begin{array}{c}\text { Lon } \\
(\mathrm{min})\end{array}$ & Region & $\begin{array}{l}\text { Publ. } \\
\text { Depth }\end{array}$ & $\begin{array}{l}\text { Pref. } \\
\text { Depth }\end{array}$ & $\begin{array}{l}\text { Publ. } \\
\text { Dist. }\end{array}$ & $\begin{array}{l}\text { Calc. } \\
\text { Dist }\end{array}$ & $\begin{array}{c}\text { Slant } \\
\text { dist }\end{array}$ & Mag class & $\begin{array}{c}\mathrm{M} \\
\text { nomo }\end{array}$ & $\begin{array}{c}\text { M M-S } \\
\text { E-W }\end{array}$ & $\underset{\mathrm{N}-\mathrm{S}}{\mathrm{M} \text { M-S }}$ & $M$ vert & $\begin{array}{c}\text { M hor } \\
\mathrm{N}-\mathrm{L}\end{array}$ & $\begin{array}{c}\mathrm{M} \\
\text { other }\end{array}$ & $\begin{array}{c}\mathrm{M} \\
\text { (other) } \\
\text { source }\end{array}$ & $\begin{array}{c}\mathrm{M} \\
\text { pref }\end{array}$ & $\begin{array}{c}\text { M } \\
\text { (pref) } \\
\text { source }\end{array}$ & $I(\max )$ & Location/felt report & Comment \\
\hline $5 / 25 / 16$ & 23:44 & & & & $\mathrm{ml} \mathrm{swr}$ ? & & & & & 40.0 & & 5.02 & & & & & & & 5.02 & nomo & felt & Presumed felt-HVO, S Hawaii. & $\begin{array}{l}\text { SBHVO (Wood, unpub.); ESPHVO, v. } \\
\text { 2, p. } 453\end{array}$ \\
\hline $5 / 26 / 16$ & 9:19 & & & & ml swr? & & & & & 43.0 & & 4.03 & & & & & & & 4.03 & nomo & & & SBHVO (Wood, unpub.). \\
\hline $5 / 26 / 16$ & 9:26 & & & & hilea? & & & & & & & & 5.08 & & & & & & 5.08 & hono & $\mathrm{V} ; \mathrm{V}(\mathrm{R}-\mathrm{F})$ & $\begin{array}{l}\text { Felt distinctly by nearly all, but without } \\
\text { stopping pendulum clocks or producing alarm. }\end{array}$ & $\begin{array}{l}\text { Not found in Honolulu Station Bulletin } \\
\text { (Hazard, 1918); seen on station HON } \\
\text { film record; SBHVO (Wood, unpub.). }\end{array}$ \\
\hline $5 / 30 / 16$ & $20: 40$ & & & & hilea & & & & & 48.0 & & 4.57 & $<5.2$ & & & & & & 4.57 & nomo & $\mathrm{v}$ & $\begin{array}{l}\text { Very sharp shock felt in Kau; time given as } \\
\text { about } 20: 15 \text {; felt outdoors at flow-source } \\
\text { [Mauna Loa southwest rift] but stronger at } \\
\text { Waiohinu. Warshauer notes: One very sharp } \\
\text { shock felt in Kau about } 8: 15 \text { p.m. }\end{array}$ & $\begin{array}{l}\text { Not found in Honolulu Station Bulletin } \\
\text { (Hazard, 1918); looked for but not seen } \\
\text { on station HON film record; ESPHVO, } \\
\text { v. 2, p. 459; SBHVO (Wood, unpub.); } \\
\text { HT, 6/7/1916; not found in PCA or } \\
\text { HSB. }\end{array}$ \\
\hline $6 / 5 / 16$ & $0: 25$ & & & & kl sf? & & & & & 24.0 & & 4.05 & & & & & & & 4.05 & nomo & & & SBHVO (Wood, unpub.). \\
\hline $6 / 5 / 16$ & $0: 36$ & & & & kl sf? & & & & & 23.0 & & 4.49 & & & & & & & 4.49 & nomo & & & Do. \\
\hline $6 / 5 / 16$ & 6:55 & & & & kl sf? & & & & & 26.0 & & 4.00 & & & & & & & 4.00 & nomo & & & Do. \\
\hline $6 / 5 / 16$ & 8:05 & & & & kl sf? & & & & & 24.0 & & 4.05 & & & & & & & 4.05 & nomo & & & Do. \\
\hline $6 / 5 / 16$ & 8:59 & & & & kl sf? & & & & & 24.0 & offscale & $>4.7$ & $<5.2$ & & & & & & 4.80 & poor & & Pens flung off; amplitude assumed. & $\begin{array}{l}\text { Not found in Honolulu Station Bulletin } \\
\text { (Hazard, 1918); looked for but not seen } \\
\text { on station HON film record; SBHVO } \\
\text { (Wood, unpub.). }\end{array}$ \\
\hline $6 / 5 / 16$ & 9:40 & & & & hualalai? & & & & & 80.0 & & 4.70 & & & & & & & 4.70 & nomo & & Near shock; fairly energetic. & SBHVO (Wood, unpub.). \\
\hline $6 / 5 / 16$ & 10:16 & & & & kl sf? & & & & & 27.0 & & 4.42 & & & & & & & 4.42 & nomo & & & Do. \\
\hline $6 / 5 / 16$ & $11: 32$ & & & & $\mathrm{kl}$ sf? & & & & & 32.0 & & 4.37 & & & & & & & 4.37 & nomo & & $\begin{array}{l}\text { Here followed continuous vibration for several } \\
\text { minutes [earthquake coda? harmonic tremor?]. }\end{array}$ & Do. \\
\hline $6 / 5 / 16$ & $11: 46$ & & & & kl sf? & & & & & 22.0 & & 4.29 & & & & & & & 4.29 & nomo & & & Do. \\
\hline $6 / 5 / 16$ & $12: 13$ & & & & kl sf? & & & & & 22.5 & & 4.23 & & & & & & & 4.23 & nomo & & & Do. \\
\hline $6 / 5 / 16$ & 12:14 & & & & kl sf? & & & & & 23.0 & & 4.85 & & & & & & & 4.85 & nomo & & & Do. \\
\hline $6 / 5 / 16$ & 12:16 & & & & kl sf? & & & & & 26.0 & & 4.08 & & & & & & & 4.08 & nomo & & & Do. \\
\hline $6 / 5 / 16$ & 13:15 & & & & kl sf? & & & & & 23.0 & & 4.62 & & & & & & & 4.62 & nomo & & & Do. \\
\hline $6 / 5 / 16$ & 13:19 & & & & kl sf? & & & & & 23.0 & & 4.40 & & & & & & & 4.40 & nomo & & & Do. \\
\hline $6 / 5 / 16$ & 20:03 & & & & kl sf? & & & & & 23 & & 4.22 & & & & & & & 4.22 & nomo & & & Do. \\
\hline $6 / 6 / 16$ & $10: 28$ & & & & k1 sf? & & & & & 22.0 & & 4.73 & & & & & & & 4.73 & nomo & & & Do. \\
\hline $6 / 6 / 16$ & 13:02 & & & & molokai? & & & & & 150.0 & & 4.28 & & & & & & & 4.28 & nomo & & Near shock. & Do. \\
\hline $6 / 6 / 16$ & $19: 26$ & & & & molokai? & & & & & 200.0 & & 4.24 & & & & & & & 4.24 & nomo & & Do. & Do. \\
\hline $6 / 7 / 16$ & $14: 34$ & & & & kl sf? & & & & & 23.0 & & 4.59 & & & & & & & 4.59 & nomo & & & Do. \\
\hline $6 / 7 / 16$ & $16: 55$ & & & & $\begin{array}{l}\mathrm{kl} \mathrm{cal} \\
\text { deep? }\end{array}$ & & & & & 31.0 & & 4.26 & & & & & & & 4.26 & poor & & $\begin{array}{l}\text { Distance calculated from Wood's catalog, using } \\
\text { the time difference between the maximum } \\
\text { signal and the inferred } P \text { arrival. }\end{array}$ & Do. \\
\hline 6/9/16 & 9:50 & & & & kl sf? & & & & & 26.0 & & $>4.9$ & $<5.2$ & & & & & & 5.00 & nomo & & Pens swept off cylinder; minimum amplitude. & $\begin{array}{l}\text { Not found in Honolulu Station Bulletin } \\
\text { (Hazard, 1918); looked for but not seen } \\
\text { on station HON film record; SBHVO } \\
\text { (Wood, unpub.); not found in HH. }\end{array}$ \\
\hline $6 / 12 / 16$ & 6:45 & & & & kl sf? & & & & & & off scale & & 5.41 & & & & & & 5.41 & hono & $\mathrm{V}$; low VI (R-F) & $\begin{array}{l}\text { HON notes: Apparently local. Lyman notes: } 2 \\
\text { shocks at 6:45 a.m. Warshauer notes: Severe in } \\
\text { Hilo although less than last year's quake e Mar. } \\
28,1915] \text {, animals alarmed, pictures swung, } \\
\text { crockery rattled; duration, 10-15 s; direction, } \\
\text { south to north. }\end{array}$ & $\begin{array}{l}\text { Hazard, 1918; WKC, 1992, p. } 31 \text { [this } \\
\text { is the last Lyman entry-time agrees } \\
\text { with the Honolulu Station Bulletin ]; } \\
\text { HH, 6/16/1916. }\end{array}$ \\
\hline $6 / 24 / 16$ & 8:01 & & & & kl sf? & & & & & 21.0 & & 4.30 & & & & & & & 4.30 & nomo & felt & Felt at HVO. & $\begin{array}{l}\text { ESPHVO, v. 2, p. 479; SBHVO } \\
\text { (Wood, unpub.). }\end{array}$ \\
\hline $7 / 11 / 16$ & 21:41 & & & & kl sf? & & & & & 42.0 & & 5.04 & $<5.2$ & & & & & & 5.04 & nomo & felt & $\begin{array}{l}\text { Pens swept off cylinder, distance from } 4 \mathrm{~s} \text { s-p; } \\
\text { amplitude assumed; severe shock feft in Hilo at } \\
\text { 9:55 p.m.; duration almost } 1 \text { minute [wood } \\
\text { time assumed to be } 12 \text { hours off for consistency } \\
\text { with note about the preceding quake being lost } \\
\text { in next]. }\end{array}$ & $\begin{array}{l}\text { Not found in Honolulu Station Bulletin } \\
\text { t(Hazard, 1918); looked for but not seen } \\
\text { on station HON film record; SBHVO } \\
\text { (Wood, unpub.); HH, 7/14/1916 [wood } \\
\text { time G.m.t. 20:11 7/12-see note to } \\
\text { right]. }\end{array}$ \\
\hline $7 / 21 / 16$ & 8:00 & & & & a2025 & & & & & 24.0 & & 4.35 & & & & & & & 4.35 & nomo & & & SBHVO (Wood, unpub.). \\
\hline $9 / 4 / 16$ & 10:50 & & & & kaoiki? & & & & & 21.0 & & 4.02 & & & & & & & 4.02 & nomo & & & Do. \\
\hline $9 / 28 / 16$ & $11: 46$ & & & & $\mathrm{ml} \mathrm{mok}$ ? & & & & & 34.0 & & 4.51 & & & & & & & 4.51 & nomo & & & Do. \\
\hline $11 / 12 / 16$ & $6: 22$ & & & & a2025 & & & & & 23.5 & & 4.18 & & & & & & & 4.18 & nomo & & & Do. \\
\hline
\end{tabular}


क) Table 13. All earthquakes of $M \geq 4.0$ during the period 1903-59-Continued

\begin{tabular}{|c|c|c|c|c|c|c|c|c|c|c|c|c|c|c|c|c|c|c|c|c|c|c|c|c|}
\hline Date & $\begin{array}{c}\text { Time } \\
\text { (HST) }\end{array}$ & $\begin{array}{l}\text { Lat } \\
(\mathrm{deg})(1\end{array}$ & $\begin{array}{c}\text { Lat } \\
(\mathrm{min})\end{array}$ & $\begin{array}{l}\text { Lon } \\
\text { (deg) }\end{array}$ & $\begin{array}{l}\text { Lon } \\
\text { (min) }\end{array}$ & Region & $\begin{array}{l}\text { Publ. } \\
\text { Depth }\end{array}$ & $\begin{array}{l}\text { Pref. } \\
\text { Depth }\end{array}$ & $\begin{array}{l}\text { Publ. } \\
\text { Dist. }\end{array}$ & $\begin{array}{l}\text { Calc. } \\
\text { Dist }\end{array}$ & $\begin{array}{c}\text { Slant } \\
\text { dist }\end{array}$ & Mag class & $\begin{array}{c}\mathrm{M} \\
\text { nomo }\end{array}$ & $\begin{array}{c}\text { M M-S } \\
\text { E-W }\end{array}$ & $\begin{array}{c}\text { M M-S } \\
\text { N-S }\end{array}$ & M vert & $\begin{array}{c}\text { M hor } \\
\text { N-L }\end{array}$ & $\begin{array}{c}\mathrm{M} \\
\text { other }\end{array}$ & $\begin{array}{l}\mathrm{M} \\
\text { (other) } \\
\text { source }\end{array}$ & $\begin{array}{c}\mathrm{M} \\
\text { pref }\end{array}$ & $\begin{array}{c}\mathrm{M} \\
\text { (pref) } \\
\text { source }\end{array}$ & $I(\max )$ & Location/felt report & Comment \\
\hline $11 / 12 / 16$ & 13:26 & & & & & a2025 & & & & & 22.0 & & 4.25 & & & & & & & 4.25 & nomo & felt & Felt locally, more strongly in Hilo. & $\begin{array}{l}\text { ESPHVO, v. 2, p. 529; SBHVO } \\
\text { (Wood, unpub.); not found in HH or } \\
\text { HT }\end{array}$ \\
\hline $12 / 5 / 16$ & $13: 15$ & & & & & hilea? & & & & & 40.0 & & 4.12 & & & & & & & 4.12 & nomo & IIII & Rattled windows at HVO; not perceived. & $\begin{array}{l}\text { ESPHVO, v. 2, p. 539; SBHVO } \\
\text { (Wood, unpub.); not found in HH. }\end{array}$ \\
\hline $1 / 31 / 17$ & 18:04 & & & & & a3035 & & & & & 34.0 & & 4.03 & & & & & & & 4.03 & nomo & & & SBHVO (Wood, unpub.). \\
\hline $3 / 10 / 17$ & 23:46 & & & & & $\mathrm{a} 2025$ & & & & & 22.0 & & 4.46 & & & & & & & 4.46 & nomo & felt & Felt locally, quite sharply. & $\begin{array}{l}\text { SBHVO (Wood, unpub.); not found in } \\
\text { HH or HT. }\end{array}$ \\
\hline $3 / 14 / 17$ & 4:57 & & & & & kona? & & & & & 72.0 & & 4.09 & & & & & & & 4.09 & nomo & felt & Felt locally, rattled windows(?). & Do. \\
\hline $6 / 27 / 17$ & 3:08 & & & & & a3035 & & & & & 32.0 & & 4.11 & & & & & & & 4.11 & nomo & & $\begin{array}{l}\text { This is the last earthquake recorded in the } \\
\text { Wood unpublished archive. }\end{array}$ & SBHVO (Wood, unpub.). \\
\hline $7 / 28 / 17$ & 20:05 & & & & & $\mathrm{kl} \mathrm{sf?}$ & & & & & & & & $<5.2$ & & & & & & 5.20 & poor & VI & $\begin{array}{l}\text { Warshauer notes: Earthquake shook Hilo } \\
\text { shortly after } 8 \text { p.m. [Jul. } 28 \text { ], swaying } \\
\text { buildings, sending people into the streets; } \\
\text { began with a long tremble gradually } \\
\text { augmenting in force until windows rattled; } \\
\text { generally felt over island; severest in many } \\
\text { years. }\end{array}$ & $\begin{array}{l}\text { Not found in Honolulu Station Bulletin } \\
\text { (Hazard, 1920); looked for but not seen } \\
\text { on station HON film record; PCA, } \\
\text { 8/1/1917; HH, 8/3/1917. }\end{array}$ \\
\hline $7 / 29 / 17$ & 2:05 & & & & & $\mathrm{kl} \mathrm{sf?}$ & & & & & & & & $<5.2$ & & & & & & 5.20 & poor & $\mathrm{V}-\mathrm{VI}$ & $\begin{array}{l}\text { Warshauer notes: A second quake followed } 6 \\
\text { hours later, and again buildings shook and } \\
\text { people ran into the streets. No damage is } \\
\text { reported except near Laupahoehoe, where a } \\
\text { huge stone rolled down and tore up the road. }\end{array}$ & $\begin{array}{l}\text { Not found in Honolulu Station Bulletin } \\
\text { (Hazard, 1920); looked for but not seen } \\
\text { on station HON film record; PCA, } \\
\text { 8/1/1917; not found in HH. }\end{array}$ \\
\hline $5 / 21 / 18$ & $15: 30$ & & & & & $\begin{array}{l}\mathrm{kl} \mathrm{cal} \\
\text { deep? }\end{array}$ & & & & & & & & 5.14 & & & & & & 5.14 & hono & IV & $\begin{array}{l}\text { Generally felt on the Island of Hawaii; felt at } \\
\text { HVO as a prolonged N-S rocking. }\end{array}$ & $\begin{array}{l}\text { Not found in Honolulu Station Bulletin } \\
\text { (Hazard, 1920); seen on station HON } \\
\text { film record; ESPHVO, v. 2, p. } 777 \text {. }\end{array}$ \\
\hline $5 / 21 / 18$ & 19:27 & & & & & $\begin{array}{l}\mathrm{kl} \mathrm{cal} \\
\text { deep? }\end{array}$ & & & & & 25.0 & & 4.3 & & & & & & & 4.27 & desp & & Moderate. & ESPHVO, v. 2, p. 777 \\
\hline $5 / 22 / 18$ & $15: 30$ & & & & & $\begin{array}{l}\text { kl cal } \\
\text { deep? }\end{array}$ & & & & & 25.0 & & 4.27 & & & & & & & 4.27 & desp & & Do. & Do. \\
\hline $6 / 7 / 18$ & $11: 21$ & & & & & hawaii? & & & & & & & & 5.16 & & & & & & 5.16 & hono & & $\begin{array}{l}\text { Time differences and seismogram consistent } \\
\text { with local shock or part of a teleseism; } \\
\text { magnitude calculated assumes Hawaii origin. }\end{array}$ & $\begin{array}{l}\text { Honolulu Station Bulletin (Hazard, } \\
\text { 1920); not mentioned in ESPHVO; not } \\
\text { found in PCA, HSB, HDT, HH, or } \\
\text { DPH. }\end{array}$ \\
\hline $6 / 14 / 18$ & 11:13 & & & & & $\mathrm{ml}$ wf? & & & & & & off scale & & 5.76 & & & & & & 5.76 & hono & V-VI (naalehu) & $\begin{array}{l}\text { HON notes: Local shock, very irregular; } \\
\text { generally felt, seismograph pens flung in S. } 80^{\circ} \\
\text { E. direction, near shock of great intensity, items } \\
\text { thrown from shelves in Naalehu in westerly } \\
\text { direction (ground displaced to E); long, slow } \\
\text { swaying; duration, } 45 \text { min. }\end{array}$ & $\begin{array}{l}\text { Honolulu Station Bulletin (Hazard, } \\
\text { 1920); ESPHVO v. 2, p. 785, } 787 .\end{array}$ \\
\hline $11 / 1 / 18$ & $23: 33$ & 19 & 24 & 155 & & kaoiki & & & & & & st & & 6.40 & & & & 6.2 & w\&K & 6.40 & aver & VII (W\&K) & $\begin{array}{l}\text { HON notes: Sharp earthquake from the Island } \\
\text { of Hawaii, with renewed activity at KKlauea; } \\
\text { felt-all island of Hawaii, most strongly in Kau } \\
\text { with damage at Kapapala; first movement } \\
\text { WNW, toward Mokuaweoweo; duration, } 53 \\
\text { min. }\end{array}$ & $\begin{array}{l}\text { Isoseismal map in W\&K [wrong date } \\
\text { given]; Honolulu Station Bulletin } \\
\text { (Hazard, 1920); ESPHVO v. 2, p. } 840 \text {, } \\
\text { 843; preferred mag calculated as } \\
\text { average of HON and W\&K; Hilea } \\
\text { observer recorded time as 11:36 p.m. }\end{array}$ \\
\hline $11 / 1 / 18$ & 23:38 & & & & & kaoiki? & & & & & 22.1 & s? & 4.2 & & & & & & & 4.19 & poor & felt & Felt-Hilea; lost in main shock(?). & $\begin{array}{l}\text { Aftershock; ESPHVO, v. 2, p. } 840 \text {, } \\
843 .\end{array}$ \\
\hline $11 / 1 / 18$ & 23:44 & & & & & kaoiki? & & & & & 22.1 & s? & 4.19 & & & & & & & 4.19 & poor & felt & $\begin{array}{l}\text { Recorded instrumentally; felt Hilea, time } \\
\text { recorded as 11:46. }\end{array}$ & Do. \\
\hline $11 / 1 / 18$ & 23:52 & & & & & kaoiki? & & & & & 22.1 & s? & 4.19 & & & & & & & 4.19 & poor & felt & $\begin{array}{l}\text { Recorded instrumentally; felt Hilea, time } \\
\text { recorded as midnight. }\end{array}$ & Aftershock; ESPHVO, v. 2, p. 843. \\
\hline $11 / 2 / 18$ & 5:00 & & & & & kaoiki? & & & & & 22.1 & s? & 4.19 & & & & & & & 4.19 & poor & felt & Pronounced; felt Hilea. & \\
\hline $1 / 27 / 19$ & $16: 53$ & & & & & molokai? & & & & & & & & 4.77 & & & & & & 4.77 & hono & $\begin{array}{c}\mathrm{V} \text { (W\&K) II-III } \\
\text { (Hon) }\end{array}$ & $\begin{array}{l}\text { HON \& USEQ notes: Felt by many persons in } \\
\text { the islands. Wurshauer notes: A very brief but } \\
\text { sharp earthquake shock was felt on Maui by } \\
\text { many persons in different parts of the island; } \\
\text { also felt on Oahu; Romberg says local to Oahu } \\
\text { within } 20 \text { mi of Honolulu. }\end{array}$ & 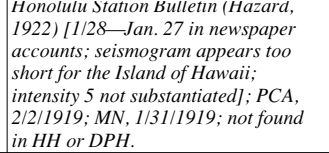 \\
\hline
\end{tabular}


Table 13. All earthquakes of $M \geq 4.0$ during the period 1903-59-Continued

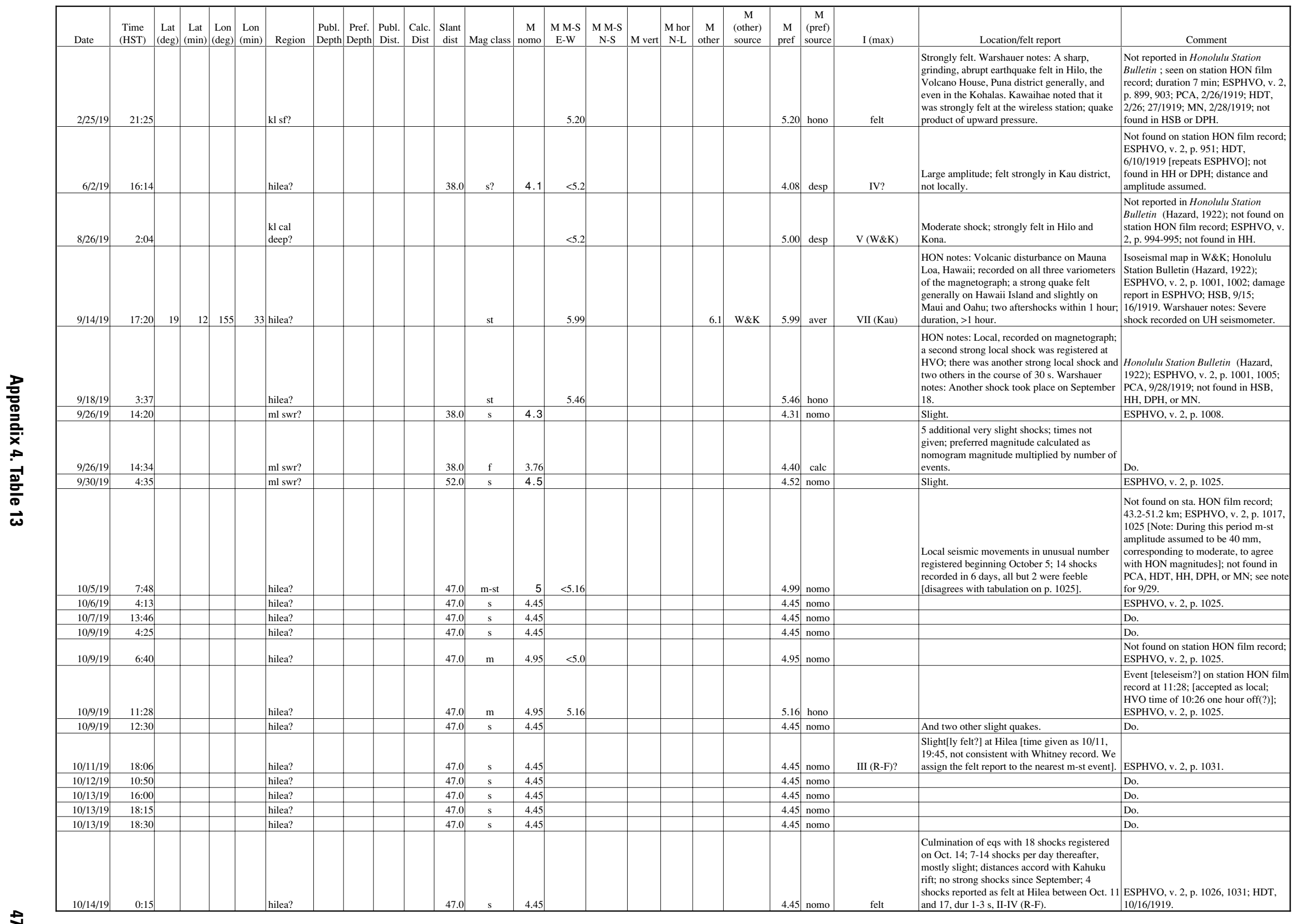


$\stackrel{\infty}{\infty}$ Table 13. All earthquakes of $M \geq 4.0$ during the period 1903-59-Continued

\begin{tabular}{|c|c|c|c|c|c|c|c|c|c|c|c|c|c|c|c|c|c|c|c|c|c|c|c|}
\hline Date & $\begin{array}{l}\text { Time } \\
\text { (HST) }\end{array}$ & $\begin{aligned} \text { Lat } & \text { Lat } \\
(\mathrm{deg}) & (\mathrm{min})\end{aligned}$ & $\begin{array}{l}\text { Lon } \\
(\mathrm{deg})\end{array}$ & $\begin{array}{l}\text { Lon } \\
(\min )\end{array}$ & Region & $\begin{array}{l}\text { Publ. } \\
\text { Depth }\end{array}$ & $\begin{array}{l}\text { Pref. } \\
\text { Depth }\end{array}$ & $\begin{array}{l}\text { Publ. } \\
\text { Dist. }\end{array}$ & $\begin{array}{l}\text { Calc. } \\
\text { Dist }\end{array}$ & $\begin{array}{c}\text { Slant } \\
\text { dist }\end{array}$ & Mag class & $\begin{array}{c}\mathrm{M} \\
\text { nomo }\end{array}$ & $\begin{array}{l}\text { M M-S } \\
\text { E-W }\end{array}$ & $\begin{array}{c}\text { M M-S } \\
\text { N-S }\end{array}$ & $M$ vert & $\begin{array}{c}\text { M hor } \\
\text { N-L }\end{array}$ & $\begin{array}{c}\mathrm{M} \\
\text { other }\end{array}$ & $\begin{array}{c}\mathrm{M} \\
\text { (other) } \\
\text { source }\end{array}$ & $\begin{array}{c}\mathrm{M} \\
\text { pref }\end{array}$ & $\begin{array}{c}\mathrm{M} \\
\text { (pref) } \\
\text { source }\end{array}$ & $I(\max )$ & Location/felt report & Comment \\
\hline 10/14/19 & $6: 52$ & & & & hilea? & & & & & 47.0 & m-st & 4.99 & $<5.0$ & & & & & & 4.99 & nomo & IV (R-F)? & $\begin{array}{l}\text { Moderate[ly felt?] at Hilea [time given as } \\
10 / 13,7: 15 \text {, not consistent with Whitney } \\
\text { record. We assign the felt report to the nearest } \\
\text { m-st event]. }\end{array}$ & $\begin{array}{l}\text { Looked for but not seen on station } \\
\text { HON film record; ESPHVO, v. 2, p. } \\
\text { 1031; see note for 10/5/19. }\end{array}$ \\
\hline $10 / 14 / 19$ & 13:52 & & & & hilea? & & & & & 47.0 & $\mathrm{~s}$ & 4.45 & & & & & & & 4.45 & nomo & & & ESPHVO, v. 2, p. 1031. \\
\hline 10/14/19 & 23:06 & & & & hilea? & & & & & 47.0 & $\mathrm{~s}$ & 4.45 & & & & & & & 4.45 & nomo & & And three other small disturbances. & Do. \\
\hline 10/15/19 & $8: 28$ & & & & hilea? & & & & & 47.0 & m-st & 4.99 & $<5.0$ & & & & & & 4.99 & nomo & IV (R-F)? & $\begin{array}{l}\text { Moderate[ly felt?? at Hilea [time given as } \\
10 / 15,0,00 \text {, not consistent with Whitney } \\
\text { record. We assign the felt report to the nearest } \\
\text { m-st event]. Warshauer notes: Recurrence of } \\
\text { earthquakes yesterday. }\end{array}$ & $\begin{array}{l}\text { Not found on station HON film record; } \\
\text { 43.2-51.2 km; ESPHVO, v. 2, p. 1031; } \\
\text { PCA, 10/16/1919; HDT, 10/16/1919; } \\
\text { see note for 10/5/19. }\end{array}$ \\
\hline $10 / 15 / 19$ & 10:20 & & & & hilea? & & & & & 47.0 & $\mathrm{~s}$ & 4.45 & & & & & & & 4.45 & nomo & & & ESPHVO, v. 2, p. 1031 \\
\hline $10 / 15 / 19$ & $15: 40$ & & & & hilea? & & & & & 47.0 & $\mathrm{~s}$ & 4.45 & & & & & & & 4.45 & nomo & & & Do. \\
\hline $10 / 16 / 19$ & 9:00 & & & & hilea? & & & & & 47.0 & st & 5.23 & $<5.16$ & & & & & & 5.23 & nomo & & $\begin{array}{l}\text { None of the four strong ones registered October } \\
16-18 \text { was reported at Hilea. }\end{array}$ & $\begin{array}{l}\text { Not found on station HON film record; } \\
\text { r 43.2-51.2 km; } 43.2-51.2 \mathrm{~km} \text {; ESPHVO, } \\
\text { v. } 2 \text {, p. } 1030,1031 .\end{array}$ \\
\hline $10 / 16 / 19$ & 9:05 & & & & hilea? & & & & & 47.0 & $\mathrm{~s}$ & 4.45 & & & & & & & 4.45 & nomo & & & ESPHVO, v. 2, p. 1031 \\
\hline $10 / 16 / 19$ & 15:35 & & & & hilea? & & & & & 47.0 & $\mathrm{~s}$ & 4.45 & & & & & & & 4.45 & nomo & & & Do. \\
\hline $10 / 16 / 19$ & 20:20 & & & & hilea? & & & & & 47.0 & m-st & 4.99 & $<5.0$ & & & & & & 4.99 & nomo & & $\begin{array}{l}\text { None of the four strong ones registered October } \\
16-18 \text { was reported at Hilea. }\end{array}$ & $\begin{array}{l}\text { Not found on station HON film record; } \\
43.2-51.2 \mathrm{~km} ; 43.2-51.2 \mathrm{~km} \text {; ESPHVO, } \\
\text { r v. 2, p. 1030, 1031; see note for } \\
\text { 10/5/19. }\end{array}$ \\
\hline $10 / 17 / 19$ & $5: 40$ & & & & hilea? & & & & & 47.0 & $\mathrm{~s}$ & 4.45 & & & & & & & 4.45 & nomo & & & ESPHVO, v. 2, p. 1031 \\
\hline $10 / 17 / 19$ & 8:35 & & & & hilea? & & & & & 47.0 & $\mathrm{~s}$ & 4.45 & & & & & & & 4.45 & nomo & & & Do. \\
\hline 10/17/19 & $23: 25$ & & & & hilea? & & & & & 47.0 & $\mathrm{~m}$-st & 4.99 & $<5.0$ & & & & & & 4.99 & nomo & II (R-F)? & $\begin{array}{l}\text { None of the four strong ones registered October } \\
16-18 \text { was reported at Hilea; and three other } \\
\text { small disturbances; weak [ly felt?] at Hilea } \\
\text { [time given as 10/15, } 0: 00 \text {, not consistent with } \\
\text { Whitney record. We assign the felt report to the } \\
\text { nearest m-st event]. }\end{array}$ & $\begin{array}{l}\text { r } \\
\text { Not found on station HON film record; } \\
\text { e3.2-51.2 km; ESPHVO, v. 2, p. 1030, } \\
1031 \text {; see note for 10/5/19. }\end{array}$ \\
\hline $10 / 18 / 19$ & 13:14 & & & & hilea? & & & & & 47.0 & m-st & 4.99 & $<5.0$ & & & & & & 4.99 & nomo & & $\begin{array}{l}\text { None of the four strong ones registered October } \\
16-18 \text { was reported at Hilea. }\end{array}$ & $\begin{array}{l}\text { Not found on station HON film record; } \\
\text { r } 43.2-51.2 \mathrm{~km} \text {; ESPHVO, v. 2, p. 1030, } \\
1033 \text {; see note for 10/5/19. }\end{array}$ \\
\hline 10/19/19 & 3:50 & & & & hilea? & & & & & 47.0 & $\mathrm{~s}$ & 4.45 & & & & & & & 4.45 & nomo & & & ESPHVO, v. 2, p. 1033. \\
\hline 10/19/19 & $7: 10$ & & & & hilea? & & & & & 47.0 & $\mathrm{~s}$ & 4.45 & & & & & & & 4.45 & nomo & & & Do. \\
\hline $10 / 19 / 19$ & 12:10 & & & & hilea? & & & & & 47.0 & $\mathrm{~m}$-st & 4.99 & $<5.0$ & & & & & & 4.99 & nomo & & & $\begin{array}{l}\text { Not found on station HON film record; } \\
\text { ESPHVO, v. 2, p. 1033; see note for } \\
10 / 5 / 19 \text {. }\end{array}$ \\
\hline $10 / 21 / 19$ & 11:00 & & & & hilea? & & & & & 47.0 & $\mathrm{~s}$ & 4.45 & & & & & & & 4.45 & nomo & & & ESPHVO, v. 2, p. 1033. \\
\hline $10 / 21 / 19$ & $12: 23$ & & & & hilea? & & & & & 47.0 & $\mathrm{~m}$-st & 4.99 & $<5.0$ & & & & & & 4.99 & nomo & & & $\begin{array}{l}\text { Not found on station HON film record; } \\
\text { ESPHVO, v. 2, p. 1033; see note for } \\
10 / 5 / 19 \text {. }\end{array}$ \\
\hline 10/22/19 & $12: 40$ & & & & hilea? & & & & & 47.0 & st & 5.23 & $<5.0$ & & & & & & 5.23 & nomo & & Probably not strong. & $\begin{array}{l}\text { Not found on station HON film record; } \\
\text { ESPHVO, v. 2, p. } 1033 \text {. }\end{array}$ \\
\hline 10/22/19 & 14:08 & & & & hilea? & & & & & 47.0 & vst & 5.53 & 5.57 & & & & & & 5.57 & hono & felt & HON notes: Local shock; very strong, felt. & $\begin{array}{l}\text { Honolulu Station Bulletin (Hazard, } \\
\text { 1922); ESPHVO, v. 2, p. } 1034 .\end{array}$ \\
\hline $10 / 23 / 19$ & $0: 20$ & & & & hilea? & & & & & 47.0 & m-st & 4.99 & $<5.0$ & & & & & & 4.99 & nomo & & & $\begin{array}{l}\text { Not found on station HON film record; } \\
\text { ESPHVO, v. 2, p. 1034; see note for } \\
\text { 10/5/19. }\end{array}$ \\
\hline 10/23/19 & 16:35 & & & & hilea? & & & & & 47.0 & m-st & 4.99 & $<5.0$ & & & & & & 4.99 & nomo & & And one other small disturbance. & $\begin{array}{l}\text { Not found on station HON film record; } \\
\text { ESPHVO, v. 2, p. 1034; see note for } \\
\text { 10/5/19. }\end{array}$ \\
\hline 10/24/19 & $12: 30$ & & & & hilea? & & & & & 47.0 & $\mathrm{~s}$ & 4.45 & & & & & & & 4.45 & nomo & & & ESPHVO, v. 2, p. 1034. \\
\hline 10/24/19 & 13:12 & & & & hilea? & & & & & 47.0 & vst & 5.23 & $<5.0$ & & & & & & 5.23 & nomo & & Cannot be very strong. & $\begin{array}{l}\text { Not found on station HON film record; } \\
\text { ESPHVO, v. 2, p. } 1034 \text {. }\end{array}$ \\
\hline $10 / 25 / 19$ & $16: 30$ & & & & hilea? & & & & & 47.0 & $\mathrm{~s}$ & 4.45 & & & & & & & 4.45 & nomo & & & ESPHVO, v. 2, p. 1043. \\
\hline $10 / 25 / 19$ & 20:00 & & & & hilea? & & & & & 47.0 & $\mathrm{~s}$ & 4.45 & & & & & & & 4.45 & nomo & & & Do. \\
\hline 10/26/19 & 4:18 & & & & hilea? & & & & & 47.0 & $\mathrm{~s}$ & 4.45 & & & & & & & 4.45 & nomo & felt & $\begin{array}{l}\text { Felt at Hilea; none on this day felt at eruption } \\
\text { site. }\end{array}$ & Do. \\
\hline 10/26/19 & 7:15 & & & & hilea? & & & & & 47.0 & $\mathrm{~s}$ & 4.45 & & & & & & & 4.45 & nomo & & & Do. \\
\hline $10 / 26 / 19$ & $9: 58$ & & & & hilea? & & & & & 47.0 & $\mathrm{~s}$ & 4.45 & & & & & & & 4.45 & nomo & & & Do. \\
\hline 10/26/19 & 10:49 & & & & hilea? & & & & & 47.0 & s & 4.45 & & & & & & & 4.45 & nomo & & & Do. \\
\hline 10/26/19 & $12: 48$ & & & & hilea? & & & & & 47.0 & $\mathrm{~s}$ & 4.45 & & & & & & & 4.45 & nomo & & Listed in error as AM. & Do. \\
\hline
\end{tabular}


Table 13. All earthquakes of $M \geq 4.0$ during the period 1903-59-Continued

\begin{tabular}{|c|c|c|c|c|c|c|c|c|c|c|c|c|c|c|c|c|c|c|c|c|c|c|c|c|}
\hline Date & $\begin{array}{c}\text { Time } \\
\text { (HST) }\end{array}$ & $\begin{array}{r}\text { Lat } \\
(\operatorname{deg})\end{array}$ & $\begin{array}{l}\text { Lat } \\
(\mathrm{min})\end{array}$ & $\begin{array}{c}\text { Lon } \\
(\operatorname{deg})\end{array}$ & $\begin{array}{l}\text { Lon } \\
(\min )\end{array}$ & Region & $\begin{array}{l}\text { Publ. } \\
\text { Depth }\end{array}$ & $\begin{array}{l}\text { Pref. } \\
\text { Depth }\end{array}$ & $\begin{array}{l}\text { Publ. } \\
\text { Dist. }\end{array}$ & $\begin{array}{l}\text { Calc. } \\
\text { Dist }\end{array}$ & $\begin{array}{c}\text { Slant } \\
\text { dist }\end{array}$ & Mag class & $\begin{array}{c}\mathrm{M} \\
\text { nomo }\end{array}$ & $\begin{array}{l}\text { M M-S } \\
\text { E-W }\end{array}$ & $\begin{array}{c}\text { M M-S } \\
\text { N-S }\end{array}$ & $M$ vert & $\begin{array}{l}\text { M hor } \\
\text { N-L }\end{array}$ & $\begin{array}{c}\mathrm{M} \\
\text { other }\end{array}$ & $\begin{array}{c}\mathrm{M} \\
\text { (other) } \\
\text { source }\end{array}$ & $\begin{array}{c}\mathrm{M} \\
\text { pref }\end{array}$ & $\begin{array}{c}\mathrm{M} \\
\text { (pref) } \\
\text { source }\end{array}$ & $I(\max )$ & Location/felt report & Comment \\
\hline $10 / 26 / 19$ & 19:02 & & & & & hilea? & & & & & 47.0 & $\mathrm{~s}$ & 4.45 & & & & & & & 4.45 & nomo & & & Do. \\
\hline $10 / 26 / 19$ & 20:10 & & & & & hilea? & & & & & 47.0 & $\mathrm{~s}$ & 4.45 & & & & & & & 4.45 & nomo & & & Do. \\
\hline $10 / 26 / 19$ & $20: 43$ & & & & & hilea? & & & & & 47.0 & $\mathrm{~s}$ & 4.45 & & & & & & & 4.45 & nomo & & & Do. \\
\hline $10 / 27 / 19$ & $1: 30$ & & & & & hilea? & & & & & 47.0 & $\mathrm{~s}$ & 4.45 & & & & & & & 4.45 & nomo & & & Do. \\
\hline $10 / 27 / 19$ & $5: 17$ & & & & & hilea? & & & & & 47.0 & m-st & 4.99 & $<5.2$ & & & & & & 4.99 & nomo & & & $\begin{array}{l}\text { Not found on station HON film record; } \\
\text { ESPHVO, v. 2, p. 1043; see note for } \\
10 / 5 / 19 \text {. }\end{array}$ \\
\hline $10 / 29 / 19$ & 5:00 & & & & & hilea? & & & & & 47.0 & m-st & 4.99 & $<5.2$ & & & & & & 4.99 & nomo & felt & Felt in Kona. & Do. \\
\hline $10 / 31 / 19$ & 5:12 & & & & & hilea? & & & & & 47.0 & m-st & 4.99 & $<5.27$ & & & & & & 4.99 & nomo & & & Do. \\
\hline $11 / 11 / 19$ & 8:42 & & & & & hilea? & & & & & 47.0 & $\mathrm{~s}$ & 4.45 & & & & & & & 4.45 & nomo & IV (R-F) at Hilea & Felt at Hilea. & $\begin{array}{l}10 \text { s duration; ESPHVO, v. 2, p. 1050; } \\
\text { time of felt report 9:00-assigned to this } \\
\text { quake. }\end{array}$ \\
\hline $11 / 13 / 19$ & $11: 52$ & & & & & hilea? & & & & & 47.0 & $\mathrm{~s}$ & 4.45 & & & & & & & 4.45 & nomo & $\mathrm{V}(\mathrm{R}-\mathrm{F})$ at Hilea & Do. & $\begin{array}{l}15 \text { s duration; ESPHVO, v. 2, p. 1050; } \\
\text { time of felt report 12:00-assigned to } \\
\text { this quake. }\end{array}$ \\
\hline $\begin{array}{r}11 / 25 / 19 \\
1 / 18 / 20\end{array}$ & $\begin{array}{l}21: 58 \\
8 \cdot 10\end{array}$ & & & & & maui? & & & & & 176.0 & & & 4.87 & & & & & & 4.87 & hono & IV & $\begin{array}{l}\text { HON notes: Amp 0.2; strongly felt in Maui. } \\
\text { Warshauer notes: Sharply felt in Maui at 10:03 } \\
\text { p.m., rattled doors and windows; duration, } \\
\text { several seconds; no damage; shook upper floors } \\
\text { of frame buildings. }\end{array}$ & $\begin{array}{l}\text { Honolulu Station Bulletin (Hazard, } \\
\text { 1922); ESPHNO, v. 2, p. 105; HSB, } \\
\text { 11/26/1919; MN, 11/28/1919; not } \\
\text { found in PCA, HDT, HH, or DPH. }\end{array}$ \\
\hline $1 / 18 / 20$ & $8: 10$ & & & & & kl sf? & & & & 19.5 & 21.5 & $\mathrm{~s}$ ? & 4.17 & & & & & & & 4.17 & desp & felt & Felt at Hilea. & ESPHVO, v. 2, p. 1100. \\
\hline $1 / 24 / 20$ & 15:15 & & & & & kl sf? & & & & 19.5 & 21.5 & m-st & 4.44 & & & & & & & 4.44 & nomo & felt & $\begin{array}{l}\text { Recorded at Hilo; strongly felt at Hilea as a } \\
\text { double jolt accompanied by a loud rumbling. }\end{array}$ & $\begin{array}{l}\text { Not reported in Honolulu Station } \\
\text { Bulletin (Hazard, 1922); ;ooked for but } \\
\text { not seen on station HON film record- } \\
\text { possible event at 14:28, amp 0.3 mm; } \\
\text { possible teeleseism; ESPVVO, v. 2, p. } \\
1103 \text {; see note for 10/5/19; not found in } \\
\text { HDT, HH, or DPH. }\end{array}$ \\
\hline $3 / 26 / 20$ & 5:35 & & & & & hilea? & & & & & 48.0 & $\mathrm{~s}$ & 4.469 & & & & & & & 4.47 & nomo & & & ESPHVO, v. 2, p. 1137. \\
\hline $5 / 15 / 20$ & 2:20 & & & & & maui? & & & & & 190.0 & $\mathrm{~m}$ ? & 5.683 & & & & & & & 5.68 & int & $\begin{array}{l}\text { III-IV (Honolulu); } \\
\text { 3, III (R-F) (Hilea); } \\
\text { V (Maui) }\end{array}$ & $\begin{array}{l}\text { Felt in Honolulu as a very perceptible shock; } \\
\text { felt in Hilea. Warshauer notes: Sharpest shock } \\
\text { on Maui in years, sleepers awakened; duration, } \\
\text {; several seconds; no damage; felt in Honolulu as } \\
\text { two distinct shocks. }\end{array}$ & $\begin{array}{l}\text { Not reported in Honolulu Station } \\
\text { Bulletin (Hazard, 1922); looked for but } \\
\text { not seen on station HON film record } \\
\text { [disturbed instrument-working?] } \\
\text { ESPHVO, v. 2, p. 1158; MN, } \\
\text { 5/21/1920; not found in HDT, HSB, or } \\
\text { PCA. }\end{array}$ \\
\hline $5 / 24 / 20$ & 6:00 & & & & & hilea? & & & & & 48.0 & $\mathrm{~m}$ & 4.96 & 5.08 & & & & & & 5.08 & hono & $\begin{array}{l}\text { IV-V; IV (R-F) at } \\
\text { Hilea }\end{array}$ & Felt in Hilea. & $\begin{array}{l}\text { Not reported in Honolulu Station } \\
\text { Bulletin (Hazard, 1922); event seen on } \\
\text { station HON film record at 05:55, amp } \\
0.15 \mathrm{~mm} \text { [HVO time wrong?]; } \\
\text { ESPHVO, v. 2, p. 1162; not found in } \\
\text { PCA, HSB, HDT, HH, DPH, or MN. }\end{array}$ \\
\hline $5 / 26 / 20$ & 1:55 & & & & & hilea? & & & & & 48.0 & $\mathrm{~m}$ & 4.96 & $<5.16$ & & & & & & 4.96 & nomo & $\begin{array}{l}\text { IV-V; IV (R-F) at } \\
\text { Hilea }\end{array}$ & Do. & $\begin{array}{l}\text { Not reported in Honolulu Station } \\
\text { Bulletin (Hazard, 1922); looked for but } \\
\text { not seen on station HON film record; } \\
\text { ESPHVO, v. 2, p. 1162; not found in } \\
\text { PCA, HSB, HDT, HH, DPH, or MN. }\end{array}$ \\
\hline $8 / 16 / 20$ & 19:20 & & & & & hilea? & & & & & 40.0 & m-st & 4.9 & & & & & & & 4.88 & nomo & felt & Felt at $\mathrm{HVO}$ and Hilea. & $\begin{array}{l}\text { Not found on station HON film record; } \\
\text { ESPHVO, v. } 2 \text {, p. } 1195 \text {; see note for } \\
\text { 10/5/19; not found in PCA, HSB, HDT, } \\
\text { HH, DPH, or MN. }\end{array}$ \\
\hline 9/9/20 & 23:59 & & & & & hilea? & & & & & 43.2 & $\mathrm{~s}$ & 4.396 & & & & & & & 4.40 & nomo & & & ESPHVO, v. 2, p. 1204 \\
\hline $10 / 27 / 20$ & $5: 33$ & & & & & kl sf? & & & & & 16.0 & $\mathrm{~m} ?$ & 4.201 & & & & & 5.3 & int & 4.20 & aver & $\mathrm{v}$ & $\begin{array}{l}\text { Felt locally; NW or SE from Whitney. } \\
\text { Warshauer notes: At } 5: 35 \text { a.m., a pronounced } \\
\text { earthquake shock, three distinct rocking } \\
\text { motions followed by lengthy shivering. Houses } \\
\text { tipped back and forth, and sleepers awakened; } \\
\text { felt in all districts of Hilo. }\end{array}$ & $\begin{array}{l}\text { Not reported in Honolulu Station } \\
\text { Bulletin (Hazard, 1922); looked for but } \\
\text { not seen on sta. HON film record; } \\
\text { ESPHVO, v. 2, p. 1232; DPH, } \\
10 / 27 / 1920 ; \mathrm{HH}, 10 / 29 / 1920 ; \text { not } \\
\text { found in PCA dist assumed }>5 \text { mi to } \\
\text { fit felt rpt; pref mag avg of int mag and } \\
\text { nomo mag. }\end{array}$ \\
\hline $3 / 8 / 21$ & $16: 24$ & & & & & a2530 & & & & & 28.8 & $\mathrm{~s}$ & 4.11 & & & & & & & 4.11 & nomo & & Azimuth NE-SW. & ESPHVO, v. 3, p. 79 \\
\hline $3 / 17 / 21$ & $13: 27$ & & & & & kona? & & & & & 66.0 & $\mathrm{f}$ & 4.15 & & & & & & & 4.15 & nomo & felt & Probably felt in Kona. & Do. \\
\hline
\end{tabular}


동 Table 13. All earthquakes of $M \geq 4.0$ during the period 1903-59-Continued

\begin{tabular}{|c|c|c|c|c|c|c|c|c|c|c|c|c|c|c|c|c|c|c|c|c|c|c|c|}
\hline Date & $\begin{array}{l}\text { Time } \\
\text { (HST) }\end{array}$ & $\begin{array}{ll}\text { Lat } & \text { Lat } \\
(\mathrm{deg}) & \text { (min) }\end{array}$ & $\begin{array}{l}\text { Lon } \\
(\operatorname{deg})\end{array}$ & $\begin{array}{l}\text { Lon } \\
\text { (min) }\end{array}$ & Region & $\begin{array}{l}\text { Publ. } \\
\text { Depth }\end{array}$ & $\begin{array}{l}\text { Pref. } \\
\text { Depth }\end{array}$ & $\begin{array}{l}\text { Publ. } \\
\text { Dist. }\end{array}$ & $\begin{array}{l}\text { Calc. } \\
\text { Dist }\end{array}$ & $\begin{array}{c}\text { Slant } \\
\text { dist }\end{array}$ & Mag class & $\begin{array}{c}\mathrm{M} \\
\text { nomo }\end{array}$ & $\begin{array}{l}\text { M M-S } \\
\text { E-W }\end{array}$ & $\begin{array}{c}\text { M M-S } \\
\text { N-S }\end{array}$ & M vert & $\begin{array}{c}\text { M hor } \\
\text { N-L }\end{array}$ & $\begin{array}{c}\mathrm{M} \\
\text { other }\end{array}$ & $\begin{array}{c}\mathrm{M} \\
\text { (other) } \\
\text { source }\end{array}$ & $\begin{array}{c}\mathrm{M} \\
\text { pref }\end{array}$ & $\begin{array}{c}\mathrm{M} \\
\text { (pref) } \\
\text { source }\end{array}$ & $I(\max )$ & Location/felt report & Comment \\
\hline $3 / 19 / 21$ & $15: 44$ & & & & kaoiki? & & & & & 28.8 & $\mathrm{~m}$ & 4.61 & & & & & & & 4.61 & nomo & felt & Felt in Hilea and probably in Pahala. & $\begin{array}{l}\text { Bulletin (Hazard, 1924); station HON } \\
\text { film record not available; ESPHVO, v. } \\
\text { 3, p. } 79 \text {. }\end{array}$ \\
\hline $4 / 1 / 21$ & $5: 26$ & & & & a3035 & & & & & 33.6 & $\mathrm{~m}$ & 4.72 & & & & & & & 4.72 & nomo & felt & Azimuth NE-SW; felt generally on Hawaii. & $\begin{array}{l}\text { Not reported in Honolulu Station } \\
\text { Bulletin (Hazard, 1924); station HON } \\
\text { film record not available; ESPHVO, v. } \\
\text { 3, p. 96; not in HH. }\end{array}$ \\
\hline $5 / 6 / 21$ & $16: 55$ & & & & a3035 & & & & & 32.0 & $\mathrm{~s}$ & 4.19 & & & & & & & 4.19 & nomo & felt & Azimuth NW-SE; felt locally. & ESPHVO, v. 3, p. 117. \\
\hline $5 / 19 / 21$ & $21: 21$ & & & & $\begin{array}{l}\text { south } \\
\text { hawaii? }\end{array}$ & & & & & 25.0 & $\mathrm{~m}$ & 4.51 & & & & & & & 4.50 & nomo & felt & $\begin{array}{l}\text { Felt over most of Hawaii; distance assumed to } \\
\text { agree with felt report }(M \text { range } 4-5) \text {. }\end{array}$ & $\begin{array}{l}\text { Not reported in Honolulu Station } \\
\text { Bulletin (Hazard, 1924); station HON } \\
\text { film record not available; ESPHVO, v. } \\
\text { 3, p. 117; not in HH. }\end{array}$ \\
\hline $6 / 24 / 21$ & $12: 24$ & & & & a2530 & & & & & 28.8 & $\mathrm{~m}$ & 4.61 & & & & & & & 4.61 & nomo & felt & Azimuth NW-SE; felt locally and in Hilo. & $\begin{array}{l}\text { Not reported in Honolulu Station } \\
\text { Bulletin (Hazard, 1924); station HON } \\
\text { film record not available; ESPHVO, v. } \\
\text { 3, p. } 133 \text {. }\end{array}$ \\
\hline $7 / 29 / 21$ & 19:01 & & & & $\begin{array}{l}\text { mauna } \\
\text { kea? }\end{array}$ & & & & & 59.2 & $\mathrm{f}$ & 4.07 & & & & & & & 4.07 & nomo & felt & Felt strongly in Waimea. & ESPHVO, v. 3, p. 154. \\
\hline $9 / 30 / 21$ & $0: 39$ & & & & a2530 & & & & & 28.8 & $\mathrm{~s}$ & 4.11 & & & & & & & 4.11 & nomo & & & ESPHVO, v. 3, p. 187. \\
\hline $11 / 7 / 21$ & 12:59 & & & & a2530 & & & & & 27.2 & $\mathrm{~s}$ & 4.07 & & & & & & & 4.07 & nomo & & & ESPHVO, v. 3, p. 217. \\
\hline $1 / 26 / 22$ & 8:35 & & & & $\begin{array}{l}\text { mauna } \\
\text { kea? }\end{array}$ & & & & & 64.0 & $\mathrm{~s}$ & 4.67 & & & & & & & 4.67 & nomo & felt & Felt in Kohala. & $\begin{array}{l}\text { Not reported in Honolulu Station } \\
\text { Bulletin (Hazard, 1924); ESPHVO, v. } \\
\text { 3, p. } 234 \text {. }\end{array}$ \\
\hline $2 / 3 / 22$ & $0: 33$ & & & & a2530 & & & & & 28.8 & $\mathrm{~s}$ & 4.11 & & & & & & & 4.11 & nomo & & Azimuth SW-NE. & ESPHVO, v. 3, p. 241 \\
\hline $2 / 21 / 22$ & $7: 55$ & & & & kl sf? & & & & & 32.0 & $\mathrm{~m}$ [st?] & 4.68 & 5.78 & 5.65 & & & & & 5.72 & hono & VI & $\begin{array}{l}\text { HON notes: (Local shock; strongly felt and } \\
\text { prolonged earthquake causing avalanches at } \\
\text { Uwekahuna; azimuth WNW-ESEE Felt over E } \\
\text { half of Hawaii). Warshauer notes: Felt in Hilo, } \\
\text { clothes pole and construction pole swayed } \\
\text { wildly, one person fell down stairs. }\end{array}$ & $\begin{array}{l}\text { Honolulu Station Bulletin (Hazard, } \\
\text { 1924); ESPHVO, v. 3, p. 239, } 241 \\
\text { [listed as moderate, must be strong]; } \\
\text { DPH, 2/21/1922; not in HA or HSB. }\end{array}$ \\
\hline $2 / 21 / 22$ & 14:56 & & & & $\mathrm{kl} \mathrm{sf?}$ & & & & & 32.0 & $\mathrm{~s}$ & 4.19 & & & & & & & 4.19 & nomo & felt & Aftershock(?); felt locally. & ESPHVO, v. 3, p. 241 \\
\hline $3 / 12 / 22$ & $14: 33$ & & & & $\begin{array}{l}\text { kl cal } \\
\text { deep?? }\end{array}$ & & & & & 32.0 & $\mathrm{~m}$ & 4.68 & & & & & & & 4.68 & nomo & $\mathrm{v}$ & $\begin{array}{l}\text { Azimuth, ESE; felt locally and in Hilo; } \\
\text { dismantled instruments. Warshauer notes: On } \\
\text { Sunday afternoon, an earthquake shock, } \\
\text { slightly more severe than [last month's, shook } \\
\text { Hilo for possibly } 30 \text { s. Some crashes of china } \\
\text { on plate rails; no other damage. }\end{array}$ & $\begin{array}{l}\text { Not reported in Honolulu Station } \\
\text { Bulletin (Hazard, 1924); HVO, v. 3, p. } \\
\text { 252; HDT, 3/14/1922. Warshauer } \\
\text { notes-con.: Houses and buildings } \\
\text { quivered and shimmied. }\end{array}$ \\
\hline $3 / 12 / 22$ & $16: 55$ & & & & $\begin{array}{l}\text { kl cal } \\
\text { deep?? }\end{array}$ & & & & & 32.0 & $\mathrm{~s}$ & 4.19 & & & & & & & 4.19 & nomo & & Aftershock(?). & ESPHVO, v. 3, p. 252. \\
\hline $5 / 21 / 22$ & 10:13 & & & & $\mathrm{kl} \mathrm{sf?}$ & & & & & 16.0 & $\mathrm{~m}$ & 4.20 & & & & & & & 4.20 & nomo & felt & Felt locally. & ESPHVO, v. 3, p. 288, 290. \\
\hline $5 / 22 / 22$ & $16: 53$ & & & & $\mathrm{kl} \mathrm{sf??}$ & & & & & 16.0 & $\mathrm{~m}$ [st?] & 4.20 & 5.98 & 6.08 & & & & & 6.03 & hono & felt & $\begin{array}{l}\text { Hilo, Honomu, and Waiohinu. Warshauer } \\
\text { notes: Several papers note earthquakes; DPH } \\
\text { says "earthquakes are frequent in all the } \\
\text { region," "earthquakes felt in Hilo for a } \\
\text { fortnight." }\end{array}$ & $\begin{array}{l}\text { Honolulu Station Bulletin (Hazard, } \\
\text { 1924); ESPHVO, v. 3, p. 275, 288, } \\
\text { 290; DPH, 5/27, 29/1922; HDT, 5/30, } \\
\text { 31/11922, HSB, 5/301/1922 [quotes } \\
\text { Jaggar]; not found in HA or MN. }\end{array}$ \\
\hline $5 / 22 / 22$ & 22:24 & & & & kl sf? & & & & & 16.0 & $\mathrm{~m}$ & 4.48 & & & & & & & 4.48 & nomo & III & Dismantled instruments; felt locally. & $\begin{array}{l}\text { ESPHVO, v. 3, p. } 288,290 \text {; distance } \\
\text { assumed. }\end{array}$ \\
\hline $5 / 24 / 22$ & $21: 58$ & & & & kl sf? & & & & & 16.0 & $\mathrm{~m}$ & 4.20 & & & & & & & 4.20 & nomo & felt & Felt locally; and at Hilo, and? & $\begin{array}{l}\text { ESPHVO, v. 3, p. 275, 288, 290; } \\
\text { distance assumed. }\end{array}$ \\
\hline $5 / 25 / 22$ & $0: 43$ & & & & kl sf? & & & & & 16.0 & $\mathrm{~m}$ & $\begin{array}{l}4.20 \\
4.20\end{array}$ & & & & & & & 4.20 & nomo & $\begin{array}{l}\text { felt } \\
\text { felt }\end{array}$ & Do. & $\begin{array}{l}\text { ESPHVO, v. 3, p. 288, 290; distance } \\
\text { assumed. }\end{array}$ \\
\hline $5 / 25 / 22$ & 2:00 & & & & kl sf? & & & & & 16.0 & $\mathrm{~m}$ & 4.20 & & & & & & & & & felt & & \\
\hline $5 / 25 / 22$ & $6: 15$ & & & & $\mathrm{kl} \mathrm{sf}$ & & & & & 16.0 & $\mathrm{~m}$ & 4.48 & & & & & & & 4.48 & nomo & III & $\begin{array}{l}\text { Instruments dismantled; felt locally; and at } \\
\text { Hilo, and? }\end{array}$ & ESPHVO, v. 3, p. 288, 290. \\
\hline $5 / 25 / 22$ & $21: 36$ & & & & kl sf? & & & & & 16.0 & $\mathrm{~m}$ & 4.48 & 5.15 & 5.27 & & & & & 5.21 & hono & felt & $\begin{array}{l}\text { Dismantled instruments; felt locally and at } \\
\text { Hilo, Honomu, and Waiohinu(?). }\end{array}$ & $\begin{array}{l}\text { ESPHVO, v. 3, p. 288; distance } \\
\text { assumed. }\end{array}$ \\
\hline $5 / 25 / 22$ & 23:24 & & & & $\mathrm{kl} \mathrm{sf}$ & & & & & 14.4 & $\mathrm{~m}$ & 4.40 & & & & & & & 4.40 & nomo & III & Do. & ESPHVO, v. 3, p. 289, 290. \\
\hline $5 / 25 / 22$ & 23:26 & & & & $\mathrm{kl} \mathrm{sf?}$ & & & & & 16.0 & $\mathrm{~m}$ & 4.20 & & & & & & & 4.20 & nomo & felt & $\begin{array}{l}\text { Felt locally, and at Hilo, Honomu, and } \\
\text { Waiohinu(?). }\end{array}$ & $\begin{array}{l}\text { ESPHVO, v. 3, p. 289, 290; distance } \\
\text { assumed. }\end{array}$ \\
\hline $5 / 25 / 22$ & 23:43 & & & & $\mathrm{kl}$ sf & & & & & 17.6 & $\mathrm{~m}$ & 4.27 & & & & & & & 4.27 & nomo & felt & Do. & ESPHVO, v. 3, p. 289,290 \\
\hline $5 / 27 / 22$ & 18:54 & & & & kl sf? & & & & & 16.0 & $\mathrm{~m}$ & 4.48 & & & & & & & 4.48 & nomo & III & Dismantled instruments; felt locally. & $\begin{array}{l}\text { ESPHVO, v. 3, p. 289; distance } \\
\text { assumed. }\end{array}$ \\
\hline $5 / 27 / 22$ & 20:04 & & & & $\mathrm{kl}$ uer? & & & & & 8.0 & $\mathrm{~m}$ & 4.00 & & & & & & & 4.00 & nomo & III & Do. & ESPHVO, v. 3, p. 289. \\
\hline
\end{tabular}


Table 13. All earthquakes of $M \geq 4.0$ during the period 1903-59-Continued

\begin{tabular}{|c|c|c|c|c|c|c|c|c|c|c|c|c|c|c|c|c|c|c|c|c|c|c|c|c|}
\hline Date & $\begin{array}{l}\text { Time } \\
\text { (HST) }\end{array}$ & $\begin{array}{l}\text { Lat } \\
\text { (deg) }\end{array}$ & $\begin{array}{c}\text { Lat } \\
(\mathrm{min})\end{array}$ & $\begin{array}{l}\text { Lon } \\
(\mathrm{deg})\end{array}$ & $\begin{array}{l}\text { Lon } \\
(\mathrm{min})\end{array}$ & Region & $\begin{array}{l}\text { Publ. } \\
\text { Depth I }\end{array}$ & $\begin{array}{l}\text { Pref. } \\
\text { Depth }\end{array}$ & $\begin{array}{l}\text { Publ. } \\
\text { Dist. }\end{array}$ & $\begin{array}{l}\text { Calc. } \\
\text { Dist }\end{array}$ & $\begin{array}{c}\text { Slant } \\
\text { dist }\end{array}$ & Mag class & $\begin{array}{c}\mathrm{M} \\
\text { nomo }\end{array}$ & $\begin{array}{l}\text { M M-S } \\
\text { E-W }\end{array}$ & $\begin{array}{c}\text { M M-S } \\
\text { N-S }\end{array}$ & M vert & $\begin{array}{c}\mathrm{M} \text { hor } \\
\mathrm{N}-\mathrm{L}\end{array}$ & $\begin{array}{c}\mathrm{M} \\
\text { other }\end{array}$ & $\begin{array}{c}\mathrm{M} \\
\text { (other) } \\
\text { source }\end{array}$ & $\begin{array}{c}\mathrm{M} \\
\text { pref }\end{array}$ & $\begin{array}{c}\mathrm{M} \\
\text { (pref) } \\
\text { source }\end{array}$ & $I(\max )$ & Location/felt report & Comment \\
\hline $5 / 28 / 22$ & $15: 40$ & & & & & $\mathrm{kl} \mathrm{sf?}$ & & & & & 17.6 & $\mathrm{~m}$ & 4.54 & & & & & & & 4.54 & nomo & III & Do. & Do. \\
\hline $5 / 28 / 22$ & 19:57 & & & & & $\mathrm{kl}$ mer? & & & 12 & & 13.0 & $\mathrm{~m}$ & 4.33 & & & & & & & 4.33 & nomo & III & $\begin{array}{l}\text { instruments; felt locally. Warshauer notes: } \\
\text { Precursory earthuake created rift through } \\
\text { which eruption could take place timplies the } \\
\text { creation of a fracture associated with a rift } \\
\text { earthquake]. }\end{array}$ & $\begin{array}{l}\text { ESPHVO, v. 3, p. 284, 289; distance } \\
\text { assumed; HA, 5/30/1922; HSB, 5/29; } \\
\text { 30/1922; DPH, 5/29/1922; HDT, 5/30; } \\
\text { 31/1922; HH, 6/1 missing. }\end{array}$ \\
\hline 6/2/22 & $6: 21$ & & & & & kl uer? & & & & & 9.6 & $\mathrm{~m}$ & 4.12 & & & & & & & 4.12 & nomo & III & Do.; dismantled instruments; felt locally. & $\begin{array}{l}\text { ESPHVO, v. 3, p. 302; distance } \\
\text { assumed. }\end{array}$ \\
\hline $7 / 20 / 22$ & 19:58 & & & & & hilea?? & & & & & 40.0 & $\mathrm{~s}$ & 4.34 & & & & & & & 4.34 & nomo & & & $\begin{array}{l}\text { Not found in Honolulu Station Bulletin } \\
\text { (Hazard, 1924); ESPHVO, v. 3, p. } 319 .\end{array}$ \\
\hline $7 / 24 / 22$ & $16: 59$ & & & & & hilea?? & & & & & 38.4 & $\mathrm{~s}$ & 4.31 & & & & & & & 4.31 & nomo & felt & $\begin{array}{l}\text { Felt locally. Warshauer notes: There was a } \\
\text { sharp shock of earthquake yesterday afternoon } \\
\text { at exactly } 5 \text { o'clock, and it was more especially } \\
\text { noticeable in the center of the city [Hilo], } \\
\text { although no damage was done; not felt at } \\
\text { Volcano House. }\end{array}$ & $\begin{array}{l}\text { Not found in Honolulu Station Bulletin } \\
\text { (Hazard, 1924); ESPHVO, v. 3, p. 319; } \\
\text { HDT, 7/25/1922. }\end{array}$ \\
\hline $10 / 13 / 22$ & 23:08 & & & & & $\begin{array}{l}\text { mauna } \\
\text { kea? }\end{array}$ & & & & & 64.0 & $\mathrm{~s}$ & 4.67 & & & & & & & 4.67 & nomo & felt & Felt in Hilo and strongly in Kohala. & $\begin{array}{l}\text { Not found in Honolulu Station Bulletin } \\
\text { (Hazard, 1924); ESPHVO, v. 3, p. } 354 .\end{array}$ \\
\hline 10/18/22 & 11:13 & & & & & a3035 & & & & & 32.0 & $\mathrm{~s}$ & 4.19 & & & & & & & 4.19 & nomo & & & $\begin{array}{l}\text { Not found in Honolulu Station Bulletin } \\
\text { (Hazard, 1924); ESPHVO, v. 3, p. } 354 .\end{array}$ \\
\hline 10/29/22 & $22: 13$ & & & & & a2530 & & & & & 25.6 & $\mathrm{~s}$ & 4.03 & & & & & & & 4.03 & nomo & felt & Felt in Hilo. & ESPHVO, v. 3, p. 354 \\
\hline $11 / 21 / 22$ & 3:27 & & & & & kl sf?? & & & & & & & & 5.32 & 5.67 & & & & & 5.50 & hono & VI & $\begin{array}{l}\text { Felt over island; heavy shaking in Kona, Kau, } \\
\text { Hamakua, also locally, Hilea, Hilo; dur 10-15 } \\
\text { s; dismantled inst. Warshauer notes: Strongly } \\
\text { felt-Hilo, Volcano; cracked houses and broke } \\
\text { mirrors; two distinct shocks, 1st slight, 2d felt } \\
\text { in six separate waves. }\end{array}$ & $\begin{array}{l}\text { Honolulu Station Bulletin (Hazard, } \\
\text { 1924); not mentioned in WK; } \\
\text { ESPHVO, v. 3, p. 357, 358, 359, 363; } \\
\text { DPH, 11/21/1922; HH, 11/23/1922; } \\
\text { HDT, 11/21; 23/1922; HA, 11/22/1922; } \\
\text { duration, 5 ininues on Hilo } \\
\text { seismograph; see references. }\end{array}$ \\
\hline $11 / 22 / 22$ & $0: 15$ & & & & & $\mathrm{kl} \mathrm{sf??}$ & & & & & 14.4 & $\mathrm{~m}$ & 4.13 & nomo & & & & & & 4.13 & nomo & $\mathrm{v}$ & $\begin{array}{l}\text { E-W component dismantled. Warshauer notes: } \\
\text { Slight earthquake sufficient to awaken light } \\
\text { sleepers felt in Hilo; two separate shocks at } \\
12: 20 \text { a.m., with a slight interval between. }\end{array}$ & $\begin{array}{l}\text { Aftershock; not in Honolulu Station } \\
\text { Bulletin (Hazard, 1924); ESPHVO, v. } \\
\text { 3, p. 358, 363; DPH, 11/22/1922; HDT, } \\
\text { 11/23/1922; duration, } 5 \text { minutes on } \\
\text { Hilo seismograph, }\end{array}$ \\
\hline $12 / 16 / 22$ & 5:00 & & & & & $\mathrm{ml} \mathrm{mok??}$ & & & & & 35.2 & $\mathrm{~s}$ & 4.25 & nomo & & & & & & 4.25 & nomo & & & $\begin{array}{l}\text { Not found in Honolulu Station Bulletin } \\
\text { (Hazard, 1924); ESPHVO, v. 3, p. } 374 .\end{array}$ \\
\hline $1 / 14 / 23$ & 1:00 & & & & & hilea?? & & & & & & & & & & & & & & 4.00 & felt & IV? & $\begin{array}{l}\text { Foreshock(?). Warshauer notes: Reports of an } \\
\text { earlier temblor at about } 1 \text { o'clock are also heard } \\
\text { from several persons. }\end{array}$ & MN, $1 / 15 / 1923$ \\
\hline $1 / 14 / 23$ & $2: 28$ & & & & & hilea? & & & & & & st & & 6.01 & 5.91 & & & & & 5.95 & hono & $\begin{array}{l}\text { IV (oahu); V-VI } \\
\text { (hilea) }\end{array}$ & $\begin{array}{l}\text { HON notes: Local shock; felt locally and in all } \\
\text { parts of Oahu; felt over Hawaii; slight damage, } \\
\text { stone walls down in Hilea. Cox notes: Felt-all } \\
\text { Oahu, Hawaii. }\end{array}$ & $\begin{array}{l}\text { Honolulu Station Bulletin (McFarland, } \\
\text { 1929); Cox, } 1986 \text { [awakened thousands } \\
\text { implies int 5, more typically 4]; } \\
\text { ESPHVO, v. 3, p. 378, 381, 386. }\end{array}$ \\
\hline $1 / 24 / 23$ & 2:29 & & & & & hilea?? & & & & & 38.4 & $\mathrm{~m}$ & 4.57 & & & & & & & 4.57 & nomo & & & $\begin{array}{l}\text { Not reported in Honolulu Station } \\
\text { Bulletin (McFarland, 1929); } \\
\text { aftershock(?); ESPHVO, v. 3, p. 386; } \\
\text { not in HA or HSB. }\end{array}$ \\
\hline 2/9/23 & 20:41 & & & & & hilea?? & & & & & 45.0 & $\mathrm{~m}$ & 4.68 & 4.50 & 4.50 & & & & & 4.50 & hono & IV-V & $\begin{array}{l}\text { HON notes: An irregularity in the microseisms; } \\
\text { quake felt [at HVO]; dismantled instruments, } \\
\text { felt over Istand of Hawaii. Warshauer notes: } \\
\text { Quake last night felt all along this line of } \\
\text { territory but not at volcano; slight quake caused } \\
\text { rockslide at Kilauea. }\end{array}$ & $\begin{array}{l}\text { Honolulu Station Bulletin (McFarland, } \\
1929 \text { [no amplitude reported; assume } \\
2 \text { mm]; ESPHVO, v. 3, p. 390, 393; } \\
\text { APH, 2/10/1923; HA, 2/11/1923; not in } \\
\text { HH. }\end{array}$ \\
\hline $3 / 3 / 23$ & $23: 46$ & & & & & a1320 & & & & & 19.2 & $\mathrm{~m}$ & 4.09 & & & & & & & 4.09 & nomo & felt & Felt in Hilo. & ESPHVO, v. 3, p. 401 \\
\hline $4 / 1 / 23$ & $10: 45$ & & & & & $\begin{array}{l}\text { mauna } \\
\text { kea?? }\end{array}$ & & & & & 36.8 & $\mathrm{~s}$ & 4.28 & & & & & & & 4.28 & nomo & & NW-SE. & $\begin{array}{l}\text { Not found in Honolulu Station Bulletin } \\
\text { (McFarland, 1929); ESPHVO, v. 3, p. } \\
\text { 413; not in HTH. }\end{array}$ \\
\hline $5 / 30 / 23$ & 12:06 & & & & & a2530 & & & & & 28.8 & $\mathrm{~s}$ & 4.11 & & & & & & & 4.11 & nomo & & SE-NW. & ESPHVO, v. 3, p. 429. \\
\hline
\end{tabular}


N Table 13. All earthquakes of $M \geq 4.0$ during the period 1903-59-Continued

\begin{tabular}{|c|c|c|c|c|c|c|c|c|c|c|c|c|c|c|c|c|c|c|c|c|c|c|c|c|}
\hline Date & $\begin{array}{l}\text { Time } \\
\text { (HST) }\end{array}$ & $\begin{array}{r}\text { Lat } \\
(\operatorname{deg})\end{array}$ & $\begin{array}{l}\text { Lat } \\
(\mathrm{min})\end{array}$ & $\begin{array}{c}\text { Lon } \\
(\operatorname{deg})\end{array}$ & $\begin{array}{c}\text { Lon } \\
(\min )\end{array}$ & Region & $\begin{array}{l}\text { Publ. } \\
\text { Depth }\end{array}$ & $\begin{array}{l}\text { Pref. } \\
\text { Depth }\end{array}$ & $\begin{array}{l}\text { Publ. } \\
\text { Dist. }\end{array}$ & $\begin{array}{l}\text { Calc. } \\
\text { Dist }\end{array}$ & $\begin{array}{c}\text { Slant } \\
\text { dist }\end{array}$ & Mag class & $\begin{array}{c}\mathrm{M} \\
\text { nomo }\end{array}$ & $\begin{array}{c}\text { M M-S } \\
\text { E-W }\end{array}$ & $\begin{array}{c}\text { M M-S } \\
\text { N-S }\end{array}$ & $M$ vert & $\begin{array}{c}\text { M hor } \\
\text { N-L }\end{array}$ & $\begin{array}{c}\mathrm{M} \\
\text { other }\end{array}$ & $\begin{array}{c}\mathrm{M} \\
\text { (other) } \\
\text { source }\end{array}$ & $\begin{array}{c}\mathrm{M} \\
\text { pref }\end{array}$ & $\begin{array}{c}\mathrm{M} \\
\text { (pref) } \\
\text { source }\end{array}$ & $I(\max )$ & Location/felt report & Comment \\
\hline $11 / 15 / 23$ & $10: 40$ & & & & & a3035 & & & & & 35.2 & $\mathrm{~s}$ & 4.25 & & & & & & & 4.25 & nomo & & & $\begin{array}{l}\text { Not in Honolulu Station Bulletin } \\
\text { (McFarland, 1929); ESPHVO, v. 3, p. } \\
488 .\end{array}$ \\
\hline $12 / 14 / 23$ & 5:34 & & & & & $\mathrm{ml} \mathrm{mok??}$ & & & & & 36.8 & $\mathrm{~s}$ & 4.28 & & & & & & & 4.28 & nomo & felt & Felt in Hilo, Kona, and Kau. & $\begin{array}{l}\text { Not in Honolulu Station Bulletin } \\
\text { (McFarland, 1929); ESPHVO, v. 3, p. } \\
\text { 497. }\end{array}$ \\
\hline $12 / 25 / 23$ & $18: 46$ & & & & & molokai? & & & & & 260.0 & vf & 4.83 & & & & & & & 4.83 & nomo & IV (oahu) & $\begin{array}{l}\text { Felt-Oahu, Molokai, and Lanai. Cox notes: UH } \\
\text { seismograph out of commission, felt-tahu, } \\
\text { Molokai, Maui, and Lanai (not Hawaii). } \\
\text { Warshauer notes: Felt as sharp but short on } \\
\text { Maaiu, no damage; not felt at Hilo, but felt on } \\
\text { Oahu. }\end{array}$ & $\begin{array}{l}\text { Not reported in Honolulu Station } \\
\text { Bulletin (McFarland, 1929); ESPHVO, } \\
\text { v.3, p. 497; Cox, 1986; MN, } \\
\text { 12/28/1923. }\end{array}$ \\
\hline $12 / 28 / 23$ & $16: 37$ & & & & & $\begin{array}{l}\text { mauna } \\
\text { kea?? }\end{array}$ & & & & & 43.2 & $\mathrm{~m}$ & 4.65 & & & & & & & 4.65 & nomo & III & $\begin{array}{l}\text { Instruments dismantled; felt over E Hawaii. } \\
\text { Warshauer notes: Quake exceptionally severe } \\
\text { in Kau district; felt at HVO and along the } \\
\text { Hamakua coast as far as Honomu. }\end{array}$ & $\begin{array}{l}\text { Not reported in Honolulu Station } \\
\text { Bulletin (McFarland, 1929); ESPHVO, } \\
\text { v. 3, p. 497; HTH, 12/31/1923. }\end{array}$ \\
\hline $1 / 8 / 24$ & $10: 46$ & & & & & $\mathrm{ml}$ wf?? & & & & & 45.0 & $\mathrm{~s}$ & 4.20 & & & & & & & 4.20 & nomo & felt & Felt in Kona. & $\begin{array}{l}\text { Not reported in Honolulu Station } \\
\text { Bulletin (McFarland, 1929); ESPHVO, } \\
\text { v. 3, p. 504; distance assumed. }\end{array}$ \\
\hline $3 / 10 / 24$ & $17: 45$ & & & & & kl sf? & & & & & 28.8 & $\mathrm{~s}$ & 4.11 & & & & & & & 4.11 & nomo & & & ESPHVO, v. 3, p. 512, 513 \\
\hline $3 / 29 / 24$ & $1: 27$ & & & & & kl sf? & & & & & 43.2 & $\mathrm{~s}$ & 4.40 & & & & & & & 4.40 & nomo & IV & $\begin{array}{l}\text { Felt-Hilo. Warshauer notes: Hilo felt a pretty } \\
\text { strong quake at } 1: 35 \text { a.m. today. Houses in } \\
\text { several parts of the town rocked, but no } \\
\text { damage was done. }\end{array}$ & $\begin{array}{l}\text { Not reported in Honolulu Station } \\
\text { Bulletin (McFarland, 1929); ESPHVO, } \\
\text { v. 3, p. 512, 513; HTH, 3/29/1924. }\end{array}$ \\
\hline $4 / 10 / 24$ & $22: 46$ & & & & & kl sf? & & & & & 30.4 & $\mathrm{~s}$ & 4.15 & & & & & & & 4.15 & nomo & $\mathrm{V}$ ? & $\begin{array}{l}\text { Strongish earthquake in Puna, felt in Hilo and } \\
\text { reported quite severe in some districts; felt } \\
\text { locally, and in Hilo; [distance of } 9 \text { mi actually } \\
19 ? \text { (assume sf from felt reports); east rift } \\
\text { traversed on } 4 / 111 \text { and again on } 4 / 16 \text {, no new } \\
\text { cracks observed]. }\end{array}$ & $\begin{array}{l}\text { Not reported in Honolulu Station } \\
\text { Bulletin (McFarland, 1929); ESPHVO, } \\
\text { v. 3, p. 516, 525. }\end{array}$ \\
\hline $4 / 19 / 24$ & 7:23 & & & & & kl ler? & & & & & 40.0 & $\mathrm{~s}$ & 4.34 & & & & & & & 4.34 & nomo & & & $\begin{array}{l}\text { ESPHVO, v. 3, p. } 525 \text {; distance } \\
\text { assumed. }\end{array}$ \\
\hline $4 / 28 / 24$ & $11: 35$ & & & & & $\mathrm{kl}$ ler & & & & & 43.2 & $\mathrm{~s}$ & 4.40 & & & & & & & 4.40 & nomo & & & $\begin{array}{l}\text { Not reported in Honolulu Station } \\
\text { Bulletin (McFarland, 1929); ESPHVO, } \\
\text { v. 3, p. 527. }\end{array}$ \\
\hline $5 / 10 / 24$ & 23:59 & & & & & kl cal $0-5$ ? & & & & & 4.0 & $\mathrm{f}$ & 2.20 & & & & & & & 4.01 & nomo & & See note for $5 / 1 / 24$; untabulated feeble = 98 . & $\begin{array}{l}\text { Phreatic explosions begin evening of } \\
5 / 10 \text {, lasting through } 5 / 27 ; \text { ESPHVO, } \\
\text { v. 3, p. 529-560; 101 earthquakes, } 3 \\
\text { felt: 2 explosions; ESPHVO, v. 3, p. } \\
557 \text {, table. }\end{array}$ \\
\hline $5 / 11 / 24$ & 23:59 & & & & & kl cal $0-5$ ? & & & & & 4.0 & $\mathrm{f}$ & 2.20 & & & & & & & 4.04 & nomo & & $\begin{array}{l}\text { See note for May } 1,1924 \text {; untabulated feeble = } \\
107 \text {; beginning of diary of observations made } \\
\text { during } 1924 \text { crisis; no earthquakes mentioned. }\end{array}$ & $\begin{array}{l}111 \text { earthquakes, } 3 \text { felt; } 1 \text { explosions; } \\
\text { ESPHVO, v. 3, p. 557, table; Jaggar, } \\
\text { 1947, p. } 214 \text {. }\end{array}$ \\
\hline $5 / 14 / 24$ & 23:59 & & & & & $\mathrm{kl}$ cal $0-5$ ? & & & & & 4.0 & $\mathrm{f}$ & 2.20 & & & & & & & 4.00 & nomo & & See note for $5 / 1 / 24$; untabulated feeble $=96$. & $\begin{array}{l}113 \text { earthquakes, } 17 \text { felt; } 3 \text { explosions; } \\
\text { ESPHVO, v. 3, p. } 557 \text {, table. }\end{array}$ \\
\hline $5 / 15 / 24$ & 23:59 & & & & & kl cal $0-5$ ? & & & & & 4.0 & $\mathrm{f}$ & 2.20 & & & & & & & 4.07 & nomo & & See note for $5 / 1 / 24$; untabulated feeble $=116$. & $\begin{array}{l}132 \text { earthquakes, } 15 \text { felt; } 2 \text { explosions; } \\
\text { ESPHVO, v. } 3 \text {, p. } 557 \text {, table. }\end{array}$ \\
\hline $5 / 16 / 24$ & $17: 33$ & & & & & $\begin{array}{l}\text { kl cal } \\
\text { deep? }\end{array}$ & & & & & 31.0 & st? & 4.94 & 5.04 & 5.38 & & & & & 5.21 & hono & & $\begin{array}{l}\text { HON notes: Timing very similar to quake of } \\
\text { May } 30 .\end{array}$ & $\begin{array}{l}\text { Honolulu Station Bulletin (McFarland, } \\
\text { 1929); not reported in Jaggar, 1947, p. } \\
\text { 218; not found in MN. }\end{array}$ \\
\hline $5 / 16 / 24$ & 23:59 & & & & & $\mathrm{kl}$ cal $0-5$ ? & & & & & 4.0 & $\mathrm{f}$ & 2.20 & & & & & & & 4.35 & nomo & & See note for $5 / 1 / 24$; untabulated feeble $=231$. & $\begin{array}{l}276 \text { earthquakes, } 45 \text { felt; } 4 \text { explosions; } \\
\text { ESPHVO, v. 3, p. } 557 \text {, table. }\end{array}$ \\
\hline $5 / 16 / 24$ & $23: 59$ & & & & & kl cal $0-5$ ? & & & & & 4.0 & $\mathrm{~s}$ & 2.74 & & & & & & & 4.22 & nomo & & See note for $5 / 1 / 24$; untabulated slight $=42$. & Do. \\
\hline $5 / 17 / 24$ & 23:59 & & & & & kl cal 0-5? & & & & & 4.0 & $\mathrm{~s}$ & 2.74 & & & & & & & 4.10 & nomo & & See note for $5 / 1 / 24$; untabulated slight = 31 . & $\begin{array}{l}150 \text { earthquakes, } 30 \text { felt; } 3 \text { explosions; } \\
\text { ESPHVO, v. } 3 \text {, p. } 557 \text {, table. }\end{array}$ \\
\hline $5 / 17 / 24$ & 23:59 & & & & & $\mathrm{kl}$ cal $0-5$ ? & & & & & 4.0 & $\mathrm{f}$ & 2.20 & & & & & & & 4.07 & nomo & & See note for $5 / 1 / 24$; untabulated feeble $=115$. & Do. \\
\hline $5 / 18 / 24$ & 23:59 & & & & & kl cal 0-5? & & & & & 4.0 & $\mathrm{f}$ & 2.20 & & & & & & & 4.14 & nomo & & See note for $5 / 1 / 24$; untabulated feeble $=138$. & $\begin{array}{l}165 \text { earthquakes, } 25 \text { felt; } 3 \text { explosions; } \\
\text { ESPHVO, v. 3, p. } 557 \text {, table. }\end{array}$ \\
\hline
\end{tabular}


Table 13. All earthquakes of $M \geq 4.0$ during the period 1903-59-Continued

\begin{tabular}{|c|c|c|c|c|c|c|c|c|c|c|c|c|c|c|c|c|c|c|c|c|c|c|c|c|}
\hline Date & $\begin{array}{c}\text { Time } \\
\text { (HST) }\end{array}$ & $\begin{array}{l}\text { Lat } \\
(\mathrm{deg})\end{array}$ & $\begin{array}{l}\text { Lat } \\
(\mathrm{min})\end{array}$ & $\begin{array}{c}\text { Lon } \\
(\mathrm{deg})\end{array}$ & $\begin{array}{l}\text { Lon } \\
(\mathrm{min})\end{array}$ & Region & $\begin{array}{l}\text { Publ. } \\
\text { Depth }\end{array}$ & $\begin{array}{l}\text { Pref. } \\
\text { Depth }\end{array}$ & $\begin{array}{l}\text { Publ. } \\
\text { Dist. }\end{array}$ & $\begin{array}{l}\text { Calc. } \\
\text { Dist }\end{array}$ & $\begin{array}{c}\text { Slant } \\
\text { dist }\end{array}$ & Mag class & $\begin{array}{c}\mathrm{M} \\
\text { nomo }\end{array}$ & $\begin{array}{c}\text { M M-S } \\
\text { E-W }\end{array}$ & $\begin{array}{c}\text { M M-S } \\
\text { N-S }\end{array}$ & M vert & $\begin{array}{c}\text { M hor } \\
\mathrm{N}-\mathrm{L}\end{array}$ & $\begin{array}{c}\mathrm{M} \\
\text { other }\end{array}$ & $\begin{array}{c}\mathrm{M} \\
\text { (other) } \\
\text { source }\end{array}$ & $\begin{array}{c}\mathrm{M} \\
\text { pref }\end{array}$ & $\begin{array}{c}\mathrm{M} \\
\text { (pref) } \\
\text { source }\end{array}$ & $I(\max )$ & Location/felt report & Comment \\
\hline $5 / 19 / 24$ & $21: 23$ & & & & & a0513 & & & & & 10.0 & m-st & 4.04 & & & & & & & 4.04 & nomo & IV & $\begin{array}{l}\text { A heavy quake, N-S component dismantled, } \\
\text { felt strongly at Glenwood. }\end{array}$ & $\begin{array}{l}\text { Jaggar, 1947, p. } 227 \text { [for quakes felt } \\
\text { away from Kilauea caldera, we assign a } \\
10 \text {-km slant distance and region } \\
\text { "a0513"; calc magnitudes are } \\
\text { constrained by lack of recognition in } \\
\text { the Honolulu Station Bulletin } \\
\text { (McFarland, 1929); film records } \\
\text { unavailable]. }\end{array}$ \\
\hline $5 / 19 / 24$ & 23:59 & & & & & kl cal $0-5$ ? & & & & & 4.0 & $\mathrm{f}$ & 2.20 & & & & & & & 4.18 & nomo & & See note for $5 / 1 / 24$; untabulated feeble $=150$. & $\begin{array}{l}180 \text { earthquakes, } 21 \text { felt; } 3 \text { explosions; } \\
\text { ESPHVO, v. 3, p. } 557 \text {, table. }\end{array}$ \\
\hline $5 / 20 / 24$ & 6:17 & & & & & kaoiki? & & & 19 & 19.00 & 21.0 & m-st & 4.56 & & & & & & & 4.56 & nomo & III & $\begin{array}{l}\text { Moderate, sharp; instruments dismantled. } \\
\text { Warshauer notes: Four heavy quakes felt at } \\
\text { Hilea during the day [5/20]. }\end{array}$ & $\begin{array}{l}\text { ESPHVO, v. 3, p. 552; Jaggar, 1947, p. } \\
\text { 230; HA, 5/21/1924. }\end{array}$ \\
\hline $5 / 20 / 24$ & 7:03 & & & & & kaoiki? & & & 19 & 19.00 & 21.0 & st & 4.67 & & & & & & & 4.67 & nomo & & $\begin{array}{l}\text { Strong; instruments not operating; a very heavy } \\
\text { quake. Warshauer notes: Four heavy quakes } \\
\text { felt at Hilea during the day }[5 / 20] \text {. }\end{array}$ & $\begin{array}{l}\text { y ESPHVO, v. 3, p. 552; Jaggar, 1947, p. } \\
\text { 230; HA, 5/21/1924. }\end{array}$ \\
\hline $5 / 20 / 24$ & $14: 40$ & & & & & kaoiki & & & 19 & 19.00 & 21.0 & m-st & 4.56 & & & & & & & 4.56 & nomo & III & $\begin{array}{l}\text { A moderate quake, dismantled both pens; } \\
\text { origin more distant than Halemaumau, thought } \\
\text { to be in Kau. Warshauer notes: Four heavy } \\
\text { earthquakes felt at Hilea during this day [May } \\
\text { 20]. }\end{array}$ & $\begin{array}{l}\text { Distance of } 19 \mathrm{~km} \text { in Kau direction } \\
\text { assumed from report of road cracks } \\
\text { (ESPHVO, v. 3, p. } 576 \text { ) not reported } \\
\text { in Honolulu Station Bulletin } \\
\text { (McFarland, 1929); see ESPHVO, v. 3, } \\
\text { p. 576; Jaggar, 1947, p. 231; HA, } \\
5 / 21 / 1924 \text {. }\end{array}$ \\
\hline $5 / 20 / 24$ & 20:46 & & & & & kaoiki? & & & 19 & 19.00 & 21.0 & m-st & 4.56 & & & & & & & 4.56 & nomo & III & $\begin{array}{l}\text { Heavy shock dismantles pen. Warshauer notes: } \\
\text { Four heavy quakes felt at Hilea during the day } \\
\text { [5/20]. }\end{array}$ & Jaggar, 1947, p. 232; HA, 5/21/1924. \\
\hline $5 / 20 / 24$ & 23:59 & & & & & kl cal $0-5$ ? & & & & & 4.0 & $\mathrm{f}$ & 2.20 & & & & & & & 4.21 & nomo & & See note for $5 / 1 / 24 ;$ untabulated feeble = 164 & $\begin{array}{l}201 \text { earthquakes, } 41 \text { felt; } 3 \text { explosions; } \\
\text { ESPHVO, v. 3, p. } 557 \text {, table. }\end{array}$ \\
\hline $5 / 21 / 24$ & 23:59 & & & & & kl cal $0-5$ ? & & & & & 4.0 & $\mathrm{f}$ & 2.20 & & & & & & & 4.34 & nomo & & $\begin{array}{l}\text { See note for May 1, 1924; untabulated feeble }= \\
225 \text {. Warshauer notes: Almost continual quakes } \\
\text { have been recorded during the past } 2 \text { days } \\
\text { [May 19-20] at Hilea. }\end{array}$ & $\begin{array}{l}\text { is } 275 \text { earthquakes, } 50 \text { felt; } 4 \text { explosions; } \\
\text { ESPHVO, v. 3, p. } 557 \text {, table; HA, } \\
\text { 5/22/1924. }\end{array}$ \\
\hline $5 / 21 / 24$ & 23:59 & & & & & kl cal $0-5$ ? & & & & & 4.0 & $\mathrm{~s}$ & 2.74 & & & & & & & 4.19 & nomo & & $\begin{array}{l}\text { See note for May 1, 1924; untabulated slight = } \\
\text { 39. Warshauer notes: Almost continual quakes } \\
\text { have been recorded during the past } 2 \text { days } \\
\text { [May 19-20] at Hilea. }\end{array}$ & Do. \\
\hline $5 / 22 / 24$ & 23:59 & & & & & kl cal $0-5$ ? & & & & & 4.0 & $\mathrm{f}$ & 2.20 & & & & & & & 4.38 & nomo & & $\begin{array}{l}\text { See note for May 1, 1924; untabulated feeble = } \\
\text { 255. Warshauer notes: Visit to Kau found no } \\
\text { new cracks [but see ESPHVO, v. 3, p. 576]; } \\
\text { Kapoho area continues to experience slight } \\
\text { earthquakes. }\end{array}$ & $\begin{array}{l}339 \text { earthquakes, } 75 \text { felt; } 3 \text { explosions; } \\
\text { ESPHVO, v. 3, p. } 557 \text {, table; HA. } \\
\text { 5/23/1924. }\end{array}$ \\
\hline $5 / 22 / 24$ & 23:59 & & & & & kl cal $0-5 ?$ & & & & & 4.0 & $\mathrm{~s}$ & 2.74 & & & & & & & 4.13 & nomo & & $\begin{array}{l}\text { See note for May 1, 1924; untabulated slight = } \\
\text { 34. Warshauer notes: Visit to Kau found no } \\
\text { new cracks [but see ESPHVO, v. 3, p. 576]; } \\
\text { Kapoho area continues to experience slight } \\
\text { earthquakes. }\end{array}$ & Do. \\
\hline $5 / 23 / 24$ & 23:59 & & & & & $\mathrm{kl} \mathrm{cal} 0-5 ?$ & & & & & 4.0 & f & 2.20 & & & & & & & 4.28 & nomo & & $\begin{array}{l}\text { See note for May 1, 1924; untabulated feeble = } \\
\text { 198. Warshauer notes: : ilea is recording an } \\
\text { almost continuous tremble on the seismograph, } \\
\text { but no perceptible earthquakes; no activity in } \\
\text { Hilo, other than a few scattered and } \\
\text { inconsiderable earthquakes. }\end{array}$ & $\begin{array}{l}\text { la } \\
\text { EST earthquakes, } 59 \text { felt; } 3 \text { explosions; } \\
\text { 5/24/1924, v. p. p. } 557 \text {, table; HA, } \\
\end{array}$ \\
\hline $5 / 23 / 24$ & 23:59 & & & & & kl cal $0-5$ ? & & & & & 4.0 & $\mathrm{~s}$ & 2.74 & & & & & & & 4.22 & nomo & & $\begin{array}{l}\text { See note for May 1, 1924; untabulated slight = } \\
\text { 42. Warshauer notes: Hilea is recording an } \\
\text { almost continuous tremble on the seismograph, } \\
\text { but no perceptible earthquakes; no activity in } \\
\text { Hilo, other than a few scattered and } \\
\text { inconsiderable earthquakes. }\end{array}$ & $\begin{array}{l}257 \text { earthquakes, } 59 \text { felt; } 3 \text { explosions; } \\
\text { ESPHVO, v. 3, p. 557, table; HA, } \\
\text { 5/24/1924, p. 2. }\end{array}$ \\
\hline $5 / 24 / 24$ & 3:48 & & & & & a0513 & & & & & 10.0 & m-st & 4.04 & & & & & & & & nomo & IV & $\begin{array}{l}\text { This quake, as with many others, caused the E } \\
\text { or SE part of the building to creak first, } \\
\text { followed by windows rattling on } W \text { side. } \\
\text { Warshauer notes: Quakes shake Hilo Saturday } \\
\text { morning; a rather rstrong earthquake shock was } \\
\text { felt [in Pahalala] early this morning. }\end{array}$ & $\begin{array}{l}\text { See note for May 19, 1924; time 11:23; } \\
\text { Jaggar, } 9477 \text {, p. 246; HA, 5/24, } \\
\text { 27/1924. }\end{array}$ \\
\hline
\end{tabular}


cM Table 13. All earthquakes of $M \geq 4.0$ during the period 1903-59-Continued

\begin{tabular}{|c|c|c|c|c|c|c|c|c|c|c|c|c|c|c|c|c|c|c|c|c|c|c|c|c|}
\hline Date & $\begin{array}{l}\text { Time } \\
\text { (HST) }\end{array}$ & $\begin{array}{c}\text { Lat } \\
(\operatorname{deg})\end{array}$ & $\begin{array}{l}\text { Lat } \\
(\min )\end{array}$ & $\begin{array}{c}\text { Lon } \\
(\operatorname{deg})\end{array}$ & $\begin{array}{c}\text { Lon } \\
(\min )\end{array}$ & Region & $\begin{array}{l}\text { Publ. } \\
\text { Depth }\end{array}$ & $\begin{array}{l}\text { Pref. } \\
\text { Depth }\end{array}$ & $\begin{array}{l}\text { Publ. } \\
\text { Dist. }\end{array}$ & $\begin{array}{c}\text { Calc. } \\
\text { Dist }\end{array}$ & $\begin{array}{c}\text { Slant } \\
\text { dist }\end{array}$ & Mag class & $\begin{array}{c}\mathrm{M} \\
\text { nomo }\end{array}$ & $\begin{array}{l}\text { M M-S } \\
\text { E-W }\end{array}$ & $\begin{array}{c}\text { M M-S } \\
\text { N-S }\end{array}$ & M vert & $\begin{array}{c}\text { M hor } \\
\text { N-L }\end{array}$ & $\begin{array}{c}\text { M } \\
\text { other }\end{array}$ & $\begin{array}{c}\mathrm{M} \\
\text { (other) } \\
\text { source }\end{array}$ & $\underset{\text { pref }}{\mathrm{M}}$ & $\begin{array}{c}\mathrm{M} \\
\begin{array}{c}\text { (pref) } \\
\text { source }\end{array}\end{array}$ & $I(\max )$ & Location/felt report & Comment \\
\hline $5 / 24 / 24$ & $5: 51$ & & & & & a0513 & & & & & 10.0 & $\mathrm{~m}$-st & 4.04 & & & & & & & 4.04 & nomo & III & $\begin{array}{l}\text { Both components dismantled. Warshauer notes: } \\
\text { Quakes shake Hilo Saturday morning. }\end{array}$ & $\begin{array}{l}\text { See note for May 19, 1924; time 11:23; } \\
\text { Jaggar, 1947, p. 246; HA, 5/24/1924. }\end{array}$ \\
\hline $5 / 24 / 24$ & 23:59 & & & & & kl cal $0-5$ ? & & & & & 4.0 & $\mathrm{f}$ & 2.20 & & & & & & & 4.56 & nomo & felt & $\begin{array}{l}\text { See note for May 1, 1924; untabulated feeble = } \\
400 \text {. Warshauer notes: Earthquakes were } \\
\text { distinctly felt in Hilo last night [May 23-24], } \\
\text { but no tremors were reported from any section } \\
\text { today. }\end{array}$ & $\begin{array}{l}467 \text { earthquakes, } 67 \text { felt; } 2 \text { explosions; } \\
\text { ESPHVO, v. 3, p. } 557 \text {, table; HA, } \\
5 / 25 / 1924 \text {. }\end{array}$ \\
\hline $5 / 24 / 24$ & 23:59 & & & & & $\mathrm{kl}$ cal $0-5$ ? & & & & & 4.0 & $\mathrm{~s}$ & 2.74 & & & & & & & 4.23 & nomo & felt & $\begin{array}{l}\text { See note for May 1, 1924; untabulated slight = } \\
\text { 43. Warshauer notes: Earthquakes were } \\
\text { distinctly felt in Hilo last night [May 23-24], } \\
\text { but no tremors were reported from any section } \\
\text { today. }\end{array}$ & $\begin{array}{l}\text { 467 earthquakes, } 67 \text { felt; } 2 \text { explosions; } \\
\text { ESPHVO, v. 3, p. } 557 \text {, table; HA, } \\
\text { 5/25/1924. }\end{array}$ \\
\hline $5 / 25 / 24$ & 23:59 & & & & & kl cal 0-5? & & & & & 4.0 & $\mathrm{f}$ & 2.20 & & & & & & & 4.29 & nomo & & See note for $5 / 1 / 24$; untabulated feeble $=202$. & $\begin{array}{l}248 \text { earthquakes, } 45 \text { felt; } 2 \text { explosions; } \\
\text { ESPHVO, v. 3, p. } 557 \text {, table. }\end{array}$ \\
\hline $5 / 25 / 24$ & $23: 59$ & & & & & $\mathrm{kl} \mathrm{cal} \mathrm{0-5?}$ & & & & & 4.0 & $\mathrm{~s}$ & 2.74 & & & & & & & 4.10 & nomo & & See note for $5 / 1 / 24 ;$ untabulated slight $=31$. & Do. \\
\hline $5 / 26 / 24$ & 8:06 & & & & & a0513 & & & & & 10.0 & m-st & 4.04 & & & & & & & 4.04 & nomo & IV & $\begin{array}{l}\text { A moderate quake; dismantled both } \\
\text { instruments. Warshauer notes: A strong } \\
\text { earthquake shook the entire Kilauea district at } 9 \\
\text { o'clock [time wrong?]. }\end{array}$ & $\begin{array}{l}\text { See note for May 19, 1924; time 11:23; } \\
\text { Jaggar, 1947, p. 253; HA, 5/27/1924. }\end{array}$ \\
\hline $5 / 26 / 24$ & 23:59 & & & & & $\mathrm{kl}$ cal $0-5$ ? & & & & & 4.0 & $\mathrm{f}$ & 2.20 & & & & & & & 4.14 & nomo & & See note for $5 / 1 / 24$; untabulated feeble $=137$. & $\begin{array}{l}156 \text { earthquakes, } 19 \text { felt; } 1 \text { explosion; } \\
\text { ESPHVO, v. 3, p. } 557 \text {, table. }\end{array}$ \\
\hline $5 / 27 / 24$ & 23:59 & & & & & kl cal $0-5$ ? & & & & & 4.0 & $\mathrm{~s}$ & 2.74 & & & & & & & 4.74 & nomo & & See note for $5 / 1 / 24 ;$ untabulated slight = 17 . & $\begin{array}{l}195 \text { earthquakes, } 36 \text { felt; } 1 \text { explosion; } \\
\text { ESPHVO, v. 3, p. } 557 \text {, table. }\end{array}$ \\
\hline $5 / 27 / 24$ & 23:59 & & & & & kl cal $0-5$ ? & & & & & 4.0 & f & 2.20 & & & & & & & 4.20 & nomo & & See note for $5 / 1 / 24$; untabulated feeble $=158$. & Do. \\
\hline $5 / 28 / 24$ & 23:59 & & & & & kl cal $0-5$ ? & & & & & 4.0 & $\mathrm{f}$ & 2.20 & & & & & & & 4.06 & 5 nomo & & See note for $5 / 1 / 24$; untabulated feeble $=111$. & $\begin{array}{l}130 \text { earthquakes; ESPHVO, v. } 3 \text {, p. } \\
560 \text {, table. }\end{array}$ \\
\hline $5 / 30 / 24$ & $8: 42$ & & & & & $\begin{array}{l}\mathrm{kl} \mathrm{cal} \\
\text { deep? }\end{array}$ & & & & & 10.0 & st & 4.15 & 5.78 & 5.91 & & & & & 5.85 & 5 hono & $\mathrm{v}$ & $\begin{array}{l}\text { HON notes: Evidently not far away; unusually } \\
\text { strong; both instruments dismantled; raised } \\
\text { dustcloud at pit; N-S component set back } 0.5 \\
\text { in. on drum; tilt strong NE; strongest quake felt } \\
\text { here in a long time. }\end{array}$ & $\begin{array}{l}\text { Honolulu Station Bulletin (McFarland, } \\
\text { 1929); ESPHVO, v. 3, p. } 556 \text {; Jaggar, } \\
\text { 1947, p. } 259 .\end{array}$ \\
\hline $7 / 20 / 24$ & 13:25 & & & & & hilo & & & & & 43.2 & s & 4.40 & & & & & & & 4.40 & nomo & VI & $\begin{array}{l}\text { Felt locally. Warshauer notes: Quake duration } \\
\text { several seconds, severe, rocked Hilo, knocked } \\
\text { pictures and vases down; seemed to come in a } \\
\text { wave, which shook their houses in sections at a } \\
\text { time as the wave seemed to pass on. }\end{array}$ & $\begin{array}{l}\text { ESPHVO, v. 3, p. 586; not in } \\
\text { Honolulu Station Bulletin ; HTH, } \\
\text { 7/21/1924. }\end{array}$ \\
\hline $8 / 20 / 24$ & $6: 20$ & & & & & kaoiki & & & & & 25.6 & $\mathrm{~m}$ & 4.80 & & & & & 5 & W\&K & 5.00 & nomo & $\mathrm{V}(\mathrm{Kau})$ & $\begin{array}{l}\text { Earthquake centering near Kapapala, felt-HVO, } \\
\text { Hilo, Pahala, and Kona, but not Kapoho; } \\
\text { distance, } 16 \text { mi, felt all over Hawaii; isoseismal } \\
\text { map in W\&K, who suggest a Hilea epicenter. }\end{array}$ & $\begin{array}{l}\text { ESPHVO, v. 3, p. 590, } 592,595 \\
\text { [M 5.5 predicts an amp of } 4 \text { mm on } \\
\text { Milne-Shaw, which was not reported in } \\
\text { Honolulu Station Bulletin }] ; \text { HTH, } \\
\text { 8/20/1924; see references. }\end{array}$ \\
\hline $8 / 20 / 24$ & 22:48 & & & & & kaoiki? & & & & & 25.6 & $\mathrm{~s}$ & 4.03 & & & & & & & 4.03 & nomo & & & $\begin{array}{l}\text { Aftershocks(?)-distance and region } \\
\text { assumed; ESPHVO, v. 3, p. } 595 .\end{array}$ \\
\hline $8 / 23 / 24$ & $0: 10$ & & & & & $\mathrm{ml} \mathrm{mok}$ & & & & & 32.0 & $\mathrm{~s}$ & 4.19 & & & & & & & 4.19 & nomo & $\mathrm{V}$ ? & $\begin{array}{l}\text { Sharply felt at HVO; felt very severe at } \\
\text { Mokuaweoweo. }\end{array}$ & $\begin{array}{l}\text { [Distance of } 2 \text { mi inconsistent with felt } \\
\text { report; misprint for 20?] ESPHVO, v. } \\
\text { 3, p. 590, 592, 595. }\end{array}$ \\
\hline $8 / 23 / 24$ & $0: 13$ & & & & & $\mathrm{ml} \mathrm{mok}$ & & & & & 32.0 & $\mathrm{~m}$ & 4.68 & & 5.59 & & & & & 5.59 & 9 hono & $\mathrm{V}-\mathrm{VI}$ & $\begin{array}{l}\text { Sharply felt at HVO; felt very severe, and stone } \\
\text { monuments hsaken down and ground cracked } \\
\text { open at Mokuaweoweo; seismographs } \\
\text { dismantled; distance, } 20 \text { mi. HON notes: Onset } \\
\text { to max } 1 \text { min } 10 \text { s; } 1 \text {-s period. }\end{array}$ & $\begin{array}{l}\text { Honolulu Station Bulletin (McFarland, } \\
\text { 1929); ESPHVO, v. 3, p. } 590,592, \\
595 \text {; probably larger than } 8 / 20 / 24 \\
M=5.0 \text { at Hilea, which was not } \\
\text { reported in Honolulu Station Bulletin }] \text {; } \\
\text { not in HTH. }\end{array}$ \\
\hline $8 / 24 / 24$ & $7: 48$ & & & & & $\mathrm{ml} \mathrm{mok}$ ? & & & & & 32.0 & $\mathrm{~s}$ & 4.19 & & & & & & & 4.19 & 9 nomo & felt & Presumed felt more strongly in Kau than Puna. & $\begin{array}{l}\text { [Distance of } 2 \text { mi inconsistent with } \\
\text { statement on p. 590; misprint for 20?] } \\
\text { ESPHVO, v. 3, p. 590, 595. }\end{array}$ \\
\hline 9/8/24 & 22:07 & & & & & kona & & & & & 57.6 & $\mathrm{~s}$ & 4.37 & & & & & & & 4.37 & 7 nomo & felt & Felt in Kona. & $\begin{array}{l}\text { Not found in Honolulu Station Bulletin } \\
\text { (McFarland, 1929); ESPHVO, v. 3, p. } \\
600,602 \text {. }\end{array}$ \\
\hline 9/10/24 & $17: 03$ & & & & & $\begin{array}{l}\text { mauna } \\
\text { kea? }\end{array}$ & & & & & 40.0 & $\mathrm{~s}$ & 4.12 & & & & & & & 4.12 & 2 nomo & felt & $\begin{array}{l}\text { ESPHVO v. 3, p. 604, notes: (Felt in Hilo and } \\
\text { Honokaa). }\end{array}$ & $\begin{array}{l}\text { Not found in Honolulu Station Bulletin } \\
\text { (McFarland, 1929); ESPHVO, v. 3, p. } \\
604 .\end{array}$ \\
\hline $10 / 10 / 24$ & $0: 21$ & & & & & $\mathrm{ml} \mathrm{swr}$ ? & & & & & 51.2 & $\mathrm{~s}$ & 4.29 & & & & & & & 4.29 & 9 nomo & felt & Felt in Hilea. & $\begin{array}{l}\text { Not found in Honolulu Station Bulletin } \\
\text { (McFarland, 1929); ESPHVO, v. 3, p. } \\
615 .\end{array}$ \\
\hline
\end{tabular}


Table 13. All earthquakes of $M \geq 4.0$ during the period 1903-59-Continued

\begin{tabular}{|c|c|c|c|c|c|c|c|c|c|c|c|c|c|c|c|c|c|c|c|c|c|c|c|c|}
\hline Date & $\begin{array}{l}\text { Time } \\
\text { (HST) }\end{array}$ & $\begin{array}{c}\text { Lat } \\
\text { (deg) }\end{array}$ & $\begin{array}{c}\text { Lat } \\
(\mathrm{min})\end{array}$ & $\begin{array}{l}\text { Lon } \\
(\mathrm{deg})\end{array}$ & $\begin{array}{l}\text { Lon } \\
(\mathrm{min})\end{array}$ & Region & $\begin{array}{l}\text { Publ. } \\
\text { Depth }\end{array}$ & $\begin{array}{l}\text { Pref. } \\
\text { Depth }\end{array}$ & $\begin{array}{l}\text { Publ. } \\
\text { Dist. }\end{array}$ & $\begin{array}{l}\text { Calc. } \\
\text { Dist }\end{array}$ & $\begin{array}{l}\text { Slant } \\
\text { dist }\end{array}$ & Mag class & $\begin{array}{c}\mathrm{M} \\
\text { nomo }\end{array}$ & $\begin{array}{c}\text { M M-S } \\
\text { E-W }\end{array}$ & $\begin{array}{c}\text { M M-S } \\
\text { N-S }\end{array}$ & M vert & $\begin{array}{c}\text { M hor } \\
\text { N-L }\end{array}$ & $\begin{array}{c}\mathrm{M} \\
\text { other }\end{array}$ & $\begin{array}{c}\mathrm{M} \\
\text { (other) } \\
\text { source }\end{array}$ & $\begin{array}{c}\mathrm{M} \\
\text { pref }\end{array}$ & $\begin{array}{c}\mathrm{M} \\
\text { (pref) } \\
\text { source }\end{array}$ & $I(\max )$ & Location/felt report & Comment \\
\hline $10 / 18 / 24$ & & & & & & hilea?? & & & & & & $\mathrm{m}$ & & & & & & & & & nomo & felt & Felt locally. & \\
\hline $2 / 18 / 25$ & 10:18 & & & & & kohala? & & & & & 90 & $\mathrm{f}$ & 4.09 & & & & & & & 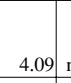 & nomo & felt & Probably in Kohala; felt in Kohala. & $\begin{array}{l}\text { Not in Honolulu Station Bulletin } \\
\text { (Neumann, 1926); ESPHVO, v. 3, p. } \\
661,669 ; \text { VL 9. }\end{array}$ \\
\hline 2/23/25 & 10:20 & & & & & a2025 & & & & & 20.77 & $\mathrm{~m}$ & 4.15 & & & & & & & $4.15 \mathrm{r}$ & nomo & III & Dismantled instruments. & $\begin{array}{l}\text { Not in Honolulu Station Bulletin } \\
\text { (Neumann, 1926); ESPHVO, v. 3, p. } \\
661,669 ; \text { VL 9. }\end{array}$ \\
\hline $4 / 15 / 25$ & $5: 28$ & & & & & a3035 & & & & & 30.35 & $\mathrm{~s}$ & 4.15 & & & & & & & $4.15 \mathrm{r}$ & nomo & IV & Awakened a few at Volcano House. & ESPHVO, v. 3, p. 687, 689; VL 16. \\
\hline $4 / 20 / 25$ & 20:52 & & & & & $\mathrm{ml} \mathrm{mok}$ ? & & & & & 33.55 & $\mathrm{~s}$ & 4.22 & & & & & & & $4.22 \mathrm{r}$ & nomo & felt & $\begin{array}{l}\text { Felt locally; gave the appearance of a Mauna } \\
\text { Loa shake. }\end{array}$ & ESPHVO, v. 3, p. 687, 689; VL 17. \\
\hline $5 / 17 / 25$ & 2:02 & & & & & kaoiki? & & & & & 28.75 & $\mathrm{~s}$ & 4.11 & & & & & & & $4.11 \mathrm{r}$ & nomo & IV & Felt locally, strong at Hilea. & ESPHVO, v. 3, p. 695, 696; VL 21. \\
\hline $7 / 4 / 25$ & 19:55 & & & & & $\mathrm{ml} \mathrm{mok}$ ? & & & & & 35.14 & $\mathrm{~s}$ & 4.25 & & & & & & & 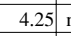 & nomo & felt & Felt locally and in Hilo (VL). & ESPHVO, v. 3, p. 719; VL 28. \\
\hline $7 / 6 / 25$ & 13:47 & & & & & a1320 & & & & & 17.57 & $\mathrm{~m}$ & 4.27 & & & & & & & $4.27 \mathrm{r}$ & nomo & III & Dismantled instruments; felt locally. & ESPHVO, v. 3, p. 719 \\
\hline $7 / 8 / 25$ & 5:45 & & & & & a1320 & & & & & 17.6 & $\mathrm{~s}$ & 4.03 & & & & & & & $4.03 \mathrm{r}$ & nomo & IV (USE) & $\begin{array}{l}\text { Felt all over Hawaii (moderate or strong?, or } \\
\text { greater distance?); VL } 28 \text { has incorrect(?) time } \\
\text { of 0645. HON notes: Not registered but felt } \\
\text { report received - time } 16: 20 \text {, felt by several at } \\
\text { Kapaua; rapid bump; sounds faint rattle; two } \\
\text { shocks. }\end{array}$ & $\begin{array}{l}\text { Honolulu Station Bulletin (Neumann, } \\
\text { 1926c); ESPHVO, v. 3, p. 719; VL } 29 .\end{array}$ \\
\hline $7 / 14 / 25$ & 3:23 & & & & & hilea? & & & & & 43.13 & $\mathrm{~s}$ & 4.17 & & & & & & & 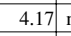 & nomo & felt & Felt at Pahala (VL). & ESPHVO, v. 3, p. 713, 719; VL 29 \\
\hline $7 / 27 / 25$ & 2:42 & & & & & a3035 & & & & & 30.35 & $\mathrm{~s}$ & 4.15 & & & & & & & $4.15 \mathrm{r}$ & nomo & felt & Felt locally. & ESPHVO, v. 3, p. 714, 720; VL 31. \\
\hline $8 / 19 / 25$ & 11:32 & & & & & $\begin{array}{l}\text { mauna } \\
\text { kea? }\end{array}$ & & & & & 65.5 & $\mathrm{~s}$ & 4.46 & & & & & & & 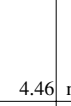 & nomo & IV (Kohala) & $\begin{array}{l}\text { Felt in Hilo and Kohala. HON notes: Not } \\
\text { recorded; felt report from Kohala, time 10:35, } \\
\text { "felt by sev; rpd bump rkg trm ls; sounds Id } \\
\text { rmb rtl bef." }\end{array}$ & $\begin{array}{l}\text { ESPHVO, v. 3, p. 723, 725; VL 35; } \\
\text { Seismological Report (Honolulu } \\
\text { Magnetic Observatory), July- } \\
\text { September } 1925 \text { (Neumannn, 1926). }\end{array}$ \\
\hline $8 / 19 / 25$ & $15: 48$ & & & & & $\begin{array}{l}\text { mauna } \\
\text { kea? }\end{array}$ & & & & & 63.9 & $\mathrm{~s}$ & 4.44 & & & & & & & 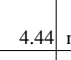 & nomo & & & ESPHVO, v. 3, p. 725. \\
\hline $8 / 28 / 25$ & 21:03 & & & & & $\begin{array}{l}\text { mauna } \\
\text { kea? }\end{array}$ & & & & & 68.69 & $\mathrm{f}$ & 4.17 & & & & & & & $4.17 \mathrm{r}$ & nomo & V; IV (Kohala) & $\begin{array}{l}\text { Felt at Kona and Honokaa; plainly felt } \\
\text { Kealakekua; not felt HVO. HON notes: Not } \\
\text { registered; felt report from Kohala: "felt by sev; } \\
\text { doors mvd; rapid trm short dur; sounds rtl." } \\
\text { USEQ notes: : ime 07:36; felt by several in } \\
\text { Kohala; doors moved; short duration. }\end{array}$ & $\begin{array}{l}\text {; ESPHVO, v. 3, p. 723, 725; VL 36; } \\
\text { Seismological Report (Honolulu } \\
\text { Magnetic Observatory), July- } \\
\text { September } 1925 \text { (Neumannn, 1926). }\end{array}$ \\
\hline $9 / 5 / 25$ & $15: 34$ & & & & & $\begin{array}{l}\text { mauna } \\
\text { kea? }\end{array}$ & & & & & 62.3 & $\mathrm{~s}$ & 4.43 & & & & & & & $4.43 \mathrm{r}$ & nomo & felt & Felt locally. & $\begin{array}{l}\text { Not in Honolulu Station Bulletin } \\
\text { (Neumann, 1926c); ESPHVO, v. 3, p. } \\
734 ; \text { VL 37. }\end{array}$ \\
\hline $10 / 28 / 25$ & 16:52 & & & & & a2530 & & & & & 28.75 & $\mathrm{~s}$ & 4.11 & & & & & & & $4.11 \mathrm{r}$ & nomo & felt & Felt locally (VL), 8 mi (18?) to SE. & ESPHVO, v. 3, p. 750; VL 45 \\
\hline $12 / 8 / 25$ & $22: 16$ & & & & & hilea? & & & & & 30.4 & $\mathrm{~s}$ & 4.15 & & & & & & & $4.15 \mathrm{r}$ & nomo & $\mathrm{V}-\mathrm{VI}$ & $\begin{array}{l}\text { Around } 10: 14 \text { p.m. a prolonged quake, } \\
\text { pheasants squawked much during and after } \\
\text { main shock, and a dog jumped up and showed } \\
\text { alarm; felt locally; felt locally and in Hilo. } \\
\text { Warshauer notes: Knocked down books and } \\
\text { dishes in Pahala, sent furniture across floor. }\end{array}$ & $\begin{array}{l}\text { Distance given as } 9 \mathrm{mi}, 19 \mathrm{mi} \text { more } \\
\text { consistent with felt report; not in } \\
\text { Honolulu Station Bulletin (Neumann, } \\
\text { 1927a); ESPHVO, v. 3, p. 762, 767, } \\
\text { 768; VL 50; HTH, 12/9/1925. See } \\
\text { references. }\end{array}$ \\
\hline $1 / 16 / 26$ & $12: 33$ & & & & & kaoiki? & & & & & 22.36 & $\mathrm{~s}$ & 4.20 & & & & & & & 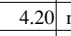 & nomo & felt & Felt in Hilo and Kona; plainly felt in Hilo. & ESPHVO, v. 3, p. 772, 782; VL 56. \\
\hline $2 / 7 / 26$ & $11: 28$ & & & & & maui? & & & & & & & & 4.30 & 4.29 & & & & & 4.30 & hono & $\begin{array}{l}\text { IV (Maui); III } \\
\text { (Honolulu) }\end{array}$ & $\begin{array}{l}\text { Felt-Honolulu and Maui. Cox notes: } 124 \mathrm{mi} \\
\text { from Kilauea. Warshauer notes: Sharp shock } \\
\text { on Maui (like an explosion) and Honolulu; two } \\
\text { shocks on Maui } 2 \text { minutes apart, second one at } \\
11: 30 \text { brought people out doors; also felt on } \\
\text { Oahu. }\end{array}$ & $\begin{array}{l}\text { ESPHVO, v. 3, p. 785, 793 [time given } \\
\text { as } 11: 30 \text { in table]; V L } 59 \text {; Cox, 1986, } \\
\text { p. 64; HTH, 2/8/1926; MN, 2/10/1926 }\end{array}$ \\
\hline $2 / 28 / 26$ & 6:41 & & & & & kaoiki? & & & & & 19.17 & $\mathrm{~m}$ & 4.33 & & & & & & & $4.33 \mathrm{r}$ & nomo & $\mathrm{V}(\mathrm{W} \& \mathrm{~K})$ & $\begin{array}{l}\text { ESPHVO, v. 3, p. } 786 \text {-con.: Strongest eq felt } \\
\text { on Kapapala Ranch within past } 2 \text { years; also } \\
\text { felt at Puu Oo on S Slope of Mauna Kea; } \\
\text { epicenter estimated under Mauna Loa NE rift; } \\
\text { VL } 62 \text { notes repeats ESPHVO. USEQ notes: } \\
\text { (Felt by many standing); see references. }\end{array}$ & $\begin{array}{l}\text { ESPHVO, v. 3, p. } 786,793 \text { notes: } \\
\text { quake centered under Mauna Loa; felt } \\
\text { generally throughout the Island of } \\
\text { Hawaii, duration more than } 10 \mathrm{~s} \text { at } \\
\text { Kilauea; dismantled seismographs at } \\
\text { HVO and Kona; dispodged rock and } \\
\text { broke pipe at Kapapala; HTH, } \\
\text { 3/1/1926. }\end{array}$ \\
\hline $3 / 19 / 26$ & $22: 33$ & & & & & $\begin{array}{l}\text { alenuihah } \\
\text { a }\end{array}$ & & & & & 118.2 & $\mathrm{~m}$ & 5.59 & & 5.52 & & & $\geq 6$ & W\&K & 5.52 & hono & $\begin{array}{c}\mathrm{V} \text { (Kohala); IV-V } \\
\text { (Honolulu) }\end{array}$ & $\begin{array}{l}\text { HON notes: Heeia (Oahu)—felt tremor, dur } 1.5 \\
\text { s; Ewa (Oahu)-distinctly felt by sev, Haiku } \\
\text { (Maui)-felt abt } 1 \text { min, E to NW; Kohala-felt } \\
\text { by many; rpd trm } 1 \mathrm{~m} \text {; rtl sounds; } \\
\text { Honomu-felt by many; grd rg S abt } 20 \mathrm{~m} \text {.; } \\
\text { Volcano House-felt distinctly by all. }\end{array}$ & $\begin{array}{l}\text { Intensity map in W\&K; Seismological } \\
\text { Report (Honolulu Magnetic } \\
\text { Observatory), January-March } 1926 \\
\text { (Neumann and Service, 1927). }\end{array}$ \\
\hline
\end{tabular}


응 Table 13. All earthquakes of $M \geq 4.0$ during the period 1903-59-Continued

\begin{tabular}{|c|c|c|c|c|c|c|c|c|c|c|c|c|c|c|c|c|c|c|c|c|c|c|c|}
\hline Date & $\begin{array}{c}\text { Time } \\
\text { (HST) }\end{array}$ & $\begin{array}{ll}\text { Lat } & \text { Lat } \\
\text { (deg) } & \text { (min) }\end{array}$ & $\begin{array}{l}\text { Lon } \\
(\mathrm{deg})\end{array}$ & $\begin{array}{c}\text { Lon } \\
(\min )\end{array}$ & Region & $\begin{array}{l}\text { Publ. } \\
\text { Depth }\end{array}$ & $\begin{array}{l}\text { Pref. } \\
\text { Depth }\end{array}$ & $\begin{array}{l}\text { Publ. } \\
\text { Dist. }\end{array}$ & $\begin{array}{l}\text { Calc. } \\
\text { Dist }\end{array}$ & $\begin{array}{c}\text { Slant } \\
\text { dist }\end{array}$ & Mag class & $\begin{array}{c}\mathrm{M} \\
\text { nomo }\end{array}$ & $\begin{array}{c}\text { M M-S } \\
\text { E-W }\end{array}$ & $\underset{\mathrm{N}-\mathrm{S}}{\mathrm{M} \text { M-S }}$ & M vert & $\begin{array}{c}\text { M hor } \\
\mathrm{N}-\mathrm{L}\end{array}$ & $\begin{array}{c}\mathrm{M} \\
\text { other }\end{array}$ & $\begin{array}{c}\mathrm{M} \\
\text { (other) } \\
\text { source }\end{array}$ & $\begin{array}{c}\mathrm{M} \\
\text { pref }\end{array}$ & $\begin{array}{c}\mathrm{M} \\
\text { (pref) } \\
\text { source }\end{array}$ & $I(\max )$ & Location/felt report & Comment \\
\hline $3 / 20 / 26$ & 7:27 & & & & $\begin{array}{l}\text { alenuihah } \\
\text { a }\end{array}$ & & & & & 118.2 & $\mathrm{~s}$ & 4.87 & & 4.10 & & & & & 4.10 & hono & felt & $\begin{array}{l}\text { HON notes: felt; aftershock felt at Kohala, felt } \\
\text { locally; recorded at Hilo, Kona, Hilea and } \\
\text { HVO. Warshauer notes: Felt at Kohala } 7: 30 \\
\text { a.m., not as strong as lass night's shock; a very } \\
\text { light quake was felt in Hilo shortly after } 7 \text {. }\end{array}$ & $\begin{array}{l}\text { Neumann and Service, 1927a; } \\
\text { ESPHVO, v. 3, p. 796, 798, 803; vL } \\
\text { 65; HTH, , /20/1926; HSB, 3/2/1926; } \\
\text { HA, 3/21; 27/1926; MN, 3/24/1926 }\end{array}$ \\
\hline $3 / 29 / 26$ & $0: 34$ & & & & $\mathrm{ml}$ ner? & & & & & 30.35 & $\mathrm{~m}$ & 4.41 & & & & & & & 4.41 & nomo & III & Dismantled one seismograph component. & $\begin{array}{l}\text { Not in Honolulu Station Bulletin } \\
\text { (Neumann and Service, 1927); } \\
\text { ESPPVO, v. 3, p. 796, 803; VL } 66 .\end{array}$ \\
\hline $4 / 1 / 26$ & 23:59 & & & & $\mathrm{ml} \mathrm{mok}$ ? & & & & & 35 & f-s & 4.03 & & & & & & & 4.66 & nomo & & $\begin{array}{l}\text { Preferred magnitude calculated as Richter } \\
\text { distribution assuming } b=1.8 \text { and } 76 \text { events of } \\
M>3.25 \text { apportioned over the month. }\end{array}$ & $\begin{array}{l}\text { Distance and region assumed; } 5 \text { shakes; } \\
\text { ESPHVO, v. 3, p. } 836 \text {, table. }\end{array}$ \\
\hline $4 / 2 / 26$ & 23:59 & & & & $\mathrm{ml} \mathrm{mok}$ ? & & & & & 35 & f-s & 4.03 & & & & & & & 4.30 & nomo & & 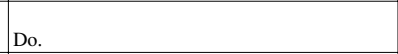 & $\begin{array}{l}\text { Distance and region assumed; } 2 \text { shakes; } \\
\text { ESPHVO, v. } 3 \text {, p. } 836 \text {, table. }\end{array}$ \\
\hline $4 / 4 / 26$ & 23:59 & & & & $\mathrm{ml} \mathrm{mok}$ ? & & & & & 35 & f-s & 4.03 & & & & & & & 4.79 & nomo & & Do. & $\begin{array}{l}\text { Distance and region assumed; } 7 \text { shakes; } \\
\text { ESPHVO, v. } 3 \text {, p. } 836 \text {, table. }\end{array}$ \\
\hline $4 / 5 / 26$ & 23:59 & & & & $\mathrm{ml} \mathrm{mok?}$ & & & & & 35 & f-s & 4.03 & & & & & & & 4.30 & nomo & & Do. & 2 shakes; ESPHVO, v. 3, p. 836, table. \\
\hline 4/7/26 & 23:59 & & & & $\mathrm{ml} \mathrm{mok?}$ & & & & & 35 & f-s & 4.03 & & & & & & & 4.03 & nomo & & Do. & $\begin{array}{l}\text { Distance and region assumed; } 1 \text { shake; } \\
\text { ESPHVO, v. 3, p. } 836 \text {, table. }\end{array}$ \\
\hline $4 / 8 / 26$ & 23:59 & & & & $\mathrm{ml} \mathrm{mok?}$ & & & & & 35 & f-s & 4.03 & & & & & & & 4.57 & nomo & & See note for April 1, 1926 & $\begin{array}{l}\text { Distance and region assumed; } 4 \text { shakes; } \\
\text { ESPHVO, v. } 3 \text {, p. } 836 \text {, table. }\end{array}$ \\
\hline 4/9/26 & $16: 30$ & & & & $\mathrm{ml} \mathrm{mok}$ ? & & & & & 35 & $\mathrm{~s}-\mathrm{m}$ & 4.51 & & & & & & & 4.51 & nomo & felt & $\begin{array}{l}\text { Not registered; felt report from the Island of } \\
\text { Hawaii: several shocks preceded eruption of } \\
\text { Mauna Loa. "Shocks almost incessant until } \\
\text { 20th." }\end{array}$ & $\begin{array}{l}\text { Seismological Report (Honolulu } \\
\text { Magnetic Observatory), April-June } \\
1926 \text { (Neumann, 1928). }\end{array}$ \\
\hline 4/9/26 & 23:59 & & & & $\mathrm{ml} \mathrm{mok?}$ & & & & & 35 & f-s & 4.03 & & & & & & & 4.30 & nomo & & 2 shocks not reported. & $\begin{array}{l}\text { Distance and region assumed; } 3 \text { shakes; } \\
\text { ESPHVO, v. 3, p. } 836 \text {, table. }\end{array}$ \\
\hline $4 / 10 / 26$ & $1: 50$ & & & & $\mathrm{ml} \mathrm{mok}$ ? & & & & & 35 & $\mathrm{~s}-\mathrm{m}$ & 4.51 & & & & & & & 4.51 & nomo & felt & $\begin{array}{l}\text { Felt widely on } E \text { half of the Island of Hawaii; } \\
\text { epicenter at upper end of Mauna Loa southwest } \\
\text { rift to east of Mokuaweoweo. Warshauer notes: } \\
\text { Felt widely on east half of island. }\end{array}$ & $\begin{array}{l}\text { Not reported at Honolulu Magnetic } \\
\text { Observatory (Neumann, 1928); } \\
\text { ESPHVO, v. 3, p. 807, 812; VL 68; } \\
\text { HTH, 04/15. }\end{array}$ \\
\hline $4 / 10 / 26$ & 2:04 & & & & $\mathrm{ml} \mathrm{mok}$ ? & & & & & 35 & $\mathrm{~s}-\mathrm{m}$ & 4.51 & & & & & & & 4.51 & nomo & & $\begin{array}{l}\text { Do.; small tidal waves noted at Hilo and Kona } \\
\text { [HA] following these two quakes. }\end{array}$ & $\begin{array}{l}\text { Not reported at Honolulu Magnetic } \\
\text { Observatory (Neumann, 1928); } \\
\text { ESPHVO, v. 3, p. 807, 812; VL 68; } \\
\text { HA, 04/10; HTH, 04/15. }\end{array}$ \\
\hline $4 / 10 / 26$ & 23:59 & & & & $\mathrm{ml} \mathrm{mok}$ ? & & & & & 35 & f-s & 4.03 & & & & & & & 5.71 & nomo & & Do. & $\begin{array}{l}\text { Do.; } 71 \text { quakes not felt at } \mathrm{HVO} \text {, not } \\
\text { reported separately. }\end{array}$ \\
\hline $4 / 10 / 26$ & 23:59 & & & & $\mathrm{ml} \mathrm{mok}$ ? & & & & & 35 & $\mathrm{~m}$ & 4.91 & & & & & & & 4.96 & nomo & felt & $\begin{array}{l}4 \text { felt at HVO; local earthquakes during the last } \\
\text { few months with origin distance about } 19 \mathrm{mi} \\
(30.4 \mathrm{~km} \text { ) and line of direction suggesting the } \\
\text { northeast summit region of Mauna Loa; } \\
\text { additional notes on the eruption in VL } 68-72 \text {; } \\
\text { see note for April 1, } 1926 \text {. }\end{array}$ & $\begin{array}{l}75 \text { earthquakes; ESPHVO, v. 3, p. } 811, \\
\text { table, p. } 813 \text { [seismic prelude to Mauna } \\
\text { Loa southwest rift eruption]; } 1.128 \\
\text { quakes assumed to have dismantled } \\
\text { seismograph; see note for May } 1,1926 .\end{array}$ \\
\hline $4 / 10 / 26$ & 23:59 & & & & $\mathrm{ml} \mathrm{mok?}$ & & & & & 35 & $\mathrm{~s}-\mathrm{m}$ & 4.51 & & & & & & & 4.45 & nomo & & Do. & $\begin{array}{l}\text { Do.; } 0.872 \text { quakes felt at HVO, not } \\
\text { reported separately. }\end{array}$ \\
\hline $4 / 11 / 26$ & 23:59 & & & & $\mathrm{ml} \mathrm{swr}$ ? & & & & & 47.3 & f-s & 4.24 & & & & & & & 5.63 & nomo & & Do. & $\begin{array}{l}\text { Do.; } 71 \text { quakes not felt at } \mathrm{HVO} \text {, not } \\
\text { reported separately. }\end{array}$ \\
\hline $4 / 11 / 26$ & 23:59 & & & & $\mathrm{ml} \mathrm{swr}$ ? & & & & & 47.3 & $\mathrm{~m}$ & 5.12 & & & & & & & 4.62 & nomo & felt & 1 felt at $\mathrm{HVO}$; see note for April 1, 1926. & $\begin{array}{l}35 \text { earthquakes; ESPHVO, v. 3, p. } 811 \text {, } \\
\text { table; } 1.128 \text { quakes assumed to have } \\
\text { dismantled seismograph; see note for } \\
\text { May 1, } 1926 \text {. }\end{array}$ \\
\hline $4 / 11 / 26$ & 23:59 & & & & $\mathrm{ml} \mathrm{swr}$ ? & & & & & 47.3 & $\mathrm{~s}-\mathrm{m}$ & 4.72 & & & & & & & 4.59 & nomo & & (1) & $\begin{array}{l}\text { Do.; } 0.872 \text { quakes felt at } \mathrm{HVO} \text {, not } \\
\text { reported separately. }\end{array}$ \\
\hline $4 / 12 / 26$ & 11:41 & & & & $\mathrm{ml} \mathrm{swr}$ ? & & & & & 48 & $\mathrm{~s}-\mathrm{m}$ & 4.73 & & & & & & & 4.73 & nomo & felt & $\begin{array}{l}\text { Swaying eq, producing the effect of E-W } \\
\text { rocking; felt-Pahala and HVO. }\end{array}$ & ESPHVO, v. 3, p. 812. \\
\hline $4 / 12 / 26$ & 11:48 & & & & $\mathrm{ml}$ ner? & & & & & 25 & $\mathrm{~s}-\mathrm{m}$ & 4.27 & & & & & & & 4.27 & nomo & III (Honomu) & $\begin{array}{l}\text { Felt by many at Honomu, rpd trm; } 2 \mathrm{~s} \text {, val. } \\
\text { USEQ notes: } 22: 25 \text {, felt by many (int IIII; } \\
\text { stronger than } 11: 41 \text { quake; not individually } \\
\text { listed in table; feett-Pahala and HVO; most } \\
\text { shakes from extension of mlswr; some from } \\
\text { mok and mlner. }\end{array}$ & $\begin{array}{l}\text { Neumann, 1928; ESPHVO, v. 3, p. } \\
812 ; \text { VL } 68 .\end{array}$ \\
\hline $4 / 12 / 26$ & 23:59 & & & & $\mathrm{ml} \mathrm{swr?}$ & & & & & 47.3 & f-s & 4.24 & & & & & & & 5.95 & nomo & & Do. & $\begin{array}{l}\text { Do.; } 71 \text { quakes not felt at } \mathrm{HVO} \text {, not } \\
\text { reported separately. }\end{array}$ \\
\hline
\end{tabular}


Table 13. All earthquakes of $M \geq 4.0$ during the period 1903-59-Continued

\begin{tabular}{|c|c|c|c|c|c|c|c|c|c|c|c|c|c|c|c|c|c|c|c|c|c|c|c|c|}
\hline Date & $\begin{array}{l}\text { Time } \\
\text { (HST) }\end{array}$ & $\begin{array}{r}\text { Lat } \\
(\operatorname{deg})\end{array}$ & $\begin{array}{l}\text { Lat } \\
(\mathrm{min})\end{array}$ & $\begin{array}{l}\text { Lon } \\
(\operatorname{deg})\end{array}$ & $\begin{array}{l}\text { Lon } \\
(\mathrm{min})\end{array}$ & Region & $\begin{array}{l}\text { Publ. } \\
\text { Depth }\end{array}$ & $\begin{array}{l}\text { Pref. } \\
\text { Depth }\end{array}$ & $\begin{array}{l}\text { Publ. } \\
\text { Dist. }\end{array}$ & $\begin{array}{l}\text { Calc. } \\
\text { Dist }\end{array}$ & $\begin{array}{c}\text { Slant } \\
\text { dist }\end{array}$ & Mag class & $\begin{array}{c}\mathrm{M} \\
\text { nomo }\end{array}$ & $\begin{array}{c}\text { M M-S } \\
\text { E-W }\end{array}$ & $\begin{array}{c}\text { M M-S } \\
\text { N-S }\end{array}$ & M vert & $\begin{array}{c}\text { M hor } \\
\text { N-L }\end{array}$ & $\begin{array}{c}\mathrm{M} \\
\text { other }\end{array}$ & $\begin{array}{c}\mathrm{M} \\
\text { (other) } \\
\text { source }\end{array}$ & $\begin{array}{c}\mathrm{M} \\
\text { pref }\end{array}$ & $\begin{array}{c}\mathrm{M} \\
\text { (pref) } \\
\text { source }\end{array}$ & $I(\max )$ & Location/felt report & Comment \\
\hline $4 / 12 / 26$ & 23:59 & & & & & $\mathrm{ml} \mathrm{swr}$ ? & & & & & 47.3 & $\mathrm{~m}$ & 5.12 & & & & & & & 5.26 & nomo & felt & $\begin{array}{l}5 \text { felt at HVO, many felt at Pahala in forenoon; } \\
\text { earthuakes feftt at MLO camp during the day; } \\
\text { see note for April 1, 1926. }\end{array}$ & $\begin{array}{l}81 \text { earthquakes; ESPHVO, v. 3, p. } 811 \text {, } \\
\text { table, p. } 812,816 ; 1.128 \text { quakes } \\
\text { assumed to have dismantled } \\
\text { seismograph; see note for May 1, 1926. }\end{array}$ \\
\hline $4 / 12 / 26$ & 23:59 & & & & & $\mathrm{ml} \mathrm{swr}$ ? & & & & & 47.3 & $\mathrm{~s}-\mathrm{m}$ & 4.72 & & & & & & & 4.90 & nomo & & Do. & $\begin{array}{l}\text { do; } 0.872 \text { quakes felt at } \mathrm{HVO} \text {, not } \\
\text { reported separately }\end{array}$ \\
\hline $4 / 13 / 26$ & 4:30 & & & & & $\mathrm{ml} \mathrm{swr}$ ? & & 5 & 47 & & 47.27 & $s-m$ & 4.72 & & & & & & & 4.72 & nomo & & $\begin{array}{l}\text { One of } 2 \text { strongest shakes of series [confused } \\
\text { with quake at 19:46?]; Waiohinu telephone } \\
\text { operator timed shock Tuesday morning [Apr. } \\
\text { 13], dur } 1 \text { min. }\end{array}$ & $\begin{array}{l}\text { Not reported by Honolulu Magnetic } \\
\text { Observatory; ESPHVO, v. 3, p. } 812 \text {; } \\
\text { HSB, 4/14/26. }\end{array}$ \\
\hline $4 / 13 / 26$ & $7: 30$ & & & & & $\mathrm{ml} \mathrm{swr}$ ? & & 5 & 47 & & 47.27 & $\mathrm{~s}-\mathrm{m}$ & 4.72 & & & & & & & 4.72 & nomo & felt & Felt at HVO. & ESPHVO, v. 3 , p. 812 \\
\hline $4 / 13 / 26$ & $14: 30$ & & & & & $\mathrm{ml} \mathrm{swr}$ ? & & 5 & 47 & & 47.27 & $\mathrm{~s}-\mathrm{m}$ & 4.72 & & & & & & & 4.72 & nomo & felt & Sharp shock felt at $\mathrm{HVO}$. & Do. \\
\hline $4 / 13 / 26$ & 19:46 & & & & & hilea & & & 45 & & 45.89 & $\mathrm{~m}$ & 5.10 & 5.21 & 5.05 & & & & & 5.13 & hono & felt & $\begin{array}{l}\text { Unusually sharp quake felt on Mauna Loa this } \\
\text { evening; quake with strong, twisting motion } \\
\text { felt at HVO, dur }>30 \text { ( Whitney); alarming } \\
\text { shock at } 7: 45 \text { p.m. with wrenching movement } \\
\text { and creaking of rocks; Honolulu time, } 19: 41 \text {. } \\
\text { Warshauer notes: hm crack widened. }\end{array}$ & $\begin{array}{l}\text { Neumann, 1928; ESPHVO, v. 3, p. } \\
\text { 807, 813, 817; HTH, 4/15/1926. }\end{array}$ \\
\hline $4 / 13 / 26$ & 23:59 & & & & & $\mathrm{ml} \mathrm{swr}$ ? & & & & & 47.3 & f-s & 4.24 & & & & & & & 5.94 & nomo & & Do. & $\begin{array}{l}\text { Do.; } 71 \text { quakes not felt at } \mathrm{HVO} \text {, not } \\
\text { reported separately. }\end{array}$ \\
\hline $4 / 13 / 26$ & 23:59 & & & & & $\mathrm{ml} \mathrm{swr}$ ? & & & & & 47.3 & $\mathrm{~m}$ & 5.12 & & & & & & & 5.21 & nomo & felt & $\begin{array}{l}9 \text { felt at HVO; see note for April 1, } 1926 . \\
\text { Warshauer notes: } 50 \text { slight shocks between } 3 \\
\text { and } 4 \text { p.m.; } 150 \text { recorded at HVO, } 12 \text { felt, } 6 \\
\text { severe; earthquakes felt on higher slopes of } \\
\text { Mauna Loa, including rift cones. }\end{array}$ & $\begin{array}{l}83 \text { earthquakes; ESPHVO, v. 3, p. } 811, \\
\text { table; HSB, 4/14/26; HA, 4/14/1926; } \\
\text { HTH, 4/15/1926; 1.128 quakes } \\
\text { assumed to have dismantled } \\
\text { seismograph; see note for May 1, } 1926 .\end{array}$ \\
\hline $4 / 13 / 26$ & 23:59 & & & & & $\mathrm{ml} \mathrm{swr}$ ? & & & & & 47.3 & $\mathrm{~s}-\mathrm{m}$ & 4.72 & & & & & & & 5.12 & nomo & & Do. & $\begin{array}{l}\text { Do.; } 0.872 \text { quakes felt at HVO, not } \\
\text { reported separately. }\end{array}$ \\
\hline $4 / 14 / 26$ & 2:45 & & & & & $\mathrm{ml} \mathrm{swr}$ ? & & & & & 47 & $\mathrm{~s}-\mathrm{m}$ & 4.71 & & & & & & & 4.71 & nomo & felt & $\begin{array}{l}\text { Earthquake with E-W motion felt at Wingate } \\
\text { camp. }\end{array}$ & ESPHVO, v. 3, p. 817. \\
\hline $4 / 14 / 26$ & 3:50 & & & & & $\mathrm{ml} \mathrm{swr}$ ? & & & & & 47 & $\mathrm{~s}-\mathrm{m}$ & 4.71 & & & & & & & 4.71 & nomo & felt & $\begin{array}{l}\text { Vertical jolt followed by N-S motion felt at } \\
\text { Wingate camp. }\end{array}$ & ESPHVO, v. 3, p. 817. \\
\hline $4 / 14 / 26$ & $8: 30$ & & & & & $\mathrm{ml} \mathrm{swr}$ ? & & & & & 47 & $\mathrm{~s}-\mathrm{m}$ & 4.71 & & & & & & & 4.71 & nomo & felt & $\begin{array}{l}\text { Light earthquake felt at Wingate camp. } \\
\text { Warshauer notes: Vigorous fountains in the } \\
\text { Alika source about 8:30 a.m. April } 14 .\end{array}$ & $\begin{array}{l}\text { ESPHVO, v. } 3, \text { p. } 817 ; \text { HTH, } \\
\text { 4/15/1926 [beginning of Mauna Loa's } \\
\text { lower southwest rift eruption]. }\end{array}$ \\
\hline $4 / 14 / 26$ & 12:00 & & & & & $\mathrm{ml} \mathrm{swr}$ ? & & & & & 47 & $\mathrm{~s}-\mathrm{m}$ & 4.71 & & & & & & & 4.71 & nomo & felt & Felt (at Wingate camp?). & ESPHVO, v. 3, p. 818 \\
\hline $4 / 14 / 26$ & $15: 30$ & & & & & $\mathrm{ml} \mathrm{swr?}$ & & & & & 47 & $\mathrm{~s}-\mathrm{m}$ & 4.71 & & & & & & & 4.71 & nomo & felt & Do. & Do. \\
\hline $4 / 14 / 26$ & $15: 45$ & & & & & $\mathrm{ml} \mathrm{swr}$ ? & & & & & 47 & $\mathrm{~s}-\mathrm{m}$ & 4.71 & & & & & & & 4.71 & nomo & felt & Do. & Do. \\
\hline $4 / 14 / 26$ & $21: 45$ & & & & & $\mathrm{ml} \mathrm{swr?}$ & & & & & 47 & $\mathrm{~s}-\mathrm{m}$ & 4.71 & & & & & & & 4.71 & nomo & felt & Do. & Do. \\
\hline $4 / 14 / 26$ & 23:59 & & & & & $\mathrm{ml} \mathrm{swr}$ ? & & & & & 47.3 & $f-s$ & 4.24 & & & & & & & 5.79 & nomo & & Do. & $\begin{array}{l}\text { Do.; } 71 \text { quakes not felt at } \mathrm{HVO} \text {, not } \\
\text { reported separately. }\end{array}$ \\
\hline $4 / 14 / 26$ & 23:59 & & & & & $\mathrm{ml} \mathrm{swr}$ ? & & & & & 47.3 & $\mathrm{~m}$ & 5.12 & & & & & & & 5.49 & nomo & felt & 9 felt at HVO; see note for April 1, 1926. & $\begin{array}{l}60 \text { earthquakes; ESPHVO, v. } 3 \text {, p. } 811 \text {, } \\
\text { table; } 1.128 \text { quakes assumed to have } \\
\text { dismantled seismograph; see note for } \\
\text { May } 1,1926 \text {. }\end{array}$ \\
\hline $4 / 14 / 26$ & 23:59 & & & & & $\mathrm{ml} \mathrm{swr}$ ? & & & & & 47.3 & s-m & 4.72 & & & & & & & 5.07 & nomo & & Do. & $\begin{array}{l}\text { Do.; } 0.872 \text { quakes felt at HVO, not } \\
\text { reported separately. }\end{array}$ \\
\hline $4 / 15 / 26$ & $5: 45$ & & & & & $\mathrm{ml} \mathrm{swr}$ ? & & & & & & & & 4.99 & 4.69 & & & & & 4.85 & hono & felt & Felt (at Wingate camp?); Honolulu time, 5:46. & ESPHVO, v. 3, p. 818 \\
\hline $4 / 15 / 26$ & $7: 50$ & & & & & $\mathrm{ml} \mathrm{swr}$ ? & & & & & 47 & $\mathrm{~s}-\mathrm{m}$ & 4.71 & & & & & & & 4.71 & nomo & felt & Felt (at Wingate camp?). & Do. \\
\hline $4 / 15 / 26$ & $12: 12$ & & & & & $\mathrm{ml} \mathrm{swr}$ ? & & & & & 47 & $\mathrm{~s}-\mathrm{m}$ & 4.71 & & & & & & & 4.71 & nomo & felt & Do. & Do. \\
\hline $4 / 15 / 26$ & 14:05 & & & & & $\mathrm{ml} \mathrm{swr}$ ? & & & & & 47 & $\mathrm{~s}-\mathrm{m}$ & 4.71 & & & & & & & 4.71 & nomo & felt & Do. & Do. \\
\hline $4 / 15 / 26$ & $15: 20$ & & & & & $\mathrm{ml} \mathrm{swr}$ ? & & & & & 47 & $\mathrm{~s}-\mathrm{m}$ & 4.71 & & & & & & & 4.71 & nomo & felt & Do. & Do. \\
\hline $4 / 15 / 26$ & 17:21 & & & & & $\mathrm{ml} \mathrm{swr}$ ? & & & & & 47 & $s-m$ & 4.71 & & & & & & & 4.71 & nomo & felt & Do. & Do. \\
\hline $4 / 15 / 26$ & 19:15 & & & & & $\mathrm{ml} \mathrm{swr}$ ? & & & & & 47 & $\mathrm{~s}-\mathrm{m}$ & 4.71 & & & & & & & 4.71 & nomo & felt & Do. & Do. \\
\hline $4 / 15 / 26$ & 21:09 & & & & & $\mathrm{ml} \mathrm{swr}$ ? & & & & & 47 & $\mathrm{~s}-\mathrm{m}$ & 4.71 & & & & & & & 4.71 & nomo & felt & Do. & Do. \\
\hline $4 / 15 / 26$ & $21: 15$ & & & & & $\mathrm{ml} \mathrm{swr}$ ? & & & & & 47 & $\mathrm{~s}-\mathrm{m}$ & 4.71 & & & & & & & 4.71 & nomo & felt & Do. & Do. \\
\hline $4 / 15 / 26$ & $21: 45$ & & & & & $\mathrm{ml} \mathrm{swr}$ ? & & & & & 47 & $\mathrm{~s}-\mathrm{m}$ & 4.71 & & & & & & & 4.71 & nomo & felt & Do. & Do. \\
\hline $4 / 15 / 26$ & 23:59 & & & & & $\mathrm{ml} \mathrm{swr}$ ? & & & & & 47.3 & $f-s$ & 4.24 & & & & & & & 5.92 & nomo & & Do. & $\begin{array}{l}\text { do; } 71 \text { quakes not felt at HVO, not } \\
\text { reported separately }\end{array}$ \\
\hline $4 / 15 / 26$ & 23:59 & & & & & $\mathrm{ml} \mathrm{swr}$ ? & & & & & 47.3 & $\mathrm{~m}$ & 5.12 & & & & & & & 5.64 & nomo & felt & 13 felt at HVO; see note for April 1, 1926 & $\begin{array}{l}86 \text { earthquakes; ESPHVO, v. 3, p. } 811, \\
\text { table; } 1.128 \text { quakes assumed to have } \\
\text { dismantled seismograph; see note for } \\
\text { May 1,1926 }\end{array}$ \\
\hline $4 / 16 / 26$ & $1: 15$ & & & & & $\mathrm{ml} \mathrm{swr}$ ? & & & & & 47 & $\mathrm{~s}-\mathrm{m}$ & 4.71 & & & & & & & 4.71 & nomo & felt & Felt (at Wingate camp?). & ESPHVO, v. 3, p. 818 \\
\hline
\end{tabular}


ભ Table 13. All earthquakes of $M \geq 4.0$ during the period 1903-59-Continued

\begin{tabular}{|c|c|c|c|c|c|c|c|c|c|c|c|c|c|c|c|c|c|c|c|c|c|c|c|c|}
\hline Date & $\begin{array}{c}\text { Time } \\
\text { (HST) }\end{array}$ & $\begin{array}{l}\text { Lat } \\
(\mathrm{deg})(1\end{array}$ & $\begin{array}{c}\text { Lat } \\
(\mathrm{min})\end{array}$ & $\begin{array}{c}\text { Lon } \\
\text { (deg) }\end{array}$ & $\begin{array}{l}\text { Lon } \\
(\mathrm{min})\end{array}$ & Region & $\begin{array}{l}\text { Publ. } \\
\text { Depth }\end{array}$ & $\begin{array}{l}\text { Pref. } \\
\text { Depth }\end{array}$ & $\begin{array}{l}\text { Publ. } \\
\text { Dist. }\end{array}$ & $\begin{array}{l}\text { Calc. } \\
\text { Dist }\end{array}$ & $\begin{array}{c}\text { Slant } \\
\text { dist }\end{array}$ & Mag class & $\begin{array}{c}\mathrm{M} \\
\text { nomo }\end{array}$ & $\begin{array}{c}\text { M M-S } \\
\text { E-W }\end{array}$ & $\begin{array}{c}\text { M M-S } \\
\text { N-S }\end{array}$ & M vert & $\begin{array}{c}\text { M hor } \\
\mathrm{N}-\mathrm{L}\end{array}$ & $\begin{array}{c}\mathrm{M} \\
\text { other }\end{array}$ & $\begin{array}{l}\mathrm{M} \\
\text { (other) } \\
\text { source }\end{array}$ & $\begin{array}{c}\mathrm{M} \\
\text { pref }\end{array}$ & $\begin{array}{c}\mathrm{M} \\
\text { (pref) } \\
\text { source }\end{array}$ & $I(\max )$ & Location/felt report & Comment \\
\hline $4 / 16 / 26$ & 1:17 & & & & & $\mathrm{ml} \mathrm{swr?}$ & & & & & 47 & $\mathrm{~s}-\mathrm{m}$ & 4.71 & & & & & & & 4.71 & nomo & felt & Do. & Do. \\
\hline $4 / 16 / 26$ & 6:16 & & & & & $\mathrm{ml} \mathrm{swr}$ ? & & & & & 47 & $\mathrm{~s}-\mathrm{m}$ & 4.71 & & & & & & & 4.71 & nomo & felt & Do. & Do. \\
\hline $4 / 16 / 26$ & 9:30 & & & & & $\mathrm{ml} \mathrm{swr}$ ? & & & & & 47 & $\mathrm{~s}-\mathrm{m}$ & 4.71 & & & & & & & 4.71 & nomo & felt & Do. & Do. \\
\hline $4 / 16 / 26$ & $10: 10$ & & & & & $\mathrm{ml} \mathrm{swr?}$ & & & & & 47 & $\mathrm{~s}-\mathrm{m}$ & 4.71 & & & & & & & 4.71 & nomo & felt & Do. & Do. \\
\hline $4 / 16 / 26$ & 11:00 & & & & & $\mathrm{ml} \mathrm{swr}$ ? & & & & & 47 & $\mathrm{~s}-\mathrm{m}$ & 4.71 & & & & & & & 4.71 & nomo & felt & Do. & Do. \\
\hline $4 / 16 / 26$ & $11: 58$ & & & & & $\mathrm{ml} \mathrm{swr}$ ? & & & & & 47 & $\mathrm{~s}-\mathrm{m}$ & 4.71 & & & & & & & 4.71 & nomo & felt & Do. & Do. \\
\hline $4 / 16 / 26$ & $12: 03$ & & & & & $\mathrm{ml} \mathrm{swr}$ ? & & & & & 47 & $\mathrm{~s}-\mathrm{m}$ & 4.71 & & & & & & & 4.71 & nomo & felt & Do. & Do. \\
\hline $4 / 16 / 26$ & $13: 10$ & & & & & $\mathrm{ml} \mathrm{swr}$ ? & & & & & 47 & $\mathrm{~s}-\mathrm{m}$ & 4.71 & & & & & & & 4.71 & nomo & felt & Do. & Do. \\
\hline $4 / 16 / 26$ & $13: 18$ & & & & & $\mathrm{ml} \mathrm{swr}$ ? & & & & & 47 & $\mathrm{~s}-\mathrm{m}$ & 4.71 & & & & & & & 4.71 & nomo & felt & Do. & Do. \\
\hline $4 / 16 / 26$ & $13: 34$ & & & & & $\mathrm{ml} \mathrm{swr}$ ? & & & & & 47 & $\mathrm{~s}-\mathrm{m}$ & 4.71 & & & & & & & 4.71 & nomo & felt & Do. & Do. \\
\hline $4 / 16 / 26$ & 13:59 & & & & & $\mathrm{ml} \mathrm{swr}$ ? & & & & & 47 & $\mathrm{~s}-\mathrm{m}$ & 4.71 & & & & & & & 4.71 & nomo & felt & Do. & Do. \\
\hline $4 / 16 / 26$ & $16: 10$ & & & & & $\mathrm{ml} \mathrm{swr}$ ? & & & & & 47 & $\mathrm{~s}-\mathrm{m}$ & 4.71 & & & & & & & 4.71 & nomo & felt & Do. & Do. \\
\hline $4 / 16 / 26$ & 17:27 & & & & & $\mathrm{ml} \mathrm{swr}$ ? & & & & & 47 & $\mathrm{~s}-\mathrm{m}$ & 4.71 & & & & & & & 4.71 & nomo & felt & Do. & Do. \\
\hline $4 / 16 / 26$ & $19: 56$ & & & & & $\mathrm{ml} \mathrm{swr}$ ? & & & & & 47 & $\mathrm{~s}-\mathrm{m}$ & 4.71 & & & & & & & 4.71 & nomo & felt & Do. & Do. \\
\hline $4 / 16 / 26$ & 20:08 & & & & & $\mathrm{ml}$ swr? & & & & & 47 & $\mathrm{~s}-\mathrm{m}$ & 4.71 & & & & & & & 4.71 & nomo & felt & Do. & Do. \\
\hline $4 / 16 / 26$ & 21:59 & & & & & $\mathrm{ml} \mathrm{swr}$ ? & & & & & 47 & $\mathrm{~s}-\mathrm{m}$ & 4.71 & 4.42 & 4.51 & & & & & 4.46 & hono & & & $\begin{array}{l}\text { Not specifically mentioned in } \\
\text { ESPHVO or VL. }\end{array}$ \\
\hline $4 / 16 / 26$ & 23:08 & & & & & $\mathrm{ml} \mathrm{swr}$ ? & & & & & 47 & $\mathrm{~s}-\mathrm{m}$ & 4.71 & & & & & & & 4.71 & nomo & felt & Felt (at Wingate camp?). & ESPHVO, v. 3 , p. 818 \\
\hline $4 / 16 / 26$ & 23:59 & & & & & $\mathrm{ml} \mathrm{swr}$ ? & & & & & 47.3 & f-s & 4.24 & & & & & & & 5.73 & nomo & & Do. & $\begin{array}{l}\text { Do.; } 71 \text { quakes not felt at HVO, not } \\
\text { reported separately. }\end{array}$ \\
\hline $4 / 17 / 26$ & $1: 16$ & & & & & $\mathrm{ml} \mathrm{swr?}$ & & & & & 47 & s-m & 4.71 & & & & & & & 4.71 & nomo & felt & Do. & ESPHVO, v. 3, p. 818 \\
\hline $4 / 17 / 26$ & $7: 26$ & & & & & $\mathrm{ml} \mathrm{swr}$ ? & & & & & 47 & $\mathrm{~s}-\mathrm{m}$ & 4.71 & & & & & & & 4.71 & nomo & felt & Do. & Do. \\
\hline $4 / 17 / 26$ & 12:06 & & & & & $\mathrm{ml} \mathrm{swr}$ ? & & & & & 47 & $\mathrm{~s}-\mathrm{m}$ & 4.71 & & & & & & & 4.71 & nomo & felt & Do. & Do. \\
\hline $4 / 17 / 26$ & $12: 12$ & & & & & $\mathrm{ml} \mathrm{swr}$ ? & & & & & 47 & $\mathrm{~s}-\mathrm{m}$ & 4.71 & & & & & & & 4.71 & nomo & felt & Do. & Do. \\
\hline $4 / 17 / 26$ & $15: 44$ & & & & & $\mathrm{ml} \mathrm{swr}$ ? & & & & & 47 & $\mathrm{~s}-\mathrm{m}$ & 4.71 & & & & & & & 4.71 & nomo & felt & Do. & Do. \\
\hline $4 / 17 / 26$ & $15: 45$ & & & & & $\mathrm{ml} \mathrm{swr}$ ? & & & & & 47 & $\mathrm{~s}-\mathrm{m}$ & 4.71 & & & & & & & 4.71 & nomo & felt & Do. & Do. \\
\hline $4 / 17 / 26$ & 23:59 & & & & & $\mathrm{ml} \mathrm{swr}$ ? & & & & & 47.3 & f-s & 4.24 & & & & & & & 5.72 & nomo & & Do. & $\begin{array}{l}\text { Do.; } 71 \text { quakes not felt at } \mathrm{HVO} \text {, not } \\
\text { reported separately. }\end{array}$ \\
\hline $4 / 17 / 26$ & 23:59 & & & & & $\mathrm{ml} \mathrm{swr}$ ? & & & & & 47.3 & $\mathrm{~m}$ & 5.12 & & & & & & & 5.39 & nomo & felt & 7 felt at $\mathrm{HVO}$; see note for April 1, 1926. & $\begin{array}{l}53 \text { earthquakes; ESPHVO, v. 3, p. } 811 \text {, } \\
\text { table, } 1.128 \text { quakes assumed to have } \\
\text { dismantled seismograph; see note for } \\
\text { May } 1,1926 \text {. }\end{array}$ \\
\hline $4 / 18 / 26$ & 2:35 & & & & & $\mathrm{ml} \mathrm{swr}$ ? & & & & & 47 & s-m & 4.71 & 4.42 & 4.69 & & & & & 4.55 & hono & felt & Felt (at Wingate camp?); Honolulu time, 2:45. & ESPHVO, v. 3, p. 818 \\
\hline $4 / 18 / 26$ & 3:50 & & & & & $\mathrm{ml} \mathrm{swr}$ ? & & & & & 47 & $\mathrm{~s}-\mathrm{m}$ & 4.71 & & & & & & & 4.71 & nomo & felt & Felt (at Wingate camp?). & Do. \\
\hline $4 / 18 / 26$ & 4:22 & & & & & $\mathrm{ml} \mathrm{swr}$ ? & & & & & 47 & $\mathrm{~s}-\mathrm{m}$ & 4.71 & 4.50 & 4.51 & & & & & 4.50 & hono & felt & Felt (at Wingate camp?); Honolulu time, 4:33. & Do. \\
\hline $4 / 18 / 26$ & 11:03 & & & & & $\mathrm{ml} \mathrm{swr}$ ? & & & & & 47 & $\mathrm{~s}-\mathrm{m}$ & 4.71 & & & & & & & 4.71 & nomo & felt & Felt (at Wingate camp?). & Do. \\
\hline $4 / 18 / 26$ & 11:09 & & & & & $\mathrm{ml} \mathrm{swr}$ ? & & & & & 47 & $\mathrm{~s}-\mathrm{m}$ & 4.71 & & & & & & & 4.71 & nomo & felt & $\begin{array}{l}\text { Felt (at Wingate camp?). Warshauer notes: } 250 \\
\text { quakes recorded at HVO from } 4 / 14 \text { to } 4 / 18 \\
\text { a.m., none of great strength. }\end{array}$ & $\begin{array}{l}\text { ESPHVO, v. 3, p. } 818 ; \text { HSB, } \\
\text { 4/20/1926. }\end{array}$ \\
\hline $4 / 18 / 26$ & $12: 27$ & & & & & $\mathrm{ml} \mathrm{swr}$ ? & & & & & 47 & $\mathrm{~s}-\mathrm{m}$ & 4.71 & & & & & & & 4.71 & nomo & felt & Felt (at Wingate camp?). & ESPHVO, v. 3, p. 818. \\
\hline $4 / 18 / 26$ & 13:58 & & & & & $\mathrm{ml} \mathrm{swr}$ ? & & & 45 & & 45.89 & $\mathrm{~m}$ & 5.10 & 5.16 & 5.21 & & & & & 5.18 & hono & felt & $\begin{array}{l}\text { HON notes: Origin time accepted over HVO } \\
\text { felt times; sharp earthquake felt at HVO and } \\
\text { elsewhere at 14:05; felt (at Wingate camp?) at } \\
\text { 13:45. USEQ notes: Strong shock; Honolulu } \\
\text { time, 13:57; distance, } 325 \mathrm{~km} \text {. }\end{array}$ & $\begin{array}{l}\text { Neumann, } 1928 \text {, has earthquake at } \\
\text { 14:00, 325 km distant; ESPHVO, v. } 3 \text {, } \\
\text { p. } 813,818,831 .\end{array}$ \\
\hline $4 / 18 / 26$ & 23:59 & & & & & $\mathrm{ml} \mathrm{swr}$ ? & & & & & 47.3 & $\mathrm{~m}$ & 5.12 & & & & & & & 5.36 & nomo & felt & 10 felt at HVO; see note for April 1, 1926. & $\begin{array}{l}26 \text { earthquakes; ESPHVO, v. 3, p. } 811 \text {, } \\
\text { table, } 1.128 \text { quakes assumed to have } \\
\text { dismantled seismograph; see note for } \\
\text { May 1, } 1926 \text {. }\end{array}$ \\
\hline $4 / 18 / 26$ & 23:59 & & & & & $\mathrm{ml} \mathrm{swr}$ ? & & & & & 47.3 & f-s & 4.24 & & & & & & & 5.33 & nomo & & Do. & $\begin{array}{l}\text { Do.; } 71 \text { quakes not felt at HVO, not } \\
\text { reported separately. }\end{array}$ \\
\hline $4 / 18 / 26$ & 23:59 & & & & & $\mathrm{ml} \mathrm{swr}$ ? & & & & & 47.3 & $\mathrm{~s}-\mathrm{m}$ & 4.72 & & & & & & & 4.78 & nomo & & Do. & $\begin{array}{l}\text { Do.; } 0.872 \text { quakes felt at } \mathrm{HVO} \text {, not } \\
\text { reported separately. }\end{array}$ \\
\hline $4 / 19 / 26$ & 9:13 & & & & & $\mathrm{ml} \mathrm{swr}$ ? & & 5 & 47 & & 47.27 & $\mathrm{~s}-\mathrm{m}$ & 4.72 & & & & & & & 4.72 & nomo & III & $\begin{array}{l}\text { Dismantled seismographs at Hilea, Hilo, and } \\
\text { Kealakekua; felt at, said to be the strongest yet. } \\
\text { Warshauer notes: Severe earthquakes at } 9: 06 \\
\text { and } 9: 46 \text { this morning were reported from, but } \\
\text { were not felt at, Kau; felt locally. }\end{array}$ & $\begin{array}{l}\text { Not reported at Honolulu Magnetic } \\
\text { Observatory; ESPHVO, v. 3, p. 831; } \\
\text { HSB, 4/19/1926; HTH, 4/25/1926. }\end{array}$ \\
\hline $4 / 19 / 26$ & $23: 59$ & & & & & $\mathrm{ml} \mathrm{swr}$ ? & & & & & 47.3 & f-s & 4.24 & & & & & & & 5.33 & nomo & & 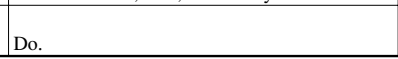 & $\begin{array}{l}\text { Do.; } 71 \text { quakes not felt at } \mathrm{HVO} \text {, not } \\
\text { reported separately. }\end{array}$ \\
\hline
\end{tabular}


Table 13. All earthquakes of $M \geq 4.0$ during the period 1903-59-Continued

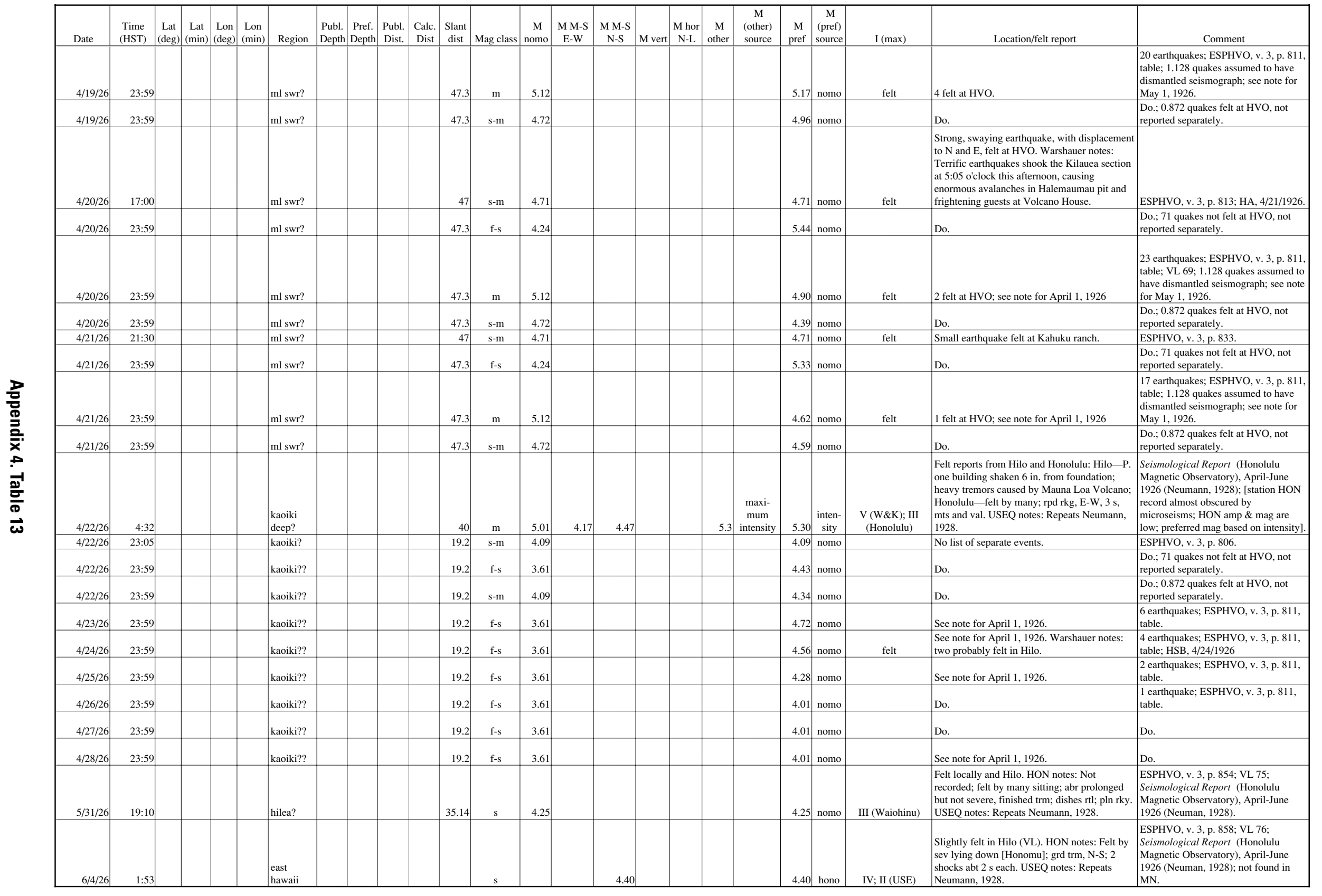


용 Table 13. All earthquakes of $M \geq 4.0$ during the period 1903-59-Continued

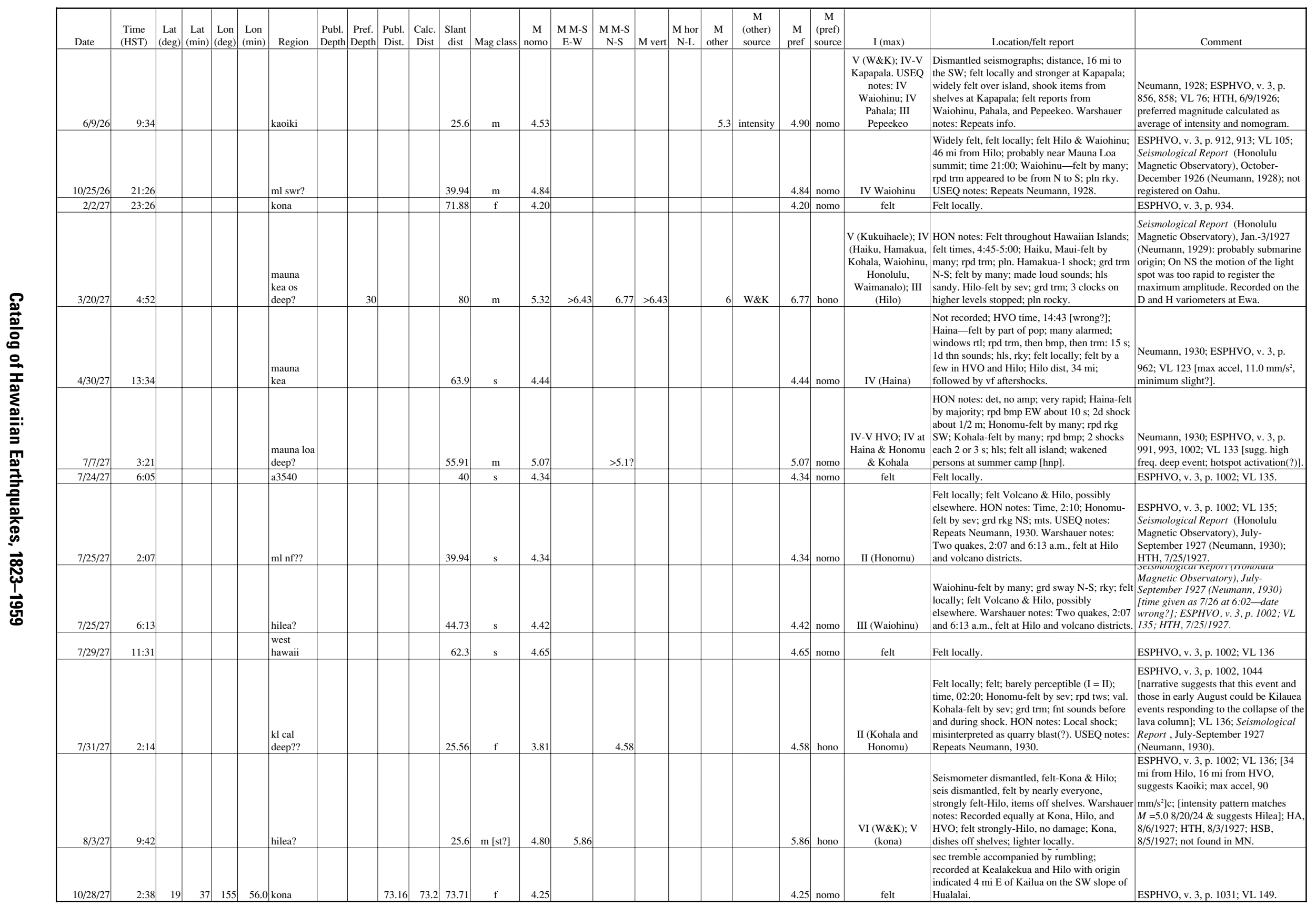


Table 13. All earthquakes of $M \geq 4.0$ during the period 1903-59-Continued

\begin{tabular}{|c|c|c|c|c|c|c|c|c|c|c|c|c|c|c|c|c|c|c|c|c|c|c|c|c|}
\hline Date & $\begin{array}{c}\text { Time } \\
\text { (HST) }\end{array}$ & $\begin{array}{c}\mathrm{Lat} \\
\text { (deg) }\end{array}$ & $\begin{array}{c}\text { Lat } \\
(\min )\end{array}$ & $\begin{array}{l}\text { Lon } \\
\text { (deg) }\end{array}$ & $\begin{array}{c}\text { Lon } \\
\text { (min) }\end{array}$ & Region & $\begin{array}{l}\text { Publ. } \\
\text { Depth }\end{array}$ & $\begin{array}{l}\text { Pref. } \\
\text { Depth }\end{array}$ & \begin{tabular}{l|l} 
Publ. & \\
Dist.
\end{tabular} & $\begin{array}{l}\text { Calc. } \\
\text { Dist }\end{array}$ & $\begin{array}{c}\text { Slant } \\
\text { dist }\end{array}$ & Mag class & $\begin{array}{c}\mathrm{M} \\
\text { nomo }\end{array}$ & $\begin{array}{c}\text { M M-S } \\
\text { E-W }\end{array}$ & $\begin{array}{l}\text { M M-S } \\
\text { N-S }\end{array}$ & $M$ vert & $\begin{array}{c}\mathrm{M} \text { hor } \\
\mathrm{N}-\mathrm{L}\end{array}$ & $\begin{array}{c}\mathrm{M} \\
\text { other }\end{array}$ & $\begin{array}{l}\mathrm{M} \\
\text { (other) } \\
\text { source }\end{array}$ & $\underset{\text { pref }}{M} \stackrel{s}{s}$ & $\begin{array}{c}\mathrm{M} \\
\text { (pref) } \\
\text { source }\end{array}$ & $I(\max )$ & Location/felt report & Comment \\
\hline $1 / 4 / 28$ & 13:07 & & & & & a3035 & & & & & 33.55 & $\mathrm{~m}$ & 4.48 & & & & & & & $4.48 \mathrm{r}$ & nomo & felt & $\begin{array}{l}\text { Felt locally; felt locally and in south Kau, Hilo, } \\
\text { and other places; not listed in Honolulu } \\
\text { Station Bulletin. }\end{array}$ & $\begin{array}{l}\text { ESPHVO, v. 3, p. 1066; VL 159; not } \\
\text { found in HTH or HA. }\end{array}$ \\
\hline $4 / 27 / 28$ & $17: 16$ & & & & & hualalai? & & & & & 84.66 & $\mathrm{f}$ & 4.32 & & & & & & & $4.32 \mathrm{r}$ & nomo & felt & $\begin{array}{l}\text { Time given as 5:01 p.m., might have been felt } \\
\text { (VL). }\end{array}$ & ESPHVO, v. 3, p. 1100; VL 175. \\
\hline $2 / 5 / 29$ & $2: 25$ & & & & & $\begin{array}{l}\text { kl cal } \\
\text { deep }\end{array}$ & & 30 & 5 & 5 & 50.41 & st & 4.92 & 5.36 & 5.36 & & & & & 5.36 & hono & $\mathrm{V}(\mathrm{W} \& \mathrm{~K}) ; \mathrm{IV}(\mathrm{R}-$ & $\begin{array}{l}\text { HON notes: Felt-Mauna Loa section of } \\
\text { Honolulu; local to Kilauea; deep quake under E } \\
\text { side of issand, S Kilaueae; dismantled seis, } \\
\text { waked people all Island of Hawaii, fel hnp, } \\
\text { Hilo, Kohala. Warshauer notess: Strongly felt } \\
\text { eq; felt as far as Kona and Kohala. }\end{array}$ & $\begin{array}{l}\text { Peters, 1929; ESPHVO, v. 3, p. } 1184, \\
\text { 1185, 1189; VL 215, 216; HA, } \\
\text { 2/11/1929; HSB, 2/5/1929; not found } \\
\text { in HTH or MN. }\end{array}$ \\
\hline $3 / 2 / 29$ & $10: 24$ & & & & & kaoiki & & & 27 & 27 & 28.46 & $\mathrm{~m} ?$ & 4.60 & 5.26 & 5.31 & & & & & 5.28 & hono & IV; III R-F (VL) & $\begin{array}{l}\text { HON notes: Registered; small landslide in } \\
\text { Halemaumau; } 17 \text { mi from HVO in Kapapala } \\
\text { direction, felt-hnp, strong eq caused small } \\
\text { landslide on E side of Halemaumau. }\end{array}$ & $\begin{array}{l}\text { 1194; VL 219; moderate(?) (see } \\
\text { reference to amplitudes of slight } \\
\text { earthquakes in VL 251, col 2, } \\
\text { paragraph 3!) }\end{array}$ \\
\hline $6 / 18 / 29$ & 8:42:00 & & & & & kaoiki? & & & 17.6 & 17.6 & 19.77 & $\mathrm{~s}(\mathrm{~m})$ & 4.62 & 4.87 & 4.90 & & & & & 4.88 & hono & IV & $\begin{array}{l}\text { HON notes: Local; very short period; slides at } \\
\text { Halemaumau and W wall of Kilauea crater, } \\
\text { strongly felt at hnp, dismantled seismograph. } \\
\text { Warshauer notes: The first of three tremors was } \\
\text { barely noticeable in Hilo. }\end{array}$ & $\begin{array}{l}\text { Peters, 1929; ESPHVO, v. 3, p. 1205, } \\
\text { 1206; V L 234; HTH, 6/18/1929; HSB, } \\
\text { 6/18/1929; not found in HA or MN. }\end{array}$ \\
\hline $6 / 18 / 29$ & 9:31:00 & & & & & kona? & & & 40 & 40 & 41 & $\mathrm{~m}$ & 5.13 & 5.83 & 5.95 & & & & & 5.89 & hono & VI & $\begin{array}{l}\text { HON notes: Local shock; not rep felt; strongly } \\
\text { felt at hnp, buildingg creaked, prolonged E-W } \\
\text { swaying, dismantled seismograph; felt at } \\
\text { halfway house (Kau), acc by rumble, trees set } \\
\text { in motion; felt at Hilo-articles displaced from } \\
\text { shelves. }\end{array}$ & $\begin{array}{l}\text { Peters, 1929; ESPHVO, v. 3, p. 1206; } \\
\text { VL 234 [distance of } 44 \text { mi doesn't } \\
\text { match felt reports; intensity map } \\
\text { suggests Hilea, as do newspaper reports } \\
\text { of } 20-30 \text { mi]. }\end{array}$ \\
\hline $9 / 18 / 29$ & 23:59 & & & & & hualalai & & & 22 & 22 & 23.77 & $\begin{array}{l}\text { vf; m } \\
\text { (kona) }\end{array}$ & 4.24 & & & & & & & $5.11 \mathrm{r}$ & nomo & V? (W\&K) & $\begin{array}{l}\text { Seismic crisis on Hualalai begins after noon; } \\
\text { many more events reported locally on Hualalai } \\
\text { than the } 221 \text { events recorded on the Kona } \\
\text { seismometer, details given in VL } 248 ; \\
\text { additional analysis and statistics given in VL } \\
309 \text {, p. 1-2. }\end{array}$ & $\begin{array}{l}\text { Eqs; } 9 \text { [8?-see VL 247] events (very } \\
\text { feeble at Whitney, moderate at Kona) } \\
\text { occurred 9/12-18 inclusive (VL 251 } \\
\text { list, col. 2, 3d paragraph from bottom); } \\
\text { not recorded in Honolulu; minimum } \\
\text { nomogram mag assumed. }\end{array}$ \\
\hline $9 / 22 / 29$ & $18: 34: 00$ & & & & & hualalai & & & 22 & 22 & 23.77 & $\mathrm{~m}$ (kona) & 4.48 & 4.65 & 4.65 & & & & & 4.65 & hono & & $\begin{array}{l}\text { The following shocks with origin in the } \\
\text { volcano district on Hawaii Island were } \\
\text { recorded. The period is short, between } 1 \text { and } 2 \\
\text { s, and only the "P" phase is definitely } \\
\text { distinguishable }\end{array}$ & $\begin{array}{l}\text { Peters, 1929; VL 248: } 79 \text { seismic spells } \\
\text { in } 22 \text { hours felt at Puu Waawaa. }\end{array}$ \\
\hline $9 / 22 / 29$ & $21: 28: 00$ & & & & & hualalai & & & 22 & 22 & 23.77 & $\mathrm{~m}$ (kona) & 4.48 & 4.95 & 4.95 & & & & & 4.95 & hono & $\mathrm{V} ?$ & $\begin{array}{l}\text { Time from Hon record. HON notes: The } \\
\text { following shocks with origin in the volcano } \\
\text { district on Hawaii Island were recorded. The } \\
\text { period is short, between } 1 \text { and } 2 \text { s, and only the } \\
\text { "P" phase is definitely distinguishable. }\end{array}$ & $\begin{array}{l}\text { Peters, 1929; VL 248: } 79 \text { seismic spells } \\
\text { in } 22 \text { hours felt at Puu Waawa; WK } \\
\text { table shows 9/23 night; should be } 9 / 22 .\end{array}$ \\
\hline $9 / 24 / 29$ & 7:44:40 & & & & & hualalai & & & 22 & 22 & 23.77 & $\mathrm{~m}$ (kona) & 4.48 & 5.25 & 5.12 & & & & & 5.19 & hono & V? (BSSA, 1929) & $\begin{array}{l}\text { Warshauer notes: The hardest tremor in this } \\
\text { city [Hilo] was felt at 7:45 this morning. }\end{array}$ & $\begin{array}{l}\text { Time from Honolulu record-10.5 hours } \\
\text { subtracted; HTH, } 9 / 25 / 1929 .\end{array}$ \\
\hline $9 / 24 / 29$ & $13: 59: 30$ & & & & & hualalai & & & 22 & 22 & 23.77 & st (kona)? & 4.75 & 4.87 & 5.25 & & & & & 5.06 & hono & V? (W\&K) & $\begin{array}{l}\text { hnp(?)-time } 1: 50 \text { p.m., strong shock, swayed } \\
\text { ferns and rocked house, E-W vibration. }\end{array}$ & $\begin{array}{l}\text { Time from Honolulu record-10.5 hours } \\
\text { subtracted; HVO, unpub. }\end{array}$ \\
\hline $9 / 25 / 29$ & 18:20:56 & 19 & 42.0 & 155 & $54.0 \mathrm{~h}$ & hualalai & & & 22 & 22 & 23.8 & st (kona) & 4.75 & 6.12 & 6.19 & & & $\begin{array}{l}5.6 ; \\
6.1\end{array}$ & $\begin{array}{l}\text { GUTE; } \\
\text { WK }\end{array}$ & 6.15 & hono & VIII (VL; USE?) & $\begin{array}{l}\text { Felt generally-Hawaiian island chain; damage } \\
\text { rpt in VL 249. Warshauer notes: Ship captain } \\
\text { in Kealakekua Bay felt quake as quivering, } \\
\text { watched landslide into bay; time given as } 6: 23 \\
\text { p.m.; Kona Inn twisted on its foundations; also } \\
\text { severe in Kohala and Hilo. }\end{array}$ & $\begin{array}{l}\text { Isoseismal map in W\&K-magnitude } \\
66 \text { assumes subcrustal depth based on } \\
\text { intensity distribution and teleseismic } \\
\text { magnitude; HA, 9/26/1929; HTH, } \\
\text { 9/29/1929; MN, 10/2/1929. }\end{array}$ \\
\hline $9 / 25 / 29$ & 23:59:00 & & & & & hualalai & & & 22 & 22 & 23.77 & $\mathrm{~s} \mathrm{(kona)}$ & 3.98 & & & & & & & $5.30 \mathrm{r}$ & nomo & & Do. & $\begin{array}{l}\text { Eqs; } 28 \text { events (slight at Kona) } \\
\text { assumed for week of } 9 / 19-25 / 1929 ; \\
\text { total event count of } 221 \text { reported in } \mathrm{VL} \\
251 \text { list, col. 2, 3d paragraph from } \\
\text { bottom. }\end{array}$ \\
\hline $9 / 25 / 29$ & 23:59:00 & & & & & hualalai & & & 22 & 22 & 23.77 & $\mathrm{~m}$ (kona) & 4.24 & & & & & & & $5.11 \mathrm{r}$ & nomo & & $\begin{array}{l}\text { Seismic crisis on Hualalai begins after noon; } \\
\text { many more events reported locally on Hualalai } \\
\text { than the } 22 \text { 1 events recorded on the Kona } \\
\text { seismometer; details given in VL } 248 ; \\
\text { preferred mag calculated as nomogram } \\
\text { magnitude multiplied by number of events. }\end{array}$ & $\begin{array}{l}\text { Eqs; } 9 \text { events (moderate at Kona) } \\
\text { occurred 9/19-25/1929 inclusive (VL } \\
251 \text { list, col. 2, 3d paragraph from } \\
\text { bottom); not recorded in Honolulu; } \\
\text { minimum nomogram mag assumed. }\end{array}$ \\
\hline
\end{tabular}


S Table 13. All earthquakes of $M \geq 4.0$ during the period 1903-59-Continued

\begin{tabular}{|c|c|c|c|c|c|c|c|c|c|c|c|c|c|c|c|c|c|c|c|c|c|c|c|c|}
\hline Date & $\begin{array}{l}\text { Time } \\
\text { (HST) }\end{array}$ & $\begin{array}{c}\text { Lat } \\
\text { (deg) }\end{array}$ & $\begin{array}{c}\text { Lat } \\
(\mathrm{min})\end{array}$ & $\begin{array}{l}\text { Lon } \\
\text { (deg) }\end{array}$ & $\begin{array}{c}\text { Lon } \\
(\min )\end{array}$ & Region & $\begin{array}{l}\text { Publ. } \\
\text { Depth } 1\end{array}$ & $\begin{array}{l}\text { Pref. } \\
\text { Depth }\end{array}$ & $\begin{array}{l}\text { Publ. } \\
\text { Dist. }\end{array}$ & $\begin{array}{l}\text { Calc. } \\
\text { Dist }\end{array}$ & $\begin{array}{c}\text { Slant } \\
\text { dist }\end{array}$ & Mag class & $\begin{array}{c}\mathrm{M} \\
\text { nomo }\end{array}$ & $\begin{array}{c}\text { M M-S } \\
\text { E-W }\end{array}$ & $\begin{array}{c}\text { M M-S } \\
\text { N-S }\end{array}$ & M vert & $\begin{array}{c}\text { M hor } \\
\mathrm{N}-\mathrm{L}\end{array}$ & $\begin{array}{c}\mathrm{M} \\
\text { other }\end{array}$ & $\begin{array}{l}\mathrm{M} \\
\text { (other) } \\
\text { source }\end{array}$ & $\begin{array}{c}\mathrm{M} \\
\text { pref }\end{array}$ & $\begin{array}{c}\text { M } \\
\text { (pref) } \\
\text { source }\end{array}$ & $I(\max )$ & Location/felt report & Comment \\
\hline 9/25/29 & 23:59:00 & & & & & hualalai & & & 22 & 22 & 23.77 & $\mathrm{f}$ (kona) & 3.44 & & & & & & & 5.04 & nomo & & Do. & $\begin{array}{l}\text { Eqs; } 58 \text { events (feeble at Kona) } \\
\text { assumed for week of } 9 / 19-25 / 1929 ; \\
\text { total event count of } 221 \text { reported in } \mathrm{VL} \\
251 \text {, list, col. 2, 3d paragraph from } \\
\text { bottom. }\end{array}$ \\
\hline 9/25/29 & 23:59:00 & & & & & hualalai & & & 22 & 22 & 23.77 & vf (kona) & 2.42 & & & & & & & 4.31 & nomo & & Do. & $\begin{array}{l}\text { Eqs; } 121 \text { events (very feeble at Kona) } \\
\text { assumed for week of 9/19-25/1929; } \\
\text { total event count of } 221 \text { reported in } \mathrm{VL} \\
251 \text {, list, col. 2, 3d paragraph from } \\
\text { bottom. }\end{array}$ \\
\hline $9 / 25 / 29$ & $23.59 \cdot 00$ & & & & & hellai & & & 27 & & 2377, & (f) (kong) & 242 & & & & & & & & & & Warshauer notes: 63 shocks recorded at HVO & (1) \\
\hline $9 / 26 / 29$ & 10:23:30 & & & & & hualalai & & & 22 & 22 & 23.77 & st (kona) & 4.45 & 4.77 & 4.95 & & & & & $\begin{array}{l}4.06 \\
4.86\end{array}$ & $\begin{array}{l}\text { nomo } \\
\text { hono }\end{array}$ & & & HА, $10 / 2 / 1929$ \\
\hline 9/27/29 & 22:19:50 & & & & & hualalai & & & 22 & 22 & 23.77 & st (kona) & 4.75 & 4.95 & 5.07 & & & & & 5.01 & hono & $\mathrm{VI}(\mathrm{HTH})$ & & $\begin{array}{l}\text { VL } 249 \text { lists time } 10: 50 \text { a.m.; WK lists } \\
\text { time } 11: 20 \text { a.m.; neither fits Honolulu } \\
\text { record. }\end{array}$ \\
\hline $9 / 27 / 29$ & 22:27:35 & & & & & hualalai & & & 22 & 22 & 23.77 & st (kona) & 4.75 & & 4.77 & & & & & 4.77 & hono & & & \\
\hline 9/27/29 & 22:45:30 & & & & & hualalai & & & & & & & & 5.07 & 5.17 & & & & & 5.12 & hono & & & $\begin{array}{l}\text { Not in VL; time from station HON } \\
\text { record. }\end{array}$ \\
\hline 9/28/29 & 7:10:15 & & & & & hualalai & & & 22 & 22 & 65 & vst (kona) & 5.75 & 5.62 & 5.65 & & & & & 5.63 & hono & VII (HTH; USE) & $\begin{array}{l}\text { Bull. Seis. Soc. Am. (1929, v. 119, p. 185) } \\
\text { gives location " } 15 \text { mi E o filo in the Puu Oo } \\
\text { district." Warshauer notes: The Hilo district } \\
\text { experienced several heavy shocks during the } \\
\text { day, strongest shocks at } 7 \text { a.m. and } 2 \text { p.m.; } \\
\text { distances, } 14-35 \text { mi from HVO. }\end{array}$ & VL time 7:08; HA, 9/29/1929. \\
\hline 9/28/29 & 15:17:35 & & & & & hualalai & & & 22 & 22 & 23.77 & st (kona) & 4.75 & 5.62 & 5.55 & & & & & 5.58 & hono & $\mathrm{VI}(\mathrm{HTH})$ & $\begin{array}{l}\text { Warshauer notes: The Hilo district experienced } \\
\text { several heavy shocks during the day; strongest } \\
\text { shocks at } 7 \text { a.m. and } 2 \text { p.m. [3? p.m.]; } \\
\text { distances, } 14-35 \text { mi from HVO. }\end{array}$ & VL time 15:18; HA, 9/29/1929. \\
\hline $9 / 28 / 29$ & $17: 46: 10$ & & & & & hualalai & & & 22 & 22 & 23.77 & st (kona) & 4.75 & 5.51 & 5.32 & & & & & 5.41 & hono & & & $\begin{array}{l}\text { Time from Honolulu record, } 10.5 \text { hours } \\
\text { subtracted; not listed in WK. }\end{array}$ \\
\hline $9 / 29 / 29$ & $5: 31: 15$ & & & & & hualalai & & & 22 & 22 & 23.77 & st (kona) & 4.75 & 5.25 & 5.25 & & & & & 5.25 & hono & & & \\
\hline $9 / 29 / 29$ & 22:49:00 & & & & & hualalai & & & 22 & 22 & 23.77 & st (kona) & 4.75 & 5.17 & 5.17 & & & & & 5.17 & hono & & & $\begin{array}{l}\text { Time from Honolulu record, } 10.5 \text { hrs } \\
\text { subtracted. }\end{array}$ \\
\hline $9 / 30 / 29$ & $11: 54: 00$ & & & & & hualalai & & & 22 & 22 & 23.77 & st (kona) & 4.75 & 5.37 & 5.32 & & & & & 5.35 & hono & $\mathrm{VI}(\mathrm{HTH})$ & $\begin{array}{l}\text { Warshauer notes: Two severe shocks were felt } \\
\text { in Hilo and Kona today. One of these, } \\
\text { occurring at } 11: 55 \text { a.m., was extremely heavy, } \\
\text { destroying several stone fences on the slopes of } \\
\text { Hualalai. }\end{array}$ & VL time 11:55; HA, 10/1/1929 \\
\hline $10 / 2 / 29$ & $18: 37: 40$ & & & & & hualalai & & & 22 & 22 & 23.77 & st (kona) & 4.75 & 4.54 & 4.54 & & & & & 4.54 & hono & & & $\begin{array}{l}\text { Time from Honolulu record, } 10.5 \text { hrs } \\
\text { subtracted; not listed in WK. }\end{array}$ \\
\hline $10 / 2 / 29$ & 23:59:00 & & & & & hualalai & & & 22 & 22 & 23.77 & st (kona) & 4.75 & & & & & & & 5.39 & nomo & & $\begin{array}{l}\text { Preferred magnitude calculated as nomogram } \\
\text { magnitude multiplied by number of events. }\end{array}$ & $\begin{array}{l}\text { Eqs; } 5 \text { events (strong at Kona), 9/26- } \\
10 / 2 / 29 \text {, cited in VL } 251 \text { list, col. 2, 3d } \\
\text { paragraph from bottom, are not } \\
\text { accounted for in Honolulu records; } \\
\text { minimum magnitude preferred; } \\
\text { magnitude fit improved if closer to } \\
\text { Kealakekua. }\end{array}$ \\
\hline $10 / 2 / 29$ & 23:59:00 & & & & & hualalai & & & 22 & 22 & 23.77 & m (kona) & 4.24 & & & & & & & 5.38 & nomo & & Do. & $\begin{array}{l}\text { Eqs; } 18 \text { events (moderate at Kona), } \\
\text { 9/26-10/2/29, cited in VL } 251 \text { list, col. } \\
2,3 \text { paragraph from bottom, are not } \\
\text { accounted for in Honolulu records; } \\
\text { minimum magnitude preferred. }\end{array}$ \\
\hline $10 / 2 / 29$ & 23:59:00 & & & & & hualalai & & & 22 & 22 & 23.77 & s (kona) & 3.98 & & & & & & & 5.37 & nomo & & Do. & $\begin{array}{l}\text { Eqs; } 34 \text { events (slight at Kona) } \\
\text { assumed for week of } 9 / 26-10 / 2 / 1929 ; \\
\text { total event count of } 244 \text { reported in VL } \\
251 \text { list, col. 2, 3d paragraph from } \\
\text { bottom. }\end{array}$ \\
\hline $10 / 2 / 29$ & 23:59:00 & & & & & hualalai & & & 22 & 22 & 23.77 & $\mathrm{f}$ (kona) & 3.44 & & & & & & & 5.09 & nomo & & Do. & $\begin{array}{l}\text { Eqs; } 65 \text { events (feeble at Kona) } \\
\text { assumed for week of } 9 / 26-10 / 2 / 1929 ; \\
\text { total event count of } 244 \text { reported in VL } \\
251 \text { list, col. 2, 3d paragraph from } \\
\text { bottom. }\end{array}$ \\
\hline
\end{tabular}


Table 13. All earthquakes of $M \geq 4.0$ during the period 1903-59-Continued

\begin{tabular}{|c|c|c|c|c|c|c|c|c|c|c|c|c|c|c|c|c|c|c|c|c|c|c|c|c|}
\hline Date & $\begin{array}{l}\text { Time } \\
\text { (HST) }\end{array}$ & $\begin{array}{c}\text { Lat } \\
(\operatorname{deg})\end{array}$ & $\begin{array}{c}\text { Lat } \\
(\mathrm{min})\end{array}$ & $\begin{array}{l}\text { Lon } \\
\text { (deg) }\end{array}$ & $\begin{array}{l}\text { Lon } \\
(\mathrm{min})\end{array}$ & Region & $\begin{array}{l}\text { Publ. } \\
\text { Depth } 1\end{array}$ & $\begin{array}{l}\text { Pref. } \\
\text { Depth }\end{array}$ & $\begin{array}{l}\text { Publ. } \\
\text { Dist. }\end{array}$ & $\begin{array}{r}\text { Calc. } \\
\text { Dist }\end{array}$ & $\begin{array}{c}\text { Slant } \\
\text { dist }\end{array}$ & Mag class & $\begin{array}{c}\mathrm{M} \\
\text { nomo }\end{array}$ & $\begin{array}{c}\text { M M-S } \\
\text { E-W }\end{array}$ & $\begin{array}{c}\text { M M-S } \\
\text { N-S }\end{array}$ & M vert & $\begin{array}{c}\text { M hor } \\
\mathrm{N}-\mathrm{L}\end{array}$ & $\begin{array}{c}\mathrm{M} \\
\text { other }\end{array}$ & $\begin{array}{c}\mathrm{M} \\
\text { (other) } \\
\text { source }\end{array}$ & $\begin{array}{c}\mathrm{M} \\
\text { pref }\end{array}$ & $\begin{array}{c}\mathrm{M} \\
\text { (pref) } \\
\text { source }\end{array}$ & $I(\max )$ & Location/felt report & Comment \\
\hline $10 / 2 / 29$ & $23: 59: 00$ & & & & & hualalai & & & 22 & 22 & 23.77 & vf (kona) & 2.42 & & & & & & & 4.29 & nomo & & Do. & $\begin{array}{l}\text { Eqs, } 114 \text { events (very feeble at Kona) } \\
\text { assumed for week of } 9 / 26-10 / 2 / 1929 ; \\
\text { total event count of } 244 \text { reported in VL } \\
251 \text { list, col. 2, 3d paragraph from } \\
\text { bottom. }\end{array}$ \\
\hline $10 / 3 / 29$ & $9: 42: 43$ & & & & & hualalai & & & 22 & 22 & 23.77 & st (kona) & 4.75 & 5.04 & 4.54 & & & & & 4.79 & hono & & & $\begin{array}{l}\text { Time from Honolulu record, } 10.5 \text { hours } \\
\text { subtracted; time not listed in W\&K. }\end{array}$ \\
\hline $\begin{array}{l}10 / 5 / 29 \\
10 / 8 / 29\end{array}$ & $\begin{array}{r}21: 22: 31 \\
0: 37: 45\end{array}$ & & & & & $\begin{array}{l}\text { hualalai } \\
\text { hualalai }\end{array}$ & & & $\begin{array}{l}74 \\
22\end{array}$ & $\begin{array}{r}75.5 \\
22\end{array}$ & $\begin{array}{l}76.01 \\
23.77\end{array}$ & $\begin{array}{c}\text { st; vst } \\
\text { (kona) } \\
\text { st (kona) }\end{array}$ & $\begin{array}{l}5.56 \\
4.75\end{array}$ & 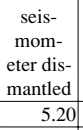 & $\begin{array}{r}\text { seis- } \\
\text { mom- } \\
\text { eter dis- } \\
\text { mantled } \\
5.51\end{array}$ & & & 6.5 & GUTE & $\begin{array}{l}6.50 \\
5.35\end{array}$ & $\begin{array}{l}\text { gute } \\
\text { hono }\end{array}$ & VIII (VL; USE?) & $\begin{array}{l}\text { Felt generally-Hawaiian Island chain; damage } \\
\text { report in VL 250. Warshauer notes: See } \\
\text { references. }\end{array}$ & $\begin{array}{l}\text { Isoseismal map in W\&K, who accept } \\
\text { GUTE magnitude } 6.5 ; \text {; crustal depth is } \\
\text { consistent with sisoseismal gradients; } \\
\text { HA, 10/6-9/1929. }\end{array}$ \\
\hline 10/9/29 & $23: 59: 00$ & & & & & hualalai & & & 22 & 22 & 23.77 & $\mathrm{~m}$ (kona) & 4.24 & & & & & & & 5.11 & nomo & & Do. & $\begin{array}{l}\text { Eqs; } 9 \text { events (moderate at Kona), 10/3- } \\
\text { 9/1929, cited in VL 251 list, col. 2, 3d } \\
\text { paragraph from bottom, are not } \\
\text { accounted for in Honolulu records; } \\
\text { minimum magnitude preferred. }\end{array}$ \\
\hline 10/9/29 & 23:59:00 & & & & & hualalai & & & 22 & 22 & 23.77 & $\mathrm{~s}$ (kona) & 3.98 & & & & & & & 5.10 & nomo & & Do. & $\begin{array}{l}\text { Eqs; } 17 \text { events (slight at Kona) } \\
\text { assumed for week of 10/3-9/1929; total } \\
\text { event count of } 129 \text { reported in VL 251 } \\
\text { list, col. 2, 3d paragraph from bottom. }\end{array}$ \\
\hline 10/9/29 & $23: 59: 00$ & & & & & hualalai & & & 22 & 22 & 23.77 & f(kona) & 3.44 & & & & & & & 4.87 & nomo & & Do. & $\begin{array}{l}\text { Eqs; } 32 \text { events (feeble at Kona) } \\
\text { assumed for week of 10/3-9/1929; total } \\
\text { event count of } 129 \text { reported in VL } 251 \\
\text { list, col. 2, 3d paragraph from bottom. }\end{array}$ \\
\hline 10/9/29 & 23:59:00 & & & & & hualalai & & & 22 & 22 & 23.77 & st (kona) & 4.75 & & & & & & & 4.75 & nomo & & $\begin{array}{l}\text { Preferred magnitude calculated as nomogram } \\
\text { magnitude multiplied by number of events. }\end{array}$ & $\begin{array}{l}\text { Eqs; } 1 \text { event (strong at Kona), 10/3- } \\
\text { 9/29, cited in VL } 251 \text { list, col. 2, 3d } \\
\text { paragraph from bottom, are not } \\
\text { accounted for in Honolulu records; } \\
\text { minimum magnitude preferred; } \\
\text { magnitude fit improved if closer to } \\
\text { Kealakekua. }\end{array}$ \\
\hline 10/9/29 & 23:59:00 & & & & & hualalai & & & 22 & 22 & 23.77 & vf (kona) & 2.42 & & & & & & & 4.07 & nomo & & 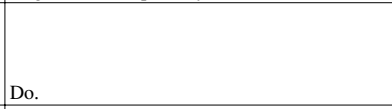 & $\begin{array}{l}\text { Eqs; } 66 \text { events (very feeble at Kona) } \\
\text { assumed for week of 10/3-9/1929; total } \\
\text { event count of } 129 \text { reported in VL 251 } \\
\text { list, col. 2, 3d paragraph from bottom. }\end{array}$ \\
\hline $10 / 14 / 29$ & 23:35:00 & & & & & hualalai & & & 22 & 22 & 23.77 & $\begin{array}{c}\mathrm{m} ; \mathrm{st} \\
\text { (kona) }\end{array}$ & 4.75 & & & & & & & 4.75 & nomo & felt & Felt-Kona; barely felt-hnp. & $\begin{array}{l}\text { Assume this event is the one strong } \\
\text { event cited in VL } 251 \text { list, col. 2, 2d } \\
\text { paragraph from top and 3d paragraph } \\
\text { from bottom; not recorded in Honolulu. }\end{array}$ \\
\hline $10 / 15 / 29$ & 9:59:00 & & & & & hualalai & & & 22 & 22 & 23.77 & $\begin{array}{l}\text { s?; m } \\
\text { (kona) }\end{array}$ & 4.24 & & & & & & & 4.24 & nomo & & $\begin{array}{l}\text { (The next four earthquakes) registered with 3- } \\
\text { to 4-cm amplitude on the seismograms of about } \\
\text { 120-times magnification (ed. note: Whitney is } \\
\text { 115). They would rank as slight earthquakes. }\end{array}$ & $\begin{array}{l}\text { Slight class conflicts with later } \\
\text { amplitude ranges which define } \\
\text { : moderate" as } 2.5-6 \mathrm{~cm} \text { amplitude; } \\
\text { conflict resolved if amplitudes refer to } \\
\text { Kona seismometer. }\end{array}$ \\
\hline $10 / 15 / 29$ & 13:04:00 & & & & & hualalai & & & 22 & 22 & 23.77 & $\begin{array}{l}\mathrm{s} 2 ; \mathrm{m} \\
\text { (kona) }\end{array}$ & 4.24 & & & & & & & 4.24 & nomo & & Do. & \\
\hline $10 / 15 / 29$ & $17: 41: 00$ & & & & & hualalai & & & 22 & 22 & 23.77 & $\begin{array}{l}\text { s?; m } \\
\text { (kona) }\end{array}$ & 4.24 & & & & & & & 4.24 & nomo & & Do. & \\
\hline $10 / 15 / 29$ & 22:05:00 & & & & & hualalai & & & 22 & 22 & 23.77 & $\begin{array}{l}\text { s?; m } \\
\text { (kona) }\end{array}$ & 4.24 & & & & & & & 4.24 & nomo & & Do. & \\
\hline $10 / 16 / 29$ & 23:59:00 & & & & & hualalai & & & 22 & 22 & 23.77 & $\mathrm{~s}$ (kona) & 3.98 & & & & & & & 4.96 & nomo & & Do. & $\begin{array}{l}\text { Eqs; } 12 \text { events (slight at Kona) } \\
\text { assumed for week of 10/10-16/1929; } \\
\text { total event count of } 97 \text { reported in VL } \\
251 \text { list, col. 2, 3d paragraph from } \\
\text { bottom. }\end{array}$ \\
\hline $10 / 16 / 29$ & 23:59:00 & & & & & hualalai & & & 22 & 22 & 23.77 & $\mathrm{f}$ (kona) & 3.44 & & & & & & & 4.71 & nomo & & Do. & $\begin{array}{l}\text { Eqs; } 25 \text { events (feeble at Kona) } \\
\text { assumed for week of 10/10-16/1929; } \\
\text { total event count of } 97 \text { reported in VL } \\
251 \text { list, col. 2, 3d paragraph from } \\
\text { bottom. }\end{array}$ \\
\hline
\end{tabular}


Table 13. All earthquakes of $M \geq 4.0$ during the period 1903-59-Continued

\begin{tabular}{|c|c|c|c|c|c|c|c|c|c|c|c|c|c|c|c|c|c|c|c|c|c|c|c|c|}
\hline Date & $\begin{array}{l}\text { Time } \\
\text { (HST) }\end{array}$ & $\begin{array}{l}\text { Lat } \\
\text { (deg) }\end{array}$ & $\begin{array}{c}\text { Lat } \\
(\mathrm{min})\end{array}$ & $\begin{array}{l}\text { Lon } \\
\text { (deg) }\end{array}$ & $\begin{array}{l}\text { Lon } \\
(\mathrm{min})\end{array}$ & Region & $\begin{array}{l}\text { Publ. } \\
\text { Depth }\end{array}$ & $\begin{array}{l}\text { Pref. } \\
\text { Depth }\end{array}$ & $\begin{array}{l}\text { Publ. } \\
\text { Dist. }\end{array}$ & $\begin{array}{l}\text { Calc. } \\
\text { Dist }\end{array}$ & $\begin{array}{c}\text { Slant } \\
\text { dist }\end{array}$ & Mag class & $\begin{array}{c}\mathrm{M} \\
\text { nomo }\end{array}$ & $\begin{array}{c}\text { M M-S } \\
\text { E-W }\end{array}$ & $\begin{array}{c}\text { M M-S } \\
\text { N-S }\end{array}$ & M vert & $\begin{array}{c}\text { M hor } \\
\text { N-L }\end{array}$ & $\begin{array}{c}\mathrm{M} \\
\text { other }\end{array}$ & $\begin{array}{l}\mathrm{M} \\
\text { (other) } \\
\text { source }\end{array}$ & $\begin{array}{c}\mathrm{M} \\
\mathrm{pref}\end{array}$ & $\begin{array}{c}\text { M } \\
\text { (pref) } \\
\text { source }\end{array}$ & $I(\max )$ & Location/felt report & Comment \\
\hline $10 / 16 / 29$ & 23:59:00 & & & & & hualalai & & & 22 & 22 & 23.77 & $\mathrm{~m}$ (kona) & 4.24 & & & & & & & $4.24 \mathrm{I}$ & nomo & & $\begin{array}{l}\text { Preferred magnitude calculated as nomogram } \\
\text { magnitude multiplied by number of events. }\end{array}$ & $\begin{array}{l}\text { Eqs; } 1 \text { event (moderate at Kona), 10/10 } \\
16 / 1929 \text { cited in VL 251 list, col. } 2,3 \mathrm{~d} \\
\text { paragaraph from bottom, are not } \\
\text { accounted for in Honolulu records; } \\
\text { minimum magnitude preferred. }\end{array}$ \\
\hline $10 / 21 / 29$ & 12:00:00 & & & & & hualalai & & & 22 & 22 & 23.77 & $\begin{array}{l}\mathrm{f} ? ; \mathrm{m} ? \\
\text { (kona) }\end{array}$ & 4.24 & & & & & & & $4.24 \mathrm{I}$ & nomo & felt & 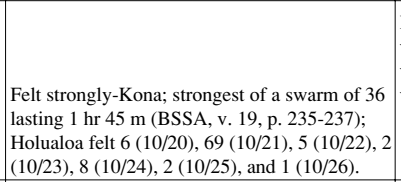 & 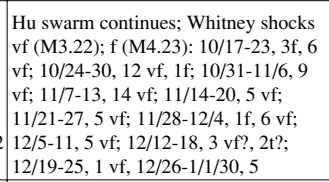 \\
\hline $10 / 21 / 29$ & 23:59:00 & & & & & hualalai & & & & & & & & & & & & & & $4.67^{c}$ & $\begin{array}{l}\text { calcu- } \\
\text { lated }\end{array}$ & felt & $\begin{array}{l}69 \text { shocks felt at Holualoa; } 41 \text { registered; } \\
\text { assume average } M=3 \text {; preferred magnitude } \\
\text { calculated as } M=3 \text { multiplied by number of } \\
\text { events, yeilding a minimum moment } \\
\text { magnitude. }\end{array}$ & VL 253. \\
\hline $11 / 10 / 29$ & 20:19:00 & & & & & $\begin{array}{l}\text { south } \\
\text { hawaii }\end{array}$ & & & 54.4 & 54.4 & 55.14 & $\mathrm{f}$ & 4.02 & & & & & & & $4.02 \mathrm{I}$ & nomo & felt & Felt-generally Island of Hawaii. & VL 255 . \\
\hline $11 / 24 / 29$ & 6:59:00 & & & & & kona? & & & 64 & 64 & 64.63 & $\mathrm{f}$ & 4.13 & & & & & & & $4.13 \mathrm{I}$ & nomo & felt & $40 \mathrm{mi}$ from HVO; felt strongly-Kona. & $\begin{array}{l}\text { Hualalaiai?-most distances are greater } \\
\text { for the Hualalai swarm; not noted in } \\
\text { Honolulu Station Bulletin } ; \mathrm{VL} 257 .\end{array}$ \\
\hline $12 / 1 / 29$ & 14:06:00 & & & & & kona? & & & 67.2 & 67.2 & 267.8 & $\mathrm{f}$ & 4.16 & & & & & & & 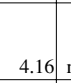 & nomo & felt & 42 mi from HVO; felt-Kona. & $\begin{array}{l}\text { Hualalaia(?)-most distances are greater } \\
\text { for the Hualalai swarm; not noted in } \\
\text { Honolulu Station Bulletin ; VL } 258 \text {. }\end{array}$ \\
\hline $1 / 29 / 30$ & 18:42:00 & & & & & hualalai? & & & & & 76.8 & $\mathrm{~s}$ & 4.80 & & & & & & & 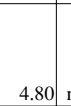 & nomo & felt & $\begin{array}{l}\text { shock [no amplitude given]; felt locally, } \\
\text { probably felt generally on the Ilsand of Hawaii. } \\
\text { [Magnitude fits if referenced to Whitney rather } \\
\text { than Kona.] }\end{array}$ & $\begin{array}{l}\text { Peters, 1930; VL 267, p. 3-4; not found } \\
\text { in MN. }\end{array}$ \\
\hline $2 / 9 / 30$ & 9:43:00 & & & & & kona? & & & & & 64 & $\mathrm{f}$ & 4.12 & & & & & & & $4.12 \mathrm{I}$ & nomo & felt & Felt in some places on the island. & VL 268, p. 3 \\
\hline $2 / 19 / 30$ & $17: 42: 00$ & & & & & hilea? & & & & & 43.2 & $\mathrm{~s}$ & 4.40 & & & & & & & 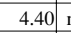 & nomo & felt & Felt strongest in Kau district. & Not registered on Oahu; VL 270, p. 4. \\
\hline $5 / 20 / 30$ & 2:47:00 & & & & & $\begin{array}{l}\text { hualalai } \\
\text { os? }\end{array}$ & & & & & 169.6 & $\mathrm{f}$ & 4.80 & & & & & & & 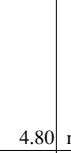 & nomo & felt & $\begin{array}{l}\text { Felt locally, more strongly in } N \text { Hilo; period } \\
\text { slow on E side of island, quicker in N Kona, } \\
\text { suggesting a Hualalai source. Warshauer notes: } \\
\text { [Shocks at 2:47 a.m. and } 6: 52 \text { p.m.] were } \\
\text { strongly felt at Puu Waawaa and, also noticed } \\
\text { in Hilo at Puueo. }\end{array}$ & $\begin{array}{l}\text { Peters, 1930. HON notes: Registered at } \\
\text { 13:18 G.m.t.; sharp local shock, no } \\
\text { amplitude given, dur 6.2 min; VL 283, } \\
\text { p. 3-4; HTH, 5/21/1930. Warshauer } \\
\text { notes-con.: Similar felt pattern to } \\
\text { Hualalaia eqs of Sept.-Oct./1929. }\end{array}$ \\
\hline $5 / 20 / 30$ & 18:52:00 & & & & & $\begin{array}{l}\text { hualalai } \\
\text { os? }\end{array}$ & & & 97.6 & 97.6 & 98.01 & $\mathrm{f}$ & 4.42 & & & & & & & $4.42 \mathrm{I}$ & nomo & $\mathrm{V}$ (HTH; USE) & $\begin{array}{l}\text { HON notes: Registered at 5:23, } 5 / 21 / 30 \\
\text { (Gm.t.); local shock, no amplitude given, dur } \\
3.7 \text { min; felt locally, more strongly in N Hilo; } \\
\text { period slow on E side of island, quicker in } \mathrm{N} \\
\text { Kona, suggesting a Hualalai source. }\end{array}$ & $\begin{array}{l}\text { Peters, 1930; VL 283, p. 3-4; HTH, } \\
\text { 5/21/1930. }\end{array}$ \\
\hline $5 / 25 / 30$ & 20:17:00 & 19 & 26.0 & 155 & 25.01 & $\mathrm{kl}$ sf? & & & & 25 & 26.57 & $\mathrm{~m}$ & 4.55 & & & & & 4.7 & wK & $4.55 \mathrm{r}$ & nomo & $\mathrm{V}$ (USE) & $\begin{array}{l}\text { Felt-all Hawaii Island, no objects overturned; } \\
\text { stronger motion in Kau \& Puna (strong at } \\
\text { Keaau beach) than in Kona or Kohala; } \\
\text { seismographs dismantled; WK } M=4.7 \text { based } \\
\text { on intensity distribution; VL } 283, \text {, } 4 \text { sugggests } \\
\text { deep origin beneath Kilauea or Mauna Loa. }\end{array}$ & $\begin{array}{l}\text { VL 283-cont.: Whitney-first motion } \\
\text { down to S and E; Hilo-began W } \\
\text { swaying, then strong jerks that quickly } \\
\text { ended, first to NE, then to SW; Puu } \\
\text { Waawaa-vibration long, not strong; } \\
\text { Honokahau-a moderate shock with } \\
\text { thunderous noise; Kealakekua- } \\
\text { alarmingly sudden. }\end{array}$ \\
\hline $6 / 3 / 30$ & 4:54:00 & & & & & $\begin{array}{l}\text { north } \\
\text { hawaii }\end{array}$ & & & & & 107.2 & $\mathrm{f}$ & 4.48 & & & & & & & 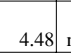 & nomo & felt & Felt on both east and west sides of island. & Not registered on Oahu; VL 285. p. 3. \\
\hline $6 / 14 / 30$ & 0:25:00 & & & & & $\mathrm{kl} \mathrm{sf?}$ & & & & & 19.2 & $\mathrm{~s}$ & 4.09 & & & & & & & $4.09 \mathrm{r}$ & nomo & IV & $\begin{array}{l}\text { HON notes: Registered at } 0: 26 \text {; nearby type, no } \\
\text { amplitude given; genenallly felt on } E \text { side of } \\
\text { island; movement prolonged and moderate at } \\
\text { Kilauea, shorter and ending in a sharp jerk at } \\
\text { Hilo; vertical component pronounced on } \\
\text { Kilauea seismogram; [moderate?]. }\end{array}$ & Peters, 1930; VL 286. p. 3. \\
\hline $7 / 22 / 30$ & 13:53:00 & & & & & $\mathrm{mlnf}$ ? & & & & & 56 & $\mathrm{~m}$ & 5.07 & & & & & & & $5.07 \mathrm{r}$ & nomo & $\mathrm{V}-\mathrm{VI}$ & $\begin{array}{l}\text { Felt generally on island of Hawaii, especially in } \\
\text { N Kona; workmen severely jolted at halfway } \\
\text { house on the Mauna Loa atrail; shock alleged to } \\
\text { be strongest since the Hualalai series last } \\
\text { autumn; epicenter in saddle between Mauna } \\
\text { Kea, Mauna Loa, and Hualalai. }\end{array}$ & $\begin{array}{l}\text { n VL 292, p. 3; HTH, 7/22/1930; not } \\
\text { found in HA. Warshauer notes: Felt } \\
\text { most strongly in Kohala (objects } \\
\text { thrown off shelves) and Puu Waawaa. } \\
\text { Said to be strongest at since Hualalai } \\
\text { series; see references. }\end{array}$ \\
\hline
\end{tabular}


Table 13. All earthquakes of $M \geq 4.0$ during the period 1903-59-Continued

\begin{tabular}{|c|c|c|c|c|c|c|c|c|c|c|c|c|c|c|c|c|c|c|c|c|c|c|c|c|}
\hline Date & $\begin{array}{c}\text { Time } \\
\text { (HST) }\end{array}$ & $\begin{array}{l}\text { Lat } \\
(\operatorname{deg})(\end{array}$ & $\begin{array}{c}\text { Lat } \\
(\mathrm{min})\end{array}$ & $\begin{array}{l}\text { Lon } \\
\text { (deg) }\end{array}$ & $\begin{array}{l}\text { Lon } \\
(\min )\end{array}$ & Region & $\begin{array}{l}\text { Publ. } \\
\text { Depth } 1\end{array}$ & $\begin{array}{l}\text { Pref. } \\
\text { Depth }\end{array}$ & $\begin{array}{l}\text { Publ. } \\
\text { Dist. }\end{array}$ & $\begin{array}{l}\text { Calc. } \\
\text { Dist }\end{array}$ & $\begin{array}{c}\text { Slant } \\
\text { dist }\end{array}$ & Mag class & $\begin{array}{c}\mathrm{M} \\
\text { nomo }\end{array}$ & $\begin{array}{c}\text { M M-S } \\
\text { E-W }\end{array}$ & $\begin{array}{c}\text { M M-S } \\
\text { N-S }\end{array}$ & $M$ vert & $\begin{array}{c}\text { M hor } \\
\mathrm{N}-\mathrm{L}\end{array}$ & $\begin{array}{c}\mathrm{M} \\
\text { other }\end{array}$ & $\begin{array}{c}\mathrm{M} \\
\text { (other) } \\
\text { source }\end{array}$ & $\begin{array}{c}\mathrm{M} \\
\text { pref }\end{array}$ & $\begin{array}{c}\mathrm{M} \\
\text { (pref) } \\
\text { source }\end{array}$ & $I(\max )$ & Location/felt report & Comment \\
\hline $9 / 28 / 30$ & $20: 35: 00$ & & & & & $\begin{array}{l}\mathrm{kl} \text { cal } \\
\text { deep? }\end{array}$ & & & & & 25.6 & $\mathrm{~m}$ & 4.53 & & & & & & & 4.53 & nomo & III & $\begin{array}{l}\text { Dismantled instruments, strong vertical } \\
\text { movements felt as v gentle rocking motion by } \\
\text { few; distance given as } 12 \text { mi on some } \\
\text { instruments, } 20 \text { mi on others; inferred deep } \\
\text { from Kona and Hilo records; felt hnp, kona; } \\
\text { felt by some in all parts of island. }\end{array}$ & $\begin{array}{l}\text { VL 301, p. 4; VL 302, p. } 4 \text { [Powers } \\
\text { inferred location as deep under } \\
\text { Mokuaweoweo-distances fit Kilauea } \\
\text { deep]; Peters, 1930. HON notes: } \\
\text { Registered at 20:36:33; no amplitude } \\
\text { given; not found in HTH. }\end{array}$ \\
\hline $10 / 20 / 30$ & $8: 25: 00$ & & & & & $\begin{array}{l}\text { kl cal } \\
\text { deep? }\end{array}$ & & 30 & 3 & 3 & 30.15 & $\mathrm{~m}$ & 4.92 & & & & & 5.6 & intensity & 5.25 & nomo & $\mathrm{V}-\mathrm{VI} ; \mathrm{V}(\mathrm{W} \& \mathrm{~K})$ & $\begin{array}{l}\text { Dismantled seismographs; felt-all Hawaii } \\
\text { Island, strongest on Kilauea slopes; } \\
\text { seismograms indicate source under Kilauea } \\
\text { crater. Warshauer notes: Felt in Hilo, Honoka, } \\
\text { Puu Waawa, Kohala, and Waiohinu. Articles } \\
\text { off shelves in Hilo and Waiohinu. }\end{array}$ & $\begin{array}{l}\text { Peters, } 1930 \text {. HON notes: Registered at } \\
\text { 8:25:24; felt sharply at Kilauea, where } \\
\text { all instruments were dismantled; no } \\
\text { amplitude given, dur 20.5 min; distance } \\
\text { assumed; VL } 304, \text { p. } 4 \text {; HTH, } \\
\text { 10/20/1930; see references. }\end{array}$ \\
\hline $10 / 31 / 30$ & $18: 23: 00$ & & & & & $\begin{array}{l}\text { south } \\
\text { hawaii }\end{array}$ & & & & & 51.2 & $\mathrm{~s}$ & 4.29 & & & & & & & 4.29 & nomo & felt & $\begin{array}{l}\text { Felt locally by many persons, and by a few } \\
\text { persons in Hilo; probably felt in Kau and Kona, } \\
\text { but not strong enough to cause comment. }\end{array}$ & Not registered on Oahu; VL 306, p. 2. \\
\hline $12 / 1 / 30$ & $20: 55: 00$ & & & & & $\begin{array}{l}\text { south } \\
\text { hawaii }\end{array}$ & & & & & 51.2 & s? & 4.29 & & & & & & & 4.29 & nomo & felt & Felt from Hilo to Kona (slight?-given as vf). & VL 311, p. 3. \\
\hline $1 / 16 / 31$ & 20:44:00 & & & & & $\begin{array}{l}\mathrm{ml} \mathrm{ner} \\
\text { deep? }\end{array}$ & & & & & 48 & s? & 4.25 & & & & & & & 4.25 & nomo & felt & $\begin{array}{l}\text { Felt generally, more in Hilo and Hamakua } \\
\text { districts than elsewhere; epicenter apparently } \\
\text { under center of island; origin deep under NE } \\
\text { slope of Mauna Loa. }\end{array}$ & $\begin{array}{l}\text { Not registered on Oahu; VL 317, p. 3; } \\
\text { VL 319, p. 3. }\end{array}$ \\
\hline $1 / 29 / 31$ & 23:39:00 & & & & & $\begin{array}{l}\mathrm{kl} \mathrm{cal} \\
\text { deep? }\end{array}$ & & & 22 & 22 & 30 & $\mathrm{~s}$ & 4.40 & & & & & & & 4.40 & nomo & $\begin{array}{l}\text { V (Halemaumau); } \\
\text { V (Waiohinu; } \\
\quad \text { USE) }\end{array}$ & $\begin{array}{l}\text { HON notes: Registered 23:38:08, dur } 10 \mathrm{~s} ; \\
\text { reported felt in Honolulu [Hawaii?]; no amp } \\
\text { given; felt all Hawaii Island; suggest origin } \\
\text { beneath Mauna Loa. Warshauer notes: Felt all } \\
\text { island; duration, } 30 \text { s; no damage; felt all Kona, } \\
\text { Kohala, Hamakua, and Puna. }\end{array}$ & $\begin{array}{l}\text { Distance of } 30 \mathrm{~km} \text { assumed to better fit } \\
\text { data; [VL distance is } 22 \mathrm{~km} \text { ]; Peters, } \\
\text { 1931; VL } 319, \text { p. } 3 \text { [rockfalls in } \\
\text { Halemaumau during quake]; HTH, } \\
\text {, 1/30/1931 [moderate(?) and (or) } \\
\text { deeper(?)] not found in MN. }\end{array}$ \\
\hline $3 / 8 / 31$ & 6:53:00 & & & & & $\begin{array}{l}\text { east } \\
\text { hawaii }\end{array}$ & & & & & 48 & $\mathrm{~s}$ & 4.47 & & & & & & & 4.47 & nomo & felt & Felt in Hilo. & Not registered on Oahu; VL 324, p. 4. \\
\hline $6 / 11 / 31$ & 18:51:00 & & & & & $\mathrm{ml}$ wf? & & & & & 60 & $\mathrm{~s}$ & 4.88 & & & & & & & 4.88 & nomo & $\mathrm{v}$ & $\begin{array}{l}\text { Felt stronger and quicker at Honokahau, small } \\
\text { objects overturned; felt as a slow motion at } \\
\text { Waimea, Hilo, Kau, and hnp. Warshauer notes: } \\
\text { Felt generally on the island, pronounced at } \\
\text { Holualoa, definite in Hilo (Puueo). }\end{array}$ & $\begin{array}{l}\text { Peters, 1931; VL 338, p. 4. HON notes: } \\
\text { Registered at 18:52; local, dur 8 min, } \\
\text { no amplitude given; HTH, 6/12/1931. } \\
\text { Warshauer notes - con.: Powers quoted } \\
\text { : as saying quake } 27 \mathrm{mi} \text { from HVO, on } \\
\text { slopes of Mauna Loa [distance low(?)- } \\
\text { increased to raise mag]. }\end{array}$ \\
\hline $8 / 30 / 31$ & 6:53:00 & & & & & mauna loa & & & & & 24 & st? & 5.00 & & & & & & & 5.00 & nomo & IV & $\begin{array}{l}\text { Time given [in error] as 7:53; felt generally on } \\
\text { Island of Hawaii; dismantled instruments in } \\
\text { Kona, Hilo, and Kilauea; felt as slight and } \\
\text { prolonged tremor at Kilauea, more strongly in } \\
\text { Hilo, Olaa, and Kona; vertical seismograph } \\
\text { indicates origin NW of HVO. }\end{array}$ & $\begin{array}{l}\text { VL 349, p. } 3[15 \mathrm{mi} \text { from HVO; } 30 \mathrm{mi} \\
\text { from Hilo]. }\end{array}$ \\
\hline $12 / 8 / 31$ & 10:22:00 & & & & & kaoiki? & & & & & 22.4 & $\mathrm{~m}$ & 4.43 & & & & & & & 4.43 & nomo & $\mathrm{v}$ & $\begin{array}{l}\text { HON notes: Registered at 10:22:36; local; } \\
\text { amplitude not given; dismantled seismographs; } \\
\text { persons near Mauna Iki reported noise } \\
\text { seemingly from Mauna Loa progressing } \\
\text { underfoot and heard rocks falling down cracks. }\end{array}$ & $\begin{array}{l}\text { Peters, 1931; VL 364, p. 4; not found } \\
\text { in HTH. }\end{array}$ \\
\hline $4 / 26 / 32$ & 1:59:00 & 19 & 36.5 & 155 & $38.5 \mathrm{r}$ & $\mathrm{mlnf}$ & 8 & 8 & & 44.1 & 46.87 & f & 4.23 & & & & & & & 4.23 & nomo & IV-V & $\begin{array}{l}23 \text { mi from Kealakekua, } 32 \text { mi from HVO, } 42 \\
\text { mi from Hilo; saddle between Mauna Loa and } \\
\text { Hualalaia; fett-Haina, Honomu, Hilo, Kamuela, } \\
\text { Kohala, Waikii, hnp. }\end{array}$ & $\begin{array}{l}\text { VL 384, p. 3; Note: distances from } \\
\text { three stations incompatible; lat and } \\
\text { long at center of intersection given; } \\
\text { Honolulu records unavailable; HVO, } \\
\text { unpub. }\end{array}$ \\
\hline $6 / 14 / 32$ & $\begin{array}{r}4: 51: 45 \\
23 \cdot 59 \cdot 00\end{array}$ & 19 & 28.0 & 155 & 22.01 & kaoiki & 13 & 13 & & 11.2 & $\begin{array}{r}17.13 \\
240\end{array}$ & $\mathrm{~m}$ & $\begin{array}{r}4.25 \\
403\end{array}$ & & & & & & & $\begin{array}{r}4.25 \\
4.03\end{array}$ & nomo & $\begin{array}{l}\mathrm{V} ; \mathrm{V} \text { (W\&K); III R } \\
\quad \mathrm{F}(\mathrm{VL})\end{array}$ & $\begin{array}{l}\text { Felt generally Hawaii Island, Maui. Warshauer } \\
\text { notes: Severe earthquake recorded at } 4: 55 \text { a.m.; } \\
\text { dismantled both seismograph components, } \\
\text { strong vertical motion; felt by practically } \\
\text { 2 everyone in Hilo and volcano, not felt in Kona; } \\
\text { no damage, } 9 \text { mi from HVO. }\end{array}$ & $\begin{array}{l}\text {; VL 388; HTH, 6/14/1932 [kl sf better } \\
\text { fits felt reports(?)]; not found in MN. }\end{array}$ \\
\hline
\end{tabular}


8) Table 13. All earthquakes of $M \geq 4.0$ during the period 1903-59-Continued

\begin{tabular}{|c|c|c|c|c|c|c|c|c|c|c|c|c|c|c|c|c|c|c|c|c|c|c|c|}
\hline Date & $\begin{array}{l}\text { Time } \\
\text { (HST) }\end{array}$ & $\begin{array}{c}\text { Lat } \\
\text { (deg) }\end{array}$ & $\begin{array}{c}\text { Lat } \\
\text { (min) }\end{array}$ & $\begin{array}{c}\text { Lon } \\
\text { (deg) }\end{array}$ & $\begin{array}{l}\text { Lon } \\
\text { (min) }\end{array}$ & $\begin{array}{l}\text { Publ. } \\
\text { Depth I }\end{array}$ & $\begin{array}{l}\text { Pref. } \\
\text { Depth }\end{array}$ & $\begin{array}{l}\text { Publ. } \\
\text { Dist. }\end{array}$ & $\begin{array}{l}\text { Calc. } \\
\text { Dist }\end{array}$ & $\begin{array}{l}\text { Slant } \\
\text { dist }\end{array}$ & Mag class & $\begin{array}{c}\mathrm{M} \\
\text { nomo }\end{array}$ & $\begin{array}{c}\text { M M-S } \\
\text { E-W }\end{array}$ & $\begin{array}{c}\text { M M-S } \\
\text { N-S }\end{array}$ & M vert & $\begin{array}{c}\mathrm{M} \text { hor } \\
\mathrm{N}-\mathrm{L}\end{array}$ & $\begin{array}{c}\mathrm{M} \\
\text { other }\end{array}$ & $\begin{array}{l}\mathrm{M} \\
\text { (other) } \\
\text { source }\end{array}$ & $\underset{\mathrm{pref}}{\mathrm{M}} \mathrm{s}$ & $\begin{array}{c}\mathrm{M} \\
\text { (pref) } \\
\text { source }\end{array}$ & $I(\max )$ & Location/felt report & Comment \\
\hline $7 / 7 / 32$ & 22:25:00 & & & & $\mathrm{kl} \mathrm{sf?}$ & & & & & 16 & $\mathrm{~m} ?$ & 4.20 & & & & & & & $4.20 \mathrm{r}$ & nomo & felt & $\begin{array}{l}\text { Warshauer notes: An earthquake, the strongest } \\
\text { in Hilo in many monthss, rocked a section of the } \\
\text { Big Island at } 10: 25 \text { p.m. last night. No damage } \\
\text { was reported from any districts. Felt most } \\
\text { strongly at Hilo, also felt at volcano, slight at } \\
\text { Puu Waawaa \& Kapoho. }\end{array}$ & $\begin{array}{l}\text { Not in VL; HTH, 7/8/1932. Warshauer } \\
\text { notes - con.: Apparently not felt at } \\
\text { Hamakua, Kau, and Kohala. }\end{array}$ \\
\hline $7 / 7 / 32$ & 22:30:49 & 19 & 18.8 & 155 & $15.9 \mathrm{kl} \mathrm{sf}$ & 9.6 & 9.6 & 12.8 & 13.3 & 16.41 & $\mathrm{~m}$ & 4.22 & & & & & & & $4.22 \mathrm{I}$ & nomo & IV-V; V? (PCA) & $\begin{array}{l}8 \mathrm{mi} \text { s of HVO; felt generally Hawaii Island, } \\
\text { Oahu; [kcaldeep?]. Warshauer notes: Hilo } \\
\text { shaken Thursday night by an earthquake which } \\
\text { lasted a full minute at } 10: 29 \text { p.m.; } 15 \mathrm{mif} \text { from } \\
\text { HVO in the direction of Hilo; similar intensity } \\
\text { to event of } 6 / 13 ; \text { no damage. }\end{array}$ & $\begin{array}{l}\text { VL 389; HTH, 7/8/1932; not found in } \\
\text { MN. }\end{array}$ \\
\hline $8 / 19 / 32$ & $12: 30: 00$ & 19 & 47.0 & 156 & $\begin{array}{l}\text { hualalai } \\
4.7 \text { os }\end{array}$ & 19.2 & 19.2 & & 94 & 95.94 & $\mathrm{f}$ & 4.40 & & & & & & & $4.40 \mathrm{r}-2 \mathrm{r}$ & nomo & felt & $\begin{array}{l}3 \mathrm{mi} \mathrm{N} \text { of Keahole pt and } 2 \mathrm{mi} \text { at sea; felt- } \\
\text { Kona, Kohala; Hawi-4; Hilo-felt lying in bed; } \\
\text { Kukuihaele-3. }\end{array}$ & $\begin{array}{l}\text { VL 390; time given by felt reports } \\
\text { (12:25-12:41 p.m.); HVO, unpub. }\end{array}$ \\
\hline $8 / 31 / 32$ & 23:59:00 & & & & kona? & & & & & 72 & $\mathrm{t}$ & 2.72 & & & & & & & $4.06 \mathrm{I}$ & nomo & & $\begin{array}{l}\text { Eqs: } 30 \text { tremors, } 30-60 \text { mi distance; preferred } \\
\text { magnitude calculated a nomogram magnitude } \\
\text { multiplied by number of events. }\end{array}$ & $\begin{array}{l}\text { No specific date or time between } 8 / 29 \\
\text { and } 8 / 31 / 1932 ; \mathrm{VL} 391 \text {. }\end{array}$ \\
\hline $1 / 11 / 33$ & 12:00:00 & & & & kona os? & & & & 320.0 & 320.1 & vf & 4.23 & & & & & & & $4.23 \mathrm{I}$ & nomo & & $\begin{array}{l}\text { A very feeble shock, about } 200 \mathrm{mi} \text { west to } \\
\text { southwest of Hawaii, preceded [the event at } \\
12: 45 \text { ]. This shock was probably in the vicinity } \\
\text { of a large submarine mountain. Note: Loihi } \\
\text { distance about } 53 \mathrm{~km} \text { from Kilauea's summit }\end{array}$ & VL 395 . \\
\hline $1 / 11 / 33$ & 12:45:00 & 20 & 0.0 & 154 & $\begin{array}{l}\text { mauna } \\
49.5 \text { kea? }\end{array}$ & & & & 78.2 & 78.7 & $\mathrm{f}$ & 4.00 & & & & & & & $4.00 \mathrm{r}$ & nomo & & $\begin{array}{l}\text { Location uncertain; } 20-30 \mathrm{mi} \mathrm{NE} \text { of Hilo; } \\
\text { preceded, during the noon hour, by four } \\
\text { foreshocks or tremors at unknown distance. }\end{array}$ & Do. \\
\hline $2 / 4 / 33$ & 6:17:00 & 18 & 42.00 & 155 & $\begin{array}{l}\mathrm{kl} \text { kuer sf } \\
15.00 \text { os deep? }\end{array}$ & & 40.0 & & 81.3 & 90.6 & $\mathrm{f}$ & 4.69 & 4.62 & no trace & & & & & 4.83 & aver & IV & $\begin{array}{l}\text { Felt-Holualoa, Hakalau, Hilo, hnp; Honaunau- } \\
\text { 2; Hakalau-4; hnp-windows rattled, pheasants } \\
\text { squawked; Holualoa-4; preferred magnitude } \\
\text { calculated as average of Honolulu and } \\
\text { nomogram. }\end{array}$ & $\begin{array}{l}50 \text { mi due S of HVO; recorded at three } \\
\text { stations; Honolulu amplitude average } \\
\text { of two readings; VL 396; HVO, unpub. }\end{array}$ \\
\hline $6 / 29 / 33$ & 0:44:00 & 19 & 40.0 & 155 & 48.0 hualalai & 1 & 1 & & 62.6 & 62.6 & $\mathrm{~s}$ & 4.43 & no trace & no trace & & & & & $4.43 \mathrm{r}$ & nomo & VI & $\begin{array}{l}\text { Reported at three or more stations-moved } \\
\text { furniture; damaged stone walls; Puu Ulaula-5, } \\
\text { awakened campers; duration, } 4-5 \mathrm{~s} \text {, dishes } \\
\text { moved; Honomu-4, long and feeble; } \\
\text { Kealakekua-6, building shuddered violently 3-4 } \\
\text { s; Hookena-4, objects moved, stone wall down. }\end{array}$ & $\begin{array}{l}\text { VL 400; HVO, unpub. [intensities- } \\
\text { arabic numerals-in remarks column } \\
\text { refer to HVO postcards]; postcard data } \\
\text { c cont.; Holualoa-4, reported from north } \\
\text { and south Kona; Hilo-3 }\end{array}$ \\
\hline $7 / 31 / 33$ & 11:56:00 & 19 & 20.0 & 155 & 30.0 kaoiki & 16 & 16 & & 27.4 & 31.8 & $\mathrm{~s}$ & 4.44 & 4.76 & $\begin{array}{l}\text { no } \\
\text { record }\end{array}$ & & & & & 4.76 & hono & IV & $\begin{array}{l}\text { Felt sharply Kapapala ranch; Pahala, Naalehu, } \\
\text { Hookena, HNP; Hookena-2, water agitated in } \\
\text { tank;-2, slight; Naalehu-4, stone wall down??; } \\
\text { Paauilo-4, building shook, windows rattled; } \\
\text { Kapapala-house shook strongly. }\end{array}$ & $\begin{array}{l}\text { VL 402; HVO, unpub. [intensities- } \\
\text { arabic numerals-in remarks column } \\
\text { refer to HVO postcards]. }\end{array}$ \\
\hline $9 / 2 / 33$ & 12:00:00 & 19 & 2.0 & 155 & 40.0 hilea & 8 & 8 & & 61.5 & 62.0 & $\mathrm{f}$ & 4.10 & & & & & & & $4.10 \mathrm{r}$ & nomo & & & VL 403 \\
\hline 9/7/33 & 14:40:00 & 19 & 18.0 & 155 & 27.0 hilea & 40 & 40 & & 24.7 & 47.0 & $\mathrm{~s}$ & 4.45 & $<4.37$ & $<4.37$ & & & & & $4.45 \mathrm{I}$ & nomo & III & $\begin{array}{l}\text { Felt-HVO, Hilo; Hilo-2, slight shaking and } \\
\text { creaking of building. }\end{array}$ & $\begin{array}{l}\text { looked for but not found on station } \\
\text { HON film record; time from felt report; } \\
\text { VL 403; HVO, unpub. [intensities- } \\
\text { arabic numerals-in remarks column } \\
\text { refer to HVO postcards] }\end{array}$ \\
\hline $9 / 26 / 33$ & 21:15:00 & 19 & 42.0 & 155 & $23.0 \mathrm{mlnf}$ & 10 & 10 & & 32.6 & 34.1 & $\mathrm{f}$ & 4.01 & & & & & & & $4.01 \mathrm{I}$ & nomo & $\mathrm{v}$ & $\begin{array}{l}\text { Felt-Honomu, Hakalau, Hilo, Pahala, Olaa, } \\
\text { Papaikou. Warshauer notes: Slight quake, felt } \\
\text { in some parts of Hilo;-4, hanging objects } \\
\text { shook, felt all Onomea; Hakalau-6; Olaa-3, jolt, } \\
\text { also felt in Pahala, Hilo-3, mirror swung; } \\
\text { Honomu-6, strong. }\end{array}$ & $\begin{array}{l}\text { VL 403; HTH, 9/27/1933; HVO, } \\
\text { unpub. [intensities-arabic numerals-in } \\
\text { remarks column refer to HVO } \\
\text { postcards] }\end{array}$ \\
\hline $10 / 13 / 33$ & 3:01:00 & 19 & 15.00 & 154 & $\begin{array}{l}\mathrm{kl} \mathrm{ler} \mathrm{sf} \\
23.00 \text { os? }\end{array}$ & & 10.0 & & 94.7 & 95.2 & $\mathrm{~m}$ & 5.20 & $<4.80$ & $<4.66$ & & & & & 4.50 & hono & felt & $\begin{array}{l}\text { Lightly felt; Kealakekua-prolonged gentle } \\
\text { swaying east to west; Hilo-2, felt in Kaumana; } \\
\text { preferred magnitude estimated from Honolulu } \\
\text { data, consistent with felt report. }\end{array}$ & $\begin{array}{l}\text { Closer(?); slight(?); VL 404; HVO, } \\
\text { unpub.; not found in HTH. }\end{array}$ \\
\hline $10 / 19 / 33$ & $5: 57: 00$ & & & & $\mathrm{ml} \mathrm{nf?}$ & & & 28 & 28.0 & 29.4 & $\mathrm{~s}$ & 4.13 & $<4.40$ & $<4.32$ & & & & & $4.13 \mathrm{I}$ & nomo & $\mathrm{V}$ & $\begin{array}{l}\text { Felt-Hilo, Honomu. Warshauer notes: Sharp } \\
\text { temblor rocked Hilo; Hilo-2, III, mirror swung, } \\
\text { building creaked slightly; duration, }, 15-20 \mathrm{~s} ; \\
\text { Honomu-2-3;-3, building creaked. }\end{array}$ & $\begin{array}{l}\text { Looked for but not found on station } \\
\text { HON film record; time given as 5:37- } \\
\text { corrected from felt reports; VL 404; } \\
\text { HTH, 10/19/1933; HVO, unpub. } \\
\text { [intensities-arabi numerals-in remarks } \\
\text { column refer to HVO postcards]. }\end{array}$ \\
\hline
\end{tabular}


Table 13. All earthquakes of $M \geq 4.0$ during the period 1903-59-Continued

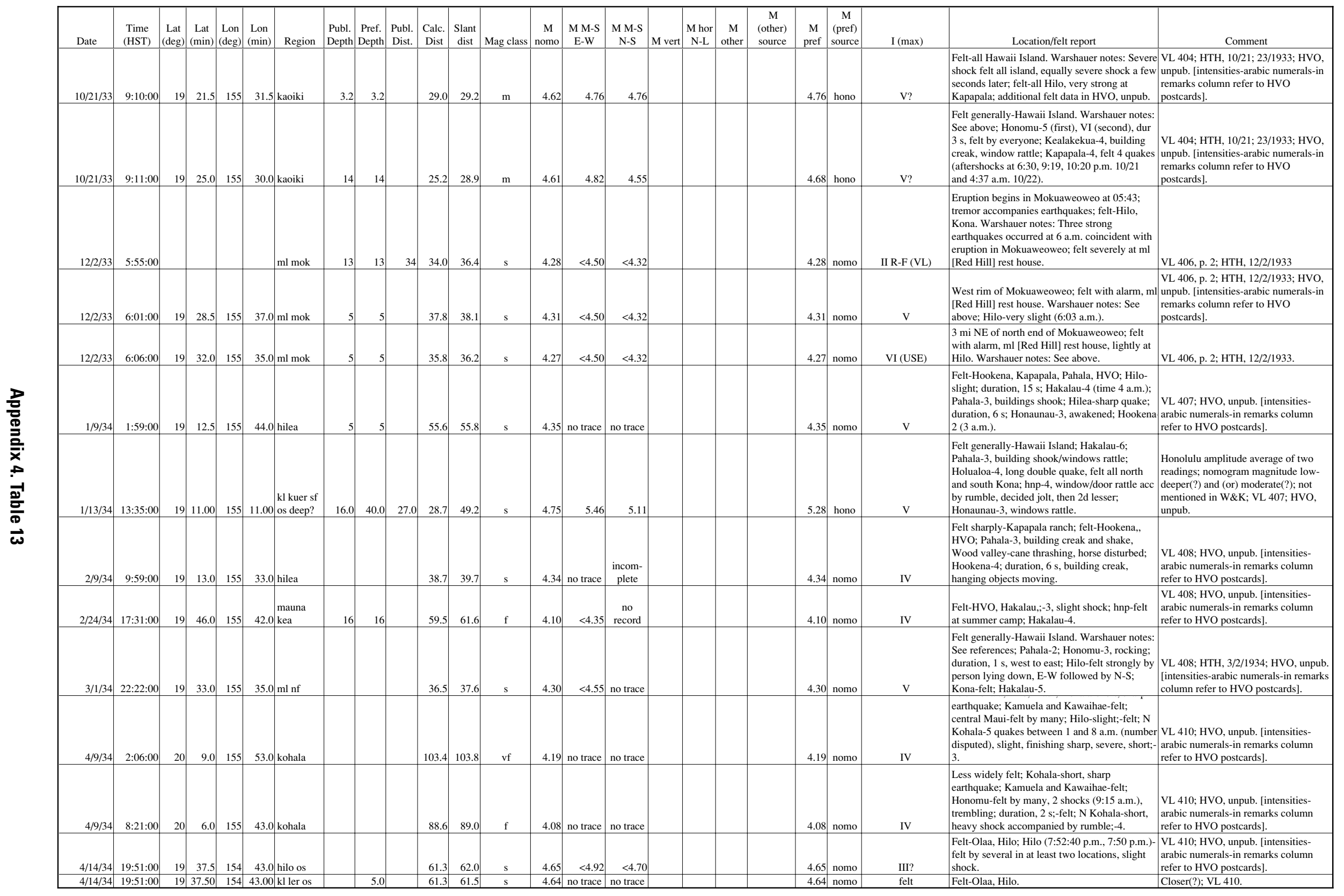


요 Table 13. All earthquakes of $M \geq 4.0$ during the period 1903-59-Continued

\begin{tabular}{|c|c|c|c|c|c|c|c|c|c|c|c|c|c|c|c|c|c|c|c|c|c|c|c|}
\hline Date & $\begin{array}{c}\text { Time } \\
\text { (HST) }\end{array}$ & $\begin{array}{c}\text { Lat } \\
(\mathrm{deg})\end{array}$ & $\begin{array}{c}\text { Lat } \\
(\mathrm{min})\end{array}$ & $\begin{array}{r}\text { Lon } \\
(\operatorname{deg})\end{array}$ & $\begin{array}{c}\text { Lon } \\
(\min )\end{array}$ & $\begin{array}{l}\text { Publ. } \\
\text { Depth }\end{array}$ & $\begin{array}{l}\text { Pref. } \\
\text { Depth }\end{array}$ & $\begin{array}{l}\text { Publ. } \\
\text { Dist. }\end{array}$ & $\begin{array}{l}\text { Calc. } \\
\text { Dist }\end{array}$ & $\begin{array}{c}\text { Slant } \\
\text { dist }\end{array}$ & Mag class & $\begin{array}{c}\mathrm{M} \\
\text { nomo }\end{array}$ & $\begin{array}{c}\text { M M-S } \\
\text { E-W }\end{array}$ & $\begin{array}{c}\text { M M-S } \\
\text { N-S }\end{array}$ & M vert & $\begin{array}{c}\text { M hor } \\
\text { N-L }\end{array}$ & $\begin{array}{c}\mathrm{M} \\
\text { other }\end{array}$ & $\begin{array}{c}\mathrm{M} \\
\text { (other) } \\
\text { source }\end{array}$ & $\begin{array}{c}\mathrm{M} \\
\text { pref }\end{array}$ & $\begin{array}{c}\mathrm{M} \\
\text { (pref) } \\
\text { source }\end{array}$ & $I(\max )$ & Location/felt report & Comment \\
\hline $5 / 10 / 34$ & 10:09:00 & 19 & 38.0 & 155 & $23.0 \mathrm{ml} \mathrm{nf?}$ & 25 & 25 & & 25.9 & 36.0 & m-st & $>5.04$ & 5.80 & 5.60 & & & & & 5.70 & hono & $\mathrm{VI}$ & $\begin{array}{l}\text { Felt-all Hawaii Island, Maui. Warshauer notes: } \\
\text { A strong, slow earthquake, felt severely-Hilo, } \\
\text { people ran into streets; felt slightly at Kona; } \\
\text { much less at Kapapala than Hilo and volcano; } \\
\text { minor damage in N Kohala; dur } 26 \text { s, beginning } \\
\text { light, end sharp. }\end{array}$ & $\begin{array}{l}\text { Depth, } 28 \mathrm{~km} \text { in HVO catalog; VL } 411 \\
\text { [detailed damage report given]; HTH, } \\
\text { g 5/10; } 14 \text { [see below]/1934; additional } \\
\text { felt reports in HVO, unpub. }\end{array}$ \\
\hline $5 / 13 / 34$ & 15:23:00 & 19 & 22.5 & 155 & 22.5 kaoiki & 20 & 20 & & 13.5 & 24.2 & $\mathrm{~s}$ & 4.25 & 4.45 & no trace & & & & & 4.45 & hono & $\mathrm{v}$ & $\begin{array}{l}\text { Felt-HVO, Hilo. Warshauer notes: Hilo rocked } \\
\text { by } 2 \text { shocks } 3 \text { minutes apart, } 2 \mathrm{dmore} \text { feeble; } \\
\text { generally felt, strongly in Kohala, minor } \\
\text { damage; Hilo-3-4, building rocked, felt } \\
\text { moderately, furniture rattled; Honokaa-4. }\end{array}$ & $\begin{array}{l}\text { VL 411; HTH, 5/14/1934; HVO, } \\
\text { unpub. [intensities-arabic numerals-in } \\
\text { remarks column refer to HVO } \\
\text { postcards]. }\end{array}$ \\
\hline $5 / 13 / 34$ & 15:25:00 & 19 & 13.0 & 155 & 39.0 hilea & 4 & 4 & & 47.4 & 47.6 & s & 4.24 & det.? & $\begin{array}{c}\text { over- } \\
\text { exposed }\end{array}$ & & & & & 4.24 & nomo & III & $\begin{array}{l}\text { Felt-HVO, Hilo. Warshauer notes: See above; } \\
\text { Hilo-2-3, v short, hnp-felt. }\end{array}$ & $\begin{array}{l}\text { Aftershock; VL 411; HTH, 5/14/1934; } \\
\text { HVO, unpub. [intensities-arabic } \\
\text { numerals-in remarks column refer to } \\
\text { HVO postcards]. }\end{array}$ \\
\hline $6 / 26 / 34$ & 19:07:00 & 19 & 12.00 & 155 & $\begin{array}{l}\mathrm{kl} \mathrm{mer} \mathrm{sf} \\
5.00 \mathrm{os} ?\end{array}$ & 10.0 & 10.0 & & 31.8 & 33.3 & $\mathrm{~m}$ & 4.71 & 4.75 & 4.75 & & & & & 4.75 & hono & $\mathrm{v}$ & $\begin{array}{l}\text { Felt-Hilo, HVO; more detail given in HVO, } \\
\text { unpub. Warshauer notes: Felt strongly in some } \\
\text { parts of Hilo, and more generally on the island; } \\
\text { no damage. }\end{array}$ & $\begin{array}{l}\text { VL 412; HVO, unpub.; HTH, } \\
6 / 27 / 1934 .\end{array}$ \\
\hline 9/17/34 & 11:56:00 & 19 & 2.0 & 155 & 13.0 loihi & 17 & 17 & & 44.5 & 47.6 & $\mathrm{f}$ & 4.24 & & & & & & & 4.24 & nomo & II & Felt-HVO, Honomu; Honomu-2; duration, 1 s. & $\begin{array}{l}\text { VL } 415 ; \mathrm{HVO} \text {, unpub. [intensities- } \\
\text { arabic numerals-in remarks column } \\
\text { refer to HVO postcards]. }\end{array}$ \\
\hline $10 / 13 / 34$ & 19:14:00 & 19 & 28.0 & 155 & $\begin{array}{l}\text { mauna loa } \\
30.0 \text { deep }\end{array}$ & 65 & 65 & & 25.5 & 69.8 & $\mathrm{~m}$ & 5.22 & 5.22 & 5.18 & & & & & 5.20 & hono & $\mathrm{v}$ & $\begin{array}{l}\text { Felt generally-Hawaii Island. Warshauer notes: } \\
\text { The entire island rocked by an earthquake; } \\
\text { duration, } 30 \text { s, no damage; felt widely in Kona, } \\
\text { also at Waimea, and the Hamakua Coast; } \\
\text { motion gentle swaying, two parts with long } \\
\text { intervals between. }\end{array}$ & $\begin{array}{l}\text { VL 416; HTH, 10/15/1934; extensive } \\
\text { felt reports in HVO, unpub. }\end{array}$ \\
\hline $10 / 19 / 34$ & 0:20:00 & 19 & 30.0 & 155 & $\begin{array}{l}\text { mauna loa } \\
40.0 \text { deep }\end{array}$ & 60 & 60 & & 43.5 & 74.1 & $\mathrm{f}$ & 4.22 & $<4.32$ & $\begin{array}{l}\text { no } \\
\text { record }\end{array}$ & & & & & 4.22 & nomo & $\mathrm{v}$ & $\begin{array}{l}\text { Earthquake of moderate intensity rocked the } \\
\text { Big sland, hard enough in Hilio to awaken } \\
\text { sleepers, no damage; } 3 \text { sharp quakes felt in } \\
\text { Waimea, followed by several of slighter } \\
\text { intensity. }\end{array}$ & $\begin{array}{l}\text { VL 416; [some aftershocks evidently } \\
\text { not recorded at Whitney vault]; HTH, } \\
\text { 10/19/1934; extensive felt reports in } \\
\text { HVO, unpub. [felt reports give date as } \\
\text { 10/19]. }\end{array}$ \\
\hline $1 / 2 / 35$ & 6:47:17 & 19 & 25.50 & 155 & $\begin{array}{r}\mathrm{kl} \mathrm{cal} \\
17.00 \text { deep }\end{array}$ & 3.0 & 30.0 & & 2.4 & 30.1 & $\mathrm{~m}$ & 4.64 & 4.75 & 4.80 & & & 5.90 & $\begin{array}{l}\text { W\&K; } \\
\text { S\&C }\end{array}$ & 5.15 & aver & $\begin{array}{l}\mathrm{VI}(\mathrm{W} \& \mathrm{~K}) ; \mathrm{V} \\
\quad(\mathrm{C} \& \mathrm{~S})\end{array}$ & $\begin{array}{l}\text { Felt generally-Hawaii Island, objects fell in } \\
\text { Hilo, landllide at Halemaumau. Warshauer } \\
\text { notes: Felt-all island, least in Kohala; two } \\
\text { waves, slight, then heavy; bottles, pictures } \\
\text { broken in Hilo; pref mag calculated as } \\
\text { weighted average of WK(1) and Hono( } 2 \text { ). }\end{array}$ & $\begin{array}{l}\text { Isoseismal map in W\&K ( } M=5.9 \text { too } \\
\text { high because intensity V in Kau and } \\
\text { Kona incorrect); depth changed to } \\
\text { improve magnitude agreement, } \\
\text { consistent with felt reports; VL } 419 ; \\
\text { HTH, 1/2/1935; additional felt data in } \\
\text { HVO, unpub. }\end{array}$ \\
\hline $3 / 3 / 35$ & 0:12:00 & & & & maui? & & & & & 240.0 & vf & 4.03 & 4.27 & 4.43 & & & & & 4.35 & hono & $\mathrm{v}$ & $\begin{array}{l}\text { Haleakala-4, movement up and down, cement } \\
\text { cornice of building fell off; Wailuku-not very } \\
\text { strong; felt-all Maui, Oahu, and in Kohala. }\end{array}$ & $\begin{array}{l}\text { Not separately reported in VL } 420 \text {, but } \\
\text { included in table; time from station } \\
\text { HON film record, } \text { HVO, unpub. } \\
\text { [intensities-arabic numerals-in remarks } \\
\text { column refer to HVO postcards]; } \\
\text { Maui/Molokai consistent with Hon } \\
\text { mag and felt reports. }\end{array}$ \\
\hline $6 / 5 / 35$ & 6:55:00 & 19 & 28.0 & 155 & 48.0 kona & 24 & 24 & & 57.0 & 61.8 & $\mathrm{f}$ & 4.10 & $<4.62$ & $<4.55$ & & & & & 4.10 & nomo & III & $\begin{array}{l}\text { Felt-HVO and Honokaa; Honokaa-felt a light } \\
\text { shake. }\end{array}$ & $\begin{array}{l}\text { VL 424; HVO, unpub. [intensities- } \\
\text { arabic numerals-in remarks column } \\
\text { refer to HVO postcards]; stronger trace } \\
\text { on Kona seismograph. }\end{array}$ \\
\hline $6 / 25 / 35$ & 0:45:00 & 19 & 26.50 & 155 & $\begin{array}{l}\mathrm{kl} \mathrm{cal} \mathrm{10-} \\
16.5020\end{array}$ & 5.0 & 15.0 & & 1.9 & 15.1 & $\mathrm{~m}$ & 4.16 & $<4.37$ & $<4.42$ & & & & & 4.16 & nomo & $\mathrm{v}$ & $\begin{array}{l}\text { Awakened people generally south side Hawaii } \\
\text { Island, dismantled seismographs; Anuhea-3, } \\
\text { building creaked;-quite a shock; hnp-wakened } \\
\text { many, quite hard at; Puu Ulaula-wakened party } \\
\text { at rest house; Papaikou-felt, Hilo-many } \\
\text { awakened. }\end{array}$ & $\begin{array}{l}\text { Greater depth assumed consistent with } \\
\text { felt reports; VL 424; HVO unpub. }\end{array}$ \\
\hline $6 / 27 / 35$ & 8:14:00 & 19 & 40.0 & 156 & 0.0 hualalai & & & & 82.2 & 82.7 & $\mathrm{vf}$ & 4.03 & $<4.07$ & $<4.07$ & & & & & 4.03 & nomo & $\mathrm{v}$ & $\begin{array}{l}\text { Felt-north Kona, Puu Waawaa. Warshauer } \\
\text { notes: While the Kona district yesterday } \\
\text { morning June 27] experienced one of the } \\
\text { worst quakes in the past } 6 \text { years, the entire } \\
\text { district being rocked; dishes knocked off in } \\
\text { Kona, felt hard at Puu Waawaa. }\end{array}$ & $\begin{array}{l}\text { Looked for but not found on station } \\
\text { HON film record; VL } 424 ; \mathrm{HTH}, \\
6 / 28 / 1935 \text {. }\end{array}$ \\
\hline
\end{tabular}


Table 13. All earthquakes of $M \geq 4.0$ during the period 1903-59-Continued

\begin{tabular}{|c|c|c|c|c|c|c|c|c|c|c|c|c|c|c|c|c|c|c|c|c|c|c|c|}
\hline Date & $\begin{array}{l}\text { Time } \\
\text { (HST) }\end{array}$ & $\begin{array}{c}\text { Lat } \\
\text { (deg) }\end{array}$ & $\begin{array}{c}\text { Lat } \\
\text { (min) }\end{array}$ & $\begin{array}{c}\text { Lon } \\
\text { (deg) }\end{array}$ & $\begin{array}{l}\text { Lon } \\
\text { (min) }\end{array}$ & $\begin{array}{l}\text { Publ. } \\
\text { Depth D }\end{array}$ & $\begin{array}{l}\text { Pref. } \\
\text { Depth }\end{array}$ & $\begin{array}{l}\text { Publ. } \\
\text { Dist. }\end{array}$ & $\begin{array}{l}\text { Calc. } \\
\text { Dist }\end{array}$ & $\begin{array}{l}\text { Slant } \\
\text { dist }\end{array}$ & Mag class & $\begin{array}{c}\mathrm{M} \\
\text { nomo }\end{array}$ & $\begin{array}{l}\text { M M-S } \\
\text { E-W }\end{array}$ & $\begin{array}{c}\text { M M-S } \\
\text { N-S }\end{array}$ & M vert & $\begin{array}{c}\text { M hor } \\
\text { N-L }\end{array}$ & $\begin{array}{c}\mathrm{M} \\
\text { other }\end{array}$ & $\begin{array}{l}\mathrm{M} \\
\text { (other) } \\
\text { source }\end{array}$ & $\begin{array}{c}\mathrm{M} \\
\text { pref }\end{array}$ & $\begin{array}{c}\mathrm{M} \\
\text { (pref) } \\
\text { source }\end{array}$ & $I(\max )$ & Location/felt report & Comment \\
\hline $6 / 28 / 35$ & 9:00:00 & & & & $\mathrm{kl} \mathrm{sf?}$ & 8.0 & 10.0 & & 19.2 & 21.6 & m-st & 4.69 & 5.71 & 5.82 & & & $\begin{array}{l}5.6 ; \\
5.7\end{array}$ & $\begin{array}{l}\text { GUTE; } \\
\text { W\&K }\end{array}$ & 5.76 & aver & $\begin{array}{l}\text { VI; VI (W\&K; } \\
\text { S\&C); V (USE) }\end{array}$ & $\begin{array}{l}\text { Dismantled seismographs; some damage in } \\
\text { Hilio; felt generally-Hawaii Island; extensive } \\
\text { felt reports in HVO, unpub. Warshauer notes: } \\
\text { hard in Hilo/Kapoho, less in Kona//Kohala; } \\
\text { preferred magnitude calculated as an average of } \\
\text { GUTE, W\&K, and Honolulu. }\end{array}$ & $\begin{array}{l}\text { Isoseismal map in W\&K [location } \\
\text { given in VL (19.6, 155.18-Mauna Loa } \\
\text { NE rift) disagrees with felt reports } \\
\text { f which strongly favor ks sff; VL 424; } \\
\text { HVO, unpub.; HTH, 6/28/1935. }\end{array}$ \\
\hline $9 / 30 / 35$ & 22:36:00 & 19 & 22.0 & 155 & $39.5 \mathrm{ml} \mathrm{swr}$ & 45 & 45 & & 42.5 & 61.9 & $\mathrm{~m}$ & 4.90 & 4.70 & 4.80 & & & & & 4.75 & hono & IV & $\begin{array}{l}\text { Felt generally-Hawaii Island. Warshauer notes: } \\
\text { Felt locally (long, swaying), one of } 4 \text { shocks } \\
\text { felt islandwide, no damage. }\end{array}$ & $\begin{array}{l}\text { Seismogram pictured in VL 444, p. } 3 \text {; } \\
\text { VL 428; HTH, 10/1/1935. }\end{array}$ \\
\hline $9 / 30 / 35$ & 23:58:00 & 19 & 38.7 & 155 & $26.3 \mathrm{mlnf}$ & 26 & 26 & & 30.3 & 39.9 & m-st & 5.61 & 5.46 & 5.79 & & & & & 5.62 & hono & V; IV (S\&C) & $\begin{array}{l}\text { Felt-all Hawaii Island, some damage in Hilo. } \\
\text { Warshauer notes: Strongest of series; felt Hilo, } \\
\text { volcano, Kau, Kona; no damage. }\end{array}$ & $\begin{array}{l}\text { Seismogram pictured in VL 444, p. } 3 \text {, } \\
\text { E-W labeled m-dismantled, p. 5, n-s } \\
\text { labeled slight; assume drum moves at } \\
60 \mathrm{~mm} / \mathrm{min} \text {, amp > } 142 \mathrm{~mm} \text { E-W, } 95 \\
\mathrm{~mm} \mathrm{~N}-\mathrm{S} \text { [st, as measured]; } \mathrm{VL} \text { L } 28 ; \\
\text { HTH, 10/1/1935; additional felt reports } \\
\text { in HVO, unpub. }\end{array}$ \\
\hline $10 / 1 / 35$ & 0:02:00 & 19 & 38.7 & 155 & $26.3 \mathrm{ml} \mathrm{nf} ?$ & & & & 30.3 & 31.6 & $\mathrm{~m}$ & 4.67 & $\begin{array}{c}\text { lost in } \\
\mathrm{ms}\end{array}$ & $\begin{array}{c}\text { lost in } \\
\text { ms }\end{array}$ & & & & & 4.67 & nomo & felt & $\begin{array}{l}\text { Felt as a continuation of M=5.6 eq; location } \\
\text { uncertain. Warshauer notes: Felt-Hilo, } \\
\text { Volcano, Kau, Kona (Holualoa-light shock); } \\
\text { Honomu-felt(?). }\end{array}$ & $\begin{array}{l}\text { VL 428; HTH, 10/1/1935; HVO, } \\
\text { unpub. [intensities-arabic numerals-in } \\
\text { remarks column refer to HVO } \\
\text { postcards]. }\end{array}$ \\
\hline $10 / 1 / 35$ & 0:34:00 & 19 & 38.7 & 155 & $26.3 \mathrm{ml} \mathrm{nf?}$ & & & & 30.3 & 31.6 & $\mathrm{~s}$ & 4.18 & & & & & & & 4.18 & nomo & felt & $\begin{array}{l}\text { Associated with preceding two quakes. } \\
\text { Warshauer notes: Felt-Hilo, not volcano. }\end{array}$ & VL 428; HTH, 10/1/1935. \\
\hline $10 / 1 / 35$ & 10:22:00 & 19 & 38.3 & 155 & $19.2 \mathrm{ml}$ ner & & & & 23.9 & 25.5 & $\mathrm{~m}$ & 4.29 & $<4.63$ & 4.15 & & & & & 4.15 & hono & II & $\begin{array}{l}\text { Felt-Hilo and HVO; felt at Pahala and Hilo } \\
\text { (10:37); Hilo-2. }\end{array}$ & $\begin{array}{l}\text { Honolulu data average of two readings; } \\
\text { VL 428; HVO, unpub. [intensities- } \\
\text { arabic numerals-in remarks column } \\
\text { refer to HVO postcards]. }\end{array}$ \\
\hline $11 / 21 / 35$ & 1:11:00 & 19 & 31.0 & 155 & $31.5 \mathrm{ml} \mathrm{ner}$ & 5 & 5 & & 29.4 & 29.8 & $\mathrm{~m}(\mathrm{st}$ ?) & 5.64 & 5.03 & 5.05 & & & 5.6 & $\mathrm{~W} \& \mathrm{~K}$ & 5.43 & aver & VI; V (S\&C) & $\begin{array}{l}\text { Felt-Waikiki (Oahu), Hana (Maui), Kapapala } \\
\text { ranch; duration, } 90 \text {, items soff shelves, } \\
\text { window broke. Warshauer notes: See } \\
\text { references; extensive felt reports in HVO, } \\
\text { unpub.; preferred magnitude calculated as } \\
\text { average of Honolulu, Whitney as read, and } \\
\text { W\&K. }\end{array}$ & $\begin{array}{l}\text { Isoseismal map in W\&K; seismogram } \\
\text { pictured in VL 444, p. 1, assume drum } \\
\text { moves at } 60 \mathrm{~mm} / \mathrm{min}, \text { amp } 210 \mathrm{~mm} \mathrm{N-} \\
\text { S [st, as measured]]; seesmogram s-p } \\
\text { agrees with VL distance; HTH, } \\
11 / 21 / 1935 ; \mathrm{HVO} \text {, unpub.--see } \\
\text { references. }\end{array}$ \\
\hline $11 / 21 / 35$ & 18:35:00 & & & & $\mathrm{ml}$ ner & & 5 & 34 & 34.0 & 34.4 & $\mathrm{~s}$ & 4.01 & & & & & & & 4.01 & nomo & & Do. & $\begin{array}{l}\text { Mauna Loa eruption begins, from north } \\
\text { bay of Mokuaweoweo to Red Hill, } 4 \mathrm{mi} \\
\text { down Mauna Loa northeast rift zone; } \\
\text { VL } 429 \text {. }\end{array}$ \\
\hline $11 / 21 / 35$ & 18:42:00 & & & & $\mathrm{ml} \mathrm{ner}$ & & 5 & 34 & 34.0 & 34.4 & $\mathrm{~s}$ & 4.01 & & & & & & & 4.01 & nomo & & Do. & VL 429. \\
\hline $2 / 5 / 36$ & 12:00:00 & 19 & 35.8 & 155 & $41.3 \mathrm{ml} \mathrm{nf}$ deep & 33.6 & 33.6 & & 48.7 & 59.1 & $\mathrm{f}$ & 4.07 & $<5.22$ & $<5.22$ & & & & & 4.07 & nomo & felt & $5 \mathrm{mi} \mathrm{NW}$ of Puu Koli; felt-Hilo, hnp. & VL 432, p. 2; time not given. \\
\hline $3 / 21 / 36$ & 15:50:00 & & & & hualalai & & & 77 & 77.0 & 77.5 & $\mathrm{f}$ & 4.26 & $<4.77$ & no trace & & & & & 4.26 & nomo & & W slope Hualalai. & VL 433, p. 3 \\
\hline $4 / 15 / 36$ & 8:27:00 & 19 & 24.00 & 155 & $\begin{array}{l}\mathrm{kl} \mathrm{cal} \\
15.00 \text { deep }\end{array}$ & 30.0 & 30.0 & & 3.6 & 30.2 & $\mathrm{~m}$ & 4.64 & 4.72 & 4.60 & & & & & 4.66 & hono & $\begin{array}{l}\mathrm{V} \text { (USE); IV } \\
\text { (kona) }\end{array}$ & $\begin{array}{l}\text { Felt generally-Hawaii Island, specificic reports } \\
\text { from Olaa, Hookena, and Hamakua coast; felt } \\
\text { rather strongly in volcano; E-W component } \\
\text { dismantled; Hookena-3, building creaked. }\end{array}$ & VL 434, p. 2; HVO, unpub. \\
\hline $1 / 31 / 37$ & 7:33:00 & 19 & 45.5 & 155 & 55.3 hualalai & 28.8 & 28.8 & & 78.6 & 83.7 & $\mathrm{~s}$ & 4.63 & $<4.77$ & $<4.77$ & & & & & 4.63 & nomo & IV & $\begin{array}{l}\text { Felt-Hookena, Kamuela. Warshauer notes: The } \\
\text { entire island was rocked by an earthquake at } \\
\text { 7:34 a.m. Sunday; estimated to originate in } \\
\text { Hualalai direction; Hookena-4 ( } 7: 02 \\
\text { a.m- - same event??), building creaked, hanging } \\
\text { objects moved. }\end{array}$ & $\begin{array}{l}\text { VL 444, p. 6; HTH, 2/1/1937; HVO, } \\
\text { unpub. [intensities-arabic numerals-in } \\
\text { remarks column refer to HVO } \\
\text { postcards]. }\end{array}$ \\
\hline $4 / 9 / 37$ & 7:29:00 & 19 & 16.30 & 155 & $12.20 \mathrm{kl} \mathrm{kuer} \mathrm{sf}$ & 11.2 & 11.2 & & 18.7 & 21.8 & $\mathrm{~m}$ & 4.42 & $<4.65$ & $<4.81$ & & & & & 4.42 & nomo & & & VL 446, p. 7. \\
\hline 4/18/37 & 4:10:00 & 19 & 41.7 & 155 & 52.3 hualalai & & & & 70.8 & 71.3 & $\mathrm{f}$ & 4.20 & $<4.35$ & $<4.47$ & & & & & 4.20 & nomo & IV & $\begin{array}{l}\text { Waawaa (strong). Warshauer notes: Felt } \\
\text { sharply throughout island, more in Waimea } \\
\text { and; v strong at; additional felt reports in HVO, } \\
\text { unpub. }\end{array}$ & $\begin{array}{l}\text { VL 446, p. } 7 ; \mathrm{HTH}, 4 / 19 / 1937 ; \mathrm{HVO} \text {, } \\
\text { unpub. [intensities-arabic numerals-in } \\
\text { remarks column refer to HVO } \\
\text { postcards]. }\end{array}$ \\
\hline $7 / 30 / 37$ & 14:40:00 & 19 & 32.0 & 155 & $28.0 \mathrm{ml} \mathrm{ner}$ & & & & 24.5 & 26.1 & $\mathrm{~m}$ & 4.30 & 4.28 & 4.20 & & & & & 4.24 & hono & & Near Puu Ulaula. & VL 449, p. 7. \\
\hline $1 / 22 / 38$ & 22:03:00 & 21 & 12.0 & 156 & 6.0 maui & & & & 215.7 & 215.9 & m-st & 6.29 & $>6.2$ & $>6.2$ & & & 6.8 & GUTE & 6.80 & gute & $\begin{array}{l}\text { VIII; VIII (W\&K; } \\
\text { Cox); VII (S\&C) }\end{array}$ & $\begin{array}{l}\text { Felt throughout the Hawaiian chain. Warshauer } \\
\text { notes: A quake, duration, } 90 \mathrm{~s} \text {, felt in every } \\
\text { section of the big island, also on Maui, Oahu, } \\
\text { and Kauai; channel between Maui and Kohala; } \\
\text { maximum damage (broken dishes and } \\
\text { rearranged furniture) in both places. }\end{array}$ & $\begin{array}{l}\text { Isoseismal map in W\&K; Neumann, } \\
\text { 1940a Honolulu station dismantled]; } \\
\text { VL 455, p. 6-7 [damage report given]; } \\
\text { Jaggar, 1938 [damage reports from all } \\
\text { islands]; HTH, 1/24-28/1938; extensive } \\
\text { felt reports in HVO, unpub. }\end{array}$ \\
\hline
\end{tabular}


¿ Table 13. All earthquakes of $M \geq 4.0$ during the period 1903-59-Continued

\begin{tabular}{|c|c|c|c|c|c|c|c|c|c|c|c|c|c|c|c|c|c|c|c|c|c|c|c|}
\hline Date & $\begin{array}{l}\text { Time } \\
\text { (HST) }\end{array}$ & $\begin{array}{l}\text { Lat } \\
\text { (deg) }\end{array}$ & $\begin{array}{c}\text { Lat } \\
(\mathrm{min})\end{array}$ & $\begin{array}{l}\text { Lon } \\
\text { (deg) }\end{array}$ & $\begin{array}{c}\text { Lon } \\
(\mathrm{min})\end{array}$ & $\begin{array}{l}\text { Publ. } \\
\text { Depth D }\end{array}$ & $\begin{array}{ll}\text { Pref. } & \text { P } \\
\text { Depth } & \text { I }\end{array}$ & $\begin{array}{l}\text { Publ. } \\
\text { Dist. }\end{array}$ & $\begin{array}{l}\text { Calc. } \\
\text { Dist }\end{array}$ & $\begin{array}{c}\text { Slant } \\
\text { dist }\end{array}$ & Mag class & $\begin{array}{c}\mathrm{M} \\
\text { nomo }\end{array}$ & $\begin{array}{l}\text { M M-S } \\
\text { E-W }\end{array}$ & $\begin{array}{c}\text { M M-S } \\
\text { N-S }\end{array}$ & M vert & $\begin{array}{c}\text { M hor } \\
\text { N-L }\end{array}$ & $\begin{array}{c}\mathrm{M} \\
\text { other }\end{array}$ & $\begin{array}{c}\mathrm{M} \\
\text { (other) } \\
\text { source }\end{array}$ & $\begin{array}{c}\mathrm{M} \\
\text { pref }\end{array}$ & $\begin{array}{c}\mathrm{M} \\
\text { (pref) } \\
\text { source }\end{array}$ & $I(\max )$ & Location/felt report & Comment \\
\hline $2 / 17 / 38$ & 2:18:00 & 19 & 33.0 & 155 & $27.0 \mathrm{ml} \mathrm{ner}$ & 12.8 & 12.8 & & 23.9 & 27.1 & $\mathrm{~m}$ & 4.33 & 4.27 & no trace & & & & & 4.27 & hono & IV-V & $\begin{array}{l}\text { Felt strongly in Kona and hnp, slightly by } \\
\text { many in Hilo; Kealakekua-very slight single } \\
\text { shake; duration, } 3-5 \mathrm{~s} \text {. }\end{array}$ & $\begin{array}{l}\text { VL 456, p. 3; HVO, unpub. [intensities- } \\
\text { arabic numerals-in remarks column } \\
\text { refer to HVO postcards]. }\end{array}$ \\
\hline $3 / 7 / 38$ & $5: 56: 00$ & 19 & 42.0 & 155 & $\begin{array}{l}\text { mauna loa } \\
32.0 \text { deep }\end{array}$ & 44.8 & 44.8 & & 41.5 & 61.0 & $\mathrm{~m}$ & 4.89 & 4.91 & 4.28 & & & & & 4.60 & hono & $\mathrm{v}$ & $\begin{array}{l}\text { Felt-Hilo, Kona, hnp. Warshauer notes: rocked } \\
\text { entire island; double shock in Hilo and volcano, } \\
\text { both prolonged; mod strong, duration, } 30 \text { s, } \\
\text { waking many; strong at, slight at Kohala and } \\
\text { Puu Waawaa; prolonged at Kona; HVO } \\
\text { seismometers dismantled. }\end{array}$ & $\begin{array}{l}\text { VL 457, p. 6; HTH, 3/7/1938; } \\
\text { additional felt reports in HVO, unpub. }\end{array}$ \\
\hline $5 / 28 / 38$ & 6:35:00 & & & & $\begin{array}{l}\mathrm{kl} \mathrm{cal} \\
\text { deep? }\end{array}$ & & 30.0 & & 5.1 & 30.4 & s? & 4.15 & 4.30 & 4.07 & & & & & 4.18 & hono & felt & $\begin{array}{l}\text { Should be feeble if kcaldeep, slight if south } \\
\text { flank, moderate if uer; obscured by tremor(?); } \\
\text { felt(?). }\end{array}$ & $\begin{array}{l}\text { Not in VL } 459 \text {; kuer sf or kcaldeep(?) } \\
\text { to be consistent with being recorded on } \\
\text { Oahu. }\end{array}$ \\
\hline $6 / 1 / 38$ & 10:38:00 & 19 & 18.20 & 155 & $11.50 \mathrm{kl}$ kuer sf & 11.2 & 10.0 & & 16.0 & 18.8 & $\mathrm{~m}$ & 4.31 & $\begin{array}{l}\text { no } \\
\text { record }\end{array}$ & $\begin{array}{l}\text { no } \\
\text { record }\end{array}$ & & & & & 4.31 & nomo & & $\begin{array}{l}\text { Warshauer notes: A moderate shock about } \\
\text { 10:45 a.m. Wednesday dismantled the } \\
\text { instruments }\end{array}$ & $\begin{array}{l}\text { Station HON film record missing; VL } \\
\text { 460, p. } 3 ; \text { HTH, 6/6/1938; not found in } \\
\text { PCA. }\end{array}$ \\
\hline $6 / 2 / 38$ & 15:33:00 & 19 & 21.70 & 155 & $\begin{array}{l}\mathrm{kl} \mathrm{cal} \\
19.50 \text { deep }\end{array}$ & 24.0 & 24.0 & & 10.2 & 26.1 & $\mathrm{~s}$ & 4.05 & $<4.50$ & $<4.42$ & & & & & 4.05 & nomo & & & VL 460, p. 3; not found in PCA. \\
\hline $8 / 8 / 38$ & 23:59:00 & & & & kl uer & & 3.0 & 5.6 & 5.6 & 6.4 & $\mathrm{~s}$ & 3.06 & & & & & & & 4.42 & calc & & $\begin{array}{l}\text { Assume uer/Koae; average depth, } 3 \mathrm{~km} \text {; } \\
\text { average distance, } 5.6 \mathrm{~km} \text {; preferred magnitude } \\
\text { calculated as nomogram magnitude multiplied } \\
\text { by number of events. }\end{array}$ & $\begin{array}{l}\text { Earthquake swarm; } 31 \text { events (slight) } \\
\text { not separately tabulated in VL } 462 \text { or } \\
\text { recorded in Honolulu. }\end{array}$ \\
\hline $8 / 8 / 38$ & 23:59:00 & & & & kl uer & & 3.0 & 5.6 & 5.6 & 6.4 & $\mathrm{f}$ & 2.52 & & & & & & & 4.02 & calc & & $\begin{array}{l}\text { Assume uer/Koae; av depth }=3 \mathrm{~km} \text {; average } \\
\text { distance, } 5.6 \mathrm{~km} ; \text { preferred magnitude } \\
\text { calculated as nomogram magnitude multiplied } \\
\text { by number of events. }\end{array}$ & $\begin{array}{l}\text { Earthquake swarm; } 45 \text { events (feeble) } \\
\text { not separately tabulated in VL } 462 \text { or } \\
\text { recorded in Honolulu. }\end{array}$ \\
\hline $10 / 25 / 38$ & 12:18:00 & 19 & 27.80 & 155 & $\begin{array}{c}\mathrm{kl} \mathrm{gln} \\
9.50 \text { deep }\end{array}$ & 25.6 & 25.6 & & 11.4 & 28.0 & $\mathrm{~s}$ & 4.10 & $<4.2$ & $<4.2$ & & & & & 4.10 & nomo & III & $\begin{array}{l}\text { Felt-Hilo, hnp. Warshauer notes: An } \\
\text { earthquake, classified as slight at Kilauea } \\
\text { observatory, was sharply felt in Hilo yesterday } \\
\text { about 12:20 p.m. }\end{array}$ & VL 462, p. 5; HTH, 10/26/1938. \\
\hline $10 / 27 / 38$ & 18:11:00 & 19 & 42.0 & 155 & 50.2 hualalai & 24 & 9 & & 67.7 & 68.3 & $\mathrm{~s}$ (kona?) & 4.00 & $<3.95$ & $<4.07$ & & & & & 4.00 & nomo & $\mathrm{v}$ & $\begin{array}{l}\text { Felt-Kona,; Hookena-5, sharp perpendicular } \\
\text { shock followed by gentle side motion for } 5-6 \mathrm{~s} \text {, } \\
\text { buildings creak, hanging objects move, water } \\
\text { tanks slopped over; Kealakekua-telephone } \\
\text { central reports strong shock. }\end{array}$ & $\begin{array}{l}\text { Better fit if distance referenced to } \\
\text { Kona, not Whitney; shallower(?); VL } \\
462, \text { p. } 5 ; \text { HVO, unpub. [intensities- } \\
\text { arabic numerals-in remarks column } \\
\text { refer to HVO postcards]. }\end{array}$ \\
\hline $1 / 19 / 39$ & 14:58:00 & 19 & 41.6 & 155 & 52.0 hualalai & 25.6 & 25.6 & & 20.8 & 33.0 & $\mathrm{~s}$ & 4.21 & 4.35 & 4.16 & & & & & 4.25 & hono & IV & $\begin{array}{l}\text { Felt strongly-Kona, Kohala; lightly-Hilo, Kau. } \\
\text { Warshauer notes: An earthuaake rocked the } \\
\text { Kona area at 2:58 p.m.t today for about } 15 \\
\text { seconds. No damage was reported; felt strongly } \\
\text { Kona, short and sharp at, slight in Kau, not felt } \\
\text { at Volcano or Hilo. }\end{array}$ & $\begin{array}{l}\text { Magnitudes agree if amplitude } \\
\text { referenced to distance from Kona } \\
\text { seismometer; VL } 463, \mathrm{p} .2 ; \mathrm{HA}, \\
1 / 20 / 1939 ; \mathrm{HTH}, 1 / 20 / 1939 ; \text { see } \\
\text { references for complete felt report. }\end{array}$ \\
\hline $4 / 12 / 39$ & 4:18:00 & 19 & 27.00 & 155 & $\begin{array}{c}\mathrm{kl} \mathrm{gln} \\
14.00 \text { deep }\end{array}$ & 28.8 & 28.8 & & 3.6 & 29.0 & $\mathrm{~s}$ & 4.12 & $<4.32$ & $<4.32$ & & & & & 4.12 & nomo & $\mathrm{v}$ & $\begin{array}{l}\text { Felt-Hilo, Olaa, hnp; Hilo-3. Warshauer notes: } \\
\text { felt generally on Big island; awakened sleepers } \\
\text { in Hilo; no damage. }\end{array}$ & $\begin{array}{l}\text { VL 464, p. 5; HVO unpub; HTH, } \\
\text { 4/12/19939 }\end{array}$ \\
\hline $5 / 15 / 39$ & 10:28:00 & 19 & 22.00 & 155 & $8.00 \mathrm{kl} \mathrm{mer} \mathrm{sf}$ & 16.0 & 10.0 & & 15.2 & 18.2 & m-st & 4.74 & 5.06 & 4.73 & & & & & 4.90 & hono & VI; VI (S\&C) & $\begin{array}{l}\text { Strongly felt-all Hawaii Island except Kohala; } \\
\text { strongest in Hilo (slight damagee to masonry } \\
\text { and plaster) and hnp. Warshauer notes: Felt } \\
\text { strongly in all districts except Kohala; minor } \\
\text { damage in Hilo, household articles knocked } \\
\text { from shelves, building cracks. }\end{array}$ & $\begin{array}{l}\text { south flank (likely considering high } \\
\text { mag and not felt in Kohala); ; L 464, p. } \\
\text { 6; additional felt reports in HVO, } \\
\text { unpub.; HTH, 5/15/1939; see HVO, } \\
\text { unpub., and references for complete } \\
\text { felt report. }\end{array}$ \\
\hline $5 / 23 / 39$ & 14:14:00 & 19 & 28.5 & 155 & 22.0 kaoiki & 19.2 & 19.2 & & 12.2 & 22.7 & m-st & 4.72 & 4.88 & 5.07 & & & 4.8 & W\&K & 4.97 & hono & VI & $\begin{array}{l}\text { Felt generally-Hawaii Island; all seismographs } \\
\text { on island dismantled. Warshauer notes: Felt in } \\
\text { all districts except Kohala; strong like last } \\
\text { week; Kona, Hilo, and volcano stronger than } \\
\text { last week; Kauu strong; duration, } 30 \text { s; many } \\
\text { aftershocks. }\end{array}$ & $\begin{array}{l}\text { Isoseismal map in W\&K; Cox, 1986; } \\
\text { Honolulu records suggest that quake } \\
\text { has different source from 5/24/39 kl cal } \\
\text { deep; mag agreement OK for Kaoiki } \\
\text { quake at depth given; VL 464, p. 6; } \\
\text { HTH 5/23; 224/1939; additional felt } \\
\text { reports in references and HVO, unpub. }\end{array}$ \\
\hline $\begin{array}{l}5 / 24 / 39 \\
5 / 24 / 39 \\
\end{array}$ & $\begin{array}{l}\text { 12:59:00 } \\
\text { 13:09:00 } \\
\end{array}$ & $\begin{array}{l}19 \\
19 \\
\end{array}$ & $\begin{array}{r}25.00 \\
25.00 \\
\end{array}$ & $\begin{array}{l}155 \\
155 \\
\end{array}$ & $\begin{array}{l}\mathrm{kl} \text { cal } \\
14.00 \text { deep } \\
14.00 \text { deep } \\
\end{array}$ & $\begin{array}{l}24.0 \\
32.0 \\
\end{array}$ & $\begin{array}{l}30.0 \\
32.0 \\
\end{array}$ & & $\begin{array}{l}3.3 \\
3.3 \\
\end{array}$ & $\begin{array}{l}30.2 \\
32.2 \\
\end{array}$ & $\begin{array}{c}\mathrm{m}-\mathrm{st} \\
\mathrm{s}\end{array}$ & $\begin{array}{r}4.92 \\
4.19 \\
\end{array}$ & $\begin{array}{r}5.26 \\
\text { no trace } \\
\end{array}$ & $\begin{array}{r}5.52 \\
\text { no trace } \\
\end{array}$ & & & & & $\begin{array}{l}5.39 \\
4.19 \\
\end{array}$ & $\begin{array}{l}\text { hono } \\
\text { nomo }\end{array}$ & VI & $\begin{array}{l}\text { Felt-entire Hawaii Island, dismantling all } \\
\text { instruments. Warshauer notes: Felt in all } \\
\text { districts of Hawaii Island, also Oahu [denied, } \\
\text { HTH, May 26]; objects knocked from shelves } \\
\text { in volcano district, duration, } 15 \mathrm{~s} \text { (felt), } 6 \text { min } \\
\text { (instr.); deep Kilauea origin. } \\
\text { hnp-felt, caused landslide in Halemaumau. }\end{array}$ & $\begin{array}{l}\text { Honolulu amplitude average of two } \\
\text { readings; VL 464, p. 6; HTH, 5/24; } \\
\text { 26/1939; see also HVO, unpub., and } \\
\text { references for additional felt reports. } \\
\text { VL 464, p. 6; HVO, unpub. }\end{array}$ \\
\hline
\end{tabular}


Table 13. All earthquakes of $M \geq 4.0$ during the period 1903-59-Continued

\begin{tabular}{|c|c|c|c|c|c|c|c|c|c|c|c|c|c|c|c|c|c|c|c|c|c|c|c|}
\hline Date & $\begin{array}{l}\text { Time } \\
\text { (HST) }\end{array}$ & $\begin{array}{l}\text { Lat } \\
\text { (deg) }\end{array}$ & $\begin{array}{c}\text { Lat } \\
(\mathrm{min})\end{array}$ & $\begin{array}{l}\text { Lon } \\
\text { (deg) }\end{array}$ & $\begin{array}{cc}\text { Lon } \\
(\min ) & \text { Region }\end{array}$ & $\begin{array}{l}\text { Publ. } \\
\text { Depth I }\end{array}$ & $\begin{array}{l}\text { Pref. } \\
\text { Depth }\end{array}$ & $\begin{array}{l}\text { Publ. } \\
\text { Dist. }\end{array}$ & $\begin{array}{l}\text { Calc. } \\
\text { Dist }\end{array}$ & $\begin{array}{l}\text { Slant } \\
\text { dist }\end{array}$ & Mag class & $\begin{array}{c}\mathrm{M} \\
\text { nomo }\end{array}$ & $\begin{array}{c}\text { M M-S } \\
\text { E-W }\end{array}$ & $\begin{array}{c}\text { M M-S } \\
\text { N-S }\end{array}$ & $M$ vert & $\begin{array}{c}\mathrm{M} \text { hor } \\
\mathrm{N}-\mathrm{L}\end{array}$ & $\begin{array}{c}\mathrm{M} \\
\text { other }\end{array}$ & $\begin{array}{l}\mathrm{M} \\
\text { (other) } \\
\text { source }\end{array}$ & $\begin{array}{c}\mathrm{M} \\
\text { pref }\end{array}$ & $\begin{array}{c}\mathrm{M} \\
\begin{array}{c}\text { (pref) } \\
\text { source }\end{array}\end{array}$ & $I(\max )$ & Location/felt report & Comment \\
\hline $5 / 29 / 39$ & 19:15:00 & 19 & 30.0 & 156 & 50.0 lanai se & 40 & 40 & & 166.0 & 170.7 & vf & 4.53 & 4.91 & 4.78 & & & & & 4.85 & hono & $\mathrm{v}$ & $\begin{array}{l}\text { Felt widely-Oahu, Maui; } 20-30 \mathrm{mi} \text { deep, } 90 \mathrm{mi} \\
\text { S of Lanai. Warashauer notes: Felt sharply } \\
\text { throughout Oahu, not felt on Hawaii; } 150 \mathrm{mi} \\
\text { from Honolulu, duration, } 10 \text { s (felt), } 5 \mathrm{~min} \\
\text { (instr.;); recorded at HVO; felt on Oahu, Maui, } \\
\text { and Hawaii. }\end{array}$ & $\begin{array}{l}\text { Attenuated at Whitney(?); VL 464, p. } \\
6 ; \text { HTH, 5/30/1939; HA, 5/30/1939; } \\
\text { see additional felt reports in references } \\
\text { and HVO, unpub. }\end{array}$ \\
\hline $5 / 31 / 39$ & 15:10:00 & 19 & 18.50 & 155 & $14.50 \mathrm{kl}$ kuer sf & 17.6 & 10.0 & & 13.8 & 17.0 & m-st & 4.52 & 4.71 & 4.63 & & & & & 4.67 & hono & $\mathrm{v}$ & hnp-6. & $\begin{array}{l}\text { Honolulu amplitude average of two } \\
\text { readings; VL 464, p. } 6 ; \mathrm{HVO} \text {, unpub. }\end{array}$ \\
\hline $5 / 31 / 39$ & 20:38:00 & 19 & 37.5 & 155 & $15.5 \mathrm{ml} \mathrm{ner}$ & 19.2 & 19.2 & & 21.6 & 28.9 & $\mathrm{~s}$ & 4.12 & & & & & & & 4.12 & nomo & $\mathrm{v}$ & $\begin{array}{l}\text { Felt-Hilo, hnp. Warshauer notes: Generally felt } \\
\text { throughout volcano and by a few persons in } \\
\text { Hilo; hnp-6. }\end{array}$ & $\begin{array}{l}\text { VL 464, p. 6; HTH, 6/1/1939; HVO, } \\
\text { unpub. [intensities-arabic numerals-in } \\
\text { remarks column refer to HVO } \\
\text { postcards]. }\end{array}$ \\
\hline $5 / 31 / 39$ & 20:51:00 & 19 & 34.0 & 155 & 10.5 kaoiki & 17.6 & 17.6 & & 17.6 & 24.9 & m-st & 4.78 & 4.45 & 4.60 & & & & & 4.52 & hono & $\mathrm{v}$ & $\begin{array}{l}\text { Felt-all Kau, Hilo, all island, strong at hnp. } \\
\text { Warshauer notes: Very hard in volcano and all } \\
\text { Hilo, windows and doors rattled; duration, }>30 \\
\text { s; slight in Kohala and Kona; hnp-6; Paauhau- } \\
3 \text {, quite sharp, duration, } 5 \text { s; Hilo-slight, felt by } \\
\text { most. }\end{array}$ & $\begin{array}{l}\text { Shallower(?); VL 464, p. 6; HTH, } \\
\text { 6/1/1939; HVO, unpub. [intensities- } \\
\text { arabic numerals-in remarks column } \\
\text { refer to HVO postcards]. }\end{array}$ \\
\hline $6 / 12 / 39$ & 1:11:00 & 192 & 21.00 & 155 & $\begin{array}{r}\mathrm{kl} \mathrm{cal} \\
17.00 \text { deep }\end{array}$ & 20.8 & 20.8 & & 9.3 & 22.8 & m-st & 4.72 & 4.64 & 4.65 & & & & & 4.65 & hono & $\mathrm{v}$ & $\begin{array}{l}\text { Felt generally-Hawaii Island, strongest in Hilo } \\
\text { and hnp; Kealakekua-short tremor, slight } \\
\text { shake, short tremor; hilo-mod, wakened many; } \\
\text { hnp-3, wakened persons. Warshauer notes: } \\
\text { Hilo-wakened person, prolonged rattling of } \\
\text { windows/doors; dismantled instruments }\end{array}$ & $\begin{array}{l}\text { Honolulu amplitude average of two } \\
\text { readings, possible surface waves noted } \\
\text { on Honolulu seismogram; VL } 464, \mathrm{p} \text {. } \\
6 ; \text { HVO, unpub.; HTH, 6/12/1939; } \\
\text { weaker than earlier four shocks; felt } \\
\text { duration, } 30 \mathrm{~s} \text {. }\end{array}$ \\
\hline $6 / 19 / 39$ & 3:49:00 & 192 & 25.30 & 155 & $\begin{array}{r}\mathrm{kl} \mathrm{cal} \\
15.00 \text { deep }\end{array}$ & 24.0 & 24.0 & & 1.6 & 24.1 & $\mathrm{~m}$ & 4.25 & $<4.60$ & $<4.53$ & & & & & 4.25 & nomo & III & $\begin{array}{l}\text { Felt-Hilo, hnp; Hilo (time } 3: 38: 15 \text {-same } \\
\text { event?), } 2 \text { mild waves, slight, felt by a few. } \\
\text { Warshauer notes: Slight to moderate quake was } \\
\text { generally felt in the Hilo and volcano districts } \\
\text { at } 3448 \text {; } 5 \text { a.m. In Hilo, felt as a prolonged } \\
\text { shock, not strong. }\end{array}$ & $\begin{array}{l}\text { Time changed to agree with newspaper } \\
\text { and postcard data; VL 464, p. } 7 ; \text { HVO, } \\
\text { unpub.; HTH, 6/19/1939. }\end{array}$ \\
\hline $7 / 1 / 39$ & 0:20:00 & 192 & 23.00 & 155 & $\begin{array}{l}\mathrm{kl} \text { cal 10- } \\
11.5020 ?\end{array}$ & 17.6 & 17.6 & & 9.0 & 19.8 & $\mathrm{~m}$ & 4.35 & 4.30 & 4.48 & & & & & 4.39 & hono & $\mathrm{v}$ & $\begin{array}{l}\text { Awakened many in Hilo and hnp, dism seis; } \\
\text { hale Pohaku (Mauna Kea)-fairly sharp quake, } \\
\text { dur } 3-4 \mathrm{~s} \text {, wakened most sleepers; hilo-3, } \\
\text { wakened. Warshauer notes: Felt-all Hilo and } \\
\text { volcano dist; dur } \sim 6 \text { min, felt } ~ 15 \mathrm{~s} \text {; rattled } \\
\text { windows, awakened many, no damage. }\end{array}$ & $\begin{array}{l}\text { Honolulu amplitude average of two } \\
\text { readings; VL } 464, \text { p. } 7 ; \mathrm{HVO} \text {, unpub.; } \\
\text { HTH, 7/1/1939. }\end{array}$ \\
\hline $7 / 14 / 39$ & 3:51:00 & 191 & 19.50 & 155 & $7.00 \mathrm{kl} \mathrm{mer} \mathrm{sf}$ & 8.0 & 8.0 & & 19.2 & 20.8 & m-st & 4.66 & 4.99 & 5.08 & & & 5.50 & $\begin{array}{l}\text { W\&K; } \\
\text { S\&C }\end{array}$ & 5.04 & hono & $\mathrm{V} ; \mathrm{V}(\mathrm{S} \& \mathrm{C})$ & $\begin{array}{l}\text { Felt generally-Hawaii Island; intensity greatest } \\
\text { in Kau, Puna; sleepers wakened in Hilo, hnpp; } \\
\text { unuusually strong at Pahoo. Warshauer notes: } \\
\text { Felt-entire island, strongest in Puna \& volcano } \\
\text { district, sleepers awakened and windows } \\
\text { rattled, but no damage done. }\end{array}$ & $\begin{array}{l}\text { Honolulu amplitude average of two } \\
\text { readings; isoseismal map in W\&K } \\
\text { (mag too high?); VL 465, p. } 5 \text {; HTH, } \\
\text { 7/14/1939; see HVO, unpub., and } \\
\text { references for complete felt report. }\end{array}$ \\
\hline $8 / 5 / 39$ & 13:46:00 & 19 & 31.0 & 156 & 2.0 hualalai? & 12.8 & 12.8 & & 82.0 & 83.0 & vf & 4.03 & & & & & & & 4.03 & nomo & IV & $\begin{array}{l}\text { Felt-Holualoa, Hookena; Hookena-2; Kau and } \\
\text { Kona-rather sharp and short, single shake with } \\
\text { vertical motion; Holualoa-5. }\end{array}$ & $\begin{array}{l}\text { VL } 465 \text {, p. 5; HVO, unpub. [intensities- } \\
\text { arabic numerals-in remarks column } \\
\text { refer to HVO postcards]; not found in } \\
\text { HTH. }\end{array}$ \\
\hline $8 / 17 / 39$ & 5:57:00 & 191 & 19.50 & 155 & $6.50 \mathrm{kl} \mathrm{mer} \mathrm{sf}$ & 12.8 & 10.0 & & 20.0 & 22.3 & $\mathrm{~m}$ & 4.43 & 4.26 & 4.46 & & & & & 4.36 & hono & & No intensity reports! & $\begin{array}{l}\text { Honolulu amplitude average of two } \\
\text { readings; VL } 465 \text {, p. } 6 \text {; not found in } \\
\text { HTH. }\end{array}$ \\
\hline $8 / 17 / 39$ & 6:18:00 & 192 & 21.50 & 155 & $7.00 \mathrm{kl} \mathrm{mer} \mathrm{sf}$ & 6.4 & 6.4 & & 17.2 & 18.4 & $\mathrm{~m}$ & 4.30 & $<4.46$ & $<4.46$ & & & & & 4.30 & nomo & & Do. & VL 465, p. 6; not found in HTH. \\
\hline $6 / 11 / 40$ & $17: 32: 00$ & 19 & 26.8 & 155 & 31.6 kaoiki & 28.8 & 28.8 & & 28.1 & 40.2 & $\mathrm{~s}-\mathrm{m}(\mathrm{f}-\mathrm{s}$ ?) & 4.12 & $<4.27$ & $<4.02$ & & & & & 4.12 & nomo & $\mathrm{v}$ & $\begin{array}{l}\text { Felt-Hookena, Kealakekua, hnp; Kealakekua- } \\
\text { slight tremor followed by shake that dwindled } \\
\text { away; duration, } 5 \mathrm{~s} \text {; Hookena-4, slight tremble } \\
\text { followed by sharp shake, buildings shook, } \\
\text { objects on shelves moved. }\end{array}$ & $\begin{array}{l}\text { Feeble-slight(?); shallower(?); VL 468, } \\
\text { p. 12; HVO, unpub. [intensities-arabic } \\
\text { numerals-in remarks column refer to } \\
\text { HVO postcards]. }\end{array}$ \\
\hline $6 / 16 / 40$ & 23:56:49 & 21 & 0.0 & 155 & 18.0 maui east & & & & 174.5 & 174.8 & st & 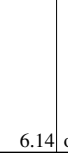 & off scale & off scale & & & 6.0 & GUTE & 6.00 & gute & VI; V (S\&C) & $\begin{array}{l}\text { Felt generally-Hawaiian chain, particularly on } \\
\text { Oahu, Maui, Hawaii. Warshauer notes: At least } \\
2 \text { sharp earthquakes felt in Honolulu; ; irst } \\
\text { lasted several seconds, windows rattled, houses } \\
\text { creaked; also Hilo, Maui, Molokai (articles off } \\
\text { shelves); no damage. }\end{array}$ & $\begin{array}{l}\text { Isoseismal map in W\&K; VL 468, p. } \\
12 \text { [detailed felt report given]; HSB; } \\
\text { HTH; HA, 6/17/1940; additional felt } \\
\text { reports in HVO, unpub. }\end{array}$ \\
\hline
\end{tabular}


N Table 13. All earthquakes of $M \geq 4.0$ during the period 1903-59-Continued

\begin{tabular}{|c|c|c|c|c|c|c|c|c|c|c|c|c|c|c|c|c|c|c|c|c|c|c|c|}
\hline Date & $\begin{array}{l}\text { Time } \\
\text { (HST) }\end{array}$ & $\begin{aligned} \text { Lat } \\
\text { (deg) }\end{aligned}$ & $\begin{array}{c}\text { Lat } \\
(\mathrm{min})\end{array}$ & $\begin{array}{l}\text { Lon } \\
\text { (deg) }\end{array}$ & $\begin{array}{c}\text { Lon } \\
(\min )\end{array}$ Region & $\begin{array}{l}\text { Publ. } \\
\text { Depth I }\end{array}$ & $\begin{array}{l}\text { Pref. } \\
\text { Depth }\end{array}$ & $\begin{array}{l}\text { Publ. } \\
\text { Dist. }\end{array}$ & $\begin{array}{l}\text { Calc. } \\
\text { Dist }\end{array}$ & $\begin{array}{c}\text { Slant } \\
\text { dist }\end{array}$ & Mag class & $\begin{array}{c}\mathrm{M} \\
\text { nomo }\end{array}$ & $\begin{array}{c}\text { M M-S } \\
\text { E-W }\end{array}$ & $\begin{array}{c}\text { M M-S } \\
\text { N-S }\end{array}$ & $M$ vert & $\begin{array}{c}\text { M hor } \\
\mathrm{N}-\mathrm{L}\end{array}$ & $\begin{array}{c}\mathrm{M} \\
\text { other }\end{array}$ & $\begin{array}{l}\mathrm{M} \\
\text { (other) } \\
\text { source }\end{array}$ & $\begin{array}{c}\mathrm{M} \\
\text { pref }\end{array}$ & $\begin{array}{c}\mathrm{M} \\
\text { (pref) } \\
\text { source }\end{array}$ & $I(\max )$ & Location/felt report & Comment \\
\hline $6 / 17 / 40$ & 0:14:00 & 21 & 0.0 & 155 & 18.0 maui east & & & & 174.5 & 174.8 & $\mathrm{~s}$ & 5.37 & $\begin{array}{c}\text { lost in } \\
\mathrm{ms}\end{array}$ & $\begin{array}{c}\text { lost in } \\
\mathrm{ms}\end{array}$ & & & & & 5.37 & nomo & IV & $\begin{array}{l}\text { Aftershock of 6/16/40 earthquake. Warshauer } \\
\text { notes: Slight shock; duration, } 2 \mathrm{~s} \text {; second slight } \\
\text { quake; Kealakekua-very slight and very short; } \\
\text { Hookena-2; duration, } 5 \mathrm{~s} \text {, sort of bubbling } \\
\text { motion; (Maui)-4, shook windows. }\end{array}$ & $\begin{array}{l}\text { VL 468, p. 12; HSB; HTH, 6/17/1940; } \\
\text { HVO, unpub. [intensities-arabic } \\
\text { numerals-in remarks column refer to } \\
\text { HVO postcards]. }\end{array}$ \\
\hline $6 / 17 / 40$ & 7:47:00 & 21 & 0.0 & 155 & 18.0 maui east & & & & 174.5 & 174.8 & m (f?) & 4.82 & 4.59 & 4.72 & & & & & 4.65 & hono & $\mathrm{V}(\mathrm{S} \& \mathrm{C})$ & $\begin{array}{l}\text { Aftershock of 6/16/40 earthquake; felt-Hawaii, } \\
\text { Maui, Oahu. Warshauer notes: A moderate } \\
\text { quake. }\end{array}$ & $\begin{array}{l}\text { Honolulu data average of two readings; } \\
\text { nomogram agrees only if earthquake is } \\
\text { "feeble"; error in VL(?); VL 468, p. 12; } \\
\text { HSB; HTH, 6/17/1940. }\end{array}$ \\
\hline $6 / 17 / 40$ & 12:39:00 & 21 & 0.0 & 155 & 18.0 maui east & & & & 174.5 & 174.8 & $\mathrm{~s}$ & 5.37 & 5.42 & 5.00 & & & & & 5.20 & hono & $\begin{array}{l}\mathrm{V} \text { (S\&C); III } \\
\text { (hamakua) }\end{array}$ & $\begin{array}{l}\text { Aftershock of 6/16/40 quake; felt-Hawaii, } \\
\text { Maui, Oahu. Warshauer notes: Another } \\
\text { aftershock bet slight and moderate; Hakalau- } \\
\text { moderate; Kealakekua-very slight shake of 2-s } \\
\text { dur, felt by few; Paauhau-3,2-s med vib, } 2 \\
\text { lighter vibs; Wailuku-3, shook windows. }\end{array}$ & $\begin{array}{l}\text { VL 468, p. 12; HTH, 6/17/1940; HVO, } \\
\text { unpub. [intensities-arabic numerals-in } \\
\text { remarks column refer to HVO } \\
\text { postcards]. }\end{array}$ \\
\hline $7 / 4 / 40$ & $15: 55: 00$ & 20 & 4.9 & 154 & $\begin{array}{r}\text { mauna } \\
42.2 \text { kea os }\end{array}$ & & & & 93.2 & 93.7 & $\mathrm{f}$ & 4.12 & 4.05 & 4.00 & & & & & 4.03 & hono & & $40 \mathrm{mi} \mathrm{NE}$ of Hilo. & VL 469, p. 5. \\
\hline $7 / 9 / 40$ & 19:30:00 & 20 & 8.6 & 155 & $\begin{array}{r}\text { mauna } \\
9.1 \text { kea os }\end{array}$ & & & & 80.0 & 80.6 & $\mathrm{f}$ & 4.61 & 4.78 & 4.78 & & & & & 4.78 & hono & & Offshore $12 \mathrm{mi} \mathrm{NE}$ of Ookala. & Do. \\
\hline $7 / 15 / 40$ & $16: 48: 00$ & 20 & 54.0 & 155 & 8.0 maui east & & & & 163.9 & 164.2 & $\mathrm{~m}$ & 5.82 & 5.90 & 5.91 & & & 5.6 & GUTE & 5.90 & hono & $\mathrm{V} ; \mathrm{V}(\mathrm{S} \& \mathrm{C})$ & $\begin{array}{l}\text { Main shock: felt-all islands exc Kauai. } \\
\text { Warshauer notes: Strong at Kohala; duration, } \\
30 \mathrm{~s} \text { s slight in Hilo, felt by many; Paauhau-3, } \\
\text { single brief very noticeable vibration; } \\
\text { Ulupalakua (Maui-)-ilight shock; duration, } 20 \mathrm{~s} ; \\
\text { visible bouncing of bed mattresses. }\end{array}$ & $\begin{array}{l}\text { W\&K report M } 5.5 \text {-not derived from } \\
\text { felt area; VL } 469, \text { p. } 5 ; \text { HTH, } \\
7 / 16 / 1940 ; \text { HA, } 7 / 18 / 1940 ; \text { HVO, } \\
\text { unpub. [intensities-arabic numerals-in } \\
\text { remarks column refer to HVO } \\
\text { postcards]. }\end{array}$ \\
\hline $7 / 15 / 40$ & 21:13:00 & 20 & 54.0 & 155 & 8.0 maui east & & & & 163.9 & 164.2 & $\mathrm{vf}$ & 4.51 & 4.52 & 4.52 & & & & & 4.52 & hono & II & $\begin{array}{l}\text { Paauhau, Maui (Ulupalakua); Ulupalakua } \\
\text { (Maui)-extremely slight, horizontal E-W } \\
\text { motion, double shake with 1/2-s separation; } \\
\text { Paauhau-2, single vibration, brief and very } \\
\text { weak. }\end{array}$ & $\begin{array}{l}\text { VL } 469, \text { p. } 5 \text {; HVO, unpub. [intensities- } \\
\text { arabic numerals-in remarks column } \\
\text { refer to HVO postcards]. }\end{array}$ \\
\hline $9 / 1 / 40$ & 22:15:00 & 21 & 0.0 & 155 & 16.0 maui east & & & & 174.5 & 174.7 & $\mathrm{~m}$ & 5.62 & 5.58 & 5.20 & & & 5.6 & GUTE & 5.39 & hono & $\begin{array}{l}\text { IV (S\&C); V } \\
\text { (USE) }\end{array}$ & Felt generally-Hawaii Island. & $\begin{array}{l}\text { W\&K report M 5.5-not derived from } \\
\text { felt area; VL 469, p. 5; not found in } \\
\text { HTH. }\end{array}$ \\
\hline $1 / 17 / 41$ & 7:30:00 & 19 & 40.3 & 156 & 3.5 hualalai & 22.4 & 22.4 & & 88.2 & 91.0 & $\mathrm{~s}$ & 4.91 & 4.77 & 3.93 & & & & & 4.77 & hono & VI & $\begin{array}{l}\text { Felt strongly-Puu Waawaa; also, Kailua, } \\
\text { Hookena, Hilo; Puu Waawaa ranch-6, } \\
\text { buildings shook quite hard, some objects fell } \\
\text { off shelves; Hookena-2, building shaken; } \\
\text { Waimea-rattled windows; duration, } 15 \mathrm{~s} \text {. }\end{array}$ & $\begin{array}{l}\text { VL 471, p. 4; not found in HTH; HVO, } \\
\text { unpub. [intensities-arabic numerals-in } \\
\text { remarks column refer to HVO } \\
\text { postcards]. }\end{array}$ \\
\hline $1 / 18 / 41$ & 9:34:00 & 20 & 12.3 & 155 & $\begin{array}{r}\text { mauna } \\
13.2 \text { kea os }\end{array}$ & & & & 86.2 & 86.6 & f & 4.33 & 4.62 & 4.44 & & & & & 4.53 & hono & & $\begin{array}{l}15 \mathrm{mi} \mathrm{N} \text { of Papaaloa near earthquakes of } \\
\text { summer } 1940 \text {. }\end{array}$ & VL 471, p. 4; not found in HTH. \\
\hline $2 / 8 / 41$ & 9:19:00 & 20 & 10.2 & 155 & $\begin{array}{r}\text { mauna } \\
0.0 \text { kea os }\end{array}$ & & & & 86.7 & 87.1 & $\mathrm{f}$ & 4.34 & 4.56 & 4.69 & & & & & 4.62 & hono & & & Do. \\
\hline $2 / 11 / 41$ & $21: 56: 00$ & 20 & 34.0 & 154 & 49.0 kohala os & & & & 134.7 & 135.0 & $\mathrm{f}$ & 4.37 & 4.13 & 4.01 & & & & & 4.07 & hono & & & VL 471, p. 4. \\
\hline $2 / 18 / 41$ & $11: 53: 00$ & 19 & 41.0 & 155 & 39.0 deep & 48 & 48 & & 49.7 & 69.1 & $\mathrm{~s}$ & 4.72 & 4.56 & 4.56 & & & & & 4.56 & hono & & & VL 471, p. 4; not found in HTH. \\
\hline $4 / 20 / 41$ & 10:46:00 & 19 & 23.90 & 155 & $\begin{array}{r}\mathrm{kl} \mathrm{cal} \\
16.00 \text { deep }\end{array}$ & 1.6 & 25.0 & & 3.7 & 25.3 & $\mathrm{~m}$ & 4.52 & 4.58 & 4.47 & & & & & 4.53 & hono & IV & $\begin{array}{l}\text { Felt-hnp, Kau, Kona, Hilo. Warshauer notes: A } \\
\text { moderate earthquake felt throughout East } \\
\text { Hawaii dismantled instruments at } \mathrm{HVO} \text { and } \\
\text { Halemaumau; felt duration, about } 30 \mathrm{~s} ; \\
\text { occurred at } 1114 \text { a amm [time off?], preceded by } \\
\text { a series of lesser quakes. }\end{array}$ & $\begin{array}{l}\text { VL 472, p. 3; HTH, 4/21/1941; see } \\
\text { HVO, unpub., for additional felt } \\
\text { reports. }\end{array}$ \\
\hline $9 / 25 / 41$ & 7:18:00 & 19 & 21.0 & 155 & 27.0 kaoiki & 11.2 & 11.2 & & 21.9 & 24.6 & m-st & 4.78 & 5.80 & 5.85 & & & 6.0 & & 5.82 & hono & VII; VII (S\&C) & $\begin{array}{l}\text { SE flank ml, } 4 \text { mi N of Kapapala ranch house; } \\
\text { felt generally-Hawaii Island, by some in } \\
\text { Honolulu. Warshauer notes: Felt most strongly- } \\
\text { Pahala and Kapapala, dishes fell, bottles } \\
\text { broken; plaster cracked in Hilo; strong at } \\
\text { Kohala, Puna, and Kona; no damage. }\end{array}$ & $\begin{array}{l}\text { Isoseismal map in W\&K; strong(?); VL } \\
473 \text { [includes damage report; } \\
\text { - dismantled all seismographs, low mag } \\
\text { instrument not operating], p. 3; HTH, } \\
9 \text { /25/1941; extensive felt reports in } \\
\text { HVO, unpub. }\end{array}$ \\
\hline $10 / 25 / 41$ & 8:54:00 & & & & $\begin{array}{l}\text { mauna } \\
\text { kea }\end{array}$ & & 40 & 73 & 73.0 & 83.2 & $\mathrm{f}$ & 4.63 & 4.96 & 5.20 & & & & & 5.08 & hono & felt & $\begin{array}{l}\text { N slope Mauna Kea near, felt generally-Hawaii } \\
\text { Island; this and subsequent quakes precursory } \\
\text { to Mauna Kea swarm starting November } 13 \text {. } \\
\text { Warshauer notes: Felt at Hawaii National Park, } \\
\text { Hilo, and Kohala. }\end{array}$ & $\begin{array}{l}\text { Slight(?); VL 474, p. 3; HTH, } \\
\text { 10/30/1941. }\end{array}$ \\
\hline $11 / 13 / 41$ & 20:07:00 & 20 & 4.0 & 155 & $\begin{array}{c}\text { mauna } \\
42.0 \text { kea? }\end{array}$ & & 43 & 83.2 & 84.5 & 94.8 & $\mathrm{f} ; \mathrm{s}(\mathrm{ml})$ & 4.40 & $\begin{array}{r}3.99 ; \\
4.61\end{array}$ & $\begin{array}{l}\text { thick } \\
\text { line }\end{array}$ & & & & & 4.30 & hono & felt & $\begin{array}{l}52 \text { mi from HVO; felt- Warshauer notes: Felt } \\
\text { at; felt in Kohala, north Kona, Hamakua, and } \\
\text { [probably] at Kilauea. }\end{array}$ & $\begin{array}{l}\text { HON magnitude average of two } \\
\text { readings; VL 474, p. 3; HTH, 11/15; } \\
21 / 1941 \text {. }\end{array}$ \\
\hline
\end{tabular}


Table 13. All earthquakes of $M \geq 4.0$ during the period 1903-59-Continued

\begin{tabular}{|c|c|c|c|c|c|c|c|c|c|c|c|c|c|c|c|c|c|c|c|c|c|c|c|}
\hline Date & $\begin{array}{l}\text { Time } \\
\text { (HST) }\end{array}$ & $\begin{array}{l}\text { Lat } \\
\text { (deg) }\end{array}$ & $\begin{array}{c}\text { Lat } \\
(\mathrm{min})\end{array}$ & $\begin{array}{c}\text { Lon } \\
\text { (deg) }\end{array}$ & $\begin{array}{l}\text { Lon } \\
(\min )\end{array}$ & $\begin{array}{l}\text { Publ. } \\
\text { Depth I }\end{array}$ & $\begin{array}{l}\text { Pref. } \\
\text { Depth }\end{array}$ & $\begin{array}{l}\text { Publ. } \\
\text { Dist. }\end{array}$ & $\begin{array}{l}\text { Calc. } \\
\text { Dist }\end{array}$ & $\begin{array}{c}\text { Slant } \\
\text { dist }\end{array}$ & Mag class & $\begin{array}{c}M \\
\text { nomo }\end{array}$ & $\begin{array}{c}\text { M M-S } \\
\text { E-W }\end{array}$ & $\begin{array}{l}\text { M M-S } \\
\text { N-S }\end{array}$ & M vert & $\begin{array}{c}\text { M hor } \\
\mathrm{N}-\mathrm{L}\end{array}$ & $\begin{array}{c}\mathrm{M} \\
\text { other }\end{array}$ & $\begin{array}{l}\mathrm{M} \\
\text { (other) } \\
\text { source }\end{array}$ & $\begin{array}{c}\mathrm{M} \\
\text { pref }\end{array}$ & $\begin{array}{c}\mathrm{M} \\
\text { (pref) } \\
\text { source }\end{array}$ & $I(\max )$ & Location/felt report & Comment \\
\hline $11 / 15 / 41$ & 6:53:00 & 20 & 4.0 & 155 & $\begin{array}{l}\text { mauna } \\
42.0 \text { kea? }\end{array}$ & 43.2 & 43.2 & 83.2 & 84.5 & 94.9 & $\mathrm{~s}$ & 5.20 & 5.73 & 4.91 & & & & & 5.32 & hono & felt & $\begin{array}{l}52 \text { mi from HVO; Hilo dismantled. Warshauer } \\
\text { notes: The strongest earthquake [in a series] } \\
\text { was reported at 6:58 a.m. today [doesn't say } \\
\text { whether felt!l] felt islandwide by a few and by } \\
\text { many in Kohala, north Kona, and Hamakua. }\end{array}$ & $\begin{array}{l}\text { VL 474, p. } 3 ; \text { HTH, 11/15; 21/1941; } \\
\text { not found in HA. }\end{array}$ \\
\hline $11 / 15 / 41$ & 18:37:00 & & & & $\begin{array}{l}\text { mauna } \\
\text { kea? }\end{array}$ & & 43 & 83.2 & 83.2 & 93.7 & f & 4.39 & 4.02 & 4.22 & & & & & 4.12 & hono & felt & $\begin{array}{l}52 \text { mi from HVO; felt generally-N Hawaii } \\
\text { Island. Warshauer notes: Felt in northern part } \\
\text { of island and by several in Hilo. }\end{array}$ & VL 474, p. 3; HTH, 11/21/1941. \\
\hline $11 / 16 / 41$ & 2:31:00 & & & & $\begin{array}{l}\text { mauna } \\
\text { kea? }\end{array}$ & 43.2 & 43.2 & 81.9 & 81.9 & 92.6 & $\mathrm{f}$ & 4.11 & $<4.10$ & $<4.10$ & & & & & 4.11 & nomo & felt & $\begin{array}{l}\text { Near } 52 \mathrm{mi} \text { from HVO; newspaper time } \\
\text { accepted. Warshauer notes: Felt in Hilo; felt at } \\
\text { and perhaps other places in N Hawaii. }\end{array}$ & Do. \\
\hline $11 / 16 / 41$ & 9:41:00 & 20 & 4.0 & 155 & $\begin{array}{l}\text { mauna } \\
42.0 \text { kea? }\end{array}$ & 43.2 & 43.2 & 83.2 & 84.5 & 94.9 & $\mathrm{~m}$ & 5.71 & 5.83 & 5.83 & & & & & 5.83 & hono & $\mathrm{V} ; \mathrm{V}(\mathrm{S} \& \mathrm{C})$ & $\begin{array}{l}\text { Near } 52 \text { mi from HVO; felt generally Hawaii } \\
\text { Island; slight damage. Warshauer notes: Felt by } \\
\text { many in all parts of Hawaii; no damage } \\
\text { reported; not felt on Oaaul. }\end{array}$ & Do. \\
\hline $11 / 18 / 41$ & 2:56:00 & 20 & 4.0 & 155 & $\begin{array}{l}\text { mauna } \\
42.0 \text { kea? }\end{array}$ & 43.2 & 43.2 & 83 & 84.5 & 94.9 & $\mathrm{~m}$-st & 5.71 & 6.07 & 6.17 & & & & & 6.12 & hono & VI; V (S\&C) & $\begin{array}{l}\text { Near, slight damage; felt strongly-Hawaii } \\
\text { Island, less on Maui. Warshauer notes: Dishes } \\
\text { and bottles were broken at early this morning } \\
\text { by an earthuake also felt strongly in Hilo; } \\
\text { approximate time of the quake was 2:53 a.m. }\end{array}$ & VL 474, p. 3; HTH, 11/18/1941. \\
\hline $11 / 18 / 41$ & 10:30:00 & 20 & 4.0 & 155 & $\begin{array}{l}\text { mauna } \\
42.0 \text { kea? }\end{array}$ & & 43 & 83 & 84.5 & 94.8 & $\mathrm{f}$ & 4.72 & 5.05 & 4.50 & & & & & 4.72 & hono & felt & Felt generally-Hawaii Island. & VL 474, p. 3. \\
\hline $11 / 18 / 41$ & 10:33:00 & 20 & 4.0 & 155 & $\begin{array}{l}\text { mauna } \\
42.0 \text { kea? }\end{array}$ & & 43 & 83 & 84.5 & 94.8 & $\mathrm{f}$ & 4.40 & $<4.22$ & $<4.22$ & & & & & 4.40 & nomo & felt & Do. & Do. \\
\hline $11 / 19 / 41$ & 7:43:00 & 20 & 4.0 & 155 & $\begin{array}{l}\text { mauna } \\
42.0 \text { kea? }\end{array}$ & & 43 & 83.2 & 84.5 & 94.8 & $\mathrm{f}$ & 4.72 & 5.17 & 5.40 & & & & & 5.29 & hono & felt & $52 \mathrm{mi}$ from $\mathrm{HVO}$; felt widely. & Slight(?); VL 474, p. 3. \\
\hline $11 / 22 / 41$ & 10:04:00 & 20 & 4.0 & 155 & $\begin{array}{l}\text { mauna } \\
42.0 \text { kea? }\end{array}$ & & 43 & 83 & 84.5 & 94.8 & $\mathrm{f}$ & 4.13 & & & & & & & 4.13 & nomo & & Near. & VL 474, p. 4. \\
\hline $11 / 22 / 41$ & 21:23:00 & 20 & 4.0 & 155 & $\begin{array}{l}\text { mauna } \\
42.0 \text { kea? }\end{array}$ & & 43 & 83 & 84.5 & 94.8 & $\mathrm{~s}$ & 5.20 & 5.61 & 5.50 & & & & & 5.56 & hono & $\mathrm{V}(\mathrm{W} \& \mathrm{~K})$ & $\begin{array}{l}\text { Near; felt generally-Hawaii Island, few on } \\
\text { Maui. }\end{array}$ & Moderate(?); VL 474, p. 4. \\
\hline $11 / 22 / 41$ & 22:12:00 & 20 & 4.0 & 155 & $\begin{array}{l}\text { mauna } \\
42.0 \text { kea? }\end{array}$ & & 43 & 83 & 84.5 & 94.8 & vf & 4.13 & & & & & & & 4.13 & nomo & felt & ( & VL 474, p. 4. \\
\hline $1 / 25 / 42$ & 6:13:00 & & & & kaoiki? & & & 25.6 & 25.6 & 27.1 & $\mathrm{~s}$ & 4.07 & & & & & & & 4.07 & nomo & $\mathrm{V}-\mathrm{VI}$ & $\begin{array}{l}16 \mathrm{mi} \text { from HVO; felt-hnp; broke dishes at } \\
\text { KMC. }\end{array}$ & VL 475, p. 2 \\
\hline $2 / 8 / 42$ & 17:48:00 & 19 & 38.0 & 155 & 10.0 hilo deep & 48 & 48 & 24.5 & 24.6 & 53.9 & $\mathrm{~s}$ & 4.81 & 5.15 & 5.23 & & & & & 5.19 & hono & felt & $\begin{array}{l}8 \mathrm{mi} \text { SW of Hilo; felt-Hilo, hnp; Hilo } \\
\text { seismograph dismantled. }\end{array}$ & $\begin{array}{l}\text { Farther away(?) or moderate(?); VL } \\
475 \text {, p. 2; not found in HTH. }\end{array}$ \\
\hline $2 / 18 / 42$ & 11:09:00 & 192 & 25.80 & 155 & $\begin{array}{l}\text { kl cal 10- } \\
16.6020\end{array}$ & 12.8 & 12.8 & 2.0 & 1.7 & 12.9 & $\mathrm{~m}$ & 4.05 & $\begin{array}{l}\text { no } \\
\text { record }\end{array}$ & $\begin{array}{l}\text { no } \\
\text { record }\end{array}$ & & & & & 4.05 & nomo & $\mathrm{v}$ & $\begin{array}{l}\mathrm{N} \text { end Kilauea crater, felt-hnp, awakened } \\
\text { many, dismantled HVO and mlo seismographs. }\end{array}$ & VL 475, p. 2. \\
\hline $2 / 21 / 42$ & 8:11:00 & 19 & 32.0 & 155 & $28.0 \mathrm{ml}$ ner & 8 & 8 & 24 & 24.5 & 25.8 & $\mathrm{~m}$ & 4.81 & 6.09 & 6.09 & & & & & 6.09 & hono & VI & $\begin{array}{l}\text { Felt widely. Warshauer notes: Hilo-dishes and } \\
\text { bottles fell, plaster cracked, parked cars shook } \\
\text { from two strong quakes; dismantled } \\
\text { seismographs, slides in Kilauea crater; bottles } \\
\text { broken at Volcano House. }\end{array}$ & $\begin{array}{l}\text { Strong(?) or deep(?); VL 475, p. 2; } \\
\text { HTH, , } 2 / 21 ; 22 / 1942 ; \mathrm{HSB}, 2 / 21 / 1942 ; \\
\text { time given as "shortly after } 9 \text { a.m. } \\
\text { today" [Hawaii war time, } 1 \text { hour later]. }\end{array}$ \\
\hline $2 / 21 / 42$ & 8:14:00 & 19 & 32.0 & 155 & $28.0 \mathrm{ml} \mathrm{ner}$ & 8 & 8 & 24 & 24.5 & 25.8 & $\mathrm{~m}$ & 4.81 & 6.14 & 6.09 & & & & & 6.11 & hono & VI & $\begin{array}{l}\text { Do.; felt widely; another and stronger shock } \\
\text { occurred at about 9:14 a.m. }\end{array}$ & $\begin{array}{l}\text { VL 475, p. 2; HTH, } 2 / 21 ; 22 / 1942 \text {; } \\
\text { HSB, 2/21/1942; time given as "shortly } \\
\text { after } 9 \text { a.m. today" [Hawaii war time, } 1 \\
\text { hour later]. }\end{array}$ \\
\hline $2 / 21 / 42$ & 8:36:00 & 19 & 32.0 & 155 & $28.0 \mathrm{ml}$ ner & 8 & 8 & 24 & 24.5 & 25.8 & $\mathrm{~s}$ & 4.04 & no trace & no trace & & & & & 4.04 & nomo & & $\begin{array}{l}\text { Warshauer notes: Then, at } 9: 37 \text { there was } \\
\text { another shake, strong enough to dismantle the } \\
\text { east-west component of the seismograph at the } \\
\text { Volcano House. }\end{array}$ & $\begin{array}{l}\text { [Times are Hawaii war time, } 1 \text { hour } \\
\text { later]; VL 475, p. 2; HTH, 2/22/1942. }\end{array}$ \\
\hline $2 / 22 / 42$ & 14:47:00 & & & & $\mathrm{ml}$ ner? & & 8 & 25.6 & 25.6 & 26.8 & $\mathrm{~s}$ & 4.06 & & & & & & & 4.06 & nomo & & 16 mi from HVO. & VL 475, p. 2. \\
\hline $2 / 22 / 42$ & 15:05:00 & & & & ml ner? & & 8 & 24 & 24.0 & 25.3 & $\mathrm{~s}$ & 4.02 & & & & & & & 4.02 & nomo & & $15 \mathrm{mi}$ from HVO. & Do. \\
\hline $3 / 7 / 42$ & 6:41:00 & 19 & 29.4 & 155 & $35.0 \mathrm{ml} \mathrm{mok}$ & & 8 & 36 & 34.6 & 35.5 & $\mathrm{~s}$ & 4.04 & & & & & & & 4.04 & nomo & & $\mathrm{N}$ end of Mokuaweoweo. & Do. \\
\hline $3 / 15 / 42$ & 9:35:00 & 19 & 27.2 & 155 & $35.8 \mathrm{ml} \mathrm{mok}$ & & 8 & 34 & 35.5 & 36.4 & $\mathrm{~s}$ & 4.05 & & & & & & & 4.05 & nomo & & S end of Mokuaweoweo. & Do. \\
\hline $3 / 16 / 42$ & 21:57:00 & 19 & 27.2 & 155 & $35.8 \mathrm{ml} \mathrm{mok}$ & & 5 & 34 & 35.5 & 35.8 & $\mathrm{~s}$ & 4.04 & & & & & & & 4.04 & nomo & felt & Do.; felt-Kona. & Do. \\
\hline $3 / 19 / 42$ & 0:17:00 & & & & $\mathrm{ml} \mathrm{mok}$ & & 5 & 35 & 35.0 & 35.4 & $\mathrm{~s}$ & 4.03 & & & & & & & 4.03 & nomo & & Near Mokuaweoweo; E-W dismantled. & Do. \\
\hline $3 / 20 / 42$ & 23:05:00 & & & & $\mathrm{ml} \mathrm{swr}$ & & 5 & 43 & 43.0 & 43.3 & $\mathrm{~m}$ & 5.17 & $>5.67$ & 5.88 & & & & & 5.88 & hono & $\mathrm{V}$ & $\begin{array}{l}\text { SW rift; felt widely; stopped clocks in S Kona. } \\
\text { Warshauer notes: Deep-seated earthquake felt } \\
\text { generally in Hilo; dismantled seismic } \\
\text { equipment; no damage. }\end{array}$ & $\begin{array}{l}\text { Strong(?); must be deep to fit felt } \\
\text { reports and HON magnitudes; VL } 475 \text {, } \\
\text { p. 2; HTH, 3/21/1942; time given as } \\
\text { "12:04 a.m. today" [daylight saving } \\
\text { time in effect; see VL 476, p. 2, 1st } \\
\text { paragraph]. }\end{array}$ \\
\hline $3 / 21 / 42$ & 20:14:00 & & & & $\mathrm{ml} \mathrm{swr}$ & & 5 & 53 & 53.0 & 53.2 & $\mathrm{f}$ & 4.00 & & & & & & & 4.00 & nomo & felt & SW rift; felt-S Kona. & VL 475, p. 2 . \\
\hline
\end{tabular}


$\$ \quad$ Table 13. All earthquakes of $M \geq 4.0$ during the period 1903-59-Continued

\begin{tabular}{|c|c|c|c|c|c|c|c|c|c|c|c|c|c|c|c|c|c|c|c|c|c|c|c|c|}
\hline Date & $\begin{array}{l}\text { Time } \\
\text { (HST) }\end{array}$ & $\begin{array}{c}\text { Lat } \\
\text { (deg) }\end{array}$ & $\begin{array}{c}\text { Lat } \\
(\min )\end{array}$ & $\begin{array}{l}\text { Lon } \\
\text { (deg) }\end{array}$ & $\begin{array}{l}\text { Lon } \\
(\mathrm{min})\end{array}$ & Region & $\begin{array}{l}\text { Publ. } \\
\text { Depth I }\end{array}$ & $\begin{array}{c}\text { Pref. } \\
\text { Depth }\end{array}$ & $\begin{array}{l}\text { Publ. } \\
\text { Dist. }\end{array}$ & $\begin{array}{l}\text { Calc. } \\
\text { Dist }\end{array}$ & $\begin{array}{l}\text { Slant } \\
\text { dist }\end{array}$ & Mag class & $\begin{array}{c}\mathrm{M} \\
\text { nomo }\end{array}$ & $\begin{array}{l}\text { M M-S } \\
\text { E-W }\end{array}$ & $\begin{array}{l}\text { M M-S } \\
\text { N-S }\end{array}$ & $M$ vert & $\begin{array}{c}\text { M hor } \\
\text { N-L }\end{array}$ & $\begin{array}{c}\mathrm{M} \\
\text { other }\end{array}$ & $\begin{array}{l}\mathrm{M} \\
\text { (other) } \\
\text { source }\end{array}$ & $\begin{array}{c}\mathrm{M} \\
\text { pref }\end{array}$ & $\begin{array}{c}\mathrm{M} \\
\text { (pref) } \\
\text { source }\end{array}$ & $I(\max )$ & Location/felt report & Comment \\
\hline $3 / 28 / 42$ & $21: 55: 00$ & & & & & $\mathrm{ml} \mathrm{ner}$ & & 5 & 25 & 25.0 & 25.5 & $\mathrm{~s}$ & 4.03 & no trace 1 & no trace & & & & & 4.03 & nomo & felt & NE rift; felt-hnp, Hilo. & Do. \\
\hline $4 / 26 / 42$ & 23:41:00 & & & & & $\mathrm{ml} \mathrm{ner}$ & 5 & 5 & 34 & 34.0 & 34.4 & $\mathrm{~m}$ & 4.73 & 4.61 & 4.98 & & & & & 4.79 & hono & felt & Upper NE rift; felt-hnp, Hilo. & VL 476, p. 7. \\
\hline $4 / 27 / 42$ & 0:01:00 & & & & & $\mathrm{ml} \mathrm{ner}$ & & 5 & 34 & 34.0 & 34.4 & s & 4.24 & & & & & & & 4.24 & nomo & & Upper NE rift. & Do. \\
\hline $4 / 27 / 42$ & 4:21:00 & & & & & $\mathrm{ml} \mathrm{ner}$ & & 5 & 34 & 34.0 & 34.4 & $\mathrm{~s}$ & 4.24 & & & & & & & 4.24 & nomo & & Do. & Do. \\
\hline $4 / 27 / 42$ & 8:49:00 & & & & & $\mathrm{ml} \mathrm{ner}$ & & 5 & 34 & 34.0 & 34.4 & $\mathrm{~s}$ & 4.50 & 4.97 & 4.61 & & & & & 4.79 & hono & & Do. & Deeper(?); VL 476, p. 7. \\
\hline 4/27/42 & 9:52:00 & & & & & $\mathrm{ml} \mathrm{mok}$ & & 5 & 35 & 35.0 & 35.4 & $\mathrm{~s}$ & 4.26 & & & & & & & 4.26 & nomo & & Near Mokuaweoweo. & VL 476, p. 7 . \\
\hline $4 / 27 / 42$ & 11:53:00 & 19 & 32.5 & 155 & $28.0 \mathrm{r}$ & $0 \mathrm{ml} \mathrm{ner}$ & & 5 & 25 & 24.9 & 25.4 & $\mathrm{~s}$ & 4.03 & & & & & & & 4.03 & nomo & & NE rift above Puu Ulaula. & Do. \\
\hline 4/27/42 & 14:12:00 & & & & & $\mathrm{ml}$ ner? & & 5 & 25 & 25.0 & 25.5 & $\mathrm{~s}$ & 4.03 & & & & & & & 4.03 & nomo & & Record confused; no location or distance given. & Do. \\
\hline $4 / 27 / 42$ & 14:23:00 & & & & & $\mathrm{ml}$ ner? & & 5 & 25 & 25.0 & 25.5 & $\mathrm{~s}$ & 4.03 & & & & & & & 4.03 & nomo & & No location or distance given. & Do. \\
\hline 4/27/42 & 16:44:00 & & & & & $\mathrm{ml}$ ner? & & 5 & 25 & 25.0 & 25.5 & $\mathrm{~s}$ & 4.03 & & & & & & & 4.03 & nomo & & Do. & Do. \\
\hline $4 / 27 / 42$ & 21:43:00 & & & & & $\mathrm{ml}$ ner? & & 5 & 25 & 25.0 & 25.5 & $\mathrm{~m}$ & 4.80 & 6.09 & $\begin{array}{l}\text { light } \\
\text { trace }\end{array}$ & & & & & 6.09 & aver & felt & $\begin{array}{l}\text { Felt strongly-Puu Ulaula; instruments } \\
\text { dismantled. }\end{array}$ & $\begin{array}{l}\text { Strong(?); VL 476, p. } 7 \text {; not found in } \\
\text { HTH. }\end{array}$ \\
\hline $4 / 29 / 42$ & 11:10:00 & & & & & $\mathrm{ml}$ ner? & & 5 & 24 & 24.0 & 24.5 & $\mathrm{~s}$ & 4.00 & & & & & & & 4.00 & nomo & & No location or distance given. & VL 476, p. 7. \\
\hline $7 / 9 / 42$ & 3:00:00 & & & & & kohala os & & & 115 & 115.0 & 115.4 & $\mathrm{~s}$ & 5.34 & 5.92 & 5.50 & & & & & 5.71 & hono & IV & $\begin{array}{l}\text { In ocean } \mathrm{N} \text { of Kohala; felt strongly-Kohala. } \\
\text { Warshauer notes: An earthquake between slight } \\
\text { and moderate was recorded at } 3: 59 \text { a.m. } \\
\text { [daylight saving time in effect]; dismantled } \\
\text { seismograph, felt strongly in district, also in } \\
\text { Hilo. }\end{array}$ & $\begin{array}{l}\text { Moderate(?); VL 477, p. 3; HTH, } \\
\text { 7/9/1942. }\end{array}$ \\
\hline $10 / 11 / 42$ & 11:43:00 & 19 & 29.4 & 155 & $35.0 \mathrm{r}$ & $\mathrm{ml} \mathrm{mok}$ & & & 34 & 34.6 & 35.8 & $\mathrm{~s}$ & 4.26 & & & & & & & 4.26 & nomo & & $\mathrm{N}$ end of Mokuaweoweo. & VL 478, p. 3; not found in HTH. \\
\hline $12 / 6 / 42$ & 12:08:00 & 19 & 6.0 & 155 & $41.3 \mathrm{r}$ & $3 \mathrm{ml} \mathrm{swr}$ & & & 59 & 58.2 & 58.9 & $\mathrm{~s}$ & 4.39 & no trace 1 & no trace & & & & & 4.39 & nomo & felt & $\begin{array}{l}\text { SW rift near source of } 1868 \text { flow; felt-Hilo to } \mathrm{S} \\
\text { Kona. }\end{array}$ & $\begin{array}{l}\text { Closer(?); VL 478, p. 4; not found in } \\
\text { HTH. }\end{array}$ \\
\hline $12 / 21 / 42$ & 23:59:00 & & & & & kl mer? & & 2.0 & 16.0 & 16.0 & 16.1 & $\mathrm{~s}$ & 3.71 & & & & & & & 4.15 & calc & & $\begin{array}{l}\text { Preferred magnitude calculates as nomogram } \\
\text { magnitude multiplied by number of events. }\end{array}$ & $\begin{array}{l}3 \text { slight events on December } 21 \text { not } \\
\text { separately tabulated; VL 478, p. } 4 .\end{array}$ \\
\hline $1 / 9 / 43$ & 20:04:00 & & & & & $\mathrm{ml} \mathrm{swr}$ ? & & & 59 & 59.0 & 59.7 & $\mathrm{f}$ & 4.07 & & & & & & & 4.07 & nomo & felt & Felt-S Kona. & VL 479, p. 5. \\
\hline $1 / 17 / 43$ & 14:08:00 & & & & & $\mathrm{ml} \mathrm{ner}$ & & & 24 & 24.0 & 25.6 & $\mathrm{~s}$ & 4.03 & & & & & & & 4.03 & nomo & felt & NE rift; felt-hnp. & Do. \\
\hline $1 / 19 / 43$ & 2:48:00 & & & & & $\mathrm{ml}$ ner? & & & 24 & 24.0 & 25.6 & $\mathrm{~s}$ & 4.03 & & & & & & & 4.03 & nomo & felt & Felt-hnp, Hilo. & Do. \\
\hline $5 / 8 / 43$ & 4:10:00 & & & & & $\mathrm{ml} \mathrm{mok}$ & & & 35 & 35.0 & 36.1 & $\mathrm{~s}$ & $4.27 \mathrm{r}$ & no trace 1 & no trace & & & & & 4.27 & nomo & felt & $\begin{array}{l}\text { [On p. 3, time given as 5:10 April 8-probably } \\
\text { the same quake, given a daylight-saving-time } \\
\text { correction and a misprint of the month]; near } \\
\text { Mokuaweoweo; felt generally-E Hawaii Island. }\end{array}$ & VL 480, p. 3, 4; not found in HTH. \\
\hline $6 / 14 / 43$ & 21:38:00 & 20 & 4.0 & 155 & 42.01 & kohala? & & & & 84.5 & 85.0 & $\mathrm{~s}$ & $4.64 \mathrm{r}$ & no trace 1 & no trace & & & & & 4.64 & nomo & felt & Near, felt widely-Hawaii Island. & $\begin{array}{l}\text { Closer(?); calc mag accepted on the } \\
\text { basis that there may have been high } \\
\text { background noise on the Honolulu } \\
\text { seismogram preventing the earthquake } \\
\text { from being seen; VL 480, p. 4; not } \\
\text { found in HTH. }\end{array}$ \\
\hline $10 / 16 / 43$ & 2:36:00 & & & & & $\begin{array}{l}\text { mauna } \\
\text { kea }\end{array}$ & & & 45 & 45.0 & 45.9 & $\mathrm{~s}$ & 4.44 & & & & & & & 4.44 & nomo & felt & E slope Mauna Kea; felt-hnp, Hakalau. & VL 482, p. 2. \\
\hline $11 / 10 / 43$ & $16: 22: 00$ & & & & & hilea? & & & 43 & 43.0 & 43.9 & $\mathrm{~m}$ & 4.90 & 4.88 & 4.88 & & & & & 4.88 & hono & $\begin{array}{l}\text { VI; VI (USE); V } \\
\text { (W\&K; S\&C) }\end{array}$ & $\begin{array}{l}\text { Felt widely-S half Hawaii Island; stone walls } \\
\text { thrown down SW of Pahala; dismantled } \\
\text { instruments. }\end{array}$ & VL 482, p. 2; not found in HTH. \\
\hline $12 / 22 / 43$ & 19:50:00 & & & & & $\mathrm{ml} \mathrm{swr?}$ & & & 45 & 45.0 & 45.9 & $\mathrm{~s}$ & $4.21 \mathrm{r}$ & no trace 1 & no trace & & & & & 4.21 & nomo & felt & SW slope Mauna Loa; felt-hnp, Hilo. & $\begin{array}{l}\text { Closer(?) or feeble(?); VL 482, p. 2; } \\
\text { not found in HTH. }\end{array}$ \\
\hline $1 / 23 / 44$ & 14:40:00 & 19 & 32.0 & 155 & & $\mathrm{ml} \mathrm{ner}$ & & & & 24.5 & 26.1 & $\mathrm{~s}$ & 4.05 & & & & & & & 4.05 & nomo & felt & NE rift near Puu Ulaula; felt-hnp, Pahala. & VL 483, p. 3. \\
\hline $7 / 2 / 44$ & 20:48:00 & & & & & kohala? & & & 90 & 90.0 & 90.4 & $\mathrm{f}$ & 4.36 & 4.74 & 4.92 & & & & & 4.83 & hono & & NW Hawaii. & Offshore(?); VL 485, p. 3. \\
\hline 10/2/44 & 17:27:00 & 20 & 1.0 & 155 & 17.01 & $\begin{array}{l}\text { mauna } \\
\text { kea }\end{array}$ & & 40 & & 65.2 & 76.5 & $\mathrm{~s}$ & 4.79 & $<4.50$ & 4.40 & & & & & 4.40 & hono & & Deep focus, near Ookala. & $\begin{array}{l}\text { shallower(?); VL 486, p. 3; not found } \\
\text { in HTH }\end{array}$ \\
\hline $10 / 17 / 44$ & 13:54:00 & & & & & $\begin{array}{l}\text { mauna } \\
\text { kea }\end{array}$ & & & 55 & 55.0 & 55.7 & $\mathrm{f}$ & 4.03 & $<4.32$ & $<4.02$ & & & & & 4.03 & nomo & felt & Mauna Kea; felt-Hilo. & VL 486, p. 3. \\
\hline $10 / 29 / 44$ & 17:17:00 & & & & & $\begin{array}{l}\text { mauna } \\
\text { kea }\end{array}$ & & & 55 & 55.0 & 55.7 & $\mathrm{f}$ & 4.03 & & & & & & & 4.03 & nomo & felt & Mauna Kea; felt-hnp, Hilo. & Do. \\
\hline $11 / 12 / 44$ & $4: 56: 00$ & 192 & 24.00 & 155 & $17.70^{\prime}$ & $\begin{array}{l}\mathrm{kl} \mathrm{cal} \\
\text { deep? }\end{array}$ & 14.4 & 30.0 & 4.5 & 5.0 & 30.4 & $\mathrm{~m}$ & 4.65 & 4.58 & 4.58 & & & & & 4.58 & hono & V (W\&K; USE) & $\begin{array}{l}\text { SW of Halemaumau, felt widely-S half Hawaii } \\
\text { Island, dismantled seismographs at Hilo, Kona, } \\
\text { and HVO. }\end{array}$ & $\begin{array}{l}\text { Depth increased to match HON } \\
\text { magnitude consistent with felt reports; } \\
\text { VL 486, p. } 3 \text {; not found in HTH. }\end{array}$ \\
\hline $12 / 27 / 44$ & 3:42:00 & 19 & 29.0 & 155 & 35.01 & $\mathrm{ml} \mathrm{mok}$ & 24 & 24 & & 34.5 & 42.0 & st & 5.15 & $\begin{array}{l}\text { light } \\
\text { trace }\end{array}$ & 5.78 & & & 5.6 & GUTE & 5.78 & hono & $\begin{array}{c}\text { VI; VI (USE; } \\
\text { S\&C) }\end{array}$ & $\begin{array}{l}\text { Island, plainly on Oahu; objects off shelves } \\
\text { Pepeekeo, and stone fences down in Hilea; } \\
\text { dismantled seismographs. Warshauer notes: } \\
\text { Sharp quake awakened people; dur few } \\
\text { seconds, no damage in Hilo; pronounced in } \\
\text { hnp. }\end{array}$ & VL 486, p. 3; HTH, 12/27/1944. \\
\hline
\end{tabular}


Table 13. All earthquakes of $M \geq 4.0$ during the period 1903-59-Continued

\begin{tabular}{|c|c|c|c|c|c|c|c|c|c|c|c|c|c|c|c|c|c|c|c|c|c|c|c|}
\hline Date & $\begin{array}{l}\text { Time } \\
\text { (HST) }\end{array}$ & $\begin{array}{c}\text { Lat } \\
(\operatorname{deg})\end{array}$ & $\begin{array}{c}\text { Lat } \\
(\mathrm{min})\end{array}$ & $\begin{array}{l}\text { Lon } \\
(\operatorname{deg})\end{array}$ & $\begin{array}{c}\text { Lon } \\
(\mathrm{min})\end{array}$ & $\begin{array}{l}\text { Publ. } \\
\text { Depth I }\end{array}$ & $\begin{array}{l}\text { Pref. } \\
\text { Depth }\end{array}$ & $\begin{array}{c}\text { Publ. } \\
\text { Dist. }\end{array}$ & $\begin{array}{c}\text { Calc. } \\
\text { Dist }\end{array}$ & $\begin{array}{c}\text { Slant } \\
\text { dist }\end{array}$ & Mag class & $\begin{array}{c}\mathrm{M} \\
\text { nomo }\end{array}$ & $\begin{array}{c}\text { M M-S } \\
\text { E-W }\end{array}$ & $\begin{array}{c}\text { M M-S } \\
\text { N-S }\end{array}$ & M vert & $\begin{array}{c}\text { M hor } \\
\mathrm{N}-\mathrm{L}\end{array}$ & $\begin{array}{c}\mathrm{M} \\
\text { other }\end{array}$ & $\begin{array}{c}\mathrm{M} \\
\text { (other) } \\
\text { source }\end{array}$ & $\begin{array}{c}\mathrm{M} \\
\text { pref }\end{array}$ & $\begin{array}{c}\mathrm{M} \\
\text { (pref) } \\
\text { source }\end{array}$ & $I(\max )$ & Location/felt report & Comment \\
\hline $12 / 27 / 44$ & 5:46:00 & 19 & 29.0 & 155 & $535.0 \mathrm{ml} \mathrm{mok}$ & 24 & 24 & & 34.5 & $5 \quad 42.0$ & $\mathrm{~s}$ & 4.38 & no trace & no trace & & & & & 4.38 & nomo & III & $\begin{array}{l}\text { Do.; dismantled seismographs. Warshauer } \\
\text { notes: The earthquake [at } 4 \text { a.m. H.s.t.] was } \\
\text { followed by two smaller quakes at } 6 \text { and } 7 \text { a.m. } \\
\text { [daylight saving times approximate?]. }\end{array}$ & VL 486, p. $3 ;$ HTH, 12/27/1944. \\
\hline $12 / 30 / 44$ & 9:21:00 & 19 & 29.0 & 155 & $35.0 \mathrm{ml} \mathrm{mok}$ & 24 & 24 & & 34.5 & $5 \quad 42.0$ & $\mathrm{~m}$ & 5.15 & 5.36 & 5.50 & & & & & 5.43 & hono & III & Do. & $\begin{array}{l}\text { Deeper(?); VL 486, p. 3; not found in } \\
\text { HTH. }\end{array}$ \\
\hline $12 / 31 / 44$ & 11:10:00 & 19 & 16.2 & 2 155 & 28.9 hilea & 20.8 & 20.8 & & 29.4 & $4 \quad 36.0$ & $\mathrm{~m}$ & 5.04 & 4.93 & 5.08 & & & & & 5.00 & hono & III & Wood valley; do. & VL 486, p. 3; not found in HTH. \\
\hline $1 / 9 / 45$ & 18:57:00 & & & & hilea? & & & 35 & 535.0 & 36.1 & $\mathrm{~s}$ & 4.27 & & & & & & & 4.27 & nomo & felt & Felt-Pahala. & VL 487, p. 5. \\
\hline $1 / 24 / 45$ & 10:38:00 & 19 & 25.00 & 155 & $\begin{array}{l}\mathrm{kl} \mathrm{cal} \\
16.20 \text { deep }\end{array}$ & 20.0 & 21.0 & & 1.9 & 21.1 & $\mathrm{~m}$ & 4.39 & 4.32 & 4.33 & & & & & 4.32 & hono & felt & $\begin{array}{l}\text { E rim Kilauea crater, felt widely-S half Hawaii } \\
\text { Island. }\end{array}$ & Do. \\
\hline $3 / 5 / 45$ & 0:00:00 & & & & $\mathrm{ml} \mathrm{swr}$ & & & 45 & $5 \quad 45.0$ & 45.9 & $\mathrm{~m}$ & 4.93 & 4.91 & 5.04 & & & & & 4.97 & hono & $\mathrm{v}$ & $\begin{array}{l}\text { SW rift; felt widely-Hawaii Island; stopped } \\
\text { clocks in S Kona. }\end{array}$ & $\begin{array}{l}\text { VL 487, p. 6; VL date } \\
\text { wrong-Honolulu record shows 3/5. }\end{array}$ \\
\hline $3 / 12 / 45$ & 19:00:00 & 19 & 19.00 & 155 & $5.00 \mathrm{kl} \mathrm{kuer} \mathrm{sf?}$ & & 10.0 & 28.0 & 27.2 & 28.9 & $\mathrm{~m}$ & 4.38 & $<4.47$ & $<4.32$ & & & & & 4.38 & nomo & felt & $\begin{array}{l}\text { In ocean off Puna-Kau boundary; felt-hnp, } \\
\text { dismantled seismograph. }\end{array}$ & $\begin{array}{l}\text { Location onshore would be more } \\
\text { consistent with modern catalog and } \\
\text { give better mag agreement with HON } \\
\text { consistent with felt report; VL 487, p. } \\
\text { 6; not found in HTH. }\end{array}$ \\
\hline $5 / 19 / 45$ & 1:48:00 & & & & kaoiki & & & 20 & 20.0 & 21.9 & $\mathrm{~m}$ & 4.70 & 5.22 & $2 \quad 5.37$ & & & & & 5.30 & hono & $\mathrm{V}(\mathrm{USE} ; \mathrm{S} \& \mathrm{C})$ & $\begin{array}{l}\text { E slope Mauna Loa; felt generally-Hawaii } \\
\text { Island, slightly on Oahu. }\end{array}$ & $\begin{array}{l}\text { Deeper(?); VL 488, p. 3; not found in } \\
\text { HTH. }\end{array}$ \\
\hline $5 / 29 / 45$ & 18:45:00 & 19 & 31.0 & 155 & 32.4 kaoiki & 20.8 & 20.8 & & 30.9 & 37.3 & $\mathrm{~s}$ & 4.29 & no trace & no trace & & & & & 4.29 & nomo & felt & $5 \mathrm{mi}$ SW of Puu Ulaula; felt-hnp, Hilo, $\mathrm{s}$ Kona & VL 488, p. 3. \\
\hline $6 / 14 / 45$ & 19:46:00 & 19 & 11.3 & 155 & 28.7 hilea & & & & 35.4 & $4 \quad 36.5$ & $\mathrm{~s}$ & 4.28 & $<4.45$ & $5 \quad 4.07$ & & & & & 4.07 & hono & felt & Near Pahala; felt-hnp, Pahala. & Do. \\
\hline $7 / 13 / 45$ & 2:15:00 & 19 & 20.00 & 155 & $\mathrm{kl}$ mer sf & 8.0 & 8.0 & & 29.6 & $5 \quad 30.6$ & $\mathrm{~m}$ & 4.65 & 4.98 & 4.60 & & & & & 4.79 & hono & IV & $\begin{array}{l}\text { Coast SW of Kalapana; felt widely-E half } \\
\text { Hawaii Island; dismantled E-W component. } \\
\text { Warshauer notes: Residents in several sections } \\
\text { of Hilo felt an earthquake that some describe as } \\
\text { "fairly strong" at 3:15 a.m. [daylight saving } \\
\text { timel; duration, }>5 \text { minutes. }\end{array}$ & VL 489, p. 4; HTH, 7/13/1945. \\
\hline 9/19/45 & 5:33:00 & & & & $\mathrm{mlnf}$ & & & 36 & 536.0 & 37.1 & $\mathrm{~s}$ & 4.29 & 4.38 & 3.89 & & & & & 4.14 & hono & $\mathrm{V}$ (USE) & $\begin{array}{l}\text { Between Mauna Loa and Mauna Kea; felt } \\
\text { widely-Hawaii Island. }\end{array}$ & VL 489, p. 4; not found in HTH. \\
\hline $12 / 16 / 45$ & 20:30:00 & & & & kaoiki & & & 20 & 20.0 & 21.9 & $\mathrm{~s}$ & 4.18 & 5.41 & 4.96 & & & & & 5.19 & hono & felt & $\begin{array}{l}\text { E flank of Mauna Loa; felt-hnp, Pahala, Hilo; E } \\
\text { W component dismantled. }\end{array}$ & $\begin{array}{l}\text { deeper(?), farther away(?) or } \\
\text { moderate(?); Honolulu mag too high } \\
\text { for felt report(?); VL 490, p. } 3\end{array}$ \\
\hline $2 / 6 / 46$ & 4:45:00 & 19 & 8.0 & 155 & 28.7 hilea & & & & 40.3 & 41.3 & $\mathrm{~s}$ & 4.36 & 4.76 & 4.76 & & & & & 4.76 & hono & felt & Near coast below Pahala; felt-Kau, S Kona. & VL 491, p. 5 . \\
\hline 2/8/46 & 6:15:00 & & & & $\mathrm{ml}$ ner & & & 30 & 30.0 & 31.3 & $\mathrm{~s}$ & 4.17 & 4.37 & 4.37 & & & & & 4.37 & hono & felt & NE rift; felt-hnp, Pahala, Hilo. & Do. \\
\hline $2 / 14 / 46$ & 9:03:00 & & & & $\mathrm{ml} \mathrm{swr}$ & & & 48 & 48.0 & 48.8 & $\mathrm{~s}$ & 4.26 & no trace & no trace & & & & & 4.26 & nomo & & Middle SW rift. & Do. \\
\hline 2/23/46 & 22:44:00 & & & & kohala? & & & 60 & 60.0 & 60.7 & $\mathrm{~s}$ & 4.41 & no trace & no trace & & & & & 4.41 & nomo & felt & Felt-N Kona, S Kohala. & Closer(?) or feeble(?); VL 491, p. 5. \\
\hline $4 / 8 / 46$ & 8:58:00 & & & & $\begin{array}{l}\text { ml mok } \\
\text { deep? }\end{array}$ & & 40 & 35 & 35.0 & 53.2 & $\mathrm{~s}$ & 4.32 & no trace & no trace & & & & & 4.32 & nomo & felt & Deep under Mauna Loa in; felt widely. & VL 492, p. 7. \\
\hline $5 / 19 / 46$ & $18: 36: 00$ & & & & $\mathrm{kl}$ ler sf? & & 10.0 & & 60.0 & 60.8 & $\mathrm{~s}$ & 4.63 & 4.73 & 4.72 & & & & & 4.72 & hono & felt & Felt-hnp, Hilo. & $\begin{array}{l}\text { Honolulu amplitude average of two } \\
\text { readings; s-p on Honolulu record, felt } \\
\text { report, and magnitude suggests ler sf; } \\
\text { ed assumed for mag agreement; VL } \\
492, \text { p. } 7 \text {. }\end{array}$ \\
\hline $8 / 8 / 46$ & 16:28:00 & & & & $\mathrm{ml}$ ner? & & & 30 & 30.0 & 31.3 & $\mathrm{~s}$ & 4.17 & no trace & no trace & & & & & 4.17 & nomo & felt & NE slope Mauna Loa; felt-hnp. & VL 493, p. 3. \\
\hline 9/4/46 & 13:21:00 & & & & $\mathrm{ml}$ ner? & & & 30 & 30.0 & 31.3 & $\mathrm{~s}$ & 4.17 & no trace & 4.12 & & & & & 4.12 & hono & III & $\begin{array}{l}\text { NE slope Mauna Loa; felt-hnp. Warshauer } \\
\text { notes: The strongest quake we've had in quite } \\
\text { awhile rocked the volcano and Kau regions; } \\
\text { felt duration, several seconds, no damage; felt } \\
\text { in Honolululu [unlikely?]. }\end{array}$ & VL 493, р. 3; HTH, 9/5; 10/6/1946. \\
\hline $10 / 8 / 46$ & 23:56:00 & 19 & 29.7 & 155 & 22.5 kaoiki & 16 & 16 & & 14.0 & 21.2 & $\mathrm{~s}$ & 3.90 & no trace & no trace & & 4.06 & & & 4.06 & hono & felt & $\begin{array}{l}\text { NE slope Mauna Loa, } 1 \mathrm{mi} \text { E of Mauna Loa } \\
\text { seismograph; felt-hnp, Hilo. }\end{array}$ & VL 494, p. 7. \\
\hline $10 / 10 / 46$ & $5: 59: 00$ & & & & $\begin{array}{l}\text { hualalai } \\
\text { deep }\end{array}$ & & 40 & 90 & 90.0 & 98.5 & $\mathrm{vf}$ & 4.15 & $\begin{array}{c}\text { obscure } \\
\text { trace }\end{array}$ & $\begin{array}{c}\text { obscure } \\
\text { trace }\end{array}$ & & 4.79 & & & 4.47 & aver & felt & $\begin{array}{l}\text { NW coast of Hualalaia; felt-Kona, Maui. } \\
\text { Warshauer notes: An earthquake October } 10 \\
\text { was widely felt on Maui and scattered points on } \\
\text { this island originated deep under the Hualalai } \\
\text { coast. }\end{array}$ & VL 494, p. 7; HTH, 11/5/1946. \\
\hline
\end{tabular}


๙े Table 13. All earthquakes of $M \geq 4.0$ during the period 1903-59-Continued

\begin{tabular}{|c|c|c|c|c|c|c|c|c|c|c|c|c|c|c|c|c|c|c|c|c|c|c|c|c|}
\hline Date & $\begin{array}{c}\text { Time } \\
\text { (HST) }\end{array}$ & $\begin{aligned} \text { Lat } \\
(\operatorname{deg})\end{aligned}$ & $\begin{array}{c}\text { Lat } \\
\text { (min) }\end{array}$ & $\begin{array}{l}\text { Lon } \\
\text { (deg) }\end{array}$ & $\begin{array}{c}\text { Lon } \\
(\min )\end{array}$ & Region & $\begin{array}{l}\text { Publ. } \\
\text { Depth }\end{array}$ & $\begin{array}{l}\text { Pref. } \\
\text { Depth }\end{array}$ & $\begin{array}{l}\text { Publ. } \\
\text { Dist. }\end{array}$ & $\begin{array}{l}\text { Calc. } \\
\text { Dist }\end{array}$ & $\begin{array}{c}\text { Slant } \\
\text { dist }\end{array}$ & Mag class & $\begin{array}{c}\mathrm{M} \\
\text { nomo }\end{array}$ & $\begin{array}{c}\text { M M-S } \\
\text { E-W }\end{array}$ & $\begin{array}{c}\text { M M-S } \\
\text { N-S }\end{array}$ & M vert & $\begin{array}{c}\text { M hor } \\
\mathrm{N}-\mathrm{L}\end{array}$ & $\begin{array}{c}\mathrm{M} \\
\text { other }\end{array}$ & $\begin{array}{c}\mathrm{M} \\
\text { (other) } \\
\text { source }\end{array}$ & $\begin{array}{c}\mathrm{M} \\
\text { pref }\end{array}$ & $\begin{array}{c}\mathrm{M} \\
\text { (pref) } \\
\text { source }\end{array}$ & $I(\max )$ & Location/felt report & Comment \\
\hline 10/29/46 & 18:43:00 & & & & & $\begin{array}{l}\text { kaoiki } \\
\text { deep }\end{array}$ & & 20 & 20 & 20.0 & 28.3 & $\mathrm{~s}$ & 4.10 & $<4.37$ & $7<<.27$ & & 3.59 & & & 4.10 & nomo & & $\begin{array}{l}\text { E slope Mauna Loa. Warshauer notes: The } \\
\text { earthquake of October } 29 \text {, which rocked most } \\
\text { of the east half of Hawaii, originated deep } \\
\text { under the east slope of Mauna Loa. }\end{array}$ & $\begin{array}{l}\text { [Not sure whether s-p horizontal has } \\
\text { the same characteristics as the } \\
\text { Neumann-LaBarre instrument after } \\
\text { Nov. 1946]; station HON film time is } \\
\text { 18:46, nomogram magnitude accepted; } \\
\text { VL 494, p. 7; HTH, 11/5/1946. }\end{array}$ \\
\hline $11 / 30 / 46$ & 1:54:00 & & & & & & & 40 & 20 & 20.0 & 44.7 & $\mathrm{~s}$ & 4.42 & 4.22 & 2 no trace & & & & & 4.22 & hono & & E slope Mauna Loa. & VL VL 494, p. 7 \\
\hline 12/22/46 & 7:02:00 & & & & & hilo & 24 & 24 & 30 & 30.0 & 38.4 & $\mathrm{f}$ & 4.09 & $<4.32$ & $<4.32$ & & 4.32 & & & 4.32 & hono & felt & Felt-E Hawaii Island. & $\begin{array}{l}\text { VL 494, p. } 7 \text {; station HON film time is } \\
7: 04 \text {. }\end{array}$ \\
\hline $1 / 15 / 47$ & 9:47:00 & & & & & $\mathrm{ml} \mathrm{ner}$ & & & 30 & 30.0 & 31.3 & $\mathrm{~s}$ & 4.17 & 4.37 & $<4.27$ & & 4.83 & & & 4.37 & hono & & NE rift; M-S magnitude accepted as preferred. & $\begin{array}{l}\text { N-L high(?); VL } 495, p .6 \text {; station } \\
\text { HON film time is 9:48. }\end{array}$ \\
\hline $2 / 26 / 47$ & 18:54:00 & & & & & $\mathrm{ml} \mathrm{ner}$ & & & 30 & 30.0 & 31.3 & $f(s ?)$ & 4.17 & $<4.55$ & 5 no trace & & $<4.47$ & & & 4.17 & nomo & felt & $\begin{array}{l}\text { NE rift; felt generally-e Hawaii Island; mag } \\
\text { calculated assuming "slight" fits felt report } \\
\text { better }\end{array}$ & VL 495, p. 6; not found in HTH. \\
\hline $3 / 19 / 47$ & 23:06:00 & & & & & $\begin{array}{l}\mathrm{ml} \mathrm{mok} \\
\text { deep }\end{array}$ & 40 & 40 & 35 & 35.0 & 53.2 & $\mathrm{~m}(\mathrm{~s} ?)$ & 4.80 & 4.38 & 4.22 & & 4.42 & & & 4.34 & hono & $\mathrm{V}$ (USE) & $\begin{array}{l}\text { Deep under Mauna Loa; felt widely-Hawaii } \\
\text { Island; dismantled MLO seismometer. } \\
\text { Warshauer notes: Strong quake under Mauna } \\
\text { Loa east slope dismantled seismographs at } \\
\text { HVO; shallower than others recently; } \\
\text { especially strong at and Kapapala; felt in Hilo. }\end{array}$ & $\begin{array}{l}\text { Shallower(?), or slight(?); VL 495, p. } \\
\text { 6; HTH, 3/20/1947. }\end{array}$ \\
\hline $3 / 21 / 47$ & $17: 37: 00$ & 19 & 44.0 & 156 & & hualalai & & & & 91.0 & 91.5 & $\mathrm{f}$ & 4.37 & $<4.17$ & $7 \quad<4.17$ & & 4.57 & & & 4.37 & nomo & & Keahole pt. & $\begin{array}{l}\text { N-L high(?); VL 495, p. 6; not found in } \\
\text { HTH. }\end{array}$ \\
\hline $4 / 12 / 47$ & 1:46:00 & & & & & kaoiki & & & 20 & 20.0 & 21.9 & $\mathrm{~s}$ & 4.18 & no trace & no trace & & trace & & & 4.18 & nomo & felt & Felt-Kapapala. & VL 496, p. 3. \\
\hline $4 / 12 / 47$ & 2:29:00 & & & & & kaoiki & & & 20 & 20.0 & 21.9 & $\mathrm{~s}$ & 4.18 & no trace & no trace & & $\begin{array}{l}\text { no } \\
\text { trace }\end{array}$ & & & 4.18 & nomo & felt & Do. & Do. \\
\hline $6 / 14 / 47$ & 23:00:00 & & & & & $\begin{array}{l}\mathrm{kl} \text { cal } 10- \\
20 ?\end{array}$ & & 15.0 & 4.0 & 4.0 & 15.5 & $\mathrm{~m}$ & 4.18 & $<4.12$ & $<4.2$ & & 4.48 & & & 4.18 & nomo & felt & $\begin{array}{l}\text { Moderate depth under Kilauea; felt locally and } \\
\text { as far as Papaikou; MLO instrument } \\
\text { dismantled. }\end{array}$ & N-L high(?); VL 496, p. 3 \\
\hline 6/19/47 & 5:24:00 & & & & & $\begin{array}{l}\mathrm{kl} \text { cal 10- } \\
20 ?\end{array}$ & & 13.0 & 4.0 & 4.0 & 13.6 & $\mathrm{~m}$ & 4.09 & 4.18 & 4.02 & & 3.85 & & & 4.02 & hono & felt & $\begin{array}{l}\text { Shallow under Kilauea; felt locally; E-W } \\
\text { dismantled. }\end{array}$ & VL 496, p. 3. \\
\hline $8 / 18 / 47$ & 9:52:00 & & & & & $\begin{array}{l}\mathrm{kl} \mathrm{cal} \\
\text { deep }\end{array}$ & & 21.0 & 5.0 & 5.0 & 21.6 & $\mathrm{~m}$ & 4.41 & 4.15 & 4.39 & & $\begin{array}{l}\text { no } \\
\text { record }\end{array}$ & & & 4.27 & hono & felt & $\begin{array}{l}\text { Deep under Kilauea; felt locally and at } \\
\text { Naalehu; E-W seismograph dismantled. } \\
\text { Warshauer notes: An earthquake at 9:52 a.m. } \\
\text { was felt as far as Hilo. }\end{array}$ & VL 497, p. $3 ;$ HTH, 8/18; 19/1947. \\
\hline $8 / 19 / 47$ & 6:44:00 & & & & & kaoiki? & & & 20 & 20.0 & 21.9 & $\mathrm{~s}$ & 4.18 & no trace & no trace & & $\begin{array}{l}\text { no } \\
\text { record }\end{array}$ & & & 4.18 & nomo & felt & $\begin{array}{l}\text { notes: Felt at and Kapapala, "much stronger" } \\
\text { than the [Kilaueal quake at } 9: 52 \text { a.m. August } \\
18 .\end{array}$ & VL 497, p. 3; HTH, 8/19/1947. \\
\hline $9 / 21 / 47$ & 5:50:00 & 19 & 42.2 & 155 & 28.0 & $\mathrm{mlnf}$ deep & 36 & 36 & & 37.2 & 51.8 & $\mathrm{~s}$ & 4.52 & 4.35 & $<4.50$ & & 4.28 & & & 4.31 & hono & IV & $\begin{array}{l}\text { Deep below Humuula; felt widely-Hawaii } \\
\text { Island, few on Maui. Warshauer notes: Big } \\
\text { Island, from to Hilo and as far west as Pahala } \\
\text { in Kau, shook for } 3.5 \text { min early Sunday; no } \\
\text { damage; slow swaying, intense for } 20 \text { s, acc by } \\
\text { rumbling. }\end{array}$ & $\begin{array}{l}\text { Honolulu data average of } 2 \text { readings; } \\
\text { shallower(?); VL 497, p. 3; HTH, } \\
\text { 9/22/1947. }\end{array}$ \\
\hline 9/30/47 & 4:04:00 & & & & & $\begin{array}{l}\mathrm{kl} \mathrm{cal} \\
\text { deep }\end{array}$ & 11.2 & 25.0 & 5.0 & 5.0 & 25.5 & $\mathrm{~m}$ & 4.52 & 4.45 & 4.63 & & 5.15 & & & 4.74 & hono & $\mathrm{v}$ & $\begin{array}{l}\text { East of Kilauea crater, felt generally-S Kona to } \\
\text { Hilo. Warshauer notes: Roused sleepers all } \\
\text { over island, duration, }>1 \text { min; toppled radio } \\
\text { antenna and caused a hole to form in Hilo; } \\
\text { movement horizontal and vertical; dismantled } \\
\text { all seismographs on island. }\end{array}$ & $\begin{array}{l}\text { N-L peak trace invisible; VL 497, p. 3; } \\
\text { HTH, 9/30/1947. }\end{array}$ \\
\hline $10 / 17 / 47$ & 0:27:00 & 19 & 16.8 & 155 & 27.2 & kaoiki & & & 26 & 26.3 & 27.8 & $\mathrm{~s}$ & 4.09 & no trace $\mathrm{I}$ & no trace & & 4.11 & & & 4.11 & hono & felt & Near Kapapala; felt generally-E Hawaii Island. & VL 498, p. 3. \\
\hline $10 / 31 / 47$ & 2:13:00 & 19 & 28.5 & 155 & 35.5 & $\mathrm{ml} \mathrm{mok}$ & & & & 35.2 & 36.3 & $\mathrm{~m}$ & 4.53 & 4.43 & 4.33 & & 4.11 & & & 4.29 & hono & $\mathrm{v}$ & $\begin{array}{l}\text { Mokuaweoweo; felt widely-E half Hawaii } \\
\text { Island; clocks stopped in S Kona. }\end{array}$ & VL 498, p. 3; not found in HTH. \\
\hline $12 / 14 / 47$ & 10:10:00 & & & & & $\begin{array}{l}\mathrm{kl} \mathrm{cal} \\
\text { deep }\end{array}$ & 32.0 & 32.0 & & 5.0 & 32.4 & $\mathrm{~m}$ & 4.69 & $<4.27$ & $<4.27$ & & 4.89 & & & 4.69 & nomo & IV & $\begin{array}{l}\text { Felt-hnp, Hilo. Warshauer notes: Deep } \\
\text { earthquake } 20 \text { mi under Kilauea, rattled } \\
\text { windows and dishes in the Hilo, Volcano, and } \\
\text { Kau districts; pronounced vertical motion; felt } \\
\text { quite plainnly in hnp region, acc. by a rumble; } \\
\text { dismantled mlo and HVO seismographs. }\end{array}$ & $\begin{array}{l}\text { N-L high, M-S low; VL 498, p. 3; } \\
\text { HTH, 12/15/1947. }\end{array}$ \\
\hline $12 / 20 / 47$ & 5:18:00 & 19 & 28.5 & 155 & 35.5 & $\mathrm{ml} \mathrm{mok}$ & & & & 35.2 & 36.3 & $\mathrm{~s}$ & 4.28 & $<4.17$ & $<4.22$ & & 4.72 & & & 4.42 & hono & felt & $\begin{array}{l}\text { Mokuaweoweo; felt-E half Hawaii Island. } \\
\text { Warshauer notes: Widely felt. }\end{array}$ & $\begin{array}{l}\text { Honolulu data average of } 2 \text { readings; } \\
\mathrm{L} \text { mag high; } \mathrm{VL} 498, \mathrm{p} .3 ; \mathrm{HTH}, \\
\text { 12/2/1947. }\end{array}$ \\
\hline
\end{tabular}


Table 13. All earthquakes of $M \geq 4.0$ during the period 1903-59-Continued

\begin{tabular}{|c|c|c|c|c|c|c|c|c|c|c|c|c|c|c|c|c|c|c|c|c|c|c|c|}
\hline Date & $\begin{array}{l}\text { Time } \\
\text { (HST) }\end{array}$ & $\begin{array}{c}\text { Lat } \\
\text { (deg) }\end{array}$ & $\begin{array}{c}\text { Lat } \\
(\min )\end{array}$ & $\begin{array}{c}\text { Lon } \\
\text { (deg) }\end{array}$ & $\begin{array}{cc}\text { Lon } \\
(\min ) & \text { Region }\end{array}$ & $\begin{array}{l}\text { Publ. } \\
\text { Depth I }\end{array}$ & $\begin{array}{l}\text { Pref. F } \\
\text { Depth }\end{array}$ & $\begin{array}{l}\text { Publ. } \\
\text { Dist. }\end{array}$ & $\begin{array}{l}\text { Calc. S } \\
\text { Dist }\end{array}$ & $\begin{array}{l}\text { Slant } \\
\text { dist }\end{array}$ & Mag class & $\begin{array}{c}\mathrm{M} \\
\text { nomo }\end{array}$ & $\begin{array}{c}\text { M M-S } \\
\text { E-W }\end{array}$ & $\begin{array}{c}\text { M M-S } \\
\text { N-S }\end{array}$ & M vert & $\begin{array}{c}\text { M hor } \\
\text { N-L }\end{array}$ & $\begin{array}{c}\mathrm{M} \\
\text { other }\end{array}$ & $\begin{array}{c}\mathrm{M} \\
\text { (other) } \\
\text { source }\end{array}$ & 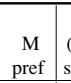 & $\begin{array}{c}\mathrm{M} \\
\text { (pref) } \\
\text { source }\end{array}$ & $I(\max )$ & Location/felt report & Comment \\
\hline $12 / 24 / 47$ & 6:38:00 & 19 & 21.5 & 155 & 25.6 kaoiki & & & & 19.2 & 21.2 & $\mathrm{~s}$ & 4.16 & no trace & no trace & & $\begin{array}{c}\text { no } \\
\text { trace }\end{array}$ & & & $4.16 \mathrm{r}$ & nomo & $\mathrm{v}$ & $\begin{array}{l}\text { E slope Mauna Loa near Ainapo; felt-hnp, } \\
\text { Hilo. Warshauer notes: The third earthquake to } \\
\text { originate under Mauna Loa in } 5 \text { days awakened } \\
\text { Big Island residents at } 6: 38 \text { a.m. today. It was } \\
\text { particularly noticeable in the Puueo section of } \\
\text { Hilo. }\end{array}$ & VL 498, p. 3; HTH, 12/24/1947. \\
\hline $1 / 8 / 48$ & 16:15:00 & & & & kaoiki & & & 20 & 20.0 & 21.9 & $\mathrm{~s}$ & 4.18 & no trace & no trace & & 4.12 & & & 4.12 & hono & felt & $\begin{array}{l}\text { E slope Mauna Loa; felt-hnp. Warshauer notes: } \\
\text { Seismographs at Hawaii National Park } \\
\text { registered a fairly deep earthquake southwest of } \\
\text { Kilauea Volcano at } 4: 30 \text { p.m. Thursday. The } \\
\text { quake was felt in the volcano district and parts } \\
\text { of Hilo. }\end{array}$ & $\begin{array}{l}\text { IL 499, p. 3; HTH, 1/9/1948 [time } \\
\text { differs from VL-same quake or a } \\
\text { separate one, possibly k k cal deep, not } \\
\text { recorded in VL 499??)]. }\end{array}$ \\
\hline $1 / 15 / 48$ & 6:16:00 & & & & $\mathrm{ml}$ ner & & & 30 & 30.0 & 31.3 & $\mathrm{~s}$ & 4.17 & $<4.37$ & no trace & & $<3.27$ & & & $4.17 \mathrm{r}$ & nomo & III & $\begin{array}{l}\text { NE slope Mauna Loa; felt-hnp, Hilo. } \\
\text { Warshauer notess: a moderate [slight in] } \\
\text { earthquake was felt at 6:16 a.m.today, lasting } \\
\text { several seconds in the Puueo section of Hilo. It } \\
\text { was felt, not severely, in the volcano region and } \\
\text { other sections of the island. }\end{array}$ & VL 499, p. $3 ;$ HTH, 1/15/1948. \\
\hline $1 / 26 / 48$ & 23:02:00 & & & & $\mathrm{ml} \mathrm{ner}$ & & & 30 & 30.0 & 31.3 & $\mathrm{~s}$ & 4.43 & no trace & no trace & & 4.61 & & & 4.61 & hono & felt & $\begin{array}{l}\text { NE rift; felt- to Hilo. Warshauer notes: A } \\
\text { moderate earthquake, originating on the } \\
\text { northeast slope of Mauna Loa, was registered at } \\
11: 02 \text { p.m.; the earthquake was felt tover a wide } \\
\text { area, including the Puueo section of Hilo }\end{array}$ & $\begin{array}{l}\text { N-L high(?); VL 499, p. 3; HTH, } \\
\text { 1/27/1948. }\end{array}$ \\
\hline $3 / 9 / 48$ & 15:46:00 & & & & kohala? & & & 65 & 65.0 & 65.6 & $\mathrm{~s}$ & 4.46 & no trace & no trace & & 4.43 & & & 4.43 & hono & felt & $\begin{array}{l}\text { Felt from Hilo to Kona; off coast north of } \\
\text { Hualalai. Warshauer notes: An earthquake, } \\
\text { originating either under Hualalai or Mauna } \\
\text { Kea, was recorded by HVO at } 3: 46 \text { p.m. } \\
\text { Tuesday. The quake was felt over a wide area, } \\
\text { including Hilo and. }\end{array}$ & $\begin{array}{l}\text { Closer(?) or feeble(?); newspaper } \\
\text { location (approx } 65 \mathrm{~km} \text { from HVO } \\
\text { gives better fit than location }(95 \mathrm{~km} \\
\text { from HVO); VL 499, p. } 3 ; \mathrm{HTH}, \\
\text { 3/10/1948. }\end{array}$ \\
\hline $3 / 19 / 48$ & 16:18:00 & & & & $\begin{array}{l}\mathrm{kl} \mathrm{cal} \\
\text { deep }\end{array}$ & & 25.0 & & 3.0 & 25.2 & $\mathrm{~m}$ & 4.52 & 4.16 & $\operatorname{det}$ & & 4.78 & & & 4.35 & hono & IV & $\begin{array}{l}\text { Deep Kilauea; felt-Hilo to Naalehu. Warshauer } \\
\text { notes: A sharp temblor shook the Big Island at } \\
\text { 4:18 p.m. Friday, the strongest in } 3 \text { months; a } \\
\text { vertical quake, strongly felt in the volcano area } \\
\text { and in most areas of Hilo. }\end{array}$ & $\begin{array}{l}\text { Honolulu amplitude average of two } \\
\text { readings; N-L high; M-S E-W detected; } \\
\text { not read because record was being } \\
\text { changed; VL 499, p. 3; HTH, } \\
\text { 3/20/1948. }\end{array}$ \\
\hline $5 / 22 / 48$ & 11:34:00 & & & & $\begin{array}{l}\text { hualalai } \\
\text { deep }\end{array}$ & & 20 & 70 & 70.0 & 72.8 & $\mathrm{~s}$ & 4.54 & 4.10 & no trace & & $\begin{array}{c}\text { no } \\
\text { record }\end{array}$ & & & 4.10 & hono & felt & $\begin{array}{l}\text { Hualalaia. Warshauer notes: An earthquake } \\
\text { originated deep under Hualalai at } 11: 33 \text { a.m. } \\
\text { Saturday. The temblor was felt in the volcano } \\
\text { district. }\end{array}$ & $\begin{array}{l}\text { Closer to Kilauea(?) and/or } \\
\text { shallower(?); VL 500, p. } 4 \text {; HTH, } \\
5 / 24 / 1948 .\end{array}$ \\
\hline $5 / 24 / 48$ & 23:16:00 & & & & $\mathrm{ml} \mathrm{ner}$ & & & 30 & 30.0 & 31.3 & $\mathrm{~s}$ & 4.17 & no trace & no trace & & trace & & & $4.17 \mathrm{r}$ & nomo & felt & NE rift; felt-hnp. & VL 500, p. 4. \\
\hline 6/28/48 & $1: 42: 00$ & 21 & 12.0 & 157 & 54.0 oahu & & & & 340.83 & 340.9 & $\mathrm{~s}$ & 5.61 & $\begin{array}{l}\text { seis } \\
\text { dism. }\end{array}$ & $\begin{array}{c}\text { seis } \\
\text { dism. }\end{array}$ & & $\begin{array}{r}\text { seis } \\
\text { dism. }\end{array}$ & 4.8 & $\begin{array}{l}\text { Cox; } \\
\text { (W\&K, p. } \\
72)\end{array}$ & 5.20 & aver & $\mathrm{VI} ; \mathrm{VI}(\mathrm{Cox} ; \mathrm{S} \& \mathrm{C})$ & $\begin{array}{l}\text { Oahu; felt-Hilo. Warshauer notes: felt in Hilo } \\
\text { and recorded at HVO; } 125-150 \text { miles away, } \\
\text { possibly in Molokai vicinity; considerable } \\
\text { damage in Honolulu, including houses shifted } \\
\text { on foundations, pipes broken and lots of broken } \\
\text { ) plaster and window panes. }\end{array}$ & $\begin{array}{l}\text { Cox, 1986; Cox mag too low(?)-even } \\
\text { HVO location near Molokia yields } \\
\text { M=5.4 5; wrong date - 6/26/48-in VL } \\
500 \text {, p. 4; HTH, 6/28/1948; see } \\
\text { references for more complete damage } \\
\text { report; preferred mag calculated as } \\
\text { average of nomogram and Cox. }\end{array}$ \\
\hline $7 / 30 / 48$ & 2:28:00 & & & & $\begin{array}{l}\mathrm{kl} \text { cal 10- } \\
20 ?\end{array}$ & 9.6 & 15.0 & & 3.0 & 15.3 & $\mathrm{~m}$ & 4.17 & 4.25 & 4.33 & & 3.70 & & & 4.10 & hono & $\mathrm{v}$ & $\begin{array}{l}\text { E of Kilauea crater, felt-hnp; awakened people. } \\
\text { Warshauer notes: Residents of the volcano } \\
\text { district were jarred by two "fairly sharp" } \\
\text { temblors at } 2: 28 \text { and } 2: 31 \text { a.m. today. Both } \\
\text { quakes were felt generally in the volcano } \\
\text { district. No reports from elsewhere. }\end{array}$ & $\begin{array}{l}\text { N-L low; VL 501, p. 3; HTH, } \\
\text { 7/30/1948; HTH, 8/5/1948. }\end{array}$ \\
\hline $7 / 30 / 48$ & 2:31:00 & & & & $\begin{array}{l}\mathrm{kl} \mathrm{cal} \mathrm{10-} \\
20 ?\end{array}$ & 9.6 & 15.0 & & 3.0 & 15.3 & $\mathrm{~m}$ & 4.17 & 4.15 & 4.25 & & 3.88 & & & 4.10 & hono & $\mathrm{v}$ & 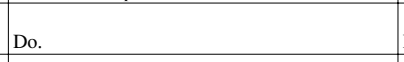 & Do. \\
\hline $9 / 13 / 48$ & 8:20:00 & & & & $\mathrm{mlnf}$ & 36 & 36 & 32 & 32.0 & 48.2 & $\mathrm{~m}$ & 4.97 & 5.15 & 5.23 & & 4.88 & & & 5.09 & hono & IV & $\begin{array}{l}\text { SE of Mauna Kea; felt-E half Hawaii Island. } \\
\text { Warshauer notes: A heavy earthquake, felt all } \\
\text { the way from Hilo to, rocked the south end of } \\
\text { the Big Island at } 8: 22 \text { a.m. today. Finch said } \\
\text { they were deep under Mauna Loa. }\end{array}$ & VL 501, p. 3; HTH, 9/13/1948. \\
\hline 9/15/48 & 9:45:00 & 19 & 28.5 & 155 & $35.5 \mathrm{ml} \mathrm{mok}$ & & & & 35.2 & 36.3 & $\mathrm{~s}$ & 4.05 & no trace & no trace & & 3.22 & & & $4.05 \mathrm{r}$ & nomo & & Mokuaweoweo. & N-L low(?); VL 501, p. 3. \\
\hline $1 / 6 / 49$ & 15:59:00 & 19 & 28.5 & 155 & $35.5 \mathrm{ml} \mathrm{mok}$ & & 8 & & 35.2 & 36.1 & $\mathrm{~m}$ & 4.531 & no trace & no trace & & $\begin{array}{l}\text { no } \\
\text { trace }\end{array}$ & & & & nomo & & $\begin{array}{l}2 \mathrm{mi} \mathrm{NE} \text { of Mokuaweoweo; one of the } \\
\text { strongest quakes of the series. }\end{array}$ & Closer(?) or slight(?); VL 503, p. 7,8 . \\
\hline
\end{tabular}


$\infty \quad$ Table 13. All earthquakes of $M \geq 4.0$ during the period 1903-59-Continued

\begin{tabular}{|c|c|c|c|c|c|c|c|c|c|c|c|c|c|c|c|c|c|c|c|c|c|c|c|}
\hline Date & $\begin{array}{l}\text { Time } \\
\text { (HST) }\end{array}$ & $\begin{array}{c}\text { Lat } \\
(\operatorname{deg})\end{array}$ & $\begin{array}{c}\text { Lat } \\
\text { (min) }\end{array}$ & $\begin{array}{l}\text { Lon } \\
(\operatorname{deg})\end{array}$ & 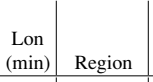 & $\begin{array}{l}\text { Publ. } \\
\text { Depth I }\end{array}$ & $\begin{array}{ll}\text { Pref. } & \text { P } \\
\text { Depth } & \text { I }\end{array}$ & $\begin{array}{c}\text { Publ. } \\
\text { Dist. }\end{array}$ & $\begin{array}{cl}\text { Calc. } & \mathrm{S} \\
\text { Dist } & \end{array}$ & $\begin{array}{c}\text { Slant } \\
\text { dist }\end{array}$ & Mag class & $\begin{array}{c}\mathrm{M} \\
\text { nomo }\end{array}$ & $\begin{array}{l}\text { M M-S } \\
\text { E-W }\end{array}$ & $\begin{array}{c}\text { M M-S } \\
\text { N-S }\end{array}$ & M vert & $\begin{array}{c}\text { M hor } \\
\mathrm{N}-\mathrm{L}\end{array}$ & $\begin{array}{c}\mathrm{M} \\
\text { other }\end{array}$ & $\begin{array}{l}\mathrm{M} \\
\text { (other) } \\
\text { source }\end{array}$ & $\begin{array}{c}\mathrm{M} \\
\text { pref }\end{array}$ & $\begin{array}{c}\mathrm{M} \\
\text { (pref) } \\
\text { source }\end{array}$ & $I(\max )$ & Location/felt report & Comment \\
\hline $1 / 15 / 49$ & 6:40:00 & & & & $\begin{array}{l}\text { ml swr } \\
\text { deep }\end{array}$ & 36 & 20 & 25 & 25.0 & 32.0 & $\mathrm{~m}$ & 4.45 & 4.45 & 5 no trace & & 4.07 & & & 4.26 & hono & IV & $\begin{array}{l}\text { Above wood valley. Warshauer notes: Hilo this } \\
\text { morning was rocked by a heavy yarthquake at } \\
6: 40 \text {, dismantled the E-W component of the } \\
\text { Hilo seismograph; the temblor was felt in all } \\
\text { parts of the island, particularly in Kona, Kau, } \\
\text { Puna, and Hilo. }\end{array}$ & $\begin{array}{l}\text { s } \\
\text { closer(?) normal Kaoiki depth(?); VL } \\
\text { 503, p. 8; HTH, K/115; 16/1949 [ time } \\
\text { given as 12:40 a.m.-newspaper time } \\
\text { fits Hon time] }\end{array}$ \\
\hline $1 / 15 / 49$ & 11:16:00 & & & & kohala os & & & 1101 & 110.01 & 110.4 & $\mathrm{~s}$ & 4.82 & 4.50 & 4.08 & & 4.78 & & & 4.45 & hono & & ocean $\mathrm{W}$ of Kohala. & closer(?); VL 503, p. 8 \\
\hline $1 / 20 / 49$ & 14:27:00 & 19 & 55.0 & 155 & $\begin{array}{l}\text { mauna } \\
46.7 \text { kea deep }\end{array}$ & & 40 & & 76.8 & 86.6 & $\mathrm{vf}$ & 4.06 & & & & & & & 4.06 & nomo & felt & $\begin{array}{l}\text { Deep; } 10 \mathrm{mi} \text { SW of. Warshauer notes: A } \\
\text { moderate earthquake at 22:28 p.m. Thursday } \\
\text { originated at Kohala or the NW part of Mauna } \\
\text { Kea; described as "very distinct" at. It was also } \\
\text { felt at Kona and Kohala and very slightly at the } \\
\text { volcano. }\end{array}$ & VL 503, p. 8; HTH, 1/21/1949 \\
\hline $1 / 26 / 49$ & 13:06:00 & 19 & 55.0 & 155 & $\begin{array}{c}\text { mauna } \\
46.7 \text { kea deep }\end{array}$ & & 40 & & 76.8 & 86.6 & $\mathrm{f}$ & 4.33 & no trace & no trace & & $\begin{array}{l}\text { no } \\
\text { trace }\end{array}$ & & & 4.33 & nomo & & $10 \mathrm{mi} \mathrm{SW}$ of Waimea. & VL 503, p. 8 \\
\hline $1 / 26 / 49$ & 23:57:00 & 19 & 24.5 & 155 & 22.7 kaoiki & 8 & 8 & & 12.6 & 14.9 & $\mathrm{~m}$ & 4.15 & 4.16 & 4.18 & & 4.38 & & & 4.24 & hono & felt & $\begin{array}{l}\text { Ohaikea. Warshauer notes: A slight temblor at } \\
11: 47 \text { p.m. originated under the east slope of } \\
\text { Mauna Loa; plainly felt at; [same as the } \\
\text { moderate quake in at 11:57?]. }\end{array}$ & $\begin{array}{l}\text { Honolulu data average of two readings; } \\
\text { VL 503, p. } 8 ; \mathrm{HTH}, 1 / 27 / 1949\end{array}$ \\
\hline $1 / 28 / 49$ & 15:50:00 & & & & kaoiki & 8 & 8 & 20 & 20.0 & 21.5 & $\mathrm{~m}$ & 4.41 & $<4.02$ & $<4.20$ & & 4.28 & & & 4.28 & hono & & E slope Mauna Loa. & $\begin{array}{l}\text { Honolulu data average of two readings; } \\
\text { VL 503, p. } 8 ; \mathrm{HTH}, 2 / 26 / 1949\end{array}$ \\
\hline 2/26/49 & 13:54:00 & 19 & 33.2 & 155 & $24.2 \mathrm{ml} \mathrm{ner}$ & & & & 20.3 & 22.2 & st & 4.70 & 4.85 & 4.71 & & 5.13 & & & 4.90 & hono & V (USE); IV & $\begin{array}{l}\text { NE rift, 7,000 ft; felt strongly-Hilo to Naalehu. } \\
\text { Warshauer notes: The large [quake] at 1:55 } \\
\text { emanated from the northeast rift at an altitude } \\
\text { of 7,000 ftt dismantled instruments at HVO and } \\
\text { Hilo; felt from Naalehu to Hilo, perhaps wider. }\end{array}$ & d VL 503, p. 8; HTH, 2/27; 28/1949. \\
\hline $4 / 11 / 49$ & 18:40:00 & & & & kaoiki & & & 20 & 20.0 & 21.9 & $\mathrm{~m}$ & 4.42 & no trace & no trace & & 4.46 & & & 4.46 & hono & felt & Kaoiki fault; felt- & Closer(?) or slight(?); VL 504, p. 5. \\
\hline $5 / 2 / 49$ & 5:02:00 & & & & kona? & & & 15 & 15.0 & 17.5 & st & 4.54 & 4.00 & det. & & 4.34 & & & 4.17 & hono & VI; V (USE; S\&C) & $\begin{array}{l}\text { W slope Mauna Loa; felt-Hilo, strongly at Puu } \\
\text { Ulaula, Holualoa to Kona seismograph broken; } \\
\text { many sleepers awakened, some rushed out of } \\
\text { doors; some objects thrown from shelves- } \\
\text { ) Honaunau to Kealakekua. }\end{array}$ & $\begin{array}{l}\text { 1; Honolulu data average of two readings; } \\
\text { distance given from crude isoseismal } \\
\text { map-assumes strong on Kona } \\
\text { seismograph; VL 504, p. } 5 \text {. }\end{array}$ \\
\hline $\begin{array}{r}5 / 7 / 49 \\
5 / 21 / 49\end{array}$ & $\begin{array}{r}23: 26: 00 \\
1: 06: 00\end{array}$ & 19 & 28.5 & 155 & $\begin{array}{c}35.5 \mathrm{ml} \mathrm{mok} \\
\mathrm{ml} \mathrm{wf}\end{array}$ & 19.2 & 19.2 & 50 & $\begin{array}{l}35.2 \\
50.0\end{array}$ & $\begin{array}{l}40.1 \\
50.8\end{array}$ & $\begin{array}{l}\text { st } \\
\text { f }\end{array}$ & $\begin{array}{l}5.12 \\
3.96\end{array}$ & $\begin{array}{l}\text { no trace } \\
\text { no trace }\end{array}$ & $\begin{array}{l}\text { no trace } \\
\text { no trace }\end{array}$ & & $\begin{array}{l}4.47 \\
4.14\end{array}$ & & & $\begin{array}{l}4.47 \\
4.14\end{array}$ & $\begin{array}{l}\text { hono } \\
\text { hono }\end{array}$ & $\begin{array}{l}\text { IV (W\&K); III } \\
\text { felt }\end{array}$ & $\begin{array}{l}\text { Both ml seismograph components dismantled; } \\
\text { Mokuaweoweo; felt-Holualoa, Kealakekua. } \\
\text { W slope Mana Lelto-Holualoa }\end{array}$ & Closer(?) or moderate(?); VL 504, p. 5. \\
\hline $5 / 23 / 49$ & 10:24:00 & 19 & 16.8 & 155 & 27.2 kaoiki & & & 26 & 26.3 & 27.8 & $\mathrm{~m}$ & 4.35 & 3.97 & det. & & 4.16 & & & 4.07 & hono & V (W\&K); IV & $\begin{array}{l}\text { S slope ml near Kapapala; felt strongly-Pahala; } \\
\text { also hnnp, Hookena; both comp. ml seismograph } \\
\text { dismantled. Warshauer notes: Sharp earthquake } \\
\text { under Mauna Loa was also recorded on the } \\
\text { Hilo seismograph; The quake was felt } \\
\text { particularly strongly at KKapapala. }\end{array}$ & $\begin{array}{l}\text { e } \\
\text { e } \\
\text { Honolulu data average of two readings; } \\
\text { VL 504, p. } 5 ; \text { HTH, 5/23/1949. }\end{array}$ \\
\hline 6/8/49 & 14:12:00 & & & & $\mathrm{ml} \mathrm{ner}$ & 5 & 5 & 25 & 25.0 & 25.5 & $\mathrm{~m}$ & 4.29 & no trace & no trace & & $\begin{array}{l}\text { no } \\
\text { trace }\end{array}$ & & & 4.29 & nomo & III & $\begin{array}{l}\text { NE rift; both components of ml seismograph } \\
\text { dismantled. }\end{array}$ & Closer(?) or slight(?); VL 504, p. 5. \\
\hline $6 / 25 / 49$ & 19:27:00 & 19 & 15.0 & 155 & 36.5 hilea & 16 & 16 & & 41.8 & 44.7 & $\mathrm{~s}$ & 4.20 & no trace & no trace & & $\begin{array}{l}\text { no } \\
\text { trace }\end{array}$ & & & 4.20 & nomo & & Do. & VL 504, p. 5. \\
\hline $7 / 5 / 49$ & 0:44:00 & 193 & 30.40 & 154 & $51.00 \mathrm{kl}$ ler sf? & 19.2 & 10.0 & & 44.1 & 45.3 & $\mathrm{~m}$ & 4.92 & 4.74 & 4.65 & & 4.70 & & & 4.70 & hono & & $\begin{array}{l}\text { E rift near Kapoho [Honolulu magnitude } \\
\text { unggests either deep rift event or adjacent south } \\
\text { flank]. }\end{array}$ & $\begin{array}{l}\text { h Shallow on Honolulu seismogram; } \mathrm{VL} \\
505, \text { p. } 3 \text {. }\end{array}$ \\
\hline $8 / 30 / 49$ & 14:27:00 & 19 & 9.20 & 155 & $\begin{array}{l}\text { kl kuer sf } \\
8.80 \text { os deep }\end{array}$ & 36.0 & 36.0 & 31.5 & 33.1 & 48.9 & $\mathrm{~s}$ & 4.48 & 4.07 & $<4.17$ & & 4.87 & & & 4.47 & hono & felt & $8 \mathrm{mi}$ SSE of Apua pt; felt-volcano. & $\begin{array}{l}\text { Honolulu amplitude average of two } \\
\text { readings; VL 505, p. } 4\end{array}$ \\
\hline 9/1/49 & 12:53:00 & 19 & 19.7 & 155 & 25.7 kaoiki & & & & 21.0 & 22.9 & $\mathrm{~m}$ & 4.45 & $<4.12$ & $<4.12$ & & 4.16 & & & 4.16 & hono & IV; V (W\&K) & $\begin{array}{l}\text { Kaoiki fault, } 3-4 \text { mi NE of Kapapala ranch; felt } \\
\text { strongly-Kapapala to, weakly-volcano to tilo, } \\
\text { pahoehoe to Holualoa. Warshauer notes: } \\
\text { "Strong" earthquake disabled mlo seismograph } \\
\text { [otherwise repeats info]. }\end{array}$ & $\begin{array}{l}\text { Honolulu data average of two readings; } \\
\text { VL 505, p. 4; HTH, 9/2/1949 }\end{array}$ \\
\hline $11 / 4 / 49$ & 12:12:00 & 19 & 49.5 & 155 & $\begin{array}{l}\text { mauna } \\
28.5 \text { kea }\end{array}$ & 32 & 32 & & 49.3 & 58.8 & $\mathrm{f}$ & 4.06 & no trace & no trace & & $\begin{array}{c}\text { no } \\
\text { trace }\end{array}$ & & & 4.06 & nomo & felt & $\begin{array}{l}\text { Mauna Kea summit; felt-hunters at } 10,000 \mathrm{ft} \text { on } \\
\text { Mauna Kea. Warshauer notes: A rapid-fire } \\
\text { series of earthquakes in a pattern often } \\
\text { indicative of an impending eruption occurred } \\
\text { November } 4 \text { directly under the summit of } \\
\text { Mauna Kea at a depth of } 20 \mathrm{mi} \text {. }\end{array}$ & VL 506, p. 4; HTH, 11/18/1949 \\
\hline $11 / 4 / 49$ & 13:02:00 & 19 & 49.5 & 155 & $\begin{array}{l}\text { mauna } \\
28.5 \text { kea }\end{array}$ & 32 & 32 & & 49.3 & 58.8 & $\mathrm{f}$ & 4.06 & no trace & no trace & & $\begin{array}{c}\text { no } \\
\text { trace }\end{array}$ & & & 4.06 & nomo & felt & $\begin{array}{l}\text { Mauna Kea summit; felt-hunters at } 10,000 \mathrm{ft} \text { on } \\
\text { Mauna Kea }\end{array}$ & \\
\hline
\end{tabular}


Table 13. All earthquakes of $M \geq 4.0$ during the period 1903-59-Continued

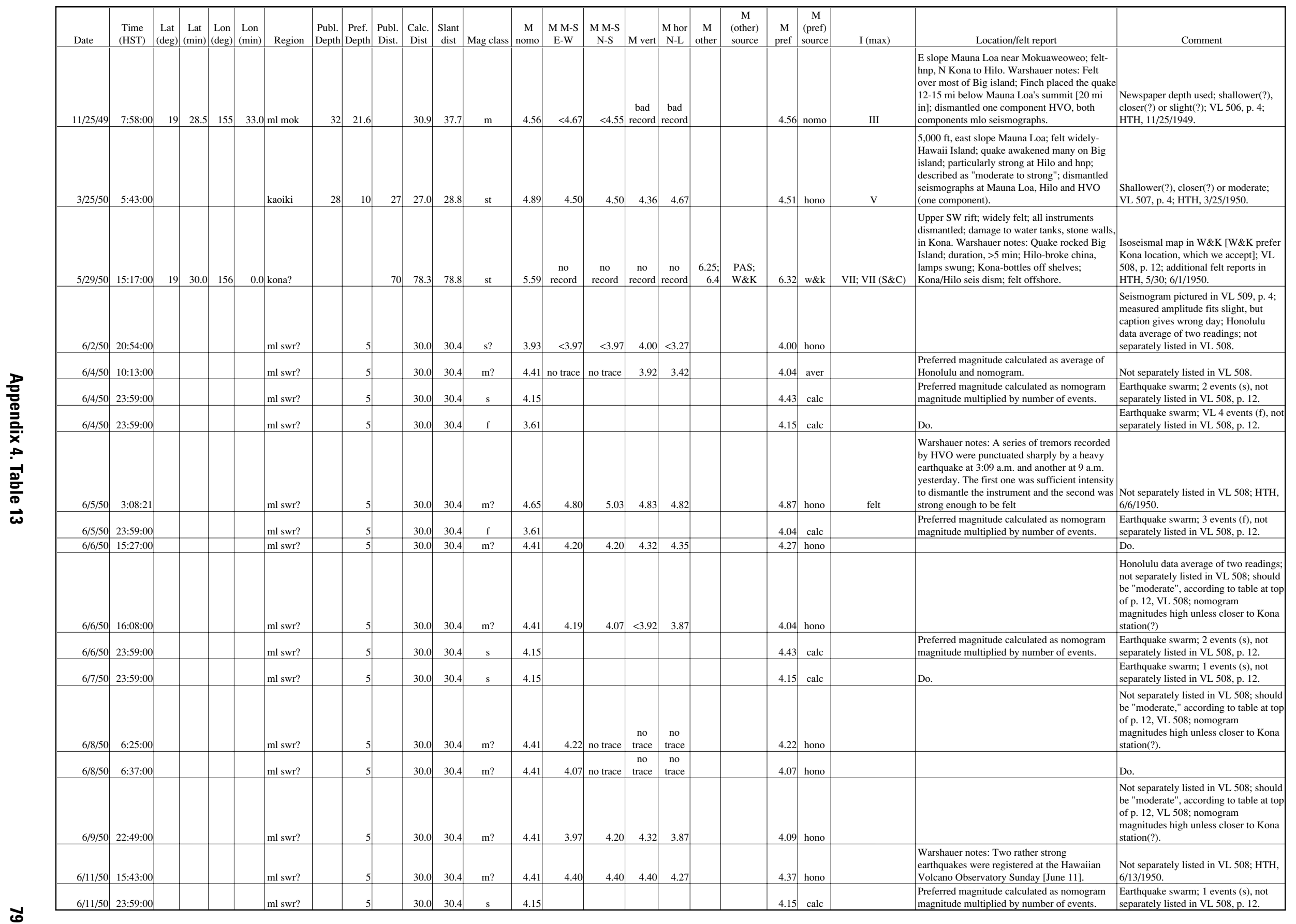


\& Table 13. All earthquakes of $M \geq 4.0$ during the period 1903-59-Continued

\begin{tabular}{|c|c|c|c|c|c|c|c|c|c|c|c|c|c|c|c|c|c|c|c|c|c|c|c|c|}
\hline \multirow{3}{*}{$\begin{array}{l}\text { Date } \\
6 / 13 / 50\end{array}$} & $\begin{array}{c}\text { Time } \\
\text { (HST) }\end{array}$ & $\begin{array}{c}\mathrm{Lat} \\
\text { (deg) }\end{array}$ & $\begin{array}{c}\text { Lat } \\
(\mathrm{min})\end{array}$ & $\begin{array}{l}\text { Lon } \\
\text { (deg) }\end{array}$ & $\begin{array}{l}\text { Lon } \\
\text { (min) }\end{array}$ & Region & $\begin{array}{l}\text { Publ. } \\
\text { Depth }\end{array}$ & $\begin{array}{c}\text { Pref. F } \\
\text { Depth }\end{array}$ & $\begin{array}{l}\text { Publ. } \\
\text { Dist. }\end{array}$ & $\begin{array}{l}\text { Calc. S } \\
\text { Dist }\end{array}$ & $\begin{array}{l}\text { Slant } \\
\text { dist }\end{array}$ & Mag class & $\begin{array}{c}\mathrm{M} \\
\text { nomo }\end{array}$ & $\begin{array}{c}\text { M M-S } \\
\text { E-W }\end{array}$ & $\begin{array}{c}\text { M M-S } \\
\text { N-S }\end{array}$ & $M$ vert & $\begin{array}{c}\text { M hor } \\
\text { N-L }\end{array}$ & $\begin{array}{c}\mathrm{M} \\
\text { other }\end{array}$ & $\begin{array}{l}\mathrm{M} \\
\text { (other) } \\
\text { source }\end{array}$ & $\begin{array}{c}\mathrm{M} \\
\text { pref }\end{array}$ & $\begin{array}{c}\mathrm{M} \\
\text { (pref) } \\
\text { source }\end{array}$ & $I(\max )$ & Location/felt report & Comment \\
\hline & 3:01:00 & & & & & ml swr? & & 5 & & 30.0 & 30.4 & $\mathrm{~m} ?$ & 4.41 & 4.28 & 4.40 & 4.32 & 4.05 & & & 4.26 & hono & & & Not in VL 508. \\
\hline & 14:04:00 & & & & & $\mathrm{ml} \mathrm{swr}$ ? & & 5 & 37 & 37.0 & 37.3 & $\mathrm{~m}$ ? & 4.55 & 4.58 & 4.50 & 4.52 & 4.47 & & & 4.52 & hono & & $\begin{array}{l}\text { Warshauer notes: Two strong earthquakes were } \\
\text { registered yesterday [June } 13] \text {, one at } 2: 05 \text { p.m. } \\
\text { and a second at } 7: 30 \text { p.m. both originating } \\
\text { under the southern rim of Mokuaweoweo, the } \\
\text { Mauna Loa summit crater }\end{array}$ & $\begin{array}{l}\text { Not separately listed in VL 508; HTH, } \\
6 / 14 / 1950 \text {. }\end{array}$ \\
\hline $6 / 13 / 50$ & 19:47:47 & & & & & $\mathrm{ml} \mathrm{swr}$ ? & & 5 & 37 & 37.0 & 37.3 & st? & 5.07 & 5.12 & & $\begin{array}{c}\text { record } \\
\text { dis- } \\
\text { turbed }\end{array}$ & 5.03 & & & 5.12 & hono & & Do. & $\begin{array}{l}\text { US C\&GS location given as lat } 20^{\circ} \mathrm{N} \text {., } \\
\text { long } 155.5^{\circ} \mathrm{W} \text {; wrong(?); not } \\
\text { separately listed in VL } 508 ; \mathrm{HTH}, \\
6 / 14 / 1950 \text {. }\end{array}$ \\
\hline $10 / 11 / 50$ & 20:06:00 & & & & & $\begin{array}{l}\text { kaoiki } \\
\text { deep }\end{array}$ & & 40 & 20 & 20.0 & 44.7 & $\mathrm{~s}$ & 4.20 & no trace & no trace & $\begin{array}{c}\text { no } \\
\text { trace }\end{array}$ & 3.88 & & & 4.04 & aver & felt & $\begin{array}{l}\text { E slope Mauna Loa; felt widely-most of Hawaii } \\
\text { Island; preferred magnitude calculated as } \\
\text { average of Honolulu and nomogram. }\end{array}$ & i \\
\hline $12 / 9 / 50$ & 5:43:00 & & & & & kl koae & 7.2 & 7.2 & 12.0 & 12.0 & 14.0 & $\mathrm{~m}$ & 4.11 & $<4.47$ & $<4.47$ & $\begin{array}{c}\text { no } \\
\text { trace }\end{array}$ & 4.40 & & & 4.40 & hono & felt & $\begin{array}{l}\text { E of Mauna Iki; felt widely. Warshauer notes: } \\
\text { See above. }\end{array}$ & $\begin{array}{l}\text { Calculated mag low; strong signal lost } \\
\text { in swarm(?), or deeper(?); Honolulu } \\
\text { amplitude average of two readings; VL } \\
510 \text {, p. } 4 \text {; HTH, 12/9/1950. }\end{array}$ \\
\hline $12 / 9 / 50$ & 20:45:00 & 19 & 19.00 & 155 & 22.001 & kl koae? & 7.2 & 7.2 & 15.5 & 16.9 & 34.4 & $\mathrm{~m}$ & 5.01 & 5.09 & 5.28 & 5.05 & 5.06 & & & 5.12 & hono & felt & $\begin{array}{l}\text { Near Kamakaia hills; felt widely. Warshauer } \\
\text { notes: Dismantled seismographs at HVO, ml, } \\
\text { and Hilo; felt in Hilo and Kau. }\end{array}$ & $\begin{array}{l}\text { Calculated mag low; strong signal lost } \\
\text { in swarm(?), or deeper(?); VL } 510 \text {, p. } \\
4 ; \text { HTH, 12/11/1950. }\end{array}$ \\
\hline $12 / 9 / 50$ & 23:59:00 & & & & & kl koae & & 4.0 & & 6.7 & 7.8 & $\mathrm{~s}$ & 3.21 & & & & & & & 4.12 & calc & & $\begin{array}{l}\text { Do.; preferred magnitude calculated from } \\
\text { nomogram magnitude multiplied by number of } \\
\text { events. }\end{array}$ & $\begin{array}{l}\text { Kilauea caldera-Koae earthquake } \\
\text { swarm; VL } 510, \text { p. } 4 \text {, col. 1; } 10 \text { slight } \\
\text { events. }\end{array}$ \\
\hline $12 / 10 / 50$ & 0:42:00 & & & & & kl koae? & & 7.2 & 16.0 & 16.0 & 17.5 & s? & 4.03 & 4.64 & 4.68 & 4.79 & 4.68 & & & 4.70 & hono & IV? & $\begin{array}{l}\text { If slight, must be kcaldeep. Warshauer notes: } \\
\text { Dismantled HVO and ml seismographs; felt in } \\
\text { Kau, most strongly at Kapapala, and probably } \\
\text { in Hilo. }\end{array}$ & Not in VL 510; HTH, 12/11/1950. \\
\hline $12 / 10 / 50$ & $5: 57: 00$ & 19 & 19.00 & 155 & 22.001 & kl koae? & 7.2 & 7.2 & 15.5 & 16.9 & 18.4 & $\mathrm{~m}$ & 4.30 & 4.44 & 4.74 & 4.85 & 4.78 & & & 4.70 & hono & IV? & $\begin{array}{l}\text { Near Kamakaia hills. Warshauer notes: } \\
\text { Dismantled HVO and ml seismographs; felt in } \\
\text { Kau, most strongly at Kapapala, and probably } \\
\text { in Hilo. }\end{array}$ & $\begin{array}{l}\text { Calculated mag low; strong signal lost } \\
\text { in swarm(?), or deeper(?); VL 510, p. } \\
4 \text {; HTH, 12/11/1950. }\end{array}$ \\
\hline $12 / 10 / 50$ & 8:23:00 & 19 & 18.00 & 155 & $22.00 \mathrm{I}$ & kl koae? & 7.2 & 7.2 & 17.0 & 18.3 & 19.7 & $\mathrm{~m}$ & 4.35 & 5.02 & 5.13 & 4.79 & 4.96 & & & 4.98 & hono & IV? & $\begin{array}{l}\text { Below Kamakaia hills. Warshauer notes: } \\
\text { Dismantled HVO and ml seismographs; felt in } \\
\text { Kau, most strongly at Kapapala, and probably } \\
\text { in Hilo. }\end{array}$ & $\begin{array}{l}\text { Calculated mag low; strong signal lost } \\
\text { in swarm(?), or deeper(?); VL } 510, \text { p. } \\
\text { 4; HTH, 12/11/1950. }\end{array}$ \\
\hline $12 / 10 / 50$ & 17:29:00 & 19 & 19.00 & 155 & $22.00 \mathrm{l}$ & kl koae? & 7.2 & 7.2 & 17.0 & 16.9 & 18.4 & $\mathrm{~m}$ & 4.57 & 4.60 & 4.71 & 4.79 & 4.68 & & & 4.70 & hono & IV? & $\begin{array}{l}\text { Kamakaia hills. Warshauer notes: Dismantled } \\
\text { HVO and ml seismographs; felt in Kau, most } \\
\text { strongly at Kapapala, and probably in Hilo. }\end{array}$ & $\begin{array}{l}\text { Calculated mag low; strong signal lost } \\
\text { in swarm(?), or deeper(?); VL } 510 \text {, p. } \\
4 ; \text { HTH, 12/11/1950. }\end{array}$ \\
\hline $12 / 10 / 50$ & 21:25:00 & 19 & 19.00 & 155 & 22.001 & kl koae? & 7.2 & 7.2 & 17.0 & 16.9 & 18.4 & st & 4.57 & 5.21 & 5.37 & 5.31 & 5.15 & & & 5.26 & hono & V? & $\begin{array}{l}\text { Kamakaia hills; felt widely. Warshauer notes: } \\
\text { Strongest of series; dismantled HVO, ml, and } \\
\text { Hilo seismographs; felt in Kau and Hilo. }\end{array}$ & $\begin{array}{l}\text { Calculated mag low; strong signal lost } \\
\text { in swarm(?), or deeper(?); VL } 510 \text {, p. } \\
4 ; \text { HTH, 12/11/1950. }\end{array}$ \\
\hline $12 / 10 / 50$ & 23:59:00 & & & & & kl koae & & 4.0 & & 6.7 & 7.8 & $\mathrm{~s}$ & 3.21 & & & & & & & 4.22 & calc & & $\begin{array}{l}\text { Do.; preferred magnitude calculated from } \\
\text { nomogram magnitude multiplied by number of } \\
\text { events. }\end{array}$ & $\begin{array}{l}\text { Kilauea caldera-Koae earthquake } \\
\text { swarm; VL } 510, \text { p. } 4 \text {, col. 1; } 13 \text { slight } \\
\text { events. }\end{array}$ \\
\hline $12 / 11 / 50$ & 12:53:00 & 19 & 15.50 & 155 & 25.301 & kl swr sf? & 7.2 & 7.2 & & 25.6 & 26.6 & $\mathrm{~m}$ & 4.55 & 3.95 & 3.95 & 4.41 & 4.34 & & & 4.16 & hono & & SW rift below upper end of 1823 flow. & $\begin{array}{l}\text { Honolulu amplitude average of two } \\
\text { readings; VL } 510, \text { p. } 4 \text {. }\end{array}$ \\
\hline $12 / 26 / 50$ & 2:55:00 & 19 & 24.50 & 155 & $15.002^{1}$ & $\begin{array}{l}\text { kl cal 10- } \\
20 ?\end{array}$ & 12.8 & 15.0 & 3.0 & 2.8 & 15.3 & $\mathrm{~m}$ & 4.17 & 4.12 & $<4.32$ & 4.20 & 4.85 & & & 4.16 & hono & $\mathrm{v}$ & $\begin{array}{l}\text { South of Kilauea Iki; felt widely. Warshauer } \\
\text { notes: A plainly felt earthquake accompanied } \\
\text { by a loud rumble and a roar startled many Hilo } \\
\text { and volcano residents out of their sleep early } \\
\text { this morning, preferred magnitude calculated } \\
\text { without N-L. }\end{array}$ & $\begin{array}{l}\text { N-L high; VL 510, p. 4; HTH, } \\
\text { 12/26/1950. }\end{array}$ \\
\hline $1 / 6 / 51$ & 4:58:00 & 19 & 17.0 & 155 & $43.0 \mathrm{r}$ & $\mathrm{ml} \mathrm{swr}$ & & & 51 & 50.8 & 51.6 & $\mathrm{~s}$ & 4.30 & no trace & no trace & $\begin{array}{c}\text { no } \\
\text { trace }\end{array}$ & 4.05 & & & 4.05 & hono & & $\begin{array}{l}\text { SW rift, } 8,000 \text { ft. Warshauer notes: Felt in Hilo } \\
\text { and, no report from Volcano, probably deep. }\end{array}$ & VL 511, p. 4; HTH, 1/6/51. \\
\hline $2 / 16 / 51$ & 7:26:00 & 19 & 32.0 & 155 & $28.0^{1}$ & $\begin{array}{l}\mathrm{ml} \text { ner } \\
\text { deep }\end{array}$ & 24 & 24 & 24.5 & 24.5 & $34.3 \mathrm{~s}$ & $\mathrm{~s} ; \mathrm{m}(\mathrm{ml})$ & 4.01 & $<4.07$ & $<4.07$ & & $<3.27$ & & & 4.01 & nomo & felt & NE rift near Puu Ulaula; felt-Hilo to. & $\mathrm{ml} \mathrm{mag} \mathrm{VL} \mathrm{4.0-4.} \mathrm{5;} \mathrm{VL} \mathrm{511,} \mathrm{p.} 4$. \\
\hline $4 / 22 / 51$ & 4:53:53 & 19 & 24.50 & 155 & $6.80^{1}$ & $\begin{array}{l}\text { kl cal } \\
\text { deepp }\end{array}$ & 33.6 & 33.6 & 9.0 & 15.8 & 37.1 & $\mathrm{~m}$ & 4.55 & $<4.20$ & $<4.27$ & $\begin{array}{c}\text { no } \\
\text { trace }\end{array}$ & 4.21 & & & 4.21 & hono & III & $\begin{array}{l}\text { E rift } 7 \mathrm{mi} \text { S15E from Glenwood; felt- } \\
\text { Kapapala, volcano to Hilo. Warshauer notes: A } \\
\text { moderate earthquake that originated on the east } \\
\text { rift of Kilauea about } 5 \mathrm{mi} \text { south of Glenwood } \\
\text { and at a depth of } 31 \mathrm{mi} \text {; Hilo- } 3 \text {. }\end{array}$ & $\begin{array}{l}\text { Honolulu amplitude average of two } \\
\text { readings; mag agreement improved if } \\
\text { shallower ( } 20 \text { km or less); epicenter } \\
\text { estimated noninstrumentally, its } \\
\text { location only approximate; VL } 512, \mathrm{p} . \\
2,4 ; \mathrm{HSB}, 4 / 24 / 1951 ; \text { HVO unpub. }\end{array}$ \\
\hline
\end{tabular}


Table 13. All earthquakes of $M \geq 4.0$ during the period 1903-59-Continued

\begin{tabular}{|c|c|c|c|c|c|c|c|c|c|c|c|c|c|c|c|c|c|c|c|c|c|c|c|}
\hline Date & $\begin{array}{l}\text { Time } \\
\text { (HST) }\end{array}$ & $\begin{array}{c}\text { Lat } \\
(\operatorname{deg})\end{array}$ & $\begin{array}{cc}\text { Lat } & \text { L } \\
(\min ) & (\mathrm{d}\end{array}$ & $\begin{array}{l}\text { Lon } \\
(\operatorname{deg})\end{array}$ & $\begin{array}{c}\text { Lon } \\
(\min )\end{array}$ & $\begin{array}{l}\text { Publ. } \\
\text { Depth I }\end{array}$ & $\begin{array}{l}\text { Pref. } \\
\text { Depth }\end{array}$ & $\begin{array}{c}\text { Publ. } \\
\text { Dist. }\end{array}$ & $\begin{array}{c}\text { Calc. } \\
\text { Dist }\end{array}$ & $\begin{array}{c}\text { Slant } \\
\text { dist }\end{array}$ & Mag class & $\begin{array}{c}\mathrm{M} \\
\text { nomo }\end{array}$ & $\begin{array}{c}\text { M M-S } \\
\text { E-W }\end{array}$ & $\begin{array}{c}\text { M M-S } \\
\mathrm{N}-\mathrm{S}\end{array}$ & M vert & $\begin{array}{c}\text { M hor } \\
\mathrm{N}-\mathrm{L}\end{array}$ & $\begin{array}{c}\mathrm{M} \\
\text { other }\end{array}$ & $\begin{array}{l}\mathrm{M} \\
\text { (other) } \\
\text { source }\end{array}$ & $\begin{array}{c}\text { M } \\
\text { pref }\end{array}$ & $\begin{array}{c}\mathrm{M} \\
\text { (pref) } \\
\text { source }\end{array}$ & $I(\max )$ & Location/felt report & Comment \\
\hline $4 / 22 / 51$ & 14:52:00 & 19 & 24.50 & 155 & $\begin{array}{l}\mathrm{kl} \mathrm{cal} \\
13.30 \text { deep }\end{array}$ & 44.0 & 35.0 & 4.0 & 4.9 & 35.3 & vst & 6.27 & 6.31 & 5.95 & 5.72 & 5.79 & $\begin{array}{l}6.5 ; \\
6.0 ; \\
6.3\end{array}$ & $\begin{array}{l}\text { Pasadena; } \\
\text { Berkeley; } \\
\text { W\&K }\end{array}$ & 6.23 & aver & $\begin{array}{l}\text { VII; VII (USE; } \\
\text { S\&C) }\end{array}$ & $\begin{array}{l}\text { Felt-entire island, Maui, Oahu; Hilo-5, N-S, } \\
\text { objects onto floor, clock stopped. Warshauer } \\
\text { notes: Little damage, Hilo-buildings } \\
\text { swayed/dishes broke, glass cracked, water main } \\
\text { broke; hnp-damage to roads, new cracks, some } \\
\text { subsidence, landslides in Halemaumau }\end{array}$ & $\begin{array}{l}\text { Isoseismal map in W\&K; E rift near } \\
\text { Kilauea crater; VL } 512 \text {, p. 4, damage } \\
\text { report on p. }-3 \text {; HVO unpub.; HTH, } \\
\text { 4/23/1951; HA, 4/23/1951; HSB, } \\
\text { 4/24/1951; preferred mag calculated as } \\
\text { 1 weighted average of Milne-Shaw avg } \\
\text { (1), Berkeley, Pasadena, and W\&K (all } \\
\text { 1). }\end{array}$ \\
\hline $4 / 26 / 51$ & 3:58:00 & 19 & 23.40 & 155 & $8.30 \mathrm{kl} \mathrm{mer}$ & 19.2 & 10.0 & 11.5 & $5 \quad 13.7$ & 17.0 & $\begin{array}{c}\text { st (m?); s } \\
\text { (hilo) }\end{array}$ & 4.00 & $<4.47$ & $<4.47$ & $<3.90$ & $<3.85$ & & & 4.00 & nomo & felt & $\begin{array}{l}\text { E rift near Makaopuhi crater, felt-volcano. } \\
\text { Warshauer notes: An earthuake described as } \\
\text { "strong" was recorded on HVO and Hilo } \\
\text { [slight] seismographs at 3:57:44 this morning. }\end{array}$ & $\begin{array}{l}\text { Strong classification inconsistent with } \\
\text { indicated hypocenter, absence of a } \\
\text { record in Honolulu, and limited felt } \\
\text { reports; Hilo (s) yields calculated mag } \\
\text { 3.90-4.38; error in VL 512, p. 5(?); } \\
\text { HTH, 4/26/1951. }\end{array}$ \\
\hline $6 / 11 / 51$ & 8:33:00 & 19 & 29.80 & 155 & $2.10 \mathrm{kl} \mathrm{gln}$ & 11.2 & 10.0 & & 24.9 & 26.9 & $\mathrm{~s}$ & 4.07 & no trace & no trace & $\begin{array}{c}\text { no } \\
\text { trace }\end{array}$ & $\begin{array}{c}\text { no } \\
\text { trace }\end{array}$ & & & 4.07 & nomo & III & $\begin{array}{l}6 \mathrm{mi} \mathrm{w} \text { of Pahoa; felt-Hilo to volcano; Hilo-2, } \\
\text { typical local quake, one short quick jerk }\end{array}$ & VL 512, p. $5 ;$ HVO, unpub. \\
\hline $8 / 21 / 51$ & 0:57:00 & 19 & 30.0 & 155 & 57.0 kona & & & 72 & 273.0 & 73.6 & st & 5.54 & 5.87 & 5.90 & 6.35 & 5.68 & $\begin{array}{r}6.75 \\
7.0 ; \\
6.9\end{array}$ & $\begin{array}{l}\text { PAS; } \\
\text { BERK; } \\
\text { GUTE }\end{array}$ & 6.90 & gute & $\begin{array}{l}\text { VIII; VIII (W\&K; } \\
\text { S\&C) }\end{array}$ & $\begin{array}{l}3 \text { mi WNW of Napoopoo-prob on Kealakekua } \\
\text { Fault; strong-all Hawaii Island, also Mauii, } \\
\text { Oahu, much damage on W side Hawaii. } \\
\text { Warshauer notes: See refs; Kapapala-severe } \\
\text { quake followed by smaller shocks, last at } 6: 16 \\
\text { am, phone service disrupted, no major damage. }\end{array}$ & $\begin{array}{l}\text { Isoseismal map in W\&K; depth } 10 \mathrm{~km} \text {; } \\
\text { location, lat } 19^{\circ} 29.5^{\prime} \mathrm{N} . \text {., long } 155^{\circ} 58.3 \\
\text { W., offshore; VL } 513 \text {, p. } 6 ; \mathrm{HTH}, \\
8 / 21 / 1951 \text {; HVO, unpub; see } \\
\text { references for detailed felt reports. }\end{array}$ \\
\hline $8 / 21 / 51$ & 8:03:00 & & & & kona & & & 10 & 10.0 & 13.5 & $5 \mathrm{~m}$ (kona) & 4.08 & 4.40 & 4.48 & 4.24 & 3.84 & & & 4.24 & hono & & & $\begin{array}{l}\text { Closer(?) or moderate at Kona; VL } \\
513, \text { p. } 6 .\end{array}$ \\
\hline $8 / 21 / 51$ & 9:57:00 & & & & kona & & & 10 & 10.0 & 13.5 & 5 st (kona) & 4.36 & 4.24 & 4.10 & 3.97 & 3.92 & & & 4.06 & hono & felt & $\begin{array}{l}\text { Felt-Kona to volcano; Kapapala ranch (10:00 } \\
\text { a.m.)-slight earthquake. }\end{array}$ & $\begin{array}{l}\text { VL 513, p. 6; HVO, unpub. [intensities- } \\
\text { arabic numerals-in remarks column } \\
\text { refer to HVO postcards]. }\end{array}$ \\
\hline $8 / 21 / 51$ & 10:12:00 & & & & kona & & & 10 & 10.0 & 13.5 & st (kona) & 4.36 & 4.18 & 4.24 & 4.27 & 4.44 & & & 4.28 & hono & felt & $\begin{array}{l}\text { Felt(?); Kapapala ranch (11:15 a.m.-time off } \\
\text { by } 1 \text { hour?)-slight earthquake. }\end{array}$ & $\begin{array}{l}\text { VL 513, p. 6; HVO, unpub. [intensities- } \\
\text { arabic numerals-in remarks column } \\
\text { refer to HVO postcards]. }\end{array}$ \\
\hline $8 / 21 / 51$ & 18:32:00 & & & & kona & & & 10 & 10.0 & 13.5 & st (kona) & 4.36 & 4.30 & 4.30 & 4.39 & 4.44 & & & 4.36 & hono & & & VL 513, p. 6. \\
\hline $8 / 21 / 51$ & 22:48:00 & & & & kona & & & 10 & 10.0 & 13.5 & 5 st (kona) & 4.36 & 4.78 & 4.70 & 4.87 & 5.01 & & & 4.84 & hono & $\mathrm{V}$ ? & $\begin{array}{l}\text { Felt-Kona to volcano; Capt. Cook (Greenwell } \\
\text { diary)-big shaker. }\end{array}$ & $\begin{array}{l}\text { VL 513, p. 6; HVO, unpub. [intensities- } \\
\text { arabic numerals-in remarks column } \\
\text { refer to HVO postcards]. }\end{array}$ \\
\hline $8 / 22 / 51$ & 6:38:00 & & & & kona & & & 10 & 10.0 & 13.5 & $5 \mathrm{~m}$ (kona) & 4.08 & 4.40 & 4.24 & 4.09 & 4.22 & & & 4.24 & hono & III & $\begin{array}{l}\text { Felt-Kona to Kapapala; Kapapala ranch (6:20 } \\
\text { a.m.)-slight earthquake; Capt. Cook (Greenwell } \\
\text { diary)-0630, good one. }\end{array}$ & $\begin{array}{l}\text { Closer(?) or moderate at Kona; VL } \\
513, \text { p. 6; HVO, unpub. [intensities- } \\
1 \text { arabic numerals-in remarks column } \\
\text { refer to HVO postcards]. }\end{array}$ \\
\hline $8 / 22 / 51$ & 17:15:00 & & & & kona & & & 10 & 10.0 & 13.5 & 5 st (kona) & 4.36 & 4.74 & 4.70 & 4.49 & 4.76 & & & 4.67 & hono & IV & $\begin{array}{l}\text { Felt-Kona to volcano; Kapapala ranch (5:18 } \\
\text { p.m.)-medium earthquake. }\end{array}$ & $\begin{array}{l}\text { VL 513, p. 6; HVO, unpub. [intensities- } \\
\text { arabic numerals-in remarks column } \\
\text { refer to HVO postcards]. }\end{array}$ \\
\hline $9 / 1 / 51$ & 12:29:00 & & & & kona & & & 60 & 60.0 & 60.7 & f; s (kona) & 4.09 & & & & & & & 4.09 & nomo & III & $\begin{array}{l}\text { Kealakekua fault; Capt. Cook (Greenwell } \\
\text { diary)-PM, fair one. }\end{array}$ & $\begin{array}{l}\text { Kona mag } 3.8-4.3 \text { if S part of fault; } \mathrm{VL} \\
513, \text { p. } 6 ; \mathrm{HVO} \text {, unpub. [intensities- } \\
\text { arabic numerals-in remarks column } \\
\text { refer to HVO postcards]. }\end{array}$ \\
\hline $9 / 16 / 51$ & 1:43:00 & 19 & 19.0 & 155 & 25.9 kaoiki & & & 21.5 & 22.0 & 23.8 & st & 4.75 & 4.87 & 5.22 & 4.94 & 4.93 & 5.0 & & 4.99 & hono & $\mathrm{V}(\mathrm{VL} ; \mathrm{S} \& \mathrm{C})$ & $\begin{array}{l}\text { Kaoiki fault, } 3 \text { mi NE of Kapapala; felt-Kona } \\
\text { to Hili; felt-Hilo-3 to I; Hillo-3 to IV [date } \\
\text { given as 9/15]. Warshauer notes: Shook the Big } \\
\text { Island; dismantled HVO and ML } \\
\text { seismographs; strong in Hilo, Volcano. Pahala, } \\
\text { and Kona; no serious damage. }\end{array}$ & $\begin{array}{l}\text { VL } 513 \text {, p. 6; HVO, unpub. [intensities- } \\
\text { arabic numerals-in remarks column } \\
\text { refer to HVO postcards]; HTH, } \\
9 / 17 / 1951 .\end{array}$ \\
\hline $9 / 25 / 51$ & 1:23:00 & 19 & 43.6 & 155 & 55.8 hualalai & & & 77 & 77.8 & 78.3 & $\begin{array}{c}\mathrm{s} ; \mathrm{m} \\
\text { (kona) }\end{array}$ & 4.59 & no trace & no trace & 3.58 & 4.07 & & & 4.17 & aver & felt & $\begin{array}{l}\text { Do.; felt generally-N Kona. Warshauer notes: } \\
\text { See above; preferred magnitude calculated as } \\
\text { average of Honolulu and nomogram. }\end{array}$ & $\begin{array}{l}\text { Kona mag VL 4.3-4.8; closer to } \\
\text { Kona(?); preferred magnitude averages } \\
\text { Whitney, Kona and two Honolulu } \\
\text { magnitudes; VL 513, p. 6; HTH, } \\
\text { 9/25/1951. }\end{array}$ \\
\hline 10/9/51 & 4:45:00 & & & & kona & & & 60 & 60.0 & 60.7 & s & 4.63 & no trace & no trace & $\begin{array}{c}\text { no } \\
\text { trace }\end{array}$ & 3.62 & & & 4.12 & aver & IV & $\begin{array}{l}\text { Central Kona; assume } 10 \mathrm{~km} \text { from Kona; felt- } \\
\text { Kona to Hilo; Kealakekua-strong and short; } \\
\text { Hilo-2, very light; preferred magnitude } \\
\text { calculated as average of Honolulu and } \\
\text { nomogram. }\end{array}$ & $\begin{array}{l}\text { VL } 514, \text { p. 4; HVO, unpub. [intensities- } \\
\text { arabic numerals-in remarks column } \\
\text { refer to HVO postcards]. }\end{array}$ \\
\hline $10 / 17 / 51$ & 21:12:00 & 19 & 33.6 & 155 & 12.1 hilo & & & 17 & 15.6 & 18.1 & $\mathrm{~s} ; \mathrm{m}-\mathrm{ml}$ & 4.05 & no trace & no trace & $\begin{array}{c}\text { no } \\
\text { trace }\end{array}$ & $\begin{array}{c}\text { no } \\
\text { trace }\end{array}$ & & & 4.05 & nomo & felt & 3,000 ft, NE rift; felt-volcano, Hilo. & $\mathrm{ml} \mathrm{mag} \mathrm{3.9-4.} \mathrm{4;} \mathrm{VL} \mathrm{514,} \mathrm{p.} 4$. \\
\hline
\end{tabular}


온 Table 13. All earthquakes of $M \geq 4.0$ during the period 1903-59-Continued

\begin{tabular}{|c|c|c|c|c|c|c|c|c|c|c|c|c|c|c|c|c|c|c|c|c|c|c|c|c|}
\hline Date & $\begin{array}{c}\text { Time } \\
\text { (HST) }\end{array}$ & $\begin{array}{c}\mathrm{Lat} \\
\text { (deg) }\end{array}$ & $\begin{array}{c}\text { Lat } \\
(\mathrm{min})\end{array}$ & $\begin{array}{l}\text { Lon } \\
(\operatorname{deg})\end{array}$ & $\begin{array}{l}\text { Lon } \\
(\mathrm{min})\end{array}$ & Region & $\begin{array}{l}\text { Publ. P } \\
\text { Depth D }\end{array}$ & $\begin{array}{l}\text { Pref. } \\
\text { Depth }\end{array}$ & $\begin{array}{l}\text { Publ. } \\
\text { Dist. }\end{array}$ & $\begin{array}{l}\text { Calc. } \\
\text { Dist }\end{array}$ & $\begin{array}{l}\text { Slant } \\
\text { dist }\end{array}$ & Mag class & $\begin{array}{c}\mathrm{M} \\
\text { nomo }\end{array}$ & $\begin{array}{c}\text { M M-S } \\
\text { E-W }\end{array}$ & $\begin{array}{c}\text { M M-S } \\
\text { N-S }\end{array}$ & M vert & $\begin{array}{c}\text { M hor } \\
\text { N-L }\end{array}$ & $\begin{array}{c}\text { M } \\
\text { other }\end{array}$ & $\begin{array}{c}\mathrm{M} \\
\text { (other) } \\
\text { source }\end{array}$ & $\underset{\text { pref }}{\mathrm{M}}$ & $\begin{array}{c}\mathrm{M} \\
\text { (pref) } \\
\text { source }\end{array}$ & $I(\max )$ & Location/felt report & Comment \\
\hline $11 / 8 / 51$ & 9:34:00 & 19 & 9.0 & 155 & $44.0 \mathrm{~m}$ & ml swr & & & 60 & 58.8 & 59.5 & st & 5.39 & 5.62 & 5.63 & 5.66 & 5.61 & & & 5.63 & hono & $\begin{array}{l}\text { VI; VI [USE; } \\
\text { S\&C] }\end{array}$ & $\begin{array}{l}\text { 4,500 ft, SW rift; felt-S Hawaii Island. } \\
\text { Warshauer notes: "Strong" quake shook the Big } \\
\text { Island; no damage, felt-all listand; Kona dur } 30 \\
\text { s; Kahuku Ranch-stone fences down, concrete } \\
\text { sidewalks cracked, few dishes broken; } \\
\text { additional felt reports in HVO, unpub. }\end{array}$ & $\begin{array}{l}\text { VL 514, p. 5; HTH, 11/8; 9/1951; } \\
\text { HVO, unpub. [intensities-arabic } \\
\text { numerals-in remarks column refer to } \\
\text { HVO postcards]. }\end{array}$ \\
\hline $11 / 23 / 51$ & 8:22:00 & 19 & 28.5 & 155 & $59.8 \mathrm{k}$ & kona & & & 75 & 77.7 & 78.2 & $\begin{array}{c}\mathrm{s} ; \mathrm{m} \\
\text { (kona) }\end{array}$ & $4.59 \mathrm{r}-2 \mathrm{r} r \mathrm{r}$ & no trace & no trace & $\begin{array}{c}\text { no } \\
\text { trace }\end{array}$ & $\begin{array}{c}\text { no } \\
\text { trace }\end{array}$ & & & 4.00 & nomo & felt & $\begin{array}{l}\text { Kealakekua fault, } 5 \mathrm{mi} W \text { of Napoopoo; felt- } \\
\text { central Kona to Kahuku. }\end{array}$ & $\begin{array}{l}\text { Kona mag 3.8-4.3; location wrong-SE } \\
\text { of Napoopoo(?); or feeble at } \\
\text { Whitney(?); Kona magnitude preferred; } \\
\text { VL 514, p. 5. }\end{array}$ \\
\hline $12 / 6 / 51$ & 20:19:00 & 19 & 25.00 & 155 & $1.00 \mathrm{k}$ & kl mer sf? & & 5.0 & & 25.8 & 26.3 & $\mathrm{st}(\mathrm{m} ?)$ & 4.55 & $<4.52$ & $<4.52$ & $<4.0$ & 4.53 & & & 4.53 & hono & IV & $\begin{array}{l}\text { E rift, } 7 \text { mi SW of Pahoa; felt-Kapapala to Hilo } \\
\text { and east Puna. Warshauer notes: A strong } \\
\text { earthquake was felt all over the Hilo and } \\
\text { Volcano districts at } 8: 19 \text { last night. }\end{array}$ & $\begin{array}{l}\text { Honolulu amplitude average of two } \\
\text { readings; [moderate(?), or closer to } \\
\text { summit??; probably kl sf rather than } \\
\text { rift]; VL 514, p. 5; additional felt data } \\
\text { in HVO unpub; HTH, } 12 / 7 / 1951\end{array}$ \\
\hline 2/2/52 & 1:16:00 & & & & & hilo deep & 48 & 48 & 31 & 31.0 & 57.1 & $\mathrm{~m}$ & 4.85 & 4.90 & 4.45 & 4.56 & 4.76 & & & 4.67 & hono & $\mathrm{v}$ & $\begin{array}{l}\text { Nearly under Kaumana [Hilo]; felt-most of } \\
\text { Hawaii Island, strongly at Hilo. Warshauer } \\
\text { notets: A short strong earthquake jerked some } \\
\text { Hiloans awake at 1:16 this morning, but no } \\
\text { damage reported; Captain Cook-4; Hilo-2 to } \\
\text { III, rattled windows; Kukuihaele-5. }\end{array}$ & $\begin{array}{l}\text { Location reasonable(?); VL } 515, \text { p. } 6 \text {; } \\
\text { HTH, 2/2/1952; HVO, unpub. } \\
\text { [intensities-arabic numerals-in remarks } \\
\text { column refer to HVO postcards]. }\end{array}$ \\
\hline $3 / 13 / 52$ & 11:38:00 & 19 & 2.40 & 155 & $6.20 \mathrm{o}$ & $\begin{array}{l}\mathrm{kl} \mathrm{mer} \mathrm{sf} \\
\text { os }\end{array}$ & & 10.0 & & 46.5 & 47.6 & st & 5.23 & 5.37 & 5.35 & 5.21 & 5.23 & & & 5.29 & hono & felt & Off south shore; felt-volcano to Naalehu. & VL 515, p. 6. \\
\hline $3 / 14 / 52$ & 18:21:00 & 19 & 2.80 & 155 & $\begin{array}{rl}k \\
4.80 & o\end{array}$ & $\begin{array}{l}\mathrm{kl} \mathrm{mer} \mathrm{sf} \\
\text { os }\end{array}$ & & 10.0 & & 46.8 & 47.9 & st & 5.24 & 5.25 & 5.07 & 5.21 & 5.23 & & & 5.19 & hono & felt & Off south shore; felt-Hilo to Kapapala. & 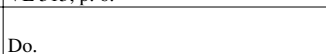 \\
\hline $3 / 17 / 52$ & 17:58:00 & 19 & 7.50 & 155 & $2.00 \mathrm{o}$ & $\begin{array}{l}\mathrm{kl} \mathrm{mer} \mathrm{sf} \\
\text { os? }\end{array}$ & & 10.0 & & 41.6 & 42.8 & st & 5.16 & 5.88 & $\begin{array}{l}\text { no } \\
\text { record }\end{array}$ & 5.50 & 5.63 & 5.00 & USE? & 5.67 & hono & V; V (USE; S\&C) & $\begin{array}{l}\text { Felt-Naalehu; small tsunami at Kalapana. } \\
\text { Warshauer notes: Tsunami at Kalapana; } \\
\text { earthquake not felt there. }\end{array}$ & $\begin{array}{l}\text { VL } 515, \text { p. } 7 \text {; HTH, } 3 / 18 / 1952 ; \text { see } \\
\text { references; coverage of the earthquake } \\
\text { swarm continues daily through } 3 / 28 \text {. }\end{array}$ \\
\hline $3 / 18 / 52$ & 9:02:00 & & & & & $\begin{array}{l}\mathrm{kl} \text { kuer sf } \\
\text { os }\end{array}$ & & & & & & & & $<4.27$ & $<4.27$ & $<4.05$ & 4.28 & & & 4.28 & hono & & Off south shore. & Not in VL 515. \\
\hline $3 / 18 / 52$ & 10:53:00 & 19 & 0.10 & 155 & $19.80 \mathrm{o}$ & $\begin{array}{l}\text { kl kuer sf } \\
\text { os }\end{array}$ & & 10.0 & & 48.3 & 49.3 & $\mathrm{~m}$ & 4.75 & 4.78 & 4.65 & 4.75 & 4.65 & & & 4.71 & hono & felt & Off south shore; felt-Naalehu. & VL 515, p. 7. \\
\hline $3 / 18 / 52$ & 13:01:00 & 19 & 6.10 & 155 & $\begin{array}{rl}k & k \\
20.50 & o\end{array}$ & $\begin{array}{l}\text { kl kuer sf } \\
\text { os }\end{array}$ & & 10.0 & & 37.6 & 38.9 & $\mathrm{~m}$ & 4.58 & $<4.27$ & $<4.27$ & $<4.05$ & 4.30 & & & 4.30 & hono & & Off south shore. & $\begin{array}{l}\text { Honolulu amplitude average of two } \\
\text { readings; VL } 515, \text { p. } 7 \text {. }\end{array}$ \\
\hline $3 / 18 / 52$ & 14:18:00 & 19 & 4.60 & 155 & $24.70 \mathrm{o}$ & $\begin{array}{l}\text { kl swr sf } \\
\text { os }\end{array}$ & & 10.0 & & 42.5 & 43.6 & st & 5.17 & 5.57 & 5.73 & 5.43 & 5.51 & & & 5.56 & hono & & Do. & VL 515, p. 7. \\
\hline $3 / 19 / 52$ & 2:55:00 & 19 & 6.50 & 155 & $1.80 \mathrm{o}$ & $\begin{array}{l}\mathrm{kl} \mathrm{mer} \mathrm{sf} \\
\text { os? }\end{array}$ & & 10.0 & & 43.4 & 44.5 & st & 5.19 & 5.48 & 5.68 & 5.40 & 5.43 & & & 5.50 & hono & felt & Off south shore; felt-Naalehu. & Do. \\
\hline $3 / 19 / 52$ & 14:15:00 & & & & & $\begin{array}{l}\mathrm{kl} \mathrm{kuer} \mathrm{sf} \\
\text { os }\end{array}$ & & 10.0 & 47.0 & 47.0 & 48.1 & s? & 4.73 & 4.60 & $\begin{array}{c}\text { no } \\
\text { record }\end{array}$ & 4.65 & 4.48 & & & 4.58 & hono & & Off south shore. & Not in VL 515. \\
\hline $3 / 19 / 52$ & 15:51:00 & 19 & 2.00 & 155 & $20.10 \mathrm{o}$ & $\begin{array}{l}\mathrm{kl} \mathrm{swr} \mathrm{sf} \\
\text { os }\end{array}$ & & 10.0 & & 44.9 & 46.0 & st & 5.21 & 5.52 & $\begin{array}{l}\text { no } \\
\text { record }\end{array}$ & 5.36 & 5.29 & & & 5.39 & hono & & Do. & VL 515, p. 7. \\
\hline $3 / 20 / 52$ & 1:22:00 & 19 & 2.30 & 155 & $\begin{aligned} \mathrm{k} & \\
18.50 \mathrm{o} & -\end{aligned}$ & $\begin{array}{l}\text { kl kuer sf } \\
\text { os }\end{array}$ & & 10.0 & & 43.9 & 45.1 & st & 5.20 & 5.52 & $\begin{array}{l}\text { no } \\
\text { record }\end{array}$ & 5.25 & 5.30 & & & 5.36 & hono & & Do. & Do. \\
\hline $3 / 20 / 52$ & 9:51:00 & 19 & 3.20 & 155 & $\begin{aligned} & \mathrm{k} \\
& 14.70 \mathrm{o}\end{aligned}$ & $\begin{array}{l}\text { kl kuer sf } \\
\text { os }\end{array}$ & & 10.0 & & 42.0 & 43.2 & st & 5.17 & 5.50 & 5.45 & 5.25 & 5.28 & & & 5.37 & hono & felt & Off south shore; felt-Naalehu. & Do. \\
\hline $3 / 20 / 52$ & 20:16:00 & 19 & 3.50 & 155 & $\begin{array}{rl}k & k \\
23.70 & o\end{array}$ & $\begin{array}{l}\text { kl swr sf } \\
\text { os }\end{array}$ & & 10.0 & & 43.8 & 44.9 & $\mathrm{~m}$ & 4.68 & 4.49 & 4.49 & 4.60 & 4.49 & & & 4.52 & hono & felt & 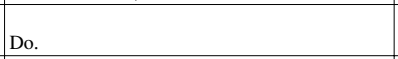 & Do. \\
\hline $3 / 20 / 52$ & 23:48:00 & 19 & 2.20 & 155 & $23.60 \mathrm{o}$ & $\begin{array}{l}\text { kl swr sf } \\
\text { os }\end{array}$ & & 10.0 & & 46.0 & 47.1 & $\mathrm{~m}$ & 4.71 & 4.49 & 4.43 & 4.70 & 4.43 & & & 4.51 & hono & felt & Do. & Do. \\
\hline $3 / 21 / 52$ & 4:35:00 & 19 & 2.70 & 155 & $\begin{aligned} \mathrm{k} \\
13.90 \mathrm{o}\end{aligned}$ & $\begin{array}{l}\text { kl kuer sf } \\
\text { os }\end{array}$ & & 10.0 & & 43.0 & 44.2 & st & 5.18 & 4.78 & 4.78 & 4.83 & 4.78 & & & 4.79 & hono & felt & Do. & $\begin{array}{l}\text { Mag agreement improved if moderate } \\
\text { rather than strong; VL } 515, \text { p. } 7 \text {. }\end{array}$ \\
\hline $3 / 21 / 52$ & 10:55:00 & & & & & $\begin{array}{l}\text { kl kuer sf } \\
\text { os }\end{array}$ & & 10.0 & 40.0 & 40.0 & 41.2 & $\mathrm{~s}$ ? & 4.62 & 4.56 & 4.54 & 4.70 & 4.40 & & & 4.55 & hono & & Off south shore. & $\begin{array}{l}\text { Honolulu amplitude average of two } \\
\text { readings; not in VL } 515 .\end{array}$ \\
\hline $3 / 21 / 52$ & 14:25:00 & 19 & 4.30 & 155 & $14.30 \mathrm{o}$ & $\begin{array}{l}\mathrm{kl} \text { kuer sf } \\
\text { os }\end{array}$ & & 10.0 & & 40.0 & 41.3 & $\mathrm{~m}$ & 4.62 & 4.40 & 4.40 & 4.35 & 4.30 & & & 4.36 & hono & & Do. & $\begin{array}{l}\text { Mag agreement improved if closer to } \\
\text { shore; VL 515, p. } 7 \text {. }\end{array}$ \\
\hline $3 / 22 / 52$ & 2:02:00 & 19 & 2.50 & 155 & $\begin{array}{r}\mathrm{k} \\
12.10 \mathrm{o}\end{array}$ & $\begin{array}{l}\text { kl kuer sf } \\
\text { os }\end{array}$ & & 10.0 & & 43.7 & 44.9 & st & 5.19 & 5.04 & 5.22 & 5.09 & 4.90 & & & 5.06 & hono & felt & Off south shore; felt-Naalehu. & VL 515, p. 7. \\
\hline $3 / 22 / 52$ & 6:19:00 & 19 & 7.80 & 155 & $0.40 \mathrm{o}$ & $\begin{array}{l}\text { kl mer sf } \\
\text { os? }\end{array}$ & & 10.0 & & 42.9 & 44.0 & $\mathrm{~m}$ & 4.67 & 4.35 & 4.35 & 4.70 & 4.53 & & & 4.48 & hono & & Off south shore. & Do. \\
\hline $3 / 22 / 52$ & 19:20:00 & 19 & 6.40 & 155 & $3.90 \mathrm{k}$ & $\begin{array}{l}\text { kl mer sf } \\
\text { os? }\end{array}$ & & 10.0 & & 41.6 & 42.8 & $\mathrm{~m}$ & 4.65 & 4.70 & 4.75 & 4.70 & 4.70 & & & 4.71 & hono & felt & Off south shore; felt-Naalehu. & Do. \\
\hline
\end{tabular}


Table 13. All earthquakes of $M \geq 4.0$ during the period 1903-59-Continued

\begin{tabular}{|c|c|c|c|c|c|c|c|c|c|c|c|c|c|c|c|c|c|c|c|c|c|c|c|c|}
\hline Date & $\begin{array}{c}\text { Time } \\
\text { (HST) }\end{array}$ & $\begin{array}{l}\text { Lat } \\
(\mathrm{deg})\end{array}$ & $\begin{array}{l}\text { Lat } \\
(\mathrm{min})\end{array}$ & $\begin{array}{l}\text { Lon } \\
(\operatorname{deg})\end{array}$ & $\begin{array}{l}\text { Lon } \\
(\min )\end{array}$ & Region & $\begin{array}{l}\text { Publ. } \\
\text { Depth I }\end{array}$ & $\begin{array}{l}\text { Pref. } \\
\text { Depth }\end{array}$ & $\begin{array}{c}\text { Publ. } \\
\text { Dist. }\end{array}$ & $\begin{array}{l}\text { Calc. } \\
\text { Dist }\end{array}$ & $\begin{array}{c}\text { Slant } \\
\text { dist }\end{array}$ & Mag class & $\begin{array}{c}\mathrm{M} \\
\text { nomo }\end{array}$ & $\begin{array}{l}\text { M M-S } \\
\text { E-W }\end{array}$ & $\begin{array}{c}\text { M M-S } \\
\text { N-S }\end{array}$ & $M$ vert & $\begin{array}{c}\text { M hor } \\
\text { N-L }\end{array}$ & $\begin{array}{c}\mathrm{M} \\
\text { other }\end{array}$ & $\begin{array}{c}\mathrm{M} \\
\text { (other) } \\
\text { source }\end{array}$ & $\begin{array}{c}\mathrm{M} \\
\text { pref }\end{array}$ & $\begin{array}{c}\mathrm{M} \\
\text { (pref) } \\
\text { source }\end{array}$ & $I(\max )$ & Location/felt report & Comment \\
\hline $3 / 22 / 52$ & 23:59:00 & & & & & $\begin{array}{l}\text { kl kuer sf } \\
\text { os? }\end{array}$ & & 10.0 & 42.0 & 42.0 & 43.2 & $\mathrm{~s}$ & 4.40 & & & & & & & 6.12 & calc & & $\begin{array}{l}\text { sf offshore; preferred magnitude calculated as } \\
\text { nomogram magnitude multiplied by number of } \\
\text { events. }\end{array}$ & $\begin{array}{l}\text { Reconciliation of the weekly tabulation } \\
\text { (VL } 515 \text {, p. 5) with the earthquake list } \\
\text { on p. } 7 \text { (including those identified at } \\
\text { Honolulu) shows } 79 \text { (s) unaccounted } \\
\text { for between } 3 / 16 \text { and } 22 / 1952, \\
\text { assuming that all belong to the swarm. }\end{array}$ \\
\hline $3 / 22 / 52$ & 23:59:00 & & & & & $\begin{array}{l}\text { kl kuer sf } \\
\text { os? }\end{array}$ & & 10.0 & 42.0 & 42.0 & 43.2 & $\mathrm{f}$ & 3.85 & & & & & & & 5.71 & calc & & Do. & $\begin{array}{l}\text { Reconciliation of the weekly tabulation } \\
\text { (VL 515, p. 5) with the earthquake list } \\
\text { on p. } 7 \text { (including those identified at } \\
\text { Honolulu) shows } 111 \text { (f) unaccoounted } \\
\text { for between } 3 / 16 \text { and } 22 / 1952 \text {, } \\
\text { assuming that all belong to the swarm. }\end{array}$ \\
\hline $3 / 22 / 52$ & 23:59:00 & & & & & $\begin{array}{l}\text { kl kuer sf } \\
\text { os? }\end{array}$ & & 10.0 & 42.0 & 42.0 & 43.2 & vf & 2.83 & & & & & & & 5.27 & calc & & Do. & $\begin{array}{l}\text { Reconciliation of the weekly tabulation } \\
\text { (VL 515, p. 5) with the earthquake list } \\
\text { on p. } 7 \text { (including those identified at } \\
\text { Honolulu) shows } 483 \text { (vf) unaccounted } \\
\text { for between } 3 / 16 \text { and } 22 / 1952 \text {, } \\
\text { assuming that all belong to the swarm. }\end{array}$ \\
\hline $3 / 23 / 52$ & 6:52:00 & 19 & 11.70 & 154 & 55.00 & $\begin{array}{l}\text { kl mer sf } \\
\text { os? }\end{array}$ & & 10.0 & & 44.8 & 45.9 & $\mathrm{~m}$ & 4.70 & 4.70 & 4.70 & 4.80 & 4.70 & & & 4.73 & hono & $\mathrm{v}$ & $\begin{array}{l}\text { Off south shore; felt-Naalehu and Pahala; } \\
\text { Pahala-3 to V, shook house, rattled windows, } \\
\text { house and bed moved. }\end{array}$ & VL 515, p. 7; HVO, unpub. \\
\hline $3 / 23 / 52$ & 15:05:00 & 19 & 2.80 & 155 & $14.40^{1}$ & $\begin{array}{l}\text { kl kuer sf } \\
\text { os }\end{array}$ & & 10.0 & & 42.8 & 43.9 & $\mathrm{~m}$ & 4.67 & 4.48 & 4.65 & 4.65 & 4.60 & & & 4.60 & hono & felt & Off south shore; felt-Naalehu and Pahala. & VL 515, p. 7. \\
\hline $3 / 24 / 52$ & 2:02:00 & 19 & 8.00 & 155 & 1.70 & $\begin{array}{l}\mathrm{kl} \mathrm{mer} \mathrm{sf} \\
\text { os? }\end{array}$ & & 10.0 & & 41.2 & 42.4 & $\mathrm{~m}$ & 4.64 & 4.53 & 4.53 & 4.80 & 4.70 & & & 4.64 & hono & felt & Off south shore; felt-Naalehu. & Do. \\
\hline $3 / 24 / 52$ & 13:29:00 & 19 & 6.30 & 155 & $2.40^{1}$ & $\begin{array}{l}\text { kl mer sf } \\
\text { os? }\end{array}$ & & 10.0 & & 43.1 & 44.2 & st & 5.18 & 4.83 & 4.92 & 4.88 & $\begin{array}{c}\text { no } \\
\text { record }\end{array}$ & & & 4.88 & hono & felt & Do. & Do. \\
\hline $3 / 25 / 52$ & 0:30:00 & ) 19 & 1.30 & 155 & $17.00^{1}$ & $\begin{array}{l}\text { kl kuer sf } \\
\text { os }\end{array}$ & & 10.0 & & 45.6 & 46.7 & $\mathrm{~m}$ & 4.71 & $<4.27$ & 3.70 & 4.59 & $\begin{array}{l}\text { no } \\
\text { record }\end{array}$ & & & 4.25 & hono & & Off south shore. & $\begin{array}{l}\text { Honolulu amplitude average of two } \\
\text { readings; VL 515, p. } 7 \text {. }\end{array}$ \\
\hline $3 / 25 / 52$ & 7:04:00 & ) 19 & 4.30 & 155 & $5.80 c^{1}$ & $\begin{array}{l}\text { kl kuer sf } \\
\text { os }\end{array}$ & & 10.0 & & 43.6 & 44.7 & st & 5.19 & 4.70 & 4.78 & 4.68 & $\begin{array}{l}\text { no } \\
\text { record }\end{array}$ & & & 4.72 & hono & felt & Off south shore; felt-Naalehu. & Do. \\
\hline $3 / 25 / 52$ & 9:17:00 & 19 & 5.20 & 155 & $5.10^{1}$ & $\begin{array}{l}\text { kl kuer sf } \\
\text { os }\end{array}$ & & 10.0 & & 42.5 & 43.7 & st & 5.18 & 5.19 & 5.20 & 5.20 & 5.18 & & & 5.19 & hono & felt & Do. & VL 515, p. 7. \\
\hline $3 / 26 / 52$ & 4:40:00 & 19 & 3.30 & ) 155 & $13.80^{1}$ & $\begin{array}{l}\text { kl kuer sf } \\
\text { os }\end{array}$ & & 10.0 & & 41.9 & 43.1 & $\mathrm{~m}$ & 4.65 & $<4.47$ & $<4.47$ & $<3.95$ & 4.10 & & & 4.10 & hono & felt & Off south shore; felt-Naalehu. & $\begin{array}{l}\text { Honolulu amplitude average of two } \\
\text { readings; VL 515, p. } 7 \text {. }\end{array}$ \\
\hline $3 / 27 / 52$ & 4:31:00 & 19 & 3.10 & 155 & $12.60^{1}$ & $\begin{array}{l}\text { kl kuer sf } \\
\text { os }\end{array}$ & & 10.0 & & 42.5 & 43.7 & $\mathrm{~m}$ & 4.66 & 4.70 & 4.60 & 4.75 & 4.60 & & & 4.66 & hono & felt & Do. & VL 515, p. 7. \\
\hline $3 / 27 / 52$ & 22:44:00 & 19 & 2.20 & 155 & $13.90^{1}$ & $\begin{array}{l}\text { kl kuer sf } \\
\text { os }\end{array}$ & & 10.0 & & 44.0 & 45.1 & $\mathrm{~m}$ & 4.68 & 4.78 & 4.60 & $\begin{array}{c}\text { no } \\
\text { trace }\end{array}$ & 4.48 & & & 4.68 & hono & IV & $\begin{array}{l}\text { Off south shore; felt-Naalehu, Pahala; Pahala- } \\
\text { shook house, rattled windows; } 4 \text {, shook bed. } \\
\text { Warshauer notes: The quake at } 10: 43 \text { p.m. was } \\
\text { reported by a Naalehu resident as "quite } \\
\text { strong" and was felt rather longer than usual. }\end{array}$ & $\begin{array}{l}\text { VL 515, p. 7; HVO unpub; HTH, } \\
\text { 3/28/1952 }\end{array}$ \\
\hline $3 / 28 / 52$ & 11:57:00 & 19 & 3.30 & 155 & $11.50^{l}$ & $\begin{array}{l}\text { kl kuer sf } \\
\text { os }\end{array}$ & & 10.0 & & 42.4 & 43.6 & $\mathrm{~m}$ & 4.66 & $<4.47$ & $<4.42$ & 4.48 & 4.28 & & & 4.38 & hono & felt & Off south shore; felt-Naalehu. & $\begin{array}{l}\text { Honolulu amplitude average of two } \\
\text { readings; VL 515, p. } 7 \text {. }\end{array}$ \\
\hline $3 / 29 / 52$ & 2:42:00 & & & & & $\begin{array}{l}\text { kl kuer sf } \\
\text { os? }\end{array}$ & & 10.0 & 42.0 & 42.0 & 43.2 & $\mathrm{~m}$ & 4.65 & 4.65 & 4.74 & det & 4.78 & & & 4.72 & hono & felt & Do. & VL 515, p. 7. \\
\hline $3 / 29 / 52$ & 23:59:00 & & & & & $\begin{array}{l}\text { kl kuer sf } \\
\text { os? }\end{array}$ & & 10.0 & 42.0 & 42.0 & 43.2 & $\mathrm{~s}$ & 4.40 & & & & & & & 6.17 & calc & & $\begin{array}{l}\text { sf offshore; preferred magnitude calculated as } \\
\text { nomogram magnitude multiplied by number of } \\
\text { events. }\end{array}$ & $\begin{array}{l}\text { Reconciliation of weekly tabulation } \\
\text { (VL 515, p. 5) with earthquake list on } \\
\text { p. } 7 \text { (including those identified at } \\
\text { Honolulu) shows } 90 \text { (s) unaccounted } \\
\text { for between } 3 / 23 \text { and } 29 / 1952, \\
\text { assuming all belong to the swarm. }\end{array}$ \\
\hline $3 / 29 / 52$ & 23:59:00 & & & & & $\begin{array}{l}\text { kl kuer sf } \\
\text { os? }\end{array}$ & & 10.0 & 42.0 & 42.0 & 43.2 & $\mathrm{f}$ & 3.85 & & & & & & & 5.50 & calc & & Do. & $\begin{array}{l}\text { Reconciliation of weekly tabulation } \\
\text { (VL } 515, \text { p. } 5 \text { ) with earthquake list on } \\
\text { p. } 7 \text { (including those identified at } \\
\text { Honoluluy) shows } 66 \text { (f) unaccounted } \\
\text { for between } 3 / 23 \text { and } 29 / 1952, \\
\text { assuming all belong to the swarm. }\end{array}$ \\
\hline $3 / 29 / 52$ & 23:59:00 & & & & & $\begin{array}{l}\text { kl kuer sf } \\
\text { os? }\end{array}$ & & 10.0 & 42.0 & 42.0 & 43.2 & $\mathrm{vf}$ & 2.83 & & & & & & & 5.10 & calc & & Do. & $\begin{array}{l}\text { Reconciliation of weekly tabulation } \\
\text { (VL 515, p. 5) with earthquake list on } \\
\text { p. } 7 \text { (including those identified at } \\
\text { Honolulu) shows } 313 \text { (vf) unaccounted } \\
\text { for between } 3 / 23 \text { and } 29 / 1952, \\
\text { assuming all belong to the swarm. }\end{array}$ \\
\hline
\end{tabular}


$\stackrel{\infty}{\infty}$ Table 13. All earthquakes of $M \geq 4.0$ during the period 1903-59-Continued

\begin{tabular}{|c|c|c|c|c|c|c|c|c|c|c|c|c|c|c|c|c|c|c|c|c|c|c|c|c|}
\hline Date & $\begin{array}{l}\text { Time } \\
\text { (HST) }\end{array}$ & $\begin{array}{c}\text { Lat } \\
(\operatorname{deg})\end{array}$ & $\begin{array}{c}\text { Lat } \\
(\mathrm{min})\end{array}$ & $\begin{array}{l}\text { Lon } \\
\text { (deg) }\end{array}$ & $\begin{array}{l}\text { Lon } \\
(\min )\end{array}$ & Region & $\begin{array}{l}\text { Publ. } \\
\text { Depth }\end{array}$ & $\begin{array}{l}\text { Pref. } \\
\text { Depth }\end{array}$ & $\begin{array}{l}\text { Publ. } \\
\text { Dist. }\end{array}$ & $\begin{array}{l}\text { Calc. } \\
\text { Dist }\end{array}$ & $\begin{array}{c}\text { Slant } \\
\text { dist }\end{array}$ & Mag class & $\begin{array}{c}\mathrm{M} \\
\text { nomo }\end{array}$ & $\begin{array}{l}\text { M M-S } \\
\text { E-W }\end{array}$ & $\begin{array}{c}\text { M M-S } \\
\mathrm{N}-\mathrm{S}\end{array}$ & M vert & $\begin{array}{c}\text { M hor } \\
\mathrm{N}-\mathrm{L}\end{array}$ & $\begin{array}{c}\mathrm{M} \\
\text { other }\end{array}$ & $\begin{array}{c}\mathrm{M} \\
\text { (other) } \\
\text { source }\end{array}$ & $\underset{\text { pref }}{\mathrm{M}}$ & $\begin{array}{c}\mathrm{M} \\
\text { (pref) } \\
\text { source }\end{array}$ & $I(\max )$ & Location/felt report & Comment \\
\hline $3 / 30 / 52$ & 13:53:00 & & & & & $\begin{array}{l}\mathrm{kl} \text { kuer sf } \\
\text { os? }\end{array}$ & & 10.0 & 42.0 & 42.0 & 43.2 & st & 5.17 & 4.84 & 4.87 & 4.75 & 4.78 & & & 4.81 & hono & IV & $\begin{array}{l}\text { Off south shore. Warshauer notes: Quakes off } \\
\text { south coast total 2,995. The only heavy } \\
\text { earthquake in the past } 24 \text { hours came at } 1: 53 \\
\text { p.m. Sunday. }\end{array}$ & VL 515, p. 7; HTH, 3/31/1952. \\
\hline $3 / 30 / 52$ & 16:03:00 & & & & & $\mathrm{kl} \mathrm{sf}$ os & & 10.0 & 42.0 & 42.0 & 43.2 & $\mathrm{~m}$ ? & 4.65 & 4.40 & 4.30 & $\begin{array}{l}\text { no } \\
\text { trace }\end{array}$ & 4.30 & & & 4.33 & hono & & Off south shore. & Not in VL 515. \\
\hline $3 / 31 / 52$ & 22:00:00 & 19 & 2.20 & 155 & 13.40 & $\begin{array}{l}\text { kl kuer sf } \\
\text { os }\end{array}$ & & 10.0 & & 44.0 & 45.2 & st & 5.20 & 4.78 & 4.78 & 4.75 & 4.81 & & & 4.78 & hono & felt & Off south shore; felt-Naalehu. & VL 515, p. 7. \\
\hline $4 / 5 / 52$ & 11:23:00 & 19 & 22.00 & 155 & 10.50 & $\mathrm{kl} \mathrm{mer}$ & 20.8 & & 11.5 & 11.5 & 14.6 & $\mathrm{~m}$ & 4.14 & no trace & no trace & $\begin{array}{c}\text { no } \\
\text { trace }\end{array}$ & $\begin{array}{l}\text { no } \\
\text { trace }\end{array}$ & & & 4.14 & nomo & & E rift near Makaopuhi crater. & Could be shallow; VL 516, p. 7. \\
\hline $4 / 5 / 52$ & 14:16:00 & & & & & $\begin{array}{l}\text { kl kuer sf } \\
\text { os }\end{array}$ & & 10.0 & 42.0 & 42.0 & 43.2 & $\mathrm{~m}$ & 4.65 & 4.40 & 4.40 & $\begin{array}{c}\text { no } \\
\text { trace }\end{array}$ & 4.40 & & & 4.40 & hono & & Off south shore. & Closer to shore(?); VL 516, p. 7. \\
\hline $4 / 5 / 52$ & 21:04:00 & 19 & 22.60 & 155 & 8.80 & $\mathrm{kl} \mathrm{mer}$ & & 5.0 & 13.5 & 13.5 & 14.4 & $\mathrm{~m}$ & 4.40 & 4.60 & 4.60 & 4.60 & 4.43 & & & 4.56 & hono & & East rift near Napau crater. & Could be deeper; VL 516, p. 7. \\
\hline $4 / 5 / 52$ & 23:59:00 & & & & & $\begin{array}{l}\mathrm{kl} \mathrm{kuer} \mathrm{sf} \\
\text { os? }\end{array}$ & & 10.0 & 42.0 & 42.0 & 43.2 & $\mathrm{~s}$ & 4.40 & & & & & & & 5.82 & calc & & $\begin{array}{l}\text { sf offshore; preferred magnitude calculated as } \\
\text { nomogram magnitude multiplied by number of } \\
\text { events. }\end{array}$ & $\begin{array}{l}\text { Reconciliation of weekly tabulation } \\
\text { (VL } 515, \text { p. 5) with earthquake list on } \\
\text { p. } 7 \text { (including those identified at } \\
\text { Honolulu) shows } 37 \text { (s) unaccounted } \\
\text { for between } 3 / 30 \text { and } 4 / 5 / 1952, \\
\text { assuming all belong to the swarm. }\end{array}$ \\
\hline $4 / 5 / 52$ & 23:59:00 & & & & & $\begin{array}{l}\mathrm{kl} \text { kuer sf } \\
\text { os? }\end{array}$ & & 10.0 & 42.0 & 42.0 & 43.2 & $\mathrm{f}$ & 3.85 & & & & & & & 5.25 & calc & & Do. & $\begin{array}{l}\text { Reconciliation of weekly tabulation } \\
\text { (VL } 515, \text { p. 5) with earthquake list on } \\
\text { p. } 7 \text { (including those identified at } \\
\text { Honolulu) shows } 55 \text { (f) unaccounted } \\
\text { for between } 3 / 30 \text { and } 4 / 5 / 1952, \\
\text { assuming all belong to the swarm. }\end{array}$ \\
\hline $4 / 5 / 52$ & 23:59:00 & & & & & $\begin{array}{l}\text { kl kuer sf } \\
\text { os? }\end{array}$ & & 10.0 & 42.0 & 42.0 & 43.2 & vf & 2.83 & & & & & & & 5.00 & calc & & Do. & $\begin{array}{l}\text { Reconciliation of weekly tabulation } \\
\text { (VL } 515, \text { p. 5) with earthquake list on } \\
\text { p. } 7 \text { (including those identified at } \\
\text { Honolulu) shows } 242 \text { (vf) unaccounted } \\
\text { for between } 3 / 30 \text { and } 4 / 5 / 1952, \\
\text { assuming all belong to the swarm. }\end{array}$ \\
\hline $4 / 6 / 52$ & 14:57:00 & & & & & $\begin{array}{l}\mathrm{kl} \mathrm{kuer} \mathrm{sf} \\
\text { os }\end{array}$ & & 10.0 & 42.0 & 42.0 & 43.2 & s? & 4.40 & 4.44 & $<4.57$ & $<4.05$ & 4.20 & & & 4.32 & hono & & Off south shore. & $\begin{array}{l}\text { Honolulu amplitude average of two } \\
\text { readings; not in VL } 516 \text {. }\end{array}$ \\
\hline $4 / 6 / 52$ & 15:10:00 & & & & & $\begin{array}{l}\text { kl kuer sf } \\
\text { os }\end{array}$ & & 10.0 & 42.0 & 42.0 & 43.2 & $\mathrm{~m}$ & 4.65 & 4.40 & 4.48 & 4.65 & 4.40 & & & 4.48 & hono & & Do. & VL 516, p. 7. \\
\hline $4 / 6 / 52$ & $15: 36: 00$ & & & & & $\begin{array}{l}\text { kl kuer sf } \\
\text { os? }\end{array}$ & & 10.0 & 42.0 & 42.0 & 43.2 & s? & 4.40 & 4.40 & 4.40 & $\operatorname{det}$ & 4.30 & & & 4.37 & hono & III & $\begin{array}{l}\text { Off south shore; Kealakekua (Greenwell diary- } \\
\text { 3:30 p.m.--4, very good shake. }\end{array}$ & Not in VL 516; HVO, unpub. \\
\hline $4 / 6 / 52$ & 21:20:00 & & & & & oahu? & & & & & & & & 4.33 & 4.56 & $\begin{array}{c}\text { off } \\
\text { scale }\end{array}$ & $\begin{array}{c}\text { off } \\
\text { scale }\end{array}$ & & & 4.45 & hono & $\begin{array}{l}\text { IV (Cox; S\&C); V } \\
\text { (USE) }\end{array}$ & $\begin{array}{l}\text { Offshore between Molokai and lanai; felt } \\
\text { widely on Oahu, houses creaked, windows } \\
\text { rattled,d, fixtures rocked; short quake centered on } \\
\text { Oahu or offshore was felt widely in Honolulu, } \\
\text { also felt tightly on Mauai and Kauai. Rated as } \\
\text { intensity IV and not damaging. }\end{array}$ & $\begin{array}{l}\text { Cox, 1986; not recorded at Whitney } \\
\text { vault; VL 516, p. 7; HTH, 4/7/1952. }\end{array}$ \\
\hline $4 / 7 / 52$ & 12:53:00 & 19 & 22.00 & 155 & 10.50 & $\mathrm{kl}$ mer sf? & 19.2 & 10.0 & 11.5 & 11.5 & 15.3 & st & 4.44 & 4.69 & 4.65 & 4.63 & 4.90 & & & 4.72 & hono & III & $\begin{array}{l}\text { East rift near Makaopuhi crater, felt-Naalehu to } \\
\text { volcano. Warshauer notes: A quake at } 12: 54 \\
\text { p.m. was lightly felt in the national park area. }\end{array}$ & VL 516, p. 7; HTH, 4/8/1952. \\
\hline 4/7/52 & 13:00:00 & & & & & $\begin{array}{l}\mathrm{kl} \mathrm{kuer} \mathrm{sf} \\
\text { os }\end{array}$ & & 10.0 & 42.0 & 42.0 & 43.2 & $\mathrm{~m}$ & 4.65 & 4.30 & 4.48 & $<4.20$ & 4.40 & & & 4.39 & hono & & Off south shore. & $\begin{array}{l}\text { Honolulu amplitude average of two } \\
\text { readings; VL 516, p. } 7 \text {. }\end{array}$ \\
\hline $4 / 7 / 52$ & 23:55:00 & 19 & 22.10 & 155 & 12.00 & kl uer & 11.2 & 11.2 & 9.0 & 9.5 & 14.7 & $\mathrm{~m}$ & 4.14 & no trace & no trace & $\begin{array}{c}\text { no } \\
\text { trace }\end{array}$ & $\begin{array}{c}\text { no } \\
\text { trace }\end{array}$ & & & 4.14 & nomo & & East rift near Alae crater. & VL 516, p. 7. \\
\hline $4 / 10 / 52$ & $16: 56: 00$ & 19 & 18.80 & 155 & 10.10 & $\mathrm{kl}$ kuer sf & & 10.0 & 15.5 & 16.3 & 19.1 & $\mathrm{~m}$ & 4.33 & 4.20 & 4.20 & $\begin{array}{c}\text { no } \\
\text { trace }\end{array}$ & 4.20 & & & 4.20 & hono & felt & $\begin{array}{l}\text { Hilina fault at Poliokeawe pali } 3.5 \mathrm{mi} \mathrm{N} 45 \mathrm{~W} \text { of } \\
\text { Kaena pt; felt-Naalehu }\end{array}$ & Do. \\
\hline $4 / 12 / 52$ & 5:53:00 & 19 & 23.30 & 155 & 14.60 & $\begin{array}{l}\mathrm{kl} \text { cal } 10- \\
20\end{array}$ & 20.8 & 15.0 & 5.0 & 5.1 & 15.8 & st & 4.47 & 4.59 & 4.55 & 4.53 & 4.40 & & & 4.52 & hono & felt & $\begin{array}{l}\text { East rift } 1 \mathrm{mi} \text { NW of Heake; felt-Naalehu, } \\
\text { Kapapala. }\end{array}$ & $\begin{array}{l}\text { Moderate(?) or shallower(?); VL 516, } \\
\text { p. } 7 .\end{array}$ \\
\hline $4 / 12 / 52$ & 6:22:00 & & & & & $\begin{array}{l}\text { kl kuer sf } \\
\text { os }\end{array}$ & & 10.0 & 44.7 & 44.7 & 45.8 & $\mathrm{~m}$ & 4.69 & 4.40 & 4.40 & det & 4.40 & & & 4.40 & hono & & Off south shore. & VL 516, p. 7. \\
\hline $4 / 12 / 52$ & 19:40:00 & 19 & 22.50 & 155 & 12.50 & $\begin{array}{l}\text { kl cal } \\
\text { deep? }\end{array}$ & & 30.0 & 8.5 & 8.3 & 31.1 & $s$ & 4.17 & & & & & & & 4.17 & nomo & IIII & $\begin{array}{l}\text { East rift near Puu Huluhulu; felt-volcano; } \\
\text { Kealakekua (Greenwell diary-7: }: 55 \text { p.m.)--slight, } \\
\text { long jiggle; Honokaa-5. Warshauer notes: A } \\
\text { quake at } 7: 50 \text { p.m. Saturday was felt in the Hilo } \\
\text { and Volcano areas. }\end{array}$ & $\begin{array}{l}\text { Depth assumed consistent with felt } \\
\text { reports; VL 516, p. 7; HVO, unpub.; } \\
\text { HTH, 4/14/1952. }\end{array}$ \\
\hline
\end{tabular}


Table 13. All earthquakes of $M \geq 4.0$ during the period 1903-59-Continued

\begin{tabular}{|c|c|c|c|c|c|c|c|c|c|c|c|c|c|c|c|c|c|c|c|c|c|c|c|c|}
\hline Date & $\begin{array}{c}\text { Time } \\
\text { (HST) }\end{array}$ & $\begin{array}{c}\text { Lat } \\
\text { (deg) }\end{array}$ & $\begin{array}{c}\text { Lat } \\
(\mathrm{min})\end{array}$ & $\begin{array}{c}\text { Lon } \\
\text { (deg) }\end{array}$ & $\begin{array}{l}\text { Lon } \\
\text { (min) }\end{array}$ & Region & $\begin{array}{l}\text { Publ. } \\
\text { Depth }\end{array}$ & $\begin{array}{l}\text { Pref. } \\
\text { Depth }\end{array}$ & $\begin{array}{l}\text { Publ. } \\
\text { Dist. }\end{array}$ & $\begin{array}{l}\text { Calc. } \\
\text { Dist }\end{array}$ & $\begin{array}{c}\text { Slant } \\
\text { dist }\end{array}$ & Mag class & $\begin{array}{c}\mathrm{M} \\
\text { nomo }\end{array}$ & $\begin{array}{c}\text { M M-S } \\
\text { E-W }\end{array}$ & $\begin{array}{c}\text { M M-S } \\
\text { N-S }\end{array}$ & M vert & $\begin{array}{c}\text { M hor } \\
\text { N-L }\end{array}$ & $\begin{array}{c}\mathrm{M} \\
\text { other }\end{array}$ & $\begin{array}{c}\mathrm{M} \\
\text { (other) } \\
\text { source }\end{array}$ & $\begin{array}{c}\mathrm{M} \\
\text { pref }\end{array}$ & $\begin{array}{c}\text { M } \\
\text { (pref) } \\
\text { source }\end{array}$ & $I(\max )$ & Location/felt report & Comment \\
\hline $4 / 12 / 52$ & 23:59:00 & & & & & $\begin{array}{l}\text { kl kuer sf } \\
\text { os? }\end{array}$ & & 10.0 & 42.0 & 42.0 & 43.2 & $\mathrm{~s}$ & 4.40 & & & & & & & 5.30 & calc & & $\begin{array}{l}\text { sf offshore; preferred magnitude calculated as } \\
\text { nomogram magnitude multiplied by number of } \\
\text { events. }\end{array}$ & $\begin{array}{l}\text { Reconciliation of weekly tabulation } \\
\text { (VL } 516, \text { p. } 7 \text { ) with earthquake list on } \\
\text { p. } 7 \text { (including those identified at } \\
\text { Honolulu) shows } 10 \text { (s) unaccounted } \\
\text { for between } 4 / 6 \text { and } 12 / 1952 \text {, assuming } \\
\text { all belong to the swarm. }\end{array}$ \\
\hline $4 / 12 / 52$ & 23:59:00 & & & & & $\begin{array}{l}\text { kl kuer sf } \\
\text { os? }\end{array}$ & & 10.0 & 42.0 & 42.0 & 43.2 & $\mathrm{f}$ & 3.85 & & & & & & & 4.80 & calc & & Do. & $\begin{array}{l}\text { Reconciliation of weekly tabulation } \\
\text { (VL } 516 \text {, p. } 7 \text { ) with earthquake list on } \\
\text { p. } 7 \text { (including those identified at } \\
\text { Honolulu) shows } 11 \text { (f) unaccounted } \\
\text { for between } 4 / 6 \text { and } 12 / 1952, \text { assuming } \\
\text { all belong to the swarm. }\end{array}$ \\
\hline $4 / 12 / 52$ & 23:59:00 & & & & & $\begin{array}{l}\text { kl kuer sf } \\
\text { os? }\end{array}$ & & 10.0 & 42.0 & 42.0 & 43.2 & vf & 2.83 & & & & & & & 4.61 & calc & & Do. & $\begin{array}{l}\text { Reconciliation of weekly tabulation } \\
\text { (VL } 516, \text { p. } 7 \text { ) with earthquake list on } \\
\text { p. } 7 \text { (including those identified at } \\
\text { Honolulu) shows } 90 \text { (vf) unaccounted } \\
\text { for between } 4 / 6 \text { and } 12 / 1952 \text {, assuming } \\
\text { all belong to the swarm. }\end{array}$ \\
\hline $4 / 16 / 52$ & 7:08:00 & & & & & $\begin{array}{l}\text { kl kuer sf } \\
\text { os }\end{array}$ & & 10.0 & 42.0 & 42.0 & 43.2 & $\mathrm{~m}$ & 4.65 & 4.40 & 4.48 & 4.53 & 4.40 & & & 4.45 & hono & & Off south shore. & VL 516, p. 7. \\
\hline $4 / 19 / 52$ & 23:59:00 & & & & & $\begin{array}{l}\text { kl kuer sf } \\
\text { os? }\end{array}$ & & 10.0 & 42.0 & 42.0 & 43.2 & $\mathrm{~s}$ & 4.40 & & & & & & & 4.94 & calc & & $\begin{array}{l}\text { sf offshore; preferred magnitude calculated as } \\
\text { nomogram magnitude multiplied by number of } \\
\text { events. }\end{array}$ & $\begin{array}{l}\text { Reconciliation of weekly tabulation } \\
\text { (VL } 516, \text { p. } 7 \text { ) with earthquake list on } \\
\text { p. } 7 \text { (including those identified at } \\
\text { Honolulu) shows } 4 \text { (s) unaccounted for } \\
\text { between } 4 \text { /13 and } 19 \text { ) 1952, assuming } \\
\text { all belong to the swarm. }\end{array}$ \\
\hline $4 / 19 / 52$ & 23:59:00 & & & & & $\begin{array}{l}\text { kl kuer sf } \\
\text { os? }\end{array}$ & & 10.0 & 42.0 & 42.0 & 43.2 & vf & 2.83 & & & & & & & 4.24 & calc & & Do. & $\begin{array}{l}\text { Reconciliation of weekly tabulation } \\
\text { (VL } 516, \text { p. } 7 \text { ) with earthquake list on } \\
\text { p. } 7 \text { (including those identified at } \\
\text { Honolulu) shows } 35 \text { (vf) unaccounted } \\
\text { for between } 4 / 13 \text { and } 19 / 1952, \\
\text { assuming all belong to the swarm. }\end{array}$ \\
\hline $4 / 19 / 52$ & 23:59:00 & & & & & $\begin{array}{l}\text { kl kuer sf } \\
\text { os? }\end{array}$ & & 10.0 & 42.0 & 42.0 & 43.2 & $\mathrm{f}$ & 3.85 & & & & & & & 4.12 & calc & & Do. & $\begin{array}{l}\text { Reconciliation of weekly tabulation } \\
\text { (VL } 516, \text { p. } 7 \text { ) with earthquake list on } \\
\text { p. } 7 \text { (including those identified at } \\
\text { Honolulu) shows } 2 \text { (f) unaccounted for } \\
\text { between } 4 / 13 \text { and } 19 / 1952 \text {, assuming } \\
\text { all belong to the swarm. }\end{array}$ \\
\hline $4 / 21 / 52$ & 17:45:00 & 19 & 1.90 & 155 & 13.70 & $\begin{array}{l}\text { kl kuer sf } \\
0 \text { os }\end{array}$ & & 10.0 & & 44.5 & 45.6 & $\mathrm{~m}$ & 4.69 & 4.54 & 4.65 & det & 4.54 & & & 4.58 & hono & & Off south shore, $16 \mathrm{mi} \mathrm{S.} 10^{\circ} \mathrm{W}$. of Apua pt. & VL 516, p. 7. \\
\hline $5 / 3 / 52$ & 18:16:00 & 191 & 12.50 & 155 & 20.80 & $\begin{array}{l}\text { kl swr sf } \\
\text { os }\end{array}$ & & 10.0 & & 26.4 & 28.2 & $\mathrm{~m}$ & 4.59 & 4.43 & 4.43 & $\begin{array}{c}\text { no } \\
\text { trace }\end{array}$ & 4.55 & & & 4.47 & hono & & Off south shore. & Do. \\
\hline $5 / 10 / 52$ & 19:14:00 & & & & & $\begin{array}{l}\mathrm{kl} \mathrm{cal} 05- \\
10\end{array}$ & 11.2 & 8.0 & 3.0 & 3.0 & 8.5 & st & 4.04 & $<4.12$ & $<4.20$ & $<3.98$ & $<3.70$ & & & 4.04 & nomo & felt & Kilauea crater; felt(?). & Do. \\
\hline $5 / 19 / 52$ & 1:16:00 & 19 & 2.70 & 155 & 7.20 & $\begin{array}{l}\text { kl kuer sf } \\
0 \text { os }\end{array}$ & & 10.0 & & 45.4 & 46.5 & $\mathrm{~s}$ & 4.22 & $<4.17$ & $<4.27$ & $<4.30$ & $<3.78$ & & & 4.22 & nomo & & Off south shore. & Do. \\
\hline $5 / 19 / 52$ & 4:08:00 & 19 & 20.2 & 155 & 28.9 & 9 kaoiki & & & 20 & 25.5 & 27.1 & $\mathrm{~s}$ & 4.07 & 4.32 & 4.19 & $<3.71$ & $<3.24$ & & & 4.19 & hono & & SE slope Mauna Loa. & Do. \\
\hline $5 / 21 / 52$ & 17:13:00 & 19 & 18.1 & 155 & 28.3 & 3 kaoiki & & & 20 & 26.5 & 27.9 & $\mathrm{~m}$ & 4.35 & 4.33 & 4.25 & 4.11 & 3.94 & & & 4.16 & hono & II & SE slope Mauna Loa; Kapapala ranch-2. & $\begin{array}{l}\text { VL 516, p. 7; HVO, unpub. [intensities- } \\
\text { arabic numerals-in remarks column } \\
\text { refer to HVO postcards]. }\end{array}$ \\
\hline $5 / 23 / 52$ & 12:13:00 & 19 & 29.0 & 155 & 59.0 & 0 kona & 9.6 & 9.6 & & 76.4 & 77.0 & st & 5.57 & 5.61 & 5.45 & 5.49 & 5.23 & 6.0 & $\begin{array}{l}\mathrm{S} \& \mathrm{C} \\
\text { (Pas) }\end{array}$ & 5.69 & aver & VI; VI (S\&C) & $\begin{array}{l}\text { Felt-all Hawaii Island, some on Maui. } \\
\text { Warshauer notes: "Strong" quake felt Kona to } \\
\text { Hilo, dur } 23 \text { min at HVO; landslides, road } \\
\text { damage, water-tank breaks, and merchandise } \\
\text { swept off shelves in Kona; preferred mag } \\
\text { calculated as average of M-S (2) and Pas (1). }\end{array}$ & $\begin{array}{l}\text { Isoseismal map in W\&K; Kealakekua } \\
\text { Fault } 3.5 \text { mi w of Napoopoo; VL } 516, \\
\text { p. } 8 \text { [damage report on p. 6]; HTH, } \\
5 / 24 / 1952 \text {; additional felt reports in } \\
\text { HVO, unpub. [intensitities-arabic } \\
\text { numerals-in remarks column refer to } \\
\text { HVO postcards]. }\end{array}$ \\
\hline $6 / 11 / 52$ & 8:01:00 & 19 & 0.70 & 155 & 16.30 & $\begin{array}{l}\text { kl kuer sf } \\
0 \text { os }\end{array}$ & 10.0 & 5.0 & & 46.6 & 46.9 & $\mathrm{~s}$ & 4.23 & $<4.17$ & $<4.27$ & $<4.05$ & $<3.70$ & & & 4.23 & nomo & & Off south shore. & VL 516, p. 8. \\
\hline $6 / 18 / 52$ & 5:17:00 & 19 & 2.10 & 155 & 19.80 & $\begin{array}{l}\text { kl kuer sf } \\
0 \text { os }\end{array}$ & & 10.0 & & 44.6 & 45.7 & $\mathrm{~s}$ & 4.44 & 4.37 & 4.40 & 4.35 & 4.20 & & & 4.33 & hono & & Do. & Do. \\
\hline
\end{tabular}


\& Table 13. All earthquakes of $M \geq 4.0$ during the period 1903-59-Continued

\begin{tabular}{|c|c|c|c|c|c|c|c|c|c|c|c|c|c|c|c|c|c|c|c|c|c|c|c|c|}
\hline Date & $\begin{array}{l}\text { Time } \\
\text { (HST) }\end{array}$ & $\begin{array}{l}\text { Lat } \\
(\mathrm{deg})\end{array}$ & $\begin{array}{c}\text { Lat } \\
(\min )\end{array}$ & $\begin{array}{c}\text { Lon } \\
\text { (deg) }\end{array}$ & $\begin{array}{c}\text { Lon } \\
(\min )\end{array}$ & Region & $\begin{array}{l}\text { Publ. } \\
\text { Depth } 1\end{array}$ & $\begin{array}{l}\text { Pref. } \\
\text { Depth }\end{array}$ & $\begin{array}{l}\text { Publ. } \\
\text { Dist. }\end{array}$ & $\begin{array}{l}\text { Calc. } \\
\text { Dist }\end{array}$ & $\begin{array}{c}\text { Slant } \\
\text { dist }\end{array}$ & Mag class & $\begin{array}{c}\mathrm{M} \\
\text { nomo }\end{array}$ & $\begin{array}{c}\text { M M-S } \\
\text { E-W }\end{array}$ & $\begin{array}{c}\text { M M-S } \\
\text { N-S }\end{array}$ & M vert & $\begin{array}{c}\text { M hor } \\
\text { N-L }\end{array}$ & $\begin{array}{c}\mathrm{M} \\
\text { other }\end{array}$ & $\begin{array}{l}\mathrm{M} \\
\text { (other) } \\
\text { source }\end{array}$ & $\underset{\text { pref }}{\mathrm{M}}$ & $\begin{array}{c}\text { M } \\
\begin{array}{c}\text { (pref) } \\
\text { source }\end{array}\end{array}$ & $I(\max )$ & Location/felt report & Comment \\
\hline $6 / 19 / 52$ & 16:03:00 & 19 & 21.30 & 155 & 21.20 & $\begin{array}{l}\text { kl cal } \\
\text { deep? }\end{array}$ & 2.0 & 25.0 & 12.5 & 12.9 & 28.1 & st & 4.87 & 4.83 & 4.96 & 4.86 & 4.79 & & & 4.86 & hono & & SW rift 0.5 mi NE of Mauna Iki; shallow. & $\begin{array}{l}\text { Honolulu amplitude average of two } \\
\text { readings: "shallow" designation in } \mathrm{VL} \\
516 \text { unlikely; Honolulu records } \\
\text { consistent with deep origin; Honolulu } \\
\text { amplitude average of two readings; VL } \\
516 \text {, p. } 8 \text {. }\end{array}$ \\
\hline $6 / 19 / 52$ & 16:27:00 & 19 & 19.00 & 155 & 22.00 & $\mathrm{kl} \mathrm{swr}$ & & 5.0 & 17.0 & 16.9 & 17.6 & $\mathrm{~m}$ & 4.03 & $<4.12$ & $<4.12$ & $<4.10$ & $<3.75$ & & & 4.03 & nomo & & SW rift near Kamakaia hills. & VL 516, p. 8. \\
\hline $7 / 6 / 52$ & 22:56:00 & & & & & $\begin{array}{l}\text { mauna } \\
\text { kea? }\end{array}$ & & & 67 & 67.0 & 67.6 & $\mathrm{f}$ & 4.16 & 4.17 & 4.17 & 3.87 & 4.00 & & & 4.05 & hono & IV & 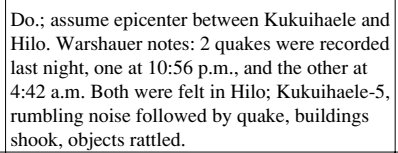 & $\begin{array}{l}\text { VL 517, p. 6; HTH, 7/7/1952; HVO, } \\
\text { unpub. [intensities-arabic numerals-in } \\
\text { remarks column refer to HVO } \\
\text { postcards]. }\end{array}$ \\
\hline 7/7/52 & 4:43:00 & & & & & $\begin{array}{l}\text { mauna } \\
\text { kea? }\end{array}$ & & & 67 & 67.0 & 67.6 & $\mathrm{~s}$ & 4.48 & 4.45 & 4.25 & 4.57 & 4.62 & & & 4.47 & hono & $\mathrm{v}$ & $\begin{array}{l}\text { Felt-Kukuihaele, Hilo; assume epicenter bet } \\
\text { Kukuihaele and Hilo. Warshauer notes: See } \\
\text { above; Kukuihaele-5, buildings shook, } \\
\text { awakened persons. }\end{array}$ & $\begin{array}{l}\text { VL 517, p. 6; HTH, } 7 / 7 / 1952 ; \mathrm{HVO} \text {, } \\
\text { unpub. [intensities-arabic numerals-in } \\
\text { remarks column refer to HVO } \\
\text { postcards]. }\end{array}$ \\
\hline $7 / 12 / 52$ & 13:38:00 & & & & & kona & & & 60 & 60.0 & 60.7 & $\begin{array}{c}\mathrm{m} ; \mathrm{st} \\
\text { (kona) }\end{array}$ & 4.89 & 3.97 & 4.05 & 3.87 & 4.36 & & & 4.38 & aver & $\mathrm{v}$ & $\begin{array}{l}\text { Central Kona; assume } 15 \mathrm{~km} \text { from Kona; felt- } \\
\text { Kona to Hilo, ;rreferred magnitude calculated } \\
\text { as average of Honolulu and nomogram; } \\
\text { Kealakekua-5, strong all over Kona, strong and } \\
\text { hard, not long, came from south, sounded like a } \\
\text { blast. }\end{array}$ & $\begin{array}{l}\text { Honolulu data average of two readings; } \\
\text { VL } 517 \text { time 13:53; Honolulu records } \\
\text { record event at } 13: 38 \text {; our calculated } \\
\text { mags are } 4.9 \text { (Whitney), } 4.5 \text { (Kona); } \\
\text { VL 517, p. 6; HVO, unpub. [intensities- } \\
\text { a arabic numerals-in remarks column } \\
\text { refer to HVO postcards]. }\end{array}$ \\
\hline $8 / 9 / 52$ & 10:31:00 & & & & & $\begin{array}{l}\text { mauna } \\
\text { kea? }\end{array}$ & & & 48 & 48.0 & 48.8 & $\begin{array}{l}\text { f; s (ml; } \\
\text { hilo) }\end{array}$ & 4.07 & & & & & & & 4.07 & nomo & & $\begin{array}{l}\text { Assume mk summit; } 37 \mathrm{~km} \text { from ml, } 43 \mathrm{~km} \\
\text { from Hilo, } 48 \mathrm{~km} \text { from Whitney. }\end{array}$ & $\begin{array}{l}\text { Hilo mag, 3.9-4. 4; ml mag, 3.8-4.2; } \\
\text { VL 517, p. 6. }\end{array}$ \\
\hline $8 / 14 / 52$ & 14:08:00 & & & & & $\begin{array}{l}\mathrm{kl} \mathrm{kuer} \mathrm{sf} \\
\text { os }\end{array}$ & & 10.0 & 44.7 & 44.7 & 45.8 & $\mathrm{~s}$ & 4.44 & $<4.17$ & $<4.17$ & $<4.25$ & 4.88 & & & 4.44 & nomo & felt & $\begin{array}{l}\text { Off south shore; felt-volcano, Kapapala, } \\
\text { Naalehu. }\end{array}$ & $\begin{array}{l}\text { Honolulu amplitude average of two } \\
\text { readings; N-L high; VL 517, p. } 6 .\end{array}$ \\
\hline $8 / 16 / 52$ & 21:07:00 & & & & & $\begin{array}{l}\text { kl kuer sf } \\
\text { os }\end{array}$ & 10.0 & 10.0 & 44.7 & 44.7 & 45.8 & $\mathrm{~m}$ & 4.69 & 4.30 & 4.30 & 4.35 & 4.40 & & & 4.34 & hono & & Off south shore. & VL 517, p. 6. \\
\hline 9/2/52 & 4:45:00 & & & & & $\begin{array}{l}\mathrm{kl} \text { cal } \\
\text { deep? }\end{array}$ & & 30.0 & 4.0 & 4.0 & 30.3 & $\mathrm{f}$ & 3.60 & $<4.20$ & $<4.02$ & $<3.8$ & 4.63 & & & 4.10 & aver & IV & $\begin{array}{l}\text { Kilauea crater; felt-Glenwood, volcano, } \\
\text { Naalehu, Hilo; Capt. Cook-3, slight rattle of } \\
\text { windows; preferred magnitude calculated as } \\
\text { average of Honolulu and nomogram. }\end{array}$ & N-L high; VL 517, p. 7; HVO, unpub. \\
\hline $11 / 16 / 52$ & 2:41:00 & & & & & $\begin{array}{l}\mathrm{kl} \text { kuer sf } \\
\text { os }\end{array}$ & & 10.0 & & 44.7 & 45.8 & $\mathrm{~s}$ & 4.21 & 4.27 & $<4.17$ & $<4.25$ & $<3.85$ & & & 4.27 & hono & & Off south coast. & VL 518, p. 12. \\
\hline $11 / 27 / 52$ & 22:14:00 & 19 & 29.0 & 155 & 38.0 & $\mathrm{ml} \mathrm{mok}$ & & & & 39.7 & 40.7 & $\mathrm{~s}$ & 4.13 & no trace & no trace & $\begin{array}{c}\text { no } \\
\text { trace }\end{array}$ & $\begin{array}{c}\text { no } \\
\text { trace }\end{array}$ & & & 4.13 & nomo & III & $\begin{array}{l}\text { Felt-Kona; Capt. Cook-2, rumble preceded } \\
\text { quake, appeared to come from Mauka, longish } \\
\text { tremor as though a wave passed through the } \\
\text { house, soft noise acc quake, dog disturbed and } \\
\text { anxious before and during quake. }\end{array}$ & $\begin{array}{l}\text { VL 518, p. 12; HVO, unpub. } \\
\text { [intensities-arabic numerals-in remarks } \\
\text { column refer to HVO postcards]. }\end{array}$ \\
\hline 1/9/53 & 16:42:00 & & & & & kona & & & 15 & 15.0 & 17.5 & vf (kona) & 2.95 & & & & & & & 4.24 & aver & felt & $\begin{array}{l}\text { Central Kona; assume } 15 \text { km from Kona; felt- } \\
\text { Kona. }\end{array}$ & VL 519, p. 6 \\
\hline $1 / 12 / 53$ & 3:27:00 & & & & & kona & & & 15 & 15.0 & 17.5 & $\begin{array}{c}\text { t; vf } \\
\text { (kona) }\end{array}$ & 2.21 & & & & & & & 4.35 & nomo & & Central Kona; assume 15 km from Kona. & Do. \\
\hline $1 / 13 / 53$ & 7:29:00 & & & & & kaoiki? & & & 25 & 25.0 & 26.6 & vf & 3.24 & & & & & & & 5.45 & hono & felt & Felt strongly-Kapapala. & Do. \\
\hline $\begin{array}{l}3 / 25 / 53 \\
4 / 16 / 53\end{array}$ & $\begin{array}{l}10: 50: 00 \\
14: 36: 00\end{array}$ & 19 & 30.4 & 155 & 33.4 & $\begin{array}{l}\mathrm{ml} \mathrm{ner} \\
\text { kona }\end{array}$ & & & $\begin{array}{l}33 \\
10\end{array}$ & $\begin{array}{l}32.3 \\
10.0\end{array}$ & $\begin{array}{l}33.5 \\
13.5\end{array}$ & $\begin{array}{l}\text { vf; s (ml) } \\
\text { vf (kona) }\end{array}$ & $\begin{array}{l}3.40 \\
2.02\end{array}$ & & & & & & & $\begin{array}{l}4.41 \\
4.04\end{array}$ & $\begin{array}{l}\text { aver } \\
\text { nomo }\end{array}$ & & $\begin{array}{l}\text { Near Mauna Loa summit, probably on NE rift } \\
\text { zone. } \\
\text { Assume } 10 \mathrm{~km} \text { from Kona. }\end{array}$ & $\begin{array}{l}\mathrm{ml} \mathrm{mag} 3.3-3.8 \text {; closer to } \mathrm{ml}(?) ; \mathrm{VL} \\
519 \text {, p. } 6 . \\
\text { VL 520, p. } 4 .\end{array}$ \\
\hline $5 / 22 / 53$ & 23:22:00 & & & & & kona & & & 60 & 60.0 & 60.7 & $\begin{array}{c}\text { vf; } \mathrm{f} \\
\text { (kona) }\end{array}$ & 3.07 & & & & & & & 4.50 & hono & $\mathrm{V}$ & $\begin{array}{l}\text { Kealakekua Fault(?); assume } 15 \mathrm{~km} \text { from } \\
\text { Kona; felt-central Kona; Capt. Cook-3 to IV, } \\
\text { came suddenly with very rapid vibrations, } \\
\text { objects on shelves vibrated, a few fell to floor; } \\
\text { strong jolt in Kealakekua. }\end{array}$ & $\begin{array}{l}\text { Kona mag, 3.0-3.5; VL } 520 \text {, p. } 4 \text {; } \\
\text { HVO, unpub. [intensities-arabic } \\
\text { numerals-in remarks column refer to } \\
\text { HVO postcards]. }\end{array}$ \\
\hline $5 / 27 / 53$ & 19:33:00 & & & & & kaoiki? & & & 20 & 20.0 & 21.9 & $\mathrm{t}$ & 1.89 & & & & & & & 4.12 & aver & felt & Felt-Kapapala. & VL 520, p. 4. \\
\hline $8 / 21 / 53$ & 17:00:00 & & & & & kona? & & & & & & & & & & & & & & 5.06 & hono & II & $\begin{array}{l}\text { Capt. Cook-felt as quiver at Kealakekua by } \\
\text { several. }\end{array}$ & $\begin{array}{l}\text { Not in VL 521-date and time from felt } \\
\text { report; HVO, unpub. [intensities-arabic } \\
\text { numerals-in remarks column refer to } \\
\text { HVO postcards]. }\end{array}$ \\
\hline $8 / 22 / 53$ & 2:00:00 & & & & & hualalai? & & & & & & & & & & & & & & 4.17 & hono & III & $\begin{array}{l}\text { Capt. Cook-3, duration, } 20 \text { s; gentle continuous } \\
\text { tremors, felt at Kalahiki, mauka to makai } \\
\text { movement. }\end{array}$ & Do. \\
\hline
\end{tabular}


Table 13. All earthquakes of $M \geq 4.0$ during the period 1903-59-Continued

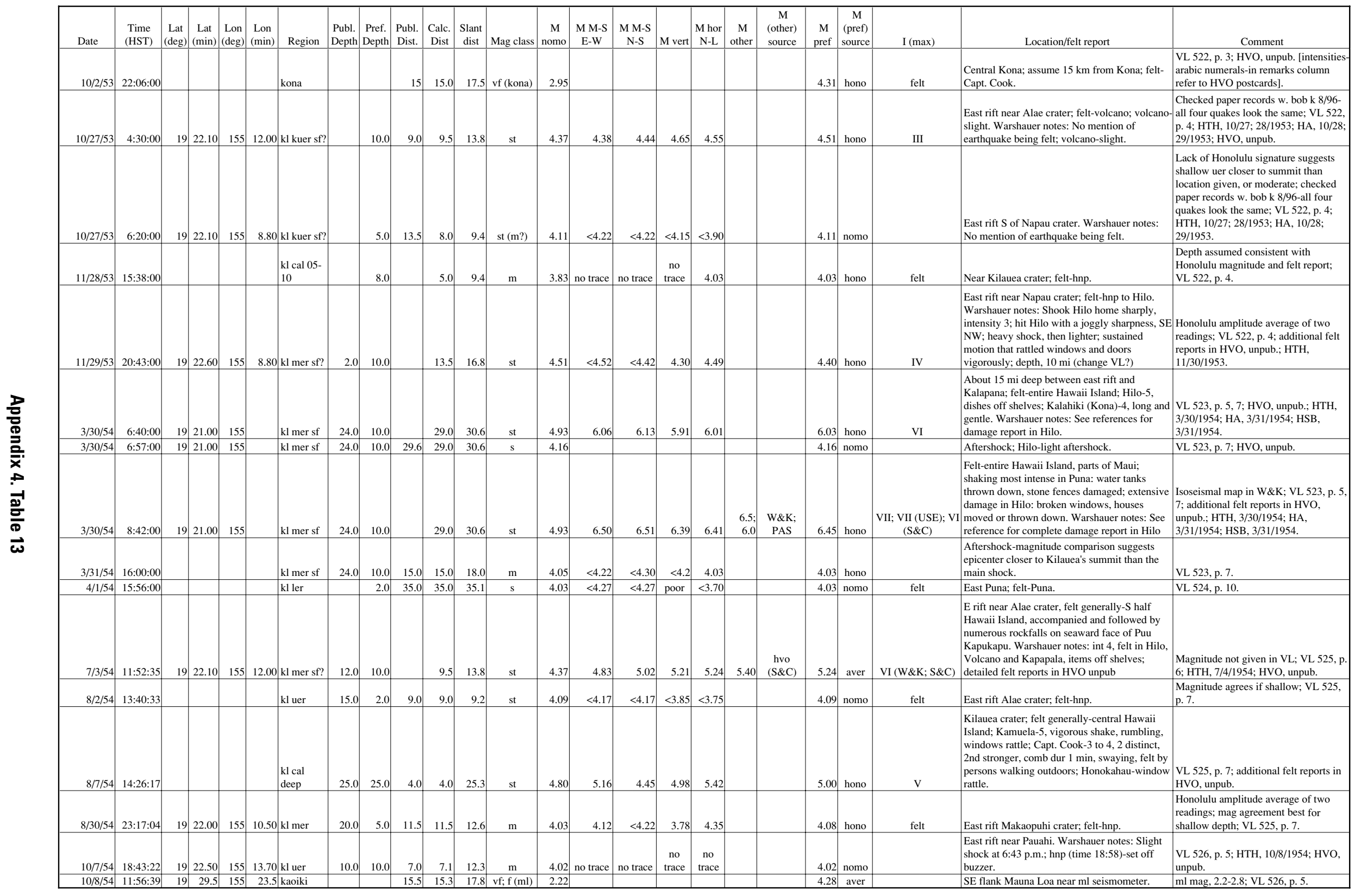


$\infty \quad$ Table 13. All earthquakes of $M \geq 4.0$ during the period 1903-59-Continued

\begin{tabular}{|c|c|c|c|c|c|c|c|c|c|c|c|c|c|c|c|c|c|c|c|c|c|c|c|}
\hline Date & $\begin{array}{c}\text { Time } \\
\text { (HST) }\end{array}$ & $\begin{array}{l}\text { Lat } \\
\text { (deg) }\end{array}$ & $\begin{array}{l}\text { Lat } \\
\text { (min) }\end{array}$ & $\begin{array}{l}\text { Lon } \\
(\operatorname{deg})\end{array}$ & $\begin{array}{l}\text { Lon } \\
(\mathrm{min})\end{array}$ & $\begin{array}{l}\text { Publ. } \\
\text { Depth }\end{array}$ & $\begin{array}{l}\text { Pref. } \\
\text { Depth }\end{array}$ & $\begin{array}{l}\text { Publ. } \\
\text { Dist. }\end{array}$ & $\begin{array}{c}\text { Calc. } \\
\text { Dist }\end{array}$ & $\begin{array}{c}\text { Slant } \\
\text { dist }\end{array}$ & Mag class & $\begin{array}{c}\mathrm{M} \\
\text { nomo }\end{array}$ & $\begin{array}{l}\text { M M-S } \\
\text { E-W }\end{array}$ & $\begin{array}{c}\text { M M-S } \\
\text { N-S }\end{array}$ & M vert & $\begin{array}{c}\text { M hor } \\
\text { N-L }\end{array}$ & $\begin{array}{c}\mathrm{M} \\
\text { other }\end{array}$ & $\begin{array}{c}\mathrm{M} \\
\text { (other) } \\
\text { source }\end{array}$ & $\underset{\text { pref }}{\mathrm{M}}$ & $\begin{array}{c}\mathrm{M} \\
\text { (pref) } \\
\text { source }\end{array}$ & $I(\max )$ & Location/felt report & Comment \\
\hline 2/23/55 & $13: 58: 49$ & 19 & 22.00 & 155 & $\begin{array}{r}\mathrm{kl} \mathrm{cal} \\
10.50 \text { deep? }\end{array}$ & 25.0 & 30.0 & 13.5 & 14.0 & 33.1 & $\begin{array}{l}\text { s (uwe, } \\
\text { ml, pahoa; } \\
\text { vf (hilo, } \\
\text { naalehu, } \\
\text { kamuela) }\end{array}$ & 4.01 & $<4.22$ & $<4.37$ & $7<4.23$ & 4.08 & & & 4.08 & hono & $\mathrm{v}$ & $\begin{array}{l}\text { East rift near Makaopuhi crater; felt-hnp, } \\
\text { volcano; volcano-awakened; felt by several } \\
\text { hnp/volcano, quite strong acc by a roar; felt; } \\
\text { depth as given or deeper gives best fit to } \\
\text { Honolulu magnitude and felt report. }\end{array}$ & $\begin{array}{l}\text { Honolulu amplitude average of two } \\
\text { readings; m m mag, , 3.8-4.3. Pahoa mag, } \\
\text { 3.8-4.43; Hilo mag, } 2.2-3.4 \text {; Naalehu } \\
\text { mag, 2.30-3.5; Kamuela mag, 2.6-3.8; } \\
\text { mags reconciled if Naalehu, Kamuela, } \\
\text { and Hilo were feeble; VL 527, p. } 5 \text {; } \\
\text { HVO, unpub. }\end{array}$ \\
\hline $3 / 1 / 55$ & 14:21:30 & 19 & 24.30 & 155 & $4.20 \mathrm{kl} \mathrm{mer}$ & & 2.0 & 13.5 & 16.4 & 16.5 & st (pahoa) & $>4.17$ & 4.35 & 4.43 & 4.70 & 4.55 & & & 4.51 & hono & $\mathrm{v}$ & $\begin{array}{l}\text { East rift near Kalalua; felt-volcano; hnp (bird } \\
\text { park)-felt like someone shaking car, hnp-rec on } \\
\text { experimental instrument, not felt; volcano-felt, } \\
\text { water tank splashed; hnp-mirror thrown to } \\
\text { floor, felt. }\end{array}$ & $\begin{array}{l}\text { Assume strong at Whitney (VL 527, p. } \\
4 \text {, table); } M \text { (Whitney) }>4.65 ; \text { VL 527, } \\
\text { p. } 5 ; \mathrm{HVO} \text {, unpub. }\end{array}$ \\
\hline $3 / 5 / 55$ & $12: 39: 08$ & 19 & 23.70 & 155 & $6.10 \mathrm{kl} \mathrm{mer}$ & 2.0 & 10.0 & 20.5 & 19.8 & 22.1 & $\begin{array}{l}\mathrm{st} ; \mathrm{m} ? \\
\text { (pahoa) }\end{array}$ & 4.38 & $\begin{array}{l}\text { no } \\
\text { record }\end{array}$ & $<4.28$ & $<3.9$ & $<3.95$ & & & 4.38 & nomo & III & $\begin{array}{l}\text { Records at Whitney and Uwekahuna } \\
\text { unreadable during first few hours of swarm; rift } \\
4 \mathrm{~km} \text { E of Napau crater; felt-Hilo; Hilo-felt by } \\
\text { many, slow and weak, dur } 3 \mathrm{~s} \text {, many near } \\
\text { quakes these days. }\end{array}$ & $\begin{array}{l}\text { Closer to Pahoa(?); VL 527, p. 5; } \\
\text { HVO, unpub. }\end{array}$ \\
\hline $3 / 5 / 55$ & 12:53:44 & 19 & 24.30 & 155 & $4.20 \mathrm{kl} \mathrm{mer}$ & 2.0 & 2.0 & 13.5 & 16.4 & 16.5 & st (pahoa) & 4.17 & poor & no trace & $\begin{array}{c}\text { no } \\
\text { trace }\end{array}$ & $\begin{array}{l}\text { no } \\
\text { trace }\end{array}$ & & & 4.17 & nomo & & East rift Kalalua. & Closer to Pahoa(?); VL 527, p. 5. \\
\hline $3 / 5 / 55$ & $12: 58: 26$ & 19 & 23.70 & 155 & $6.10 \mathrm{kl} \mathrm{mer}$ & 2.0 & 2.0 & 17.5 & 19.8 & 19.9 & st (pahoa) & 4.30 & poor & 4.73 & $3 \quad 4.70$ & 4.95 & & & 4.79 & hono & & $\begin{array}{l}4 \mathrm{~km} \text { w of Kalalua-largest quake of series; } \\
\text { assume strong at Whitney (VL 527, p. 4, table); } \\
M \text { (Whitney)>4.65. }\end{array}$ & VL 527, p. 5. \\
\hline $3 / 5 / 55$ & 14:22:08 & 19 & 24.30 & 155 & $4.20 \mathrm{kl} \mathrm{mer}$ & 2.0 & 2.0 & 13.5 & 16.4 & 16.5 & st (pahoa) & 4.17 & poor & no trace & $\begin{array}{c}\text { no } \\
\text { trace }\end{array}$ & $\begin{array}{c}\text { no } \\
\text { trace }\end{array}$ & & & 4.17 & nomo & & East rift Kalalua. & Closer to Pahoa(?); VL 527, p. 5. \\
\hline $3 / 6 / 55$ & 11:45:06 & 19 & 24.30 & 155 & $4.20 \mathrm{kl} \mathrm{mer}$ & 2.0 & 2.0 & 13.5 & 16.4 & 16.5 & st (pahoa) & $>4.17$ & no trace 1 & no trace & $\begin{array}{c}\text { no } \\
\text { trace }\end{array}$ & $\begin{array}{c}\text { no } \\
\text { trace }\end{array}$ & & & 4.20 & aver & & $\begin{array}{l}\text { East rift Kalalua; assume moderate at Whitney } \\
\text { (VL 527, p. 4, table); } M \text { (Whitney)=4.13-4.65; } \\
\text { preferred mag minimum consistent with Hon, } \\
\text { Pahoa, and Whitney. }\end{array}$ & Closer to Pahoa(?); VL 527, p. 6. \\
\hline $3 / 7 / 55$ & 22:21:31 & 19 & 21.20 & 155 & $0.30 \mathrm{kl} \mathrm{mer} \mathrm{sf}$ & 10.0 & 10.0 & 18.0 & 16.8 & 19.6 & st (pahoa) & $>4.29$ & 5.20 & 5.23 & 5.23 & 5.35 & 5.40 & $\begin{array}{l}\text { hvo } \\
\text { (S\&C) }\end{array}$ & 5.32 & aver & $\begin{array}{l}\mathrm{V}(\mathrm{W} \& \mathrm{~K}) ; \mathrm{IV} \\
(\mathrm{S} \& \mathrm{C})\end{array}$ & $\begin{array}{l}\text { Near Heiheiahulu; felt-s half Hawaii Island; } \\
\text { assume strong at Whitney (VL } 527, \mathrm{p} .4 \text {, table); } \\
\text { M (Whitney) }>4.92 ; \text { Note: A second strong } \\
\text { quake listed in table on p. } 4 \text { inconsistent with } \\
\text { Honolulu data; preferred mag average of } \\
\text { Honolulu and HVO. }\end{array}$ & $\begin{array}{l}\text { Strong at Whitney (M>4.92); location } \\
\text {; corrected to south coast of Kilauea } 2 \\
\text { mi W of Kalapana (Macdonald and } \\
\text { Eaton, 1964, p. 146); VL 527, p. 6; } \\
\text { detailed felt reports given in HVO, } \\
\text { unpub.; mag not given in VL. }\end{array}$ \\
\hline $3 / 7 / 55$ & 22:57:38 & 19 & 21.20 & 155 & $0.30 \mathrm{kl} \mathrm{mer} \mathrm{sf}$ & 10.0 & 10.0 & 18.0 & 16.8 & 19.6 & st (pahoa) & $>4.29$ & $<4.22$ & $<4.42$ & 3.78 & 4.27 & & & 4.02 & hono & IV & $\begin{array}{l}\text { Near Heiheiahulu, felt-Pahoa, Hilo, hnp, Capt. } \\
\text { Cook; Hilo-3, felt by many, slow and moderate, } \\
\text { dur } 15 \text { s, windows, doors, dishes rattled; Capt. } \\
\text { Cook (23:00)-2, v slight vibration, similar to } \\
22: 25 \text { quake but shorter and lighter, no window } \\
\text { rattle. }\end{array}$ & $\begin{array}{l}\text { Honolulu amplitude average of two } \\
\text { readings, strong at Whitney (VL } 527, \\
\text { p. } 4 \text {, table) yields } M>4.92 \text {, slight(?); } \\
\text {, location corrected to south coast of } \\
\text { Kilauea } 2 \text { mi W of Kalapana } \\
\text { (Macdonald and Eaton, 1964, p.146); } \\
\text { closer to Pahoa(?); VL 527, p. 6; HVO, } \\
\text { unpub. }\end{array}$ \\
\hline $3 / 7 / 55$ & 23:32:41 & 19 & 21.20 & 155 & $0.30 \mathrm{kl} \mathrm{mer} \mathrm{sf}$ & 10.0 & 10.0 & 18.0 & 16.8 & 19.6 & st (pahoa) & $>4.29$ & no trace & $\begin{array}{l}\text { no } \\
\text { record }\end{array}$ & $\operatorname{det} ?$ & $\begin{array}{c}\text { no } \\
\text { trace }\end{array}$ & & & 4.00 & aver & III & $\begin{array}{l}\text { Near Heiheiahulu; felt-Pahoa, Hilo, hnp; Hilo- } \\
\text { felt by few, slow and weak, door rattled, felt in } \\
\text { bed, slightly, just one jolt; preferred mag } \\
\text { average of Pahoa and Whitney. }\end{array}$ & $\begin{array}{l}\text { Whitney (VL 527, p. 4, table); } M \\
\text { (Whitney)=3.33-3.92; location } \\
\text { corrected to south coast of Kilauea } 2 \\
\text { mi W of Kalapana (Macdonald and } \\
\text { Eaton, 1964, p.146); VL 527, p. 6; } \\
\text { HVO, unpub. }\end{array}$ \\
\hline $3 / 11 / 55$ & 23:59:00 & & & & $\mathrm{kl}$ ler & & 5.0 & 7.0 & 7.0 & 8.6 & $\mathrm{~s}$ (pahoa) & 2.95 & & & & & & & 4.02 & calc & & Do. & $\begin{array}{l}\text { Lower east rift earthquake swarm; } 15 \\
\text { events; VL 527, p. } 6 \text {. }\end{array}$ \\
\hline $3 / 28 / 55$ & 14:31:00 & & & & hilea? & & & & & & & & & & & & & & 4.15 & nomo & III & $\begin{array}{l}\text { Pahala-5, felt generally, heard as well as felt, } \\
\text { movement acc by rumbling. }\end{array}$ & $\begin{array}{l}\text { Not in VL 527-date and time from felt } \\
\text { report; HVO, unpub. [intensities-arabic } \\
\text { numerals-in remarks column refer to } \\
\text { HVO postcards]. }\end{array}$ \\
\hline $3 / 30 / 55$ & 13:41:31 & 19 & 20.3 & 155 & $41.0 \mathrm{ml} \mathrm{swr}$ & & & & 32.3 & 33.5 & $\begin{array}{c}\mathrm{m} \\
\text { (naalehu) }\end{array}$ & 4.15 & no trace & no trace & $\begin{array}{l}\text { no } \\
\text { trace }\end{array}$ & $\begin{array}{c}\text { no } \\
\text { trace }\end{array}$ & & & 4.13 & nomo & & & Closer to Naalehu(?); VL 527, p. 6. \\
\hline $4 / 1 / 55$ & 4:24:28 & 19 & 24.30 & 155 & $\begin{array}{l}\mathrm{kl} \mathrm{cal} \\
17.70 \text { deep }\end{array}$ & 10.0 & 30.0 & 4.5 & 2.1 & 30.1 & st (uwe) & 4.46 & 4.75 & 4.78 & 5.13 & 5.33 & 5.20 & hvo & 5.10 & aver & $\begin{array}{l}\mathrm{V} ; \mathrm{V}(\mathrm{W} \& \mathrm{~K} ; \\
\mathrm{S} \& \mathrm{C})\end{array}$ & $\begin{array}{l}\text { South rim of Kilauea crater; felt generally- } \\
\text { Hawaii Island; few on Maui, Oahu; detailed felt } \\
\text { reports in HVO unpub. Warshauer notes: Hilo, } \\
\text { Kona seismometers dismantled; felt-Kona, } \\
\text { Kau, Hilo. Pahoa, volcano, Glenwood-Mt. } \\
\text { view; objects off shelves at Kapapala }\end{array}$ & $\begin{array}{l}\text { Depth changed to } 30 \mathrm{~km} \text { in accordance } \\
t \text { with similar felt reports over a broad } \\
\text { area of Hawaii Island; VL } 528 \text {, p. } 5 \text {; } \\
\text { HVO unpub.; HTH, 4/1/1955; mag not } \\
\text { published in VL; preferred mag } \\
\text { average of Honolulu and HVO. }\end{array}$ \\
\hline $4 / 7 / 55$ & 1:27:22 & & & & $\begin{array}{l}\begin{array}{l}\text { kl cal } \\
\text { deep }\end{array} \\
\end{array}$ & 25.0 & 25.0 & 15.0 & 15.0 & 29.2 & $\mathrm{~s}$ (uwe) & 3.93 & $<3.90$ & $<4.12$ & $2<3.75$ & 4.25 & & & 4.25 & hono & & Hilina pali. & $\begin{array}{l}\text { Honolulu amplitude average of two } \\
\text { readings; VL 528, p. } 5 \text {. }\end{array}$ \\
\hline
\end{tabular}


Table 13. All earthquakes of $M \geq 4.0$ during the period 1903-59—Continued

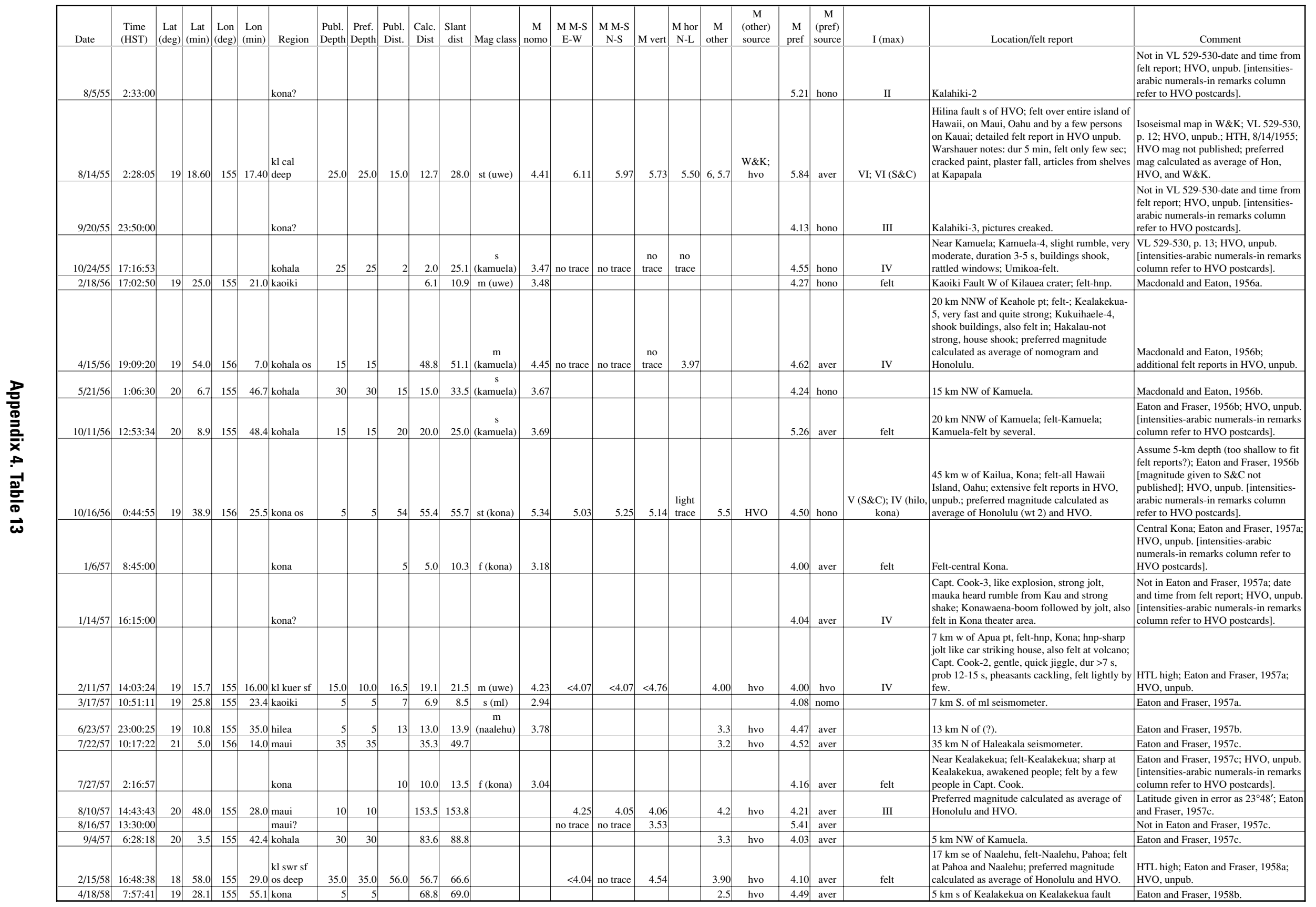


\& Table 13. All earthquakes of $M \geq 4.0$ during the period 1903-59-Continued

\begin{tabular}{|c|c|c|c|c|c|c|c|c|c|c|c|c|c|c|c|c|c|c|c|c|c|c|c|c|}
\hline Date & $\begin{array}{l}\text { Time } \\
\text { (HST) }\end{array}$ & $\begin{array}{c}\text { Lat } \\
(\operatorname{deg})\end{array}$ & $\begin{array}{c}\text { Lat } \\
(\mathrm{min})\end{array}$ & $\begin{array}{l}\text { Lon } \\
\text { (deg) }\end{array}$ & $\begin{array}{l}\text { Lon } \\
(\mathrm{min})\end{array}$ & Region & $\begin{array}{l}\text { Publ. F } \\
\text { Depth D }\end{array}$ & $\begin{array}{l}\text { Pref. } \\
\text { Depth }\end{array}$ & $\begin{array}{l}\text { Publ. } \\
\text { Dist. }\end{array}$ & $\begin{array}{l}\text { Calc. } \\
\text { Dist }\end{array}$ & $\begin{array}{c}\text { Slant } \\
\text { dist }\end{array}$ & Mag class & $\begin{array}{c}\mathrm{M} \\
\text { nomo }\end{array}$ & $\begin{array}{l}\text { M M-S } \\
\text { E-W }\end{array}$ & $\begin{array}{c}\text { M M-S } \\
\text { N-S }\end{array}$ & M vert & $\begin{array}{c}\text { M hor } \\
\mathrm{N}-\mathrm{L}\end{array}$ & $\begin{array}{c}\mathrm{M} \\
\text { other }\end{array}$ & $\begin{array}{c}\mathrm{M} \\
\text { (other) } \\
\text { source }\end{array}$ & $\begin{array}{c}\text { M } \\
\text { pref }\end{array}$ & $\begin{array}{c}\mathrm{M} \\
\text { (pref) } \\
\text { source }\end{array}$ & $I(\max )$ & Location/felt report & Comment \\
\hline $7 / 6 / 58$ & 23:59:00 & 19 & 28.5 & 155 & 12.80 & $\begin{array}{l}\mathrm{kl} \text { gln } \\
30 \text { deep }\end{array}$ & 55.0 & 55.0 & 10.0 & 7.3 & 55.5 & & & & & & & & & 4.82 & calc & & $\begin{array}{l}\text { Preferred magnitude calculated as Richter } \\
\text { distribution. }\end{array}$ & $\begin{array}{l}\text { Deep earthquake swarm north of } \\
\text { Kilauea caldera; 2,052 events of } \\
M<2.5 \text { with } b=1.5 \text { whose magnitudes } \\
\text { are not tabulated separately (Eaton and } \\
\text { Krivoy, 1958, p. 4). }\end{array}$ \\
\hline $9 / 20 / 58$ & $20: 09: 18$ & 20 & 4.0 & 155 & 36.4 & $\begin{array}{l}\text { mauna } \\
4 \text { kea deep }\end{array}$ & 40 & 40 & & 79.0 & 88.6 & & & & & & & 2.7 & hvo & 4.04 & aver & & $10 \mathrm{~km} E$ of Kamuela. & Eaton and Krivoy, 1958a. \\
\hline $10 / 22 / 58$ & $23: 43: 28$ & 19 & 12.5 & 155 & 19.00 & $\begin{array}{l}\text { kl kuer sf } \\
00 \text { os }\end{array}$ & 5.0 & 5.0 & & 25.5 & 26.0 & & & $<4.57$ & $<4.57$ & 4.53 & & 4.30 & hvo & 4.41 & aver & $\mathrm{v}$ & $\begin{array}{l}\text { Felt-hnp to Kealakekua; hnp-felt; Pahala-felt } \\
\text { by many in Kau, very strong; Capt. Cook-felt } \\
\text { [postcard time 23:50-24:00- Should be earlier } \\
\text { to agree with seismic summary felt info]; } \\
\text { preferred magnitude calculated as average of } \\
\text { HVO and Honolulu. }\end{array}$ & $\begin{array}{l}\text { Honolulu amplitude average of two } \\
\text { readings; HTLL high; Eaton and Krivoy, } \\
\text { 1958b; HVO, unpub. }\end{array}$ \\
\hline $10 / 23 / 58$ & $12: 23: 23$ & 19 & 12.5 & 155 & 19.00 & $\begin{array}{l}\text { kl kuer sf } \\
0 \text { os }\end{array}$ & 5.0 & 5.0 & & 25.5 & 26.0 & & & 4.62 & 4.74 & 4.60 & & 4.30 & hvo & 4.47 & aver & IV & $\begin{array}{l}\text { Felt-Pahala; hnp-felt; Pahala-felt by many in } \\
\text { Kau, very strong; Capt. Cook-felt; preferred } \\
\text { magnitude calculated as average of HVO and } \\
\text { Honolulu. }\end{array}$ & $\begin{array}{l}\text { Honolulu amplitude average of two } \\
\text { readings; Eaton and Krivoy, 1958b; } \\
\text { HVO, unpub. }\end{array}$ \\
\hline $11 / 2 / 58$ & $5: 55: 44$ & 19 & 24.4 & 155 & 18.40 & $\begin{array}{l}\mathrm{kl} \mathrm{cal} \\
0 \text { deep }\end{array}$ & 30.0 & 30.0 & 4.5 & 5.1 & 30.4 & & & $<4.50$ & 4.60 & 4.70 & & 4.40 & hvo & 4.40 & hvo & IV & $\begin{array}{l}4 \mathrm{~km} \mathrm{SE} \text { of Uwekahuna, felt-hnp to Hilo; } \\
\text { hnp/volcano-felt generally; Hilo-felt; Kapoho- } \\
\text { felt (ranch), wakened by gentle motion, E-W, } 2 \\
\text { distinct waves, dur } 15 \mathrm{~s} \text { s Hilo-moderate, began } \\
\text { gradually, dur } 10 \mathrm{~s} \text {, pulsating rocking motion, } \\
\text { felt generally. }\end{array}$ & $\begin{array}{l}\text { Honolulu amplitude average of two } \\
\text { readings; Eaton and Krivoy, 1958b; } \\
\text { HVO, unpub. }\end{array}$ \\
\hline $12 / 24 / 58$ & 17:05:21 & 19 & 24.5 & 155 & 25.5 & 5 kaoiki & 10 & 10 & & 16.9 & 19.6 & & & & & & & 3.5 & hvo & 4.50 & hvo & & $5 \mathrm{~km}$ w of Ohaikea. & Eaton and Krivoy, 1958b. \\
\hline $1 / 7 / 59$ & 23:59:00 & & & & & $\begin{array}{l}\mathrm{kl} \mathrm{gln} \\
\text { deep }\end{array}$ & & & & & & & & & & & & & & 4.47 & calc & & $\begin{array}{l}\text { Preferred magnitude calculated as a Richter } \\
\text { swarm }\end{array}$ & $\begin{array}{l}\text { Deep earthquake swarm north of } \\
\text { Kilauea caldera; } 571 \text { events of } M<2.5 \\
\text { with } b=1.5 \text { whose magnitudes are not } \\
\text { tabulated separately (Eaton and Krivoy, } \\
1963 \text { a, p. 2). }\end{array}$ \\
\hline $2 / 19 / 59$ & 20:00:28 & 19 & 21.0 & 155 & 9.00 & $0 \mathrm{kl} \mathrm{mer} \mathrm{sf}$ & 5.0 & 5.0 & & 15.4 & 16.2 & & & 4.62 & 4.90 & 5.11 & & 4.50 & hvo & 4.69 & aver & III (S\&C) & $\begin{array}{l}\text { Felt-Capt. Cook, Honokaa, Hilo, hnp; preferred } \\
\text { magnitude calculated as average of HVO and } \\
\text { Honolulu. }\end{array}$ & $\begin{array}{l}\text { Honolulu data is average of two } \\
\text { readings; Eaton and Krivoy, 1963a. }\end{array}$ \\
\hline $2 / 28 / 59$ & 6:54:54 & +19 & 26.0 & 155 & 29.0 & 0 kaoiki & 5 & 5 & & 22.8 & 23.4 & & & & & & & 3.2 & hvo & 4.10 & aver & & & Eaton and Krivoy, 1963a. \\
\hline $\begin{array}{l}6 / 25 / 59 \\
8 / 18 / 59\end{array}$ & $\begin{array}{l}16: 11: 30 \\
13: 54: 50\end{array}$ & $\begin{array}{l}19 \\
19\end{array}$ & $\begin{array}{l}15.0 \\
17.0\end{array}$ & $\begin{array}{l}155 \\
154\end{array}$ & $\begin{array}{r}31.0 \\
57\end{array}$ & $\begin{array}{l}0 \text { hilea } \\
7 \text { deep? }\end{array}$ & $\begin{array}{r}5 \\
45.0\end{array}$ & $\begin{array}{r}5 \\
45.0\end{array}$ & & $\begin{array}{l}33.3 \\
37.3\end{array}$ & $\begin{array}{l}33.6 \\
58.5\end{array}$ & & & no trace & no trace & det? & & $\begin{array}{r}2.6 \\
4.00\end{array}$ & $\begin{array}{l}\text { hvo } \\
\text { hvo }\end{array}$ & $\begin{array}{l}4.18 \\
4.00\end{array}$ & $\begin{array}{l}\text { aver } \\
\text { hvo }\end{array}$ & felt & Felt-hnp, Hilo. & $\begin{array}{l}\text { Eaton and Krivoy, } 1963 \mathrm{~b} . \\
\text { Eaton and Krivoy, } 1963 \mathrm{c} .\end{array}$ \\
\hline $8 / 20 / 59$ & 23:59:00 & & & & & $\begin{array}{l}\mathrm{kl} \operatorname{gln} \\
\text { deep }\end{array}$ & 51.5 & 51.5 & & 6.5 & 51.9 & & & & (1) & & & & & 4.75 & calc & & $\begin{array}{l}\text { Preferred magnitude calculated as a Richter } \\
\text { swarm. }\end{array}$ & $\begin{array}{l}\text { Deep Glenwood earthquake swarm; } \\
2,358 \text { events of } \mathrm{M}<2.5 \text { with } \mathrm{b}=1.5 \\
\text { whose magnitudes are not tabulated } \\
\text { separately (Eaton and Krivoy, } 1963 \mathrm{c}, \mathrm{p} \text {. } \\
2,10-13) \text {. }\end{array}$ \\
\hline $9 / 18 / 59$ & 14:50:04 & $4 \quad 19$ & 24.0 & 155 & & $6 \mathrm{kl} \mathrm{mer}$ & 5.0 & 5.0 & & 18.0 & 18.7 & & & $\begin{array}{c}\text { no } \\
\text { record }\end{array}$ & $\begin{array}{l}\text { no } \\
\text { record }\end{array}$ & $\begin{array}{c}\text { no } \\
\text { record }\end{array}$ & & 4.00 & hvo & 4.00 & hvo & felt & Felt-hnp, Hilo. & Eaton and Krivoy, 1963c. \\
\hline
\end{tabular}




\section{Selected Series of U.S. Geological Survey Publications}

\section{Books and Other Publications}

Professional Papers report scientific data and interpretations of lasting scientific interest that cover all facets of USGS investigations and research.

Bulletins contain significant data and interpretations that are of lasting scientific interest but are generally more limited in scope or geographic coverage than Professional Papers.

Water-Supply Papers are comprehensive reports that present significant interpretive results of hydrologic investigations of wide interest to professional geologists, hydrologists, and engineers. The series covers investigations in all phases of hydrology, including hydrogeology, availability of water, quality of water, and use of water.

Circulars are reports of programmatic or scientific information of an ephemeral nature; many present important scientific information of wide popular interest. Circulars are distributed at no cost to the public.

Fact Sheets communicate a wide variety of timely information on USGS programs, projects, and research. They commonly address issues of public interest. Fact Sheets generally are two or four pages long and are distributed at no cost to the public.

Reports in the Digital Data Series (DDS) distribute large amounts of data through digital media, including compact discread-only memory (CD-ROM). They are high-quality, interpretive publications designed as self-contained packages for viewing and interpreting data and typically contain data sets, software to view the data, and explanatory text.

Water-Resources Investigations Reports are papers of an interpretive nature made available to the public outside the formal USGS publications series. Copies are produced on request (unlike formal USGS publications) and are also available for public inspection at depositories indicated in USGS catalogs.

Open-File Reports can consist of basic data, preliminary reports, and a wide range of scientific documents on USGS investigations. Open-File Reports are designed for fast release and are available for public consultation at depositories.

\section{Maps}

Geologic Quadrangle Maps (GQ's) are multicolor geologic maps on topographic bases in 7.5- or 15-minute quadrangle formats (scales mainly 1:24,000 or 1:62,500) showing bedrock, surficial, or engineering geology. Maps generally include brief texts; some maps include structure and columnar sections only.

Geophysical Investigations Maps (GP's) are on topographic or planimetric bases at various scales. They show results of geophysical investigations using gravity, magnetic, seismic, or radioactivity surveys, which provide data on subsurface structures that are of economic or geologic significance.
Miscellaneous Investigations Series Maps or Geologic Investigations Series (I's) are on planimetric or topographic bases at various scales; they present a wide variety of format and subject matter. The series also incudes 7.5-minute quadrangle photogeologic maps on planimetric bases and planetary maps.

\section{Information Periodicals}

Metal Industry Indicators (MII's) is a free monthly newsletter that analyzes and forecasts the economic health of five metal industries with composite leading and coincident indexes: primary metals, steel, copper, primary and secondary aluminum, and aluminum mill products.

Mineral Industry Surveys (MIS's) are free periodic statistical and economic reports designed to provide timely statistical data on production, distribution, stocks, and consumption of significant mineral commodities. The surveys are issued monthly, quarterly, annually, or at other regular intervals, depending on the need for current data. The MIS's are published by commodity as well as by State. A series of international MIS's is also available.

Published on an annual basis, Mineral Commodity Summaries is the earliest Government publication to furnish estimates covering nonfuel mineral industry data. Data sheets contain information on the domestic industry structure, Government programs, tariffs, and 5-year salient statistics for more than 90 individual minerals and materials.

The Minerals Yearbook discusses the performance of the worldwide minerals and materials industry during a calendar year, and it provides background information to assist in interpreting that performance. The Minerals Yearbook consists of three volumes. Volume I, Metals and Minerals, contains chapters about virtually all metallic and industrial mineral commodities important to the U.S. economy. Volume II, Area Reports: Domestic, contains a chapter on the minerals industry of each of the 50 States and Puerto Rico and the Administered Islands. Volume III, Area Reports: International, is published as four separate reports. These reports collectively contain the latest available mineral data on more than 190 foreign countries and discuss the importance of minerals to the economies of these nations and the United States.

\section{Permanent Catalogs}

"Publications of the U.S. Geological Survey, 1879-1961" and "Publications of the U.S. Geological Survey, 19621970" are available in paperback book form and as a set of microfiche.

"Publications of the U.S. Geological Survey, 1971-1981" is available in paperback book form (two volumes, publications listing and index) and as a set of microfiche.

Annual supplements for 1982, 1983, 1984, 1985, 1986, and subsequent years are available in paperback book form. 
